DANILO PACHECO E SILVA

\title{
ANÁLISE DE DIFERENTES METODOLOGIAS EXECUTIVAS DE SOLO PREGADO A PARTIR DE ENSAIOS DE ARRANCAMENTO REALIZADOS EM CAMPO E LABORATÓRIO
}

Tese apresentada à Escola de Engenharia de São Carlos, da Universidade de São Paulo, como parte integrante dos requisitos para a obtenção do Título de Doutor em Geotecnia.

ORIENTADOR: Prof. Tit. Benedito de Souza Bueno

São Carlos

2009 



\section{Dedicatória}

À minha esposa Juliana

À querida Daniella, fonte inspiradora Aos meus pais José Carlos e Renata 
Análise de diferentes metodologias executivas de solo pregado a partir de ensaios de arrancamento realizados em campo e laboratório 


\section{Agradecimentos}

À Escola de Engenharia de São Carlos e ao Departamento de Geotecnia pela oportunidade de realizar esta pesquisa.

Ao Prof. Benedito de Souza Bueno, orientador desta tese, exemplo de dedicação e determinação. Agradeço ainda por todas as oportunidades que me concedeu sem as quais este trabalho não teria sido realizado.

A FAPESP, Fundação de Amparo à Pesquisa do Estado de São Paulo, pelo apoio na forma de bolsa de doutorado e pelo auxílio à pesquisa concedida ao orientador deste trabalho.Esta concessão foi fundamental para o desenvolvimento desta pesquisa.

Aos Diretores (Alberto, George e Azzi) da empresa Solotrat Engenharia Geotécnia Ltda., pela competência, facilidade de relacionamento e pronta disponibilização das obras.

À Escola Politécnica da USP e, em especial, ao Prof. Marcos Massao Futai pela realização dos ensaios pressiométricos na obra de Santo André-SP.

Ao amigo Sérgio Barreto de Miranda pelo companheirismo e apoio imensurável para o desenvolvimento deste trabalho ("Eu sabia que ia ser um pega pra capa").

Ao amigo Thiago de Paula Alonso pelo companheirismo, convívio, crescimento e apoio nos momentos corridos e dificeis (Valeu César!).

Aos Técnicos e estagiários do Laboratório de Geossintéticos, em especial, ao Walter pela sua prontidão nas tarefas dificeis.

A todos os Funcionários e amigos do Departamento de Geotecnia da EESC/USP em especial Heraldo Nunes Pitanga e Roger Augusto Rodrigues que são exemplos de pesquisadores.

Ao amigo Vallin pelos ensinamentos e ajuda na renovação das Energias necessárias para o desenvolvimento deste trabalho.

Em especial à Juliana, minha esposa, pelo seu amor, compreensão e incentivo nesta importante fase da minha vida.

À Deus, pois sem ele nada seria possivel. 
“Às vezes parece ser muito difícil viver neste mundo. É preciso considerar o modo como as criaturas enfrentam as diversidades e como buscam a solução de seus problemas. A solução desses momentos difíceis nunca está no desespero, na revolta e nas atitudes impensadas, mas na inteligência, na serenidade, na coragem, no bom senso dos pensamentos e atitudes, na determinação de vencer. A diferença entre o possível e o impossivel, na maioria das vezes, é questão de persistência e determinação”.

Autor Desconhecido 
Análise de diferentes metodologias executivas de solo pregado a partir de ensaios de arrancamento em campo e laboratório 


\section{SUMÁRIO}

LISTA DE FIGURAS

xiii

LISTA DE TABELAS XXV

LISTA DE ABREVIATURAS, SIGLAS E SÍMBOLOS xxvii

RESUMO XXXii

ABSTRACT Xxxiv

CAPÍTULO 1 INTRODUÇÃO 1

1.1 JUSTIFICATIVA E OBJETIVOS 3

CAPÍTULO 2 REVISÃO BIBLIOGRÁFICA 4

2.1 INTRODUÇÃO 4

2.2 CONCEITUAÇÃO BÁSICA DE SOLOS REFORÇADOS 4

$\begin{array}{lll}2.3 & \text { REFORÇOS DE SOLOS IN SITU }\end{array}$

$2.4 \quad$ HISTÓRICO DA TÉCNICA DE SOLO PREGADO 11

2.5 A TÉCNICA DE SOLO PREGADO 14

2.5.1. Escavação 16

2.5.1.1. Escavação Alternada 17

2.5.1.2. Execução de Berma Provisória 17

2.5.1.3. Lançamento de Concreto Projetado de Proteção 18

2.5.2. Execução dos Reforços 19

2.5.2.1. Reforços Cravados 19

2.5.2.2. Reforços Injetados $\quad 20$

2.5.3. Sistema de Drenagem 22

2.5.4. Revestimento de Face 24

2.5.5. Conexão do Reforço à Face 25

$\begin{array}{lllllll}2.6 & \text { COMPARAÇÃO } & \text { COM } & \text { OUTRAS } & \text { TÉCNICAS } & \text { DE } & 27\end{array}$

2.6.1. Solo Pregado e Cortina Atirantada 27

2.6.2. Solo Pregado e Terra Armada 30

viii 
Análise de diferentes metodologias executivas de solo pregado a partir de ensaios de arrancamento em campo e laboratório

2.7

2.8

2.14

2.15
VANTAGENS DA TÉCNICA DE SOLO PREGADO

AVALIAÇÃO DA APLICABILIDADE DA TÉCNICA DE SOLO PREGADO

2.8.1. Condições Favoráveis

2.8.2. Condições Desfavoráveis

MECANISMOS DE INTERAÇÃO SOLO-REFORÇO

2.9.1. Resistência ao Cisalhamento de Interface Solo-Reforço

2.9.2. Mobilização do $q_{s}$ com a Deformação

2.9.3. Empuxo do Solo Sobre o Reforço

2.9.4. Influência dos Reforços na Mobilização de Tensões

DETERMINAÇÃO DA RESISTÊNCIA AO CISALHAMENTO DE INTERFACE SOLO-REFORÇO

2.10.1. Métodos Teóricos e Empíricos de Previsão

2.10.2. Ensaios de Arrancamento

2.10.3. Pesquisas - Ensaios de Arrancamento em Campo

2.10.4. Pesquisas - Ensaios de Arrancamento em Laboratório

INJEÇÃO DE CALDA DE CIMENTO

DURABILIDADE DOS REFORÇOS EM ESTRUTURAS TEMPORÁRIAS E PERMANENTES TIPOS DE RUPTURA EM ESTRUTURAS DE SOLO PREGADO

2.13.1. Ruptura Interna

2.13.1.1. Ruptura dos Reforços

2.13.1.2. Ruptura por Falta de Aderência (Arrancamento)

2.13.1.3. Ruptura Durante as Fases de Escavação

2.13.2. Ruptura Externa e Ruptura Mista

PRÉ-DIMENSIONAMENTO DE SOLO PREGADO MÉTODOS DE PROJETO

2.15.1. Método Alemão

2.15.2. Método de Davis

2.15.3. Método Francês - Multicritério

2.15.3.1. Critério (1): Resistência ao Cisalhamento de Interface Solo-Reforço

2.15.3.2. Critério (2): Empuxo do Solo Sobre o Reforço na Interface Solo-Reforço

2.15.3.3. Critérios 3 e 4: Plastificação do Reforço

2.15.3.4. Critério 3 
Análise de diferentes metodologias executivas de solo pregado a partir de ensaios de arrancamento em campo e laboratório

2.15.3.5. Critério 4 103

2.15.3.6. Combinação dos Critérios de Ruptura 105

2.15.4. Método de Juran et al. (1990) 106

2.15.5. Análises Tensão x Deformação 111

2.16 INSTRUMENTAÇÃO DE CHUMBADORES 113

CAPÍTULO 3 MATERIAIS E MÉTODOS 116

$\begin{array}{lll}3.1 & 116\end{array}$

3.2 PROGRAMA EXPERIMENTAL DE LABORATÓRIO 117

3.2.1. Caracteristicas do Solo 117

3.2.2. Caixa Metálica de Ensaios 120

3.2.2.1. Caracteristicas dos Reforços 121

3.2.3. Instrumentação Utilizada 125

3.2.4. Preenchimento da Caixa de Ensaio 128

3.2.5. Execução do Solo Pregado 131

3.2.5.1. Preparação da Calda de Cimento 133

3.2.5.2. Equipamento de Injeção de Calda de Cimento $\quad 136$

3.2.5.3. Controle das Injeções 139

3.2.6. Ensaios de Arrancamento 142

3.2.7. Exumação dos Reforços 143

$\begin{array}{lll}3.3 & \text { PROGRAMA EXPERIMENTAL DE CAMPO }\end{array}$

3.3.1. Preparação das Barras de Aço 144

3.3.2. Instrumentação das Barras de Aço 147

3.3.3. Metodologias Executivas 151

3.3.3.1 Traço Alternativo - Calda de Solo Cimento $\quad 156$

3.3.4. Obra 1- Santo André-SP 159

3.3.4.1. Investigações Geotécnicas 160

3.3.4.2. Execução dos Chumbadores Testes 167

3.3.5. Obra 2- Osasco-SP 178

3.3.5.1. Investigações Geotécnicas 179

3.3.5.2. Execução dos Chumbadores Testes 184

3.3.6. Ensaios de Arrancamento 191

$\begin{array}{ll}\text { CAPÍTULO } 4 & \text { RESULTADOS E ANÁLISES - PROGRAMA EXPERIMENTAL } \\ & 196\end{array}$ 
Análise de diferentes metodologias executivas de solo pregado a partir de ensaios de arrancamento em campo e laboratório

$\begin{array}{lll}\text { 4.1 } & \text { ENSAIOS DE ARRANCAMENTO }\end{array}$

4.1.1. Influência do Volume Injetado 205

4.1.2. Instrumentação dos Reforços 208

4.1.3. Exumação dos Reforços 210

4.1.4. Monitoramento do Solo Pregado 213

4.1.5. Análises de Estabilidade do Solo Pregado 216

CAPÍTULO 5 RESULTADOS E ANÁLISES - PROGRAMA EXPERIMENTAL

$\begin{array}{lll}5.1 & \text { ENSAIOS REALIZADOS } & 221\end{array}$

5.2 ENSAIOS DE ARRANCAMENTO - SANTO ANDRÉ-SP (OBRA 1) 222

5.2.1. Ensaios de Arrancamento - Linha 2

5.2.1.1. Influência da Metodologia Executiva 229

5.2.1.2. Influência do Volume de Injeção de Calda de Cimento 233

5.2.1.3. Influência do Comprimento do Chumbador 235

5.2.1.4. Resultados da Instrumentação 237

5.2.2. Ensaios de Arrancamento - Linha 5

5.2.2.1. Influência da Metodologia Executiva 244

5.2.2.2. Influência do Volume de Injeção de Calda de Cimento 248

5.2.2.3. Influência do Comprimento do Chumbador 250

5.2.2.4. Resultados da Instrumentação 253

5.3 ENSAIOS DE ARRANCAMENTO - OSASCO-SP (OBRA 2) 254

5.3.1. Ensaios de Arrancamento - Linha 3

5.3.1.1. Influência da Metodologia Executiva 260

5.3.1.2. Influência do Volume de Injeção de Calda de Cimento 264

5.3.1.3. Influência do Comprimento do Chumbador 267

5.3.1.4. Resultados da Instrumentação 269

5.3.2. Ensaios de Arrancamento - Linha 5

5.3.2.1. Influência da Metodologia Executiva 276

5.3.2.2. Influência do Volume de Injeção de Calda de Cimento $\quad 280$

5.3.2.3. Influência do Comprimento do Chumbador 282

5.3.2.4. Resultados da Instrumentação 283

$5.4 \quad$ ANÁLISE GERAL DOS RESULTADOS OBTIDOS 284

5.5 COMPARAÇÃO COM MÉTODOS TEÓRICOS E EMPÍRICOS DE 288 
Análise de diferentes metodologias executivas de solo pregado a partir de ensaios de arrancamento em campo e laboratório

\section{PREVISÃO}

5.6

PROPOSTA DE METODOLOGIA PARA O CONTROLE DE QUALIDADE

CAPÍTULO 6 CONCLUSÕES

6.1

PROGRAMA EXPERIMENTAL DE LABORATÓRIO

6.2.1. Influência das Metodologias Executivas

6.2.2. Influência do Volume de Injeção de Calda de Cimento

6.2.3. Influência do Comprimento dos Chumbadores

6.2.4. Instrumentação com Strain Gages

6.2.5. Análise Geral dos Resultados Obtidos

299

6.2.6. Comparação com Métodos Teóricos e Empíricos de Previsão 


\section{USTA DE RGURAS}

\section{Capítulo 2}

Figura 2.1. Efeito do reforço em um elemento de solo: (a) amostra não reforçada e (b) amostra reforçada (BS 8006)

Figura 2.2. Situações em que se devem empregar as diferentes técnicas de reforço de solos in situ

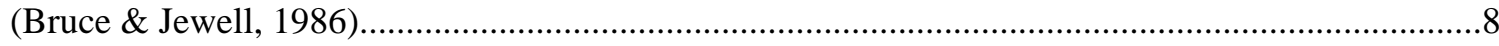

Figura 2.3. Aplicação da técnica de solo pregado na estabilização de taludes.....................................9

Figura 2.4. Aplicação da técnica de solo pregado em estruturas de contenção..................................... 9

Figura 2.5. Reticulado de micro estacas (Bruce \& Jewell, 1986)........................................................10

Figura 2.6. Estacas de grande diâmetro (Bruce \& Jewell, 1986).....................................................10

Figura 2.7. Técnicas de execução de túneis: (a) com revestimento rígido e (b) com revestimento flexível (Ortigão \& Palmeira, 1992)...............................................................................................11

Figura 2.8. Seqüência típica para a execução da estrutura de solo pregado (Elias et al., 2003)........15

Figura 2.9. Escavação realizada de forma alternada (Elias et al., 2003)..........................................17

Figura 2.10. Construção de bermas provisórias para minimizar a ocorrência de rupturas localizadas

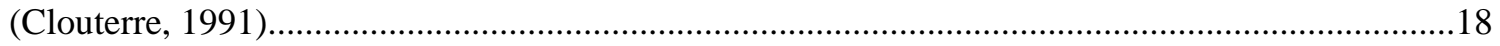

Figura 2.11. Lançamento de concreto projetado de proteção (Clouterre, 1991)..................................18

Figura 2.12. Detalhe de drenos horizontais profundos (Clouterre, 1991)........................................23

Figura 2.13. Detalhe de drenos rasos ou de subsuperfície (Clouterre, 1991).......................................23

Figura 2.14. Diferentes alternativas de conexão do reforço junto a face de concreto projetado (GeoRio, 1999).

Figura 2.15. Mecanismos de transferência de carga no solo pregado (a) e na cortina atirantada (b).28

Figura 2.16. Custo relativo entre as obras de cortina atirantada e solo pregado (Ortigão \& Palmeira, 1992).

Figura 2.17. Comparação entre os processos construtivos de Solo Pregado e Terra Armada (Bruce

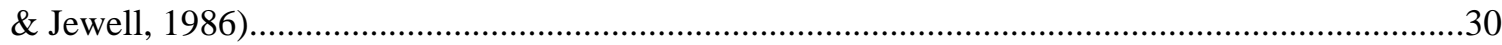

Figura 2.18. Deslocamentos horizontais máximos: (a) Terra armada e (b) Solo Pregado...................31 Figura 2.19. Desenvolvimento progressivo de esforços de tração no reforço 3 do muro experimental

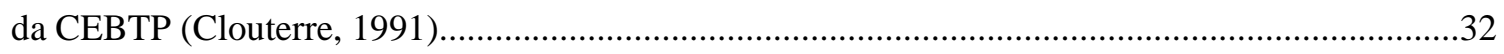

Figura 2.20. Mecanismos de interação solo-reforço na estrutura de solo pregado (Sheahan \& Alvarado, 1996) 
Figura 2.21. Mecanismo de interação solo-reforço em solo granular compactado (Schlosser, 1982).

Figura 2.22. Incremento da tensão normal devido ao efeito da restrição da dilatância ao redor do reforço solicitado à tração (Clouterre, 1991)...

Figura 2.23. Variação da resistência ao cisalhamento de interface ao longo da profundidade (Cartier

\& Gigan, 1983). .40

Figura 2.24. Avaliação da influência do teor de umidade em ensaios de arrancamento realizados em aterro composto por solo granular argiloso (Schlosser, 1982)......

Figura 2.25. Força mobilizada no reforço (Ehrlich, 2003). . .42

Figura 2.26. Modelagem de uma curva experimental de arrancamento pela lei de Frank \& Zhao (1982) (Clouterre, 1991).

Figura 2.27. Desenvolvimento dos deslocamentos horizontais no muro experimental de solo pregado de CEBTP (Clouterre, 1991).

Figura 2.28. Deslocamentos horizontais do muro de solo pregado construído em solos argilosos em Vierzon, monitorado pela CEBTP (Clouterre, 1991)...

Figura 2.29. Muro experimental $n^{\circ} 1$ realizado pela CEBTP (Clouterre, 1991)...

Figura 2.30. Determinação das deformações nos reforços de forma análoga a estaca carregada horizontalmente no seu topo (Schlosser, 1982).

Figura 2.31. Efeito da rigidez do reforço no desenvolvimento do empuxo atuante sobre o reforço: (a) reforço flexível; (b) reforço rígido (Mitchell \& Villet, 1987).

Figura 2.32. Analogia do comportamento de ruptura em talude de solo reforçado com caixa de cisalhamento direto (Jones, 2000). .51

Figura 2.33. Correlações entre $q_{s}$, PL e NSPT para areia (a), argilas e siltes (b) (Bustamante \& Doix, 1985). 55

Figura 2.34. Correlação entre o parâmetro $q_{s}$ e a pressão limite do pressiômetro de Menárd (PL) para solos arenosos (a) e argilosos (b) (Clouterre, 1991)... .56

Figura 2.35. Correlação entre $q_{s}$ e o número de golpes NSPT (Ortigão e Palmeira, 1997). .57

Figura 2.36. Critério de ruptura de arrancamento de chumbadores: (a) força máxima e (b)

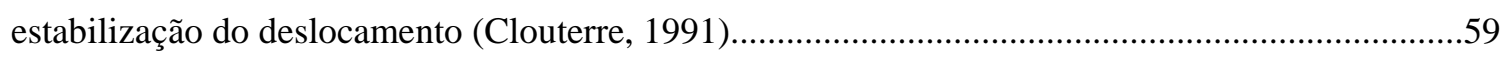

Figura 2.37. Determinação da força máxima de arrancamento (Clouterre, 1991)... .60

Figura 2.38. Esquema de montagem do ensaio de arrancamento (Adaptado Lazarte et al., 2003)...63

Figura 2.39. Zona de Transição (Chang \& Milligan, 1996)...............................................................72

Figura 2.40. Tubo de injeção com válvulas tipo “manchette” (Guimarães Filho, 1994)....................77 
Figura 2.41. Aumentos médios da pressão de reação do solo em função de sucessivas fases de injeção: (a) argila orgânica preta, obra do túnel oeste do metrô da Via Singela; (b) obra de fundação de prédio em Santos - SP (Guimarães Filho, 1994).......................................................................78

Figura 2.42. Ruptura interna por flexão e/ou cisalhamento dos reforços (Elias et al., 1993).............82

Figura 2.43. Ruptura interna por esforços de tração nos reforços (Elias et al., 1993).........................83

Figura 2.44. Ruptura interna por falta de aderência na interface solo-reforço (Elias et al., 1993)....84

Figura 2.45. Forma deformada da “Eparris Wall” após a ruptura (Clouterre, 1991)..........................85

Figura 2.46. Observações pós-ruptura do muro experimental n 3 da CEBTP (Clouterre, 1991).....86

Figura 2.47. Estabilidade das fases de escavação do muro experimental n 02 da CEBTP (Clouterre,

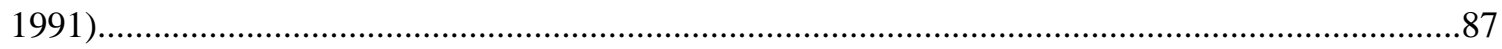

Figura 2.48. Diferentes tipos de ruptura em uma estrutura de solo pregado (Elias et al., 2003).......88

Figura 2.49. Superfície de ruptura bilinear considerada no método de Stocker et al. (1979)............92

Figura 2.50. Ábacos para cálculo da estabilidade de casos padronizados (Gassler \& Gudehus,

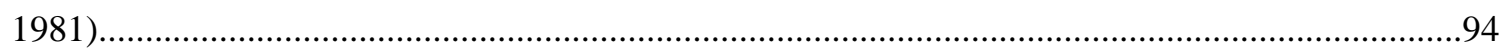

Figura 2.51. Situações consideradas no método de Davis (Clouterre, 1991). .96

Figura 2.52. Diagrama de corpo livre para a situação em que a superfície de ruptura passa atrás da zona reforçada (Mitchell \& Villet, 1987).........................................................................................96

Figura 2.53. Distribuição de esforços considerada no multicritério (Clouterre, 1991)......................100

Figura 2.54. Representação esquemática da interação solo-reforço (Clouterre, 1991).....................102

Figura 2.55. Combinações dos modos de ruptura (Clouterre, 1991).................................................105

Figura 2.56. Determinação das forças atuantes nos reforços (Clouterre, 1991)...............................106

Figura 2.57. Mecanismo de ruptura e suposições de projeto (Juran et al., 1990).............................107

Figura 2.58. Comportamento dos reforços junto à superfície potencial de ruptura (Juran \& Elias, 1991).

Figura 2.59. Método de Juran et al. (1990): ábacos utilizados para calcular os esforços de tração e cisalhamento nos reforços, considerando inclinação do reforço (i) de $15^{\circ}$, face vertical ( $\eta$ ) e superfície do terrapleno horizontal $(\beta=0)$ (Clouterre,1991).

\section{Capitulo 3}

Figura 3.1. Fluxograma de atividades do programa experimental da pesquisa.................................116

Figura 3.2. Curva granulométrica do solo utilizado..........................................................................118

Figura 3.3. Curva de compactação do solo.....................................................................................119

Figura 3.4. (a) Vista da caixa metálica e (b) da face frontal móvel adaptada para a construção do solo pregado. 
Figura 3.5. Disposição dos chumbadores na face frontal da caixa de ensaios...................................122

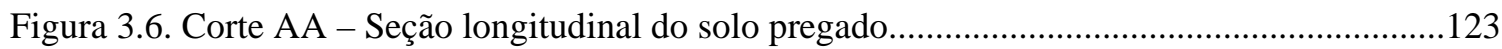

Figura 3.7. Seção transversal dos chumbadores para cada uma das metodologias executivas.........124

Figura 3.8. Detalhe das barras de aço preparadas para serem inseridas no maciço de solo..............124

Figura 3.9. Vista lateral das barras de aço instrumentadas com strain gages.....................................125

Figura 3.10. Detalhe das dimensões do rebaixo que será realizado na barra de aço.........................126

Figura 3.11. Etapas para a instalação dos strain gages. (a) Preparação da superfície, (b) colagem do strain gage, (c) cabeamento e soldagem e (d) proteção do sistema.

Figura 3.12. Calibração dos strain gages. (a) Equipamentos utilizados no procedimento; (b) comportamento durante as etapas de calibração e (c) curva de calibração típica.

Figura 3.13. Seqüência executiva do procedimento manual de compactação. (a) Lançamento do solo armazenado em bolsões (big bags); (b) espalhamento manual e (c) compactação com soquete manual.

Figura 3.14. Etapas do controle de compactação pelo método do cilindro cortante. (a) Início da cravação; (b) final da cravação; (c) escavação lateral e (d) detalhe do cilindro preenchido com solo...

Figura 3.15. Peso específico seco e teor de umidade obtidos nos controles de compactação executados.

Figura 3.16. (a) Simulação do processo de escavação do maciço de solo através da remoção sucessiva dos segmentos de madeira e (b) perfuração do maciço de solo após a pintura da face com calda de cimento. 132

Figura 3.17. (a) Detalhe do minitronco de cone e (b) esquema com as suas dimensões. .133 Figura 3.18. (a) Preparação da calda de cimento; (b) minitronco de cone preenchido com calda de cimento; (c) calda de cimento espalhada sobre a placa de vidro; (d) determinação do diâmetro de espalhamento da calda de cimento. .135

Figura 3.19. Corpos de prova da calda de cimento durante o processo de cura submersa. 135 Figura 3.20. Evolução da resistência à compressão uniaxial da calda de cimento para os diferentes tempos de cura. 136

Figura 3.21. (a) Esquema do equipamento desenvolvido e (b) detalhe do equipamento durante a realização da injeção de calda de cimento. 137 Figura 3.22. Testes de injeção realizados: (a) perfuração do solo compactado na mini caixa de madeira, (b) injeção da calda de cimento, (c) detalhe do chumbador após a exumação cuidadosa e (d) amostra de solo apresentando calda de cimento em seus vazios. 138 
Figura 3.23. Comparativo entre os volumes médios injetados para os diferentes métodos construtivos.

Figura 3.24. Vista geral do solo pregado após o término das etapas construtivas. .141

Figura 3.25. Equipamentos utilizados nos ensaios de arrancamento: (a) vista geral e (b) vista detalhada

Figura 3.26. (a) Amostra da barra de aço unida por rosca e luva metálica e (b) detalhe da amostra submetida ao ensaio de tração.

Figura 3.27. (a) Barras de aço durante a realização da rosca e (b) detalhe da luva metálica acabada.

Figura 3.28. Curvas carga $\mathrm{x}$ deslocamento para amostras de aço com e sem emenda.

Figura 3.29. Distribuição dos strain gages ao longo das barras de aço dos chumbadores curtos (a) e longos (b)

Figura 3.30. Etapas de instrumentação das barras de aço utilizadas no campo: (a) preparação da superfície, (b) colagem do strain gage, (c) cabeamento e soldagem e (d) proteção mecânica.........148 Figura 3.31. Equipamento desenvolvido para a realização da calibração das barras de aço: (a) detalhe das fixações, (b) detalhe do sistema de aplicação de cargas e (c) vista geral durante a calibração das barras 149

Figura 3.32. Curva típica de calibração do strain gage. 150

Figura 3.33. Barras de aço devidamente instrumentadas, calibradas e prontas para serem utilizadas na construção dos chumbadores: (a) detalhe dos chumbadores curtos e (b) longos. 150

Figura 3.34. Localização das válvulas nos tubos de injeção dos chumbadores curtos (a) e longos (b) executados com a metodologia B

Figura 3.35. Localização das válvulas nos tubos de injeção dos chumbadores curtos (a) e longos (b) executados com a metodologia C

Figura 3.36. Localização das válvulas nos tubos de injeção dos chumbadores curtos (a) e longos (b) executados com a metodologia $\mathrm{D}$

Figura 3.37. Localização das válvulas nos tubos de injeção dos chumbadores curtos (a) e longos (b) executados com a metodologia $\mathrm{E}$

Figura 3.38. Localização das válvulas nos tubos de injeção dos chumbadores curtos (a) e longos (b) executados com a metodologia $\mathrm{F}$

Figura 3.39. Corpos de prova utilizados no ensaio de compressão uniaxial (Lima, 2009). .158

Figura 3.40. Variação da resistência à compressão uniaxial com o tempo de cura (Lima, 2009)...158

Figura 3.41. Vista em planta das contenções com destaque para a área de estudo. 159

Figura 3.42. Distribuição das camadas de solo na obra de Santo André-SP. 160 
Figura 3.43. (a) Detalhe da coleta de amostra indeformada e (b) do armazenamento em caixa de madeira.

Figura 3.44. Envoltórias de resistência total e efetiva obtidas a partir de ensaios triaxias em amostras de solos das linhas 2 (a) e 5 (b) (Lima, 2009).

Figura 3.45. Curva Tensão Cisalhante x Deslocamento para os solos das linhas 2 (a) e 5 (c) e envoltória de resistência para os solos das linhas 2 (b) e 5 (d) (Lima, 2009)...

Figura 3.46. (a) Detalhe do pressiômetro Camkometer, (b) do sistema de aplicação de pressão, (c) e (d) da cravação do pressiômetro auto perfurante.

Figura 3.47. (a) Curva pressão total $\mathrm{x}$ deslocamento da cavidade do ensaio e (b) detalhe para a obtenção do p0 para o ensaio pressiométrico da linha 5 (ensaio B54T2). 166

Figura 3.48. Curva tensão de cisalhamento x deformação da cavidade para o ensaio pressiométrico da linha 5 (ensaio B54T2). 167

Figura 3.49. Distribuição, numeração, comprimento e metodologia executiva adotada na execução dos chumbadores testes ao longo das linhas 2 e 5 . 168 Figura 3.50. Detalhe da preparação das barras de aço. (a) Junção das barras de aço com luvas metálicas, (b) fixação de centralizadores a cada 0,5 m, (c) fixação dos tubos de injeção, (d) proteção das válvulas de injeção com fitas adesivas, (e) obturador de espuma enrolada no inicio do trecho livre e (f) proteção do trecho livre com mangueira plástica e graxa.

Figura 3.51. (a) Localização do trecho estudado após o termino da linha 1 de chumbadores e (b) detalhe da escavação, em nichos, para a realização da segunda linha de chumbadores. 170 Figura 3.52. (a) Detalhe da perfuração com lavagem de água, (b) do preenchimento do furo com calda de cimento e (c) da inserção da barra de aço no maciço de solo... 171

Figura 3.53. (a) Jateamento de concreto projetado e (b) vista dos chumbadores executados 172 Figura 3.54. (a) Detalhe da fixação da mangueira de injeção nos tubos de injeção, (b) da preparação da calda de cimento no misturador, (c) do controle de calda de cimento injetado e (d) do manômetro na saída da bomba de injeção. 173

Figura 3.55. Etapas de construção os chumbadores testes da linha 5. (a) Etapa de escavação em nichos, (b) após a execução dos chumbadores da obra e (c) após a execução dos chumbadores testes. 176

Figura 3.56. Vista em planta das contenções, com destaque para a área de estudo. 179

Figura 3.57. Distribuição das camadas de solo na obra de Osasco-SP.. 180

Figura 3.58. (a) Detalhe da coleta de amostra indeformada e (b) da proteção com parafina.. 181 Figura 3.59. Envoltórias de resistência total e efetiva obtidas a partir de ensaios triaxias em amostras de solos das linhas 3 (a) e 5 (b) (Lima, 2009). 182 
Figura 3.60. Curva Tensão Cisalhante x Deslocamento para os solos das linhas 3 (a) e 5 (c) e envoltória de resistência para os solos das linhas 3 (b) e 5 (d) (Lima, 2009). 183

Figura 3.61. Distribuição, numeração, comprimento e metodologia executiva adotada na execução dos chumbadores testes das linhas 3 e 5 .

Figura 3.62. (a) Vista geral do local em que foram construídos os chumbadores testes e detalhes das etapas de escavação, em nichos, para a execução dos chumbadores testes das linhas 3 (b) e 5 (c). 185

Figura 3.63. Etapas de execução dos chumbadores testes das linhas 3 e 5. (a) Preparação dos chumbadores, (b) perfuração com lavagem de água, (c) preenchimento do furo com calda de cimento (bainha), (d) inserção da barra de aço no maciço de solo e (e) injeção de calda de cimento 187

Figura 3.64. (a) Vista geral e (b) detalhada da cortina de solo pregado após a realização dos chumbadores testes das linhas 3 e 5 .

Figura 3.65. Detalhes dos equipamentos utilizados para a realização dos ensaios de arrancamento no programa experimental de campo...... 193

Figura 3.66. Detalhe do sistema de aquisição utilizado nos ensaios. 194 Figura 3.67. Detalhe dos equipamentos e esquema de montagem utilizada para a realização dos ensaios de arrancamento na linha 2 (a) e linha 5 (b) da obra 1 e na linha 3 (c) e linha 5 (d) da obra 2. 195

Figura 3.68. Detalhe das trincas horizontais e verticais que sugiram durante a realização do ensaio 195

\section{Capitulo 4}

Figura 4.1. Curvas carga $\mathrm{x}$ deslocamento para as diferentes metodologias executivas empregadas em cada linha de reforço.

Figura 4.2. Curvas carga $\mathrm{x}$ deslocamento comparativas para as diferentes linhas de reforço, para cada metodologia construtiva.

Figura 4.3. Variação de $q_{s}$ com a profundidade, para cada uma das metodologias

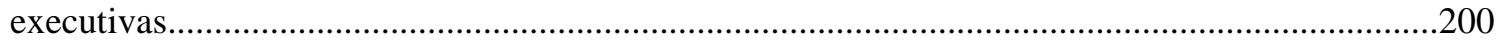

Figura 4.4. Distribuição das tensões verticais efetivas ao longo da profundidade..............................201

Figura 4.5. Curvas tensão vertical efetiva $\mathrm{x} q_{s}$ para as diferentes metodologias construtivas..........202

Figura 4.6. Curva carga $\mathrm{x}$ deslocamento típica dos ensaios de arrancamento realizados. .203 
Figura 4.7. Variações de $q_{s}$ e dos volumes de injeção para as diferentes metodologias executivas das Linhas 1 , 2 e 3. 206

Figura 4.8. Variações de $q_{s}$ e dos volumes de injeção para as diferentes metodologias executivas das Linhas 1 , 2 e 3 (a) e para todos os chumbadores (b). 207

Figura 4.9. Proposta para otimização de projeto e controle de desempenho na técnica de solo pregado. 208

Figura 4.10. Distribuição de carga ao longo do comprimento do reforço (percentagem de carga em relação à carga de ruptura), durante os ensaios. 210

Figura 4.11. Chumbadores após o processo de exumação: (a) linha 1; (b) linha 2 e (c) linha 3......211 Figura 4.12. Variação do diâmetro médio ao longo trecho injetado: (a) linha 1, (b) linha 2 e (c) linha 3. 212

Figura 4.13. Evolução das cargas de tração ao longo do tempo nos reforços instrumentados... .214 Figura 4.14. Análise de estabilidade da caixa de ensaios após o processo de compactação (a) e após a aplicação da sobrecarga (b). .217 Figura 4.15. Análise de estabilidade para os diferentes métodos construtivos. (a) Bainha, (b) Bainha + 1 Fase, (c) Bainha +2 Fases. 218

\section{Capítulo 5}

Figura 5.1. Curvas carga x deslocamento dos chumbadores curtos (a) e longo (b) construídos com a metodologia A 224

Figura 5.2. Curvas carga $x$ deslocamento dos chumbadores curto (a) e longo (b) construídos com a metodologia B.

Figura 5.3. Curvas carga $x$ deslocamento dos chumbadores curto (a) e longo (b) construídos com a metodologia C.......

Figura 5.4. Curvas carga $x$ deslocamento dos chumbadores curto (a) e longo (b) construídos com a metodologia D... .226

Figura 5.5. Curva carga x deslocamento do chumbador curto construído com a metodologia E....227 Figura 5.6. Curvas carga $x$ deslocamento dos chumbadores curto (a) e longo (b) construídos com a metodologia $\mathrm{F}$.

Figura 5.7. Curvas carga $\mathrm{x}$ deslocamento dos chumbadores curtos executados com as diferentes metodologias executivas.

Figura 5.8. Curvas carga $\mathrm{x}$ deslocamento dos chumbadores longos executados com as diferentes metodologias executivas. .230 
Figura 5.9. Análise comparativa entre os valores de $q_{s}$ obtidos para os chumbadores curtos executados com as diferentes metodologias executivas......

Figura 5.10. Análise comparativa entre os valores de $q_{s}$ obtidos para os chumbadores longos executados com as diferentes metodologias executivas.

Figura 5.11. Variações de $q_{s}$ e dos volumes de injeção dos chumbadores curtos para as diferentes metodologias executivas.

Figura 5.12. Valores de $q_{s} \mathrm{x}$ Fator $\mathrm{V}$ para os chumbadores curtos executados com as diferentes metodologias executivas.

Figura 5.13. Curvas carga $\mathrm{x}$ deslocamento dos chumbadores curtos e longos executados com as metodologias A (a) e B (b) .235

Figura 5.14. Variação de $q_{s}$ para os diferentes tipos de chumbadores (curtos e longos), considerando as metodologias A e B. .236

Figura 5.15. Distribuição das cargas ao longo do comprimento dos chumbadores curto (a) e longo (b), em percentagem em relação à carga de ruptura. 237

Figura 5.16. Curvas carga x deslocamento dos chumbadores curto (a) e longo (b) construídos com a metodologia A. .238

Figura 5.17. Curvas carga $x$ deslocamento dos chumbadores curto (a) e longo (b) construídos com a metodologia $\mathrm{A}^{*}$

Figura 5.18. Curvas carga $x$ deslocamento dos chumbadores curto (a) e longo (b) construídos com a metodologia $\mathrm{B}$ 240

Figura 5.19. Curvas carga x deslocamento dos chumbadores curtos 21 (a) e 22 (b) construídos com a metodologia C. 240

Figura 5.20. Curvas carga x deslocamento dos chumbadores curtos 27 (a) e 28 (b) construídos com a metodologia D.

Figura 5.21. Curvas carga x deslocamento dos chumbadores curtos 17 (a) e 18 (b), construídos com a metodologia $\mathrm{E}$

Figura 5.22. Curvas carga x deslocamento dos chumbadores curtos 25 (a) e 26 (b) construídos com a metodologia F...

Figura 5.23. Curvas carga $\mathrm{x}$ deslocamento dos chumbadores curtos executados com as diferentes metodologias executivas.

Figura 5.24. Curvas carga x deslocamento dos chumbadores longos executados com as diferentes metodologias executivas. 245

Figura 5.25. Análise comparativa entre os valores de $q_{s}$ obtidas para os chumbadores curtos executados com as diferentes metodologias executivas. 
Figura 5.26. Análise comparativa entre os valores de $q_{s}$ obtidos para os chumbadores longos executados com as diferentes metodologias executivas......

Figura 5.27. Variações de $q_{s}$ e dos volumes de injeção dos chumbadores curtos executados com as diferentes metodologias executivas.

Figura 5.28. Valores de $q_{s} \mathrm{x}$ volume de injeção para os chumbadores curtos, executados com as diferentes metodologias executivas.

Figura 5.29. Curvas carga $x$ deslocamento para chumbadores curtos e longos executados com as metodologias A (a), A* (b) e B (c).

Figura 5.30. Variação de $q_{s}$ para os diferentes tipos de chumbadores (curtos e longos), considerando-se as metodologias $\mathrm{A}, \mathrm{A} * \mathrm{e} \mathrm{B}$

Figura 5.31. Distribuição das cargas ao longo do comprimento para chumbadores curto (a) e longo (b), em porcentagem, em relação à carga de ruptura.

Figura 5.32. Curvas carga x deslocamento dos chumbadores curto (a) e longo (b), construídos com a metodologia A .255

Figura 5.33. Curvas carga x deslocamento dos chumbadores curto (a) e longo (b), construídos com a metodologia B... .256

Figura 5.34. Curvas carga x deslocamento dos chumbadores curto (a) e longo (b), construídos com a metodologia C

Figura 5.35. Curvas carga x deslocamento dos chumbadores curtos 07 (a) e 08 (b) construídos com a metodologia D.

Figura 5.36. Curva carga x deslocamento do chumbador curto construído com a metodologia E. 258

Figura 5.37. Curvas carga x deslocamento dos chumbadores curtos 11 (a) e 12 (b) construídos com a metodologia F.

Figura 5.38. Curvas carga $\mathrm{x}$ deslocamento dos chumbadores curtos executados com as diferentes metodologias executivas.

Figura 5.39. Curvas carga x deslocamento dos chumbadores longos executados com as diferentes metodologias executivas.

Figura 5.40. Análise comparativa entre os valores de $q_{s}$ obtidos para os chumbadores curtos executados com as diferentes metodologias executivas.

Figura 5.41. Análise comparativa entre os valores de $q_{s}$ obtidos para os chumbadores longos executados com as diferentes metodologias executivas.

Figura 5.42. Variações de $q_{s}$ e dos volumes de injeção dos chumbadores curtos executados com as diferentes metodologias executivas. 
Figura 5.43. Valores de $q_{s} \mathrm{x}$ volume de injeção para os chumbadores curtos executados com as diferentes metodologias executivas.

Figura 5.44. Curvas carga $\mathrm{x}$ deslocamento para chumbadores curtos e longos executados com as metodologias A (a), B (b) e C (c).. .268

Figura 5.45. Variação de $q_{s}$ para os diferentes tipos de chumbadores (curtos e longos), considerando as metodologias $\mathrm{A}$, B e C.

Figura 5.46. Distribuição das cargas ao longo do comprimento para chumbadores curto (a) e longo (b), em percentagem em relação à carga de ruptura.

Figura 5.47. Curvas carga x deslocamento dos chumbadores curto (a), longo (b) e experimental (c) construídos com a metodologia A. 271

Figura 5.48. Curvas carga x deslocamento dos chumbadores curto (a), longo (b) e experimental (c) construídos com a metodologia B. .272

Figura 5.49. Curvas carga $x$ deslocamento dos chumbadores curto (a) e longo (b) construídos com a metodologia C

Figura 5.50. Curvas carga x deslocamento dos chumbadores curtos 19 (a) e 20 (b) construídos com a metodologia D.

Figura 5.51. Curvas carga x deslocamento dos chumbadores curtos 21 (a) e 22 (b), construídos com a metodologia E

Figura 5.52. Curvas carga x deslocamento dos chumbadores curtos 23 (a) e 24 (b) construídos com a metodologia F. .275

Figura 5.53. Curvas carga $\mathrm{x}$ deslocamento dos chumbadores curtos executados com as diferentes metodologias executivas.

Figura 5.54. Curvas carga x deslocamento dos chumbadores longos executados com as diferentes metodologias executivas. .277

Figura 5.55. Análise comparativa entre os valores de $q_{s}$ obtidas para os chumbadores curtos, executados com as diferentes metodologias executivas. .278

Figura 5.56. Análise comparativa entre os valores de $q_{s}$ obtidas para os chumbadores longos, executados com as diferentes metodologias executivas.

Figura 5.57. Variações de $q_{s}$ e dos volumes de injeção dos chumbadores curtos executados com as diferentes metodologias executivas. .280

Figura 5.58. Valores de $q_{s} \mathrm{x}$ Fator V para os chumbadores curtos executados com as diferentes metodologias executivas. .281

Figura 5.59. Curvas carga $\mathrm{x}$ deslocamento para chumbadores curtos, longos e experimentais executados com as metodologias A (a) e B (b). .282 
Análise de diferentes metodologias executivas de solo pregado a partir de ensaios de arrancamento em campo e laboratório

Figura 5.60. Variação de $q_{s}$ para os diferentes tipos de chumbadores (curtos, longos e experimentais), considerando-se as metodologias A e B.

Figura 5.61. Distribuição de carga ao longo do comprimento para chumbadores longo (a) e curto (b), em percentagem em relação à carga de ruptura.

Figura 5.62. Comparativo entre os ensaios de arrancamento (metodologia A) e os métodos de previsão teóricos e empíricos para a linha 2 da obra de Santo André-SP. .289

Figura 5.63. Comparativo entre os ensaios de arrancamento (metodologia A) e os métodos de previsão teóricos e empíricos para a linha 5 da obra de Santo André-SP. .290

Figura 5.64. Comparativo entre os ensaios de arrancamento (metodologia A) e os métodos de previsão teóricos e empíricos para a linha 3 da obra de Osasco-SP... 291

Figura 5.65. Comparativo entre os ensaios de arrancamento (metodologia A) e os métodos de previsão teóricos e empíricos para a linha 5 da obra de Osasco-SP. 292

Figura 5.66. Proposta para otimização de projeto e controle de desempenho na técnica de solo pregado. 


\section{USTA DE TABELAS}

\section{Capítulo 2}

Tabela 2.1. Aplicações e objetivos das técnicas de reforço de solo in situ (Schlosser \& Juran, 1979).

Tabela 2.2. Profundidades de escavação em cortes verticais (Gassler, 1990). .16

Tabela 2.3. Recomendações feitas pelos guias de solo pregado para a realização dos ensaios de campo (Barley et al., 1997).

Tabela 2.4. Resultados dos ensaios de arrancamentos realizados por Feijó e Ehrlich (2001)...... .65

Tabela 2.5. Resultados dos ensaios de arrancamento. .66

Tabela 2.6. Resumos dos ensaios de arrancamento realizados por Pitta et al. (2003). 67

Tabela 2.7. Comparação entre os resultados obtidos a partir de ensaios de arrancamento (Pitta et al., 2005).

Tabela 2.8. Ordem de grandeza das principais propriedades para dimensionamento de estruturas de solo pregado (Clouterre, 1991).

\section{Capítulo 3}

Tabela 3.1. Distribuição granulométrica em porcentagem de ocorrência para o solo estudado......118

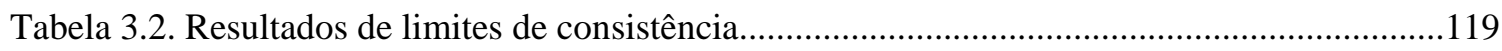

Tabela 3.3. Parâmetros de compactação.....................................................................................120

Tabela 3.4. Posição dos strain gages em relação ao trecho injetado e à face....................................125

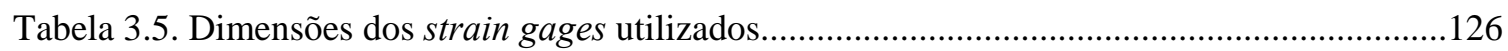

Tabela 3.6. Controle da injeção da calda de cimento para a linha 1 ..................................................139

Tabela 3.7. Controle da injeção da calda de cimento para a linha 2...............................................139

Tabela 3.8. Controle da injeção da calda de cimento para a linha 3..............................................140

Tabela 3.9. Traços utilizados e resultados dos ensaios de miniabatimento (Lima, 2009).................157

Tabela 3.10. Características geotécnicas e classificação dos solos utilizados....................................162

Tabela 3.11. Parâmetros totais e efetivos de resistência ao cisalhamento..........................................164

Tabela 3.12. Controle de execução dos chumbadores testes da linha 2 (Obra 1).............................174

Tabela 3.13. Controle de execução dos chumbadores testes da linha 5 (Obra 1).............................177 
Tabela 3.14. Características geotécnicas e classificação dos solos utilizados.....................................181

Tabela 3.15. Parâmetros totais e efetivos de resistência ao cisalhamento..........................................183

Tabela 3.16. Controle de execução dos chumbadores testes da linha 3 (Obra 2).............................188

Tabela 3.17. Controle de execução dos chumbadores testes da linha 5 (Obra 2)............................189

\section{Capítulo 4}

Tabela 4.1. Resumo dos resultados obtidos a partir dos ensaios de arrancamento. 198

Tabela 4.2. Valores médios de tensão vertical efetiva $\left(\sigma_{v}{ }^{\prime}\right)$ atuante em cada linha de

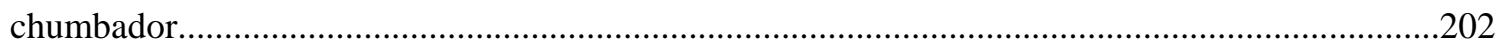

Tabela 4.3. Etapas dos ensaios de arrancamento dos chumbadores..................................................204

Tabela 4.4. Porcentuais de carga no ponto de inflexão e razão de rigidez........................................204

Tabela 4.5. Posição e cargas máximas medidas ao longo do trecho injetado.....................................215

Tabela 4.6. Fatores de Segurança das análises de estabilidade...........................................................217

Tabela 4.7. Características e parâmetros empregados nos chumbadores............................................218

\section{Capítulo 5}

Tabela 5.1. Resumo dos ensaios de arrancamento realizados............................................................221

Tabela 5.2. Identificação e características dos chumbadores da linha 2..........................................222

Tabela 5.3. Identificação e características dos chumbadores da linha 5..........................................223

Tabela 5.4. Resumo dos resultados dos ensaios de arrancamento da linha 2...................................228

Tabela 5.5. Resumo dos resultados dos ensaios de arrancamento da linha 5...................................244

Tabela 5.6. Identificação e características dos chumbadores da linha 3..........................................254

Tabela 5.7. Identificação e características dos chumbadores da linha 5...........................................254

Tabela 5.8. Resumo dos resultados dos ensaios de arrancamento da linha 3..................................260

Tabela 5.9. Resumo dos resultados dos ensaios de arrancamento da linha 5.....................................276

Tabela 5.10. Resumo dos resultados dos chumbadores curtos executados nas diferentes profundidades e obras e com as diferentes metodologias executivas..............................................2.28

Tabela 5.11. Resumo das propriedades dos solos estudados............................................................286

Tabela 5.12. Resumo dos resultados dos chumbadores longos executados nas diferentes profundidades e obras e com as diferentes metodologias executivas..............................................287 


\section{USTA DE ABREVIATURAS, SIGLAS E ŚMBOLOS}

A.R: aumento relativo

A: área da seção transversal da barra de aço

ABEF: Associação Brasileira de Empresas de Engenharia de Fundações e Geotecnia

ABMS: Associação Brasileira de Mecânica dos Solos

ASTM: American Society for Testing and Materials

c*: coesão aparente

c: coesão do solo

c’: coesão efetiva

C'a: adesão da interface solo/calda de cimento

$\mathrm{c}_{0}{ }^{*}$ : coesão teórica

C1: Coluna 1

C2: Coluna 2

C3: Coluna 3

CEBTP: Centre d’Études et de Recherches du Bâtiment et dês Travaux Public

CERMES: Centre d’Ensignement et de Reserche em Mécanique des Sols

D: diâmetro do reforço

DAEI: Des Affaires Economiques et International

DHP: Dreno Horizontal Profundo

$\mathrm{d}_{\beta}$ : deformação máxima do reforço

E: módulo de elasticidade do elemento de reforço (barra de aço)

$\mathrm{f}_{\mathrm{b}}$ : coeficiente de aderência

FHWA: Federal Highway Administration

$\mathrm{F}_{\text {máx }}$ : força de tração máxima

FNTP: Federaion National dês Travaux Publics

FS: Fator de Segurança Global

G.C: Grau de Compactação 
Análise de diferentes metodologias executivas de solo pregado a partir de ensaios de arrancamento em campo e laboratório

H: altura da contenção

I: momento de inércia do elemento de reforço (barra de aço)

IP: Índice de Plasticidade

$\mathrm{k}_{\mathrm{s}}$ : coeficiente de reação do solo de fundação

$k_{\beta}$ : rigidez

L: comprimento do reforço

$l_{0}$ : comprimento de transferência

L1: Linha 1

L2: Linha 2

L3: Linha 3

$\mathrm{L}_{\mathrm{a}}$ : comprimento de ancoragem;

LL: comprimento livre

LL: Limite de Liquidez

LP: Limite de Plasticidade

M: momento fletor

$\mathrm{M}_{0}$ : momento máximo de plastificação do solo

MDF: Método das Diferenças Finitas

MEC: Métodos dos Elementos de Contorno

MEF: Método dos Elementos Finitos

N: parâmetro adimensional

$\mathrm{N}_{1}$ : empuxo lateral do solo

NATM: New Austrian Tunneling Method

NBR: Norma Brasileira

$\mathrm{N}_{\mathrm{SPT}}$ índice de resistência à penetração

p: empuxo lateral do solo sobre o reforço

P: perímetro do reforço;

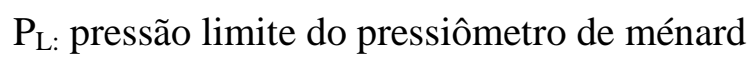

$\mathrm{P}_{\mathrm{R}}$ :força mobilizada pelo reforço

$P_{u l t}$ : força máxima de arrancamento

PVC: Policloreto de Vinila

$q_{s}$ : resistência ao cisalhamento de interface solo-reforço 
Análise de diferentes metodologias executivas de solo pregado a partir de ensaios de arrancamento em campo e laboratório

$\mathrm{R}_{\mathrm{c}}$ : resistência do reforço aos esforços cisalhantes

$\mathrm{R}_{\mathrm{n}}$ : resistência do reforço aos esforços normais

S: força tangencial

SC: Areia Argilosa

$\mathrm{S}_{\mathrm{h}}$ : espaçamento horizontal dos reforços

SPT: standard Penetration Test

$\mathrm{S}_{\mathrm{r}}$ : grau de saturação

$\mathrm{S}_{\mathrm{v}}$ : espaçamento vertical dos reforços

$\mathrm{T}_{\mathrm{c}}$ : esforço cisalhante

$\mathrm{T}_{\mathrm{G}}$ : resistência à tração

$\mathrm{T}_{\mathrm{L}}$ : resistência ao arrancamento dos reforços

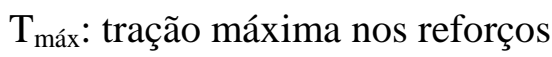

$\mathrm{T}_{\mathrm{n}}$ : esforço normal

TN: força de tração máxima

TS: força de cisalhamento máxima

$\mathrm{u}^{*}$ : coeficiente de atrito aparente

$\mathrm{V}$ : fator adimensional que representa a relação entre o volume injetado e o volume da cavidade escavada

W: peso do elemento

Wót: umidade ótima

$\mathrm{y}:$ deslocamento

z: profundidade do reforço

$\sigma_{n}^{\prime}$ : tensão normal efetiva

$\Delta \sigma$ : incremento de tensão

$\Delta \sigma_{3}$ : tensão de confinamento adicional

$\Delta \tau$ : incremento da tensão cisalhante atritiva

$\alpha$ : inclinação do paramento de face

$\beta$ : inclinação da superfície do maciço de solo

$\delta$ ': ângulo de atrito da interface solo/calda de cimento.

$\delta_{\mathrm{h}}$ : expansão lateral

$\delta_{\mathrm{hr}}$ : expansão lateral resultante 
Análise de diferentes metodologias executivas de solo pregado a partir de ensaios de arrancamento em campo e laboratório

$\delta_{\mathrm{v}}$ : compressão axial

$\delta_{\mathrm{vr}}$ : compressão axial resultante

$\phi^{*}$ : ângulo de atrito aparente

$\phi$ : ângulo de atrito do solo

$\phi '$ : ângulo de atrito efetivo

$\gamma$ : peso específico do solo

$\eta$ : fator de segurança mínimo

$\lambda_{1}$ : fator de carga

$\lambda^{*}$ : fator de carga para solo residual de gnaisse

$\theta$ : inclinação dos reforços

$\rho_{d}$ : massa específica aparente seca

$\sigma_{\mathrm{r}}^{\prime}$ : tensão normal efetiva média atuante sobre o reforço

$\sigma_{\mathrm{v}}^{\prime}$ : tensão vertical efetiva

$\sigma_{0 \text { : }}$ tensão normal atuante sobre o reforço

$\sigma_{1}$ : tensão axial

$\sigma_{3}:$ tensão de confinamento

$\tau$ : tensão cisalhante 
Análise de diferentes metodologias executivas de solo pregado a partir de ensaios de arrancamento em campo e laboratório 
Silva, D. P (2009). Análise de diferentes metodologias executivas de solo pregado a partir de ensaios de arrancamento em campo e laboratório. São Carlos, 313p. Tese (Doutorado em Geotecnia) - Escola de Engenharia de São Carlos, Universidade de São Paulo.

Apesar do largo emprego da técnica de solo pregado em nosso país, pouquíssima pesquisa foi realizada sobre a resistência ao cisalhamento de interface solo-reforço $\left(q_{s}\right)$ e sobre a importância deste parâmetro no desempenho desta técnica de reforço in situ de taludes e escavações. Busca-se com esta tese, avaliar experimentalmente, a influência de diferentes metodologias executivas do chumbador (número de injeções) neste parâmetro. As informações para o desenvolvimento deste trabalho foram obtidas a partir de ensaios de arrancamento realizados em chumbadores construídos em duas obras nas cercanias da cidade de São Paulo, ou seja, em escala real. De forma complementar, também foi construído uma estrutura de solo pregado em laboratório. A partir dos ensaios realizados, observaram-se melhorias significativas na resistência ao cisalhamento de interface a partir das injeções do chumbador e estabelecer equações que relacionam o valor de $q_{s}$ com o volume injetado de calda de cimento, sendo uma importante ferramenta para analisar o desempenho do chumbador. O monitoramento ao longo do ensaio permitiu analisar os mecanismos de distribuição das cargas. Por fim, é apresentada uma proposta de metodologia para a realização do controle de qualidade do chumbador.

Palavras-chave: Solo pregado, ensaios de arrancamento, injeção de calda de cimento e instrumentação. 
Análise de diferentes metodologias executivas de solo pregado a partir de ensaios de arrancamento em campo e laboratório 


\section{ABSTRACT}

Silva, D.P. (2009). Analysis of different soil nailing executive methods from pullout tests performed in field and laboratory. São Carlos, 313p. PhD. Thesis - Escola de Engenharia de São Carlos, Universidade de São Paulo.

Besides the soil nailing technique being common practice in Brazil, there is little research on the shear strength of the soil-reinforcement interface $\left(q_{s}\right)$ and on the importance of this parameter on the performance of this in situ reinforcement technique of slopes and excavations. Accordingly, this study has the objective to experimentally evaluate the influence of different executive methodologies of the nail (i.e. number of grout injections) on the parameter $q_{s}$. Data were obtained from in situ, full scale pullout tests performed on nails built in two construction sites near Sao Paulo city. Additionally, a soil nailing structure was built in laboratory. The results show that significant improvement is achieved on the soil-nail interface shear strength by the number of grout injections. Moreover, the pullout tests on the nails provided quantification of this improvement. Consequently, it was possible to establish equations that relate the value of $q_{s}$ to the volume of cement grout injected, which is an important tool to evaluate the performance of the nail. Monitoring of the instrumentation during execution of the pullout tests allowed evaluation of the mechanisms of load distribution along the nails. Finally, a methodology is proposed for a quality control procedure on soil-nailed walls.

Keywords: Soil Nailing, Pullout Tests, Grout Injection and Instrumentation 
Análise de diferentes metodologias executivas de solo pregado a partir de ensaios de arrancamento em campo e laboratório 


\section{INTRODUÇÃO}

O emprego de alguma técnica de reforço de solos para estabilização de taludes e escavações apresenta-se como uma alternativa técnico-econômica viável e em expansão em todo o mundo. Entre as técnicas de reforço in situ, a de solo pregado é a de maior apelo econômico. Atualmente, empregam-se no Brasil as terminologias "solo pregado" e "solo grampeado”. Entretanto, neste trabalho, será utilizado o primeiro termo, por julgar-se mais conveniente para manter uma coerência com a terminologia internacional pioneira no assunto ("soil nailing” no inglês e "sol cloué" no francês), embora a terminologia "solo grampeado” seja amplamente aceita.

Pode-se definir o solo pregado como o resultado da introdução de reforços, geralmente barras de aço, em um maciço de solo natural (corte). Este processo é aliado, normalmente, a um revestimento da face (e.g., concreto projetado armado com tela de aço eletrossoldado ou fibras de aço) e a um sistema de drenagem. A partir deste sistema de contenção, busca-se restringir os deslocamentos e transferir os esforços de uma zona potencialmente instável para uma zona resistente.

O interesse de profissionais do meio geotécnico pela técnica de solo pregado justifica-se pela sua praticidade, rapidez de execução, versatilidade e economia quando comparada a outras soluções técnicas utilizadas para estabilização de cortes e taludes naturais. Apesar do largo emprego desta técnica em nosso país, pouquíssima pesquisa foi realizada sobre o método de execução em si e sobre o desempenho em curto e longo prazo de estruturas em solo pregado. Sendo assim, um estudo científico desta técnica, que auxilie a sua compreensão e o seu desenvolvimento, é oportuno e necessário.

Ao analisar a literatura brasileira (Zirlis \& Pitta, 1992; Ortigão \& Palmeira, 1992; Guimarães Filho, 1994; Azambuja et al., 2003), percebe-se que o conhecimento e o aprimoramento da técnica de solo pregado advêm principalmente da execução e do acompanhamento das obras realizadas, ou seja, da experiência dos executores. Neste sentido, alguns conceitos e metodologias de execução estão sendo desenvolvidos, porém, 
sem uma consistência teórica que permita avanços técnicos de forma sustentável. Em virtude do grande número de variáveis existentes neste tipo de solução, projetistas, executores e pesquisadores divergem quanto a melhor forma de execução e previsão do comportamento de obras realizadas com esta técnica.

A estabilidade de uma contenção em solo pregado é estudada em seu estado limite último. Sendo assim, um parâmetro muito importante e responsável pelo mecanismo de transferência de carga e restrição do movimento do maciço de solo, durante e após a sua escavação, é a resistência ao cisalhamento desenvolvida na interface entre o reforço e o solo circundante $\left(q_{s}\right)$. Como as inclusões trabalham basicamente sob tração, quanto maior for este parâmetro, melhor será o desempenho do reforço na estabilização do maciço de solo.

A quantificação do parâmetro $q_{s}$ pode ser obtida, de forma aproximada, a partir de formulações teóricas e empíricas e, de forma real, a partir de ensaios de arrancamento do reforço. Entre os fatores que podem influenciar o desempenho do reforço e, portanto, a interação solo-reforço, estão: o tipo de solo, o diâmetro do furo, o fluído de perfuração, as características da calda de cimento, o uso de aditivos na calda de cimento, o fator águacimento, o tempo de execução e a metodologia de injeção.

Esta pesquisa abrange um amplo programa experimental que foi desenvolvido em campo, na tentativa de contribuir para o estabelecimento da melhor forma de execução dos reforços, associada às condições geotécnicas locais. O banco de dados disponibilizado nesta pesquisa é proveniente da realização de ensaios de arrancamento em reforços (chumbadores) construídos em duas obras localizadas nas cercanias da cidade de São Paulo, com diferentes metodologias executivas. Para auxiliar sobremaneira a interpretação dos resultados dos ensaios de campo, também foram realizados ensaios de arrancamento em laboratório, a partir da construção de uma estrutura de solo pregado com nove chumbadores instrumentados. Nesta estrutura construída em laboratório, foi possível conseguir um maior controle sobre os parâmetros que podem influenciar a resistência ao cisalhamento de interface solo-reforço.

Por estas razões, esta pesquisa foi uma oportunidade excelente para se catalogar a experiência disponível e aumentar o nível de conhecimento sobre a técnica de solo pregado, permitindo divulgá-la de forma mais vigorosa no âmbito da engenharia geotécnica 
Análise de diferentes metodologias executivas de solo pregado a partir de ensaios de arrancamento em campo e laboratório

brasileira. Os resultados deste trabalho encontrarão aplicação prática imediata, pois têm relação direta com o desempenho e o custo da técnica de solo pregado no nosso país.

\subsection{J USTIRCATIVA E OBj EIIVOS DA TESE}

A técnica de solo pregado carece de estudos mais detalhados sobre a influência de diferentes metodologias executivas e do tipo do solo na determinação da resistência ao cisalhamento de interface solo-reforço $\left(q_{s}\right)$. O programa experimental desta pesquisa, baseado em ensaios de arrancamento de chumbadores em escala real (campo) e em laboratório, foi definido com os seguintes objetivos:

Avaliar a influência de diferentes metodologias executivas, tais como número e localização das injeções de calda de cimento, traço da calda de cimento e comprimento dos chumbadores na resistência ao cisalhamento de interface solo-reforço;

Verificar a influência das características geológico-geotécnicas do maciço de solo no parâmetro $q_{s}$;

Estudar o comportamento mecânico e a redistribuição das tensões nos reforços durante a realização dos ensaios de arrancamento. Para isso, foram colados strain gages diretamente sobre as barras de aço dos chumbadores;

Fornecer uma base de referência para projetos futuros com a possibilidade de melhorar os procedimentos e/ou reduzir os custos de projeto;

Comparar os resultados obtidos a partir dos ensaios de campo com aqueles obtidos a partir dos ensaios de laboratório. 


\section{REVISÃO BIBUOGRÁACA}

\subsection{INTRODUÇÃO}

Este capítulo apresenta uma revisão bibliográfica sobre os principais conceitos de relevância para o desenvolvimento deste trabalho. Buscou-se abordar aspectos importantes desde a conceituação básica de solos reforçados, apresentando as principais soluções de estabilização in situ, focando na técnica de solo pregado. Entre os principais tópicos abordados, pode-se citar: a conceituação de solo pregado, incluindo suas vantagens e limitações, a comparação com outras técnicas de reforço, as metodologias executivas, os mecanismos de interação solo-reforço, os aspectos relacionados com a injeção de calda de cimento, além dos principais métodos de cálculo.

O capítulo também apresenta um enfoque especial no tocante à determinação da resistência ao cisalhamento de interface solo-reforço, apresentando uma breve revisão sobre as formulações teóricas e correlações empíricas em função de diversos fatores (tipo de solo, valores de SPT e parâmetros de resistência ao cisalhamento). Apresentam-se também os principais trabalhos em que foram realizados ensaios de arrancamento de chumbadores em campo e laboratório.

\subsection{CONCETUAÇÃO BÁSICA DE SOLOS REFORÇADOS}

Os solos são os materiais de construção mais baratos e abundantes da natureza. Em sua maioria, desde que convenientemente compactados, podem apresentar adequada resistência à compressão e ao cisalhamento, tornando-se estruturalmente úteis, mas uma baixa resistência à tração. A inclusão de reforços, resistentes à tração, melhora esta deficiência, tornando o material resultante (solo-reforçado) potencialmente mais seguro e útil à Engenharia Civil. 
O conceito de reforço de solos com materiais que apresentam resistência à tração é muito antigo. Por volta de 5.000 a 2.500 anos atrás, durante a construção de grandes templos religiosos (Ziggurats) pelos Babilônios, utilizavam-se esteiras de cana como elementos de reforço. Em alguns Ziggurats, utilizavam-se como reforço adicional cordas com $0,05 \mathrm{~m}$ de diâmetro, inseridas perpendicularmente ao talude e regularmente espaçadas nas direções vertical e horizontal. Outras civilizações antigas, no entanto, ao construírem habitações de barro, utilizavam galhos e varas como elementos de reforço. Na América Colonial, ao construírem estradas sobre terrenos moles, utilizavam-se toras de madeiras (estivas) como elementos de reforço (Mitchell \& Villet, 1987).

A era moderna dos sistemas para reforço de solos teve inicio na década de 60 a partir das análises pioneiras desenvolvidas pelo engenheiro francês Henri Vidal. O sistema de reforço desenvolvido por este engenheiro consiste em fitas metálicas, usualmente de aço galvanizado, dispostas dentro de aterros construídos com solos de boa qualidade, capazes de mobilizar uma resistência de atrito requerida entre o solo e o reforço. Estas fitas são conectadas a painéis de concreto, que consistuem a face do maciço. Esta técnica foi patenteada mundialmente com a designação de "Terra Armada" (Vidal, 1966). A primeira utilização do sistema "Terra Armada" foi em uma rodovia próxima a Nice, na França, e a partir daí, este sistema de contenção passou a ser amplamente utilizado. Embasados nos mecanismos desta técnica, novos sistemas foram desenvolvidos para serem utilizados nas mais diversas situações práticas (e.g. muros de contenção, aterros, taludes e escavações in situ).

Em todas estas aplicações, os parâmetros de projeto são condicionados pelos mecanismos de interação solo-reforço, que incorporam de forma complexa fenômenos de atrito e/ou resistência passiva, que dependem da natureza do material, do tipo de solo e da geometria do reforço. O conhecimento destes mecanismos constitui o fator crítico na elaboração de projetos racionais de estruturas em solos reforçados (Gomes, 1993).

A presença dos reforços modifica tanto os campos de tensões como os campos de deformações no interior do maciço. Consequentemente, os modelos de ruptura são bastante diferentes daqueles comumente observados nas estruturas de contenção convencionais. Assim, a interação solo-reforço, a redistribuição das tensões internas e os mecanismos 
potenciais de ruptura são fatores interdependentes e determinantes para o dimensionamento de estruturas de solos reforçados (Gomes, 1993).

Embora o maciço de solo seja submetido a tensões de compressão, podem ser desenvolvidas tensões de tração no seu interior. O comportamento de uma estrutura reforçada pode ser representado pelo modelo apresentado na Figura 2.1.

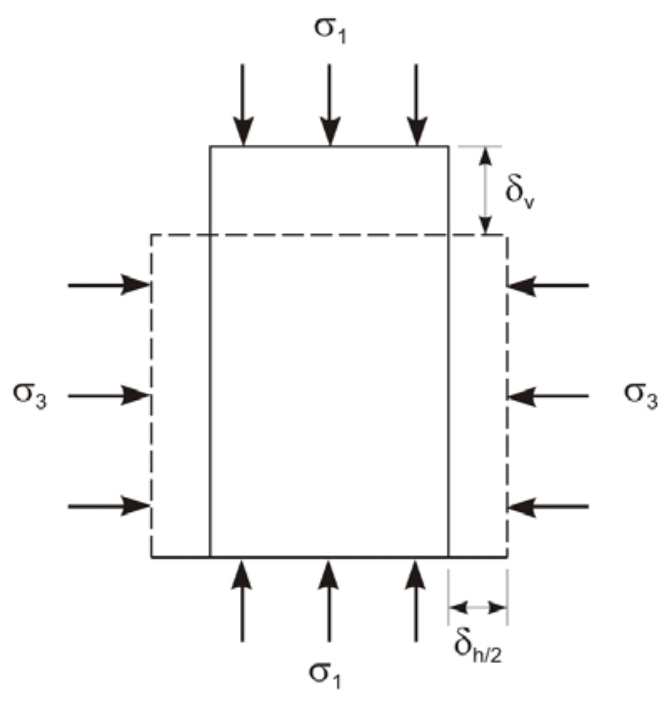

(a)

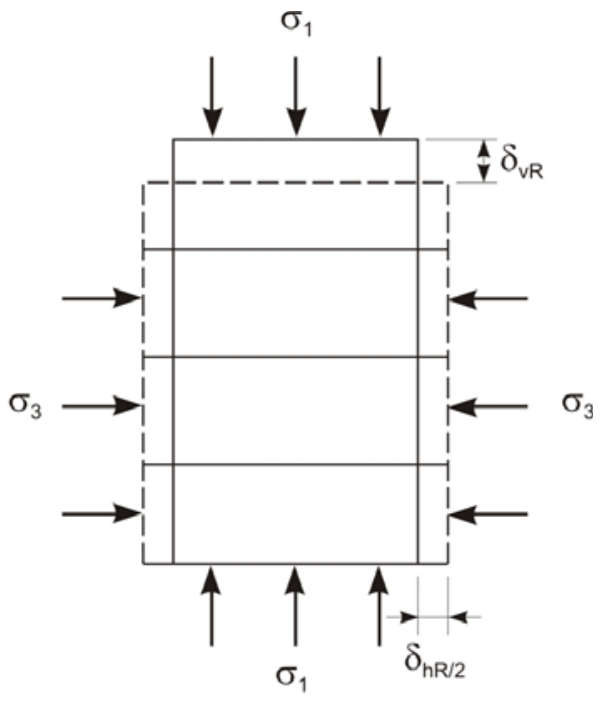

(b)

Figura 2.1. Efeito do reforço em um elemento de solo: (a) amostra não reforçada e (b) amostra reforçada (BS 8006).

As Figuras 2.1 (a) e (b) apresentam uma amostra de areia seca submetida a uma tensão de confinamento $\left(\sigma_{3}\right)$ e a uma tensão axial $\left(\sigma_{1}\right)$, com $\sigma_{1}>\sigma_{3}$. Sob esta condição de carregamento, a amostra não reforçada irá sofrer uma compressão axial $\left(\delta_{\mathrm{v}}\right)$ e uma expansão lateral $\left(1 / 2 \delta_{\mathrm{h}}\right)$, conforme apresentado na Figura 2.1 (a). Embora o solo esteja solicitado por compressão, a expansão lateral do solo pode promover o desenvolvimento de tensões de tração dentro da massa de solo (BS-8006).

Ao serem inseridas camadas de reforço no interior da massa de solo, com rigidez à tração maior que do solo, ocorrerá a movimentação do solo em relação ao reforço. Entretanto, se a superfície do reforço for suficientemente rugosa, Figura 2.1 (b), o movimento relativo do solo em relação ao reforço irá gerar tensões cisalhantes na interface solo-reforço. Estas tensões cisalhantes induzem o aparecimento de tensões de tração no 
reforço, as quais serão redistribuídas no interior do solo na forma de uma tensão de confinamento adicional $\left(\Delta \sigma_{3}\right)$. O desenvolvimento desta tensão adicional faz com que as deformações resultantes $\left(\delta_{\mathrm{vr}}\right.$ e $\left.1 / 2 \delta_{\mathrm{hr}}\right)$ sejam reduzidas, $\delta_{\mathrm{vr}}<\delta_{\mathrm{v}}$ e $1 / 2 \delta_{\mathrm{hr}}<1 / 2 \delta_{\mathrm{h}}$. Os fatores envolvidos nesta interação solo-reforço definem os princípios básicos de solo reforçado.

\subsection{REFORÇOS DE SOLOS IN STUU}

A utilização de inclusões metálicas como elementos de reforço no solo pode ser realizada de duas formas distintas: estaqueamento e reforço de solos in situ. No processo de estaqueamento, as inclusões metálicas (estacas) são inseridas no solo para suportar os carregamentos externos diretamente aplicados sobre elas. Na técnica de reforço de solo in situ, os esforços mobilizados nas inclusões (tração, compressão e/ou flexão) buscam estabelecer o equilíbrio do solo, quando este se encontra sob o efeito do seu peso próprio e das sobrecargas externas (Bruce \& Jewell, 1986).

Há três principais técnicas de reforço de solo in situ para estabilizar taludes e escavações: solo pregado, reticulado de micro-estacas e cravação de estacas (inclusões) de grande diâmetro. Schlosser \& Juran (1979) apresentam uma classificação (Tabela 2.1) que relaciona as aplicações e os objetivos destas diferentes técnicas de reforço de solo in situ.

Tabela 2.1. Aplicações e objetivos das técnicas de reforço de solo in situ (Schlosser \& Juran, 1979).

\begin{tabular}{cccc} 
& \multicolumn{3}{c}{ Reforço } \\
\cline { 2 - 4 } Aplicações e Objetivos & Prego & Micro-estacas & $\begin{array}{c}\text { Estacas de Grande } \\
\text { Diâmetro }\end{array}$ \\
\hline $\begin{array}{c}\text { Aumentar a capacidade de } \\
\text { carga do solo de fundação }\end{array}$ & - & 3 & 1 \\
$\begin{array}{c}\text { Estabilização natural de } \\
\text { taludes }\end{array}$ & 2 & 2 & 3 \\
$\begin{array}{c}\text { Estabilização de } \\
\text { escavações }\end{array}$ & 3 & 1 & - \\
Redução de recalques & - & 2 & 1
\end{tabular}

Nota: 1- Pouco eficaz; 2- Razoavelmente eficaz; 3-Muito eficaz. 
Embora existam diferenças fundamentais entre estas três técnicas de reforço in situ, há situações em que mais de uma técnica pode ser utilizada para promover a estabilização de taludes e/ou escavações. Esta utilização varia em função da intensidade da inclinação do talude e da necessidade de realizar ou não escavação (Figura 2.2).

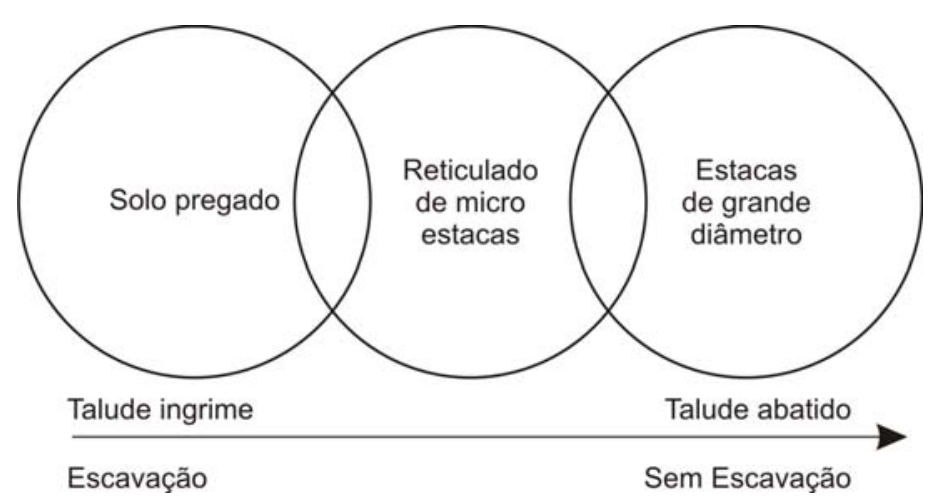

Figura 2.2. Situações em que se devem empregar as diferentes técnicas de reforço de solos in situ (Bruce \& Jewell, 1986).

$\mathrm{Na}$ técnica de solo pregado, o reforço é inserido horizontalmente ou subhorizontalmente no maciço de solo. Busca-se promover uma melhoria na resistência ao cisalhamento do solo, através da inclusão de elementos resistentes à tração que promovam a transferência de esforços da zona ativa para a zona resistente do maciço de solo. A técnica de solo pregado tem duas principais aplicações (Schlosser \& Guilloux, 1982):

Estabilização de taludes: os reforços são geralmente dispostos na direção perpendicular à superfície de ruptura. Nestas condições, são solicitados, principalmente, por tensões cisalhantes e momentos fletores (Figura 2.3). 


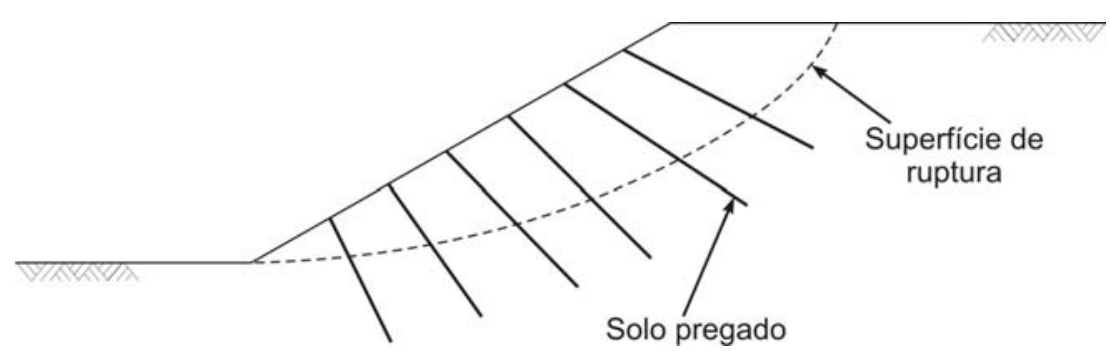

Figura 2.3. Aplicação da técnica de solo pregado na estabilização de taludes.

Estruturas de contenção: são utilizados na estabilização de escavações permanentes e temporárias e sob estas condições, os reforços são solicitados, principalmente, por tensões de tração (Figura 2.4).

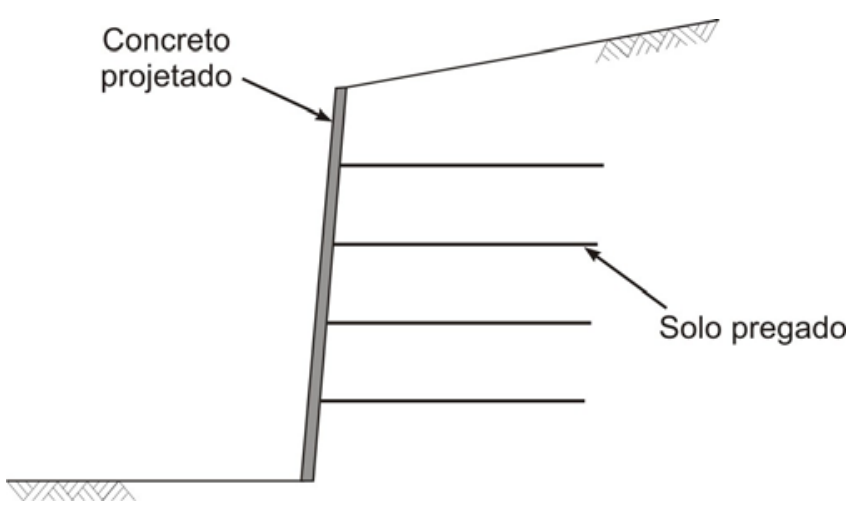

Figura 2.4. Aplicação da técnica de solo pregado em estruturas de contenção.

$\mathrm{O}$ reticulado de micro estacas apresenta-se fortemente inclinado no interior do maciço de solo, podendo apresentar-se tanto perpendicularmente quanto paralelamente à face (Figura 2.5). O objetivo deste sistema é similar ao do solo pregado, ou seja, criar um bloco reforçado que suporte a massa de solo não reforçada, trabalhando como uma estrutura de contenção de gravidade. Nesta técnica, o solo é confinado pelos múltiplos elementos de reforço que devem resistir principalmente à flexão. 


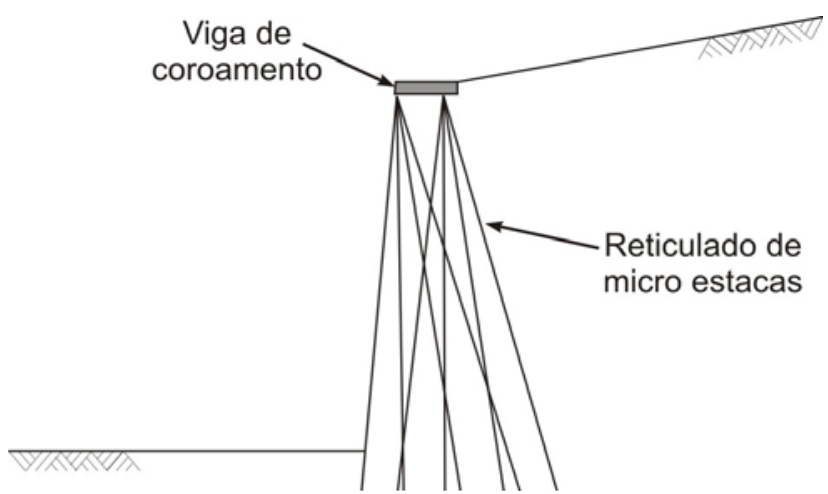

Figura 2.5. Reticulado de micro estacas (Bruce \& Jewell, 1986).

A técnica de reforço por estacas de grande diâmetro é utilizada para reduzir os deslocamentos dos taludes que apresentam uma superfície de cisalhamento bem definida (Figura 2.6). Os taludes reforçados com esta técnica são mais abatidos que os reforçados com solo pregado e reticulado de micro estacas. Pelo fato das estacas apresentarem seção transversal de grande diâmetro e, consequentemente, elevada rigidez à flexão, esta é a solução mais eficiente para melhorar a resistência ao cisalhamento ao longo da superfície potencial de ruptura (Gudehus, 1983).

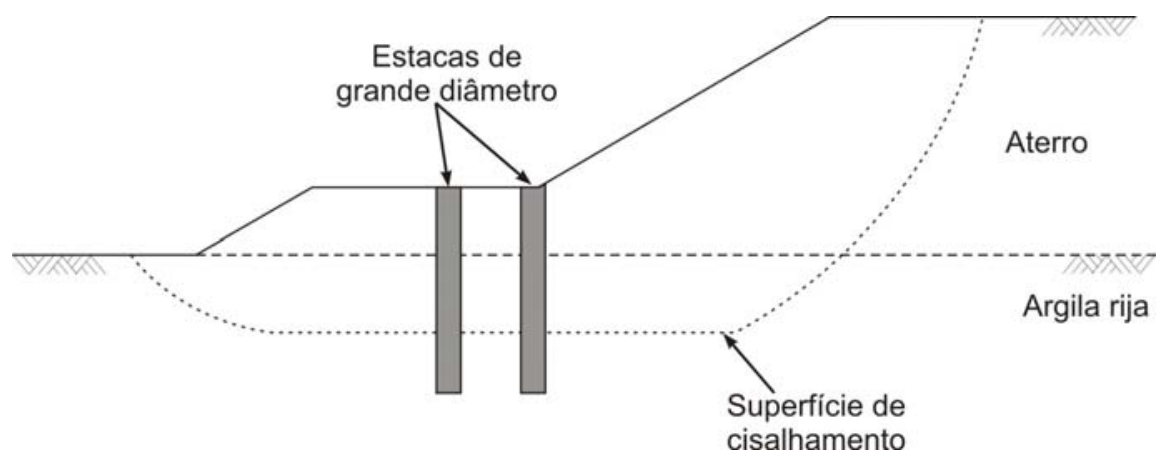

Figura 2.6. Estacas de grande diâmetro (Bruce \& Jewell, 1986).

Para atender aos objetivos deste trabalho, a técnica de solo pregado será a técnica de reforço de solo in situ discutida. Maiores informações sobre o sistema de reforço in situ por reticulado de micro estacas pode ser encontrada em Lizzi (1970, 1982), Dash \& Jovino (1980), Berardi \& La Magna (1984), Boley \& Crayne (1985). As bibliografias mais 
relevantes em relação às estacas de grande diâmetro são: Baker \& Yoder (1958) e Gudehus (1983).

\subsection{HISTÓRICO DA TÉCNICA DE SOLO PREGADO}

Os princípios e as técnicas de reforço in situ surgiram junto com a necessidade de promover a estabilização das escavações realizadas para a exploração de minérios, sendo, inicialmente, restrito à Engenharia de Minas. Estas técnicas foram difundidas após a $2^{\mathrm{a}}$ Guerra Mundial, quando, em 1959, o primeiro reforço envolvido por resina foi instalado na Alemanha (Beveredge, 1973). A partir de 1960, o New Austrian Tunneling Method (NATM) surgiu como um sistema aplicado em materiais rochosos, que combinava revestimento flexível de concreto projetado com ancoragens passivas (barras de aço) envolvidas por material ligante.

O método NATM permite que o terreno se deforme, criando uma região plastificada no entorno da escavação. Para estabilizar o maciço após a escavação, são aplicados um revestimento flexível de concreto projetado, uma tela metálica e chumbadores curtos radiais na zona plastificada. Este revestimento estará, portanto, sujeito a uma carga reduzida, face às deformações já desenvolvidas, Figura 2.7 (b). Entretanto, no método convencional de execução de túneis, Figura 2.7 (a), os deslocamentos do terreno são impedidos por um revestimento rígido, sendo, portanto, uma solução mais onerosa.

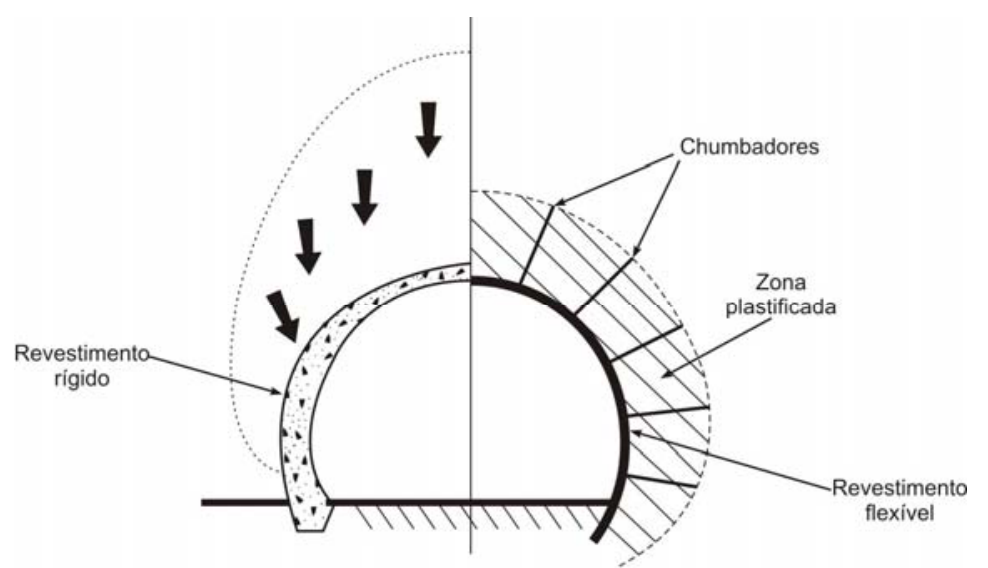

(a)

(b)

Figura 2.7. Técnicas de execução de túneis: (a) com revestimento rígido e (b) com revestimento flexível (Ortigão \& Palmeira, 1992). 
A partir da experiência adquirida em materiais rochosos, este sistema foi adaptado para ser utilizado em formações rochosas menos competentes e, posteriormente, em solos, recebendo a denominação de solo pregado. A primeira aplicação em solos ocorreu em Frankfurt, 1970, para a estabilização de uma escavação de um túnel de metrô de pequena seção transversal. Na França, foi utilizado pioneiramente em 1972, aproveitando-se da experiência adquirida com a técnica NATM. Estabilizou-se um talude ferroviário próximo a Versailles, e o sucesso desta obra viabilizou sua utilização em outros projetos de estabilização de taludes e escavações, tanto de forma permanente, como temporária.

A utilização desta técnica crescia junto com a necessidade de se obter um maior conhecimento em relação ao seu comportamento. Este fato fez com que surgissem alguns programas de pesquisas relacionados a este assunto, entre os quais:

$>$ CERMES: relacionado ao grupo de pesquisa da Escola Nacional des Ponts et Chaussés, que realizou ensaios em modelos e simulações numéricas com o método de elementos finitos;

$>$ CEBTP (Centre d’Études et de Recherches du Bâtiment et des Travaux Public): construiu e ensaiou uma estrutura de solo pregado com 7,0 $\mathrm{m}$ de altura. $\mathrm{O}$ trabalho foi financiado pela Federation National des Travaux Publics (FNTP) e pela Des Affaires Economiques et International (DAEI), uma repartição do Ministério dos Transportes Franceses (Plumelle, 1986).

A liderança da França em conhecimentos teóricos e práticos em relação à técnica de solo pregado era notório na época. Entretanto, ainda existiam algumas deficiências e necessidades, entre as quais: a divulgação da técnica, o desenvolvimento de métodos de projeto confiáveis e o estudo do seu comportamento a curto, médio e longo prazo. Para suprir estas necessidades, lançou-se na França, em 1986, um programa Nacional de pesquisa, denominado "Clouterre". Este programa não se preocupou em desenvolver e pesquisar novas técnicas construtivas, mas sim em melhorar o entendimento em relação ao comportamento e aos critérios de projeto. A originalidade do programa Clouterre estava relacionada com a construção, a instrumentação e o monitoramento das estruturas de solo pregado. Os resultados desta pesquisa foram apresentados no manual "Recommandations Clouterre" (1991), obra que se tornou referência mundial para a comunidade de engenharia interessada neste sistema de contenção. 
O desenvolvimento da técnica de solo pregado na Alemanha Ocidental se iniciou em 1975, a partir de uma associação entre a empresa Karl Bauer AG, a Universidade Karlsruhe e o Ministério de Pesquisa e Tecnologia. Durante um período de quatro anos, realizou-se um programa de pesquisa, em que foram construídas e estudadas oito estruturas de solo pregado, em escala real. Os resultados foram analisados e divulgados por Stocker, Gudehus \& Gassler (1979).

Nos Estados Unidos, o sistema foi empregado, de forma pioneira, em 1976, nas escavações para a construção do Hospital "Good Samaritan” em Portland, Oregon. Entretanto, Shen et al. (1981) mencionam que outras obras de solo pregado foram realizadas anteriormente em uma grande variedade de solos do Canadá. Em virtude da grande dificuldade em se obter informações técnicas sobre elas, essas obras são negligenciadas. A Universidade da Califórnia realizou um programa de pesquisas em que foram ensaiados protótipos instrumentados em escala real, em escala reduzida (ensaios em centrífuga), além de simulações numéricas com o método de elementos finitos. A pesquisa foi desenvolvida pela Fundação Nacional de Ciência e publicada por Shen et al (1981).

Este sistema de contenção se consolidou, de forma isolada, nestas três potências mundiais até 1979, quando houve um simpósio em Paris sobre solo pregado. Este encontro permitiu uma valiosa troca de informações entre os engenheiros destes países, proporcionando um grande avanço no desenvolvimento deste sistema de contenção em todo o mundo.

No Brasil, a utilização da técnica de solo pregado pode ser separada em duas fases distintas. A primeira fase se iniciou em 1970, quando a técnica foi empregada de forma empírica, baseando-se na experiência adquirida através do NATM, para estabilizar o emboque do túnel de adução do sistema Cantareiras, em São Paulo (Zirlis et al.,1998). Posteriormente, o mesmo procedimento foi empregado em muitos outros emboques de túneis e na estabilização de taludes ao longo da rodovia dos Imigrantes em São Paulo. A segunda fase, iniciada em 1980, está relacionada ao emprego do método de equilíbrio limite nos dimensionamentos. A adoção deste critério aumentou a confiabilidade dos projetos, o que possibilitou a construção de estruturas de maior porte.

Desde 1976, uma empresa em São Paulo, tem projetado e construído uma variação desta técnica com a utilização de blocos pré-moldados como elementos de face. Este 
processo, com denominação comercial Rimobloco, permite que a construção possa ser realizada de cima para baixo, como uma estrutura de solo pregado, ou ainda de baixo para cima, como em um sistema de reforço em aterro.

O histórico da técnica de solo pregado no Brasil, entre os anos de 1970 e 1994, foi apresentado por Ortigão et al. (1993 e 1995). Em 1999, grande parte da experiência nacional em relação a esta técnica, o que abrange um período de 13 anos (1983-1996), foi publicada em ABMS/ABEF (1999). Este trabalho apresentou um banco de dados de parâmetros geotécnicos de 60 obras, em que se empregou a técnica de solo pregado como estrutura permanente. Deste total, em apenas 18 obras utilizaram-se alguma rotina de cálculo, e somente uma obra foi instrumentada.

\subsection{A TÉCNICA DE SOLO PREGADO}

O conceito fundamental da técnica de solo pregado consiste na inclusão de barras de aço em pré-furos realizados no maciço de solo, que são posteriormente preenchidos com calda de cimento. Este material promove a transferência de tensão do solo para o reforço e protege a barra de aço contra o processo de corrosão. As barras de aço são também denominadas de inclusões passivas, já que as tensões de tração são mobilizadas ao longo de sua extensão, em resposta à deformação do maciço de solo durante as etapas de escavação. O processo construtivo é realizado em etapas sucessivas e descendentes, envolvendo, tipicamente, seis fases executivas, entre elas (Elias et al., 2003):

Fase (1): escavação;

Fase (2): perfuração do terreno;

$>$ Fase (3): instalação da barra de aço, preenchimento do furo com calda de cimento e execução do sistema de drenagem;

Fase (4): construção de uma face de concreto projetado temporária;

$>$ Fase (5): construção das etapas subseqüentes;

$>$ Fase (6): construção de face de concreto projetado permanente. 
A Figura 2.8 apresenta, de forma esquemática, a seqüência executiva utilizada para a construção do sistema de solo pregado.

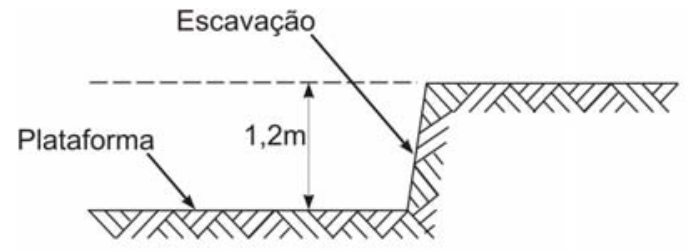

(1)

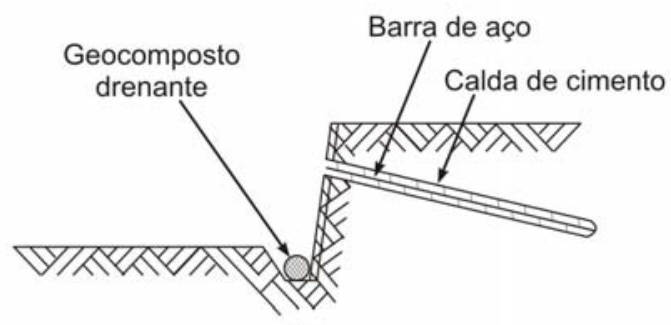

(3)

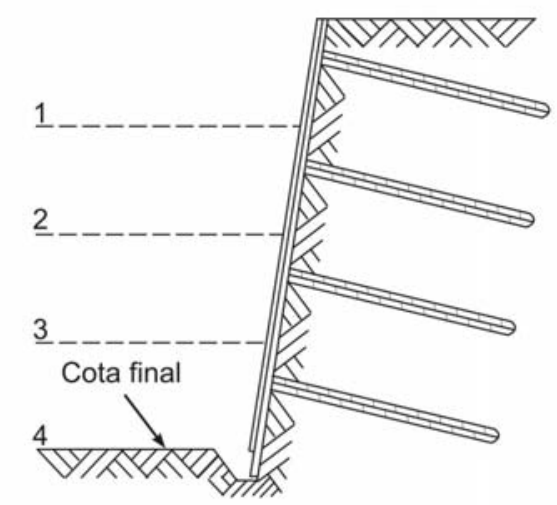

(5)

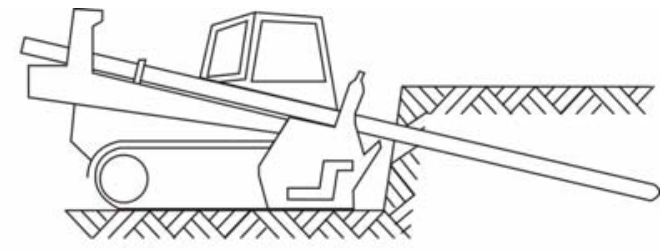

(2)

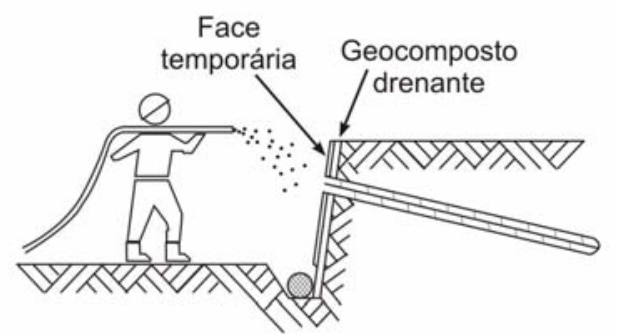

(4)

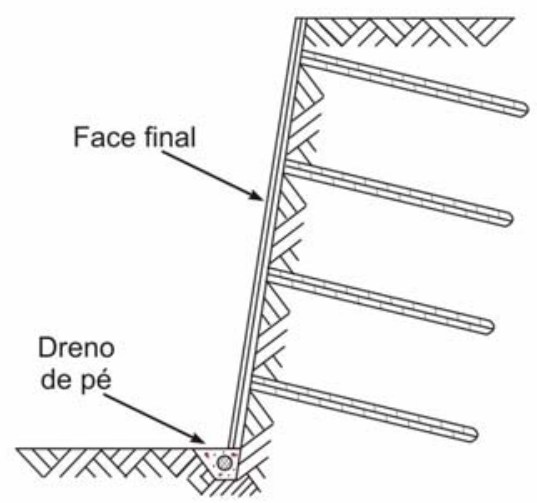

(6)

Figura 2.8. Seqüência típica para a execução da estrutura de solo pregado (Elias et al., 2003).

Conforme apresentado na Figura 2.8, a execução do sistema de solo pregado compreende três fases principais e repetitivas: escavação com altura limitada; execução dos chumbadores e do sistema de drenagem e construção da face. A seguir, apresentam-se, com maiores detalhes, cada uma destas fases construtivas. 


\subsubsection{Escavação}

O processo de escavação (corte) do terreno é realizado, geralmente, a partir do topo do maciço de solo, em fases sucessivas variando entre 1 e $2 \mathrm{~m}$, até atingir a cota final de escavação. A altura máxima da escavação depende da habilidade do terreno em manterse estável por um curto período de tempo (entre 24 e 48 horas), sendo, portanto, condicionada a muitos fatores, entre os quais, as características do solo, a presença ou não de água e a inclinação da face. A largura da escavação deve ser suficiente para permitir o acesso de equipamentos de perfuração do terreno. Gassler (1990) apresenta uma sugestão de possíveis profundidades de escavação, em cortes verticais, em função do tipo de solo.

Tabela 2.2. Profundidades de escavação em cortes verticais (Gassler, 1990).

\begin{tabular}{|c|c|c|c|}
\hline Tipo de Solo & \multicolumn{3}{|c|}{ Profundidade de Escavação (m) } \\
\hline \multirow{2}{*}{ Pedregulho } & & \multicolumn{2}{|c|}{1,5} \\
\hline & (com coesão aparente) & (solo com & atação) \\
\hline Areia & $\begin{array}{c}1,2 \\
\text { (medianamente compacta, com } \\
\text { coesão aparente) }\end{array}$ & $\begin{array}{c}1,5 \\
\text { (compacta, com } \\
\text { coesão aparente) }\end{array}$ & $\begin{array}{c}2,0 \\
\text { (com cimentação) }\end{array}$ \\
\hline Silte & 1,2 & (com ci & ção) \\
\hline Argila & $\begin{array}{c}1,5 \\
\text { (normalmente consolidada) }\end{array}$ & $\begin{array}{r}2, \\
\text { (sobrea }\end{array}$ & da) \\
\hline
\end{tabular}

Para garantir a estabilidade do maciço durante as fases de escavação, o solo deve apresentar uma coesão, a curto prazo, de pelo menos $10 \mathrm{kPa}$. Entretanto, recomenda-se que a primeira fase de escavação seja realizada com altura inferior à dimensionada, para permitir a estabilização em tempo suficiente, caso tenha ocorrido uma avaliação errônea dos parâmetros do solo. O processo de escavação (corte) do terreno deve minimizar as instabilidades locais e os deslocamentos da estrutura de solo pregado (Mitchell \& Villet, 1987). Para aumentar a estabilidade da escavação, podem ser empregadas diferentes soluções alternativas, entre as quais (Clouterre, 1991): 


\subsubsection{Escavação Altemada}

O processo de escavação alternada é recomendado quando se observam problemas de instabilidade durante a fase de escavação. Neste caso, recomenda-se que a largura da escavação não seja superior ao espaçamento horizontal dos reforços, para que o efeito de arqueamento auxilie na estabilização do maciço. Entretanto, o emprego desta metodologia faz com que a execução dos serviços seja lenta. A Figura 2.9 ilustra o processo de escavação alternada.

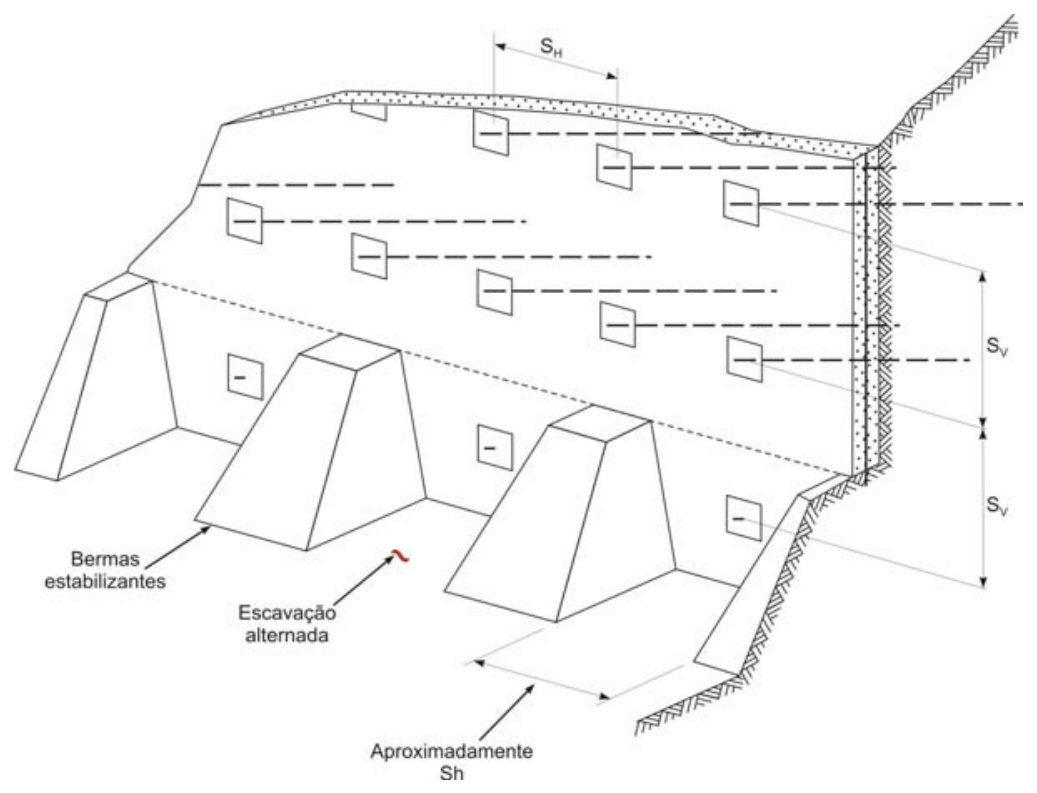

Figura 2.9. Escavação realizada de forma alternada (Elias et al., 2003).

\subsubsection{Exec ução de Berma Provisónia}

A construção de bermas provisórias é uma alternativa interessante para estabilizar as frentes de escavação que não se apresentam estáveis durante o período necessário para a realização das intervenções. Para estas situações, os reforços são inseridos e injetados através da berma, conforme apresentado na Figura 2.10. Posteriormente, a berma é escavada e o concreto projetado é lançado sobre a face. Esta alternativa pode ser mais efetiva quando as inclusões são instaladas mais próximas umas das outras e pode ser mais facilmente adaptada se os reforços forem cravados diretamente no maciço de solo. 


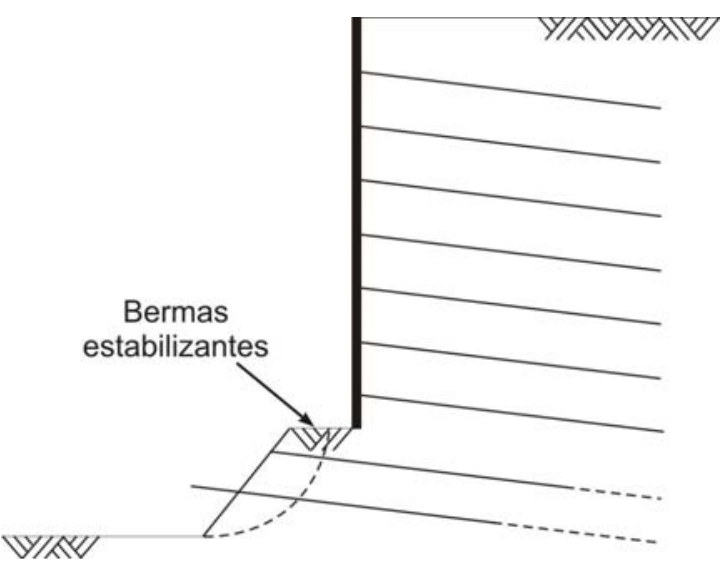

Figura 2.10. Construção de bermas provisórias para minimizar a ocorrência de rupturas localizadas (Clouterre, 1991).

\subsubsection{Lançamento de Concreto Projetado de Proteção}

O desconfinamento do maciço de solo provocado pelo processo de escavação e a conseqüente exposição a intempéries podem provocar desagregações superficiais e rupturas localizadas. Para minimizar estes problemas, pode-se lançar como proteção uma fina camada de concreto projetado logo após o processo de escavação (Figura 2.11). Após a construção do chumbador, lança-se a camada final de concreto projetado.

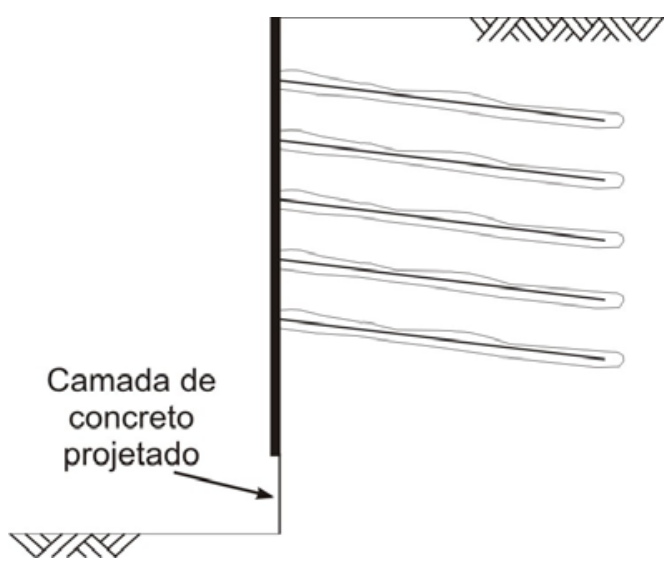

Figura 2.11. Lançamento de concreto projetado de proteção (Clouterre, 1991). 


\subsubsection{Execução dos Reforços}

A instalação do reforço no maciço de solo deve ser realizada logo após o término das respectivas fases de escavação. Este processo deve ser concluído rapidamente para evitar a redução da coesão do solo em curto prazo e minimizar a ocorrência de rupturas localizadas, provocada pela percolação de água no terreno.

Os reforços podem ser instalados no terreno tanto na direção horizontal quanto de forma inclinada (em geral de $5^{\circ}$ a $20^{\circ}$ em relação à horizontal). Os reforços podem ser metálicos (com ou sem tratamento corrosivo), de fibras de vidro, resinados, ou similares. Na maioria dos casos, são constituídos por barras de aço CA-50, com diâmetro variando entre $16 \mathrm{~mm}$ e $32 \mathrm{~mm}$. A escolha da técnica para a execução dos reforços vai depender da sua aplicabilidade no terreno local, do tempo despendido durante sua execução e, conseqüentemente, do fator custo relacionado a estes fatores. Na seqüência, apresentam-se as técnicas mais comuns empregadas para a instalação dos reforços.

\subsubsection{Reforços Cravados}

Os reforços cravados, principalmente por percussão, podem ser executados de forma satisfatória em solos de baixa resistência e que não apresentam interferências em seu interior (matacões, estacas, etc.). Por razões relacionadas à sua instalação, este tipo de reforço deve apresentar alguma rigidez e ser constituído por barras com elevada eficiência mecânica de cravação (cantoneiras de aço, tubos metálicos, etc.).

Estes reforços apresentam comprimento inferior a $8 \mathrm{~m}$, pequeno diâmetro (19 a 25 $\mathrm{mm}$ ) e são instalados com grande densidade (espaçamento entre 1,0 e 1,2 m). A resistência ao cisalhamento de interface destes reforços é obtida pelo contato direto da inclusão com o solo circundante, apresentando valores típicos de 30 a $40 \mathrm{kPa}$, quando cravados em areia, e valores inferiores, quando cravados em argilas. A cravação direta destes reforços aumenta a dificuldade em se obter proteção anticorrosiva. Sendo assim, devem ser tomados cuidados especiais quando forem utilizadas em estruturas permanentes e no interior de solos agressivos. 
Este método executivo apresenta a vantagem das cravações acontecerem com elevada velocidade, desde que sejam utilizadas guias para limitar os riscos de desviação ou flambagem destas inclusões e, consequentemente, garantir uma melhor eficiência do processo. Como controle de qualidade, recomenda-se controlar o tempo de cravação de cada reforço, já que uma redução repentina deste fator pode indicar a presença de solos de baixa resistência. Caso esta anomalia aconteça de forma localizada, deve-se realizar a cravação de um reforço adicional na vizinhança do local. Em situações que o solo apresenta elevada resistência e inviabiliza o processo de cravação, deve-se adotar outra técnica para a execução dos reforços.

Uma técnica alternativa, desenvolvida na França, consiste na cravação de um tubo de aço, por percussão, injetando-se, ao mesmo tempo, calda de cimento sob pressão pela ponta do tubo. As obras executadas com este sistema são denominadas de Hurpinoise, em reconhecimento ao técnico Hurpin, que desenvolveu o método (Ortigão \& Palmeira, 1992). Um sistema semelhante foi desenvolvido e denominado comercialmente por "Titan". Tratase de um tubo de aço ranhurado que apresenta uma coroa e é introduzido por roto percussão. Emprega-se água e ar como fluidos de perfuração. Ao final, injeta-se calda de cimento (Ortigão \& Palmeira, 1992).

\subsubsection{Reforços Injetados}

O emprego da técnica de reforços injetados com calda de cimento é a mais utilizada atualmente. O processo de construção consiste na realização de um furo no solo, com diâmetro variando entre 50 e $120 \mathrm{~mm}$, introdução de uma barra de aço e posterior preenchimento do furo com calda de cimento. Este processo permite que se obtenham valores de resistência ao cisalhamento de interface solo-reforço $\left(q_{s}\right)$ da ordem de $100 \mathrm{kPa}$ para a maioria dos solos (Ortigão et al., 1995).

A escolha do método de perfuração e do equipamento a ser utilizado é principalmente condicionada pela natureza e características do terreno em que o processo de perfuração é realizado. Pode-se utilizar uma grande quantidade de fluidos para facilitar este processo, tais como: água, ar comprimido e lama bentonítica. A perfuração pode ser 
realizada por rotação, percussão ou rotopercussão. As perfuratrizes rotativas mais comumente empregadas podem ser utilizadas em conjunto com os seguintes equipamentos:

Trados contínuos: aplicável em solos finos com baixo grau de compactação e em situações que envolvam pequenos comprimentos de perfuração;

> Dispositivo para desintegração do solo fixado no final da haste: equipamento indicado para as perfurações que não apresentam riscos de colapso ao longo da parede do furo;

Tubo aberto: utilizado para suportar a parede da perfuração quando há risco de colapso ou estreitamento do furo;

Tubo ou revestimento com ferramenta cortante: apresenta na sua extremidade uma ferramenta cortante para desagregar as frações de solo mais resistentes existentes no terreno.

Como regra geral, sugere-se que a inclinação da perfuração não seja inferior a $10^{\circ}$. Para inclinações inferiores, deverão ser tomados cuidados especiais durante $o$ preenchimento do furo com calda de cimento.

Após a instalação das barras de aço devidamente preparadas, realiza-se, a partir da tubulação acessória, o preenchimento do furo com calda de cimento de baixo para cima, a qual recebe o nome de "bainha". Pitta et al. (2003) comentam que o fator água/cimento para esta mistura varia em torno de 0,50 a 0,70. Zirlis et al. (1999) definem a bainha como sendo a fase inicial de injeção onde se pretende recompor a cavidade escavada.Em casos onde se deseja um aumento na resistência de interface solo-calda de cimento, uma segunda injeção é feita após um intervalo de tempo mínimo de 12 horas da execução da bainha (Zirlis et al., 1999). Esta injeção é realizada sob pressão por meio de tubos de injeção perdidos, fixados junto às barras de aço. Durante esta etapa, é possível controlar a pressão de injeção e o volume de calda de cimento injetado (Pitta et al., 2003).

A tubulação de injeção constitui-se em um tubo de polietileno com 8 a $10 \mathrm{~mm}$ de diâmetro, contendo válvulas de injeção instaladas entre 0,30 e $0,50 \mathrm{~m}$, até $1,5 \mathrm{~m}$ da boca do furo. Abramento et al. (1998) destacam que, além de promover uma maior ancoragem do chumbador, a injeção de calda de cimento promove ainda melhorias no maciço de solo a 
partir do preenchimento das suas fissuras. Maiores detalhes em relação ao processo de injeção serão apresentados adiante.

\subsubsection{Sistema de Drenagem}

A infiltração de água no interior do maciço reforçado pode gerar elevadas cargas hidrostáticas atrás do paramento da face e, consequentemente, provocar sua ruptura. Além disso, pode contribuir para a redução dos parâmetros de resistência do solo e para o processo de corrosão das barras de aço, principalmente quando a água apresenta substâncias agressivas em sua composição. Para evitar ou minimizar os efeitos da infiltração de águas superficiais no interior do maciço de solo, é extremamente necessário que dispositivos de drenagem sejam adequadamente dimensionados.

A estrutura de contenção do tipo solo pregado é composta por dois sistemas de drenagem:

Dreno horizontal profundo (DHP): são constituídos por tubos de PVC perfurados e envolvidos por manta geotêxtil. Estes drenos apresentam extensão superior aos reforços (variando entre 6 e $18 \mathrm{~m}$ ), diâmetro entre 40 e $100 \mathrm{~mm}$ e inclinação de $5^{\circ}$ a $10^{\circ}$ positivas em relação a horizontal, conforme apresentado na Figura 2.12. Estes drenos buscam reduzir qualquer saturação do maciço, principalmente as relacionadas com a ascensão do nível freático no terreno. O espaçamento entre estes drenos depende das condições do local. A densidade mínima destes drenos comumente utilizada é de 1 dreno para cada $50 \mathrm{~m}^{2}$ de face (Clouterre, 1991). 

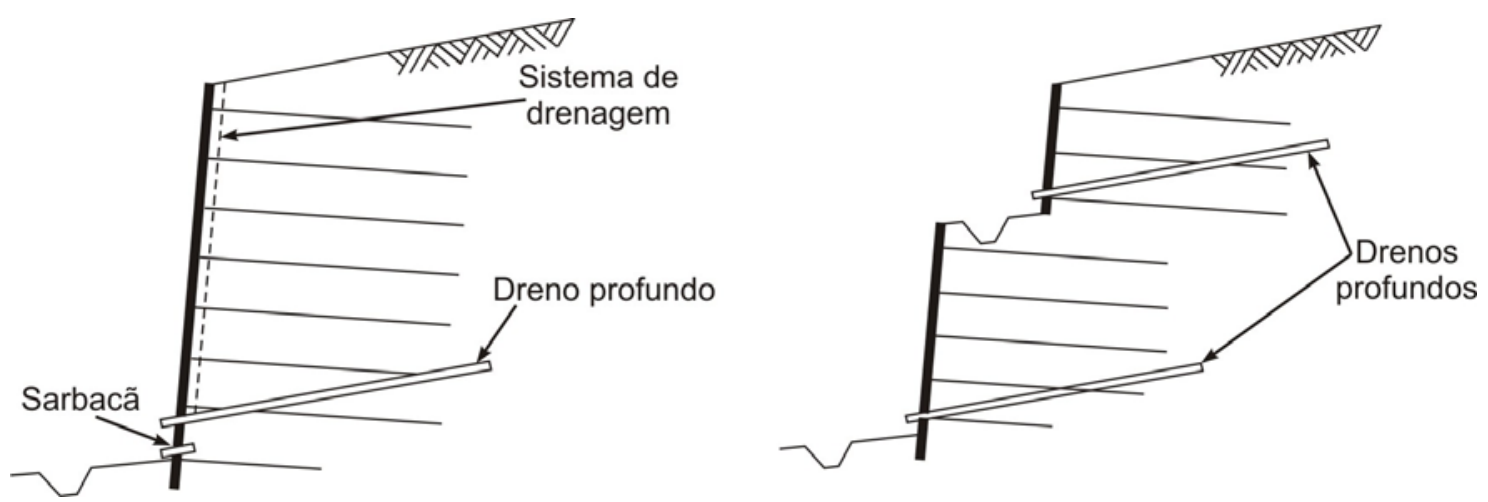

Figura 2.12. Detalhe de drenos horizontais profundos (Clouterre, 1991).

Drenos rasos ou de subsuperfície: são dimensionados para evitar o acúmulo de água atrás do paramento. Estes drenos são compostos por drenos do tipo barbacã e drenos de paramento (Figura 2.13).

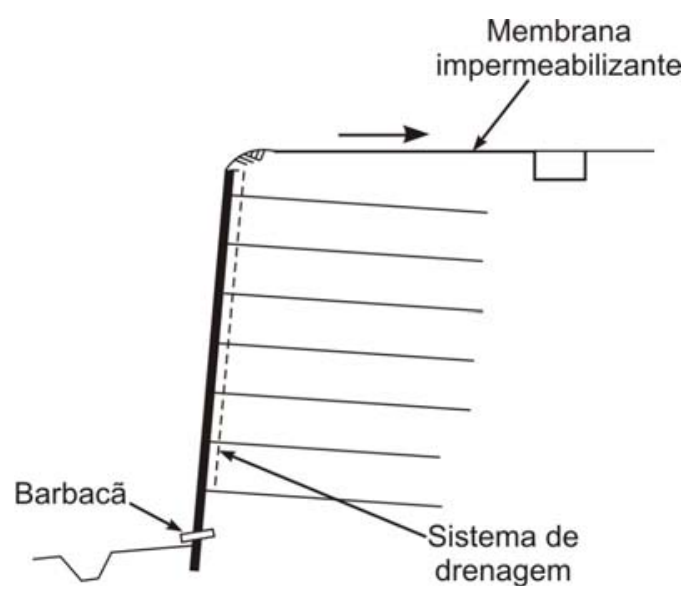

Figura 2.13. Detalhe de drenos rasos ou de subsuperfície (Clouterre, 1991).

O dreno tipo barbacã é o resultado da escavação de uma cavidade de 0,40 x 0,40 x 0,40 m, preenchida com material drenante (brita ou areia), tendo como saída um tubo de PVC (em geral com extensão variando entre 0,30 e 0,40 m, contendo 4"de diâmetro), com inclinação descendente e revestido por um filme de nylon ou camada de geotêxtil no trecho em contato direto com o material drenante. Estes tubos têm a função de coletar água da parte posterior do paramento e também conduzí-la para fora do maciço, sendo responsáveis por uma drenagem mais pontual. O seu espaçamento depende das condições encontradas no local e normalmente se aproxima do espaçamento dos reforços. 
O dreno de paramento, localizado no tardoz do muro e disposto ao longo de toda a altura da estrutura (do pé à crista do muro), pode ser composto por calha plástica ondulada revestida por manta geotêxtil, em uma escavação de 0,10 x 0,30 m que aflora na canaleta de pé. Trata-se de um dreno linear e é considerado como uma opção mais eficiente e recomendável para projeto, segundo Zirlis et al. (1999).

Como complemento para o sistema de drenagem desta estrutura, podem ser construídas canaletas de pé e de crista, bem como descidas de água. Estes dispositivos são moldados in loco e revestidos com concreto projetado.

\subsubsection{Revestimento de Face}

O revestimento de face no sistema solo pregado apresenta função secundária no processo de estabilização do maciço de solo. Sua atuação se restringe, basicamente, a impedir rupturas localizadas e garantir um controle erosivo do terreno localizado junto à face. Embora não desempenhe função primordialmente estrutural, em geral, utiliza-se concreto projetado como elemento de face.

O revestimento em concreto projetado apresenta em sua composição areia média, pedrisco, cimento e água. A armação da face pode ser realizada de forma convencional e com tela eletrossoldada. É necessário garantir o recobrimento desta armação durante a fase de projeção, para que o concreto seja bem compactado e evite que a armação funcione como anteparo e ocorram vazios atrás da mesma.

Uma forma alternativa para se executar a face em concreto projetado e que tem recebido destaque nos últimos anos, é a inclusão de fibras de aço ou polipropileno no concreto. $\mathrm{O}$ concreto resultante desta associação apresenta-se mais homogêneo, mais dúctil e com maior resistência à tração e a corrosão. Além destas melhorias, este material apresenta as seguintes vantagens: rapidez de execução, devido à eliminação da etapa de colocação da tela, redução de volume de concreto projetado, devido à redução nas perdas por reflexão, e melhor controle sobre a espessura da camada (GeoRio, 2000).

O processo de jateamento do concreto pode ser feito de duas maneiras distintas: via seca ou via úmida. A diferença básica entre os dois métodos está no preparo e na condução dos materiais que compõe o concreto. $\mathrm{Na}$ via seca, os componentes sólidos do 
concreto são misturados sem adição de água. A adição de água se dá junto ao bico de projeção, instantes antes da aplicação. Na via úmida, o concreto é misturado com todos os seus componentes e, deste modo, é conduzido através dos mangotes até o local de aplicação (Zirlis et al. 1999). Em virtude de sua maior praticidade, o jateamento por via seca é o mais utilizado nas obras. A elevada energia sob a qual a mistura é projetada promove boas condições de compactação do concreto, colaborando para sua alta resistência, bem como para o adensamento da capa superficial do solo (Abramento et al.,1998).

Nos dias atuais, o largo emprego desta técnica nos grandes centros urbanos fez com que a estética da obra passasse a ser uma preocupação relevante, tanto para os projetistas, como para os executores deste tipo de intervenção. Em alguns casos, quando os taludes apresentam-se com menor inclinação (da ordem de $45^{\circ}$ ), pode-se realizar a face com revestimento vegetal. Uma outra alternativa consiste na utilização de blocos ou painéis pré-moldados como elementos de face. Este tipo de revestimento vem se mostrando um grande aliado para a técnica, pois agrega valores estéticos à obra, possibilitando diversos desenhos arquitetônicos. Sendo assim, a utilização desta face está condicionada a um maciço que se apresente estável até a cota final de escavação (e.g. solos residuais) e em reforços de taludes já existentes, que permitam a execução do sistema de forma ascendente.

\subsubsection{Conexão do Reforço à Face}

A conexão da extremidade superior do reforço com o revestimento de concreto projetado pode ser realizada de diferentes maneiras. A Figura 2.14 apresenta as alternativas que rotineiramente são utilizadas em obras de solo pregado. 


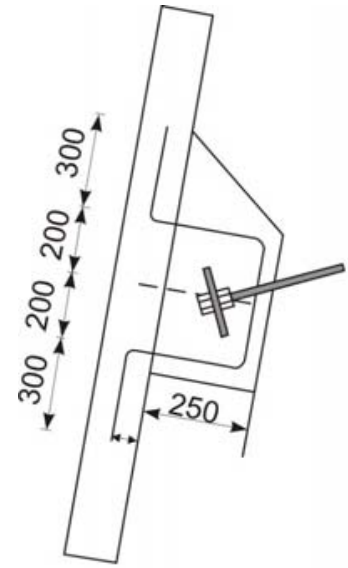

(a)

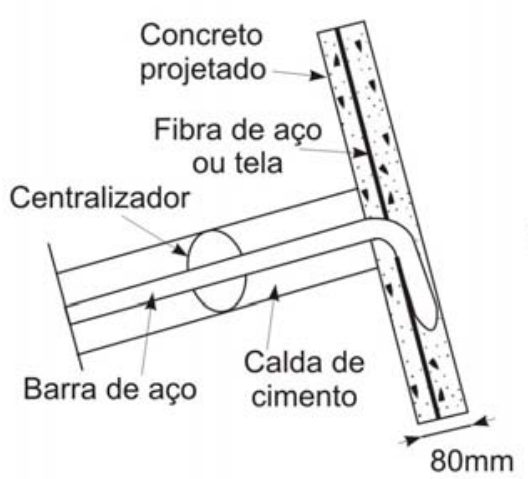

(b)

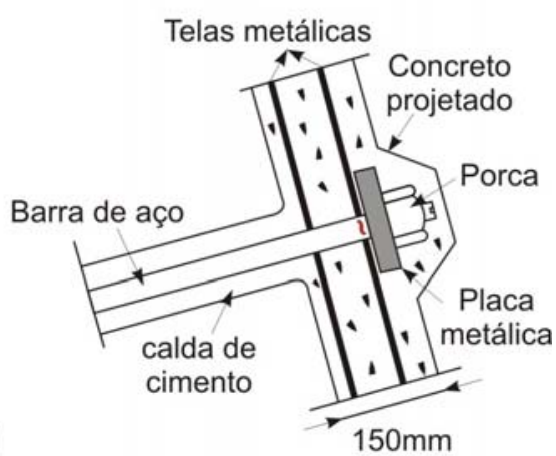

(c)

Figura 2.14. Diferentes alternativas de conexão do reforço junto a face de concreto projetado (GeoRio, 1999).

A Figura 2.14 mostra que a extremidade do reforço pode ser embutida no paramento (Figura 2.14-a), dobrada $90^{\circ}$ em relação a sua extremidade (Figura 2.14-b), e fixada por placa metálica, rosca e porca, para garantir o contato entre o solo e o concreto projetado (Figura 2.14-c).

Springer et al. (2001) estudaram o comportamento tensão $\mathrm{x}$ deformação de maciços de solo pregado a partir de simulações numéricas realizadas em escavações com paramento vertical. Buscou-se avaliar a influência destas diferentes alternativas de conexão no comportamento do maciço reforçado. O reforço foi introduzido na malha de elementos finitos de duas maneiras distintas: extremidade livre ou fixa. Cada uma delas está relacionada com um processo construtivo. Para as situações em que a extremidade do reforço é embutida ou dobrada (Figuras 2.14 (a) e (b)), pode ocorrer o puncionamento do reforço na face da escavação. Para esta situação, os autores simularam o reforço com extremidade livre. Entretanto, para a alternativa de fixação por placa metálica e porca (Figura 2.14 (c)), considerou-se que o reforço apresenta-se solidarizado à face, considerando o reforço com extremidade fixa.

A partir das simulações numéricas, verificou-se que as alternativas de conexão dos reforços (extremidade livre ou fixa) são relevantes no comportamento das estruturas reforçadas, principalmente em termos de deslocamento da face e de distribuição das tensões ao longo dos reforços. Para maiores valores de $\mathrm{L} / \mathrm{H}$ (comprimento do reforço/altura do 
maciço), o processo construtivo (reforço com extremidade fixa ou livre) mostrou não apresentar influência significativa nos deslocamentos do maciço de solo pregado. Observou-se também que o ponto de tração máxima varia em função do método de conexão do reforço junto à face. Quando os reforços se apresentam com extremidade fixa, o ponto de tração máxima ocorre junto à face. Ao considerar o reforço com extremidade livre, a tração máxima ocorre em uma região mais interna do maciço, desenvolve-se um mecanismo de ruptura, sendo portanto, a alternativa indicada para realizar a conexão junto à face.

\subsection{COMPARAÇÃO COM OUIRAS TÉCNICA DE ESTABIUZAÇÃO}

Apresenta-se a seguir um comparativo entre a técnica de Solo Pregado e outras técnicas mais antigas e consagradas de reforço de solo: Cortina Atirantada e Terra Armada.

\subsubsection{Solo Pregado e Cortina Atirantada}

A cortina atirantada apresenta, à primeira vista, uma grande similaridade com a técnica de solo pregado. No entanto, existem distinções muito claras entre as duas técnicas, que podem ser importantes na escolha da solução a ser utilizada. A seguir apresentam-se comparações entre estas duas técnicas (Bruce \& Jewel, 1986; Ortigão \& Fanin, 1992; Elias et al., 2003, Shen et al., 1981):

Os tirantes, após a instalação, são protendidos com cargas que variam entre $150 \mathrm{e}$ $1000 \mathrm{kN}$, para prevenir os deslocamentos da cortina. Por outro lado, os chumbadores sofrem, no máximo, uma pequena pré-tensão de 5 a $10 \mathrm{kN}$, com a finalidade exclusiva de garantir a ligação com o concreto projetado da face;

Os tirantes desenvolvem a capacidade de tração após a aplicação da pré-tensão (trabalho ativo), enquanto os chumbadores somente mobilizam os esforços de tração após ocorrer um deslocamento do solo circundante (trabalho passivo);

$\mathrm{Na}$ técnica de solo pregado, o contato entre o solo e o reforço se dá ao longo de toda a sua extensão, ou seja, a transferência de carga ocorre ao longo do reforço (não 
apresenta trecho livre). Na cortina atirantada, a transferência de carga somente ocorre em um trecho pré-determinado, localizado atrás da superfície potencial de ruptura. Desta forma, a distribuição das tensões no maciço de solo é diferente nos dois sistemas de contenção, conforme o esquema apresentado na Figura 2.15.

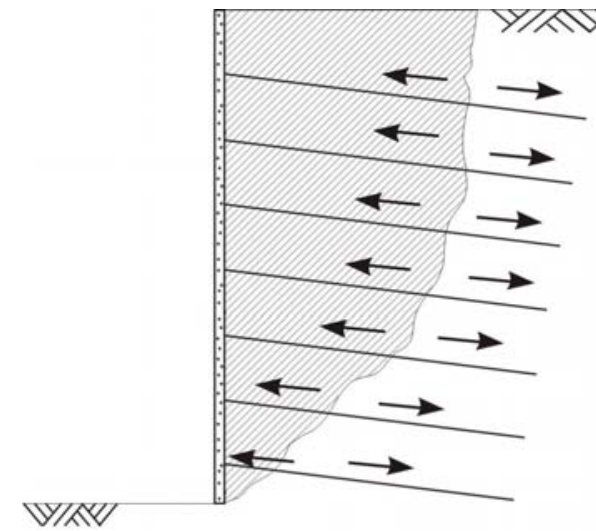

(a)

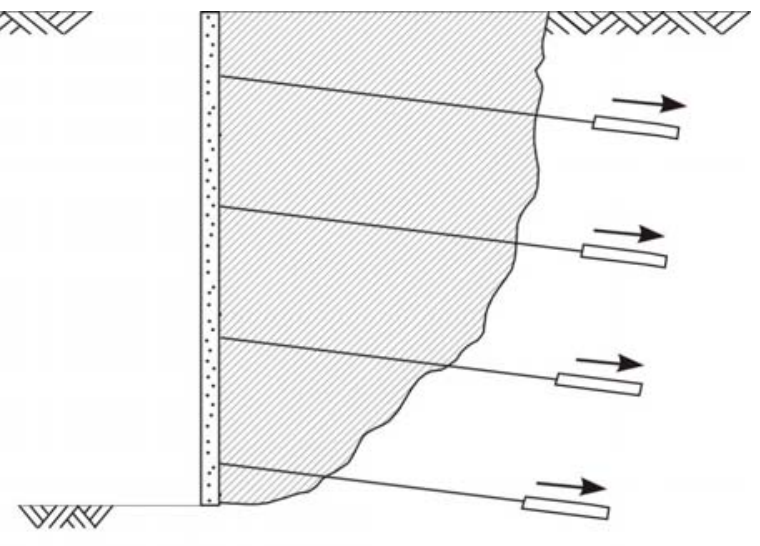

(b)

Figura 2.15. Mecanismos de transferência de carga no solo pregado (a) e na cortina atirantada (b).

Como a carga aplicada nos tirantes é geralmente elevada, a face de concreto deve ser dimensionada quanto ao puncionamento. No solo pregado, a alta densidade dos reforços implica em uma pequena magnitude de empuxo de terra atuante sobre a face. Em virtude destas pequenas cargas, o paramento não apresenta função primordialmente estrutural;

A força resistiva gerada pelo sistema solo pregado é variável ao longo do comprimento do reforço. Na cortina atirantada, a carga é aproximadamente constante ao longo do comprimento livre e variável no trecho injetado;

Os tirantes convencionais apresentam grande extensão (15 a 45 m), necessitando de equipamento de maior porte para sua execução. Os chumbadores, ao contrário, apresentam comprimento máximo da ordem da altura da escavação. Desta forma, quando as superfícies de ruptura são profundas, o tirante é a solução mais adequada. Entretanto, em cortes verticais ou subverticais, em que esta possibilidade não existe, o sistema solo pregado poderá ser utilizado com sucesso; 
Do solo pregado, o avanço dos serviços de escavação e contenção pode ser efetuado de forma contínua, não sendo necessário aguardar a cura do paramento e a protensão;

Estruturas em solo pregado são flexíveis, compactas e apresentam alta resistência a esforços dinâmicos. Conseqüentemente, demonstram ser bastante viáveis em regiões susceptíveis a terremotos;

A partir de dados de instrumentação de campo, verificou-se que, em cortinas atirantadas, o deslocamento máximo ocorre à meia altura da estrutura. No solo pregado, o deslocamento máximo concentra-se no topo da estrutura;

O processo de corrosão tende a ser maior em tirantes, visto que está exposto ao efeito da corrosão sob tensão "stress corrosion", necessitando de tratamento especial quando utilizado em obra permanente;

O custo da solução em solo pregado é significantemente menor do que a solução de cortina atirantada (Falconi \& Alonso, 1997). A Figura 2.16 apresenta os custos comparativos realizados para algumas obras no Canadá e na França.

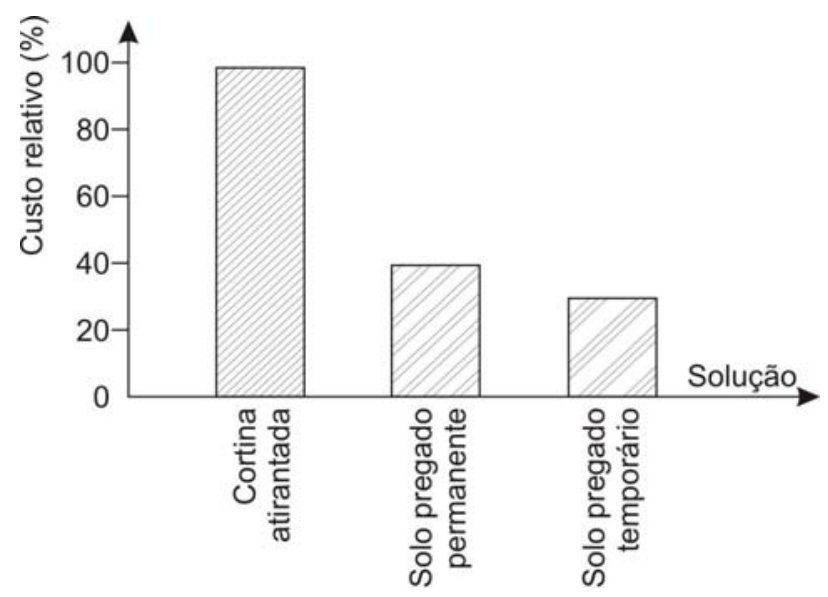

Figura 2.16. Custo relativo entre as obras de cortina atirantada e solo pregado (Ortigão \& Palmeira, 1992).

Para que a comparação apresentada na Figura 2.16 seja válida, é indispensável que ambas as soluções apresentem o mesmo grau de confiabilidade. Neste contexto, a cortina atirantada apresenta vantagem significativa, pois a NBR 5629/96 fixa critérios para a execução e o controle dos tirantes. Em solo pregado, os chumbadores são testados 
raríssimas vezes, ou quando são, o numero de ensaios é pouco significativo em relação à área contida.

\subsubsection{Solo Pregado e Terra Amada}

Em termos de conceituação e métodos de análise, a técnica de solo pregado é bastante semelhante à de Terra Armada. Em ambas as técnicas, o principal agente estabilizador é a resistência ao cisalhamento desenvolvida na interface solo-reforço, e o sistema de paramento é esbelto, sem função primordialmente estrutural. Entretanto, há três diferenças fundamentais entre estas técnicas (Schlosser, 1992):

Processo construtivo: as técnicas apresentam método construtivo completamente diferente. Enquanto os chumbadores são executados em etapas sucessivas de cima para baixo, a Terra Armada é construída de baixo para cima, a partir de aterros compactados. As etapas construtivas empregadas nestas técnicas estão apresentadas na Figura 2.17.

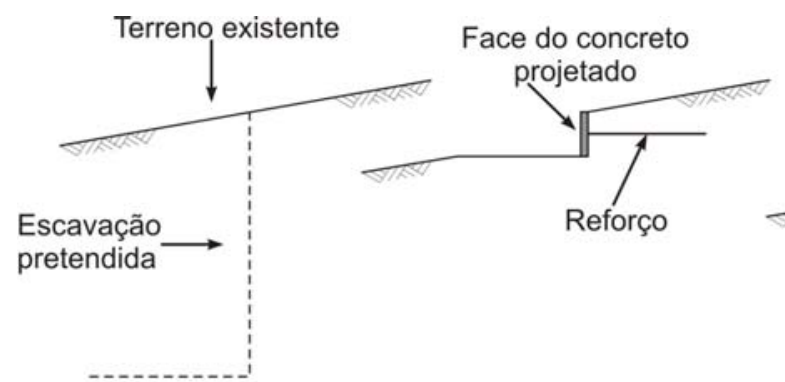

(1)
(2)

Solo Pregado

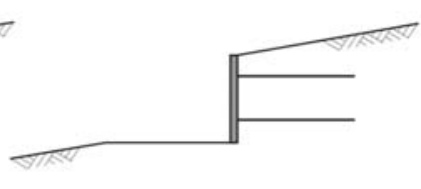

(3)

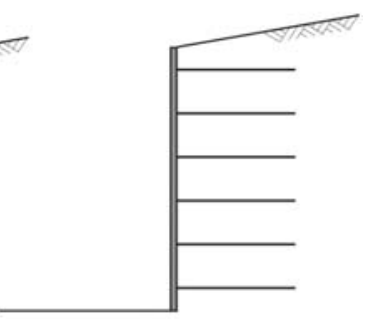

(4)

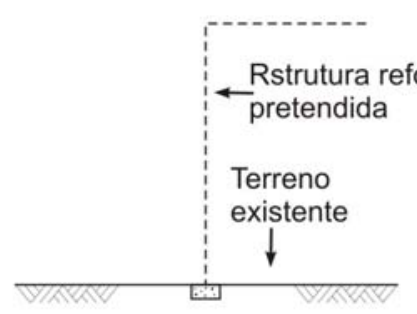

(1)

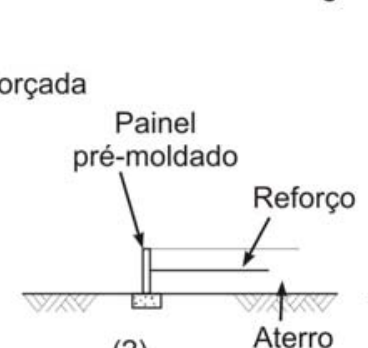

(2)

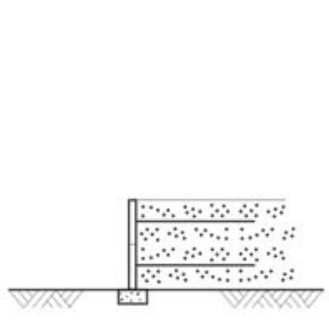

(3)

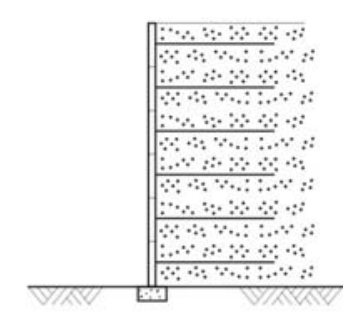

(4)

Terra Armada

Figura 2.17. Comparação entre os processos construtivos de Solo Pregado e Terra Armada (Bruce \& Jewell, 1986). 
O processo construtivo influência sobremaneira a distribuição dos esforços no maciço durante a execução. Em virtude da compressão das camadas inferiores pelo peso próprio dos solos sobrejacentes, os deslocamentos horizontais, no sistema Terra Armada, aumentam progressivamente com as sucessivas fases da construção do aterro e são máximos no pé do maciço reforçado (Figura 2.18 (a)). Em uma estrutura de solo pregado, as sucessivas fases de escavação fazem com que o maciço de solo seja submetido simultaneamente à descompressão lateral e a recalques verticais. Como resultado, ao final da construção, os deslocamentos verticais e horizontais observados serão máximos no trecho superior do maciço reforçado (Figura 2.18 (b)).

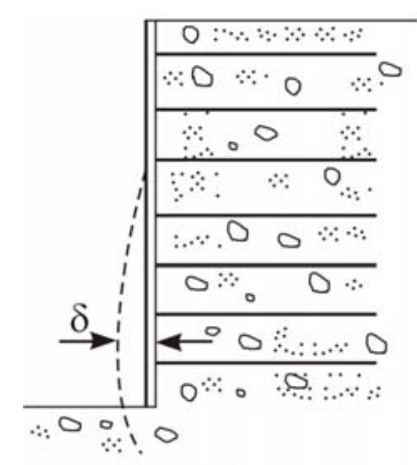

(a)

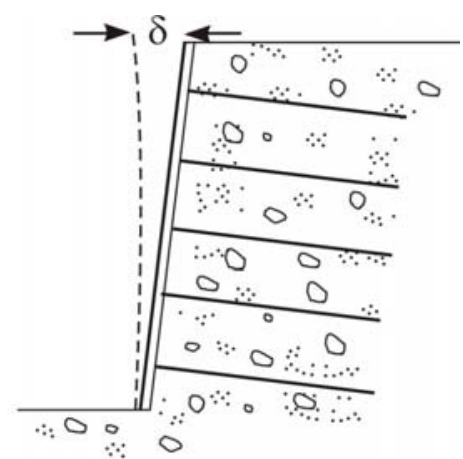

(b)

Figura 2.18. Deslocamentos horizontais máximos: (a) Terra armada e (b) Solo Pregado.

O processo de alívio de tensões horizontais no maciço de solo durante as etapas de escavação (solo pregado) gera, preferencialmente, esforços de tração nos reforços. Estes esforços são mobilizados, em cada linha de reforço, após o término do referente nível de escavação. Na Figura 2.19, apresenta-se o desenvolvimento progressivo dos esforços de tração no reforço $n^{\circ} 3$ de um muro experimental da CEBTP, para as sucessivas fases de escavação (Clouterre, 1991). 


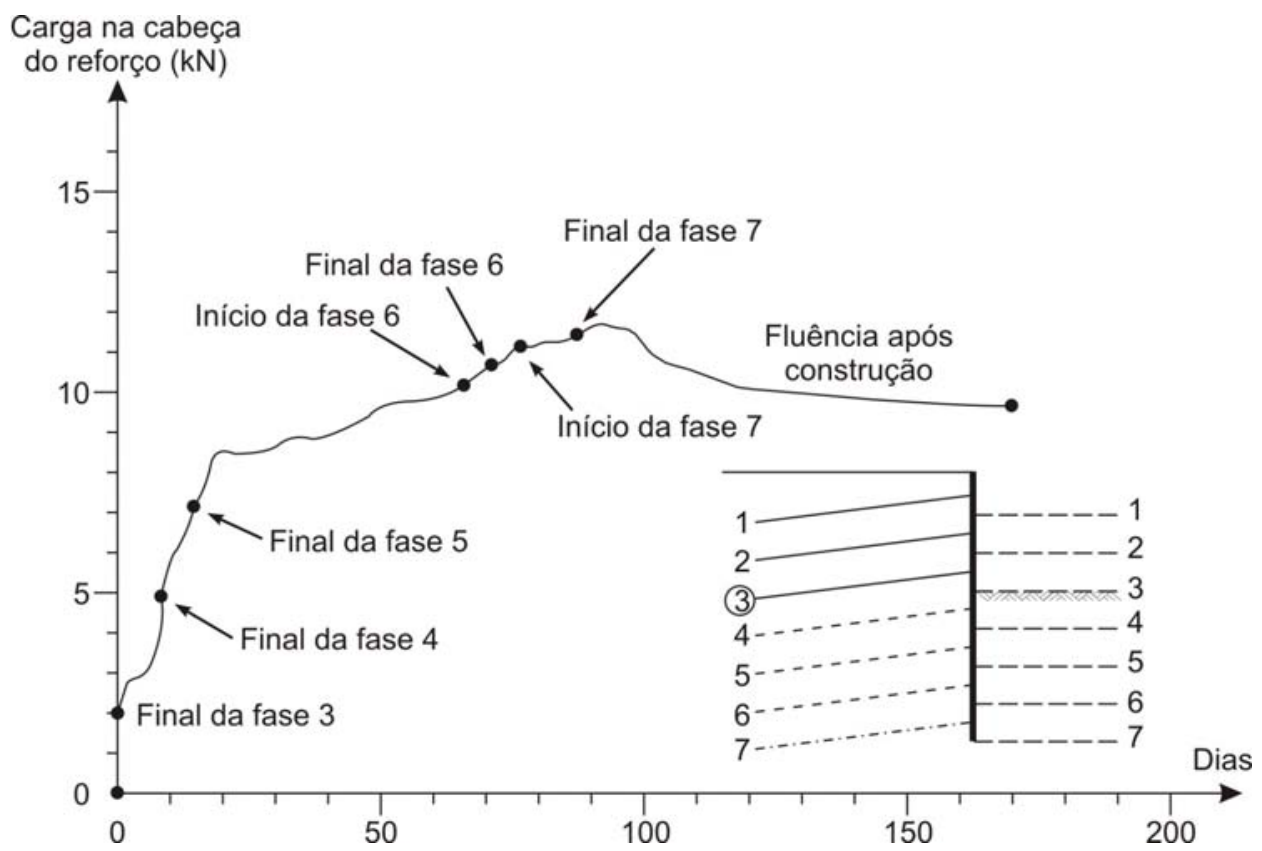

Figura 2.19. Desenvolvimento progressivo de esforços de tração no reforço 3 do muro experimental da CEBTP (Clouterre, 1991).

A partir da Figura 2.19, observa-se que os esforços de tração no reforço $\mathrm{n}^{\circ} 3$ são mobilizados de forma gradativa após a escavação das fases (4, 5, 6 e 7). Ao final da fase 7, observa-se um ligeiro decréscimo nos valores de tração em função das deformações a longo prazo. Desta forma, pode-se dizer que a mobilização dos esforços em um reforço genérico (i) está relacionada, principalmente, com as três fases subseqüentes de escavação: $i_{+1}, i_{+2} e$ $i_{+3}$. Como resultado, tem-se que as linhas de reforços situadas na porção inferior da estrutura são menos submetidas aos esforços de tração. No sistema Terra Armada, ao contrário, os reforços localizados na região inferior são os mais solicitados (Clouterre, 1991).

Rigidez do reforço: em uma estrutura de solo pregado, as barras de aço (reforços) podem resistir às solicitações de tração, cisalhamento e aos momentos fletores. A mobilização de momentos fletores e esforços cisalhantes dependem de muitos fatores, entre os quais: rigidez da barra de aço (reforço), trajetória de deformação e deslocamento do maciço de solo reforçado, orientação dos reforços e fator de segurança em relação à ruptura. A habilidade de resistir aos momentos fletores está 
principalmente relacionada à rigidez das barras de aço e é geralmente maior nos reforços injetados do que nos cravados. No sistema Terra Armada, as fitas metálicas são completamente flexíveis e resistem somente aos esforços de tração.

Natureza do solo: no sistema Terra Armada, o aterro é composto por material granular, com pequena porcentagem de finos. Conseqüentemente, a interação soloreforço é composta apenas pela parcela de atrito, e a elevada permeabilidade deste solo faz com que o teor de umidade do maciço seja muito bem controlado. No sistema solo pregado, como o processo é realizado em terrenos naturais, o solo apresenta-se mais heterogêneo, e o teor de umidade pode ser mais elevado.

\subsection{VANTAGENS DA TÉCNICA DE SOLO PREGADO}

A estabilização de taludes e escavações com a técnica de solo pregado apresenta algumas vantagens em relação às técnicas similares de reforço normalmente utilizadas, entre as quais pode-se citar:

Baixo custo: nesta técnica, o único elemento estrutural utilizado para a estabilização são os chumbadores. A proteção do talude/escavação, seja em concreto projetado ou outro tipo de estrutura tem custo relativamente baixo em relação às soluções convencionais;

D Equipamentos leves: os equipamentos utilizados nas diferentes etapas de execução (perfuração, injeção de calda de cimento e lançamento de concreto projetado) são leves e de fácil manuseio;

Velocidade de execução: as técnicas utilizadas na execução do solo pregado permitem uma boa produção. O tempo de execução é, em geral, muito menor, se comparado às soluções convencionais;

Deformabilidade: por ser uma estrutura deformável, na sua essência de funcionamento, suporta, com segurança, a ocorrência de recalques totais ou diferenciais; 
Flexibilidade: permite grande adaptação do projeto às condições geométricas do talude, além de inclinação da face, distribuição e dimensionamento dos chumbadores nos diferentes estágios de construção.

\subsection{AVAUAÇÃO DA APUCABIUDADE DA TÉCNICA DE SOLO PREGADO}

O solo pregado pode ser utilizado em uma ampla variabilidade de solos. As experiências de projeto mostram que, quando aplicada em condições favoráveis, esta solução apresenta-se muito viável e econômica. Entretanto, em condições não favoráveis, o fator custo pode inviabilizar esta solução.

\subsubsection{Condições Favoráveis}

A seguir, apresentam-se as situações mais favoráveis para a aplicação da técnica de solo pregado (Elias et al., 2003).

Solos que apresentam estabilidade durante um ou dois dias, em relação aos cortes verticais entre 1,0 e 2,0 m;

Os reforços encontram-se posicionados acima do lençol freático. Para as situações contrárias, medidas precisam ser tomadas para que o lençol freático não interfira na escavação, na resistência ao cisalhamento de interface solo-reforço e na integridade dos chumbadores (eventuais agentes químicos que podem acelerar os processos de corrosão);

As condições favoráveis podem ser comprovadas a partir da interpretação das sondagens à percussão. $\mathrm{O}$ índice $\left(\mathrm{N}_{\mathrm{spt}}\right)$ serve para indicar, preliminarmente, a competência do solo para esta finalidade. A seguir apresentam-se os materiais com propriedades adequadas para a utilização como solo pregado (Elias et al.,2003):

Solos finos e rígidos: representados por argila rígida, argila siltosa, silte argiloso, areia argilosa e areia siltosa. Estes solos finos são classificados como rígidos 
quando apresentam $\mathrm{N}_{\mathrm{spt}}$ superiores a 9. Para minimizar os deslocamentos laterais do solo pregado, estes solos devem apresentar baixa plasticidade $(\mathrm{IP}<15)$;

Solo granular denso com alguma coesão aparente: representados por areias e pedregulhos com índice $\mathrm{N}_{\mathrm{spt}}$ mínimo de 30 (Terzaghi et al., 1996), com pequena quantidade de finos em sua composição (entre 10 e 15\%) e alguma cimentação para promover uma coesão aparente;

Rochas que não apresentam planos de ruptura: podem ser considerados bons materiais quando os planos de ruptura não apresentam orientações desfavoráveis, ou seja, devem ter direção de mergulho para dentro da escavação.

\subsubsection{Condições Desfavoráveis}

Por outro lado, existem algumas situações desfavoráveis para o emprego do solo pregado. Estas limitações podem ser tecnicamente resolvidas por projetos apropriados ou construções provisórias, mas que nem sempre apresentam um custo-benefício adequado. A seguir, apresentam-se os tipos de solos ou condições em que a técnica de solo pregado não é bem adaptável (Mitchell \& Villet, 1987; Clouterre, 1991 e Springer et al., 2001).

Solos granulares fofos que apresentam densidade relativa $\left(D_{r}\right)$ inferior a 30\%. Estes tipos de solos não exibem capacidade de suporte e são sensíveis ao processo de vibração induzida pelo equipamento utilizado durante o processo de perfuração do terreno;

> Solos granulares (sem coesão), mal graduados e com coeficiente de uniformidade $\left(\mathrm{C}_{\mathrm{u}}\right)$ menor que 2. Este tipo de solo não apresenta estabilidade satisfatória durante a etapa de escavação, exceção feita quando se apresentam mais compacto;

Solos que apresentam teor de umidade excessivo ou tendência expansiva. Estes solos podem apresentar problemas de estabilidade quando a face estiver exposta, isto é, quando a coesão aparente for reduzida;

Solos orgânicos ou solos argilosos que apresentam resistência ao cisalhamento não drenada menor que $50 \mathrm{kPa}$. Para estas situações, o aumento do grau de saturação pode reduzir, significantemente, o valor de $q_{s}$. O acréscimo da saturação e a 
conseqüente redução da resistência ao cisalhamento do solo podem resultar em um aumento nos esforços de tração no reforço;

Solos que apresentam, em sua composição, elementos agressivos aos materiais que compõem o reforço e a face, principalmente quando o solo pregado é utilizado como estrutura permanente;

Rochas que apresentam fraturas (rochas calcárias) e materiais granulares que apresentam grandes vazios (pedregulhos). Estes materiais precisam de um cuidado especial durante o processo de injeção de calda de cimento. Para maximizar a eficiência do processo de injeção, devem ser tomadas algumas medidas construtivas, entre as quais a utilização de geotêxtil atrás do paramento ou calda de cimento com baixo slump;

Quando empregado em centros urbanos que apresentem edificações no seu entorno. Para esta situação, deve-se avaliar, preliminarmente, se estas construções irão tolerar os deslocamentos e/ou recalques gerados. Quando for necessário minimizar estes deslocamentos, podem-se utilizar estruturas mistas. Estas estruturas consistem em uma estrutura de solo pregado enrijecido com tirantes no seu topo. Os tirantes devem apresentar comprimentos superiores aos dos chumbadores, pois devem estar ancorados atrás do maciço reforçado.

\subsection{MECANISMO DE INTERAÇÃO SOLO-REFORÇO}

O mecanismo de interação solo-reforço no sistema solo pregado é complexo e varia amplamente com a metodologia executiva, com o tipo de aplicação (estrutura de contenção ou estabilização de taludes), com as propriedades do solo e com as características dos reforços (e.g. comprimento da barra, tipo de barra de aço, diâmetro da coluna da calda de cimento e inclinação do reforço). Com exceção das características mecânicas do solo, todos os outros fatores podem ser controlados e padronizados na execução dos chumbadores.

O processo de interação solo-reforço envolve essencialmente dois mecanismos que contribuem para a melhoria da estabilidade do maciço de solo. O primeiro mecanismo refere-se à resistência ao cisalhamento desenvolvida na interface solo-reforço, conhecida 
como $q_{s}$. Este mecanismo induz o desenvolvimento de tensões de tração nos elementos de reforço. A segunda e menos importante interação refere-se ao esforço normal (empuxo) que o solo exerce sobre o reforço. Esta solicitação faz com que seja desenvolvida uma zona cisalhante no interior da massa de solo, que, consequentemente, promove uma mobilização de momento fletor e de esforço cisalhante no reforço. Estes mecanismos, representados na Figura 2.20, ainda não se encontram totalmente esclarecidos, fato este que resulta no empirismo dos atuais métodos de projeto.

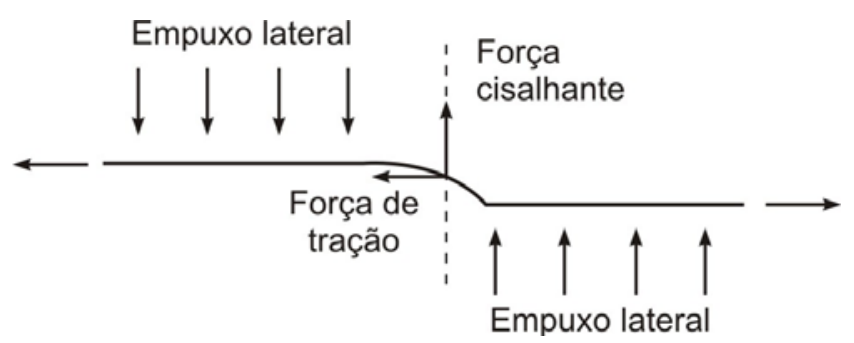

Figura 2.20. Mecanismos de interação solo-reforço na estrutura de solo pregado (Sheahan \& Alvarado, 1996).

Embora possam ocorrer os dois mecanismos, a maioria dos pesquisadores considera que a interação solo-reforço é oriunda, principalmente, da resistência ao cisalhamento de interface (Stocker et al., 1979). Na seqüência, apresentam-se os dois mecanismos fundamentais que regem a interação solo-reforço.

\subsubsection{Resistência ao Cisalhamento de Interface Solo-Reforço}

A estabilidade de uma estrutura reforçada com solo pregado é geralmente estudada em seu estado limite último. Sendo assim, o conhecimento do comportamento solo-reforço, principalmente em relação à resistência ao cisalhamento desenvolvida na interface $\left(q_{s}\right)$, é extremamente importante para fins de projeto.

A interação na interface solo-calda de cimento tem sido frequentemente estudada para tirantes ancorados em maciços rochosos sãos e brandos, ao contrário da utilização em solos, cujas informações são muito restritas. Hanna (1982) considera que a superfície de ruptura na interface é condicionada pela rugosidade da parede do furo, pela resistência do 
maciço e também pela alteração do estado de tensões nas vizinhanças da parede do furo, devido aos processos de perfuração, construção e injeção. Como conseqüência, o comportamento da interface solo-calda de cimento está longe de ser bem compreendido, devido a enorme variação de tipos de solos que ocorrem na natureza. Além disto, ao tracionar um chumbador, a transferência de carga é feita da calda de cimento para o maciço sob a forma de tensões radiais e cisalhantes. A ruptura pode ocorrer a uma determinada distância dentro do maciço ou na interface, dependendo da resistência relativa da interface e do maciço adjacente.

Frazén (1998) descreve que a resistência ao arrancamento de um chumbador é definida por quatro variáveis: a tensão normal atuando na superfície do reforço, o coeficiente de atrito, a adesão entre o chumbador e o solo, e o perímetro do chumbador. Ortigão (1997) também destaca como relevantes as características do terreno, a profundidade do ensaio, o método de perfuração e a limpeza do furo, as propriedades da calda de cimento e os fatores ambientais, tais como a temperatura e a umidade.

Em materiais granulares, a resistência ao cisalhamento de interface de um chumbador submetido a esforços de tração é governada pelo atrito desenvolvido ao longo do reforço e pelo comportamento dilatante do solo, conforme apresentado na Figura 2.21.

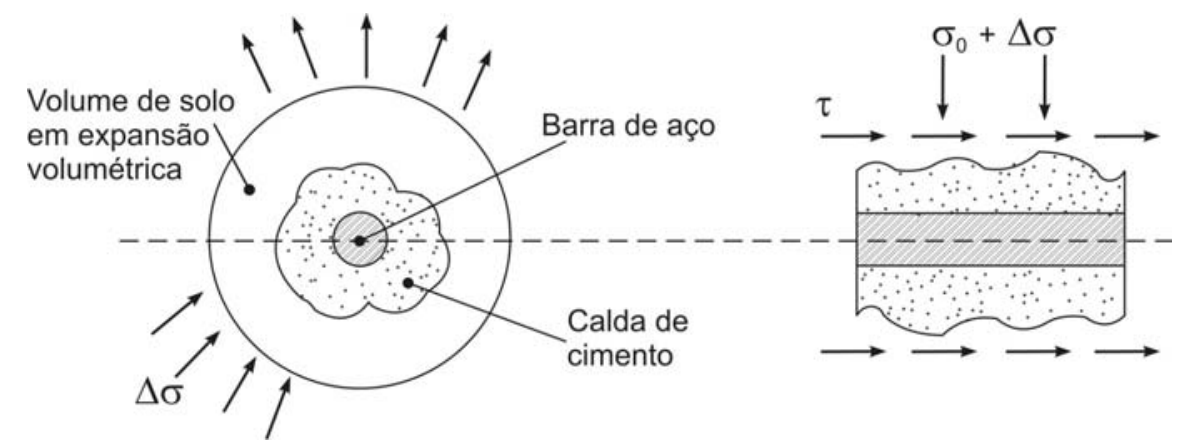

Figura 2.21. Mecanismo de interação solo-reforço em solo granular compactado (Schlosser, 1982).

A tendência de um solo granular e denso, quando submetido a um esforço de cisalhamento, é de aumentar seu volume. Entretanto, como esta condição é restringida pela baixa compressibilidade da massa de solo situada ao redor do reforço, gera-se um incremento de tensão $(\Delta \sigma)$ sobre a superfície do reforço. Este fenômeno é conhecido como restrição de dilatância e foi verificado in situ, pela primeira vez, durante a realização de 
ensaios de arrancamento em chumbadores instalados em um aterro composto pela areia Fontainebleau (Schlosser, 1982). Os resultados obtidos estão apresentados na Figura 2.22.

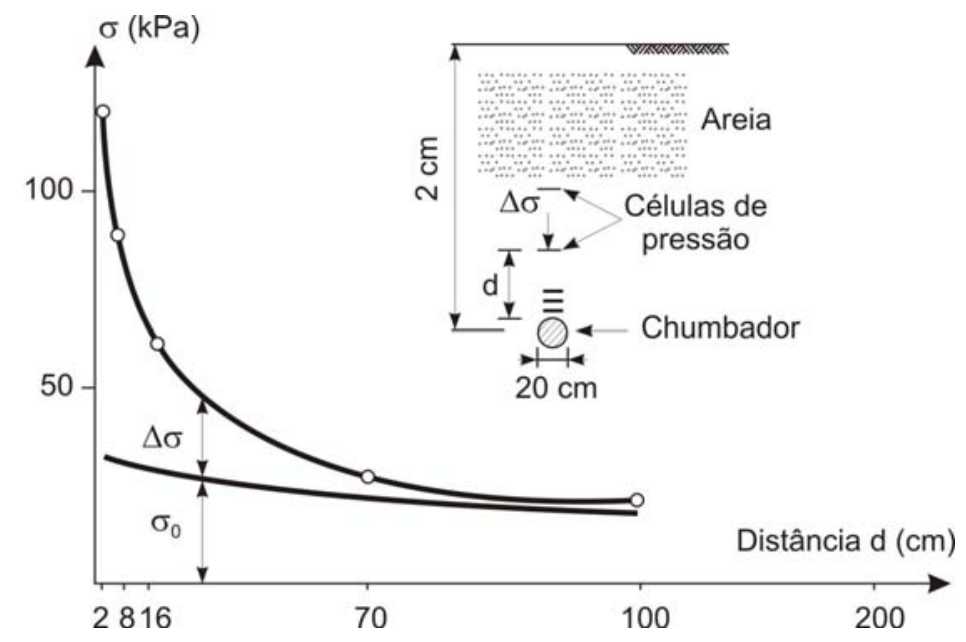

Figura 2.22. Incremento da tensão normal devido ao efeito da restrição da dilatância ao redor do reforço solicitado à tração (Clouterre, 1991).

A partir da Figura 2.22, verifica-se que o efeito da restrição da dilatância pode gerar, ao redor do chumbador, um incremento de tensão normal quatro vezes superior à tensão normal inicial $\left(\sigma_{0}\right)$.

No sistema solo pregado, a geometria da estrutura e a inclinação dos reforços dificultam a determinação da tensão normal atuante sobre o reforço $\left(\sigma_{0}\right)$. Além disto, a magnitude de $\sigma_{0}$ é altamente dependente do método de execução dos reforços. Para barras de aço cravadas horizontalmente, a tensão $\sigma_{0}$ é muito próxima da tensão geostática, entretanto, para chumbadores injetados, este valor pode ser bem baixo e aproximadamente constante com a profundidade.

Cartier \& Gigan (1983) realizaram ensaios de arrancamento em reforços cravados em material granular. Os reforços foram compostos por cantoneiras de aço, com seções

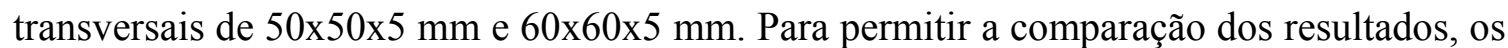
valores de $q_{s}$, obtidos para os reforços de maior seção transversal, foram recalculados considerando uma seção equivalente à menor seção transversal. Os resultados estão apresentados na Figura 2.23. 


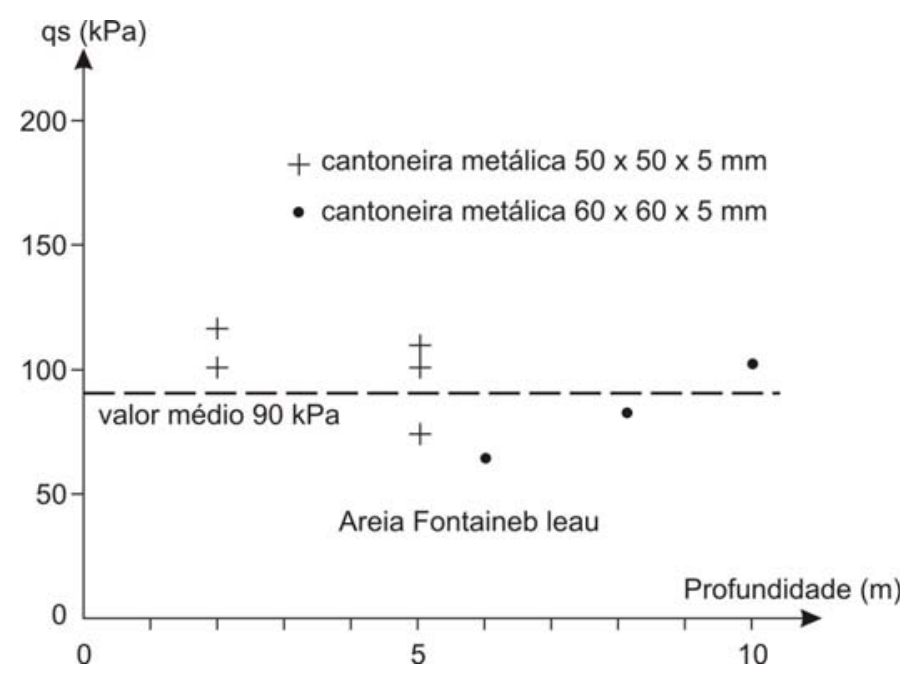

Figura 2.23. Variação da resistência ao cisalhamento de interface ao longo da profundidade (Cartier \& Gigan, 1983).

Os resultados apresentados na Figura 2.23 mostraram que o valor de $q_{s}$ é aproximadamente constante com a profundidade. A independência em relação à profundidade deve-se ao fato de que a redução do coeficiente de atrito aparente $\left(u^{*}\right)$, devido à redução da dilatância, é compensada pelo incremento de tensão normal $\left(\sigma_{0}\right)$ ao longo da profundidade.

Para solos bem graduados, ou seja, que apresentam ângulo de atrito e intercepto de coesão, a resistência ao cisalhamento de interface é fortemente influenciada pelo teor de umidade do solo. A Figura 2.24 compara os resultados de dois ensaios de arrancamento realizados em fitas nervuradas, com $0,04 \mathrm{~m}$ de largura e $2,0 \mathrm{~m}$ de comprimento, posicionadas em um aterro composto por solo granular argiloso a 5,0 $\mathrm{m}$ de profundidade. Os ensaios foram realizados considerando diferentes teores de umidade no maciço de solo. 


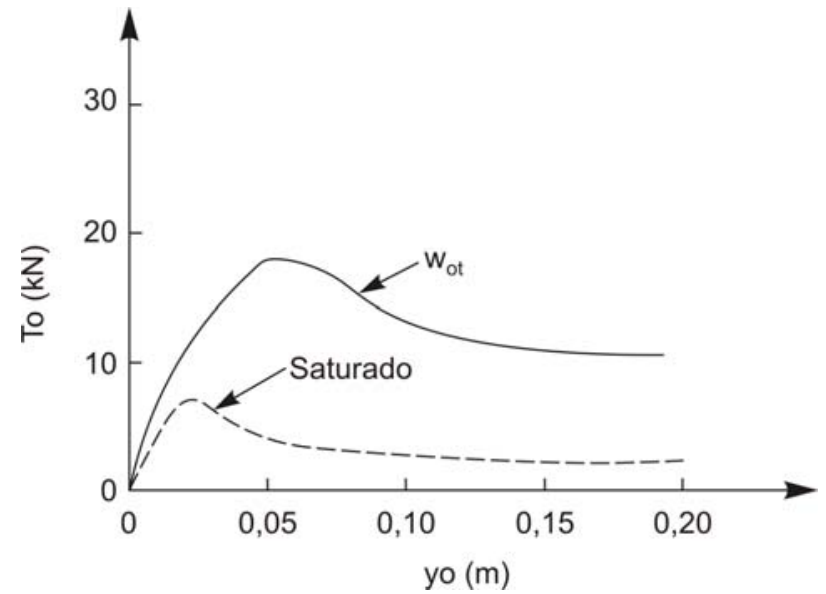

Figura 2.24. Avaliação da influência do teor de umidade em ensaios de arrancamento realizados em aterro composto por solo granular argiloso (Schlosser, 1982).

Os resultados apresentados na Figura 2.24 mostram que quando o teor de umidade do maciço é superior ao teor de umidade ótimo de compactação ( $w_{o ́ t}$ ), ou seja, quando se apresenta saturado, a magnitude da força máxima de arrancamento é dividida por um fator maior que 2, enquanto que o deslocamento, correspondente a esta força, é dividido por um fator igual a 3. O parâmetro $\left(q_{s}\right)$ para solos de granulometria fina (silte e argila) pode ser amplamente influenciado pelo grau de saturação $\left(\mathrm{S}_{\mathrm{r}}\right)$. Quando o solo está saturado, o valor de $q_{s}$ deve-se à coesão não drenada do solo, sendo insuficiente para o desenvolvimento de esforços de tração nos reforços. A utilização destes solos torna-se inadequada, se sistemas de drenagem não forem corretamente dimensionados.

De forma geral, pode-se dizer que a resistência ao cisalhamento de interface se desenvolve ao longo de toda a extensão do reforço, de forma coerente, com a tendência do movimento relativo da interface, ou seja, apresentando direções opostas nas zonas ativa e resistente (Figura 2.25). Ao contrário do preconizado na teoria clássica de empuxos de terra, os termos ativo e passivo referem-se à forma de mobilização dos esforços nos reforços. O limite entre as duas regiões (superfície de ruptura) é definido pela ligação dos pontos de tração máxima ( $\left.T_{\text {máx }}\right)$ de cada um dos reforços. (Springer et al., 2001). Ao longo do programa Clouterre foram realizados vários estudos experimentais para analisar a mobilização deste parâmetro. Assim como ocorre em fundações por estacas, é necessário um pequeno deslocamento relativo (da ordem de poucos milímetros) do reforço em relação ao solo, para mobilizá-lo. 

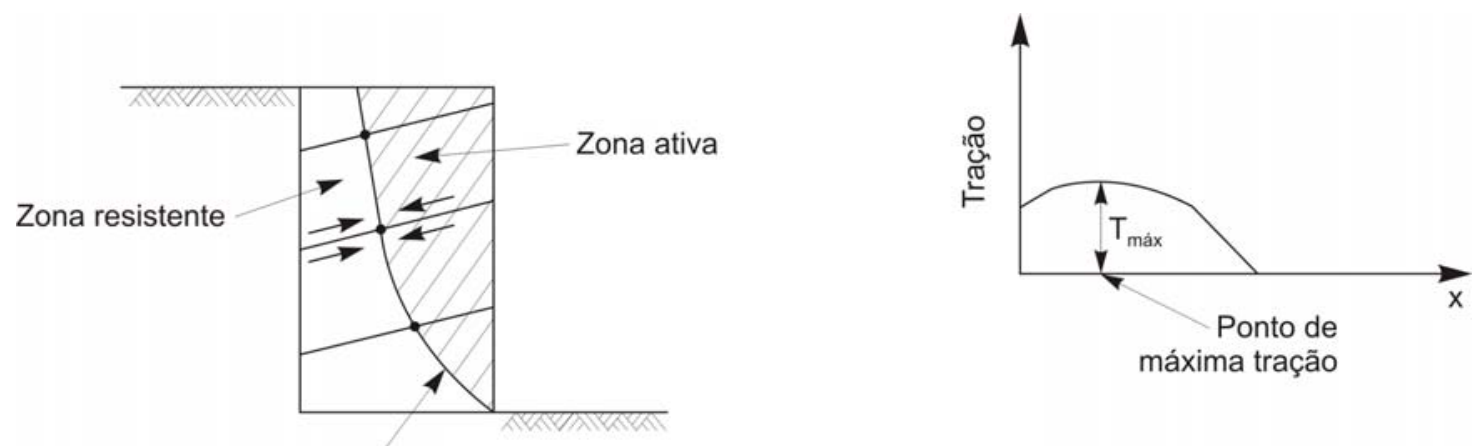

Superficie de ruptura

Figura 2.25. Força mobilizada no reforço (Ehrlich, 2003).

A partir de ensaios de arrancamento realizados na areia Fountaibleau (Clouterre,1991), constatou-se que a mobilização de $q_{s}$ pode ser representada pela curva teórica de Frank \& Zhao (1982), representada na Figura 2.26. Esta aproximação pode ser justificada pela similaridade entre as curvas teóricas e experimentais.

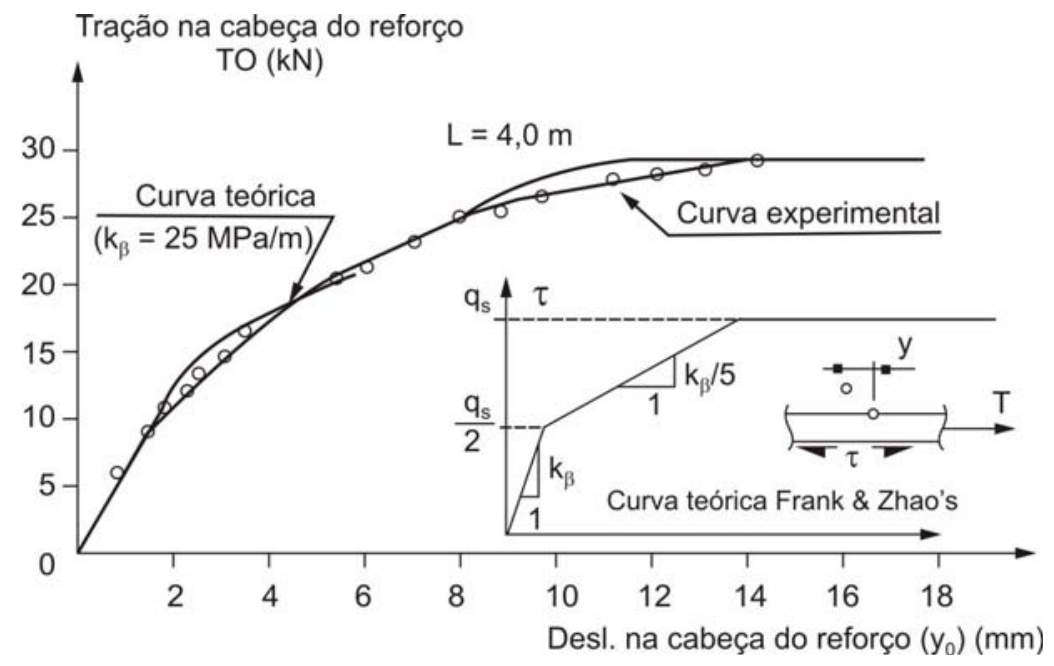

Figura 2.26. Modelagem de uma curva experimental de arrancamento pela lei de Frank \& Zhao (1982) (Clouterre, 1991).

A partir da Figura 2.26, verifica-se que a lei bi-linear de Frank \& Zhao (1982) é representada no plano $(\tau, \mathrm{y})$ por um valor limite de $q_{s}$. O ponto de inflexão das retas é representado por $q_{s} / 2$. Esta curva permite ainda caracterizar a inclinação do primeiro segmento, representado pelo parâmetro $k_{\beta}$. 


\subsubsection{Mobilização do $q_{s}$ com a Deformação}

As deformações internas, especialmente as horizontais, são desenvolvidas nas estruturas de solo pregado a partir da descompressão lateral causada pelas escavações sucessivas do maciço de solo. Estas deformações induzem a mobilização de $q_{s}$ ao longo dos reforços e, conseqüentemente, dos esforços de tração nos reforços. Como os chumbadores trabalham basicamente sob tração, quanto maior for a interação da interface, maior será a contribuição do reforço para a estabilização do sistema.

A magnitude dos deslocamentos depende de uma série de fatores, entre eles: altura do muro, ângulo de inclinação da face, densidade e rigidez do reforço, tipo de solo e metodologia executiva (Clouterre, 1991). Na tentativa de representar a influência do tipo de solo na distribuição dos deslocamentos internos da estrutura de solo pregado, apresentam-se os resultados de duas obras instrumentadas, construídas com solos distintos (arenoso e argiloso).

A primeira obra instrumentada refere-se a uma estrutura de solo pregado, de 7,0 metros de altura, construída pela CEBTP (Figura 2.27). No interior do maciço de solo composto por material granular $\left(\phi^{\prime}=38^{\circ}\right.$ e $\left.c^{\prime}=4 \mathrm{kPa}\right)$, foram posicionados dois inclinômetros a 2,0 e 4,0 m da face. Os chumbadores foram injetados com comprimento variável entre 6,0 e $8,0 \mathrm{~m}$ e instalados com $10^{\circ}$ de inclinação em relação à direção horizontal. A partir dos dados de instrumentação, verificou-se que as maiores deformações concentraram-se a uma distância de 0 a $4 \mathrm{~m}$ da face. $O$ deslocamento horizontal máximo medido no topo da face foi da ordem de $0,3 \%$ da altura $(\mathrm{H})$ da contenção. Estes deslocamentos foram se reduzindo à medida que se afastava da face. 


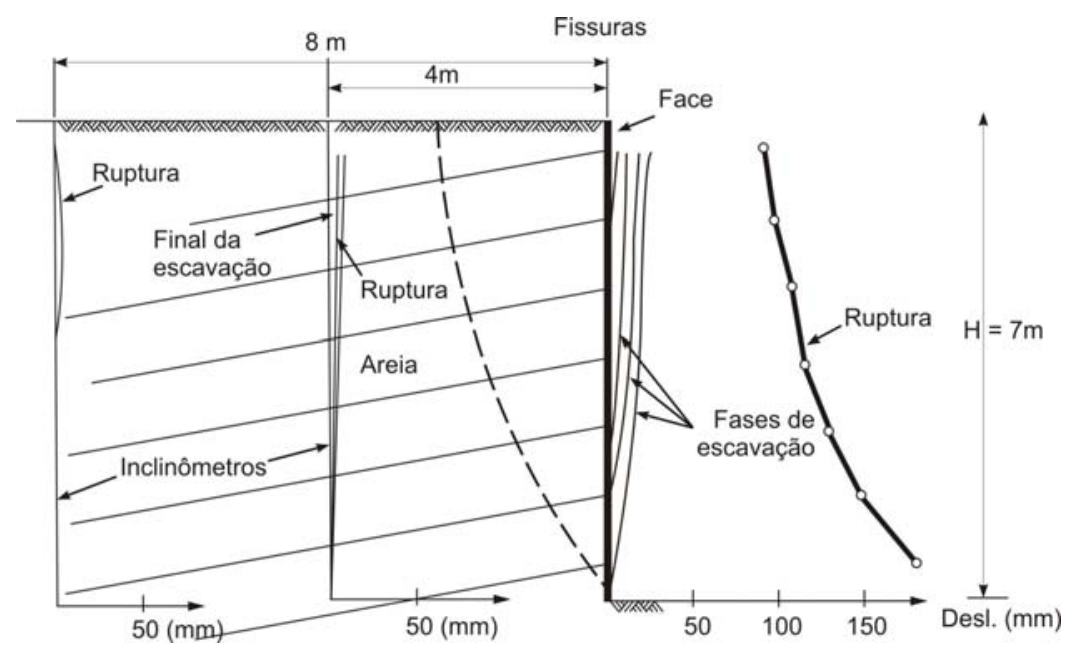

Figura 2.27. Desenvolvimento dos deslocamentos horizontais no muro experimental de solo pregado de CEBTP (Clouterre, 1991).

A segunda obra instrumentada foi construída na rodovia que liga Vierzon a Bourges e foi monitorada pela CEBTP. Trata-se de uma estrutura de solo pregado construída com solo argiloso, com 5,40 m de altura e 1,0 m de ficha. Foram inseridas quatro linhas de chumbadores, as três primeiras com $5,0 \mathrm{~m}$ e a última com $4,0 \mathrm{~m}$ de comprimento. Os deslocamentos horizontais do solo reforçado foram determinados a partir de três inclinômetros posicionados no interior do maciço de solo (Figura 2.28). Os deslocamentos horizontais apresentaram-se distribuídos de forma mais uniforme no interior do maciço de solo, apresentando magnitude máxima $(0,4 \% \mathrm{H})$ no topo da estrutura. 


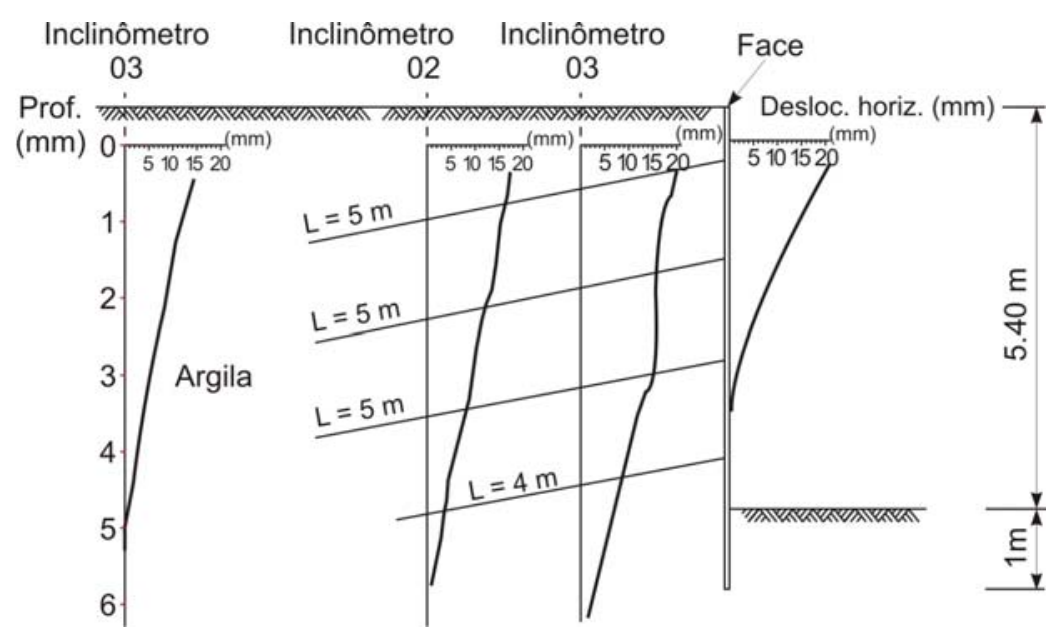

Figura 2.28. Deslocamentos horizontais do muro de solo pregado construído em solos argilosos em Vierzon, monitorado pela CEBTP (Clouterre, 1991).

Os resultados das instrumentações ajudam a definir a ordem de grandeza das deformações para fins de projeto. Dados de instrumentação em obras realizadas nos Estados Unidos mostraram deslocamentos da ordem de $0,07 \% \mathrm{H}$ e $3,0 \% \mathrm{H}$, enquanto, na Alemanha, a ordem dos deslocamentos foi de $0,25 \% \mathrm{H}$ e $0,30 \% \mathrm{H}$ (Schlosser et al., 1992).

A previsão das deformações em solo pregado também é possível a partir da utilização de ferramentas numéricas, capazes de simular seqüências construtivas e incorporar modelos constitutivos que reproduzam o comportamento dos materiais envolvidos neste tipo de obra (Lima, 2002).Vários autores têm empregado simulações numéricas para a realização de estudos paramétricos de obras de solos pregados. Maiores informações podem ser encontradas nos seguintes trabalhos: Ehrlich et al., 1996; Cardoso \& Gonçalves, 1997; Borja et al., 1999; Springer et al.2001 e Gercovich et al., 2002.

\subsubsection{Empuxo do Solo Sobre o Reforço}

Embora a resistência ao cisalhamento de interface domine o mecanismo de interação solo-reforço, o empuxo do solo também pode estar atuando sobre o reforço. Para tal, é necessário que o reforço apresente rigidez e que seja desenvolvida uma zona de cisalhamento no interior do maciço de solo. Esta solicitação ocorre, principalmente, quando se utiliza a técnica de solo pregado para estabilização de taludes. Quando empregada em 
estrutura de contenção, este tipo de solicitação apresenta-se com menor magnitude, geralmente, associada a maciços que apresentam baixos fatores de segurança. Este mecanismo foi verificado no muro experimental dimensionado com baixo fator de segurança $(\mathrm{FS}=1,1)$ pela CEBTP, visando atingir a condição de ruptura com um aumento gradual da saturação do solo a partir do topo da estrutura (Figura 2.29).

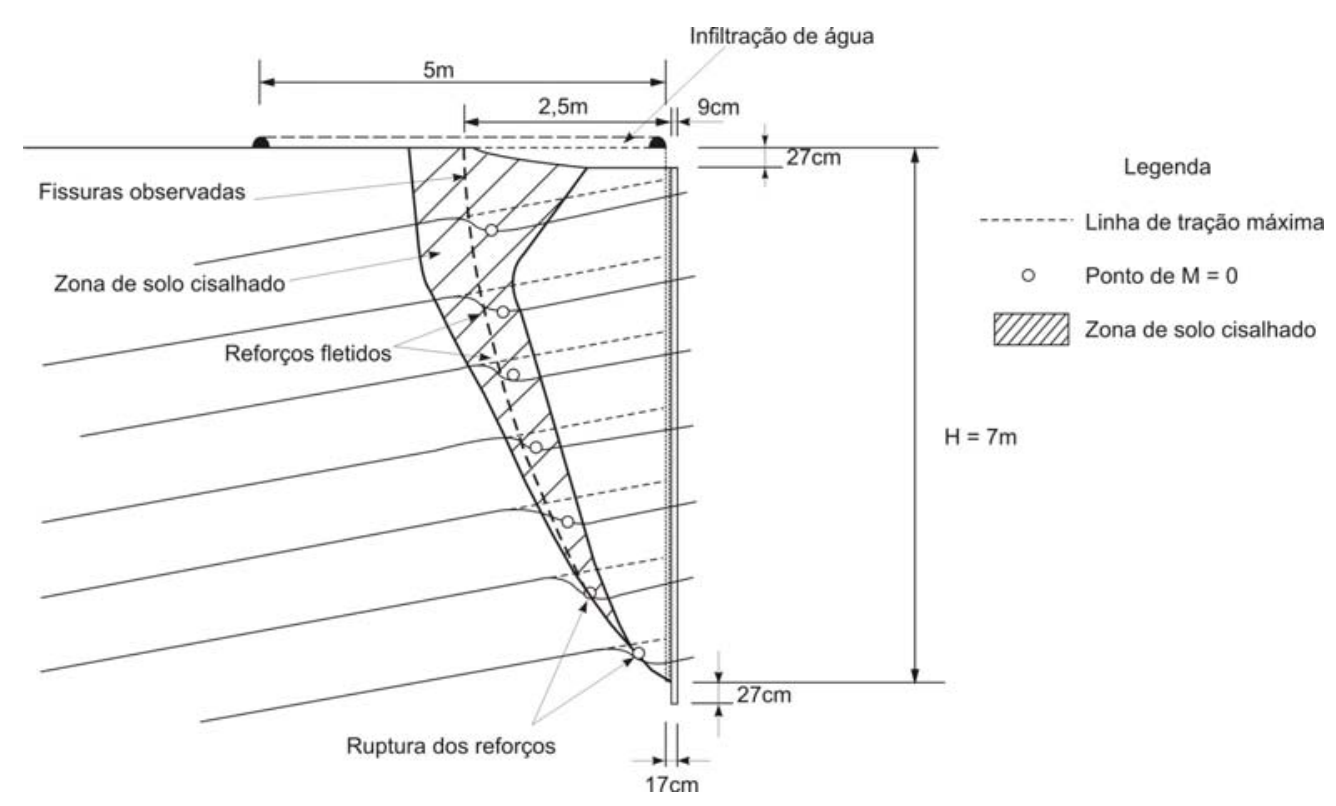

Figura 2.29. Muro experimental $n^{\circ} 1$ realizado pela CEBTP (Clouterre, 1991).

A Figura 2.29 mostra que após a ocorrência da ruptura do reforço, desenvolveu-se uma zona de cisalhamento ao redor da superfície de ruptura, onde as deformações do solo se concentraram. Neste sentido, os reforços foram solicitados por momento fletor e por esforços cisalhantes, além dos esforços de tração. Quando submetidos a estas condições e solicitações, as deformações nos reforços podem ser determinadas de forma análoga às estacas solicitadas no seu topo por carregamentos horizontais e momento fletor (Figura 2.30). 


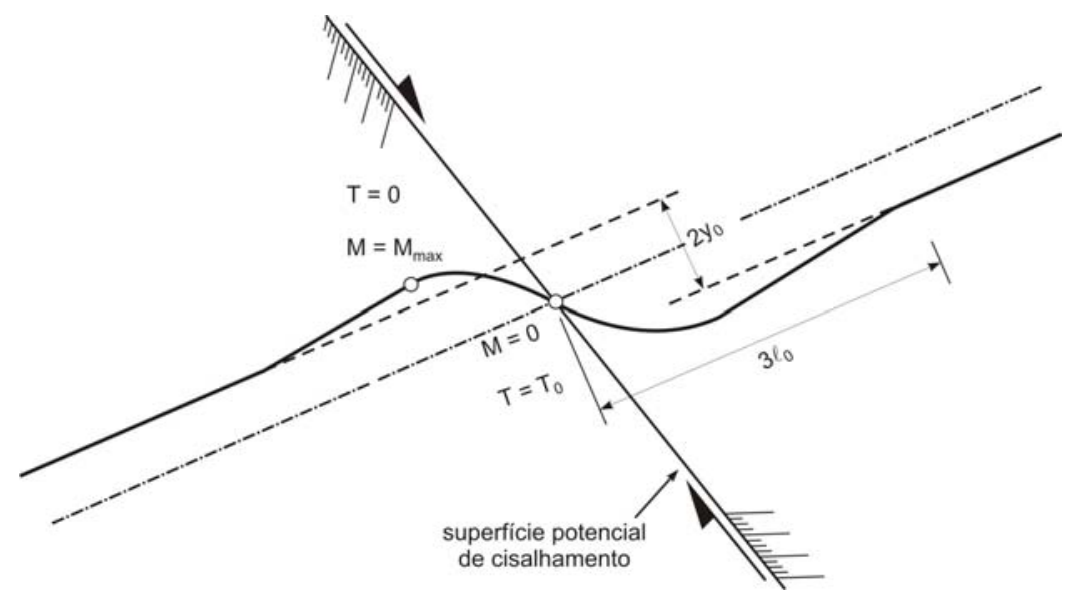

Figura 2.30. Determinação das deformações nos reforços de forma análoga a estaca carregada horizontalmente no seu topo (Schlosser, 1982).

As deformações nos reforços podem ser determinadas a partir de um método simplificado de cálculo que considera o coeficiente de reação do solo de fundação, conforme equação apresentada a seguir.

$$
E I \cdot \frac{d^{4} y}{d z}+K_{s} \cdot D \cdot y=0
$$

em que:

E: módulo de elasticidade do elemento de reforço (barra de aço);

I: momento de inércia do elemento de reforço (barra de aço);

$\mathrm{k}_{\mathrm{s}}$ : coeficiente de reação do solo de fundação;

y: deslocamento lateral do reforço;

z: cota do reforço;

p: empuxo lateral do solo sobre o reforço $\left(p=k_{s} y\right)$;

D: diâmetro do reforço.

A partir da solução desta equação, pode-se introduzir o conceito de comprimento de transferência $\left(1_{0}\right)$, parâmetro muito útil em projeto e que caracteriza a rigidez relativa entre a barra de aço e o solo, conforme equação representada por:

$$
l_{0}=\sqrt{\frac{4 E I}{K_{s} D}}
$$


O coeficiente de reação do solo de fundação $\left(\mathrm{K}_{\mathrm{s}}\right)$ é geralmente calculado a partir do módulo pressiométrico obtido por ensaios pressiométricos. Maiores informações em relação aos ensaios pressiométricos serão apresentadas no Capítulo Materiais e Métodos.

A partir da teoria da elasticidade, verifica-se que quando o comprimento do reforço (L) é maior ou igual a $31_{0}$, o reforço pode ser considerado como flexível e o desenvolvimento da resistência ao cisalhamento de interface é predominante. Quando o comprimento do reforço (L) é inferior a $31_{0}$, o empuxo do solo sobre o reforço passa a ter grande importância para fins de projeto. A influência da rigidez do reforço no desenvolvimento do empuxo do solo sobre o reforço é representada na Figura 2.31 para os dois casos limites: reforços flexíveis e completamente rígidos.

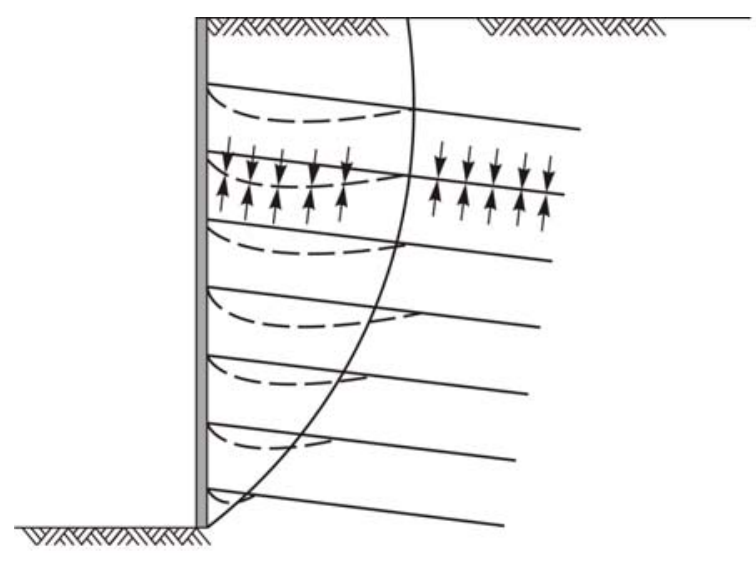

(a)

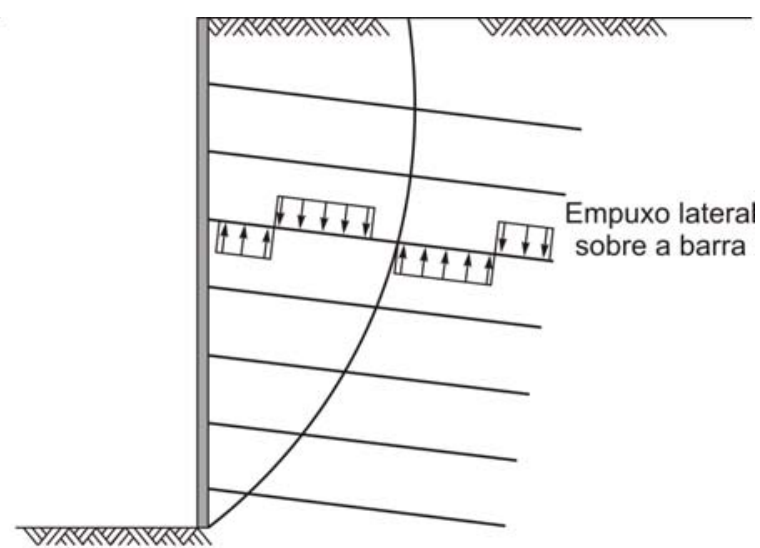

(b)

Figura 2.31. Efeito da rigidez do reforço no desenvolvimento do empuxo atuante sobre o reforço: (a) reforço flexível; (b) reforço rígido (Mitchell \& Villet, 1987).

Da análise da Figura 2.31, verifica-se que o reforço flexível deforma-se até atingir a condição de equilíbrio. Como os reforços rígidos resistem às deformações, os empuxos atuantes sobre os reforços, em ambos os lados da superfície de ruptura, geram tensões cisalhantes no reforço. Para manter a condição de equilíbrio, os reforços devem resistir aos esforços de tração, cisalhamento e momentos fletores.

As pesquisas conduzidas ao longo das últimas décadas mostram que pequenos deslocamentos são suficientes para mobilizar a resistência ao cisalhamento de interface 
solo-reforço e, conseqüentemente, forças de tração nos elementos de reforço. Entretanto, são necessários, relativamente, maiores deslocamentos para mobilizar o empuxo do solo sobre o reforço. Como a grande maioria das obras com solo pregado enquadra-se na primeira situação, o mecanismo do empuxo atuante sobre o reforço é quase sempre desconsiderado.Maiores informações sobre o efeito do empuxo do solo sobre reforços rígidos são encontrados nos seguintes trabalhos: Juran \& Elias (1991), Marchal (1984) e Plumele (1989).

\subsubsection{Influência dos Reforços na Mobilização de Tensões}

Para compreender a influência dos reforços na mobilização de tensões no solo reforçado, pode-se recorrer às analogias realizadas em ensaios de cisalhamento direto com a presença do reforço.

Juran et al. (1981) realizaram ensaios de cisalhamento direto de grandes dimensões $(0,4$ x 0,6 x 0,4 m) utilizando solos siltosos. Os reforços, constituídos por barras de aço de diferentes diâmetros, foram dispostos de forma perpendicular à superfície de ruptura. Estes ensaios buscaram avaliar a mobilização dos parâmetros de resistência ao cisalhamento do solo reforçado (coesão e o ângulo de atrito aparente). A partir dos resultados obtidos foi possível tecer alguns comentários (Schlosser, 1982):

A mobilização progressiva da resistência à flexão das barras de aço (reforço) é responsável pela coesão aparente $\left(\mathrm{c}^{*}\right)$ da estrutura de solo pregado;

O deslocamento necessário para mobilizar totalmente a coesão aparente (c*) é muito maior do que o requerido para mobilizar atrito no sistema solo-reforço;

A coesão aparente $\left(\mathrm{c}^{*}\right)$ é maior que a coesão teórica $\left(\mathrm{c}_{0}{ }^{*}\right)$, determinada a partir da força cisalhante $\left(\mathrm{T}_{0}\right)$ mobilizada pelas barras, definida como:

$$
\mathrm{C}_{0}^{*}=\frac{\Sigma \mathrm{T}_{0}}{\mathrm{~A}}
$$


em que: A é a área da seção transversal da barra de aço submetida ao esforço de cisalhamento.

O ângulo de atrito aparente do solo reforçado $\left(\phi^{*}\right)$ é menor que o ângulo de atrito interno do solo $\phi$.

Além dos resultados experimentais, a interação solo-reforço também foi analisada por simulação numérica bi-dimensional com o método de elementos finitos. Nestas análises, os reforços foram simulados com placas equivalentes, assumindo-se a condição de deformação plana (Juran et al., 1990). Os resultados das simulações apresentaram boa concordância com os resultados experimentais e confirmaram que a presença das barras, como elemento de reforço, modifica os estados de tensão e deformação desenvolvidos no interior do maciço de solo. Estes elementos, além de restringirem os deslocamentos cisalhantes do solo ao longo da superfície de ruptura, reduzem a tensão cisalhante atuante sobre o solo e o ângulo de atrito do solo reforçado. Entretanto, a presença do reforço gera uma coesão aparente anisotrópica e um aumento global da resistência ao cisalhamento do solo (Mitchell \& Villet, 1987).

Mediante o exposto, apresenta-se a envoltória de resistência ao cisalhamento do solo reforçado, que é composta por três componentes:

$$
\tau=\mathrm{c}^{*}{ }_{0}+\sigma \operatorname{tg} \phi+\Delta \tau
$$

Em que:

$\mathrm{c}_{0}{ }^{*}$ : coesão aparente definida na equação 2.4 ;

$\sigma \tan \phi$ : resistência ao cisalhamento atritiva;

$\Delta \tau$ : incremento da tensão cisalhante atritiva a partir da inclusão das barras de aço como elemento de reforço.

O efeito da inclinação dos reforços na mobilização da resistência ao cisalhamento de interface solo-reforço foi estudado por Jewell (1980). Para tal, foram realizados ensaios de cisalhamento direto em amostras de areia reforçadas com barras de aço. Os reforços foram instalados com diferentes orientações em relação à superfície de ruptura. Os ensaios 
mostraram que o incremento máximo de tensão cisalhante ocorre quando o reforço apresenta-se na mesma direção do plano de deformação de tração, que pode ser determinado a partir da ruptura de uma amostra de areia não reforçada.

Para exemplificar estes efeitos, apresentam-se os esforços atuantes sobre um reforço posicionado dentro de uma caixa de ensaios preenchida com areia e submetida ao ensaio de cisalhamento direto, fazendo-se uma analogia com o comportamento de um talude de solo reforçado. O reforço está posicionado com uma inclinação $\theta$ em relação à normal da superfície de ruptura.

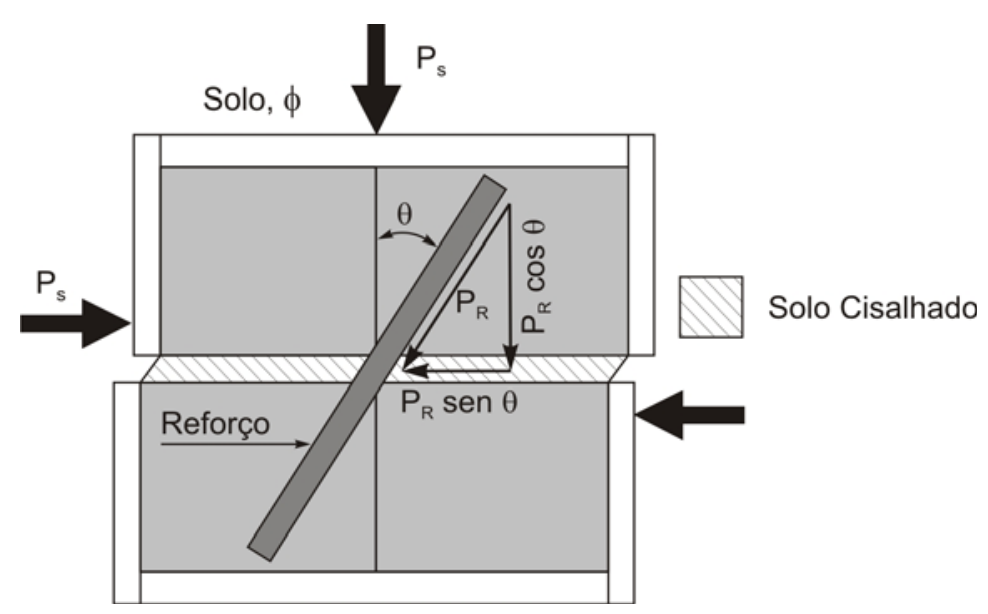

Figura 2.32. Analogia do comportamento de ruptura em talude de solo reforçado com caixa de cisalhamento direto (Jones, 2000).

Sem a presença do reforço, a resistência ao cisalhamento desenvolvida na superfície de ruptura é dada pela Equação 2.5.

$$
P_{\text {resistente }}=P_{v} \tan \phi
$$

em que: $\mathrm{P}_{\mathrm{v}}$ é o carregamento normal atuante sobre a superfície de ruptura em um talude sem reforço.

Ao incluir um reforço com inclinação $\theta$, o solo reforçado passa a ter resistência ao cisalhamento dada por: 


$$
P_{\text {resistente }}=P_{v} \tan \phi+P_{R}(\operatorname{sen} \theta+\cos \theta \tan \phi)
$$

em que: $\mathrm{P}_{\mathrm{R}}$ é a força mobilizada pelo reforço, que na prática é representada pelo menor valor entre a resistência última ao arrancamento e a resistência à tração (resistência à ruptura) do reforço.

A inclinação $\theta$ do reforço é a única geometria variável e, sendo assim, influi de maneira bastante significativa na resistência ao cisalhamento adicional gerada pela inclusão do reforço. A partir dos experimentos realizados por Jewell (1980), verificou-se que a direção ótima, para que os reforços flexíveis mobilizem os esforços de tração, corresponde à direção de máxima extensão em solo não reforçado. Em escavações ou taludes, os chumbadores devem ser instalados horizontalmente ou com pequena inclinação em relação à direção horizontal, para que apresentem um melhor comportamento quando tracionados.

\subsection{DEIERMINAÇÃO DA RESISTÉNCIA AO CISALHAMENTO DE INIERFACE SOLO- REFORÇO}

Dada a importância do conhecimento do comportamento solo-reforço, principalmente em relação à resistência ao cisalhamento de interface, muitos autores desenvolveram métodos de previsão através de modelos teóricos e empíricos. Tanto os métodos teóricos, como os empíricos, são úteis para a previsão na fase preliminar de projeto. Para a realização de projetos mais econômicos e viáveis, é necessária a confirmação destes parâmetros in situ, a partir da realização de ensaios de arrancamento. Estes ensaios fornecem resultados mais realísticos da interação solo-reforço. Na seqüência, apresentam-se as considerações em relação aos métodos de previsão (teóricos e empíricos) e aos ensaios de arrancamento.

\subsubsection{Métodos Teóric os e Empínic os de Previsão}

Muitos autores desenvolveram métodos de previsão de resistência ao cisalhamento de interface $\left(q_{s}\right)$ a partir de modelos teóricos, entre eles, Jewell (1990), Schlosser (1982), 
Bridle e Barr (1990), e Heymann et al. (1992). Estes modelos são úteis para a previsão da resistência de interface solo-reforço, principalmente no estudo da viabilidade da obra e na fase preliminar de projeto. Todos os autores mencionados anteriormente utilizaram, como ponto de partida para o cálculo da resistência ao cisalhamento de interface, a equação da resistência ao cisalhamento do solo (Heymann et al., 1992):

$$
P_{\text {ult }}=\pi \cdot D \cdot L \cdot\left(C^{\prime}+\sigma_{n}^{\prime} \tan \phi^{\prime}\right)
$$

em que:

$P_{u l t}$ força máxima de arrancamento do reforço;

$D$ : diâmetro do reforço (considerando a furo preenchido com calda de cimento);

$L$ : comprimento do reforço;

$c^{\prime}$ : coesão efetiva do solo;

$\sigma_{n}^{\prime}$ : tensão normal efetiva que atua entre o reforço e o solo, na ruptura;

$\Phi '$ ' ângulo de atrito efetivo do solo.

Alguns projetistas consideram que a resistência ao cisalhamento de interface soloreforço pode ser diretamente relacionada com a tensão geostática atuante sobre os reforços (cravados e injetados com calda de cimento). Em um dos trabalhos pioneiros relacionados ao assunto, Shen et al. (1981) assumiram que a resistência de interface é governada pelo critério de ruptura de Coulomb. Jewell (1990) apresentou a seguinte formulação para estimar a resistência ao arrancamento:

$$
T=\pi \cdot D \cdot L_{a} \cdot \sigma^{\prime}{ }_{r} \cdot f_{b} \cdot \tan \phi^{\prime}
$$

em que:

$\mathrm{T}$ : força máxima de arrancamento;

D: diâmetro do elemento do reforço (barra de aço);

$\mathrm{L}_{\mathrm{a}}$ : comprimento de ancoragem; 
$\sigma_{\mathrm{r}}$ : tensão normal efetiva média atuante sobre a circunferência do reforço $\left(0,7 \leq \sigma_{\mathrm{r}} / \sigma^{\prime}{ }_{\mathrm{v}} \leq\right.$ 1,0, para taludes inclinados constituídos por solos pré-adensados, onde $\sigma^{\prime}{ }_{v}$ é a tensão vertical efetiva);

$\mathrm{f}_{\mathrm{b}}$ : coeficiente de aderência ( 1,0 para interfaces ásperas e $0,2-0,4$ para interfaces lisas);

$\phi '$ ângulo de atrito efetivo do solo.

Cartier \& Gigan (1983) correlacionaram a resistência ao arrancamento de inclusões cravadas (cantoneiras de aço) em maciço granular com a tensão vertical e com o coeficiente de atrito aparente $\left(\mu^{*}\right)$, a fim de comparar estes resultados com os valores experimentais de atrito aparente $\left(\mu^{*}\right)$ utilizados em projetos de estruturas de solo reforçado. A correlação realizada é aplicável para solos granulares $(\mathrm{c}=0)$, embora também possa ser empregada para os reforços envolvidos por calda de cimento. A correlação está representada pela equação abaixo:

$$
T_{f}=P \cdot c^{\prime}+2 \cdot D \cdot \sigma_{v} \cdot \mu^{*}
$$

em que:

$\mathrm{T}_{\mathrm{f}}$ força de arrancamento por metro linear;

P: perímetro do reforço;

c': coesão efetiva do solo;

D: diâmetro do elemento de reforço (barra de aço);

$\sigma_{\mathrm{v}}^{\prime}$ : tensão vertical efetiva $(\gamma \cdot \mathrm{h})$.

Bustamante \& Doix (1985) relacionaram o valor de $q_{s}$ com a pressão limite do pressiômetro de Ménard $\left(\mathrm{P}_{\mathrm{L}}\right)$ e com o índice de resistência à penetração $\left(\mathrm{N}_{\mathrm{SPT}}\right)$ em solos arenosos, argilosos e siltosos. Os ensaios de arrancamento foram realizados em chumbadores construídos somente com um estágio de injeção. As correlações apresentaram dispersão considerável (Figura 2.33). A correlação entre $\mathrm{P}_{\mathrm{L}}$ e $\mathrm{N}_{\mathrm{SPT}}$ apresenta valores de $\mathrm{N}$ muito elevados, os quais podem ser atribuídos a procedimentos diferentes de ensaio realizados nos países onde os dados foram obtidos. Os autores ressaltam que as correlações apresentadas são válidas apenas para os solos estudados. 
Análise de diferentes metodologias executivas de solo pregado a partir de ensaios de arrancamento em campo e laboratório

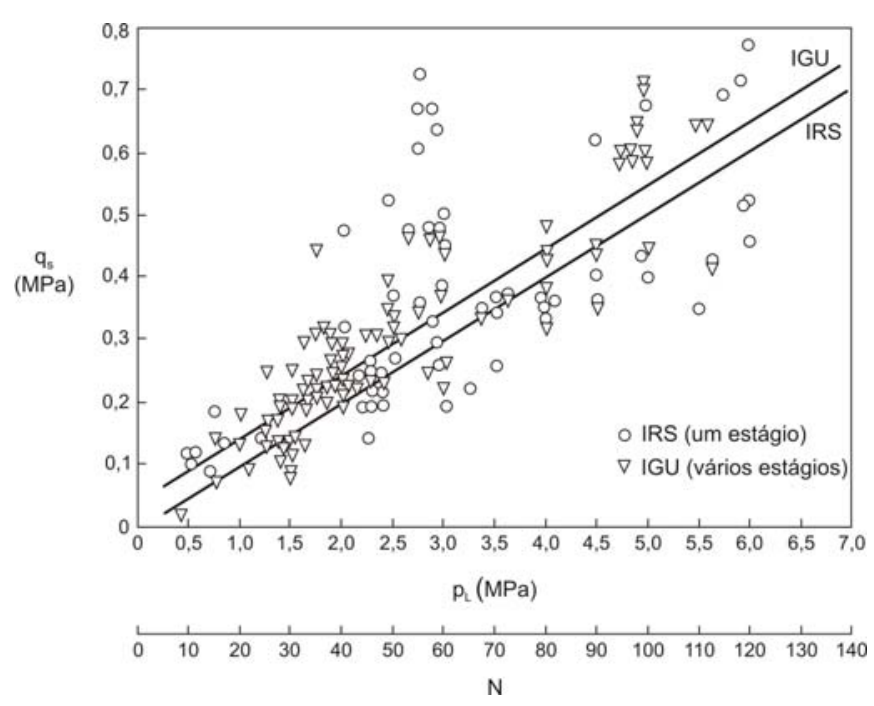

(a)

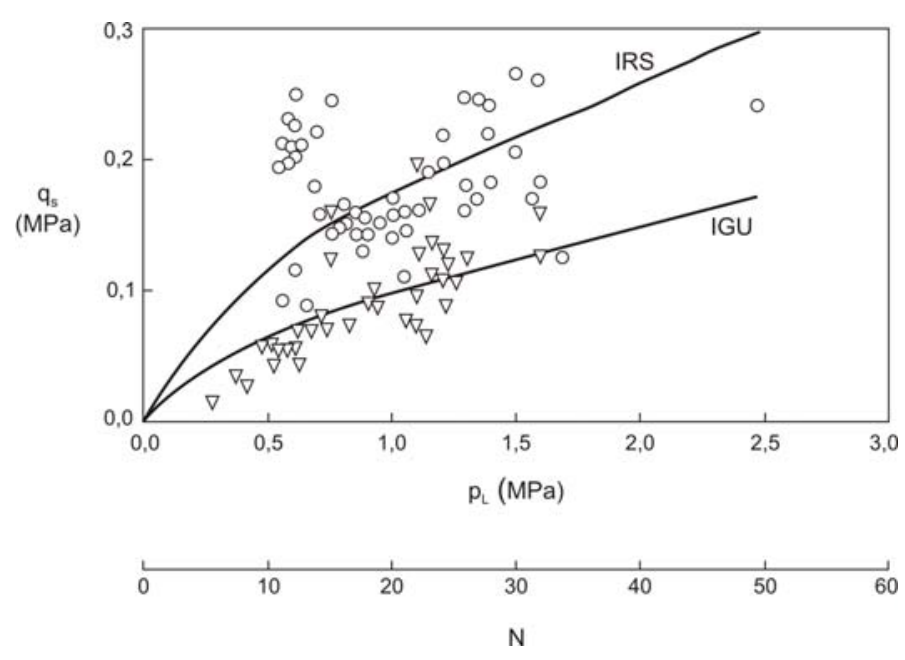

(b)

Figura 2.33. Correlações entre $q_{s}, P_{L}$ e $N_{S P T}$ para areia (a), argilas e siltes (b) (Bustamante \& Doix, 1985).

O projeto francês Clouterre (1991), após a realização de cerca de 450 ensaios de arrancamento, sumarizou os resultados em função de cinco tipos de solos e duas metodologias de instalação dos chumbadores: ábacos que correlacionam a tensão pressiométrica limite $\left(\mathrm{P}_{\mathrm{L}}\right)$ com o parâmetro $q_{s}$. Os ábacos foram construídos a partir dos resultados de 450 ensaios de arrancamento realizados em chumbadores, abrangendo cinco tipos de solos. Os reforços foram construídos com duas metodologias diferentes: envolvidos com calda de cimento sem pressão (gravidade) e cravados diretamente no terreno. A variação do parâmetro $q_{s}$ é apresentada em função da pressão limite $\left(\mathrm{P}_{\mathrm{L}}\right)$, determinada a partir de ensaios pressiométricos. A Figura 2.34 apresenta as correlações empíricas propostas para areias (a) e argilas (b), considerando os reforços envolvidos com calda de cimento. 


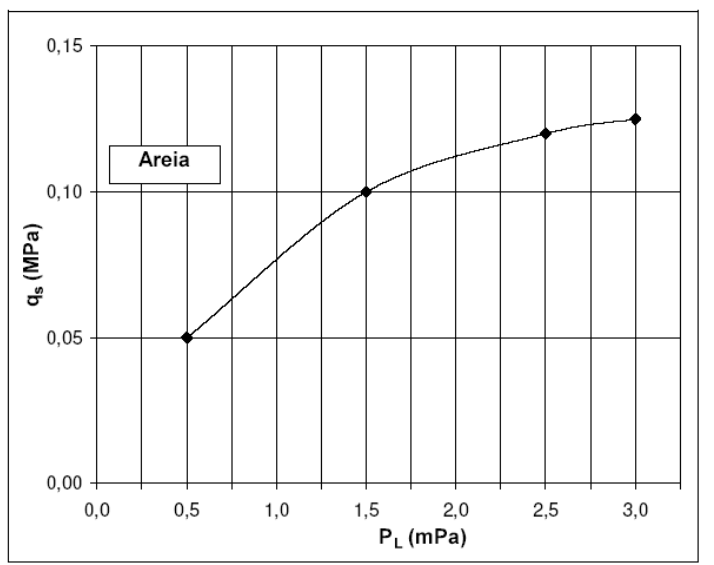

(a)

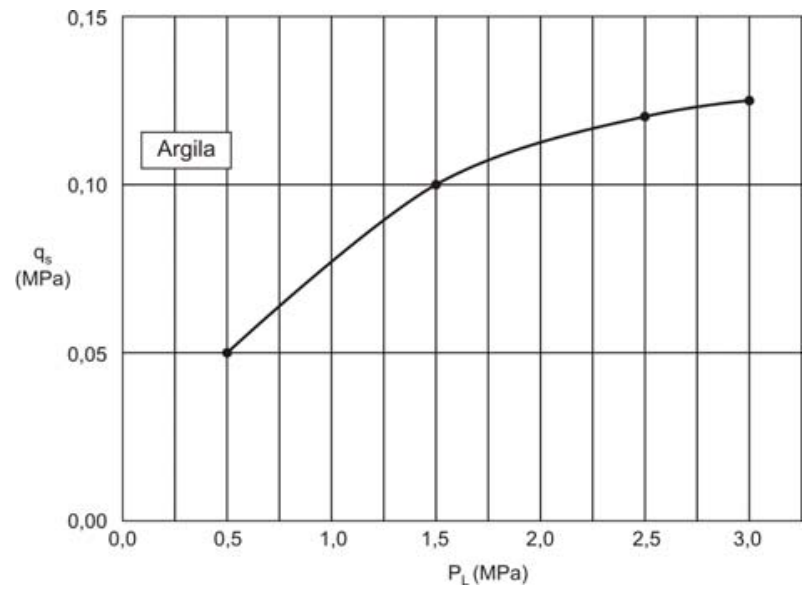

(b)

Figura 2.34. Correlação entre o parâmetro $q_{s}$ e a pressão limite do pressiômetro de Menárd $\left(\mathrm{P}_{\mathrm{L}}\right)$ para solos arenosos (a) e argilosos (b) (Clouterre, 1991).

Heymann et al. (1992) realizaram correlações entre a resistência ao arrancamento de chumbadores e os parâmetros do solo obtidos a partir de ensaios geotécnicos de laboratório e campo. Foram realizados quarenta ensaios de arrancamento em reforços implantados em solo residual (granito e andesita) da África do Sul, com comprimento injetado variando entre 1,0 e 1,5 m e $100 \mathrm{~mm}$ de diâmetro. Os resultados obtidos a partir dos ensaios de arrancamento $\left(\tau_{\text {ult }}\right)$ foram correlacionados com os parâmetros do solo obtidos a partir da investigação geotécnica. Foram considerados os seguintes parâmetros: coesão e ângulo de atrito efetivo, SPT ("Standard Penetration Test”), porcentagem de solo passante na peneira 200, fração de argila no solo $(\%<0,002 \mathrm{~mm})$, limite de liquidez (LL), limite de plasticidade (LP) e índice de plasticidade (IP). Entretanto, os autores conseguiram estabelecer correlações somente com o ângulo de atrito efetivo e com o $\mathrm{N}_{\mathrm{SPT}}$, que se encontram representadas pelas equações 2.10 e 2.11 , respectivamente.

$$
\text { Correlação 1: } \tau_{u l t}=4 . \phi^{\prime}
$$

$$
\text { Correlação 2: } \tau_{u l t}=2 . N
$$

Em que: $\phi$ 'é o ângulo de atrito efetivo do solo $\left(^{\circ}\right)$ e $N$ é o índice de penetração SPT. 
Ortigão \& Palmeira (1997) analisaram resultados de ensaios de arrancamento realizados em São Paulo, Brasília e no Rio de Janeiro, correlacionando o parâmetro $q_{s}$ com o índice de resistência à penetração $\mathrm{N}_{\mathrm{SPT}}$. Nestes ensaios, todos os chumbadores foram executados com furos de 75 a $150 \mathrm{~mm}$ de diâmetro e injeção de calda de cimento sem pressão. A correlação entre $q_{s}$ e o número de golpes $\mathrm{N}_{\mathrm{SPT}}$ é representada na Figura 2.35. A dispersão dos resultados é grande e os autores justificam que, provavelmente, se devem aos diferentes procedimentos executivos empregados pelos executores.

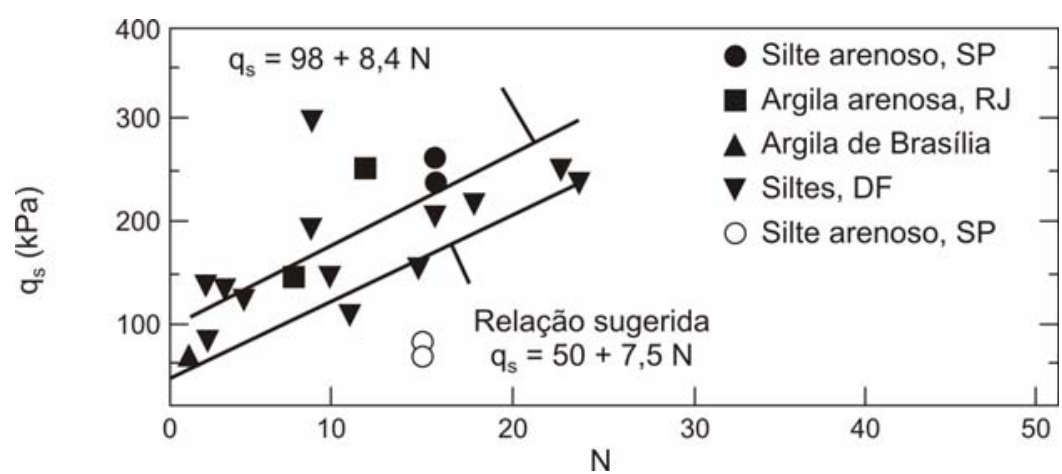

Figura 2.35. Correlação entre $q_{s}$ e o número de golpes $N_{\mathrm{SPT}}$ (Ortigão e Palmeira, 1997).

Como estimativa preliminar para aplicação em projetos, o autor propõe a seguinte equação:

$$
\mathrm{q}_{\mathrm{s}}=50+7,5 \cdot \mathrm{N}_{\mathrm{SPT}}
$$

Em que: $q_{s}$ é a resistência ao cisalhamento de interface em $\mathrm{kPa}$; $\mathrm{N}_{\mathrm{SPT}}$ é o número de golpes do ensaio SPT.

Proto Silva (2005) realizou ensaios de arrancamento em um maciço de solo residual de gnaisse e ensaios de cisalhamento direto do solo e da interface solo/calda de cimento, para a avaliação das propriedades mecânicas destes materiais. Baseado nos parâmetros de resistência da interface solo/calda de cimento determinados em laboratório, o autor apresenta uma relação semi-empírica que permite estimar o valor de $q_{s}$ em função destes parâmetros, sendo denominado correlação 1 (Equação 2.13): 


$$
q_{s}=\lambda_{1}\left(c_{a}^{\prime}+\sigma_{n} \cdot \operatorname{tg} \delta^{\prime}\right)
$$

Em que:

$\lambda_{1}$ : fator de carga que varia em função da tensão normal atuante no chumbador;

$\mathrm{c}^{\prime}$ : adesão da interface solo/calda de cimento;

$\sigma_{\mathrm{n}}$ : tensão normal atuante sobre o reforço;

$\delta$ ': ângulo de atrito da interface solo/calda de cimento.

Alternativamente, o valor de $q_{s}$ também pode ser expresso em função dos parâmetros de resistência ao cisalhamento do solo, sendo denominado correlação 2 (Equação 2.14):

$$
\mathrm{q}_{\mathrm{s}}=\lambda^{*}{ }_{1 \cdot \alpha} \alpha\left(\mathrm{c}^{\prime}+\sigma_{\mathrm{n}} \cdot \operatorname{tg} \phi^{\prime}\right)
$$

Em que:

$\lambda^{*}{ }_{1}$ : fator de carga para solo residual de gnaisse, que varia em função da tensão normal atuante no chumbador;

$\alpha$ : coeficiente de interface, que associa os parâmetros de resistência da interface solo/calda de cimento com os parâmetros do solo;

c': coesão efetiva do solo;

$\sigma_{\mathrm{n}}$ : tensão normal atuante sobre o reforço;

$\phi '$ ângulo de atrito efetivo do solo.

Embora os modelos teóricos e as correlações empíricas se baseiem em interações bastante simples e empreguem parâmetros aparentemente fáceis de serem determinados, na prática, ainda não existe um consenso em relação ao modelo ideal para estimar o $q_{s}$. Há uma grande dificuldade em se conhecer, previamente, os parâmetros de interação e a magnitude das tensões normais atuantes. Neste contexto, a realização de ensaios de arrancamento, executados in situ, é extremamente importante para a quantificação destes parâmetros e, conseqüentemente, para a realização de projetos mais econômicos e viáveis. 


\subsubsection{Ensaios de Arancamento}

O ensaio de arrancamento consiste em se testar o reforço por meio de incrementos sucessivos de carregamentos. Para cada carga aplicada, registra-se o deslocamento de arrancamento na extremidade do reforço. Clouterre (1991) estabelece que o ensaio deve ser considerado finalizado quando a força de tração atingir um valor máximo $\left(\mathrm{F}_{\text {máx }}\right)$ ou se estabilizar para deslocamentos crescentes. A Figura 2.36 representa estes critérios de ruptura.

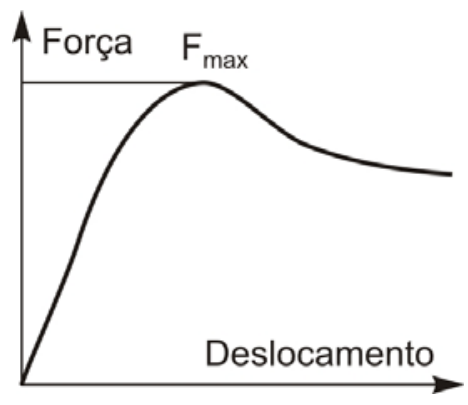

(a)

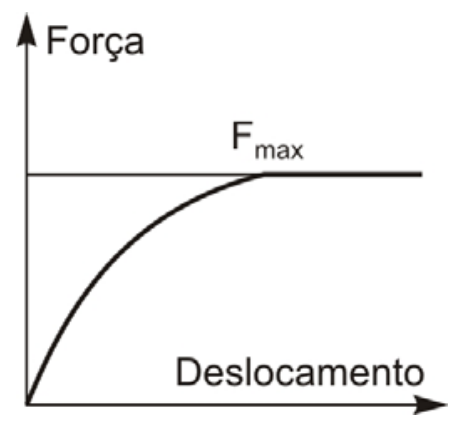

(b)

Figura 2.36. Critério de ruptura de arrancamento de chumbadores: (a) força máxima e (b) estabilização do deslocamento (Clouterre, 1991).

Após a definição da força máxima ou equivalente na condição de ruptura, determina-se a resistência ao cisalhamento de interface $\left(q_{s}\right)$. Este parâmetro possui unidade de tensão e é definido como:

$$
\mathrm{q}_{\mathrm{s}}=\frac{\mathrm{F}_{\text {máx }}}{\pi \cdot \mathrm{D} \cdot \mathrm{L}_{\mathrm{a}}}
$$

Em que:

$\mathrm{F}_{\text {máx: força de tração máxima; }}$

D: diâmetro da perfuração;

$\mathrm{L}_{\mathrm{a}}$ : comprimento ancorado ou injetado do reforço. 
A partir dos ensaios de arrancamento, também é possível determinar a carga residual e o coeficiente $\left(\mathrm{k}_{\beta}\right)$, o qual corresponde à inclinação inicial da curva carga $\mathrm{x}$ deslocamento, conforme apresentado na Figura 2.37.

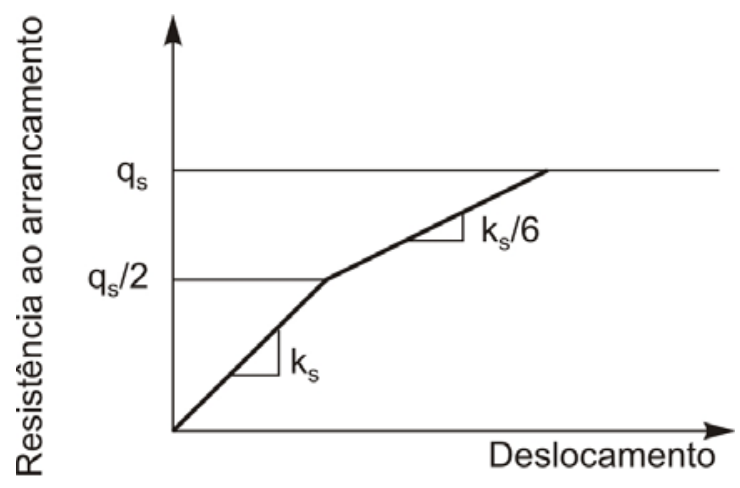

Figura 2.37. Determinação da força máxima de arrancamento (Clouterre, 1991).

A execução de ensaios de arrancamento de chumbadores não é regulamentada por nenhuma norma técnica. Entretanto, existem alguns procedimentos e recomendações de ensaios. Barley et al. (1997) apresentaram uma revisão dos atuais códigos e guias práticos relacionados à realização de ensaios de arrancamento. As principais orientações práticas em relação a esta prática são abordadas na Norma Britânica (BS-8006), no Manual da Federal Highway Administration - USA e no programa Nacional de Pesquisa Clouterre.

A Norma Britânica (BS-8006) reconhece a necessidade de se realizar os ensaios de arrancamento e sugere a criação de métodos de ensaios significantes para avaliar as estruturas de solo pregado. Entretanto, esta norma não apresenta recomendações em relação à construção do reforço que será ensaiado e aos procedimentos de ensaio (ciclos de carregamento e duração dos carregamentos), que devem ser realizados para confirmar o parâmetro $q_{s}$ adotado em projeto.

O manual da Federal Highway Administration - USA enfatiza que a estrutura de solo pregado deve ser ensaiada para que as cargas de projeto possam ser verificadas tanto para o estado limite de serviço (deslocamento excessivo) como para o estado limite último (ruptura da estrutura). É proposto por este código que os ensaios sejam realizados durante as seguintes etapas: antes do inicio das obras, para validar o método construtivo (ensaios de verificação), e durante a fase de construção (em quantidade superior a 5\% dos reforços 
executados), tanto em reforços experimentais como nos definitivos. As metodologias dos ensaios são bem definidas, mas deixam certas variáveis sem especificação, como por exemplo, sugestões para realizar os incrementos de carga, as taxas dos incrementos de carga e a duração dos carregamentos, nos ensaios de carregamento constante.

O manual Clouterre abrange todos os aspectos referentes à técnica de solo pregado e apresenta recomendações para a realização dos ensaios de arrancamento. Menciona que os ensaios de arrancamento podem ser realizados em diferentes fases de uma obra de solo pregado:

Ensaios preliminares: realizados na fase de planejamento da obra, ou seja, antes de se iniciar os trabalhos de construção da contenção em solo pregado;

Ensaios de conformidade: realizados quando se iniciam os trabalhos de execução da técnica de solo pregado, com o objetivo de confrontar os parâmetros obtidos a partir dos ensaios de campo com aqueles previstos em projeto;

$>$ Ensaios de inspeção: realizados durante o andamento da obra, cujo objetivo é verificar a qualidade de execução dos chumbadores.

Este manual apresenta dois procedimentos bem definidos para a realização dos ensaios de arrancamento: ensaios com deslocamento constante, com o objetivo de permitir a ocorrência do estado limite de ruptura, e ensaio com carregamento constante, para permitir o desenvolvimento das deformações lentas durante o carregamento. A quantidade mínima de ensaios de arrancamento varia em função da área total da face do solo pregado, entretanto, recomenda-se que no mínimo seis ensaios sejam realizados em uma obra. A Tabela 2.3 sintetiza as principais recomendações em relação à realização de ensaios de arrancamento, para os três códigos apresentados. 
Análise de diferentes metodologias executivas de solo pregado a partir de ensaios de arrancamento em campo e laboratório

Tabela 2.3. Recomendações feitas pelos guias de solo pregado para a realização dos ensaios de campo

(Barley et al., 1997).

\begin{tabular}{|c|c|c|c|c|c|c|c|c|}
\hline \multirow{2}{*}{$\begin{array}{c}\text { Guia } \\
\text { Prático }\end{array}$} & \multicolumn{2}{|c|}{ Necessidade dos ensaios } & \multirow{2}{*}{$\begin{array}{l}\text { Métodos de } \\
\text { ensaio }\end{array}$} & \multirow{2}{*}{$\begin{array}{c}\mathbf{N}^{\circ} \text { de } \\
\text { ensaios }\end{array}$} & \multirow{2}{*}{$\begin{array}{l}\text { Quando } \\
\text { realizar } \\
\text { ensaios }\end{array}$} & \multirow{2}{*}{$\begin{array}{l}\text { Inclusão } \\
\text { reforços } \\
\text { experim. }\end{array}$} & \multirow{2}{*}{$\begin{array}{l}\text { Sugestão } \\
\text { proced./ } \\
\text { equip. }\end{array}$} & \multirow{2}{*}{$\begin{array}{l}\text { Considera } \\
\text { comprim. } \\
\text { aderido }\end{array}$} \\
\hline & $\begin{array}{l}\text { Verificação } \\
\text { do projeto }\end{array}$ & Projeto & & & & & & \\
\hline BS8006 & $\mathrm{Sim}$ & - & $\begin{array}{c}\text { Ruptura \& } \\
\text { Serviço }\end{array}$ & - & - & - & - & - \\
\hline FHWA & $\operatorname{Sim}$ & - & $\begin{array}{l}\text { a) Ensaio até } \\
\text { atingir a carga } \\
\text { de ruptura; } \\
\text { b) Ensaio com } \\
\text { carga } \\
\text { constante. }\end{array}$ & $5 \%$ & $\begin{array}{l}\text { Idem processo } \\
\text { executivo }\end{array}$ & Sim & $\operatorname{Sim}$ & $\begin{array}{c}\text { Sim, mas não } \\
\text { sugere } \\
\text { proporção }\end{array}$ \\
\hline Clouterre & $\operatorname{Sim}$ & $\operatorname{Sim}$ & $\begin{array}{c}\text { (a) } \\
\text { Deslocamento } \\
\text { constante; } \\
\text { (b) } \\
\text { Carregamento } \\
\text { constante }\end{array}$ & $1-2 \%$ & $\begin{array}{l}\text { a)Antes do } \\
\text { projeto; } \\
\text { b)Inicio da } \\
\text { construção; } \\
\text { c)Durante a } \\
\text { construção. }\end{array}$ & $\begin{array}{l}\text { Sim. Ensaios } \\
\text { realizados em } \\
\text { reforços experim. }\end{array}$ & $\operatorname{sim}$ & $\begin{array}{c}\text { Para ensaios } \\
\text { preliminares, } \\
\text { mas não } \\
\text { sugere } \\
\text { proporção }\end{array}$ \\
\hline
\end{tabular}

No Brasil, a falta de uma metodologia padrão faz com que os ensaios de arrancamento sejam pouco realizados nas obras de solo pregado. Todavia, quando são empregados, são baseados na experiência empírica de seus construtores.

Zirlis et al. (2003) sugerem a execução de ensaios de arrancamento em uma quantidade de $10 \%$ do total de chumbadores, ou uma quantidade tal que garanta a representatividade dos resultados. Falconi e Alonso (1996) também propõem a realização de ensaios de arrancamento na proporção de um para cada dez chumbadores permanentes de uma massa de solo a ser estabilizada. Sugerem ainda que o número de ensaios deve ser readequado ao tamanho da obra.

O manual técnico da GeoRio (1999), recomenda que os ensaios de arrancamento devem ser realizados, durante a obra, em pelo menos dois chumbadores ou em $1 \%$ dos chumbadores, para que sejam confirmados os valores especificados em projeto. Sugere também que sejam realizados ensaios à medida que a obra avança, de forma a permitir ajustes de projeto. O esquema típico de montagem do ensaio de arrancamento é apresentado na Figura 2.38 (Elias et al., 2003). 


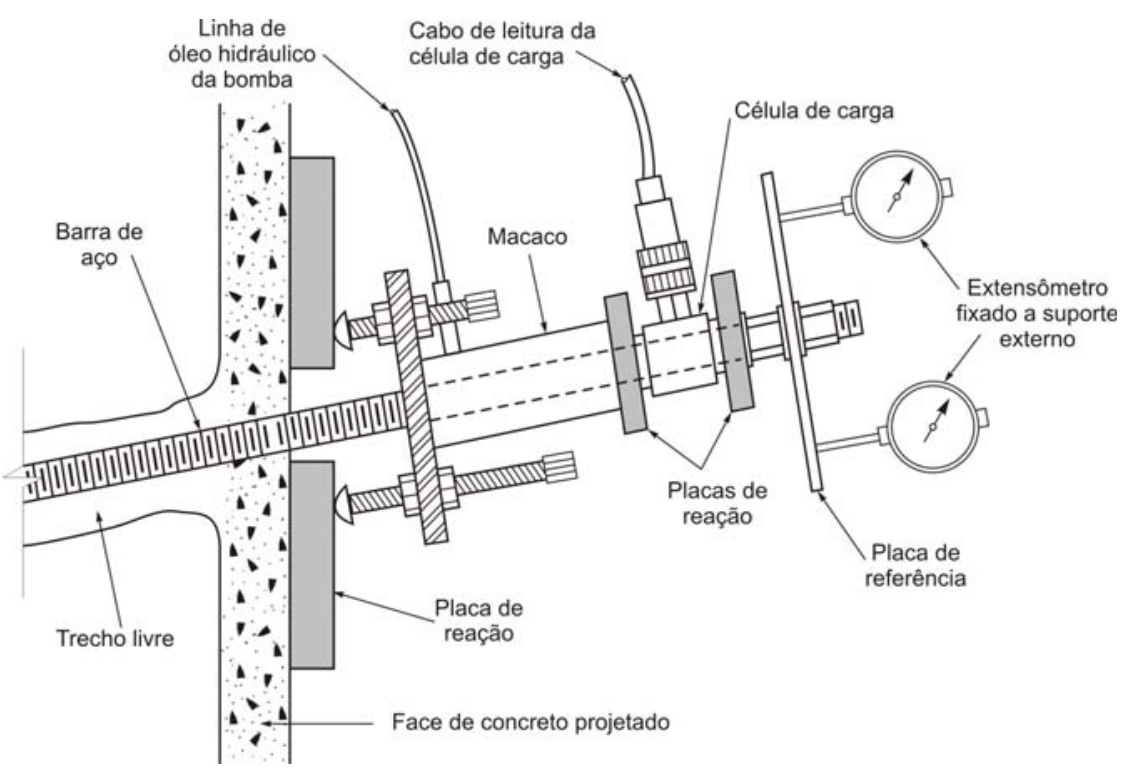

Figura 2.38. Esquema de montagem do ensaio de arrancamento (Adaptado Elias et al., 2003).

A partir da Figura 2.38 observam-se, na ordem de seqüência, os seguintes acessórios: (1) Placa de reação (aço ou concreto); (2) Grade de reação; (3) Macaco hidráulico; (4) Placas de reação; (5) Célula de carga; (6) Porcas para fixação; (7) Placa de referência; (8) Extensômetros fixados a suporte externo.

A montagem do ensaio deve possuir, preferencialmente, dois extensômetros para leitura dos deslocamentos dos chumbadores. Estes extensômetros devem estar fixados a um suporte externo que não seja afetado pelos movimentos do macaco e da parede. Estes equipamentos devem apresentar uma resolução mínima de 0,01 mm. A utilização dos dois equipamentos permite calcular a média das leituras, no caso de carregamentos levemente excêntricos, ou seja, no caso de haver alguma imperfeição no alinhamento entre os eixos do macaco e do reforço. A medição redundante dos deslocamentos pode ser vital no caso de um dos extensômetros apresentar funcionamento deficiente durante o ensaio.

O programa Clouterre (1991) recomenda que o equipamento de ensaio tenha um sistema de ajuste para aplicar uma força no mesmo eixo da barra, um macaco vazado, uma bomba e uma célula de carga. O procedimento de instalação dos chumbadores destinados ao ensaio de arrancamento (inclinação, perfuração, introdução no furo e injeção) deve ser exatamente o mesmo dos chumbadores permanentes da obra. Este programa menciona 
ainda que a metodologia empregada no ensaio pode ser com deslocamento controlado (velocidade constante) ou força controlada.

Os ensaios de arrancamento são realizados em chumbadores com um trecho livre seguido de um trecho injetado. Deve-se garantir que não haja preenchimento de calda de cimento no trecho livre. Ao se aplicar o carregamento de tração no chumbador, a face e o maciço de solo são submetidos à esforços de compressão. Caso haja preenchimento com nata, o trecho inicial estará sujeito à compressão, o que é indesejado. Clouterre (1991) e Elias et al. (2003) recomendam um comprimento livre mínimo de 1,0 m e um comprimento injetado mínimo de $3,0 \mathrm{~m}$.

Quando uma força $\mathrm{T}_{0}$ é aplicada na extremidade do chumbador, o reforço se movimenta em relação ao solo e promove a mobilização da resistência ao cisalhamento na interface solo-reforço, equilibrando assim a força $T_{0}$. A mobilização desta resistência é feita gradualmente, da face até o final do reforço. Quanto menor for o reforço, maior será a mobilização ao longo de todo o seu comprimento (Clouterre, 1991). Estas considerações poderão ser mais bem visualizadas a partir das análises dos chumbadores instrumentados.

\subsubsection{Pesquisas - Ensaios de Arancamento em Campo}

A maior gama de resultados de ensaios de arrancamento verificados na literatura concentra-se na região Sudeste. Na tentativa de compor um maior banco de dados, apresenta-se na seqüência uma descrição geral sobre os principais resultados encontrados na literatura.

Ortigão et al. (1992) relatam a experiência de campo da GeoRio obtida a partir da construção de um muro experimental de solo pregado no Morro da Formiga - Rio de Janeiro. O solo existente no local é constituído por um solo residual arenoso, apresentando ângulo de atrito efetivo de $32^{\circ}$ e nenhum intercepto de coesão efetiva. Foram realizados ensaios de arrancamento em 3 chumbadores, construídos com barras de aço CA-50 de 32 $\mathrm{mm}$ de diâmetro e instrumentadas com extensômetros elétricos (strain gages). Os chumbadores foram construídos com perfuração de $75 \mathrm{~mm}, 20^{\circ}$ de inclinação em relação à direção horizontal e fase única de injeção, sendo $3 \mathrm{~m}$ injetados e $1 \mathrm{~m}$ livre. Os resultados de $q_{s}$ foram próximos, da ordem de $250 \mathrm{kPa}$. 
Feijó \& Ehrlich (2001) realizaram 20 ensaios de arrancamento em perfis de solos residuais do Rio de Janeiro-RJ. Os ensaios foram realizados em dois locais distintos: na Colina da Covanca e no morro Dona Marta. Os autores apresentam os resultados de dez ensaios de arrancamento, sendo quatro deles realizados na Colina da Covanca e seis no morro Dona Marta. Os chumbadores foram construídos com diâmetro de perfuração de 75 mm, barras de aço CA-50 de 25 mm de diâmetro, com três injeções. A calda de cimento foi preenchida com a utilização de uma bomba manual de baixa pressão. Uma vez observada a drenagem da calda de cimento por um dos tubos de retorno, o bombeamento era interrompido e o tubo retirado. Os chumbadores foram construídos com 3 e $6 \mathrm{~m}$ de comprimento injetado e $2 \mathrm{~m}$ de trecho livre. Enquanto na Colina da Covanca os chumbadores foram construídos em duas profundidades distintas ( 1 e $2 \mathrm{~m}$ ), no morro Dona Marta foram avaliadas três profundidades distintas $(5,10$ e $15 \mathrm{~m})$. A Tabela 2.4 apresenta os resultados obtidos.

Tabela 2.4. Resultados dos ensaios de arrancamentos realizados por Feijó \& Ehrlich (2001).

\begin{tabular}{cccc}
\hline Local & Profundidade (m) & $\begin{array}{c}\text { Comprimento } \\
\text { Injetado }(\mathbf{m})\end{array}$ & $\begin{array}{c}\mathbf{q}_{\mathbf{s}} \\
\mathbf{( k P a )}\end{array}$ \\
\hline \multirow{2}{*}{ Colina da } & 1,0 & 3,0 & 145,0 \\
Covanca & 2,0 & 3,0 & 295,0 \\
& 1,0 & 6,0 & 185,0 \\
& 2,0 & 6,0 & 205,0 \\
\hline \multirow{2}{*}{ Morro Dona } & 5,0 & 3,0 & 108,0 \\
Marta & 10,0 & 3,0 & 148,0 \\
& 15,0 & 3,0 & 248,0 \\
& 5,0 & 6,0 & 95,0 \\
& 10,0 & 6,0 & 120,0 \\
& 15,0 & 6,0 & 190,0 \\
\hline
\end{tabular}

Azambuja et al. (2003) realizaram ensaios de arrancamento em seis chumbadores experimentais construídos em uma obra de contenção junto à $3^{\text {a }}$ Avenida Perimetral de Porto Alegre-RS. O local é constituído por rochas graníticas, com predominância do granito independência (Menegat et al., 1998). Entretanto, no local onde se utilizou o solo pregado, não ocorreram formações graníticas, mas sim outras duas ocorrências geológicas: um dique de riolito na face leste da escavação e um solo residual de paragnaisse na zona central e na face oeste da escavação. Estas formações apresentaram coesão efetiva de $22 \mathrm{kPa}$ e ângulo de atrito efetivo de $34^{0}$. Os chumbadores foram construídos com diâmetro de perfuração de 
$100 \mathrm{~mm}$, barras de aço CA-50 de $20 \mathrm{~mm}$ de diâmetro, com a presença de trecho livre e injetado. Os chumbadores foram dimensionados para trabalharem com uma carga de 240 $\mathrm{kN}$, executados com uma fase de injeção preliminar, e, após os trabalhos de armação da face, foi realizado um segundo estágio de injeção. Os resultados obtidos estão apresentados na Tabela 2.5. Além do valor de $q_{s}$, apresentam-se a profundidade média do trecho ancorado, a tensão de trabalho especificada para o reforço $\left(\sigma_{\mathrm{r}}\right)$ e o deslocamento do reforço na condição de ruptura. Os resultados apresentaram-se próximos e observou-se um conservadorismo exagerado nos valores previstos, principalmente referentes ao ensaio 2 , no qual o erro de previsão atingiu $350 \%$.

Tabela 2.5. Resultados dos ensaios de arrancamento.

\begin{tabular}{ccccc}
\hline Ensaio & Profundidade $(\mathbf{m})$ & $\begin{array}{c}\sigma_{\mathbf{r}} \\
(\mathbf{k P a})\end{array}$ & $\boldsymbol{q}_{\mathbf{s}}(\mathbf{k P a})$ & Deslocamento (mm) \\
\hline 1 & 2,50 & 200 & 260 & 6,50 \\
2 & 6,76 & 75 & 264 & 7,80 \\
3 & 4,60 & 150 & 261 & 15,76 \\
4 & 4,30 & 125 & 270 & 9,30 \\
5 & 1,50 & 120 & 210 & 5,40 \\
6 & 4,00 & 150 & 204 & 10,73 \\
\hline
\end{tabular}

Pitta et al. (2003) apresentaram resultados de ensaios de arrancamento realizados em cinco obras diferentes na cidade de São Paulo. Os chumbadores foram construídos com diâmetro de perfuração de $75 \mathrm{~mm}$ e barras de aço CA-50 de $20 \mathrm{~mm}$ de diâmetro, sendo posicionados entre 2,0 e 4,0 $\mathrm{m}$ abaixo da crista do talude. Os comprimentos injetados foram de 4,0 e 6,0 m, avaliando-se três metodologias executivas: bainha, bainha e mais uma fase de injeção e bainha e mais duas fases de injeção. As injeções foram realizadas por meio de tubos de polietileno de $12 \mathrm{~mm}$ e válvulas de injeção posicionadas de forma alternada, a cada $0,5 \mathrm{~m}$ uma da outra. A Tabela 2.6 apresenta o resumo dos resultados obtidos, descrevendo o local da obra, o tipo de solo, o comprimento injetado, a metodologia executiva e o valor de $q_{s}$. 
Tabela 2.6. Resumos dos ensaios de arrancamento realizados por Pitta et al. (2003).

\begin{tabular}{|c|c|c|c|c|c|}
\hline Local obra & Tipo de solo & $\begin{array}{c}\mathbf{N}^{0} \\
\text { Chumbador }\end{array}$ & $\begin{array}{c}\mathbf{L}_{\text {injetado }} \\
\text { (m) }\end{array}$ & $\begin{array}{l}\text { Metodologia } \\
\text { executiva }\end{array}$ & $\mathrm{q}_{\mathrm{s}}(\mathrm{kPa})$ \\
\hline \multirow{10}{*}{ 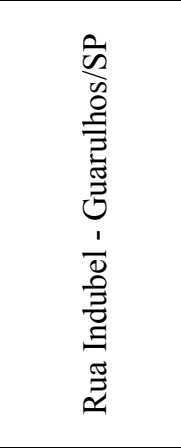 } & \multirow{10}{*}{ 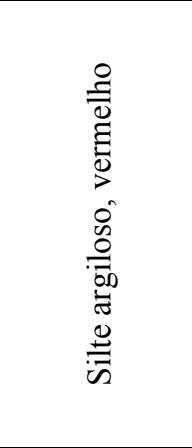 } & 1 & 4,0 & Bainha & 81,7 \\
\hline & & 2 & 4,0 & Bainha & 81,7 \\
\hline & & 3 & 4,0 & Bainha & 89,1 \\
\hline & & 4 & 4,0 & Bainha & 81,7 \\
\hline & & 5 & 4,0 & Bainha & 74,2 \\
\hline & & 6 & 4,0 & Bainha & 102,9 \\
\hline & & 7 & 4,0 & Bainha + 1 Fase & 126,3 \\
\hline & & 8 & 4,0 & Bainha + 1 Fase & 118,8 \\
\hline & & 9 & 4,0 & Bainha + 1 Fase & 126,3 \\
\hline & & 10 & 4,0 & Bainha + 1 Fase & 118,9 \\
\hline \multirow{10}{*}{ 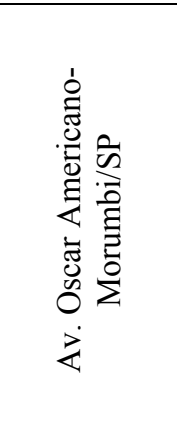 } & \multirow{10}{*}{ 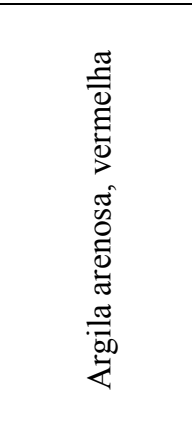 } & 1 & 6,0 & Bainha & 69,3 \\
\hline & & 2 & 6,0 & Bainha & 69,3 \\
\hline & & 3 & 6,0 & Bainha & 74,3 \\
\hline & & 4 & 6,0 & Bainha & 74,3 \\
\hline & & 5 & 6,0 & Bainha & 69,3 \\
\hline & & 6 & 6,0 & Bainha + 1 Fase & 113,9 \\
\hline & & 7 & 6,0 & Bainha + 1 Fase & 104,0 \\
\hline & & 8 & 6,0 & Bainha +1 Fase & 113,9 \\
\hline & & 9 & 6,0 & Bainha +1 Fase & 99,0 \\
\hline & & 10 & 6,0 & Bainha + 1 Fase & 108,9 \\
\hline \multirow{13}{*}{ 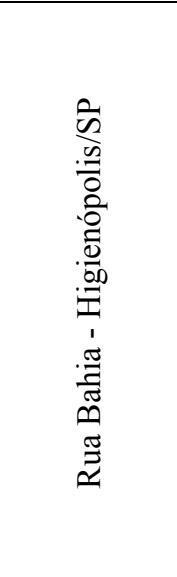 } & \multirow{13}{*}{ 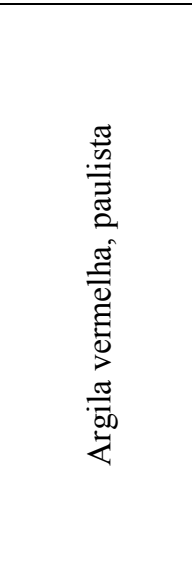 } & 1 & 6,0 & Bainha & 37,5 \\
\hline & & 2 & 6,0 & Bainha +1 Fase & - \\
\hline & & 3 & 6,0 & Bainha +1 Fase & 92,0 \\
\hline & & 4 & 6,0 & Bainha +2 Fases & 113,2 \\
\hline & & 5 & 6,0 & Bainha +2 Fases & 130,9 \\
\hline & & 6 & 6,0 & Bainha +2 Fases & 136,5 \\
\hline & & 7 & 6,0 & Bainha +2 Fases & 125,2 \\
\hline & & 12 & 4,0 & Bainha & 81,7 \\
\hline & & 13 & 4,0 & Bainha & 56,2 \\
\hline & & 10 & 4,0 & Bainha +1 Fase & 154,9 \\
\hline & & 11 & 4,0 & Bainha +1 Fase & 154,9 \\
\hline & & 8 & 4,0 & Bainha +2 Fases & 114,6 \\
\hline & & 9 & 4,0 & Bainha +2 Fases & 130,5 \\
\hline \multirow{6}{*}{ 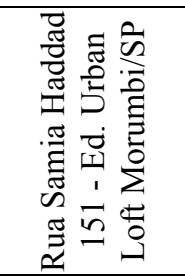 } & \multirow{6}{*}{ 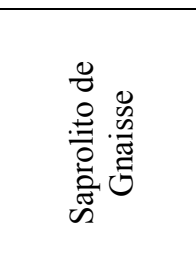 } & 5 & 6,0 & Bainha & 81,3 \\
\hline & & 6 & 6,0 & Bainha & - \\
\hline & & 1 & 6,0 & Bainha +1 Fase & 120,3 \\
\hline & & 2 & 6,0 & Bainha +1 Fase & 158,5 \\
\hline & & 3 & 6,0 & Bainha +2 Fases & 164,1 \\
\hline & & 4 & 6,0 & Bainha +2 Fases & 136,5 \\
\hline \multirow{6}{*}{ 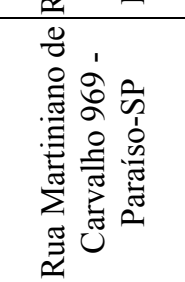 } & \multirow{6}{*}{ 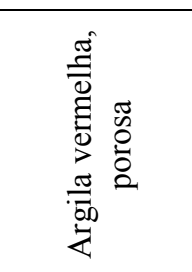 } & 1 & 6,0 & Bainha & 90,5 \\
\hline & & 2 & 6,0 & Bainha & 124,5 \\
\hline & & 3 & 6,0 & Bainha +1 Fase & - \\
\hline & & 4 & 6,0 & Bainha +1 Fase & 140,8 \\
\hline & & 5 & 6,0 & Bainha +2 Fases & 150,0 \\
\hline & & 6 & 6,0 & Bainha +2 Fases & 156,3 \\
\hline
\end{tabular}


Soares \& Gomes (2003) realizaram seis ensaios de arrancamento em um talude rodoviário localizado a montante da Usina Nuclear de Angra dos Reis-RJ. Esta região, localizada junto à Serra do Mar, é formada por rochas graníticas e gnáissicas, gerando mantos de alteração de pequena espessura. A camada superficial de solo coluvionar apresenta espessura aproximada de $6 \mathrm{~m}$ e está sobrejacente a uma camada de solo residual (areno siltoso) com espessura variável de 5,0 a 15,0 m. Estas formações foram consideradas com peso especifico de $19,0 \mathrm{kN} / \mathrm{m}^{3}$, coesão efetiva de $22 \mathrm{kPa}$ e ângulo de atrito efetivo de $34^{0}$. Os chumbadores foram construídos com diâmetro de perfuração de $50 \mathrm{~mm}$, barra de aço CA-50 de $25 \mathrm{~mm}$ de diâmetro, $25^{\circ}$ de inclinação em relação à direção horizontal e uma única fase de injeção. Quatro chumbadores foram ancorados com 3,0 $\mathrm{m}$ e dois com 5,0 m de comprimento, utilizando-se calda de cimento com fator a/c igual a 0,5 . Os chumbadores executados com $5 \mathrm{~m}$ apresentaram problemas com a placa de reação e tiveram seus resultados desconsiderados. Os chumbadores de 3,0 m apresentaram um resultados médio em termos de $q_{s}$ da ordem de $308 \mathrm{kPa}$.

Moraes \& Arduíno (2003) apresentaram os resultados de dois ensaios de arrancamento realizados em chumbadores construídos em uma encosta localizada no distrito industrial de Manaus-AM. O local é composto por solos argilo-arenosos de consistência crescente e profundidade (média a rija) com cerca de $9 \mathrm{~m}$ de espessura. Este horizonte de solo foi considerado com peso especifico de $18,0 \mathrm{kN} / \mathrm{m}^{3}$, coesão efetiva de 5 $\mathrm{kPa}$ e ângulo de atrito efetivo de $30^{\circ}$. Os chumbadores foram construídos com diâmetro de perfuração de $75 \mathrm{~mm}$, barra de aço CA-50 de $20 \mathrm{~mm}$ de diâmetro, comprimento total de 6,0 $\mathrm{m}$, comprimento ancorado de 3,0 $\mathrm{m}$ e também uma única fase de injeção. Os resultados de arrancamento apresentaram resultados médios em termos de $q_{s}$ da ordem de $162 \mathrm{kPa}$.

Pitta et al. (2005) realizaram um estudo experimental em que foram construídos 6 chumbadores em um solo residual, caracterizado como silte arenoso. Os chumbadores foram construídos com diâmetro de perfuração de $75 \mathrm{~mm}$, comprimento de $6,0 \mathrm{~m}$, inclinação de $15^{\circ}$ e barra de aço CA-50 de $16 \mathrm{~mm}$ de diâmetro. Foram realizados dois ensaios de arrancamento para cada uma das seguintes situações: chumbadores executados com a bainha somente, bainha e mais uma fase de injeção, e bainha e mais duas fases de injeção. A Tabela 2.7 apresenta os resultados dos ensaios de arrancamento realizados em 
termos da carga máxima e do parâmetro $q_{s}$. Os resultados são comparados em relação ao obtido para a bainha, considerado como referência (100\%).

Tabela 2.7. Comparação entre os resultados obtidos a partir de ensaios de arrancamento (Pitta et al., 2005).

\begin{tabular}{ccccc}
\hline $\begin{array}{c}\text { Chumbador } \\
\left(\mathbf{N}^{\circ}\right)\end{array}$ & Tipo de Injeção & $\begin{array}{c}\text { Arrancamento } \\
\text { Carga } \\
\text { Total (kN) }\end{array}$ & $\mathbf{q}_{\mathbf{s}}(\mathbf{k P a})$ & $\begin{array}{c}\text { Carga Relativa } \\
\text { (\%) }\end{array}$ \\
\hline 7 & Bainha & 50,1 & 35,4 & 100 \\
8 & Bainha & 37,6 & 26,6 & \\
12 & Bainha +1 fase & 100,0 & 70,7 & 178 \\
10 & Bainha + 1 fase & 56,4 & 39,9 & \\
9 & Bainha + 2 fases & 62,7 & 44,5 & 157 \\
$\mathbf{1 1}$ & Bainha + 2 fases & 75,2 & 53,2 & \\
\hline
\end{tabular}

Os resultados dos ensaios de arrancamento apresentados na Tabela 2.7 comprovaram a melhoria das propriedades do chumbador, a partir das injeções realizadas. O parâmetro $q_{s}$ apresentou um acréscimo de até $78 \%$ em relação ao chumbador executado somente com a bainha.

Proto Silva (2005) realizou 8 ensaios de arrancamento em chumbadores localizados no município de Niterói-RJ. Trata-se de uma obra de contenção de um perfil de solo residual de gnaisse, com inclinação média de $79^{\circ}$ e altura aproximada de $40 \mathrm{~m}$. Os ensaios foram realizados aos pares e em 4 diferentes cotas ao longo da encosta. Para cada uma das cotas, foram executados 2 ensaios, sendo um deles instrumentado. O solo existente na primeira linha de chumbadores (solo 1) foi caracterizado como uma argila-arenosa e apresentou coesão efetiva de $36,4 \mathrm{kPa}$ e ângulo de atrito efetivo igual a $29,6^{\circ}$. Para as demais linhas, o solo foi caracterizado como uma areia argilosa (solo 2), apresentando coesão efetiva de $59,0 \mathrm{kPa}$ e ângulo de atrito efetivo igual a $36,4^{\circ}$. Os chumbadores foram construídos com diâmetro de perfuração de $75 \mathrm{~mm}$, barra de aço INCO-13-D de $22 \mathrm{~mm}$ de diâmetro, comprimento total de 4,0 m, comprimento ancorado de 3,0 m e uma única fase de injeção. Os resultados médios em termos de $q_{s}$ para os chumbadores localizados nos solos 1 e 2 foram de $166 \mathrm{kPa}$ e $254 \mathrm{kPa}$, respectivamente. 
Springer (2006) realizou 25 ensaios de arrancamento em solo residual de gnaisse, objetivando estudar a influência de uma fase adicional de injeção, do tempo de cura e da execução ou não de pré-lavagem do furo. Os chumbadores foram construídos com diâmetros de perfuração de 75 e $100 \mathrm{~mm}$, inclinação de $10^{\circ}$ com a horizontal, comprimento de 4,0 m, trecho injetado de 3,0 m, barras de aço CA-50 de 25,4 mm e barras de aço INCO13-D de $22 \mathrm{~mm}$. A resistência ao cisalhamento de interface dos chumbadores executados com uma fase de injeção compreende valores entre 159 e $217 \mathrm{kPa}$. Comparando-se os resultados obtidos, a autora concluiu que, em média, os chumbadores reinjetados são cerca de $30 \%$ menos deformáveis e 50\% mais resistentes que os chumbadores sem injeção.

Leite (2007) estudou a viabilidade do emprego de grampos reforçados com fibras de polipropileno, em substituição às barras de aço. O desempenho dos grampos com fibras foi analisado através de ensaios de arrancamento, realizados em uma área experimental localizada no município de Duque de Caxias, RJ. Verificou-se também a distribuição do carregamento ao longo dos grampos durante a realização dos ensaios, por meio de strain gages. Os chumbadores convencionais foram executados com diâmetro de perfuração de 75 $\mathrm{mm}$ e barra de aço CA-50 de $32 \mathrm{~mm}$. Os chumbadores não convencionais foram constituídos por um material compósito, cuja matriz é uma argamassa de cimento, areia e água e o reforço é dado pelas fibras de polipropileno, em substituição às barras de aço. Os ensaios foram realizados em uma camada de solo residual maduro, silto arenoso, razoavelmente homogêneo. Os resultados indicaram que os chumbadores não convencionais apresentaram $q_{s}$ médio da ordem de $60 \%$ em relação aos convencionais.

Feijó (2007) apresenta resultados de vinte (20) ensaios de arrancamento realizados em duas encostas localizadas no município do Rio de Janeiro-RJ. A primeira delas, localizada na Rua Ati, é constituída por um solo residual de gnaisse (areia argilosa) e apresenta, na sua condição natural, peso especifico de $15,0 \mathrm{kN} / \mathrm{m}^{3}$, coesão efetiva de 44,3 $\mathrm{kPa}$ e ângulo de atrito efetivo de $33^{\circ}$. A segunda encosta, localizada em Laranjeiras, ao final da Rua Cardoso Junior, é constituída por um solo residual de gnaisse leptinito (areia argilosa) e apresenta, na sua condição natural, peso especifico de $17,5 \mathrm{kN} / \mathrm{m}^{3}$, coesão efetiva de $60 \mathrm{kPa}$ e ângulo de atrito efetivo de $31^{\circ}$. Todos os chumbadores foram construídos com diâmetro de perfuração de $75 \mathrm{~mm}$, barras de aço CA-50 de $25 \mathrm{~mm}, 6$ e $3 \mathrm{~m}$ de comprimento injetado, fase única de injeção por gravidade (sem pressão) e calda de 
cimento com fator a/c igual a 0,6 . Os resultados dos ensaios da Rua Ati indicam valores médios de $q_{s}$ similares para os chumbadores de $6 \mathrm{~m}$, da ordem de $185 \mathrm{kPa}$ para a cota $-1 \mathrm{~m}$ e $205 \mathrm{kPa}$ para a cota $-2 \mathrm{~m}$. Os resultados dos chumbadores de $3 \mathrm{~m}$ apresentaram grandes variações de $q_{s}$ entre si, resultando em valores médios de $145 \mathrm{kPa}$ para a cota $-1,0 \mathrm{~m}$ e 295 $\mathrm{kPa}$ para a cota $-2,0 \mathrm{~m}$. Os resultados da Rua Cardoso Junior mostraram que a média dos resultados de $q_{s}$ para os chumbadores de $6 \mathrm{~m}$ foram de $95 \mathrm{kPa}, 120 \mathrm{kPa}$ e $190 \mathrm{kPa}$, para as cotas de $-5 \mathrm{~m},-10 \mathrm{~m}$ e $-15 \mathrm{~m}$, respectivamente. Os chumbadores de $3 \mathrm{~m}$ apresentaram valores de $q_{s}$ superiores aos obtidos para os chumbadores de $6 \mathrm{~m}$ e maiores variações entre si. As médias dos resultados de $q_{s}$ para os grampos de $3 \mathrm{~m}$ foram de $108 \mathrm{kPa}, 148 \mathrm{kPa}$ e 248 $\mathrm{kPa}$, para as cotas de $-5 \mathrm{~m},-10 \mathrm{~m} \mathrm{e}-15 \mathrm{~m}$, respectivamente.

\subsubsection{Pesquisas - Ensaios de Arancamento em Laboratónio}

A realização de ensaios de arrancamento em campo pode ser considerada como a principal rotina para se verificar o parâmetro $q_{s}$ assumido na fase de projeto. Entretanto, em virtude das variáveis e incertezas encontradas em campo, os resultados destes ensaios podem ser bastante dispersos e de difícil entendimento. Neste sentido, a realização de ensaios de arrancamento em laboratório é uma alternativa muito interessante que pode ajudar sobremaneira este entendimento. Alguns pesquisadores têm investigado a resistência ao cisalhamento de interface a partir de ensaios de arrancamento realizados em laboratório, entre eles: Chang \& Milligan (1996), Franzen (1998), Lee et al. (2004), Junaideen et al (2004), Chu \& Yin (2005), Su et al. (2008) e França \& Bueno (2009).

Chang \& Milligan (1996) realizaram ensaios de arrancamento em uma caixa de laboratório que apresenta área plana de $254 \mathrm{~mm}$ x $153 \mathrm{~mm}$ (L x B) e altura (H) de $202 \mathrm{~mm}$. Foi utilizado um material granular (areia) com duas diferentes densidades relativas (78 e 94\%). O reforço foi composto por barra de aço de 2,0 $\mathrm{mm}$ de diâmetro. Também foram aplicadas duas sobrecargas distintas $(3,4$ e $6,4 \mathrm{kN})$. Buscou-se avaliar a influência do fenômeno da restrição da dilatância na resistência ao cisalhamento de interface, em diferentes zonas desenvolvidas no interior do solo, especialmente na zona de transição. A zona de transição pode ser definida como a região situada entre a zona de Rankine $\left(45^{\circ}+\right.$ $\phi_{\mathrm{ps}} / 2$ ) e a zona estável, determinada a partir do pé do muro com uma inclinação $\phi_{\mathrm{ps}}$ (ângulo 
de atrito do solo) em relação à direção horizontal, conforme apresentado na Figura 2.39. Para quantificar o parâmetro $q_{s}$ no interior das regiões apresentadas, manteve-se constante o comprimento aderido de interface solo-reforço e variaram-se os comprimentos livre e total do reforço. A partir dos resultados obtidos, verificou-se que não é necessário considerar o efeito da restrição da dilatância na zona de transição, pois o solo já pode estar sob a ação da tensão cisalhante limite. Entretanto, observou que pode ser conservativo ignorar o efeito da restrição da dilatância dentro da zona estável.

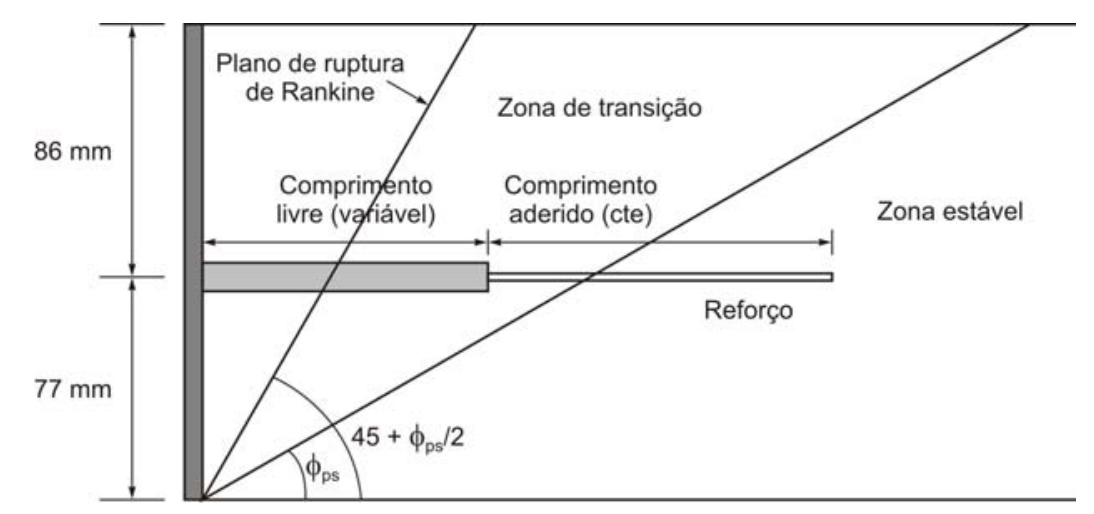

Figura 2.39. Zona de Transição (Chang \& Milligan, 1996).

Franzen (1998) desenvolveu um equipamento de laboratório de grande porte para avaliar a resistência ao arrancamento de reforços dispostos em areia fina, mal graduada e seca. $\mathrm{O}$ equipamento de arrancamento apresenta área plana de 2,00 x 4,00 m (BxL) e altura de 1,50 m. Os ensaios foram realizados variando-se a tensão vertical $(25,75$ e $125 \mathrm{kPa})$, o número de reforços e o método de instalação dos reforços cravados (cravação estática e dinâmica). Os resultados indicaram que a resistência residual de arrancamento independe do método de instalação dos reforços cravados. Entretanto, o comportamento pré-pico difere significantemente para os dois métodos de instalação. $O$ reforço cravado dinamicamente apresentou carga de pico $50 \%$ maior do que a do reforço cravado estaticamente. $\mathrm{O}$ autor concluiu que este aumento se deve ao aumento da tensão normal atuante sobre os reforços, provocado pelo volume de solo deslocado pelo reforço durante o seu processo de cravação dinâmica.

Lee et al. (2004) construíram um equipamento de laboratório para realizar ensaios de arrancamento e estudar a interação solo-reforço para um solo típico de Hong Kong 
(granito completamente decomposto). A caixa de arrancamento apresenta área plana de 1,60 x 2,00 m (BxL), altura de 1,40 m, e é composta por dois pórticos estruturais de reação, de 2,4 x 2,4 m (BxL), e por dispositivos de arrancamento constituídos por uma célula de carga e transdutores de deslocamento. Foram utilizados três tipos de reforços cravados: barra de aço nervurada de $25 \mathrm{~mm}$ de diâmetro, barra de aço lisa de $25 \mathrm{~mm}$ de diâmetro e tubo de aço com algumas ranhuras de diâmetro externo de $24 \mathrm{~mm}$ e com espessura de parede de 3,0 mm. Os ensaios foram realizados sob quatro diferentes tensões verticais $(12,0,51,5,66,5$, e $91,5 \mathrm{kPa})$, e os resultados mostraram que a resistência ao cisalhamento de interface das barras de aço lisa e dos tubos de aço aumentou com o incremento da tensão vertical atuante sobre elas. As barras de aço nervuradas não apresentaram ganho significativo de resistência com um aumento da tensão vertical aplicada. Em quase todos os casos, observou-se que as curvas carga $v_{s}$ deslocamento apresentam um valor de pico bem definido, seguido por um decréscimo da força de arrancamento. Em alguns casos, a força de arrancamento residual foi menor que $50 \%$ da carga de pico. Como esperado, o menor e o maior valor de $q_{s}$ foram observados para as barras lisa e nervurada, respectivamente.

Chu \& Yin (2005) realizaram ensaios de arrancamento em uma caixa de ensaio que apresenta área plana de 0,55 x 0,70 $\mathrm{m}(\mathrm{BxL})$ e altura de 0,60 m. Buscou-se avaliar a influência de diferentes tensões verticais $(50,100$ e $300 \mathrm{kPa})$, do grau de saturação do solo e da rugosidade da interface na resistência ao cisalhamento de interface solo-reforço. O solo, granito completamente decomposto, foi compactado no interior da caixa de ensaios em seis camadas (grau de compactação de 95\%). Foi realizado um pré-furo de $100 \mathrm{~mm}$ de diâmetro para a instalação de uma barra de aço de $32 \mathrm{~mm}$ de diâmetro e o preenchimento com calda de cimento (relação água-cimento igual a 0,45 ) sem pressão. Os reforços apresentavam superfície regular e irregular com comprimentos de $500 \mathrm{~mm}$ e $700 \mathrm{~mm}$, respectivamente. Antes de iniciar o arrancamento dos reforços, realizou-se uma simulação numérica em um programa de diferenças finitas, para avaliar se a tensão aplicada na superfície da caixa estava sendo totalmente aplicada e distribuída sobre o chumbador de $100 \mathrm{~mm}$ de diâmetro. Nos reforços de $500 \mathrm{~mm}$, as tensões verticais estavam uniformemente distribuídas em $90 \%$ da extensão do reforço, enquanto que nos reforços de $700 \mathrm{~mm}$, as tensões foram uniformemente distribuídas ao longo de toda a extensão do reforço. Após a realização dos ensaios de arrancamento, os autores concluíram que: 
A resistência ao cisalhamento apresentou-se de forma crescente com o aumento da tensão normal aplicada;

Os valores do coeficiente de atrito aparente $\left(\mu^{*}\right)$ foram maiores para menores tensões normais;

$>\mathrm{O}$ grau de saturação do solo apresentou influência significativa na resistência ao cisalhamento da interface solo-reforço. Variando-se o grau de saturação de $70 \%$ para $86 \%$, a resistência de pico sofreu uma redução de 55\%, enquanto a resistência residual sofreu uma redução da ordem de $70 \%$.

$>$ Os reforços com superfícies irregulares (ásperas) apresentaram maior resistência de interface do que os reforços com superfície regular (lisos), para maiores deslocamentos.

Su et al. (2008) estudaram a influência da tensão vertical na resistência ao cisalhamento de interface solo-reforço. Para tal, foram realizados dezesseis ensaios de arrancamento, variando-se também o grau de saturação do solo $\left(\mathrm{S}_{\mathrm{r}}\right)$. Os ensaios foram realizados em uma caixa metálica, com dimensões de $1,0 \mathrm{~m}$ x $0,6 \mathrm{~m} \mathrm{e} 0,83 \mathrm{~m}$ (comprimento, largura e altura, respectivamente). A caixa foi instrumentada com células de tensão total, transdutores de pressão neutra e tensiômetros. Os resultados da instrumentação permitiram a realização de simulações numéricas para a comparação com os resultados experimentais. O solo utilizado (areia silto-argilosa) foi compactado em camadas e com grau de compactação médio igual a 95\%. Após 24 horas da aplicação da sobrecarga vertical, para equilíbrio do estado de tensões do solo, o chumbador foi construído com diâmetro de perfuração de $100 \mathrm{~mm}$, comprimento de $1,0 \mathrm{~m}$ e inclinação horizontal. Foram utilizadas barras de aço de $25 \mathrm{~mm}$ de diâmetro. O furo foi preenchido com calda de cimento injetada, com baixa pressão, a partir de um equipamento especialmente desenvolvido. Os ensaios de arrancamento foram realizados com dois graus de saturação diferentes (38 e 75\%). Para estas duas situações, foram utilizadas cinco sobrecargas verticais distintas (40, $80,120,200$ e $300 \mathrm{kPa}$ ). A partir dos resultados dos ensaios e da instrumentação, os autores concluíram que : 
> Após a perfuração, houve uma redução de aproximadamente $70-95 \%$ das tensões atuantes ao redor do furo e após o preenchimento da cavidade escavada, houve uma mínima variação no estado de tensões.

$>$ Durante os ensaios de arrancamento, as tensões verticais atuantes ao redor do chumbador aumentaram. Este incremento se deu, principalmente, pelo efeito da dilatância restringida do solo.

Nos ensaios realizados não foi observada uma relação direta entre a resistência ao cisalhamento do reforço com a sobrecarga vertical atuante sobre o reforço.

França \& Bueno (2009) descrevem o comportamento de um modelo de solo grampeado construído em laboratório, em uma caixa metálica rígida $(1,80 \mathrm{~m} \times 1,55 \mathrm{~m} \times$ $1,80 \mathrm{~m})$ que assegura o estado plano de deformações e permite aplicação de sobrecarga. $\mathrm{O}$ modelo foi instrumentado e testado com o propósito de fornecer informações sobre o comportamento deste tipo de estrutura e obter sugestões para os parâmetros de projeto. A instrumentação incluiu a instalação de extensômetros elétricos nos grampos e medidas de deslocamento do modelo. As análises foram executadas para as condições de fim da construção e após a aplicação da sobrecarga. Foram executados ensaios de arrancamento seguidos da extração dos grampos ensaiados. Uma superfície potencial de ruptura foi sugerida para cada caso. Foi possível também avaliar o modelo em relação aos deslocamentos e forças nos grampos.

\subsection{INJ EÇÃO DE CALDA DE CIMENTO}

A divulgação de acidentes em obras executadas para arrimos de terra é muito rara, pois a intenção em divulgar este tipo de evento é mínima ou inexistente. Ao realizar uma pesquisa sobre as causas destes acidentes, descobrem-se sempre vários motivos, que somados resultam na ruptura da solução adotada. Quando se trata de uma obra de solo pregado, deve-se, obrigatoriamente, analisar os detalhes executivos do chumbador, dos sistemas de drenagem e do revestimento do paramento. O elemento de maior relevância para a queda de arrimo construído pela técnica de solo pregado é a má execução do 
chumbador (Zirlis et al., 2005). Neste sentido, julga-se necessário conhecer e entender como é realizado o processo de injeção dos chumbadores.

O processo de injeção de calda de cimento tem aproximadamente 200 anos, um curto período quando comparado ao desenvolvimento da engenharia civil, que surgiu junto com os primórdios da civilização humana. Este processo pode ser definido como um procedimento em que a calda de cimento é injetada no interior de vazios, fissuras, fendas ou cavidades existentes em formações de solos e rochas, com o objetivo de melhorar suas propriedades mecânicas. Busca-se, reduzir a condutividade hidráulica, aumentar a resistência e minorar a deformabilidade destas formações (Nonveiller, 1989). A calda de cimento é injetada no interior destas formações até atingir o critério de saturação especificado no projeto, representado por: preenchimento dos vazios ao redor da seção injetada, obtenção da pressão máxima ou fluxo mínimo de injeção.

Este tipo de tratamento pode ser realizado com vários tipos de materiais, escolhidos em função dos objetivos do tratamento e das propriedades das rochas e dos solos a serem tratados. Os materiais podem variar desde argamassas plásticas, suspensões compostas por cimento, aditivos e água até soluções e resinas compostas por componentes químicos.

Ao analisar os trabalhos teóricos apresentados por Camberfort (1964) e Nonveiller (1989), verifica-se que a escolha do tipo de injeção é sempre influenciada pela relação entre a viscosidade do fluido e a condutividade hidráulica do solo. As suspensões podem ser injetadas no interior de rochas fissuradas e de solos que apresentam granulometria média, elevada porosidade e grandes vazios. As soluções podem ser injetadas no interior de solos com granulometria fina, em que as suspensões não podem penetrar. Atualmente, a partir do avanço científico desta área, é possível utilizar muitos tipos de resinas químicas que apresentam viscosidade semelhante à viscosidade da água, mas que são mais penetráveis que as soluções. Contudo, a experiência no Brasil, após algumas décadas de serviços prestados em grandes obras, conduz para uma condição não convencional, ou seja, injetar suspensões, compostas por cimento comum, em solos finos (siltes e argilas) que apresentam condutividade hidráulica inferior a $10^{-6} \mathrm{~m} / \mathrm{s}$.

Para compreender os princípios da injeção da calda de cimento em solos com baixa permeabilidade, é necessário entender o mecanismo de fraturamento do maciço de 
solo. Neste sentido, pode-se, por analogia, analisar o funcionamento de uma válvula "manchete" após a perfuração já estar preenchida com calda de cimento (bainha). O principio de funcionamento deste sistema de injeção está representado na Figura 2.40.

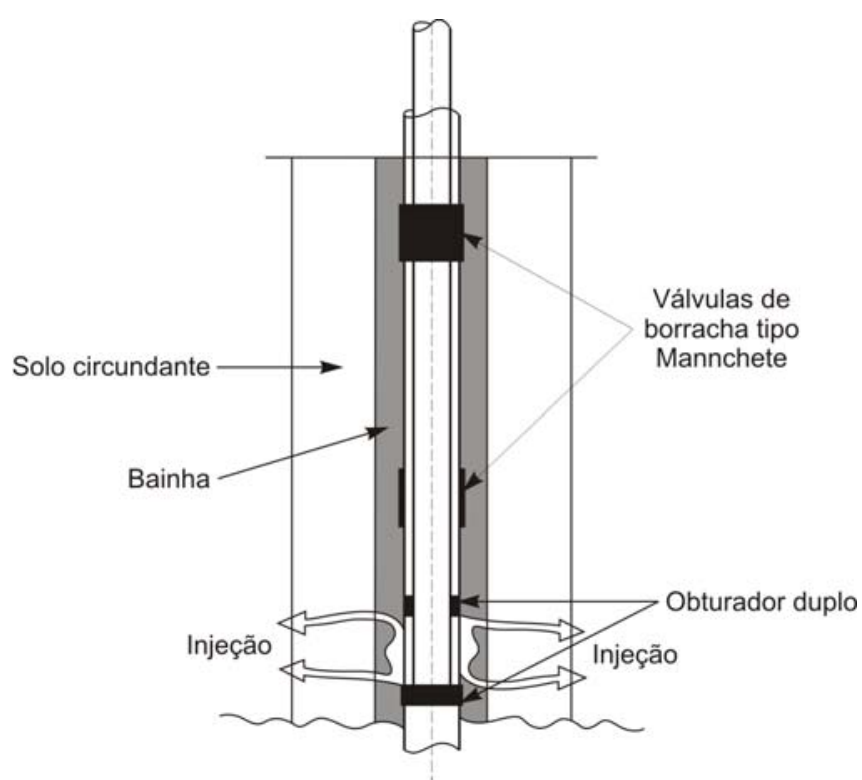

Figura 2.40. Tubo de injeção com válvulas tipo “manchette” (Guimarães Filho, 1994).

A partir da Figura 2.40, observa-se que o tubo de injeção apresenta as válvulas de borracha confinadas pela calda de cimento semi-rígida (bainha). Quando se posiciona o obturador duplo em uma determinada válvula e injeta-se o fluido de calda de cimento sob pressão, a válvula flexível se abre e o fluido fissura a bainha, para depois se comunicar com o solo circundante. A pressão de reação do terreno será baixa quando se encontrar em grandes vazios e solos de baixa consistência, e será maior para solos mais consistentes. Para melhorar a consistência dos solos, se estabelece a quantidade a injetar por fase, e verifica-se o aumento da pressão de reação do terreno de uma fase para a outra. É interessante enfatizar que a injeção de solos tem como principio básico o aumento das pressões de reações.

O processo de injeção exige especificações em relação à composição da suspensão injetada, a taxa de bombeamento e o controle de pressão, para satisfazer ao critério de saturação para um determinado intervalo de tempo. O controle destes parâmetros implica no controle de qualidade da injeção, ou seja, quando o fluxo da injeção é baixo e a pressão 
de reação do solo vai aumentando-se gradualmente, a injeção é realizada de forma contínua até atingir o critério de saturação. Entretanto, quando a vazão de bombeamento é elevada e a pressão de reação do terreno permanece baixa, é necessário aumentar a densidade da suspensão até que a pressão de reação comece a crescer e diminuir a vazão de bombeamento (Guimarães Filho, 1994).

As Figuras 2.41 (a) e (b) apresentam as pressões médias de reação do solo em função das sucessivas fases de injeção em solos distintos. A Figura 2.41 (a) representa quatro fases de injeção em argila orgânica preta, com $\mathrm{N}_{\mathrm{SPT}}$ igual a zero, enquanto a Figura 2.41 (b) representa 3 fases de injeção em solo residual, localizado a $25 \mathrm{~m}$ de profundidade.
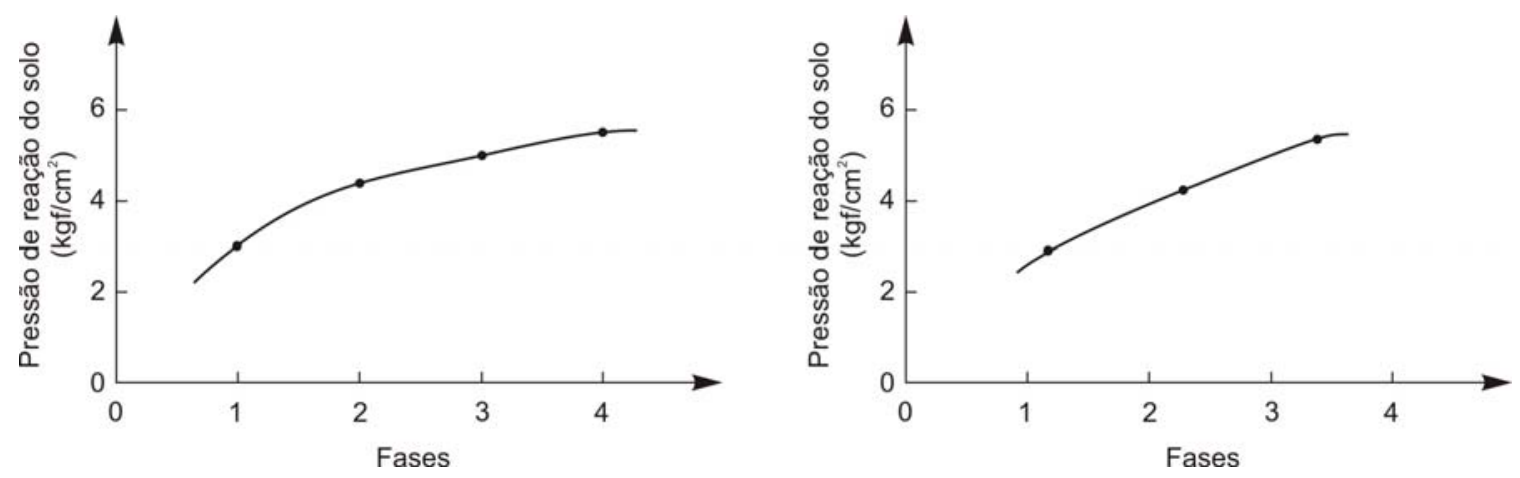

Figura 2.41. Aumentos médios da pressão de reação do solo em função de sucessivas fases de injeção: (a) argila orgânica preta, obra do túnel oeste do metrô da Via Singela; (b) obra de fundação de prédio em Santos - SP (Guimarães Filho, 1994).

A partir da curva apresentada na Figura 2.41 (a), observa-se uma variação da pressão de reação do solo (argila orgânica preta) de 3 a $6 \mathrm{kgf} / \mathrm{cm}^{2}$ entre as 4 fases de injeção, enquanto na Figura 2.41 (b), observa-se uma variação de $14 \mathrm{kgf} / \mathrm{cm}^{2}$ até 28 $\mathrm{kgf} / \mathrm{cm}^{2}$ da pressão de reação do solo (solo residual) em relação às 3 fases de injeção. Apesar dos números absolutos serem muito diferentes, os gradientes de pressão são similares. Estes gradientes podem ser chamados de "gradientes de melhoria" do solo.

A pressão de reação do solo e o volume de injeção devem ser compilados e analisados. O resultado desta análise oferecerá o diagnóstico do chumbador, podendo sugerir a necessidade da instalação de mais mangueiras de injeção ou até sua redução. Como proposta de melhoria da eficiência da injeção, a prática atual sugere a colocação de 
mangueiras com válvulas setorizadas junto às barras de aço, ou seja, a divisão do chumbador em duas ou três faixas de injeção.

\subsection{DURABIUDADE DOS REFORÇOS EM ESTRUTURAS TEMPORÁRIAS E PERMANENTES}

Uma das considerações mais importantes em estruturas de solo reforçado é a durabilidade do reforço ao longo da vida útil da obra. É extremamente importante conhecer as características dos elementos utilizados como reforço e as eventuais alterações que podem ocorrer em suas propriedades, durante sua exposição ao "ambiente" solo. Este fato remete à necessidade de dimensionar o reforço em conformidade com a vida útil da estrutura de contenção. A técnica de solo pregado pode ser utilizada como solução temporária ou permanente. Obras são consideradas permanentes quando apresentam vida útil entre 75 e 100 anos. Em obras temporárias, geralmente, sua vida útil varia entre 10 e 36 meses, podendo ser maior ou menor de acordo com as situações de projeto.

Ao utilizar o solo pregado como estrutura permanente, deve-se considerar dois tipos de degradação: danos decorrentes dos processos de instalação e deterioração por fatores físicos e químicos. Entre os fatores físicos, enquadram-se a abrasão durante o processo construtivo, o carregamento prolongado, os carregamentos cíclicos e o processo de ciclagem. A deterioração por fatores químicos pode ser provocada pela exposição do reforço ao ar, à água, aos agentes químicos existentes no terreno e à luz solar (Mitchell \& Villet, 1987). A complexidade do processo de corrosão, principal processo que conduz à degradação das inclusões, e a baixa experiência dos projetistas em relação a este assunto remetem a um conservadorismo no dimensionamento dos reforços.

A redução da resistência à tração da barra de aço está diretamente relacionada com a redução da espessura devido à corrosão. Os diferentes tipos de corrosão estão associados aos diferentes tipos de metais. O aço galvanizado e o aço preto (aços de resistência moderada) apresentam processo de corrosão relativamente uniforme na sua superfície, enquanto no aço de elevada resistência, submetido a elevadas tensões de tração, o processo é inicialmente desenvolvido na interface dos cristais, para então progredir para o interior do aço. Este processo é chamado de "corrosão intergranular" e é muito mais difícil de ser analisado e previsto. 
Quando a barra de aço apresenta-se envolvida por calda de cimento, não há contato direto entre o solo e a barra de aço. Entretanto, se este material apresentar baixa resistência e for submetido a tensões de tração, pode sofrer microfissuras e permitir que a água (com sais dissolvidos) e o oxigênio entrem em contato com a barra de aço, desencadeando o processo de corrosão. Apesar do conservadorismo exagerado, assume-se nos projetos que a calda de cimento não promove nenhuma proteção e que a taxa de corrosão é a mesma que nas barras de aço cravadas diretamente no terreno.

Como o emprego da técnica de solo pregado é crescente como estrutura permanente, medidas preventivas especiais precisam ser tomadas para prevenir o processo corrosivo. Apresentam-se a seguir algumas medidas preventivas que podem ser especificadas em projeto para proteger os reforços (Clouterre, 1991):

Espessura de sacrifício: consiste no sistema de proteção mais simples e mais utilizado. A adoção de uma espessura de sacrifício no dimensionamento de barras de aço faz com que o produto resultante da corrosão forme uma barreira de proteção entre o aço e os solos que o envolvem. Esta proteção não ocorre de forma mecânica, mas sim pela modificação do ambiente da barra de aço, alterando-se a cinética das reações químicas, que, ao se manifestarem de forma mais lenta, reduzem a taxa de corrosão.

> Proteção com revestimento plástico: este sistema consiste na instalação de um revestimento composto por algum material plástico (polipropileno, polietileno ou similar, ou, mais raramente, aço). O espaço entre o revestimento e a barra de aço é preenchido com calda de cimento ou outro material que não seja agressivo para o aço ou para o material do revestimento. Este sistema é utilizado para prevenir qualquer contato entre o solo e o reforço. Para a completa eficiência do sistema, é necessário que o revestimento seja impermeável ao longo de toda a sua extensão e resistente às tensões de tração a que é submetido. Este sistema de proteção não é recomendado em reforços cravados, pois pode sofrer avarias durante o processo de instalação.

Galvanização: este tipo de proteção deve-se a uma camada superficial formada pelo hidróxido de zinco (produto da corrosão do zinco), que retarda o processo da 
corrosão na barra de aço. Como o zinco é mais eletronegativo que o aço, este material é "sacrificado" para proteger o aço. É pouco aplicado em estruturas de solo pregado.

Proteção com cobertura não metálica: As principais coberturas não metálicas utilizadas como proteção são: tinta betuminosa, piches tradicionais, piches melhorados com resinas, resinas epóxi, etc. Estes revestimentos formam uma camada superficial que irá garantir um período limitado de proteção (em torno de 10 anos).

\subsection{TIPOS DE RUPTURA EM ESTRUTURAS DE SOLO PREGADO}

Na técnica de solo pregado, assim como em outras estruturas de solo reforçado, o processo de instabilidade pode acontecer por ruptura interna do sistema solo reforçado e por ruptura externa, no qual a estrutura comporta-se como um bloco monolítico. $\mathrm{Na}$ seqüência, apresentam-se, de forma mais especifica, os diferentes modos de ruptura do sistema solo pregado (Clouterre, 1991).

\subsubsection{Ruptura Intema}

Neste sistema de reforço de solos, quando há alguma falha no mecanismo de transferência de carga entre o solo, o reforço e a calda de cimento, pode-se dizer que ocorreu a ruptura interna do sistema. Este processo pode estar relacionado com a resistência à tração, com o comprimento do reforço, com a resistência da interface solo-reforço e com alguma falha no processo construtivo. A seguir, apresentam-se as diferentes maneiras em que o solo pregado pode entrar em colapso. 


\subsubsection{Ruptura dos Reforços}

A ruptura interna do sistema solo pregado pela falta de resistência dos reforços é a que mais tem sido estudada, a partir de modelos construídos em escala reduzida e de experimentos realizados em escala real e conduzidos à condição de ruptura.

A título de exemplo, pode-se dizer que, no já mencionado experimento $\mathrm{n}^{\circ} 1 \mathrm{da}$ CEBTP (Clouterre, 1991), o desenvolvimento de uma zona de cisalhamento no solo mobilizou a resistência à flexão do reforço. Este tipo de ruptura, conforme apresentado na Figura 2.42, serviu como aviso de que a estrutura se apresentava comprometida e não permitiu que a ruptura do reforço ocorresse ao longo da superfície de ruptura, ou seja, pela máxima carga de tração.

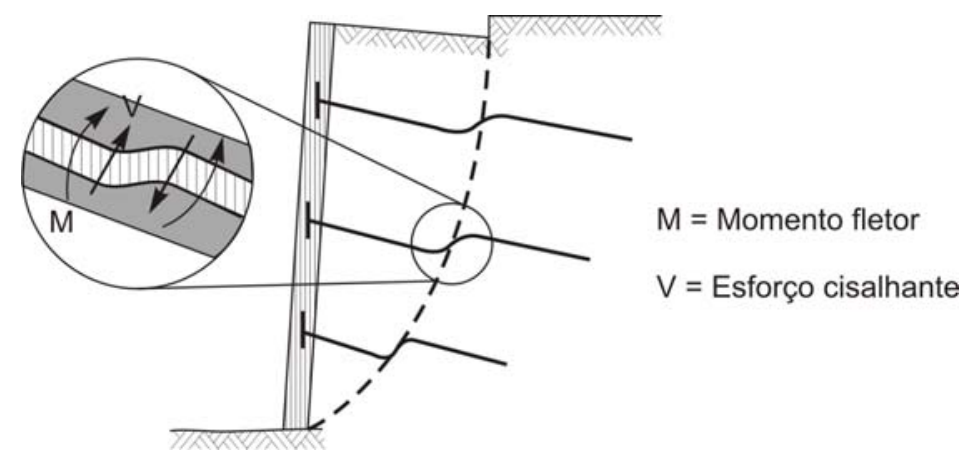

Figura 2.42. Ruptura interna por flexão e/ou cisalhamento dos reforços (Elias et al., 1993).

A ruptura dos reforços por esforços de tração pôde ser observada em ensaios realizados em modelos reduzidos, em que se utilizaram reforços mais flexíveis. Ao empregar este tipo de reforço, a ruptura ocorre de forma repentina, ou seja, sem aviso (Figura 2.43). 


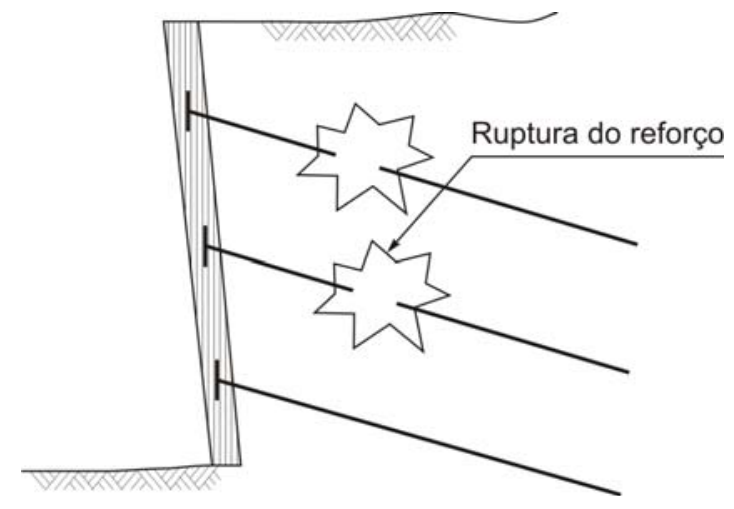

Figura 2.43. Ruptura interna por esforços de tração nos reforços (Elias et al., 1993).

Alguns fatores podem provocar o processo de ruptura dos reforços, entre os quais:

Sub-dimensionamento da seção transversal do reforço;

$>$ Processo de corrosão do reforço. Este tipo de ruptura ocorre de forma repentina ao longo da superfície de ruptura, onde as tensões de tração são máximas (Guilloux \& Jailloux, 1979).

> Sobrecarga posicionada no topo do muro, quando este não está dimensionado para suportá-la. Este tipo de ruptura foi verificado em um muro de solo pregado construído na Alemanha (Stocker et al., 1979);

Saturação da estrutura reforçada por infiltração da água;

Presença de lentes de gelo em solos susceptíveis ao congelamento. O processo de congelamento no interior do maciço de solo provoca o surgimento de tensões de tração nos reforços, podendo acarretar riscos para as faces. Quando a face é muito resistente, os reforços rompem por tração. Este processo pode ser observado em estruturas de solo pregado realizadas em regiões montanhosas e de clima frio.

\subsubsection{Ruptura por Falta de Aderência (Amancamento)}

A ruptura por falta de aderência, ou seja, por arrancamento do reforço do interior do maciço de solo, deve-se ao comprimento insuficiente dos reforços na zona passiva (zona de ancoragem). Desta forma, o processo de redistribuição das tensões da zona ativa para a 
zona passiva é comprometido, e os reforços são arrancados do maciço de solo (Figura 2.44).

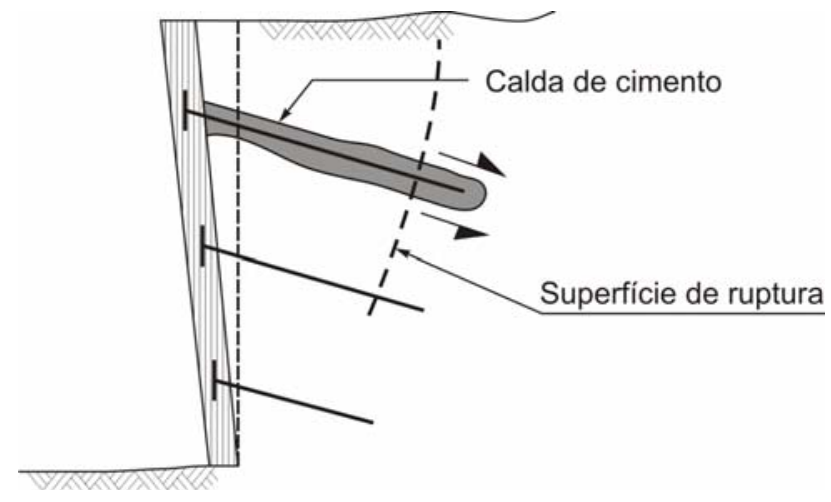

Figura 2.44. Ruptura interna por falta de aderência na interface solo-reforço (Elias et al., 1993).

Este tipo de ruptura não ocorre de forma repentina e está geralmente associado a:

Solos de granulometria fina que se apresentam sob o efeito da saturação ou de aumento excessivo do teor de umidade;

- Insuficiente comprimento dos reforços, especialmente no topo da estrutura, determinado a partir de uma consideração equivocada do parâmetro $q_{s}$.

Este tipo de ruptura apresenta maior ocorrência na prática, e é muito difícil de ser representado em modelos de laboratório e em protótipos de escala real, tornando-se menos estudado. A seguir apresentam-se dois exemplos de estruturas de solo pregado conhecidas internacionalmente por romperem por falta de aderência (arrancamento) entre o solo e o reforço. A primeira refere-se a "Eparris Wall”, cuja ruptura ocorreu em serviço, em 1980, e a outra se refere ao experimento $n^{\circ} 3$ da CEBTP.

A “Eparris Wall” foi construída para conter uma escavação em argila plástica, cujos parâmetros estão apresentados na Figura 2.45. Esta estrutura foi construída com 4,5 m de altura e 4,5 m de extensão. Os chumbadores foram compostos por barra de aço e calda de cimento injetada sob baixa pressão. Alguns meses após o final da construção, durante um período de chuvas intensas, o muro rompeu segundo um mecanismo cinemático, ou seja, o topo da estrutura se moveu sem ocorrer qualquer translação do pé da estrutura. 


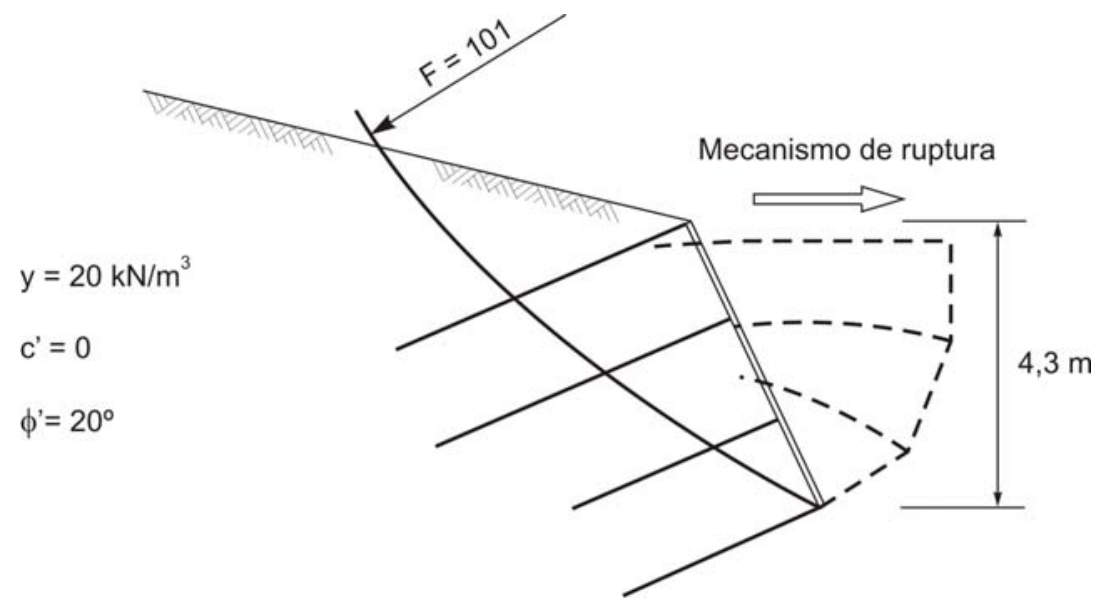

Figura 2.45. Forma deformada da "Eparris Wall” após a ruptura (Clouterre, 1991).

Após o colapso, foram realizados, no mesmo local, ensaios de arrancamento em reforços similares ao utilizado na obra. Os ensaios permitiram quantificar a carga de arrancamento $(15 \mathrm{kN} / \mathrm{m})$ e determinar o baixo fator de segurança $(0,95)$ da contenção. $\mathrm{O}$ muro foi reconstruído e os reforços foram redimensionados com um novo fator de segurança $(1,5)$. Após a reconstrução, não foram mais observadas deformações ou deslocamentos críticos.

Este processo de ruptura, também foi verificado no experimento $\mathrm{n}^{\circ} 3$ da CEBTP. O muro de solo pregado foi construído com $6,0 \mathrm{~m}$ de altura e foi levado à condição de ruptura a partir de uma redução gradual do comprimento dos reforços telescópicos (reforços instalados no interior de tubos), conforme esquema da Figura 2.46. A partir da redução gradual do comprimento dos reforços, ocorreu um recalque de $0,30 \mathrm{~m}$ do maciço reforçado e um deslizamento bem definido ao longo da superfície de ruptura. 


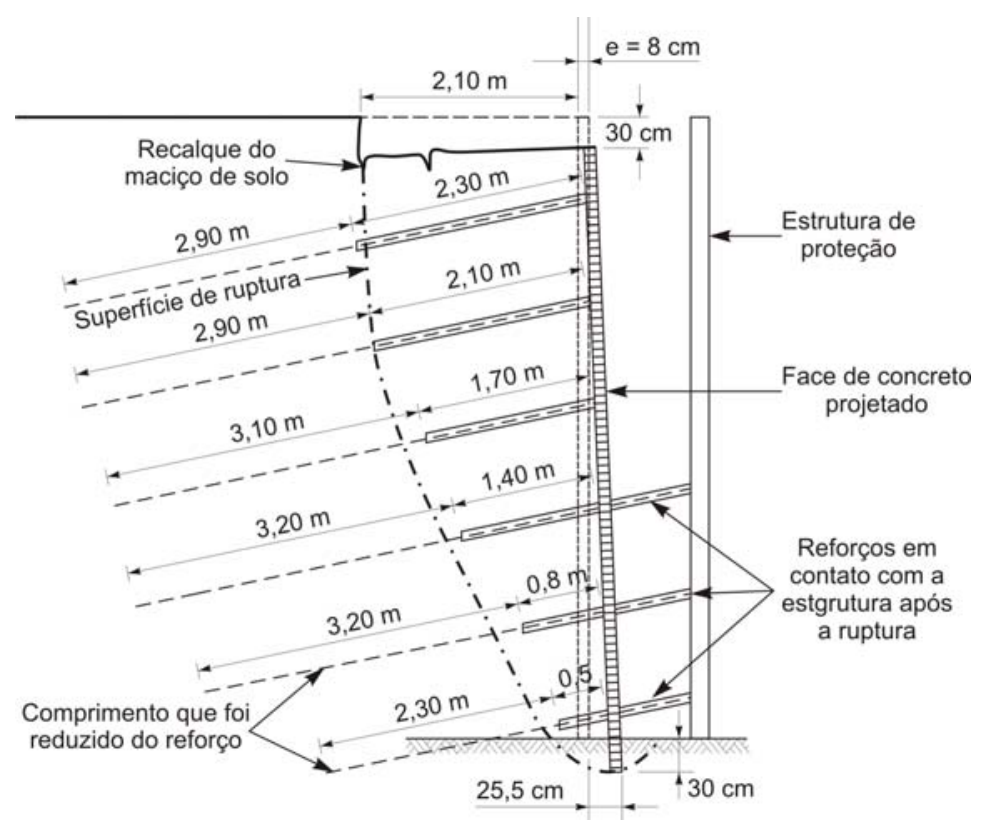

Figura 2.46. Observações pós-ruptura do muro experimental nº 3 da CEBTP (Clouterre, 1991).

\subsubsection{Ruptura Durante as Fases de Escavação}

A altura da frente de escavação é um parâmetro de grande importância na execução de uma obra de solo pregado, pois está diretamente relacionada com as propriedades geotécnicas do material escavado. Ao dimensionar uma frente de escavação muito alta, pode acontecer um processo de instabilização local que irá se propagar para o topo da estrutura, em um processo de ruptura repentina. Neste tipo de ruptura, a movimentação do solo ocorre pela sucessiva eliminação do efeito do arqueamento.

Para avaliar a estabilidade local e global do maciço de solo pregado durante as sucessivas fases de escavação, construiu-se um muro de solo pregado de 6,0 $\mathrm{m}$ de altura, com areia Fontainebleau, durante a realização do projeto Clouterre. Para conduzir esta estrutura à condição de ruptura, os avanços da frente de escavação foram realizados com alturas crescentes, conforme apresentado na Figura 2.47. 


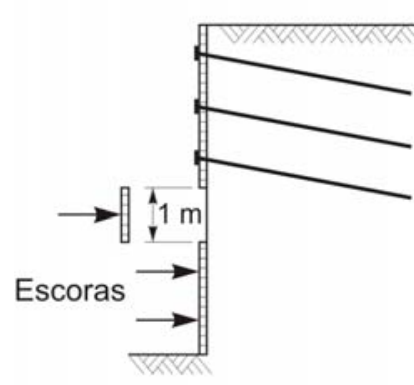

a - Estável

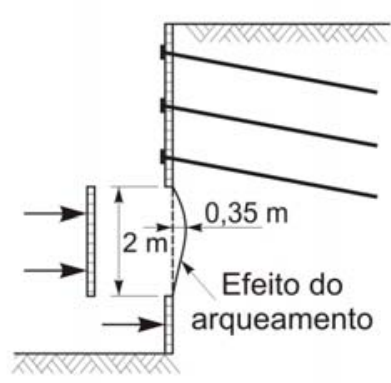

b - Estabilidade limite

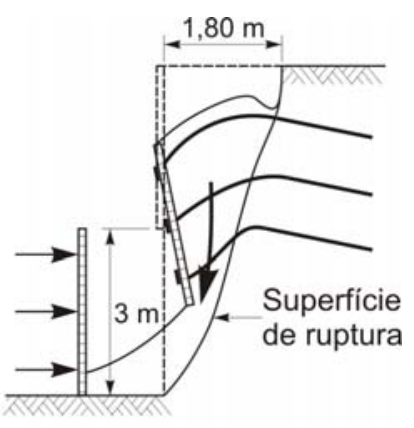

C - Ruptura

Figura 2.47. Estabilidade das fases de escavação do muro experimental $\mathbf{n}^{\circ} 02$ da CEBTP (Clouterre, 1991).

Durante a primeira fase de escavação (1,0 m de altura), a frente de escavação permaneceu estável. Na segunda fase de escavação (2,0 $\mathrm{m}$ de altura), ocorreram pequenas rupturas localizadas, que foram estabilizadas pelo fenômeno do arqueamento, e, em termos gerais, pode-se dizer que a estrutura permaneceu estável. Na terceira fase de escavação $(3,0$ $\mathrm{m}$ de altura), o efeito do arqueamento foi destruído, e a ruptura local propagou-se até o nível da superfície, fato este que provocou a ruptura interna e global da estrutura. Para evitar este tipo de ruptura, a altura da frente de escavação deve ser inferior à altura crítica de escavação, para a qual o maciço de solo permanece estável.

Outro tipo de ruptura bastante similar a anterior, principalmente em relação ao modo de ruptura, refere-se à ruptura por piping do solo. A diferença entre ambos está nas causas que geram o processo de ruptura, relacionadas com a presença de lentes de água no solo a ser reforçado. Durante a fase de escavação, a pressão neutra existente no solo, conjuntamente com as forças de percolação, destroem a estabilidade local dos solos, criando rápidas e progressivas rupturas atrás do paramento de face. Este tipo de ruptura é freqüente e pode ser atribuída à heterogeneidade do solo e à falta de um sistema de drenagem adequado durante a fase de construção.

\subsubsection{Ruptura Extema e Ruptura Mista}

O processo de ruptura externa de uma estrutura de solo pregado pode estar relacionado com o deslizamento ao longo da superfície de ruptura, afetando toda a estrutura 
até atingir o solo da fundação (Figura 2.48-a). Este tipo de ruptura é bastante comum em estruturas de contenção e deve-se à baixa capacidade do solo de fundação ou ao comprimento insuficiente dos reforços. Outro tipo de ruptura consiste no deslizamento da base do muro reforçado em relação ao solo de fundação (Figura 2.48-b). De forma complementar, também pode ser desenvolvido, um processo de ruptura misto, em que o processo de ruptura ocorre tanto internamente quanto externamente ao muro de contenção (Figura 2.48-c). Este tipo de ruptura está relacionado a um comprimento insuficiente do reforço (arrancamento) ou a uma baixa resistência à tração do reforço. Para este tipo de ruptura, deve-se combinar tanto a análise de estabilidade interna quanto a estabilidade externa.

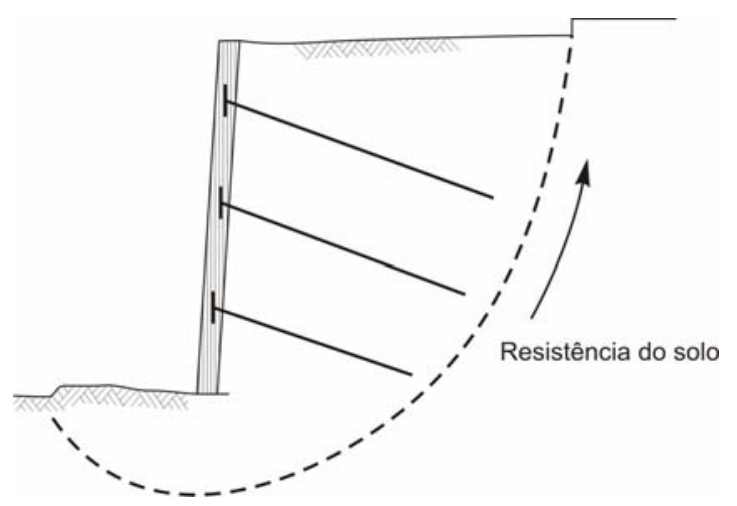

(a)

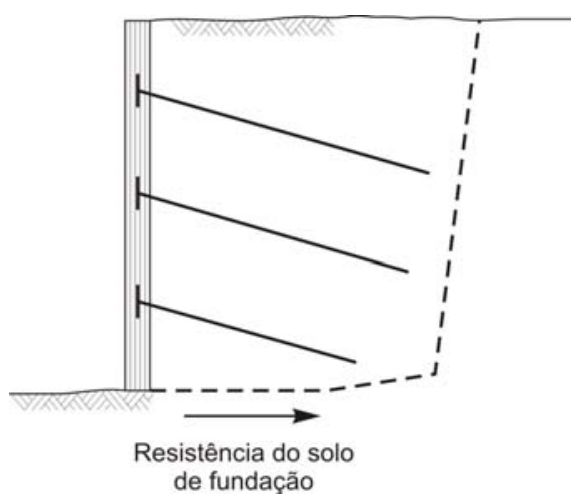

(b)

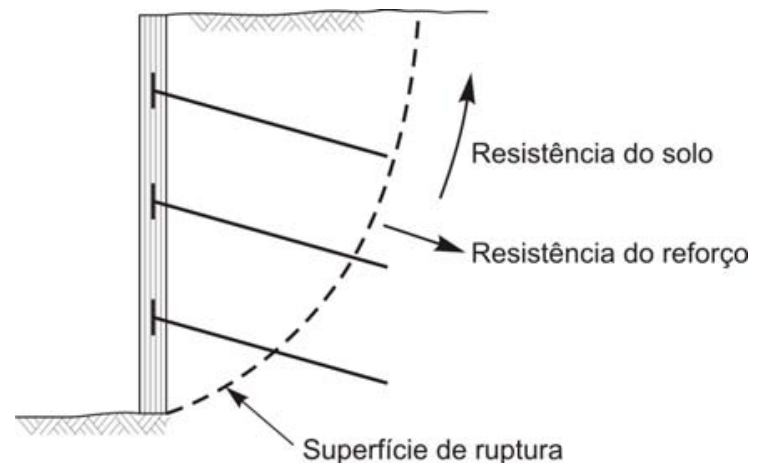

(c)

Figura 2.48. Diferentes tipos de ruptura em uma estrutura de solo pregado (Elias et al., 2003). 


\subsection{PRÉ-DIMENSIONAMENTO DE SOLO PREGADO}

A realização de estudos preliminares (pré-dimensionamento) de obras de solo pregado é muito útil na sua fase de planejamento. Este procedimento permite avaliar a viabilidade de diversas soluções alternativas e estimar os custos envolvidos. O prédimensionamento pode se basear em experiências de obras anteriores e em estudos paramétricos, realizados a partir dos métodos de equilíbrio limite, apresentados rotineiramente na forma de ábacos. Muitos ábacos, utilizados na fase de prédimensionamento, estão disponíveis na literatura, entre os quais, os apresentados por Gigan (1986) e Juran (1990). Estes ábacos permitem definir os comprimentos, os espaçamentos e a resistência ao cisalhamento de interface solo-reforço, de forma a garantir as estabilidades interna e externa desta estrutura. Ao longo desta etapa, os cálculos são realizados considerando apenas os esforços de tração, ou seja, negligencia-se a rigidez à flexão dos reforços.

A definição dos principais parâmetros nesta etapa de dimensionamento deve-se à metodologia empregada e à verificação se os níveis de deformação são aceitáveis para as estruturas existentes ao redor da escavação. Clouterre (1991) apresenta diretrizes para o pré-dimensionamento de estruturas de solo pregado (Tabela 2.8) e considera duas metodologias distintas: método de Hurpin (reforços cravados) e de reforços injetados. $\mathrm{O}$ pré-dimensionamento expedito considera que o maciço reforçado apresenta face vertical e plataforma superior horizontal.

Tabela 2.8. Ordem de grandeza das principais propriedades para dimensionamento de estruturas de solo pregado (Clouterre, 1991).

\begin{tabular}{ccc}
\hline Propriedades & $\begin{array}{c}\text { Método de Hurpin } \\
\text { (Reforços Cravados) }\end{array}$ & Reforços Injetados \\
\hline $\begin{array}{c}\text { Espaçamentos } \\
\mathrm{N}^{\circ} \text { de reforços } / \mathrm{m}^{2} \mathrm{de} \\
\text { face }\end{array}$ & Sv e Sh $<1,0 \mathrm{~m}$ & $1 \mathrm{~m}^{2} \leq \mathrm{Sv} . \mathrm{Sh} \leq 6 \mathrm{~m}^{2}$ \\
$\begin{array}{c}\text { Perímetro do reforço } \\
\text { Resistência à tração da } \\
\text { barra de aço } \\
\begin{array}{c}\text { Densidade dos } \\
\text { reforços* }\end{array}\end{array}$ & 150 a $200 \mathrm{~mm}$ & 0,15 a 0,4 \\
\hline
\end{tabular}


Nota: (*) Para estruturas de solo pregado que apresentam solos homogêneos e reforços idênticos (mesmo comprimento, mesmo diâmetro e mesma orientação), pode-se introduzir a definição de densidade de reforços $(\chi)$, definido como:

$$
\chi=\frac{T_{R}}{\gamma \cdot S_{h} \cdot S_{v} \cdot L}
$$

em que: $T_{R}$ é a força máxima de tração mobilizada no reforço (menor valor entre a resistência ao arrancamento e a ruptura); $\gamma$ é o peso específico do solo; $S_{h}$ e $S_{v}$ são os espaçamentos horizontais e verticais, respectivamente, e L é o comprimento do reforço.

A partir da Tabela 2.8, verifica-se que, no método de Hurpin (reforço cravado), os reforços apresentam maiores comprimento e densidade. Vale a pena ressaltar que a realização de um projeto preliminar é somente o primeiro passo que deve ser realizado para o dimensionamento de uma estrutura de solo pregado. Todas as considerações e os parâmetros adotados nesta etapa devem estar em conformidade com algum método de projeto disponível na bibliografia. A seguir, apresentam-se os principais métodos de projeto relacionados a este tipo de contenção.

\subsection{MÉIODOS DE PROJ ETO}

A realização de projetos de solo pregado implica na definição dos seguintes parâmetros relativos ao reforço: comprimento $(\mathrm{L})$, ângulo de instalação $(\alpha)$, espaçamento vertical $\left(\mathrm{S}_{\mathrm{v}}\right)$ e horizontal $\left(\mathrm{S}_{\mathrm{h}}\right)$. Não existe uma metodologia padrão ou única para o dimensionamento de uma estrutura de solo pregado. As bibliografias pertinentes apresentam diferentes enfoques em relação às premissas de cálculo. Em alguns casos, o maciço reforçado é considerado com comportamento semelhante ao de um muro de gravidade. Sendo assim, o solo reforçado deve ser verificado quanto ao deslizamento, ao tombamento, à capacidade de carga do solo de fundação e à estabilidade global.

Existem alguns métodos de cálculo de cunho internacional para o dimensionamento das estruturas de solo pregado. Na Europa, utilizam-se, com freqüência, 
o método Francês (Clouterre, 1991) e o Alemão (Stocker, 1979), enquanto, nos Estados Unidos, é utilizado o método de Davis (Shen et al., 1981). De forma complementar, foi desenvolvido o método Cinemático (Juran, 1990), que permite estimar as forças máximas de tração e cisalhamento atuantes nos reforços e a localização da superfície de ruptura. Estes métodos foram detalhadamente comparados por Clouterre (1991), Christopher et al. (1990) e Juran et al. (1990).

Todos os métodos mencionados admitem um mecanismo de ruptura no qual o maciço reforçado é dividido em uma zona ativa e uma zona passiva. O limite entre as duas regiões é definido pela localização, em cada reforço, do ponto de máxima força axial. A força axial é desenvolvida a partir do deslocamento do solo, causado pela descompressão lateral (escavação). As análises de estabilidade global são feitas considerando-se os esforços estabilizantes dos reforços atuando nesta cunha ativa.Entretanto, os métodos de cálculo diferem entre si quanto à forma da superfície de ruptura, quanto ao método de cálculo do equilíbrio das forças atuantes e quanto à natureza das forças (Zirlis et al., 1998).

No Brasil, entretanto, não há uma metodologia padrão bem definida para o dimensionamento do sistema solo pregado. A prática de dimensionamento baseia-se em metodologias de equilíbrio limite, em que os fatores de segurança são obtidos a partir de superfícies de ruptura pré-estabelecidas. Este fato faz com que o dimensionamento da estrutura reforçada dependa da magnitude dos parâmetros de resistência do solo e da resistência ao cisalhamento no contato solo/reforço $\left(q_{s}\right)$.

Vale lembrar que existem duas correntes de pensamento entre os pesquisadores de solo pregado. Uma delas considera a rigidez à flexão dos reforços, e a outra considera apenas os esforços de tração. Esta questão ainda precisa ser esclarecida, mas, preliminarmente, pode-se considerar que os reforços instalados na posição horizontal, atravessando à superfície potencial de ruptura, devem aumentar a resistência ao cisalhamento do solo, principalmente, por meio de seu trabalho à tração. A seguir, serão apresentados os principais métodos de projeto relacionados às estruturas de solo pregado. 


\subsubsection{Método Alemão}

Este método de cálculo foi proposto por Stocker et al. (1979) e considera, a partir do método de equilíbrio limite, que a estrutura de solo-reforço comporta-se como um muro de gravidade. Foi desenvolvido a partir de observações e resultados de ensaios realizados em modelos de escala reduzida, considerando que a superfície de ruptura é composta por dois segmentos de reta (bilinear), conforme esquema apresentado na Figura 2.49.

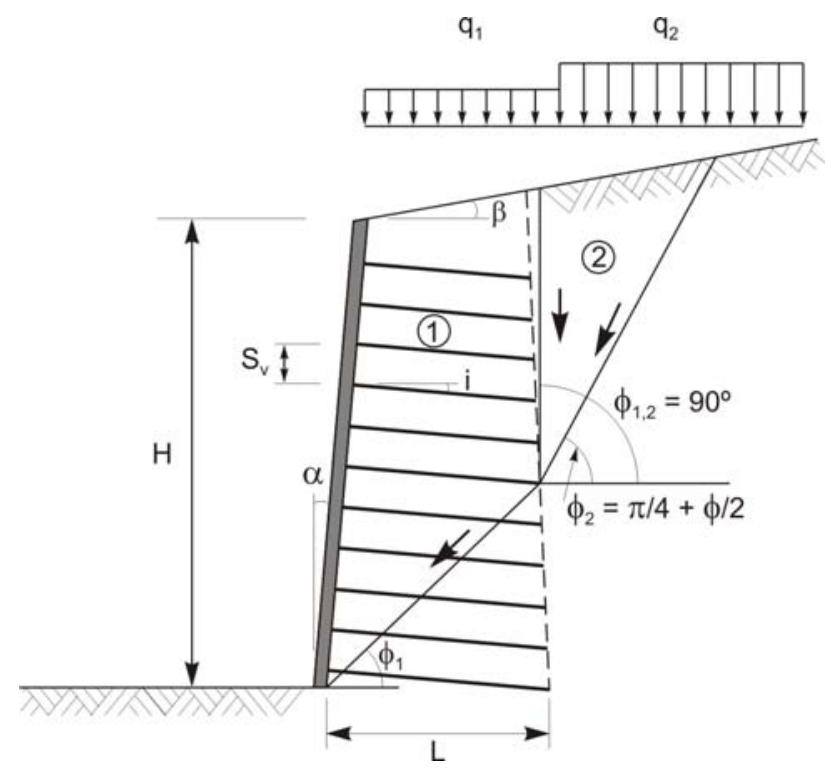

Figura 2.49. Superfície de ruptura bilinear considerada no método de Stocker et al. (1979).

O mecanismo de ruptura é composto por dois blocos que deslizam entre si, segundo uma linha vertical e fixados por três ângulos $\phi_{1}, \phi_{2}$ e $\phi_{12}$. Considera-se que o maciço de solo é homogêneo, que se apresenta sem água e que nos reforços somente atuam esforços de tração.

A partir da realização de várias análises comparativas de estabilidade, estabeleceuse que o fator de segurança mínimo, referente a este mecanismo de ruptura, pode ser determinado interativamente pela variação da inclinação de $\theta_{1}$, mantendo-se fixas as demais inclinações, ou seja, considera-se $\phi_{2}=\pi / 4+\phi / 2$ (onde $\phi$ é o ângulo de atrito interno do solo) e $\phi_{12}=90^{\circ}$. 
O fator de segurança global pode ser definido como a razão entre as forças resistivas para manter o equilíbrio limite (reação do solo ao longo da superfície de ruptura e desenvolvimento de tração nos reforços) e as forças atuantes (peso do maciço de solo e carregamentos atuantes) (Clouterre, 1991).

A resistência à ruptura $\left(\mathrm{T}_{\mathrm{R}}\right)$, considerada para cada reforço, é o menor valor obtido entre a resistência à tração $\left(\mathrm{T}_{\mathrm{G}}\right)$ e a resistência ao arrancamento $\left(\mathrm{T}_{\mathrm{L}}\right)$ do reforço, em que:

$$
T_{R}=\min \operatorname{imo}\left(T_{G}, T_{L}\right)
$$

Após comprovar a relevância do mecanismo de ruptura bi-linear, Gassler \& Gudehus (1981) buscaram avaliar a influência da variação de alguns parâmetros na determinação do fator de segurança mínimo. Estas análises foram realizadas variando-se os seguintes parâmetros:

a) inclinação do paramento de face $(\alpha)$ entre $5^{\circ}$ e $20^{\circ}$, em relação à direção vertical;

b) inclinação da superfície do maciço de solo $(\beta)$, em relação à direção horizontal, menor ou igual a $15^{\circ}$;

c) variação do comprimento $(\mathrm{L})$ das barras de aço entre e 60 e $70 \%$, em relação à altura da estrutura $(\mathrm{H})$;

d) cargas uniformemente distribuídas, $\mathrm{q}_{1}$ e $\mathrm{q}_{2}$, sobre a estrutura de solo pregado.

A partir das análises realizadas, os fatores de segurança mínimos $(\eta)$ foram calculados e apresentados em função de outras variáveis, criando-se ábacos que podem auxiliar no dimensionamento destas estruturas. A Figura 2.50 exemplifica alguns destes ábacos utilizados para alguns casos padronizados. 

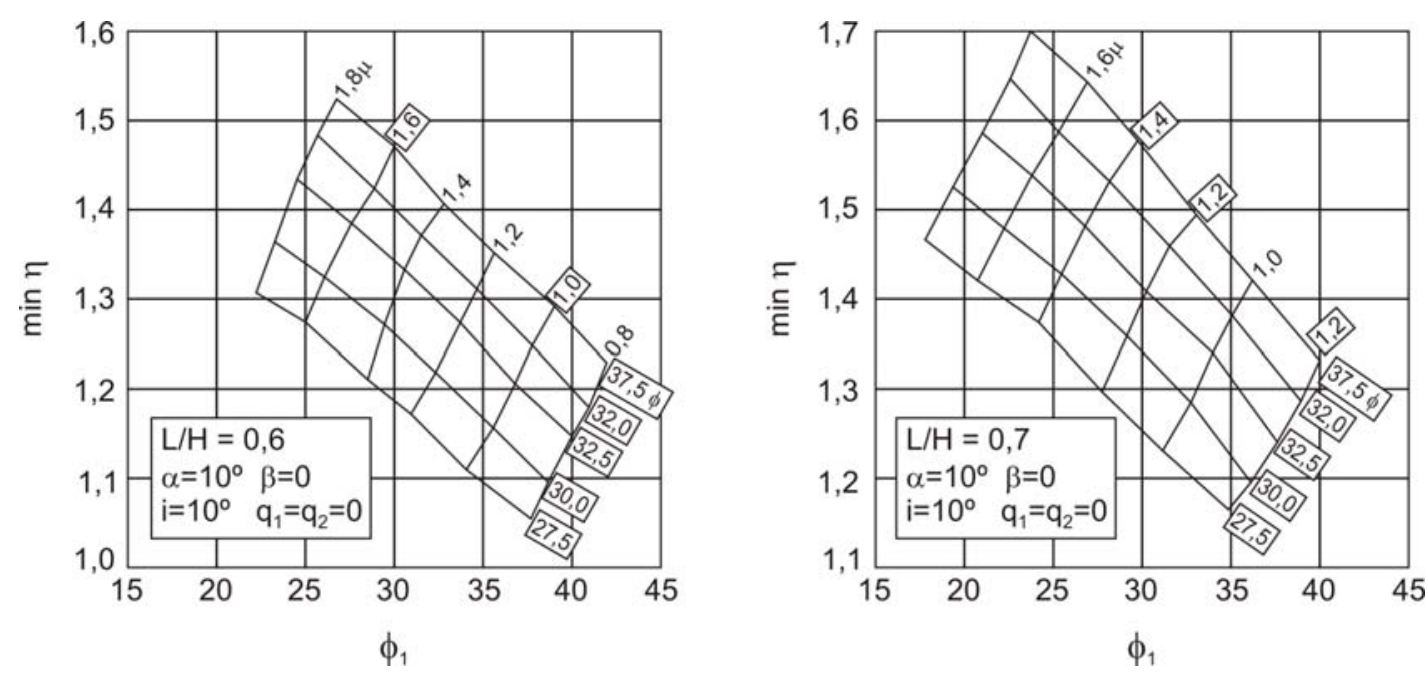

Figura 2.50. Ábacos para cálculo da estabilidade de casos padronizados (Gassler \& Gudehus, 1981).

Para a construção dos ábacos, foram consideradas as situações que ocorrem com maior freqüência na prática. Os parâmetros considerados para sua construção foram: $\mathrm{L} / \mathrm{H}=$ 0,6 e $0,7, \mathrm{c}=0, \alpha=10^{\circ}, \mathrm{i}=10^{\circ}, \beta=0, \mathrm{q}_{1}$ e $\mathrm{q}_{2}=0$. A partir destes ábacos, ao considerar um parâmetro $\phi$ e fixar um fator de segurança mínimo $(\eta)$, pode-se determinar as forças necessárias desenvolvidas nas barras de aço $\left(\mu=\mathrm{T} / \gamma \cdot \mathrm{S}_{\mathrm{v}} . \mathrm{S}_{\mathrm{h}}\right)$. A inclinação $\theta_{1}$, referente a um fator de segurança mínimo, também pode ser fornecida quando a análise for realizada sem variações significantes nos planos de deslizamento (Gassler \& Gudehus, 1981). A desvantagem deste método é a consideração de apenas um tipo de solo. Entretanto, os autores sugerem, que para solos estratificados, sejam considerados parâmetros médios de c, $\phi$ e $\gamma$, obtidos a partir da média ponderada entre os parâmetros e a espessura da camada correspondente.

Em termos gerais, pode-se dizer que o método Alemão apresenta-se de forma bastante complexa e não dispõe de informações suficientes para seu uso. Análises de estabilidade mostraram que a superfície de ruptura bilinear não se apresenta inteiramente no interior da massa de solo pregado, e que a cunha ativa considerada é maior do que a observada em estruturas instrumentadas (Juran \& Elias, 1991). Este mecanismo de ruptura está em desacordo com as rupturas observadas nos muros experimentais de solo pregado construídos ao longo do projeto Clouterre, onde foram observadas superfícies de rupturas curvas. 


\subsubsection{Método de Davis}

Este método de cálculo foi desenvolvido na Universidade da Califórnia, em Davis, por Shen et al. (1981). O procedimento de cálculo também se baseia no método de equilíbrio limite, e a superfície de ruptura considerada apresenta-se na forma de parábola. A superfície de ruptura foi deduzida a partir de simulações numéricas por elementos finitos, com o objetivo de desenvolver curvas de iguais fatores de segurança no interior do maciço de solo reforçado. A partir destas análises, conclui-se que a superfície de ruptura passa totalmente ou parcialmente no interior do maciço de solo reforçado, atingindo o pé do muro.

Neste método, assume-se que o solo é homogêneo, não saturado (sem a presença de água), que o muro apresenta-se com uma geometria simples (face vertical, superfície de solo horizontal no topo da estrutura) e os reforços com a mesma geometria (reforços paralelos, eqüidistantes e de mesmo comprimento). Assume-se também que os reforços são solicitados somente por tração, e que o mecanismo de ruptura pode ser desencadeado tanto pela ruptura quanto pelo arrancamento do reforço.

No método de Davis, está implícito que os fatores de segurança dos parâmetros de resistência do solo (e.g., $\mathrm{Fc}=\mathrm{c} / \mathrm{c}_{\mathrm{m}}$ e $\mathrm{F}_{\phi}=\tan \phi / \tan \phi_{\mathrm{m}}$, em que $\mathrm{c}_{\mathrm{m}}$ e $\phi_{\mathrm{m}}$, são, respectivamente a coesão do solo e o ângulo de atrito mobilizado ao longo da superfície potencial de ruptura) e o fator de segurança da tensão cisalhante de ruptura atuante na interface solo-reforço (e.g., $F_{L}=\tau_{\text {ult }} / \tau_{m}$, em que $\tau_{\mathrm{m}}$ é a tensão cisalhante lateral mobilizada na interface) são iguais ao fator de segurança global (FS), conforme equação apresentada a seguir (Juran, 1991).

$$
\mathrm{FS}=\mathrm{F}_{\mathrm{c}}=\mathrm{F}_{\phi}=\mathrm{F}_{\mathrm{L}}
$$

Para determinar a contribuição dos reforços na estabilidade global da estrutura, considera-se o método clássico das lamelas, rotineiramente utilizado nas análises de estabilidade de taludes. As forças de tração desenvolvidas nos reforços, ao longo da superfície potencial de ruptura, podem ser subdivididas em uma componente paralela e uma outra normal a esta superfície de ruptura. Estas forças (componente normal e tangencial) são adicionadas às forças resistivas mobilizadas no solo para a determinação do fator de 
segurança global do maciço reforçado. Para realizar as análises de estabilidade, duas situações precisam ser consideradas separadamente (Figura 2.51): (a) superfície de ruptura se estende para trás da zona reforçada, e (b) a superfície de ruptura encontra-se completamente dentro da massa de solo reforçado (Mitchell \& Villet, 1987).

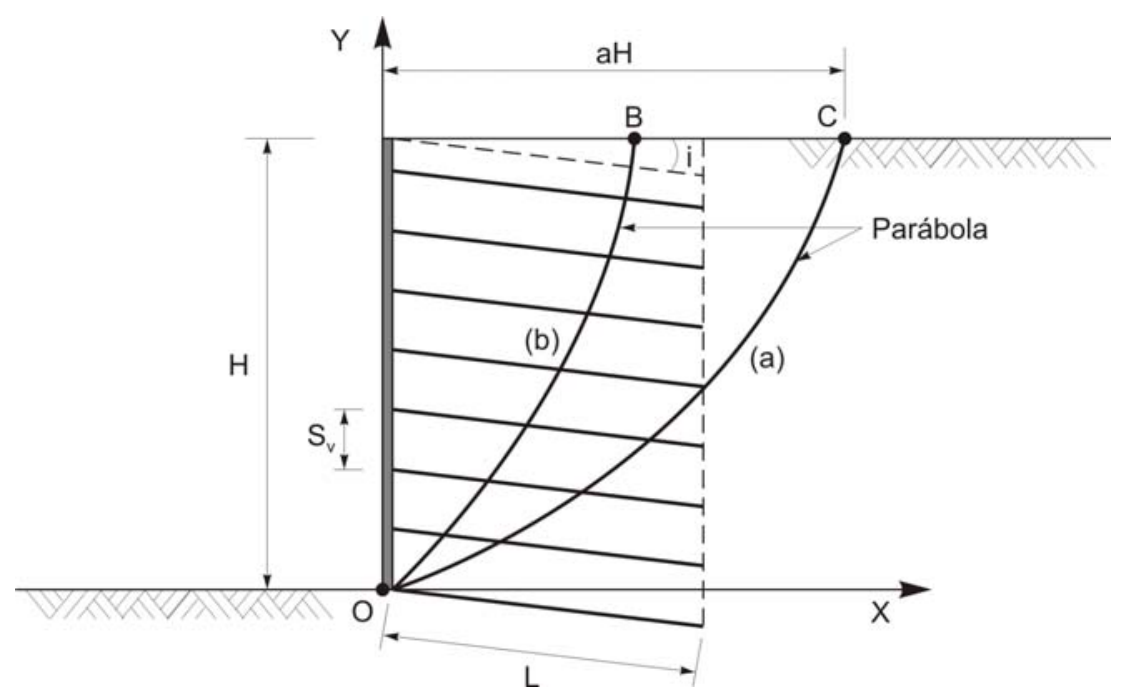

Figura 2.51. Situações consideradas no método de Davis (Clouterre, 1991).

A seguir, apresenta-se o procedimento de cálculo referente à primeira situação. $\mathrm{Na}$ Figura 2.52, encontram-se os diagramas de corpo livre, para esta situação.

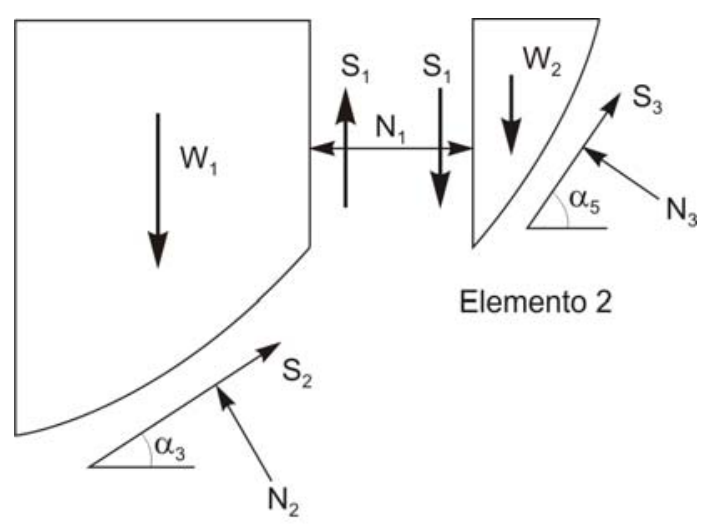

Elemento 1

Figura 2.52. Diagrama de corpo livre para a situação em que a superfície de ruptura passa atrás da zona reforçada (Mitchell \& Villet, 1987). 
Considerando que as forças cisalhantes atuantes na interface solo-solo $\left(\mathrm{S}_{2}\right.$ e $\left.\mathrm{S}_{3}\right)$ são paralelas as suas correspondentes cordas, podem-se apresentar as equações de equilíbrio para os elementos 1 e 2 (Mitchell \& Villet, 1987).

\section{Elemento 1:}

$$
\begin{aligned}
& N_{2}=\left(W_{1}-S_{1}\right)\left(\cos \alpha_{3}\right)-N_{1} \operatorname{sen} \alpha_{3} \\
& S_{2}=\left(W_{1}-S_{1}\right)\left(\operatorname{sen} \alpha_{3}\right)+N_{1} \cos \alpha_{3}
\end{aligned}
$$

em que:

$\mathrm{W}_{1}$ : peso do elemento 1 ;

$\mathrm{S}_{1}$ : força tangencial atuante entre os elementos 1 e 2 (assumindo que esta força é vertical); $\alpha_{3}$ : ângulo formado entre a superfície de ruptura do elemento 1 e a direção horizontal;

$\mathrm{N}_{1}$ : empuxo lateral do solo no contato entre os elementos $\left(\mathrm{N}_{1}=0,5 \cdot \mathrm{k} \cdot \gamma \cdot\left(\mathrm{H}-\mathrm{L}_{1}\right)^{2}\right)$, em que k é o coeficiente de empuxo na situação de repouso.

\section{Elemento 2:}

$$
\begin{aligned}
& N_{3}=\left(W_{2}+S_{1}\right)\left(\cos \alpha_{5}\right)+N_{1} \operatorname{sen} \alpha_{5} \\
& S_{3}=\left(W_{2}+S_{1}\right)\left(\operatorname{sen} \alpha_{5}\right)-N_{1} \cos \alpha_{5}
\end{aligned}
$$

em que:

$\mathrm{W}_{2}$ : peso do elemento 2;

$\alpha_{2}$ : ângulo formado entre a superfície de ruptura do elemento 2 e a direção horizontal;

A força solicitante $\left(\mathrm{S}_{\mathrm{D}}\right)$ ao longo da superfície de ruptura pode ser considerada como:

$$
S_{D}=\left(W_{1}-S_{1}\right) \operatorname{sen} \alpha_{3}+\left(W_{2}+S_{1}\right) \operatorname{sen} \alpha_{5}+N_{1}\left(\cos \alpha_{3}-\cos \alpha_{5}\right)
$$

A força resistente $\left(S_{R}\right)$ mobilizada ao longo da superfície potencial de ruptura é composta pela resistência ao cisalhamento do solo e pela resistência ao cisalhamento adicional, desenvolvida pelas componentes normal e tangencial atuantes nos elementos de reforço, conforme a equação a seguir: 


$$
S_{R}=c^{\prime} L_{T}+N_{3} \tan \phi_{2}^{\prime}+N_{2}^{\prime} \tan \phi_{1}^{\prime}+T_{T}
$$

em que:

$\mathrm{L}_{\mathrm{T}}$ : comprimento do arco que compreende à superfície de ruptura;

$\mathrm{N}_{3}, \mathrm{~N}_{2}$ : reações normais atuantes sobre o elemento 2 e o elemento 1 , respectivamente;

$\phi{ }_{1}$ : ângulo de atrito desenvolvido no elemento $1\left(\phi{ }^{\prime}{ }_{1}=\phi_{1} / \mathrm{FS}_{\phi}\right)$;

$\phi_{2}{ }_{2}$ : ângulo de atrito desenvolvido no elemento $2\left(\phi^{\prime}{ }_{2}=\phi_{2} / \mathrm{FS}_{\phi}\right)$;

c': coesão desenvolvida $\left(\mathrm{c}^{\prime}=\mathrm{c} / \mathrm{FS}_{\mathrm{c}}\right)$;

$\mathrm{FS}_{\mathrm{c}}$ : fator de segurança em relação à coesão;

$\mathrm{FS}_{\phi}$ : fator de segurança em relação ao ângulo de atrito;

$\mathrm{N}_{2}^{\prime}=\mathrm{N}_{2}+\mathrm{T}_{\mathrm{N}}$, em que $\mathrm{T}_{\mathrm{N}}$ é a componente normal da força de tração axial atuante nos reforços;

$\mathrm{T}_{\mathrm{T}}$ : componente tangencial da força de tração axial atuante nos reforços.

Para resolver a equação da força resistiva $\left(S_{R}\right)$, e, conseqüentemente, calcular o fator de segurança global, é necessário determinar a força axial atuante em cada elemento de reforço (barra de aço), representada pelas componentes normal $\left(\mathrm{T}_{\mathrm{N}}\right)$ e tangencial $\left(\mathrm{T}_{\mathrm{T}}\right)$. $A$ força axial é determinada a partir do cálculo da resistência atritiva do reforço posicionado atrás da superfície de ruptura assumida, conforme a seguinte equação:

$$
T=\pi \cdot D \cdot L_{a}\left(\sigma_{N} \tan \phi_{a}^{\prime}+C_{a}^{\prime}\right) / S_{H}
$$

em que:

T: força axial atuante em cada elemento de reforço, por unidade de comprimento do muro;

D: diâmetro do reforço;

$\mathrm{L}_{\mathrm{a}}$ : comprimento efetivo de aderência (comprimento do reforço na zona resistente);

$\mathrm{C}_{\mathrm{a}}$ : adesão entre o solo e o reforço;

$\tan \phi_{\mathrm{a}}{ }_{\mathrm{a}}$ : coeficiente de atrito desenvolvido na interface solo-reforço $\left(\tan \phi{ }_{\mathrm{a}}=\tan \left(\phi / \mathrm{FS}_{\mathrm{g}}\right)\right)$;

$\sigma_{\mathrm{N}}$ : tensão normal atuante sobre o reforço;

$\mathrm{S}_{\mathrm{H}}$ : espaçamento horizontal entre os reforços;

FS $_{\mathrm{g}}$ : fator de segurança em relação aos parâmetros de resistência ao arrancamento. 
Após a determinação da resistência atritiva de cada elemento de reforço, pode-se determinar a estabilidade global. As forças atuantes e resistentes desenvolvidas ao longo da superfície de ruptura devem estar em equilíbrio $\left(\mathrm{S}_{\mathrm{D}}=\mathrm{S}_{\mathrm{R}}\right)$, e o fator de segurança global é obtido quando os fatores de segurança dos parâmetros do solo (coesão e ângulo de atrito) e da resistência ao arrancamento se igualarem, ou seja:

$$
\mathrm{FS}_{\mathrm{c}}=\mathrm{FS}_{\phi}=\mathrm{FS}_{\mathrm{g}}
$$

A força resistente e a força solicitante apresentam fator de segurança variável, o que torna a resolução direta impossível. Entretanto, o problema pode ser solucionado por um processo interativo até atingir a convergência.

As análises de equilíbrio limite, realizadas a partir dos procedimentos apresentados anteriormente, foram comparadas, por Bang (1979), com os resultados de simulação numérica realizada pelo método dos elementos finitos, para uma escavação reforçada com o sistema solo pregado. Os resultados obtidos pelos dois métodos apresentaram uma boa concordância. Vale a pena ressaltar que este método vem sofrendo constantes modificações, com a finalidade de considerar geometrias mais complexas.

\subsubsection{Método Francês - Multicritério}

Os métodos de equilíbrio limite desenvolvidos por Stocker et al. (1979) e Shen et al. (1981) consideram somente a resistência à tração dos reforços. Neste sentido, Schlosser et al. (1982) desenvolveram uma solução mais geral, que engloba os dois mecanismos fundamentais da interação solo-reforço (resistência ao cisalhamento de interface e empuxo do solo sobre o reforço). Esta solução, além de considerar a resistência à tração, também considera a resistência ao cisalhamento e a rigidez à flexão do reforço. Na Figura 2.53, apresenta-se a distribuição dos esforços ao longo do reforço, considerada neste método de cálculo. 


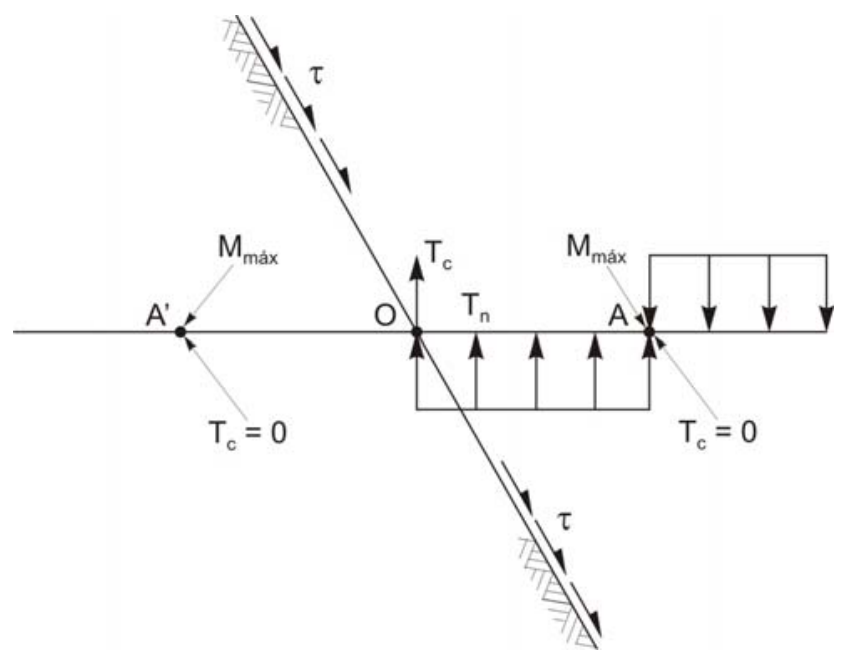

Figura 2.53. Distribuição de esforços considerada no multicritério (Clouterre, 1991).

As forças atuantes nos reforços podem ser representadas pelo esforço normal $\left(T_{n}\right)$, esforço cisalhante $\left(\mathrm{T}_{\mathrm{c}}\right)$ e momento fletor $(\mathrm{M})$. O método multicritério abrange quatro critérios básicos (Juran et al., 1990):

Resistência ao cisalhamento do solo;

$>$ Resistência ao arrancamento do reforço;

> Resistência passiva em ambos os lados da superfície de ruptura;

$>$ Resistência das inclusões aos esforços de tração e de cisalhamento.

A combinação destes quatro critérios vem sendo estudada considerando-se um comportamento elasto-plástico do sistema de solo pregado. A seguir, apresentam-se, de forma mais especifica, os quatro critérios de ruptura dos reforços.

\subsubsection{Critério (1): Resistência ao Cisalhamento de Interface Solo-Reforço}

Este critério considera que a ruptura do sistema solo pregado se dá pelo arrancamento do reforço do interior do maciço de solo. Para um reforço com seção transversal circular de diâmetro (D), assume-se que o parâmetro $q_{s}$, desenvolvido na interface solo-reforço, é constante ao longo do comprimento de aderência $\left(\mathrm{L}_{\mathrm{a}}\right)$, podendo ser representado, para um solo homogêneo, pela seguinte equação: 


$$
T_{n} \leq q_{s} \pi D L_{a}
$$

em que:

$\mathrm{q}_{\mathrm{s}}$ : é o atrito superficial unitário desenvolvido na interface solo-reforço;

$\pi \mathrm{D}$ : é o perímetro do reforço que apresenta seção transversal circular. $\mathrm{D}=\mathrm{D}_{\mathrm{c}}$ (diâmetro do furo) para os reforços injetados, e $\mathrm{D}=\mathrm{D}_{\mathrm{a}}$ (diâmetro equivalente) para reforços cravados.

$\mathrm{L}_{\mathrm{a}}$ : é o comprimento de aderência do reforço injetado, localizado atrás da superfície de ruptura.

A definição do comprimento ancorado $\left(\mathrm{L}_{\mathrm{a}}\right)$ é válida para a situação em que os reforços são conectados à face. Quando os reforços apresentam-se sem qualquer conexão com a face, considera-se $L_{a}$, como sendo a menor das seguintes distâncias: face-superfície de ruptura e superfície de ruptura-final do reforço.

\subsubsection{Critério (2): Empuxo do solo Sobre o Reforço na Interface Solo-Reforço}

Este critério considera que a ruptura do sistema solo pregado se dá pela plastificação do solo sob o reforço. A capacidade de suporte de um solo sob uma barra pode ser definida em termos da pressão $\mathrm{p}_{\mathrm{u}}$, atingida no ponto de máxima tensão cisalhante (ponto O). Este tipo de ruptura ocorre quando o empuxo aplicado pelo reforço é superior ao empuxo máximo que o solo pode suportar (suposição mais conservativa), ou quando a plastificação do solo ocorre além do máximo comprimento definido. Para a primeira situação, a análise do reforço sob um carregamento combinado (força normal, cisalhante e momento fletor) segue o seguinte critério:

$$
T_{c} \leq T_{c 2, \operatorname{máx}}
$$

com:

$$
T_{c 2, \text { máx }}=\frac{D_{c}}{2} l_{o}
$$

em que:

$\mathrm{D}_{\mathrm{c}}$ : diâmetro do chumbador (calda de cimento e reforço), 
$1_{0}$ : comprimento de transferência,

$\mathrm{p}_{\mathrm{u}}$ : pressão lateral última, determinada a partir de ensaio pressiométrico.

Na segunda situação, assume-se que a extensão do solo que se plastifica sob o reforço é limitada pela distância $\pi \mathrm{l}_{0} / 2$, que corresponde à distância entre os dois pontos em que os momentos máximos atuam ( $\mathrm{A}$ e $\mathrm{A}^{\prime}$ ). Neste trecho, considera-se que o comportamento do solo e do reforço é elástico (Figura 2.54).

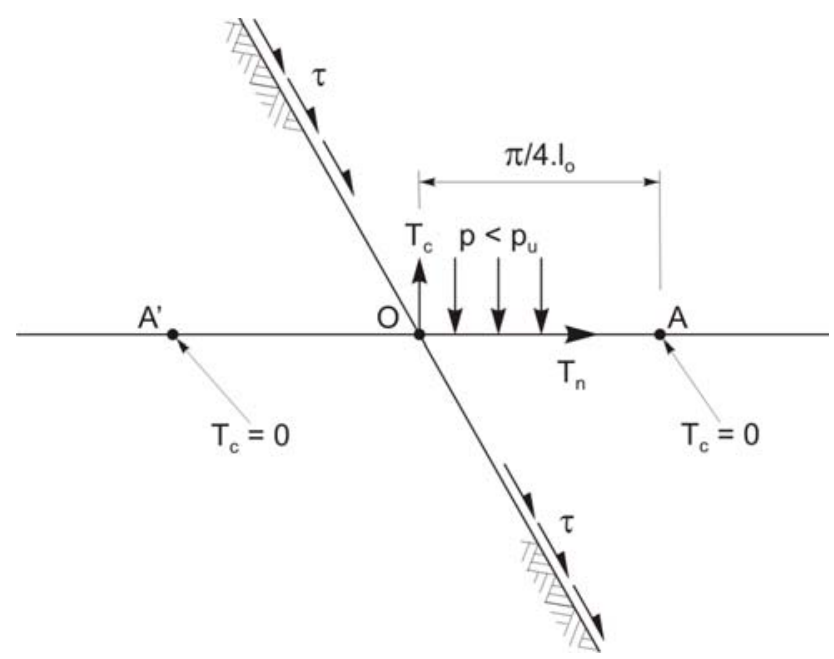

Figura 2.54. Representação esquemática da interação solo-reforço (Clouterre, 1991).

\subsubsection{Critérios 3 e 4: Plastífic ação do Reforço}

Os critérios 3 e 4 consideram que a ruptura é provocada pela plastificação do material que compõe o reforço. A resistência deste material pode ser representada por um critério simples e ligeiramente conservador (Anthoine, 1987).

$$
\left(T_{n} / R_{n}\right)^{2}+\left(T_{c} / R_{c}\right)^{2}+\left|\frac{M}{M_{0}}\right|-1 \leq 0
$$

em que:

$T_{n}$ e $T_{c}$ : forças normais e cisalhantes atuantes no reforço, respectivamente;

$R_{n}$ e $R_{c}$ : resistência do reforço aos esforços normais e cisalhantes, respectivamente; 
M: momento fletor atuante no reforço;

$\mathrm{M}_{0}$ : momento máximo que gera a plastificação do solo.

O processo de plastificação do reforço pode ocorrer tanto por cisalhamento no ponto $\mathrm{O}$ (ponto de máxima força cisalhante), como também por momento fletor nos pontos A e A' (pontos de momento máximo). Para simplificar, assume-se que a força normal $\left(\mathrm{T}_{\mathrm{n}}\right)$ não varia ao longo da zona fletida situada ao redor da superfície potencial de ruptura. $\mathrm{Na}$ seqüência, estes critérios são apresentados de forma mais detalhada.

\subsubsection{Critério 3}

O critério 3 considera que a plastificação do reforço ocorre no ponto de aplicação da máxima força cisalhante (ponto $\mathrm{O}$ ), ou seja, na intersecção do reforço com a superfície de ruptura. Como neste ponto o momento fletor é zero $(\mathrm{M}=0)$, o critério de ruptura do material, apresentado anteriormente, pode ser simplificado por uma equação que, no plano $\left(T_{n}, T_{c}\right)$, é representada por uma elipse. A resistência cisalhante do reforço $\left(R_{c}\right)$ é usualmente considerada como $\mathrm{R}_{\mathrm{c}}=\mathrm{R}_{\mathrm{n}} / 2$.

$$
\left(T_{n} / R_{n}\right)^{2}+\left(T_{c} / R_{c}\right)^{2} \leq 1
$$

\subsubsection{Critério 4}

O critério 4 considera que a plastificação do reforço ocorre nos pontos solicitados por momento máximo e força cisalhante nula (A e A'). Estes pontos apresentam-se em ambos os lados da superfície potencial de ruptura e distantes entre si $\pi \mathrm{l}_{\mathrm{o}} / 4$. Os momentos são calculados considerando-se um comportamento elástico do solo e do reforço. Este critério é representado por:

$$
M \leq M_{\text {máx }}
$$


O momento máximo $\left(\mathrm{M}_{\text {máx }}\right)$ é determinado a partir de uma simplificação do critério de ruptura do reforço, representado pela equação 2.33 :

$$
M_{\text {máx }}=M_{0}\left[1-\left(T_{n} / R_{n}\right)^{2}\right\rfloor
$$

Este critério permite calcular a força cisalhante atuante no ponto O, como:

$$
T_{c o}=a \frac{M_{o}}{l_{o}}\left[1-\left(T_{n} / R_{n}\right)^{2}\right]
$$

em que "a" é uma constante igual a 3,12.

$\mathrm{Na}$ prática, a plastificação por momento máximo não implica na ruptura do sistema. Estes pontos se comportam como duas rótulas plásticas que se movem com a contínua deformação dos reforços. O comprimento de plastificação $\left(1_{p}\right)$ dos reforços varia no interior de uma mesma estrutura, de forma a encontrar a condição de equilíbrio. Entretanto, na falta de maiores informações, supõe-se que o comprimento de plastificação é constante e igual a $\pi \mathrm{l}_{\mathrm{o}} / 4$. No ponto $\mathrm{O}$, após o desenvolvimento das rótulas plásticas em $\mathrm{A} \mathrm{e}$ A', a plastificação do solo sob o reforço deve atender ao seguinte critério:

$$
\begin{gathered}
T_{c} \leq T_{c 4, \max } \\
T_{c 4, \text { máx }}=b\left(M_{0} / l_{0}\right)\left[1-\left(T_{n} / R_{n}\right)^{2}+c D c l_{0} p_{u}\right.
\end{gathered}
$$

em que: b e c são duas constantes iguais a 1,62 e 0,24, respectivamente. 


\subsubsection{Combinação dos Critérios de Ruptura}

Os quatro critérios de ruptura apresentados são representados em um plano $\left(\mathrm{T}_{\mathrm{n}}, \mathrm{T}_{\mathrm{c}}\right)$, em que $T_{n}$ e $T_{c}$ são as forças normais e cisalhantes, respectivamente. Neste plano, cada critério é representado por uma curva de plastificação. Como já mencionado, as resistências à tração e ao cisalhamento das barras de aço apresentam superfície de plastificação na forma de elipse (critério 3). A resistência à flexão é representada por uma parábola (critério 4), a resistência ao cisalhamento de interface (critério 1) por uma linha vertical $\left(\mathrm{T}_{\mathrm{n}}<\mathrm{T}_{\mathrm{nl}}\right)$, enquanto que o empuxo atuante na interface (critério 2), por uma linha horizontal. Consequentemente, a curva de plastificação resultante destes quatro critérios é definida por um domínio de estabilidade convexo, que permite a determinação das forças atuantes nos reforços, conforme apresentado na Figura 2.55.

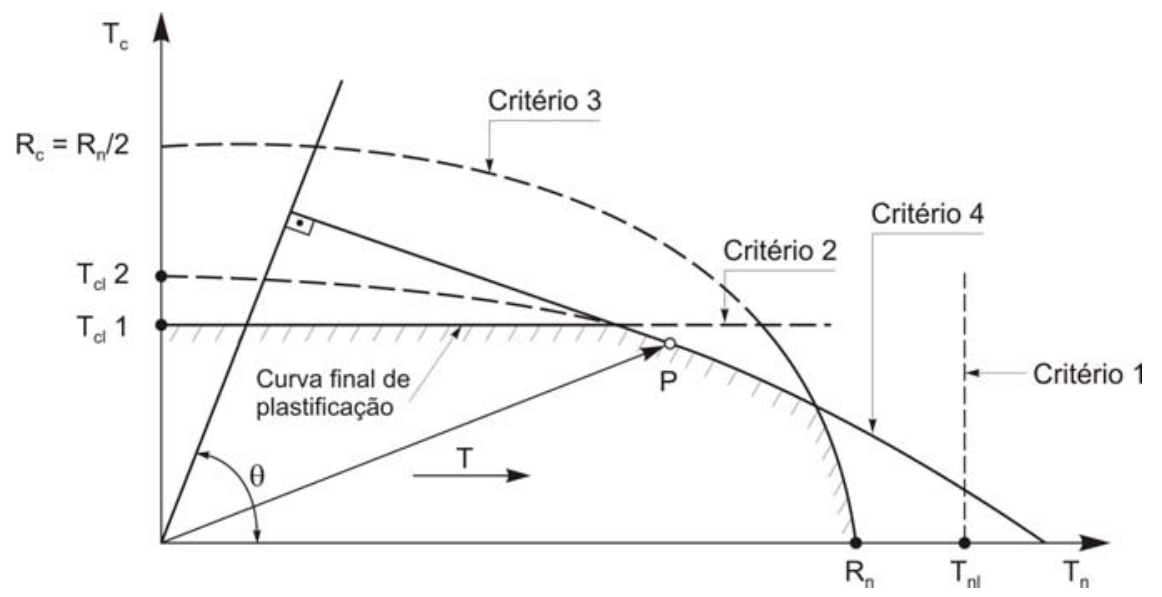

Figura 2.55. Combinações dos modos de ruptura (Clouterre, 1991).

É interessante notar a importância da determinação da pressão lateral máxima $\left(\mathrm{p}_{\mathrm{u}}\right)$ na determinação da força cisalhante máxima, $\mathrm{T}_{\mathrm{c} \text {,máx }}$, considerando-se que:

$$
T_{c 1, \operatorname{máx}}=\min \operatorname{imo}\left\{T_{c 1}, T_{c 2}\right\}
$$

em que: $T_{\mathrm{c} 1}$ e $T_{\mathrm{c} 2}$ são função da pressão lateral máxima $\left(\mathrm{p}_{\mathrm{u}}\right)$. 
Vale a pena ressaltar que, se $\mathrm{p}_{\mathrm{u}}$ for suficientemente alta, a força cisalhante máxima $\left(T_{c, \text { máx }}\right)$ pode atingir o valor da resistência ao cisalhamento $\left(\mathrm{R}_{\mathrm{c}}\right)$. Para esta situação, caso típico de um reforço instalado em um maciço rochoso que sofre cisalhamento ao longo de uma junta, a intersecção dos critérios passa a ser representada pelo critério 1 .

A criação de uma regra para a determinação das forças atuantes no reforço envolve a suposição da condição de ruptura, que pode ser representada por um ponto $\mathrm{P}$ sobre a borda externa da intersecção dos critérios mencionados. A posição do ponto $\mathrm{P}$ é escolhida de forma a maximizar o trabalho da força atuante no reforço e a sua projeção em relação ao vetor deslocamento $(\delta)$. Na prática, o ponto $\mathrm{P}$ e as forças $\mathrm{T}_{\mathrm{c}}$ e $\mathrm{T}_{\mathrm{n}}$, atuantes no reforço, sob a condição de ruptura, são determinadas considerando-se um deslocamento $\delta$ tangente ao ponto $\mathrm{O}$ da superfície potencial de ruptura. Isto significa dizer que é necessário encontrar um ponto $\mathrm{P}$ sobre a borda externa do domínio de estabilidade, onde sua tangente seja perpendicular à direção $\delta$ e forme um ângulo $\theta$ com o reforço (Figura 2.56).

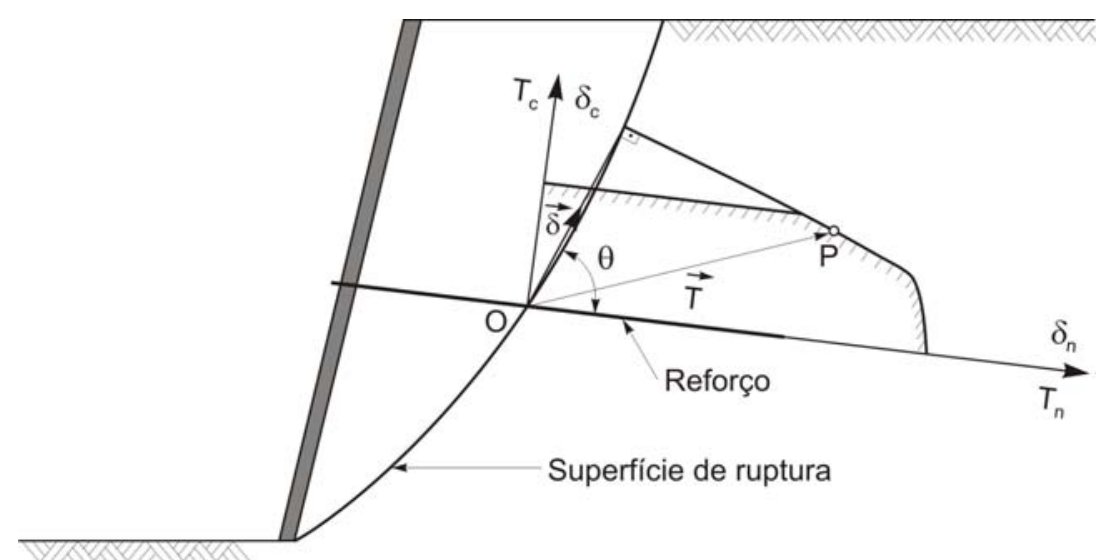

Figura 2.56. Determinação das forças atuantes nos reforços (Clouterre, 1991).

\subsubsection{Método de Juran etal (1990)}

O método de cálculo desenvolvido por Juran et al. (1990) baseia-se no método de equilíbrio limite e apresenta-se associado a um modelo de deslocamento/ruptura cinematicamente admissível. Foi desenvolvido a partir do conhecimento adquirido de outros métodos de cálculo, empregados em outras soluções de solo reforçado. Permite avaliar os efeitos dos principais parâmetros de projeto (geometria da estrutura, inclinação, 
espaçamento e rigidez à flexão dos reforços) sobre os esforços de tração e de cisalhamento desenvolvidos no reforço durante a fase de construção do sistema solo pregado. A Figura 2.57 apresenta o mecanismo de ruptura e as principais suposições de projeto do método de Juran et al., 1990.

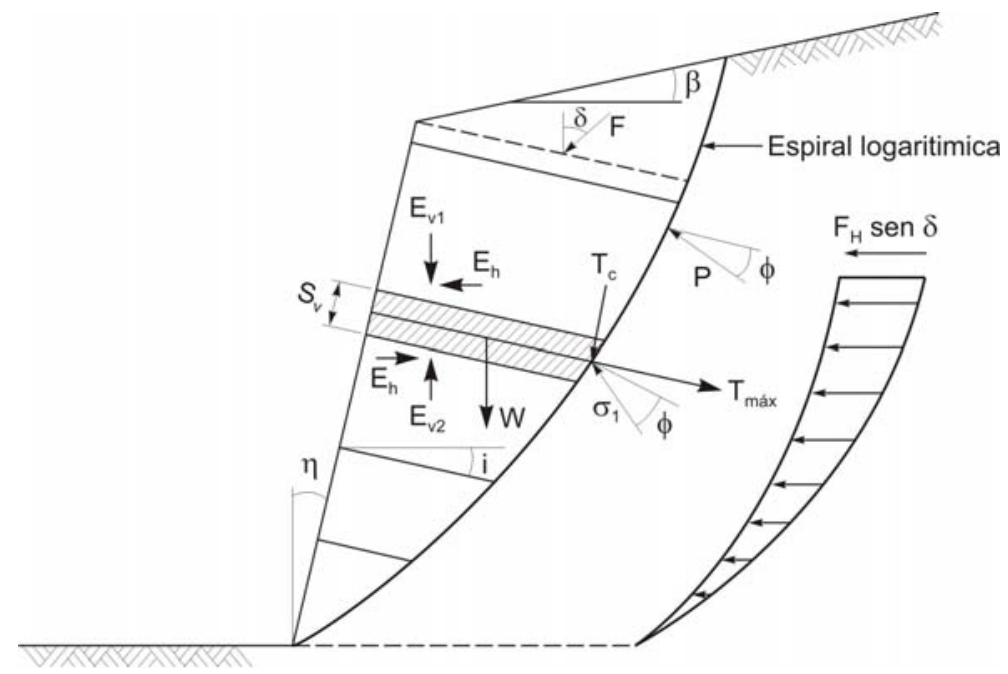

Figura 2.57. Mecanismo de ruptura e suposições de projeto (Juran et al., 1990).

A seguir, apresentam-se as principais considerações deste método de projeto (Juran \& Elias, 1991):

O processo de ruptura ocorre pela rotação do corpo semi-rígido da zona ativa, que é limitada por uma superfície de ruptura que se apresenta com a forma de espiral logarítmica;

$\mathrm{Na}$ condição de ruptura, o ponto de aplicação dos esforços de tração e de cisalhamento coincide com a superfície de ruptura desenvolvida no solo;

> As zonas semi-rígidas ativas e resistentes são separadas por uma fina camada de solo, que se apresenta no estado limite rígido-plástico;

$>$ A resistência ao cisalhamento do solo, definida pelo critério de ruptura de Mohr Coulomb, é completamente mobilizada ao longo da superfície de ruptura;

$>$ As componentes horizontais $\left(E_{h}\right)$ das forças interlamelares são iguais; 
$\mathrm{O}$ efeito da inclinação (ou sobrecarga horizontal, $\mathrm{F}_{\mathrm{h}}$ ) na parte superior do maciço de solo pregado sobre as inclusões decresce linearmente ao longo da superfície de ruptura.

O efeito da rigidez à flexão sobre as deformações e a resistência dos reforços é analisada considerando-se as seguintes situações: (a) reforços perfeitamente flexíveis, que resistem somente a solicitações de tração; (b) reforços extremamente rígidos, que resistem à tração e as forças cisalhantes e (c) reforços com rigidez à flexão finita, que limitam o desenvolvimento das deformações e das tensões de cisalhamento. Para esta última situação, a deformação $\left(\mathrm{d}_{\beta}\right)$, os esforços cisalhantes e os momentos fletores atuantes nos reforços são calculados a partir de soluções elásticas disponíveis para carregamentos laterais em estacas. A deformação máxima do reforço $\left(\mathrm{d}_{\beta}\right)$ ocorre junto da superfície potencial de ruptura e é dada por:

$$
d_{\beta}=\frac{2 T c}{K_{s} D l_{0}^{2}}
$$

em que:

$\mathrm{T}_{\mathrm{c}}$ : força cisalhante máxima;

$\mathrm{K}_{\mathrm{s}}$ : módulo de reação do solo;

D: diâmetro do reforço;

$1_{0}$ : comprimento de transferência que caracteriza a rigidez relativa da inclusão no solo;

E e I: módulos elásticos e momento de inércia do reforço, respectivamente.

Este método considera que as deformações nos reforços se desenvolvem de forma simétrica em relação à superfície de ruptura, onde o momento fletor $\left(\mathrm{M}_{0}\right)$ é zero, e as forças de tração $\left(\mathrm{T}_{\text {máx }}\right)$ e de cisalhamento $\left(\mathrm{T}_{\mathrm{c}}\right)$ são máximas, conforme apresentado na Figura 2.58. 


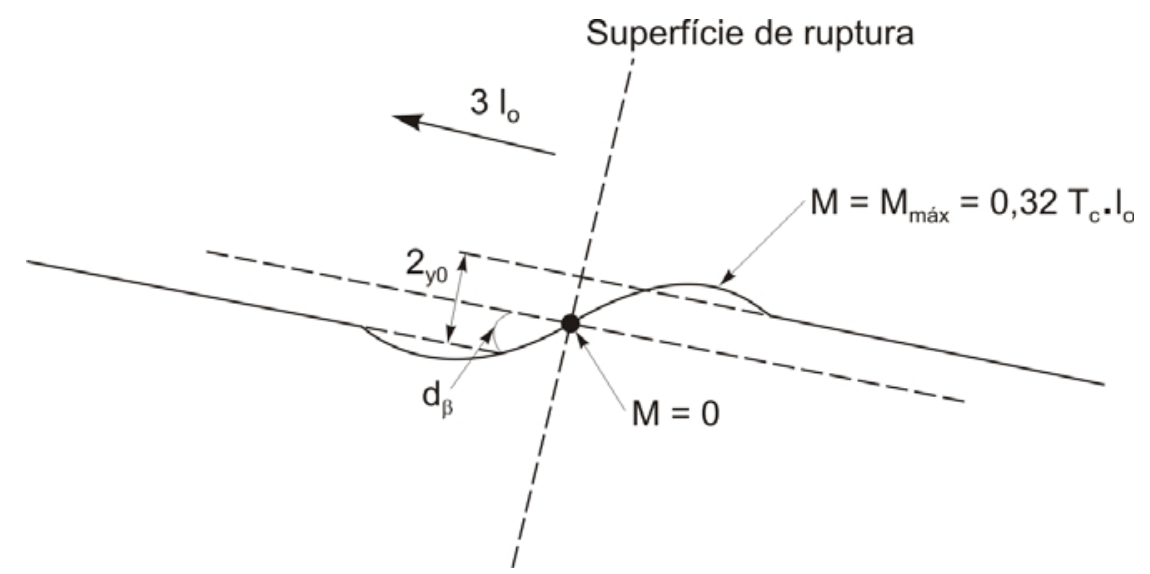

Figura 2.58. Comportamento dos reforços junto à superfície potencial de ruptura (Juran \& Elias, 1991).

A rigidez à flexão dos reforços é determinada a partir de um parâmetro adimensional $(\mathrm{N})$, definido como:

$$
N=\left(\frac{K_{s} \cdot D}{\gamma \cdot H}\right) \cdot\left(\frac{l_{0}^{2}}{S_{h} \cdot S_{v}}\right)
$$

em que:

$\mathrm{K}_{\mathrm{s}}$ : coeficiente de reação lateral do solo;

$1_{0}$ : comprimento de transferência do reforço;

D: diâmetro do reforço.

Para implementar as análises cinemáticas, foi desenvolvido um programa computacional (Juran et al., 1990), que permite, a partir de um processo interativo, calcular os parâmetros adimensionais de projeto. Estes parâmetros são representados pela força de cisalhamento máxima (TS) e pela força de tração máxima (TN). A partir das análises computacionais realizadas e dos parâmetros obtidos, foram desenvolvidos ábacos que permitem calcular os esforços de tração e de cisalhamento atuantes nos reforços. A Figura 2.59 apresenta estes ábacos. 

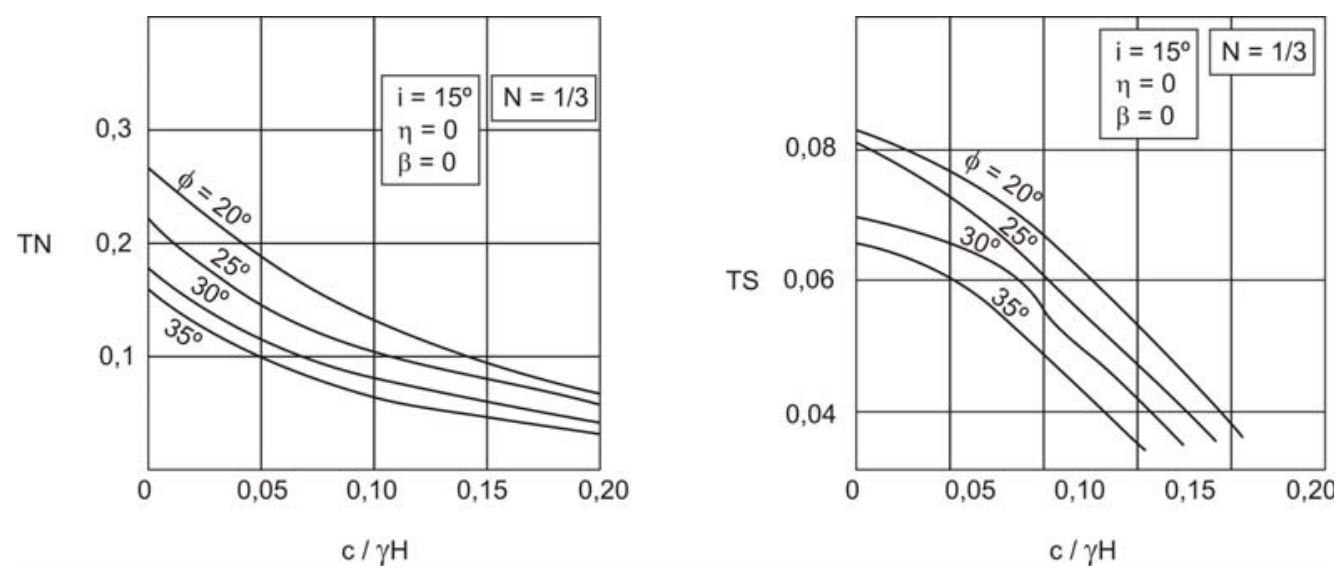

Figura 2.59. Método de Juran et al. (1990): ábacos utilizados para calcular os esforços de tração e cisalhamento nos reforços, considerando inclinação do reforço (i) de $15^{\circ}$, face vertical $(\eta=0)$ e superfície do terrapleno horizontal $(\beta=0)$ (Clouterre,1991).

Cada ábaco está relacionado com um parâmetro adimensional (N). A partir dos parâmetros do solo (c, $\phi$ e $\gamma$ ) e da altura do paramento $(H)$, o ábaco fornece os parâmetros adimensionais (TN) e (TS). A partir destes parâmetros, podem-se calcular os esforços de tração $\left(T_{n}\right)$ e de cisalhamento $\left(T_{c}\right)$, atuantes sobre os reforços, conforme as equações apresentadas a seguir.

$$
\begin{aligned}
& T N=T_{n} / \gamma H S_{V} S_{h} \\
& T S=T_{c} / \gamma H S_{V} S_{h}
\end{aligned}
$$

O método de Juran et al. (1990) considera que a resistência ao cisalhamento do solo é mobilizada sob condições de serviço ao longo da superfície potencial de ruptura. Desta forma, este método considera fatores de segurança parciais, ou seja, independe do fator de segurança global. Estas suposições basearam-se em poucas análises realizadas em estruturas de escala real, e, desta forma, precisam ser mais bem justificadas teoricamente e experimentalmente.

Camargo (2005) apresenta um estudo mais aprofundado em relação aos métodos de cálculo de estruturas de solo pregado. Inicialmente, o autor apresenta as definições, as considerações, as equações e os mecanismos de ruptura dos seguintes processos de cálculo: 
Coulomb Modificado (Vidal \& Silva, 1999), Stocker et al. (1979), Jewell et al. (1984), Davis (Shen et al., 1982), Fellenius modificado (Falconi \& Alonso, 1996), Processo de Homogeneização do conjunto solo/reforço (Clouterre, 1991), Processo Cinemático (Juran et al., 1990) e Multicritério (Schlosser, 1982). Para analisar e comparar os diferentes métodos de cálculo, o autor realizou quatro estudos de caso: (a) caso real que apresentou desempenho satisfatório (obra da Beneficiência Portuguesa-SP); (b) caso fictício apresentado por Juran (1990), que apresentou geometria semelhante ao caso anterior, porém com comportamento predominantemente granular; (c) caso fictício, considerando geometria com menor altura e reforços resistentes à flexão; (d) caso idêntico ao anterior, porém considerando reforços flexíveis. Os diferentes métodos foram comparados, exceção feita aos processos de cálculo de Coulomb modificado e de Stocker et al. (1979), por serem considerados casos especiais do processo de Jewell et al. (1984). O estudo comparativo baseou-se no consumo de reforço por metro de obra. A partir das análises, o autor concluiu que, para os casos analisados, os processos que também consideram a resistência à flexão dos reforços (Juran e Multicritério) são os mais econômicos. A economia destes métodos atingiu patamares de 19\% (Juran) e 9\% (Multicritério). Dentre os grupos que não consideram a resistência à flexão, os processos de Jewell e Homogeneização foram os que forneceram os resultados mais econômicos. O processo de Davis foi o mais conservador, resultando em um consumo de reforço/m, em média, 15\% acima dos demais métodos.

\subsubsection{ANÁUSES TENSÃO x DEFORMAÇÃO}

$\mathrm{Na}$ prática, o dimensionamento de solo pregado é realizado considerando-se a condição de ruptura (Estado Limite Último). Entretanto, em algumas situações, a condição crítica pode estar relacionada aos deslocamentos do maciço reforçado e aos conseqüentes danos provocados às edificações vizinhas da obra. Para estas situações é recomendado reavaliar o dimensionamento da estrutura de solo pregado sob a ótica do Estado Limite de Serviço, ou seja, prever a deformação do maciço reforçado a partir de análises tensão $\mathrm{x}$ deformação. Estas análises são realizadas com métodos numéricos utilizados em engenharia, entre os quais: Método das Diferenças Finitas (MDF), Método dos Elementos Finitos (MEF) e Métodos dos Elementos de Contorno (MEC). 
O MEF é o método mais utilizado em Geotecnia para elaborar análises paramétricas ou de sensibilidade de obras geotécnicas. Isso se deve à facilidade com que trata os problemas heterogêneos e não lineares (Lopes, 1995). Além disso, também possue uma versatilidade ao simular condições de geometria, carregamento e situações de contorno. A resolução de um problema com base em MEF consiste na divisão do domínio do problema em elementos, cujo comportamento pode ser facilmente formulado em função de sua geometria e de propriedades conectadas apenas em alguns pontos que interagem entre si. Como a divisão do domínio pode ser qualquer, este método apresenta grande vantagem no tratamento de casos com geometria complexa. Ainda, cada elemento pode ter propriedades próprias, o que permite resolver casos em maciços heterogêneos (Lopes, 2003). A resolução de qualquer problema com base em MEF é realizada através de etapas distintas. Estas etapas são interrelacionadas e estão descritas a seguir:

Discretização do meio contínuo: o meio a ser analisado é subdividido em um numero finito de elementos (triangulares, quadrados, tetraedros, prismas retangulares e hexaedros). Esses elementos são conectados por um numero discreto de pontos, denominado nós;

$>$ Seleção do modelo de deslocamentos: é definido um conjunto de funções, geralmente polinomiais, que descrevem o campo de deslocamentos em cada elemento, em função dos deslocamentos nodais;

> Cálculo da matriz de rigidez: composta pelos coeficientes da equação de equilíbrio, derivados da geometria, propriedades ou leis constitutivas adotadas em cada elemento;

Sistema de equações: As forças atuantes no meio são transformadas em forças nodais equivalentes, $\{\mathrm{F}\}$. A partir delas, obtém-se um sistema de equações de equilíbrio, que se relaciona com a matriz de rigidez $[\mathrm{K}]$ e o vetor de deslocamentos nodais $\{\mathrm{d}\}$, da forma $\{\mathrm{F}\}=[\mathrm{K}]\{\mathrm{d}\}$;

Cálculo das incógnitas do problema: a solução do sistema de equações gerado, respeitadas as condições de contorno do problema, fornece o vetor de deslocamentos nodais. A partir do campo de deslocamentos nodais, são obtidas as deformações e as tensões nos elementos. 
As cargas devem ser aplicadas em pequenos incrementos, podendo adotar um processo iterativo até que o equilíbrio entre os esforços internos e externos seja satisfeito. Para cada incremento de força, são calculados incrementos de deslocamentos, e, a partir destes, são calculados os incrementos de deformação. Os incrementos de tensão correspondentes são obtidos a partir dos incrementos de deformação, através dos respectivos modelos constitutivos (Farias, 2001).

Recentemente, foram desenvolvidos programas voltados especificamente para a engenharia geotécnica que trabalham com tipos de elementos (solos) anisotrópicos e de resposta não linear e elasto-plástica. Além disso, a interface gráfica facilita a entrada de dados e a visualização dos resultados obtidos (Zirlis et al., 2003). À medida que ocorre o desenvolvimento tecnológico dos microcomputadores, fica mais fácil e rápida a resolução de problemas que envolvam um número maior de elementos, análises tridimensionais e técnicas iterativas que envolvam um número extremo de cálculos para uma simulação do comportamento não-linear. Entre os principais trabalhos encontrados na literatura que envolvem simulações numéricas de estruturas de solo pregado pode-se citar: Silva (1999), Vale (2002), Oliveira (2006) e Henriques Junior (2007).

\subsection{INSTRUMENTAÇÃO DE CHUMBADORES}

É de extremo interesse o conhecimento da distribuição das tensões desenvolvidas ao longo do grampo, a fim de que se possa prever o comportamento da estrutura no processo de estabilização do terreno. Uma vez determinada esta distribuição, é possível identificar o comprimento real do grampo que estará sendo solicitado à tração, na medida em que o solo circundante tende a se deslocar (Leite, 2007).

O uso da instrumentação consiste na monitoração das deformações sofridas, com destaque para o uso de strain gages, pela sua versatilidade de aplicação, precisão das medidas e facilidade de manipulação. Além disso, são capazes de monitorar as deformações até as cargas últimas em ensaios destrutivos. São constituídos por um resistor elétrico composto por uma finíssima camada de material condutor, depositado sobre um material isolante chamado de base. O princípio de funcionamento está baseado no fato de que os 
metais sofrem uma alteração de sua resistência elétrica ao se deformarem. Assim, as deformações são convertidas em uma quantidade elétrica, que é amplificada para leitura em um local remoto. Leite (2007) apresenta várias vantagens na utilização dos strain gages, tais como:

Alta precisão;

Excelentes respostas aos fenômenos dinâmicos;

$>$ Excelente linearidade;

$>$ Medições possíveis dentro de uma ampla faixa de temperatura;

$>$ Possibilidade de medição de diversas grandezas físicas, tais como força, pressão, torque, aceleração e deslocamento;

Possibilidade de medição em locais remotos.

A resistência elétrica medida pelos strain gages pode variar com a temperatura. Para eliminar esta interferência, existem diferentes métodos de medição. Porém, muitos dos strain gages disponíveis atualmente já apresentam uma auto-compensação, isto é, são fabricados com tecnologia apropriada para sofrerem menos efeitos da temperatura. $\mathrm{Na}$ maioria dos casos encontrados na literatura, foram utilizados extensômetros elétricos, específicos para aço com resistência de $120 \Omega$, unidirecionais simples, que apresentam dimensões reduzidas, de forma a minimizar a área da barra de aço necessária para a colagem do strain gage. Os extensômetros elétricos são medidores de deformação que apresentam elevada precisão e resolução. Desta forma, o processo de instrumentação das barras exige uma serie de cuidados para garantir que as condições de instalação e de injeção dos grampos, bem como as condições naturais de campo, não interfiram nas medidas destes instrumentos.

Proto Silva (2005) alerta que, durante a instrumentação, um conjunto de detalhes pode modificar as condições ideais de trabalho dos strain gages, ressaltando-se:

Ocorrência de bolhas de ar no contato extensômetro/barra;

Interferência na corrente de alimentação devido ao contato entre os cabos de transmissão e a barra; 
Análise de diferentes metodologias executivas de solo pregado a partir de ensaios de arrancamento em campo e laboratório

Isolamento elétrico inadequado;

> Alinhamento incorreto dos strain gages durante o processo de colagem;

$>$ Umidade gerada pelo contato do operador com o strain gage;

$>$ Rugosidade da superfície de contato.

Com o objetivo de se minimizar estes efeitos, são realizados ensaios de calibração em todas as barras instrumentadas, permitindo assim obter a curva carga x deformação para cada extensômetro elétrico. 


\section{MATERIAIS E MÉIODOS}

\subsection{INIRODUÇÃO}

Este capítulo apresenta as metodologias e as considerações adotadas para o desenvolvimento do programa experimental desta pesquisa. Para atender aos objetivos propostos, o trabalho foi desenvolvido em laboratório e em campo (escala real). A Figura 3.1 apresenta um fluxograma de atividades representativo do programa experimental, relacionando-as com os objetivos propostos na presente pesquisa.

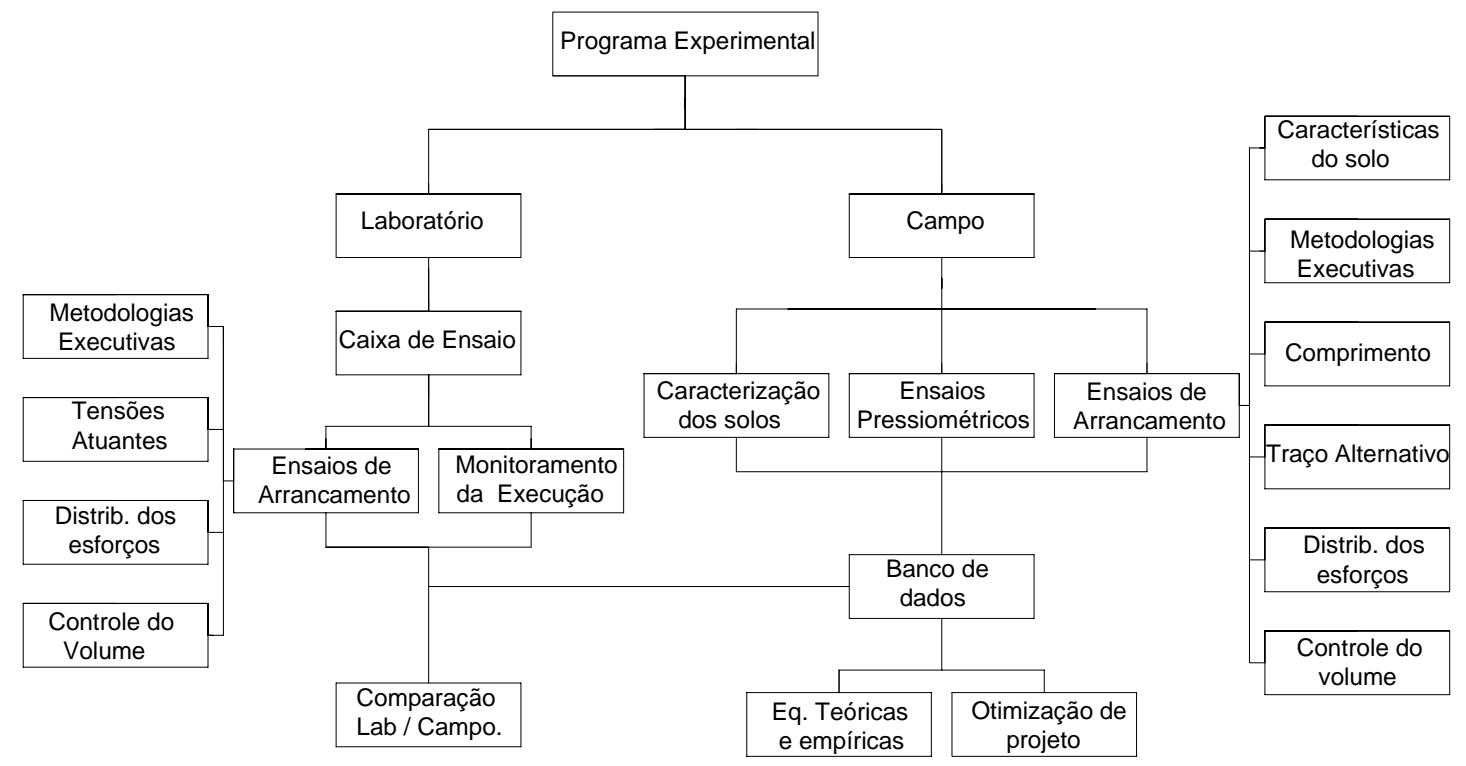

Figura 3.1. Fluxograma de atividades do programa experimental da pesquisa.

Na Figura 3.1, verifica-se que o programa experimental desenvolvido permite avaliar, de uma maneira bem ampla, os principais fatores relacionados com a resistência ao cisalhamento de interface de chumbadores na técnica de solo pregado. Estas informações são provenientes de ensaios de arrancamento de chumbadores em Laboratório e Campo. Para facilitar a apresentação e o entendimento, o programa experimental será apresentado 
Análise de diferentes metodologias executivas de solo pregado a partir de ensaios de arrancamento em campo e laboratório

separadamente, considerando-se estas duas etapas de trabalho. Os resultados experimentais obtidos (banco de dados), assim como suas implicações em formulações teóricas e empíricas e também na otimização de projetos, poderão ser analisados no Capítulo 5 Resultados e Análises do Programa Experimental de Campo.

\subsection{PROGRAMA EXPERIMENTALDE LABORATÓRIO}

O programa experimental de laboratório foi realizado partir da construção de uma estrutura de solo pregado em uma caixa de ensaio, desenvolvida no Laboratório de Geossintéticos da EESC/USP. As características dos solos, dos materiais e dos equipamentos, bem como os procedimentos adotados na execução dos ensaios de arrancamento dos chumbadores, são apresentados na seqüência.

\subsubsection{Caractenísticas do Solo}

Para a construção da estrutura de solo pregado em laboratório, foi utilizado o solo do Campus II da USP/São Carlos. A escolha deste solo deve-se às boas propriedades deste material e a maior facilidade em coletá-lo, frente ao grande volume despendido para a construção do solo pregado.

Para caracterização do material, foram realizados os seguintes ensaios: análise granulométrica conjunta, massa específica dos sólidos, limite de liquidez, limite de plasticidade e compactação Proctor Normal. A Figura 3.2 apresenta a curva granulométrica, segundo a NBR 6502/95. 


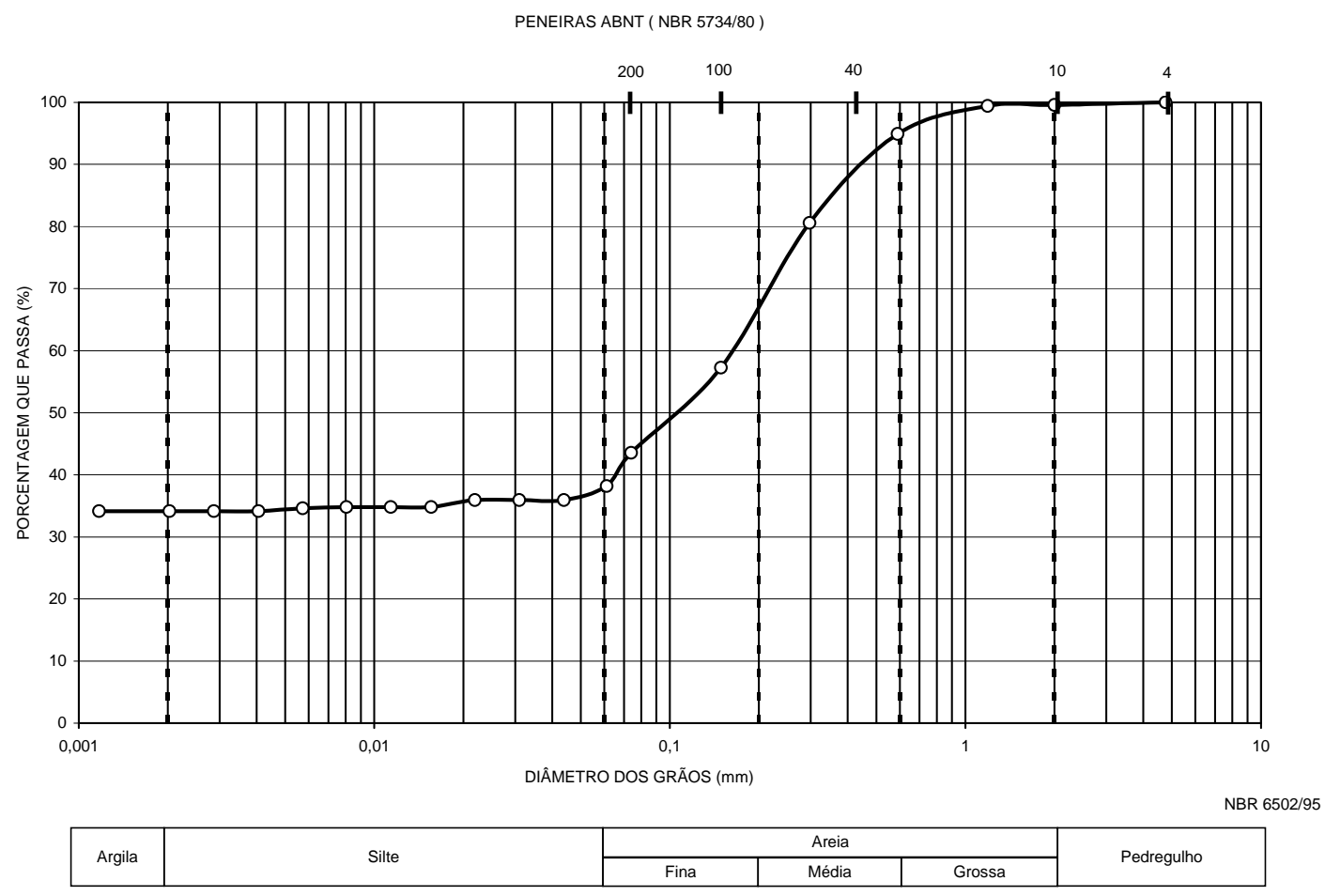

Figura 3.2. Curva granulométrica do solo utilizado.

Cada fração granulométrica, em porcentagem de ocorrência, está apresentada na Tabela 3.1.

Tabela 3.1. Distribuição granulométrica em porcentagem de ocorrência para o solo estudado.

\begin{tabular}{cc} 
Fração Granulométrica & Porcentagem de Ocorrência \\
\hline Argila (\%) & 34,0 \\
Silte (\%) & 4,0 \\
Areia (\%) & 62,0 \\
\hline
\end{tabular}

De acordo com o Sistema de Classificação Unificado dos Solos (ASTM D 2487), o solo foi classificado como areia argilosa (SC).

Os limites de Atterberg dos solos foram determinados segundo a NBR 6459 (limite de liquidez) e a NBR 9180 (limite de plasticidade). Os resultados desses ensaios e o índice de plasticidade estão apresentados na Tabela 3.2. 
Análise de diferentes metodologias executivas de solo pregado a partir de ensaios de arrancamento em campo e laboratório

Tabela 3.2. Resultados de limites de consistência.

\begin{tabular}{cccc}
\hline Tipo de Solo & LL (\%) & LP (\%) & IP (\%) \\
\hline Areia Argilosa & 39,2 & 21,4 & 17,8 \\
\hline
\end{tabular}

A determinação da massa específica dos sólidos foi realizada de acordo com a NBR-6508/84. Foram feitas dez determinações, das quais apenas duas foram descartadas pelo critério de rejeição descrito em norma. A massa específica dos sólidos deste solo é de $2,681 \mathrm{~g} / \mathrm{cm}^{3}$.

O ensaio de compactação foi realizado utilizando-se a energia Proctor Normal $\left(583 \mathrm{~kJ} / \mathrm{m}^{3}\right)$, de acordo com as normas NBR 7182. Foram obtidos sete pares de valores de massa específica seca $\mathrm{x}$ teor de umidade. A Figura 3.3 apresenta a curva de compactação obtida.

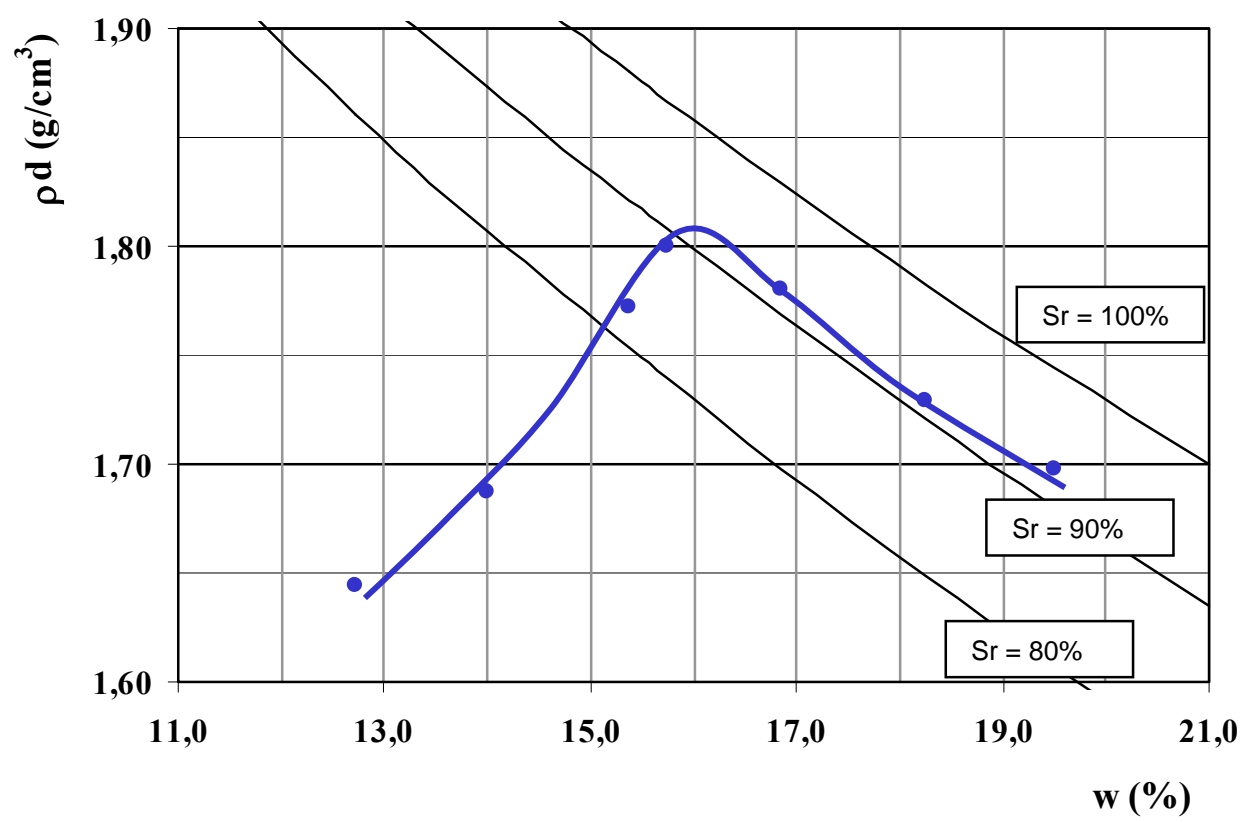

Figura 3.3. Curva de compactação do solo.

A Tabela 3.3 apresenta os parâmetros ótimos de compactação determinados a partir do ensaio de compactação realizado. 
Análise de diferentes metodologias executivas de solo pregado a partir de ensaios de arrancamento em campo e laboratório

Tabela 3.3. Parâmetros de compactação.

\begin{tabular}{ccc}
\hline Tipo de Solo & $\boldsymbol{\rho}_{\text {dmáx }}\left(\mathbf{g} / \mathbf{c m}^{3}\right)$ & $\mathbf{W}_{\text {ótima }}(\%)$ \\
\hline Areia argilosa & 1,805 & 16,0 \\
\hline
\end{tabular}

Kakuda (2005) realizou ensaios de cisalhamento direto em amostras compactadas deste solo (G.C igual a 96\%). Os parâmetros de resistência obtidos foram 30,0 kPa de coesão e $34,6^{\circ}$ de ângulo de atrito. Freitas Neto (2008) também estudou a resistência ao cisalhamento deste solo, sob diversas condições de saturação. A partir de ensaios triaxiais em amostras compactadas (G.C igual a 95,4\%) e em condições saturadas, obteve 25,0 kPa de coesão e $33^{\circ}$ de ângulo de atrito. Ao realizar ensaios triaxiais em amostras compactadas (G.C igual a 95,1\%) com teor de umidade igual à ótima, os resultados evidenciaram 28,5 $\mathrm{kPa}$ de coesão e $36^{\circ}$ de ângulo de atrito. Como estes parâmetros encontram-se muito próximos dos obtidos por Kakuda (2005), e a compactação das amostras também se aproxima do G.C obtido nesta pesquisa (G.C médio igual a 92\%), estes parâmetros foram tomados como referência nas análises de estabilidade da estrutura de solo pregado.

\subsubsection{Caixa Metálica de Ensaios}

A estrutura de solo pregado foi construída em uma caixa metálica desenvolvida por Viana (2003). A caixa de ensaio apresenta área plana de 1,80 x 1,55 m (B x L), altura de $1,80 \mathrm{~m}$ e é composta por peças metálicas rígidas (pilares, paredes e tampa). As paredes laterais da caixa de ensaio foram forradas com uma montagem de geomembranas de PVC, contendo graxa entre elas. Esta medida visou reduzir o atrito entre as paredes laterais da caixa de ensaio e o solo. A face frontal da caixa de ensaio foi dimensionada e adaptada para simular as etapas de escavação inerentes à técnica de solo pregado. A face frontal é composta por seis segmentos retangulares de madeira com $50 \mathrm{~mm}$ de espessura e $250 \mathrm{~mm}$ de altura, com exceção do segmento inferior, que possui $425 \mathrm{~mm}$ de altura. As Figuras 3.4 (a) e (b) apresentam, respectivamente, a caixa metálica e a face frontal móvel adaptada para simular as etapas de escavação. 

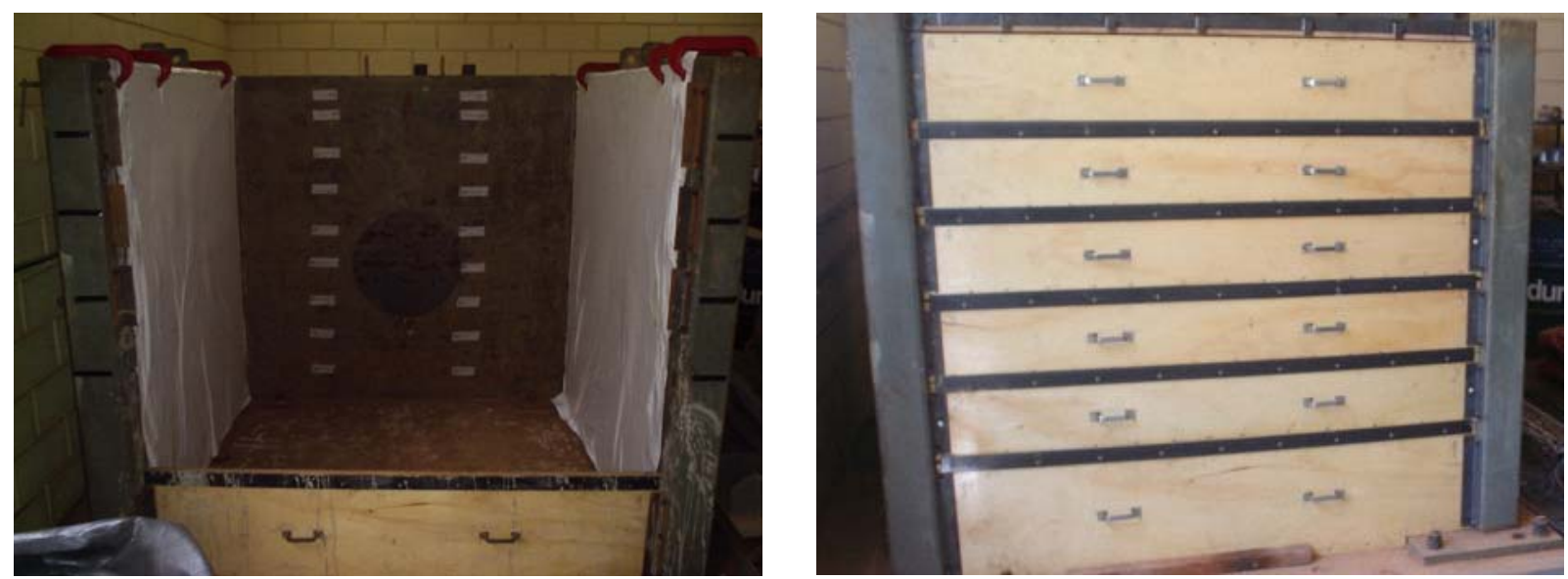

Figura 3.4. (a) Vista da caixa metálica e (b) da face frontal móvel adaptada para a construção do solo pregado.

\subsubsection{Caracteństicas dos Reforços}

Os chumbadores foram construídos com barras de aço CA-50 de 8,0 mm de diâmetro. Apesar dos reforços terem sido construídos com 1,0 m de comprimento injetado e 0,3 $\mathrm{m}$ de comprimento livre, as barras de aço foram utilizadas com 1,8 $\mathrm{m}$, deixando o comprimento excedente $(0,5 \mathrm{~m})$ disponível para a realização dos ensaios de arrancamento.

Os chumbadores foram dispostos na caixa de ensaio em 3 linhas (L1 a L3) e 3 colunas (C1 a C3), com espaçamentos verticais e horizontais iguais a 0,50 m e 0,45 m, respectivamente. Esta distribuição buscou otimizar o espaço físico da caixa para os objetivos do estudo. Ao longo das linhas, buscou-se avaliar a influência de três diferentes metodologias executivas na resistência ao cisalhamento de interface, enquanto ao longo das colunas, foi possível avaliar a influência da profundidade em cada um dos métodos executivos.A Figura 3.5 apresenta a disposição dos chumbadores na face frontal da caixa e a indicação das metodologias utilizadas para a construção de cada chumbador. 
Análise de diferentes metodologias executivas de solo pregado a partir de ensaios de arrancamento em campo e laboratório

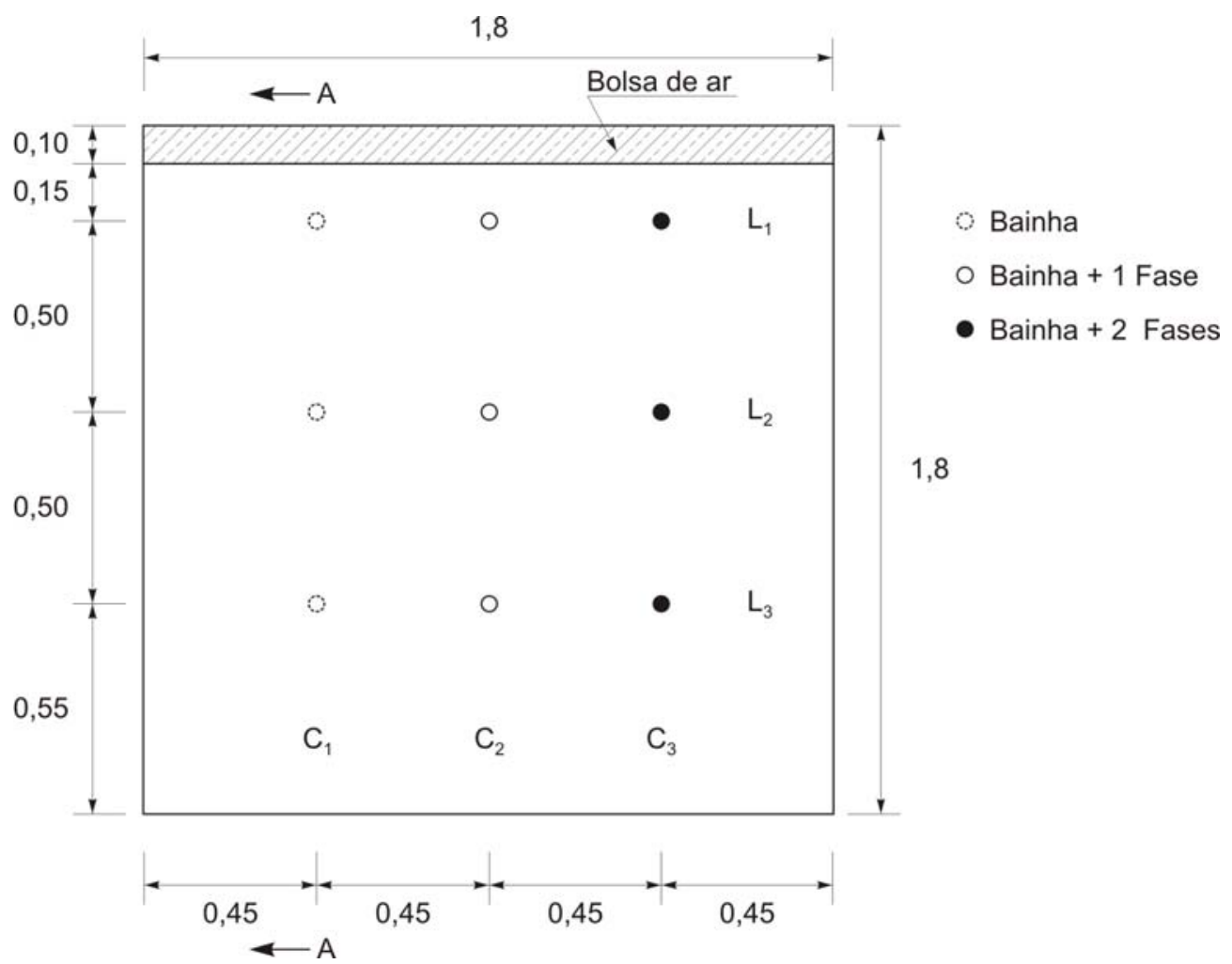

Figura 3.5. Disposição dos chumbadores na face frontal da caixa de ensaios.

A descrição das metodologias executivas empregadas em cada uma das colunas é apresentada na sequência:

Coluna 1 (C1): os reforços foram construídos somente com a bainha (preenchimento do furo com calda de cimento). Este método construtivo será denominado Bainha;

Coluna 2 (C2): os reforços foram construídos com a bainha (preenchimento do furo com calda de cimento) e mais uma fase posterior de injeção. Este método construtivo será denominado Bainha +1 Fase;

Coluna 3 (C3): os reforços foram construídos com a bainha (preenchimento do furo com calda de cimento) e mais duas fases posteriores de injeção. Este método construtivo será denominado Bainha +2 Fases; 
A Figura 3.6 apresenta um corte longitudinal (AA) e a distribuição dos chumbadores ao longo da profundidade da caixa. Os reforços foram construídos com $0,3 \mathrm{~m}$ de comprimento livre (LL) e 1,0 m.de comprimento de arrancamento (LA).

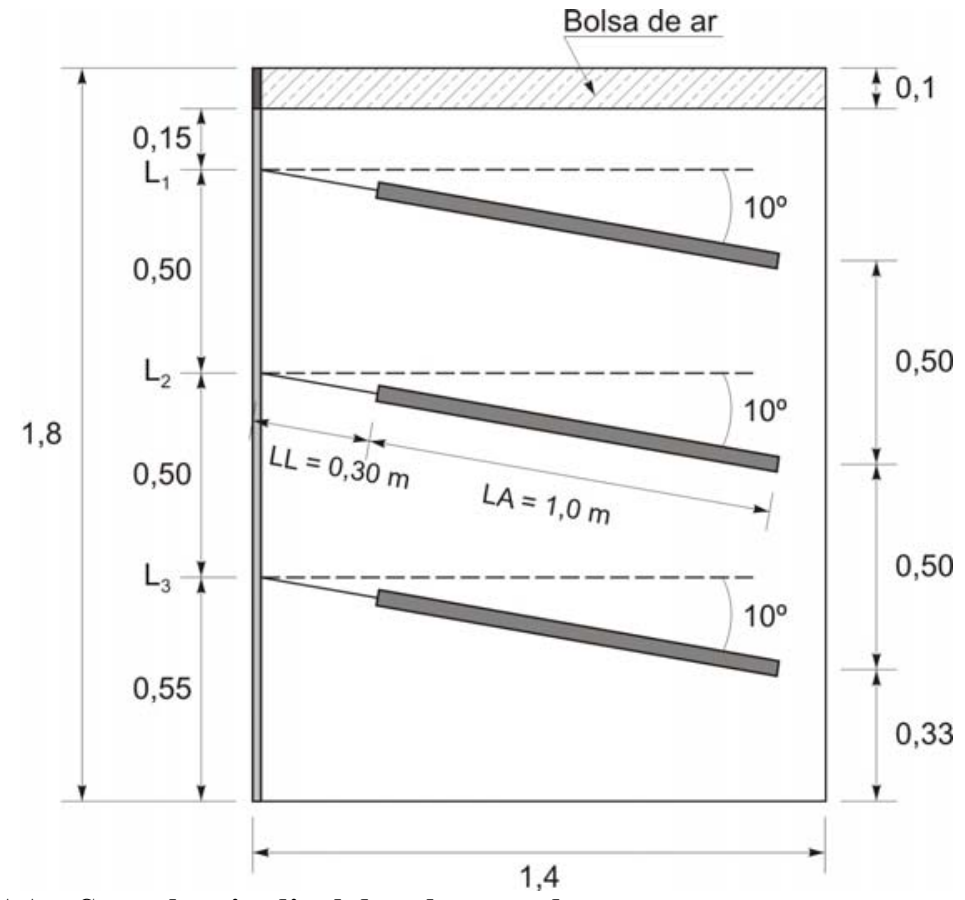

Figura 3.6. Corte AA - Seção longitudinal do solo pregado.

Para permitir a realização da Bainha e das fases posteriores de injeção, foi fixada, para cada uma destas etapas, uma tubulação "perdida" de poliamida de $6,3 \mathrm{~mm}$ de diâmetro. Estas tubulações foram dotadas de válvulas de injeção, alternadas a cada $0,10 \mathrm{~m}$ ao longo do trecho injetado de 1,0 m, e fixadas junto às barras de aço. Estas válvulas foram realizadas a partir de pequenas aberturas no tubo, sendo posteriormente vedadas com fita adesiva. Com a aplicação da pressão de injeção, as fitas rompiam-se e permitiam o fluxo da calda de cimento. A Figura 3.7 apresenta as seções transversais dos chumbadores para cada um dos métodos construtivos empregados na construção do solo pregado. 


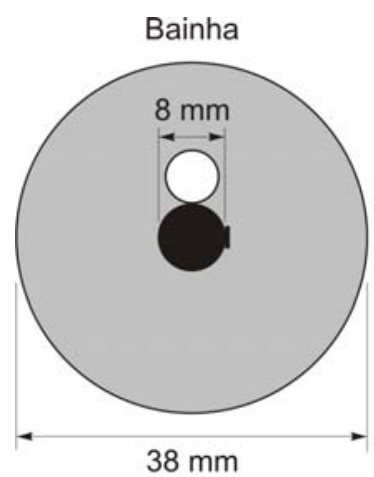

Barra de aço

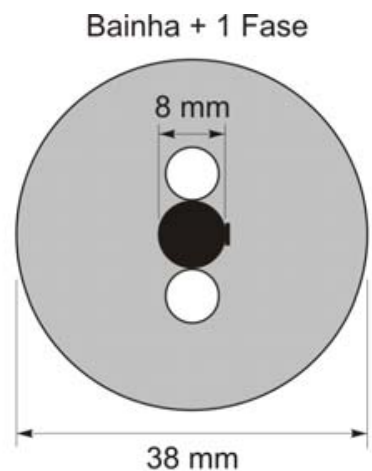

$38 \mathrm{~mm}$

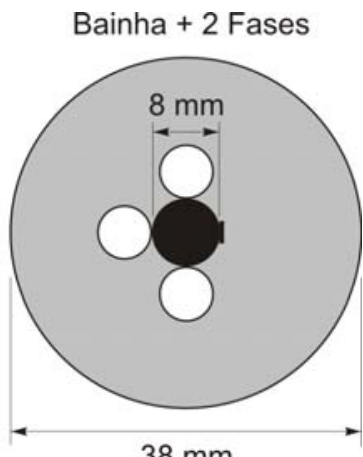

$38 \mathrm{~mm}$ $(\mathrm{D}=6,3 \mathrm{~mm})$

Calda de cimento - Strain Gage

Figura 3.7. Seção transversal dos chumbadores para cada uma das metodologias executivas.

Para garantir a integridade do trecho injetado e a manutenção do trecho livre, foram instalados, respectivamente, três centralizadores plásticos e um obturador composto por espuma enrolada e fixada junto à barra de aço. A Figura 3.8 apresenta as barra de aço devidamente preparadas e prontas para serem inseridas no maciço de solo.

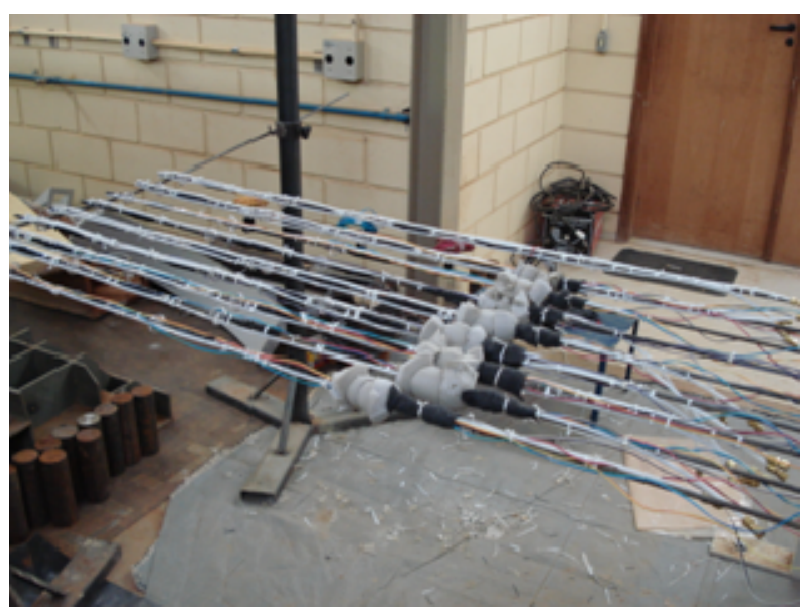

Figura 3.8. Detalhe das barras de aço preparadas para serem inseridas no maciço de solo. 


\subsubsection{Instrumentação Utilizada}

Todas as barras de aço utilizadas foram instrumentadas com extensômetros elétricos (strain gages). Cada barra de aço foi instrumentada com quatro strain gages dispostos em diferentes posições ao longo do comprimento injetado. Estes instrumentos foram alinhados na lateral das barras de aço, para reduzir a influência de possíveis momentos fletores. A Figura 3.9 apresenta a localização dos strain gages ao longo das barras de aço.

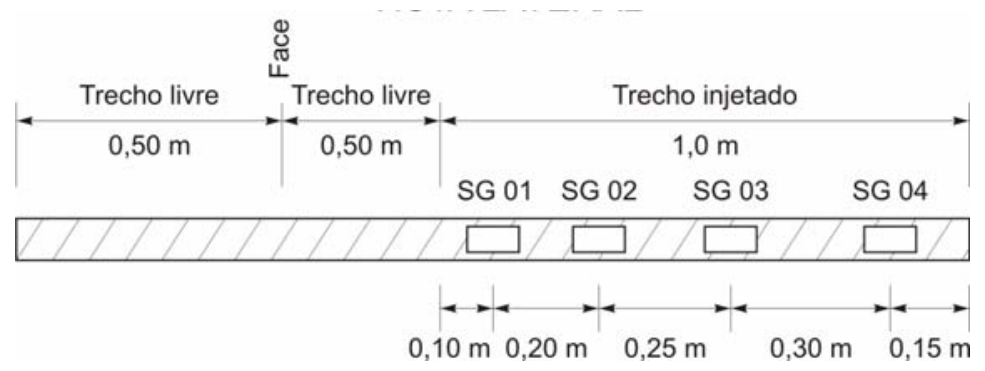

Figura 3.9. Vista lateral das barras de aço instrumentadas com strain gages.

Para facilitar a identificação, os strain gages serão denominados SG 01, SG 02, SG 03 e SG 04. A Tabela 3.4 apresenta o quadro resumo com a posição de cada um deles, em relação ao início do trecho injetado e à face do modelo.

Tabela 3.4. Posição dos strain gages em relação ao trecho injetado e à face.

\begin{tabular}{ccccc}
\hline Referência & SG 01 & SG 02 & SG 03 & SG 04 \\
\hline Início - Trecho injetado & $0,10 \mathrm{~m}$ & $0,30 \mathrm{~m}$ & $0,55 \mathrm{~m}$ & $0,85 \mathrm{~m}$ \\
Face & $0,40 \mathrm{~m}$ & $0,60 \mathrm{~m}$ & $0,85 \mathrm{~m}$ & $1,15 \mathrm{~m}$ \\
\hline
\end{tabular}

Antes de iniciar o processo de colagem dos strain gages, foi realizado um rebaixo de $8,0 \mathrm{~mm}$ ao longo de uma área retangular de 5,0 x 30,0 mm. A Figura 3.10 apresenta as dimensões dos rebaixos que foram realizados ao longo da barra de aço. 


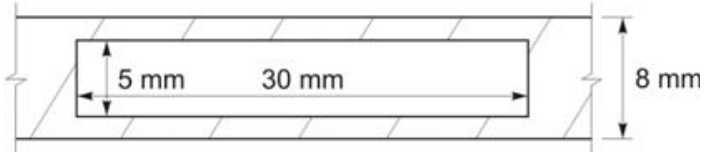

Figura 3.10. Detalhe das dimensões do rebaixo que será realizado na barra de aço.

Os strain gages utilizados na instrumentação foram fabricados pela Excel Sensores Ltda, pertencem à família dos modelos unidirecionais simples de formas tradicionais e são do tipo PA-06-125 BA-120-L. A Tabela 3.5 apresenta as dimensões dos strain gages utilizados.

Tabela 3.5. Dimensões dos strain gages utilizados.

\begin{tabular}{cccc}
\hline \multicolumn{2}{c}{ Dimensões da Grelha } & \multicolumn{2}{c}{ Dimensões Totais } \\
\hline Comprimento $(\mathrm{mm})$ & Largura $(\mathrm{mm})$ & Comprimento $(\mathrm{mm})$ & Largura $(\mathrm{mm})$ \\
3,18 & 1,52 & 5,46 & 1,57 \\
\hline
\end{tabular}

O processo de instalação dos strain gages nas barras de aço foi efetuado em diferentes etapas, tais como: marcação de eixo na barra, preparação da superfície, colagem do strain gage, cabeamento, soldagem e proteção do sistema. Estas etapas seguiram os procedimentos recomendados pela Excel Sensores Ltda e estão representadas na Figura 3.11 .

\section{SUPERFICIE PRONTA}

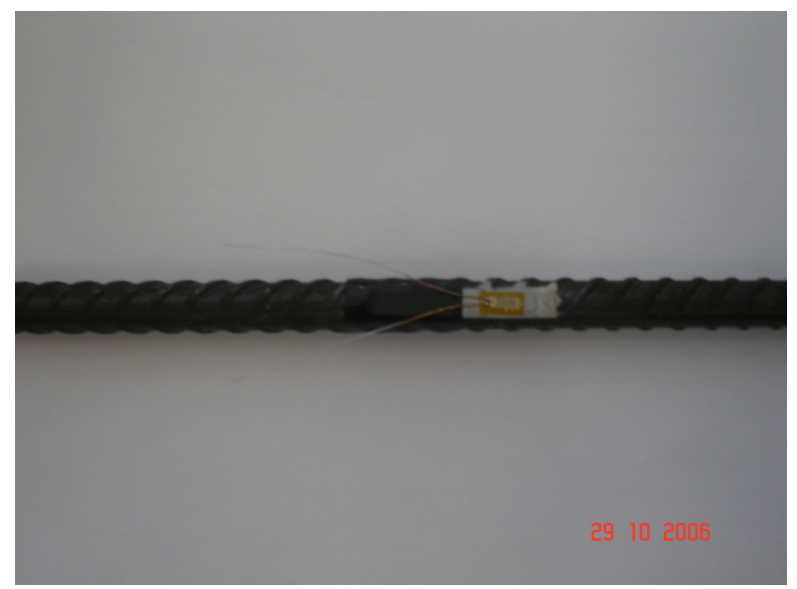

(a)

(b) 


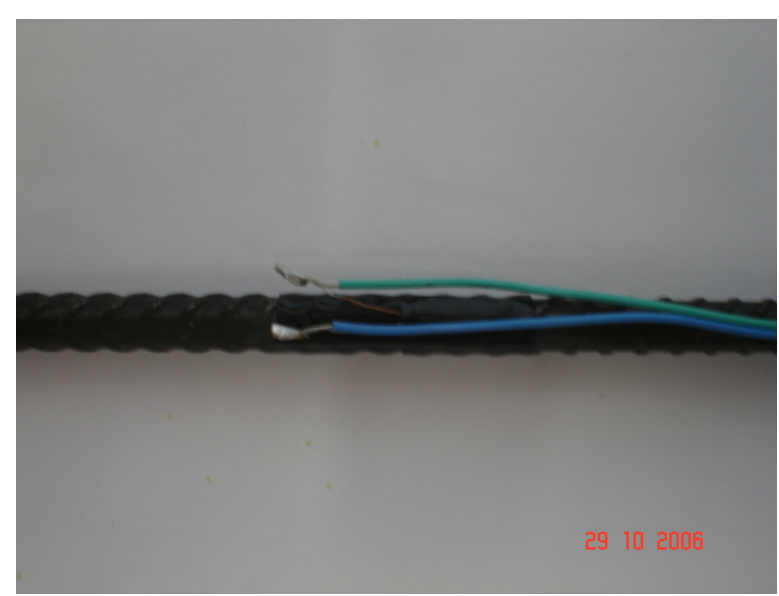

(c)

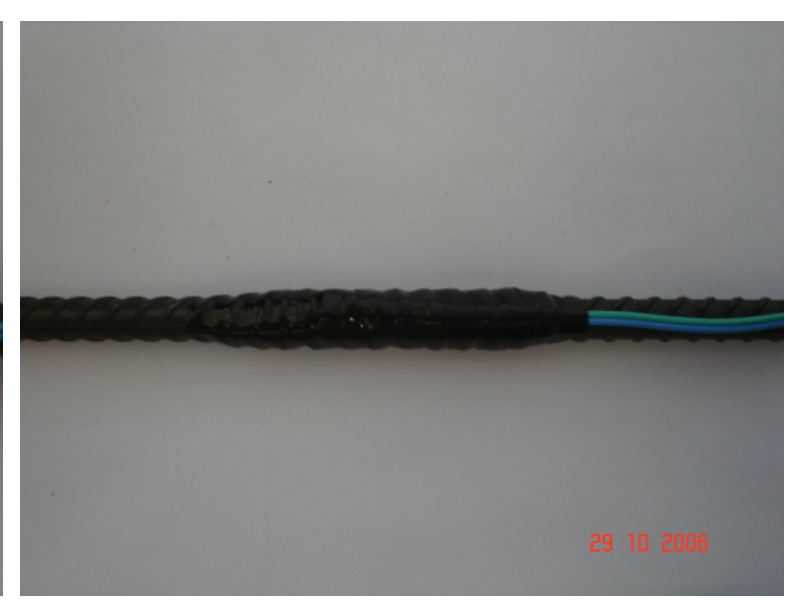

(d)

Figura 3.11. Etapas para a instalação dos strain gages. (a) Preparação da superfície, (b) colagem do strain gage, (c) cabeamento e soldagem e (d) proteção do sistema.

A correta interpretação das leituras dos strain gages durante a realização dos ensaios exigiu uma calibração apropriada dos mesmos. Para tanto, as barras de aço instrumentadas foram carregadas sob tração, em estágios crescentes e decrescentes, para verificar as leituras de cada instrumento, em cada nível de carregamento. Em seguida, cada um dos estágios foi relacionado a uma leitura do strain gage, resultando nas curvas de calibração. Foram utilizados 9 estágios de carregamento com variação de 0,54 kN. Cada estágio, portanto, corresponde a uma variação de tensão de tração de aproximadamente 10,7 MPa para as barras de aço com $8 \mathrm{~mm}$ de diâmetro nominal. A leitura dos strain gages foi realizada pelo sistema de aquisição de dados WIN 5000. A Figura 3.12 apresenta os equipamentos utilizados no processo de calibração (a), o comportamento típico durante as etapas de carregamento e descarregamento (b) e uma curva de calibração típica para um strain gage $(\mathrm{c})$. 

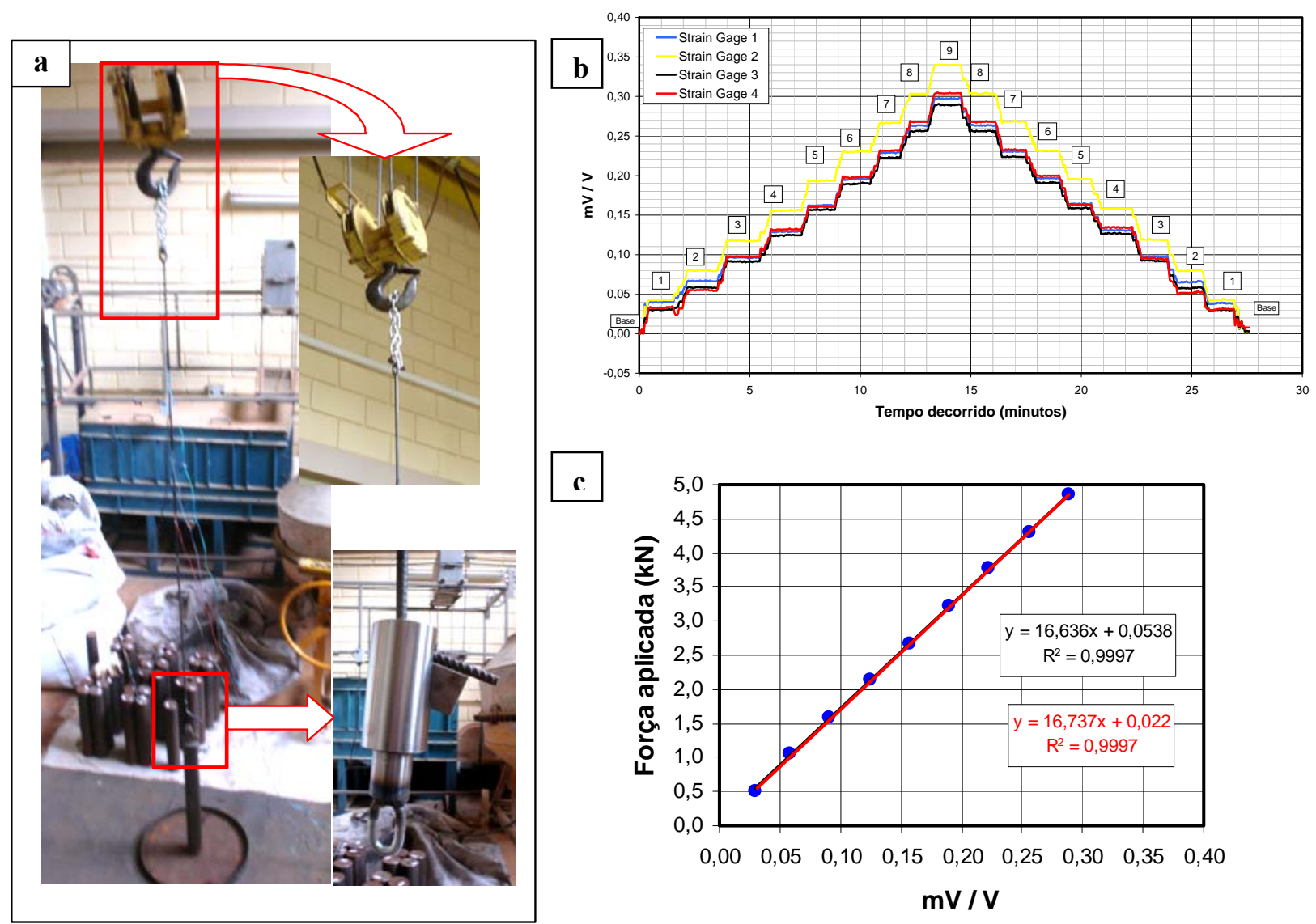

Figura 3.12. Calibração dos strain gages. (a) Equipamentos utilizados no procedimento; (b) comportamento durante as etapas de calibração e (c) curva de calibração típica.

\subsubsection{Preenchimento da Caixa de Ensaio}

A primeira etapa da construção do solo pregado foi o enchimento da caixa de ensaio com solo compactado. Inicialmente, o solo foi destorroado, peneirado e armazenado em bolsões (big bags) em quantidades aproximadas de $200 \mathrm{~kg}$. Imediatamente antes da sua utilização no processo de compactação, coletaram-se amostras do solo armazenado para a determinação do teor de umidade. Este procedimento foi realizado por meio do aquecimento da amostra no forno microondas, conforme metodologia estabelecida por França (2007). A correção do teor de umidade e a homogeneização do solo foram realizadas com o auxílio de uma betoneira elétrica.

Após a etapa de homogeneização, foram realizadas novas amostragens do solo para a confirmação do teor de umidade ótimo. Após o lançamento do solo (cerca de $200 \mathrm{~kg}$ ) 
com teor de umidade corrigido, realizou-se o processo de compactação com soquete manual. O soquete apresenta $10 \mathrm{~kg}$, e os golpes foram realizados com uma altura de queda aproximada de $200 \mathrm{~mm}$. Este procedimento resultou em camadas compactadas de aproximadamente $40 \mathrm{~mm}$ de espessura e foi repetido até o preenchimento da caixa de ensaio. A Figura 3.13 apresenta o procedimento executivo utilizado para o enchimento da caixa com solo compactado.

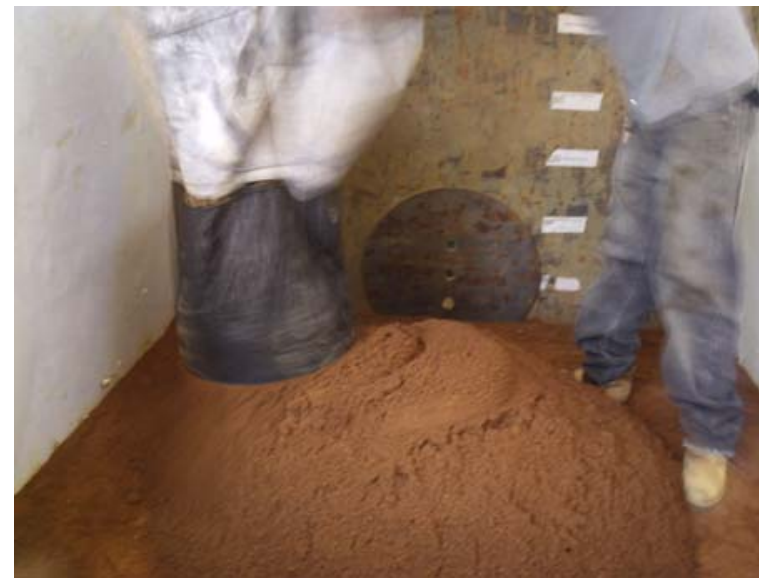

(a)

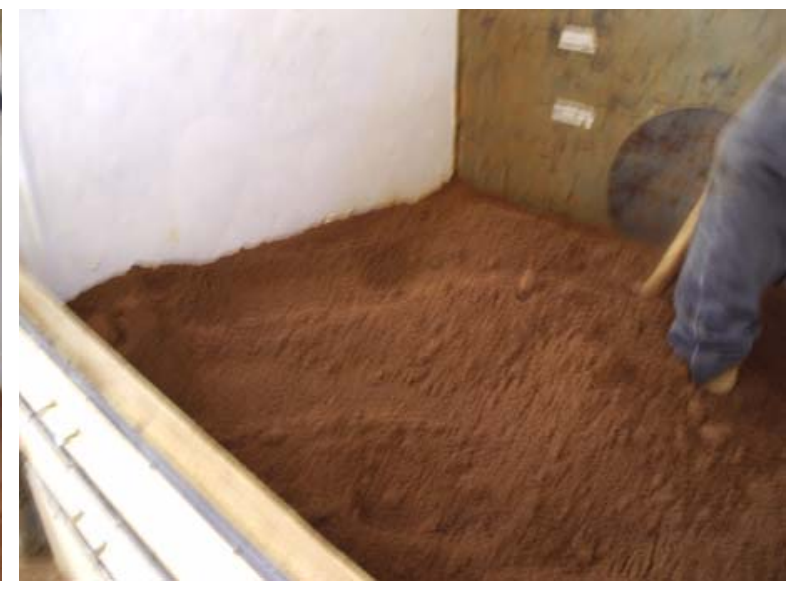

(b)

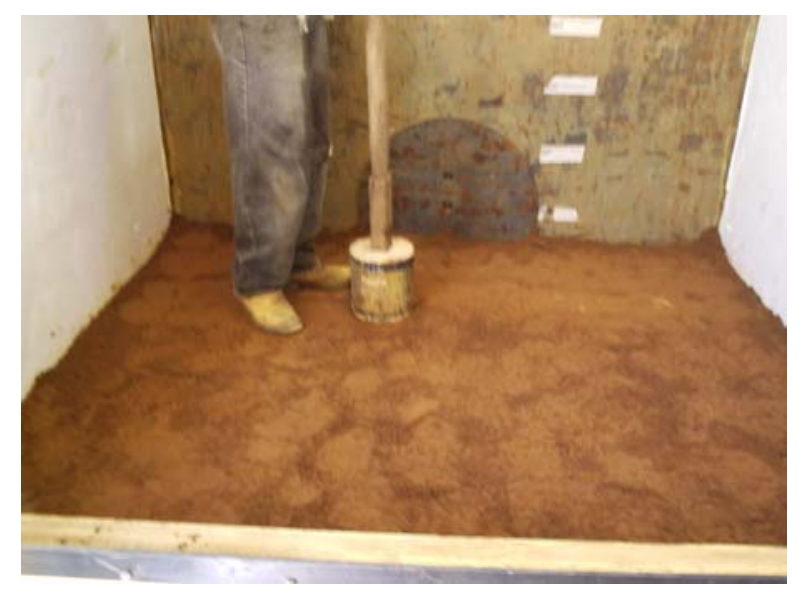

(c)

Figura 3.13. Seqüência executiva do procedimento manual de compactação. (a) Lançamento do solo armazenado em bolsões (big bags); (b) espalhamento manual e (c) compactação com soquete manual.

Após a compactação de cinco camadas consecutivas, era então realizado o controle de compactação, conforme procedimento apresentado na Figura 3.14. 
Análise de diferentes metodologias executivas de solo pregado a partir de ensaios de arrancamento em campo e laboratório

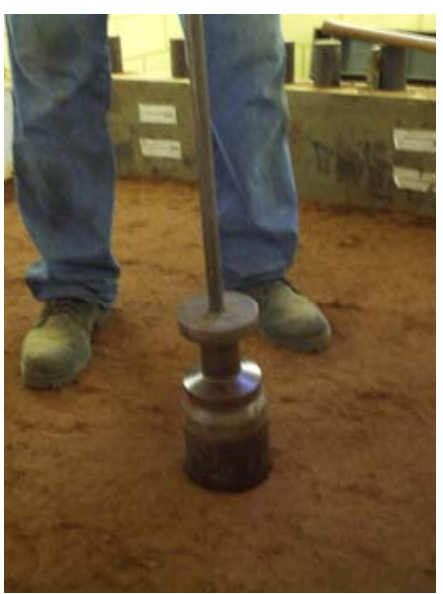

(a)

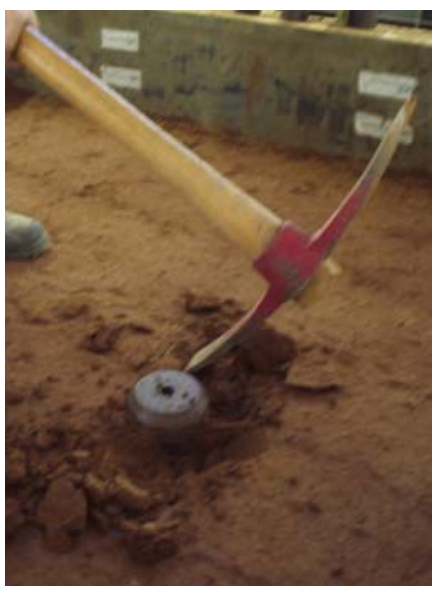

(c)

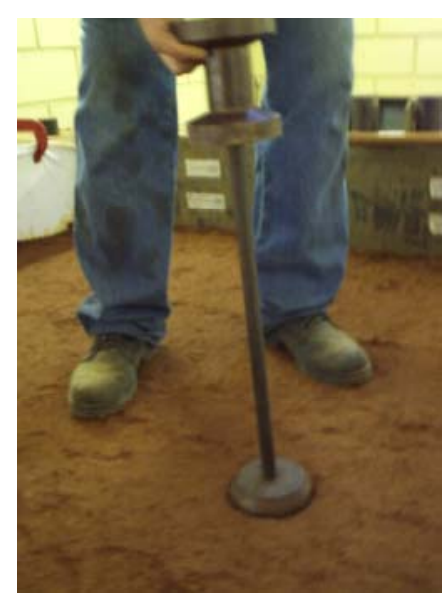

(b)

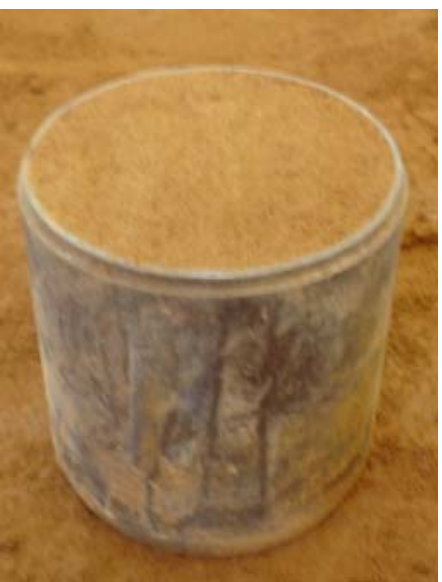

(d)

Figura 3.14. Etapas do controle de compactação pelo método do cilindro cortante. (a) Início da cravação; (b) final da cravação; (c) escavação lateral e (d) detalhe do cilindro preenchido com solo.

Foram realizadas oito determinações do peso específico seco e do teor de umidade, utilizando-se, respectivamente, o método do cilindro de cravação (NBR 9813/87) e o forno de microondas (ASTM D 4643 /93). Os resultados obtidos são apresentados ao longo da seção transversal do solo pregado (Figura 3.15). 


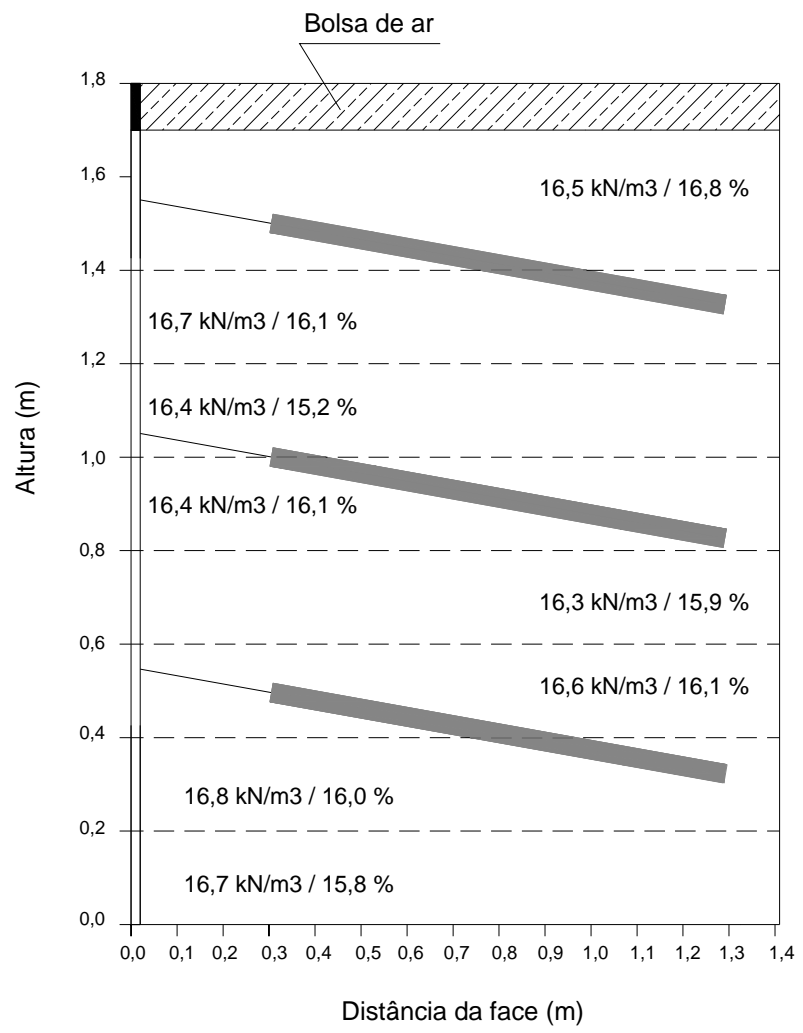

Figura 3.15. Peso específico seco e teor de umidade obtidos nos controles de compactação executados.

A partir dos ensaios realizados, foi obtido um Grau de Compactação médio de $91,7 \%$ e um teor de umidade médio de $15,9 \%$. O desvio de teor de umidade máximo foi de $\pm 0,8 \%$.

\subsubsection{Execução do Solo Pregado}

A seqüência executiva utilizada na construção do modelo de solo pregado foi a mesma que é empregada nas obras em escala real, ou seja, escavação, perfuração, instalação dos reforços e injeção da calda de cimento.

A etapa de escavação foi simulada a partir da remoção sucessiva dos segmentos móveis de madeira. Após cada etapa de escavação, aplicou-se, no solo exposto, uma pintura com calda de cimento para minimizar as perdas de umidade. $\mathrm{Na}$ etapa seguinte, foi realizada a perfuração do maciço compactado. Este processo foi realizado manualmente, com o auxílio de um trado, resultando em furos com diâmetro acabado de $38 \mathrm{~mm}$. Para 
obter a inclinação desejada, foram construídos dois suportes metálicos guias, que permitem o apoio do trado com altura variável. As Figuras 3.16 (a) e (b) apresentam, respectivamente, o processo de escavação do maciço de solo através da remoção de um segmento da face de madeira e a perfuração do maciço de solo após a pintura da face com calda de cimento.

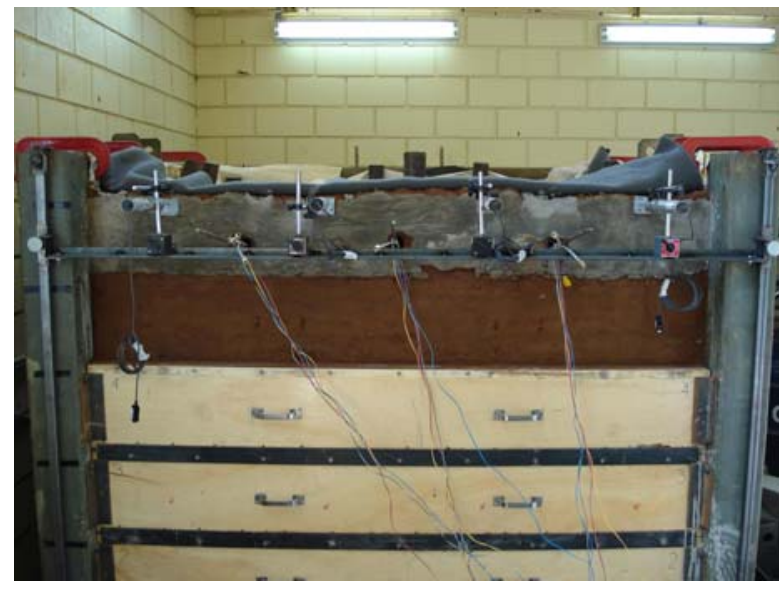

(a)

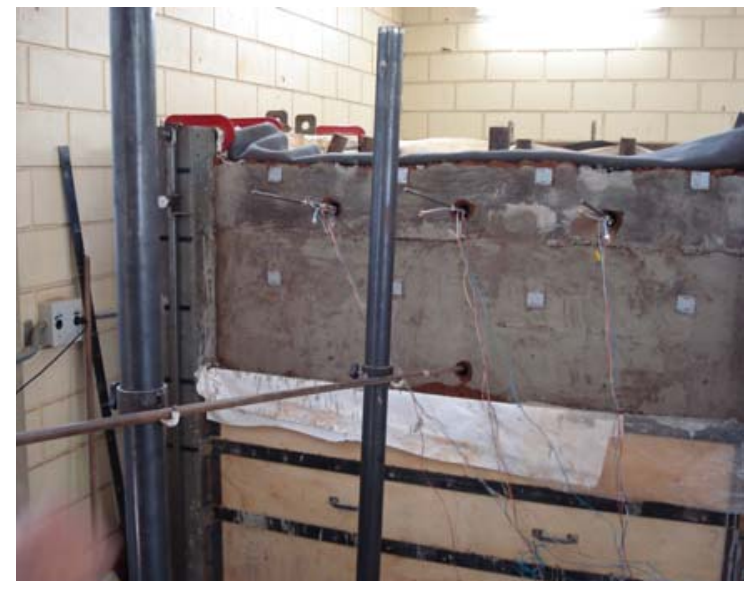

(b)

Figura 3.16. (a) Simulação do processo de escavação do maciço de solo através da remoção sucessiva dos segmentos de madeira e (b) perfuração do maciço de solo após a pintura da face com calda de cimento.

Após a realização destas etapas em uma mesma linha, os reforços eram inseridos nas perfurações realizadas. Como as injeções foram realizadas em tubulações "perdidas" de poliamida de $6,3 \mathrm{~mm}$, foi necessário realizar um estudo de traço da calda de cimento, para que calda de cimento tivesse uma fluidez que permitisse o procedimento de injeção através do tubo. Adicionalmente, como o volume de calda de cimento injetado seria pequeno, foi necessário desenvolver um equipamento específico de injeção. Os detalhes da preparação da calda de cimento, do equipamento de injeção desenvolvido e do controle de injeção realizado são apresentados na seqüência. 


\subsubsection{Preparação da Calda de Cimento}

A calda de cimento foi preparada com cimento CPII-E-32 e fator água-cimento igual a 0,6 em massa. Para aumentar a fluidez da calda de cimento, foi utilizado o super plastificante Glenium 3010. O ponto de saturação do aditivo (teor considerado ótimo) na calda de cimento foi determinado a partir de um estudo de compatibilidade entre o cimento e o super plastificante. $\mathrm{O}$ ensaio que permite verificar estas propriedades é conhecido como ensaio de miniabatimento e foi desenvolvido por Kantro em 1980 (AÏTCIN, 2000). Como o próprio nome sugere, este ensaio consiste em determinar o abatimento de pequenas quantidades de calda de cimento utilizando-se um minitronco de cone, conforme apresentado na Figura 3.17.
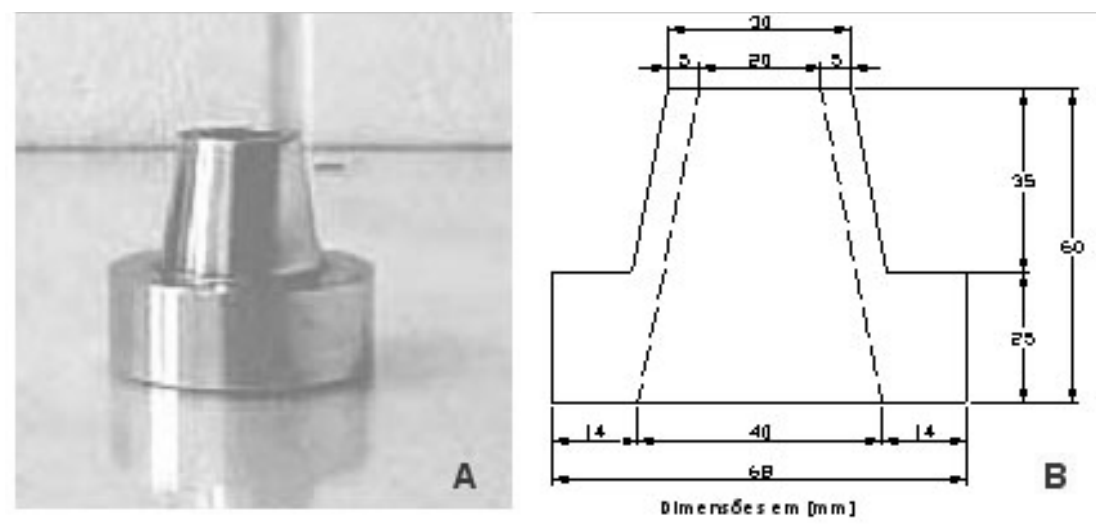

Figura 3.17. (a) Detalhe do minitronco de cone e (b) esquema com as suas dimensões.

A calda de cimento foi preparada em uma cuba, utilizando-se um misturador específico para sua homogeneização. O procedimento de preparação estabelecido por Gomes (2002) é apresentado a seguir:

Etapa 1: o cimento e a água (correspondendo a 90\% do total de água de amassamento) foram misturados por 1 minuto em velocidade baixa;

Etapa 2: o misturador foi parado por 30 segundos, e as laterais da cuba raspadas com o auxílio de uma espátula, para remover o material retido nas paredes da cuba. A pasta foi misturada por mais 1 minuto em velocidade baixa; 
Etapa 3: o processo foi interrompido mais uma vez, por mais 30 segundos, e as laterais da cuba foram novamente raspadas. Durante este intervalo, o super plastificante e o restante da água ( $10 \%$ do total de água de amassamento) foram adicionados;

$>$ Etapa 4: a mistura continuou por mais 1 minuto em velocidade baixa e 2 minutos na velocidade alta.

Após a etapa de preparação da calda de cimento, o ensaio de miniabatimento foi realizado com a seguinte metodologia:

$>$ Preparou-se uma base de vidro sem inclinação;

$>$ Lubrificou-se a placa de vidro e o minitronco de cone metálico;

$>$ O molde foi preenchido com a amostra da calda de cimento;

$>$ Aplicaram-se dez batidas no topo do minitronco de cone, nivelando-o com o auxílio de uma pequena espátula. O material em excesso foi coletado pela borda ampliada do molde metálico;

Levantou-se o minitronco de cone suavemente, mantendo-o na posição vertical;

$>$ Finalmente, mediram-se os dois diâmetros perpendiculares de pasta de cimento espalhada.

A Figura 3.18 apresenta os detalhes da etapa de preparação e do ensaio da calda de cimento.

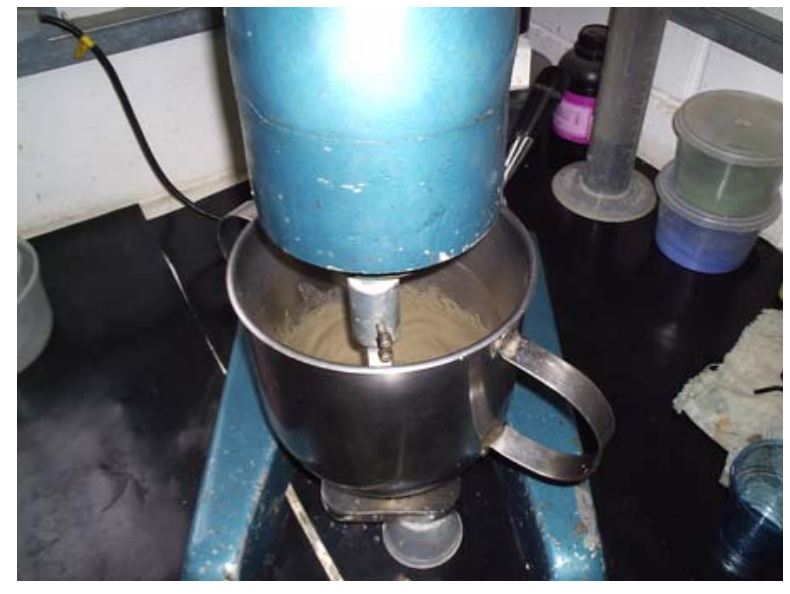

(a)

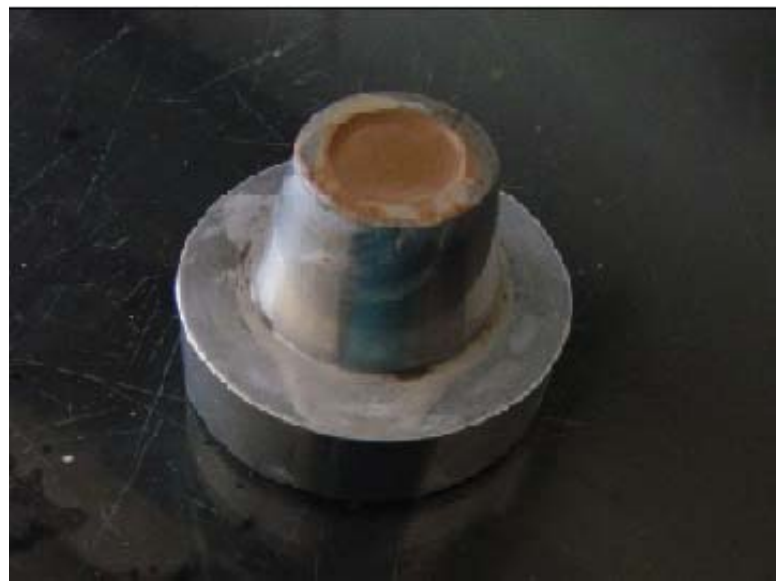

(b) 
Análise de diferentes metodologias executivas de solo pregado a partir de ensaios de arrancamento em campo e laboratório

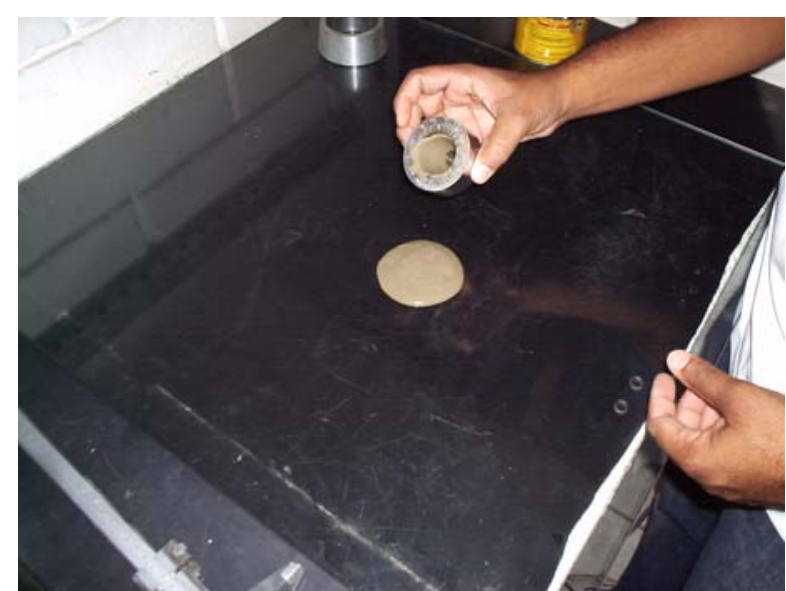

(c)

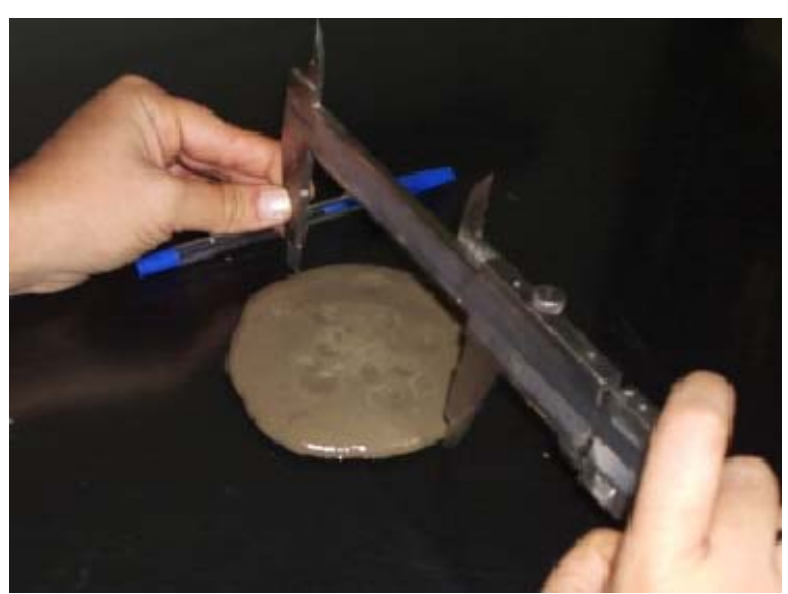

(d)

Figura 3.18. (a) Preparação da calda de cimento; (b) minitronco de cone preenchido com calda de cimento; (c) calda de cimento espalhada sobre a placa de vidro; (d) determinação do diâmetro de espalhamento da calda de cimento.

O procedimento foi repetido para várias porcentagens de aditivos em relação à massa de cimento. Para a relação água-cimento estudada, determinou-se que a massa de super plastificante utilizada na preparação da calda de cimento a ser injetada seria de $0,05 \%$ da massa de cimento utilizada. Após a definição do traço da calda de cimento, foram moldados 15 corpos de provas, que, após o tempo de pega, foram submetidos ao processo de cura submersa (Figura 3.19).

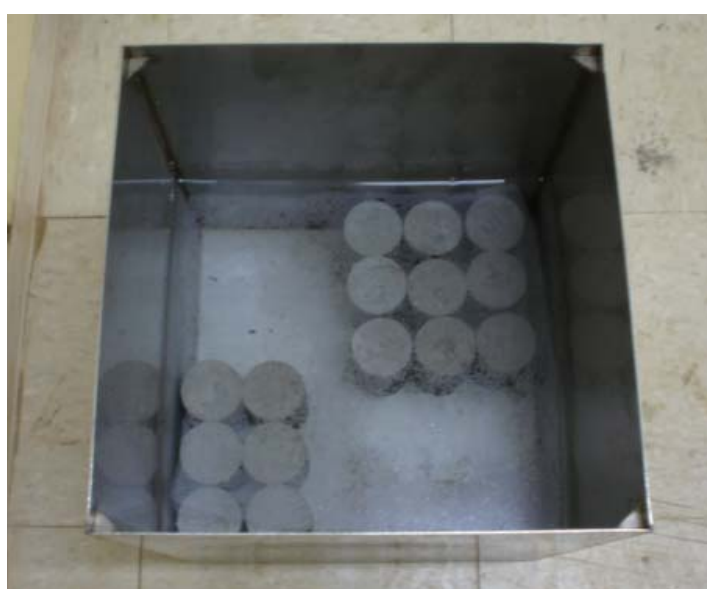

Figura 3.19. Corpos de prova da calda de cimento durante o processo de cura submersa. 
A resistência à compressão uniaxial da calda de cimento foi determinada através de ensaios em laboratório. Os ensaios foram realizados para cinco diferentes idades de cura: três, sete, quatorze, vinte e um, e vinte e oito dias. Para cada idade considerada, foram rompidos três corpos de prova. As resistências à compressão uniaxial, para os diferentes tempos de cura, são apresentadas na Figura 3.20.

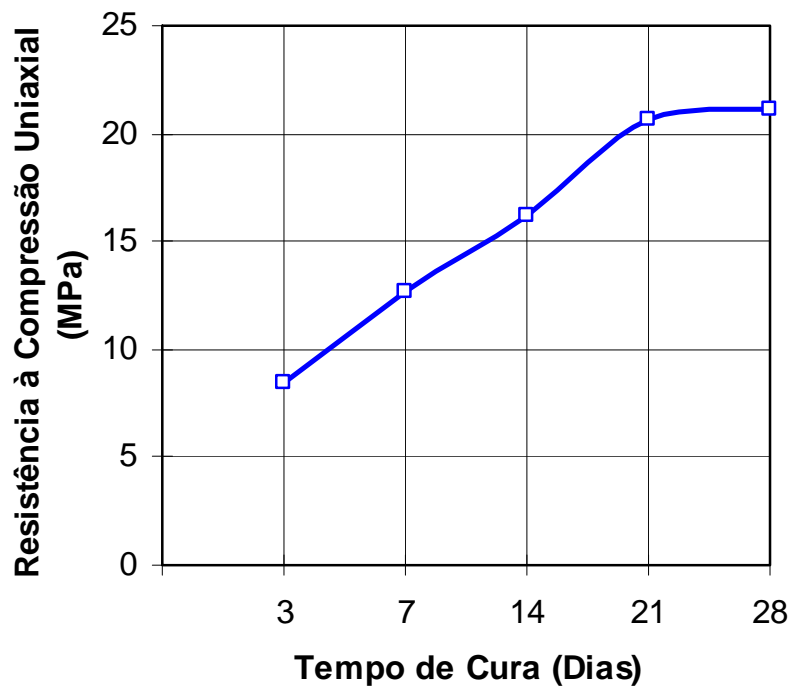

Figura 3.20. Evolução da resistência à compressão uniaxial da calda de cimento para os diferentes tempos de cura.

A partir da Figura 3.20, verifica-se que, a partir da idade de 21 dias, a Resistência à Compressão Uniaxial permaneceu-se praticamente constante, ou seja, com 21,1 MPa. Este valor apresenta-se dentro do valor mínimo estabelecido pelo manual internacional da FHWA (Lazarte et al., 2003).

\subsubsection{Equipamento de Injeção de Calda de Cimento}

O equipamento de injeção de calda de cimento foi desenvolvido com o objetivo de permitir o controle do volume e da pressão de cada etapa de injeção. As Figuras 3.21 (a) e (b) apresentam, respectivamente, um esquema geral e uma vista do equipamento durante a realização da injeção de calda de cimento. 


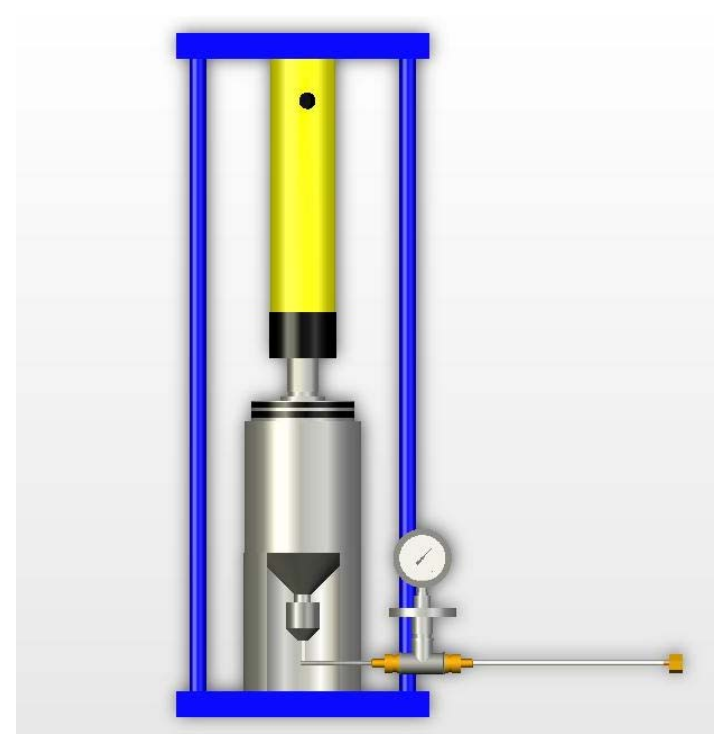

(a)

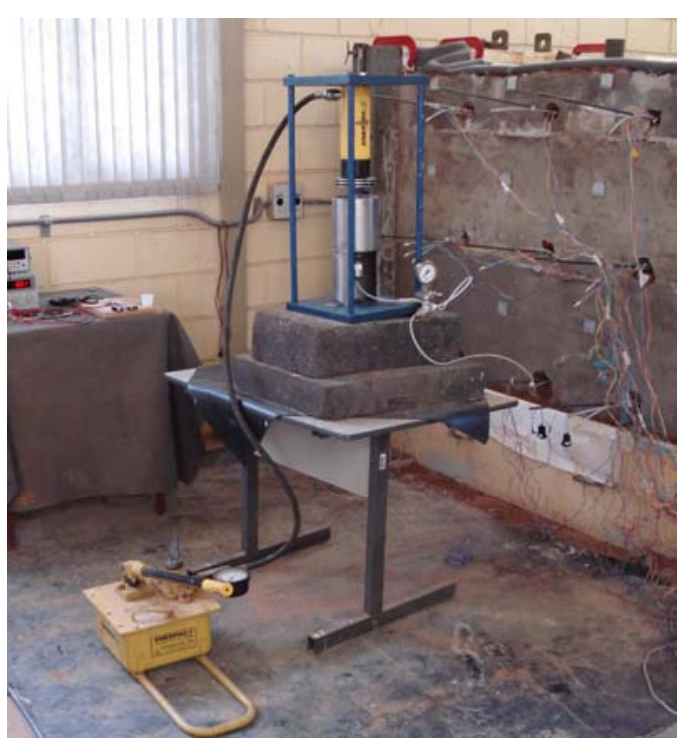

(b)

Figura 3.21. (a) Esquema do equipamento desenvolvido e (b) detalhe do equipamento durante a realização da injeção de calda de cimento.

O equipamento de injeção é composto por um reservatório de aço inox com seção circular de $120 \mathrm{~mm}$ de diâmetro, $150 \mathrm{~mm}$ de altura e $8 \mathrm{~mm}$ de espessura de parede. A região inferior do reservatório foi projetada na forma de um funil, para facilitar o escoamento da calda de cimento. O reservatório de volume conhecido (1,8 litros) permitiu quantificar, de forma aproximada, o volume de calda de cimento injetado em cada um dos métodos executivos. Para garantir a estanqueidade do sistema, foram fixados dois o-rings no êmbolo superior do reservatório. A pressão de injeção foi aplicada por um cilindro hidráulico que utilizava uma placa metálica de $15 \mathrm{~mm}$ de espessura, fixada a uma base metálica de mesma espessura como estrutura de reação. Para a quantificação da pressão de injeção, foi inserido, ao longo da tubulação de saída, um manômetro com um dispositivo de segurança (selo diafragma) para evitar sua contaminação com calda de cimento.

Antes de realizar o processo de injeção de calda de cimento, foram realizados testes preliminares com o referido equipamento. Para tal, foi construída uma mini-caixa de ensaio de madeira com seção quadrada de $0,30 \mathrm{~m}$ x 0,30 m e comprimento de 1,30 m. Compactou-se o solo no interior da mini-caixa, realizou-se a perfuração com o trado, inseriu-se o reforço e realizaram-se as injeções. O primeiro teste não foi satisfatório, já que 
o equipamento apresentou alguns vazamentos e as válvulas de injeção tiveram que sofrer algumas adaptações. Após concluir as modificações, o segundo teste apresentou resultado satisfatório. A Figura 3.22 apresenta a seqüência dos testes de injeção que foram realizados.

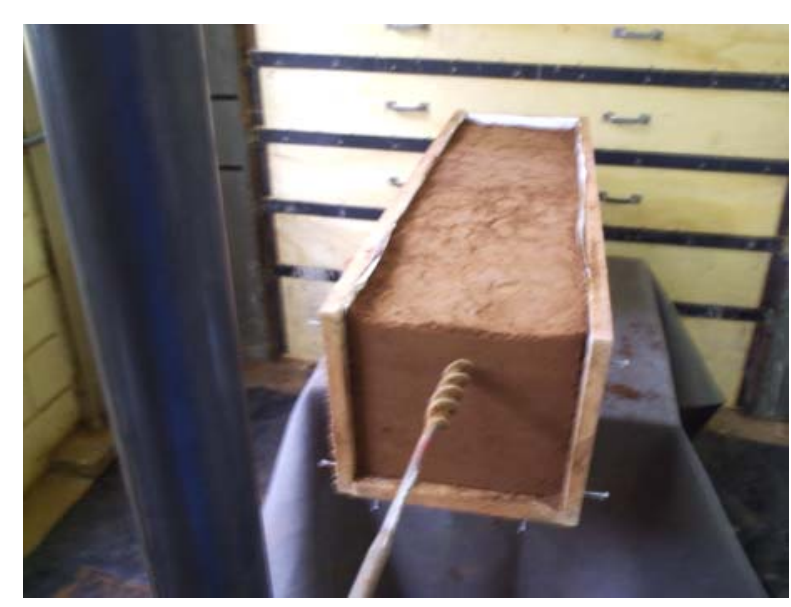

(a)

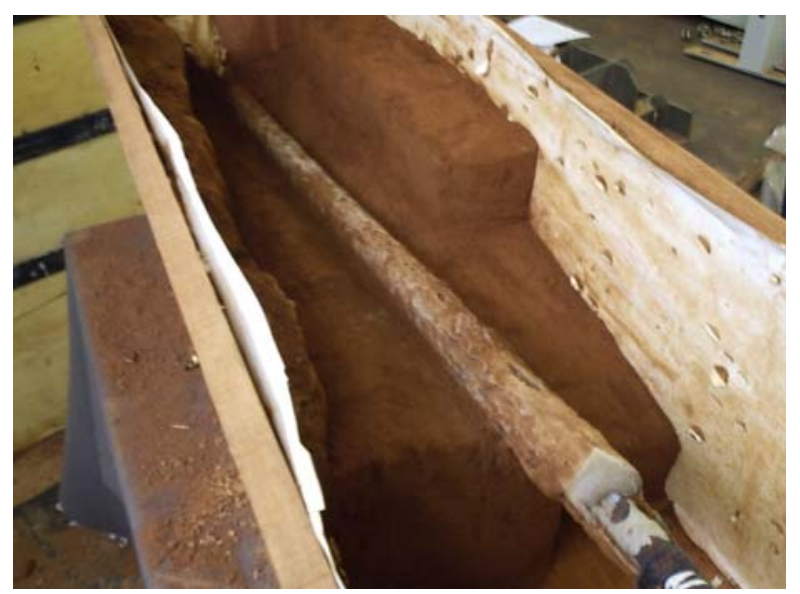

(c)

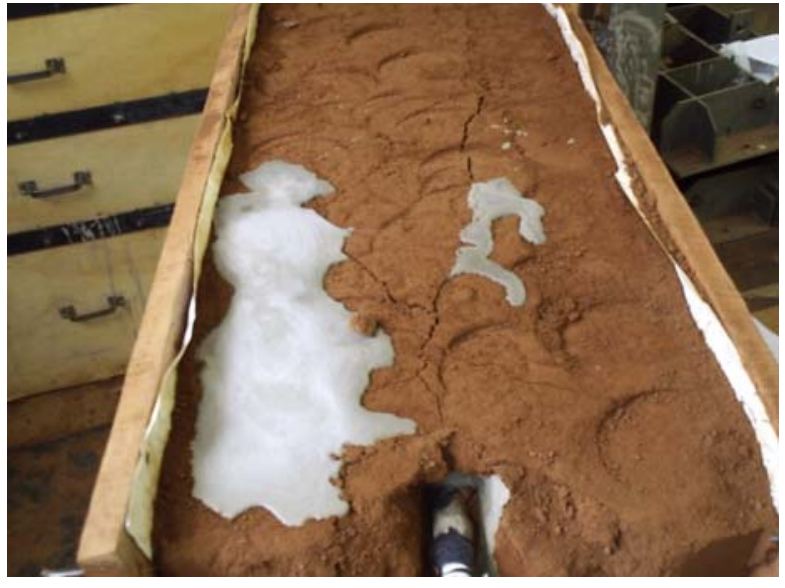

(b)

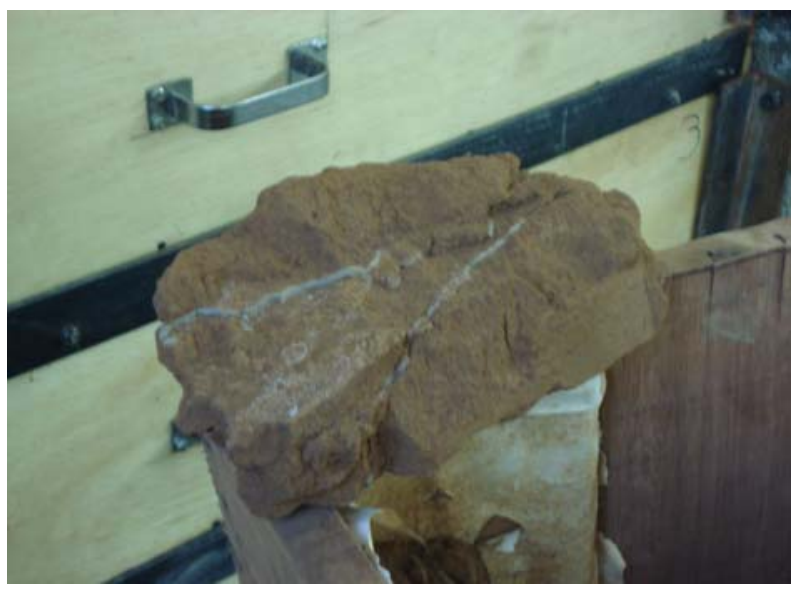

(d)

Figura 3.22. Testes de injeção realizados: (a) perfuração do solo compactado na mini caixa de madeira, (b) injeção da calda de cimento, (c) detalhe do chumbador após a exumação cuidadosa e (d) amostra de solo apresentando calda de cimento em seus vazios.

Após a confirmação da eficiência do equipamento e da metodologia empregada, realizaram-se as injeções na estrutura de solo pregado construída em laboratório. 


\subsubsection{Controle das Injeções}

O procedimento de injeção foi realizado da mesma forma para cada uma das linhas. Inicialmente, foram realizadas todas as bainhas; após um intervalo de 4 horas, realizou-se a primeira injeção de dois chumbadores, e após um intervalo de 20 horas, em relação à execução da bainha, realizou-se, em um único reforço, a segunda injeção. Estes intervalos de tempo foram determinados com o objetivo de facilitar o processo executivo. A partir de testes preliminares realizados em uma caixa de menor dimensão, constatou-se que a adoção de maiores intervalos de tempo dificultaria as injeções.

A calda de cimento foi preparada para cada uma das etapas de injeção. As Tabelas 3.6 a 3.8 apresentam, para cada linha de chumbadores, um resumo do controle do volume e da pressão de injeção realizado para cada uma das etapas de injeção de calda de cimento.

Tabela 3.6. Controle da injeção da calda de cimento para a linha 1.

\begin{tabular}{|c|c|c|c|c|c|c|}
\hline \multirow[b]{2}{*}{ Descrição } & \multicolumn{2}{|c|}{ Bainha } & \multicolumn{2}{|c|}{$1^{a}$ Fase (4 horas) } & \multicolumn{2}{|c|}{$2^{\mathrm{a}}$ Fase (20 horas) } \\
\hline & $\begin{array}{c}\text { Volume } \\
\text { (litros) }\end{array}$ & $\begin{array}{c}\text { Pressão } \\
\text { (MPa) }\end{array}$ & $\begin{array}{c}\text { Volume } \\
\text { (litros) }\end{array}$ & $\begin{array}{c}\text { Pressão } \\
\text { (MPa) }\end{array}$ & $\begin{array}{l}\text { Volume } \\
\text { (litros) }\end{array}$ & $\begin{array}{c}\text { Pressão } \\
\text { (MPa) }\end{array}$ \\
\hline Bainha & 1,13 & 0,25 & - & - & - & - \\
\hline $\begin{array}{l}\text { Bainha } \\
+1 \text { Fase }\end{array}$ & 1,13 & 0,25 & 0,18 & 0,30 & - & - \\
\hline $\begin{array}{l}\text { Bainha } \\
+2 \text { Fases }\end{array}$ & 1,13 & 0,25 & 0,28 & 0,30 & 0,11 & $0,70-2,50 *$ \\
\hline
\end{tabular}

Nota: (*) Pressão final atingida e adotada como critério de parada para a injeção.

Tabela 3.7. Controle da injeção da calda de cimento para a linha 2.

\begin{tabular}{c|cc|cc|cc}
\hline \multirow{2}{*}{ Descrição } & \multicolumn{2}{|c|}{ Bainha } & \multicolumn{2}{c|}{$\mathbf{1}^{\text {a }}$ Fase (4 horas) } & \multicolumn{2}{c}{$\mathbf{2}^{\mathbf{a}}$ Fase (20 horas) } \\
& $\begin{array}{c}\text { Volume } \\
\text { (litros) }\end{array}$ & $\begin{array}{c}\text { Pressão } \\
\text { (MPa) }\end{array}$ & $\begin{array}{c}\text { Volume } \\
\text { (litros) }\end{array}$ & $\begin{array}{c}\text { Pressão } \\
\text { (MPa) }\end{array}$ & $\begin{array}{c}\text { Volume } \\
\text { (litros) }\end{array}$ & $\begin{array}{c}\text { Pressão } \\
\text { (MPa) }\end{array}$ \\
\hline Bainha & 1,13 & 0,25 & - & - & - & - \\
$\begin{array}{c}\text { Bainha } \\
+1 \text { Fase }\end{array}$ & 1,13 & 0,25 & 0,28 & 0,30 & - & - \\
$\begin{array}{c}\text { Bainha } \\
\text { + Fases }\end{array}$ & 1,13 & 0,25 & 0,28 & 0,30 & 0,20 & $0,70-2,50^{*}$ \\
\hline
\end{tabular}


Análise de diferentes metodologias executivas de solo pregado a partir de ensaios de arrancamento em campo e laboratório

Tabela 3.8. Controle da injeção da calda de cimento para a linha 3.

\begin{tabular}{c|cc|cc|cc}
\hline \multirow{2}{*}{ Descrição } & \multicolumn{2}{|c|}{ Bainha } & \multicolumn{2}{c|}{$\mathbf{1}^{\text {a }}$ Fase (4 horas) } & \multicolumn{2}{c}{$\mathbf{2}^{\mathrm{a}}$ Fase (20 horas) } \\
& $\begin{array}{c}\text { Volume } \\
\text { (litros) }\end{array}$ & $\begin{array}{c}\text { Pressão } \\
\text { (MPa) }\end{array}$ & $\begin{array}{c}\text { Volume } \\
\text { (litros) }\end{array}$ & $\begin{array}{c}\text { Pressão } \\
\text { (MPa) }\end{array}$ & $\begin{array}{c}\text { Volume } \\
\text { (litros) }\end{array}$ & $\begin{array}{c}\text { Pressão } \\
\text { (MPa) }\end{array}$ \\
\hline $\begin{array}{c}\text { Bainha } \\
\text { Bainha } \\
\text { 1 Fase }\end{array}$ & 1,13 & 0,25 & - & - & - & - \\
$\begin{array}{c}\text { Bainha } \\
+2 \text { Fases }\end{array}$ & 1,13 & 0,25 & 0,28 & 0,35 & - & - \\
\hline
\end{tabular}

Nota: (*) Pressão final atingida e adotada como critério de parada para a injeção.

As Tabelas 3.6, 3.7 e 3.8 mostram que as pressões de injeção variaram de 0,25 a 2,5 $\mathrm{MPa}$. Estes valores encontram-se muito próximos da faixa de valores $(0,4$ a 2,0 $\mathrm{MPa})$ encontrada na literatura (Springer, 2006; Zirlis et al, 2003). Para a execução da Bainha e da Bainha +1 Fase, os valores de pressão e volume foram praticamente os mesmos para cada uma das metodologias, com exceção da pressão de injeção da linha 3, que foi um pouco superior. Os volumes injetados para a execução da segunda fase foram pequenos (Linhas 1 e 2) e até inexistentes (Linha 3), a partir do método utilizado para a sua quantificação. Nesta etapa, as pressões de injeção foram da ordem de 0,70 MPa e, após a injeção da calda de cimento, atingiram pressões da ordem de 2,50 MPa, adotada como critério de parada. Os baixos volumes e as elevadas pressões medidas nesta etapa remetem a uma melhor qualidade (integridade) do chumbador. Estas premissas são constatadas a partir dos resultados dos ensaios de arrancamento e da exumação dos chumbadores.

A Figura 3.23 apresenta um comparativo entre os volumes médios de injeção obtidos para os diferentes métodos construtivos. Estes valores se referem ao volume utilizado para o preenchimento da perfuração (bainha), considerado como 100\%. 


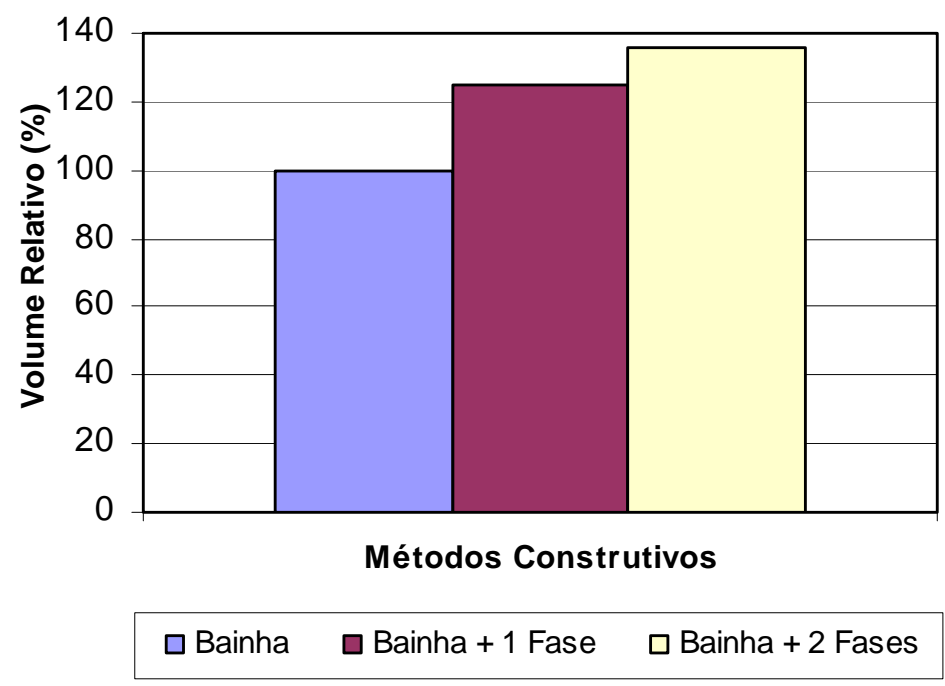

Figura 3.23. Comparativo entre os volumes médios injetados para os diferentes métodos construtivos.

A partir da Figura 3.23 verifica-se que o volume médio de calda de cimento utilizado para a realização da primeira injeção foi $25 \%$ superior ao volume utilizado para o preenchimento do furo (bainha). Para a construção do chumbador com duas fases de injeção, o volume médio de calda de cimento utilizado foi $34 \%$ superior ao volume da Bainha, sendo, portanto, a segunda fase responsável por um acréscimo de $9 \%$.

A Figura 3.24 apresenta uma vista geral da estrutura de solo pregado após o término das etapas construtivas.

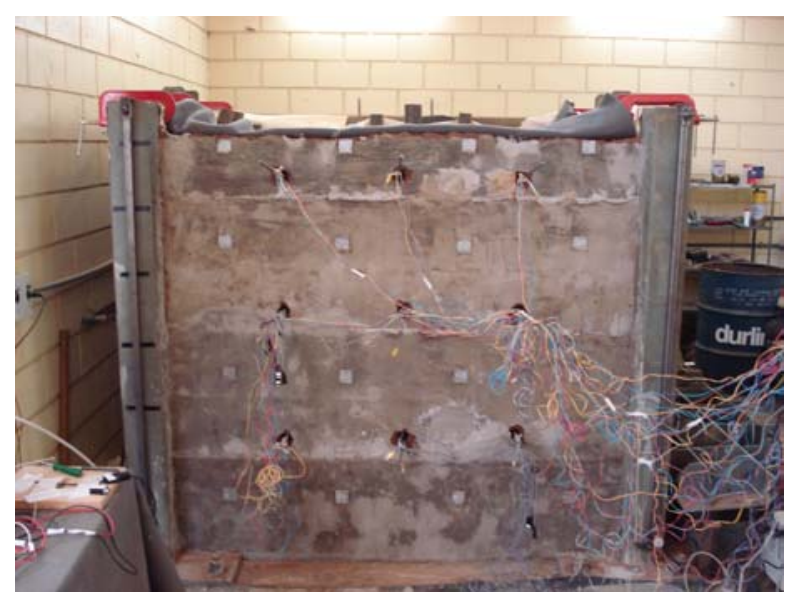

Figura 3.24. Vista geral do solo pregado após o término das etapas construtivas. 
Análise de diferentes metodologias executivas de solo pregado a partir de ensaios de arrancamento em campo e laboratório

Após o término da construção, foi aplicado sobre o solo pregado um acréscimo de tensão vertical de $50 \mathrm{kPa}$. Este processo foi realizado por meio de uma bolsa de ar, situada na parte superior da caixa de ensaio. O propósito da aplicação da sobrecarga foi simular uma altura adicional de aterro sobre a estrutura, antes de realizar os ensaios de arrancamento.

\subsubsection{Ensaios de Arrancamento}

Todos os reforços inseridos no maciço de solo foram submetidos ao ensaio de arrancamento. Buscou-se, além de determinar a resistência ao cisalhamento de interface solo-reforço, verificar a evolução dos carregamentos ao longo do seu comprimento a partir da instrumentação. Os ensaios foram realizados de maneira similar e com velocidade constante da ordem de $0,5 \mathrm{kN} / \mathrm{min}$.

Os esforços de tração foram aplicados por um conjunto bomba elétrica - cilindro hidráulico e as cargas foram medidas por uma célula de carga de $50 \mathrm{kN}$ de capacidade, devidamente conectada no cilindro hidráulico. Na outra extremidade da célula de carga, foi confeccionado um adaptador para permitir a junção com a barra de aço que seria tracionada. Nas extremidades das barras de aço, foram soldados dois elos de corrente de 5/8". O adaptador foi inserido entre estes elos, e a fixação foi realizada por meio de um conjunto porca/parafuso. Os deslocamentos do chumbador foram medidos por um transdutor de deslocamento (LVDT), fixo a um suporte externo, utilizando-se como referência uma placa metálica fixa à barra de aço. $\mathrm{O}$ conjunto foi montado sobre um pórtico de reação metálico rígido e fixo ao chão, devidamente dimensionado para esta finalidade.

Os ensaios foram conduzidos com um único e contínuo estágio de carregamento, até atingir o final do curso do LVDT (100 mm). As Figuras 3.25 (a) e (b) apresentam, respectivamente, uma vista geral e detalhada dos equipamentos e da estrutura de reação utilizados nos ensaios de arrancamento. 


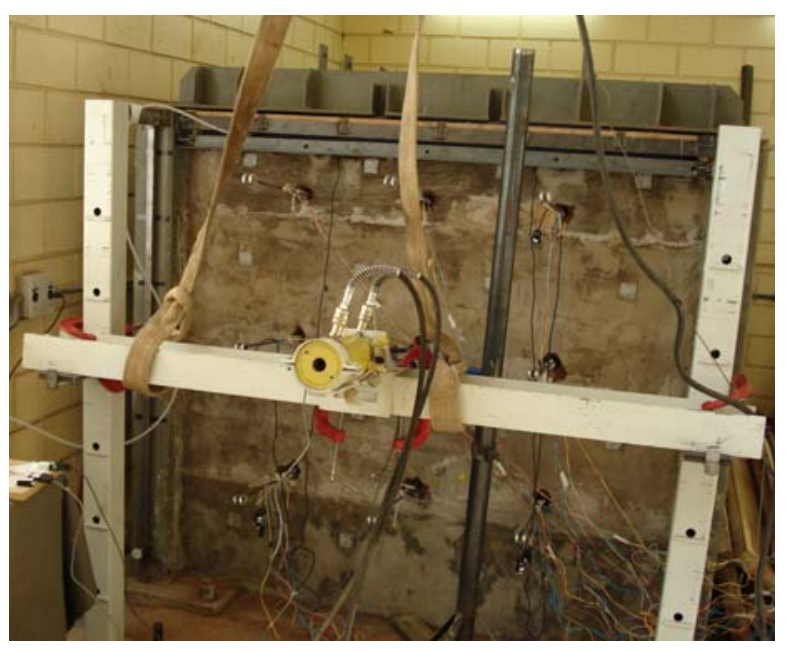

(a)

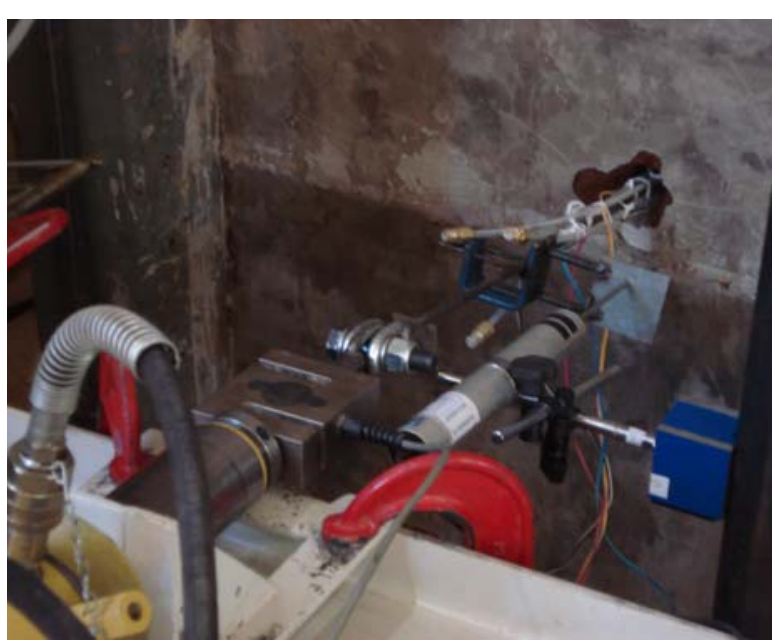

(b)

Figura 3.25. Equipamentos utilizados nos ensaios de arrancamento: (a) vista geral e (b) vista detalhada.

\subsubsection{Exumação dos Reforços}

Após os ensaios de arrancamento, realizou-se o processo de escavação e exumação dos reforços. Este processo foi realizado de forma lenta e cuidadosa, para garantir a integridade do trecho injetado e permitir análises do reforço em relação à metodologia empregada na sua execução. Após a exumação, os chumbadores foram transportados para serem examinados e fotografados. Este processo também foi realizado de forma cuidadosa, para evitar a flexão e o surgimento de fissurações ao longo do chumbador. Os detalhes das constatações obtidas a partir deste procedimento são apresentados no Capítulo 4 Resultados e Análises do Programa Experimental de Laboratório. 


\subsection{PROGRAMA EXPERIMENTALDE CAMPO}

O programa experimental de campo foi realizado em duas obras nas cercanias da cidade de São Paulo: Santo André-SP e Osasco-SP. Estas obras foram escolhidas com o objetivo de se avaliar a influência de diferentes solos e metodologias executivas na resistência ao cisalhamento da interface solo-reforço. O programa experimental foi desenvolvido com 52 ensaios de arrancamento, realizados em chumbadores "curtos" e "longos". Os chumbadores curtos foram construídos com 4,0 m de comprimento, sendo 3,0 $\mathrm{m}$ injetado e 1,0 m de trecho livre, enquanto os chumbadores longos foram construídos com 7,0 m de comprimento, sendo 6,0 m injetado e 1,0 m de trecho livre. Parte destes ensaios de arrancamento (34) foram realizados em chumbadores instrumentados com extensômetros elétricos.

Com o intuito de avaliar, em laboratório, a resistência de interface solo/calda de cimento, foram coletadas amostras deformadas e indeformadas para posterior realização de ensaios de cisalhamento direto de interface solo-calda de cimento. Na seqüência, são apresentadas, em detalhes, as metodologias utilizadas na preparação, na instrumentação, na execução e no arrancamento dos chumbadores.

\subsubsection{Preparação das Barras de Aço}

Para a construção dos chumbadores longos e curtos, foram utilizadas barras de aço CA-50 de $25 \mathrm{~mm}$ com 8,30 $\mathrm{m}$ e 5,30 $\mathrm{m}$ de comprimento, respectivamente. Para facilitar os trabalhos de instrumentação e de transporte para as obras, as barras de aço foram divididas em dois trechos. Para permitir a junção destas barras na obra, foram realizadas roscas centrais nas barras de aço e luvas de conexão. Para a construção dos chumbadores longos, foi realizada a junção de duas barras de aço de 4,20 m e 4,10 m de comprimento. Para os chumbadores curtos, a junção ocorreu entre barras de aço de 3,00 e 2,30 m de comprimento.

Para minimizar a redução na resistência à tração das barras de aço, as dimensões e o tipo da conexão foram devidamente estudados. Para tal, foram realizados ensaios de tração em amostras da barra de aço $(1,0 \mathrm{~m})$, unidas com diferentes tipos de roscas e luvas 
de conexão. A Figura 3.26 apresenta uma amostra da barra de aço unida por rosca e luva metálica, que foi submetida ao ensaio de tração.

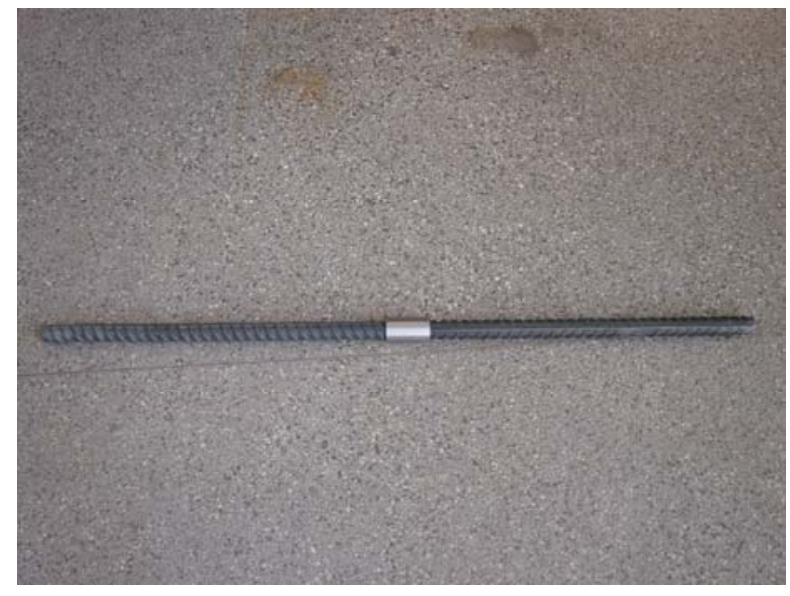

(a)

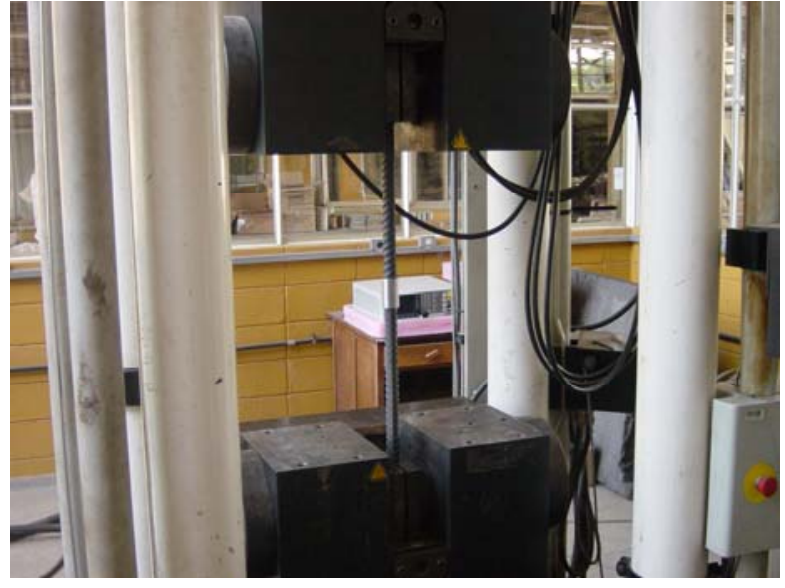

(b)

Figura 3.26. (a) Amostra da barra de aço unida por rosca e luva metálica e (b) detalhe da amostra submetida ao ensaio de tração.

Após a realização de ensaios de tração em amostras com diferentes configurações de roscas, dimensionou-se a rosca M 23 x 1,5 com extensão de 30,0 mm em cada uma das barras. As luvas metálicas de conexão das barras de aço foram confeccionadas com diâmetro externo de $36 \mathrm{~mm}$, extensão de $60,0 \mathrm{~mm}$ e a mesma rosca interna. A Figura 3.27 apresenta os detalhes das barras de aço durante o processo de usinagem para a realização das roscas e o detalhe da luva metálica utilizada para a conexão das barras de aço.

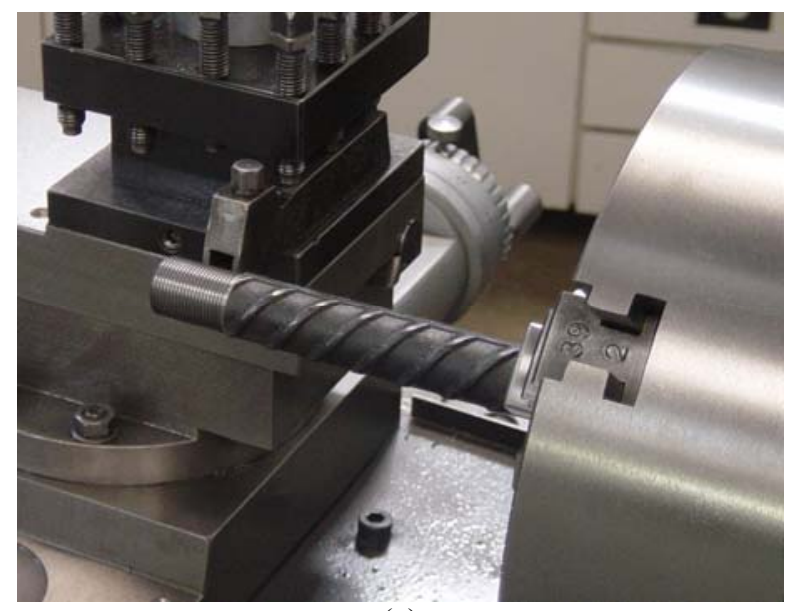

(a)

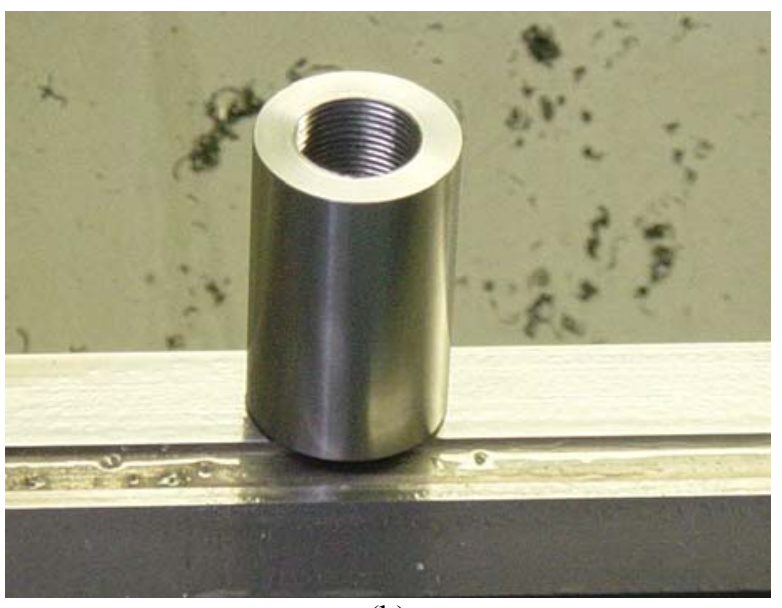

(b)

Figura 3.27. (a) Barras de aço durante a realização da rosca e (b) detalhe da luva metálica acabada. 
A Figura 3.28 apresenta as curvas carga $\mathrm{x}$ deslocamento obtidas nos ensaios de tração para as amostras de barra de aço com e sem emenda.

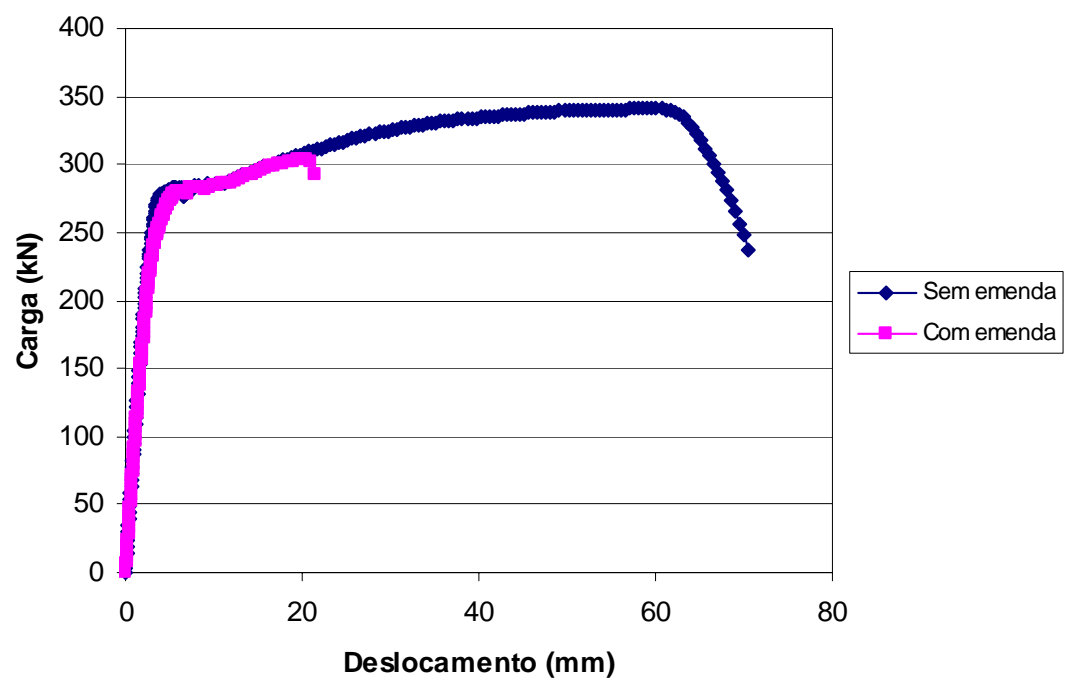

Figura 3.28. Curvas carga $x$ deslocamento para amostras de aço com e sem emenda.

A partir da Figura 3.28, verifica-se que o comportamento das barras de aço com e sem emenda é praticamente o mesmo na fase elástica. Entretanto, no trecho de escoamento, os comportamentos são distintos. A plastificação da barra de aço com emenda ocorre com menor deslocamento. Este fato deve-se à pequena diminuição da seção transversal da barra de aço a partir da usinagem das roscas. Todavia, a redução da carga de ruptura (aproximadamente 10\%) não irá interferir na realização dos ensaios de arrancamento em campo, já que a resistência da emenda $(300 \mathrm{kN})$ irá suportar os carregamentos impostos durante a realização dos ensaios de arrancamento.Vale a pena ressaltar que, no comprimento excedente das barras de aço $(1,30 \mathrm{~m})$, também foi confeccionada uma rosca ao longo de uma extensão de $0,40 \mathrm{~m}$. Esta rosca foi construída na extremidade da barra de aço, com o objetivo de garantir, por meio de porcas, a aplicação do carregamento do sistema de arrancamento. 


\subsubsection{Instrumentação das Barras de Aço}

As barras de aço dos chumbadores curtos e longos foram instrumentadas com 4 e 7 strain gages, respectivamente. Estes instrumentos foram dispostos em diferentes posições ao longo do comprimento injetado e alinhados na lateral das barras de aço, para reduzir a influência de possíveis momentos fletores. A Figura 3.29 apresenta a localização dos strain gages ao longo das barras de aço dos chumbadores curtos e longos.

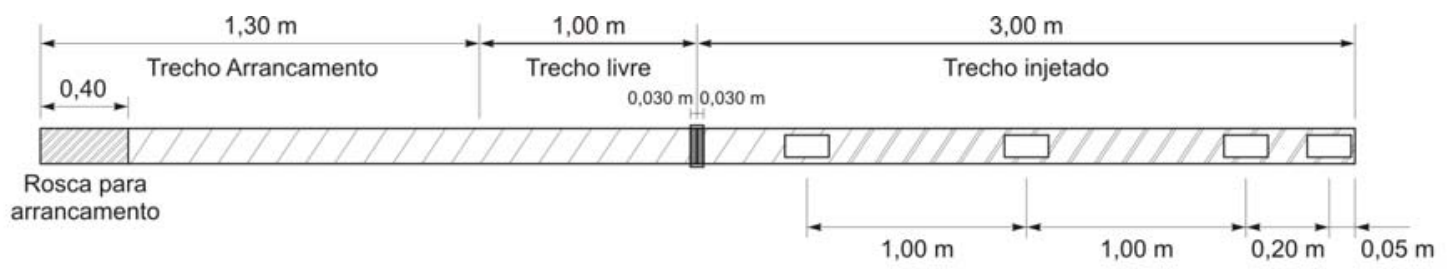

(a)

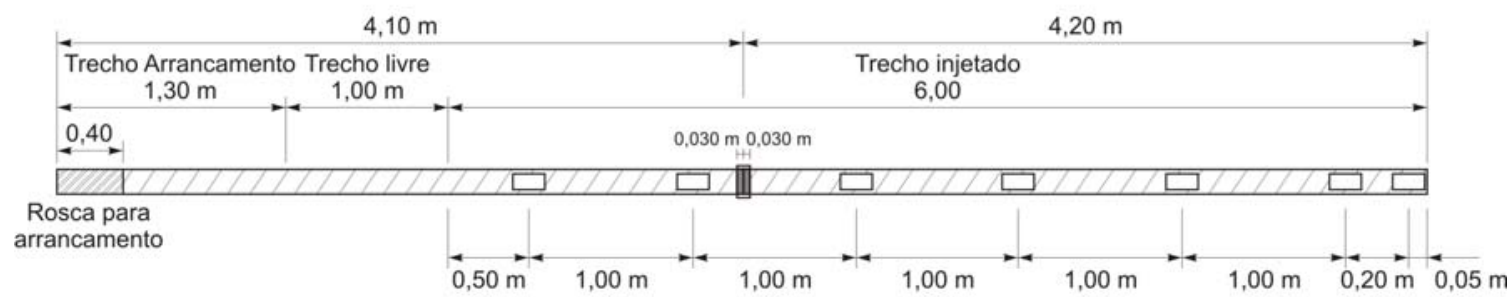

(b)

Figura 3.29. Distribuição dos strain gages ao longo das barras de aço dos chumbadores curtos (a) e longos (b).

O processo de instalação dos strain gages foi o mesmo da instrumentação das barras de aço do programa experimental de laboratório. Foram utilizados os strain gages PA-06-125 AA-120-LEN, fabricados pela Excel Sensores Ltda. A Figura 3.30 apresenta as etapas da instrumentação realizada. 


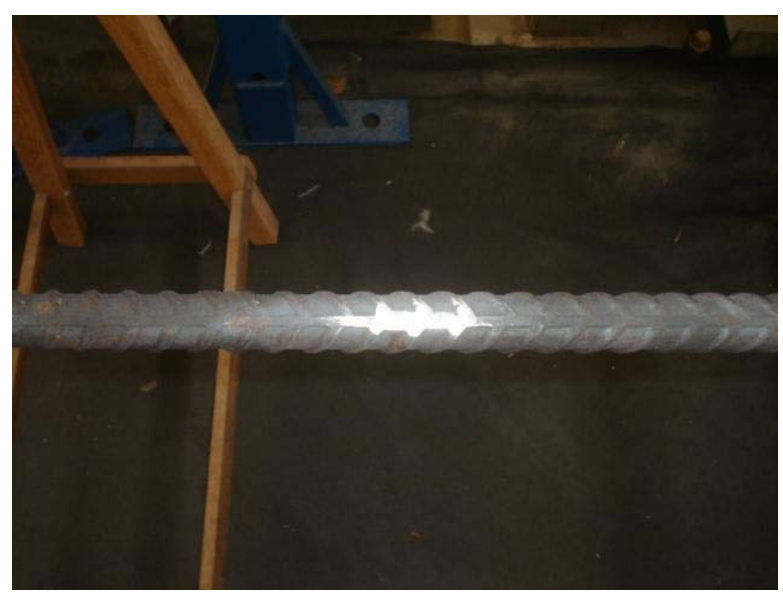

(a)

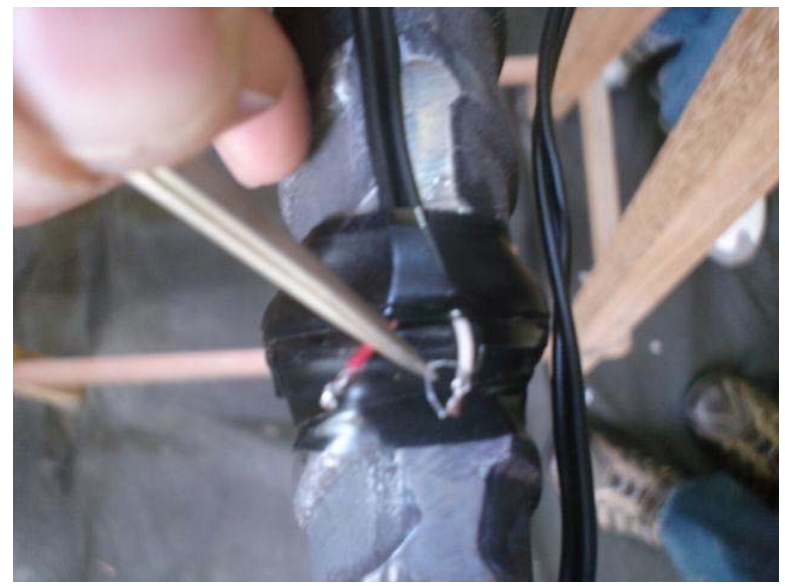

(c)

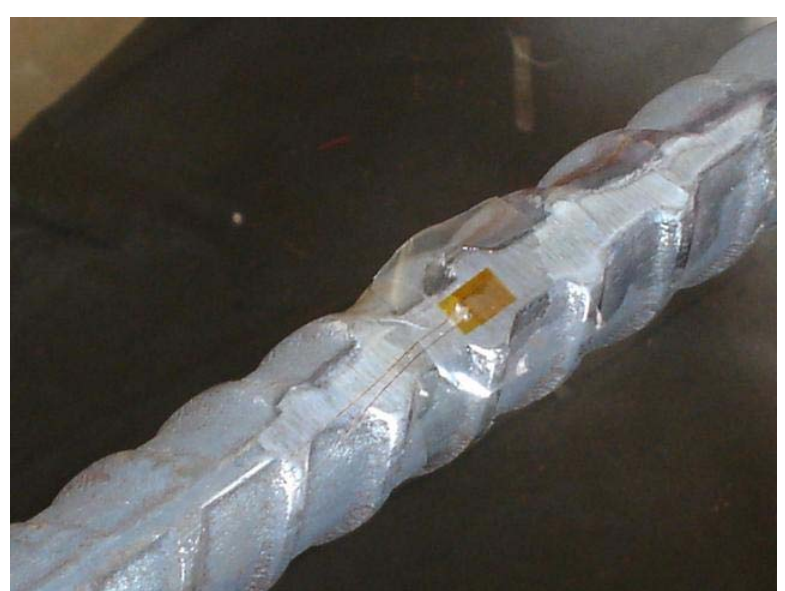

(b)

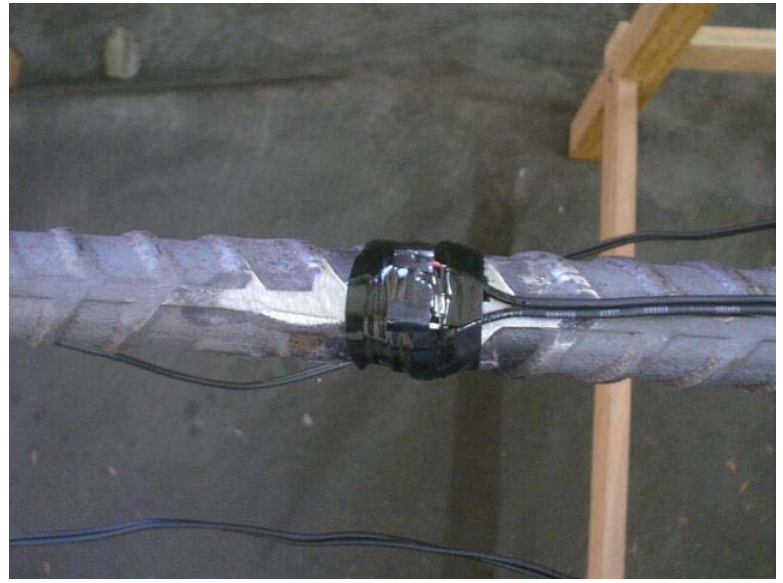

(d)

Figura 3.30. Etapas de instrumentação das barras de aço utilizadas no campo: (a) preparação da superfície, (b) colagem do strain gage, (c) cabeamento e soldagem e (d) proteção mecânica.

A interpretação das leituras dos strain gages, durante a realização dos ensaios, exigiu uma calibração apropriada dos mesmos. Para tanto, as barras de aço instrumentadas foram submetidas a esforços de tração crescentes, e, para cada estágio de carregamento, foi tomada, para cada strain gage, a respectiva leitura em $\mathrm{mv} / \mathrm{v}$, resultando nas curvas de calibração. Para a realização desta calibração, foi desenvolvido um equipamento específico. O equipamento é composto por dois pilares metálicos de $0,7 \mathrm{~m}$ de altura e seção transversal de $0,15 \mathrm{~m} \times 0,15 \mathrm{~m}$, que foram fixados na laje de reação de concreto existente no laboratório de Geossintéticos. Em um dos pilares, foi fixado um gancho para permitir a fixação da barra de aço, através de uma argola soldada em sua extremidade. Na outra 
extremidade da barra, foi adaptado um mecanismo para a aplicação da carga. Foi feita uma conexão da barra de aço (rosca) com uma célula de carga de $50 \mathrm{kN}$. A aplicação do carregamento foi realizada por um conjunto manivela/barra, apresentando um eixo que permitia a aplicação e a manutenção do carregamento sem promover o giro da barra de aço. A Figura 3.31 apresenta os detalhes do equipamento desenvolvido para aplicação de cargas na barra de aço.

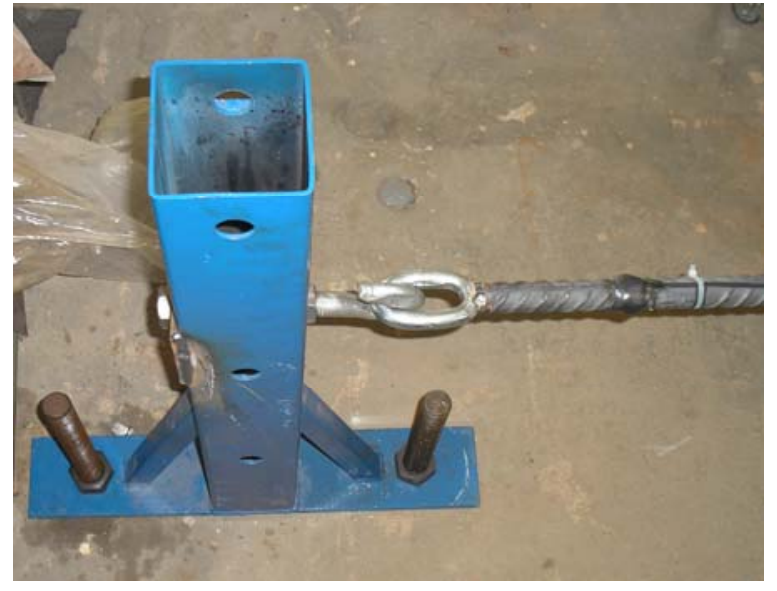

(a)

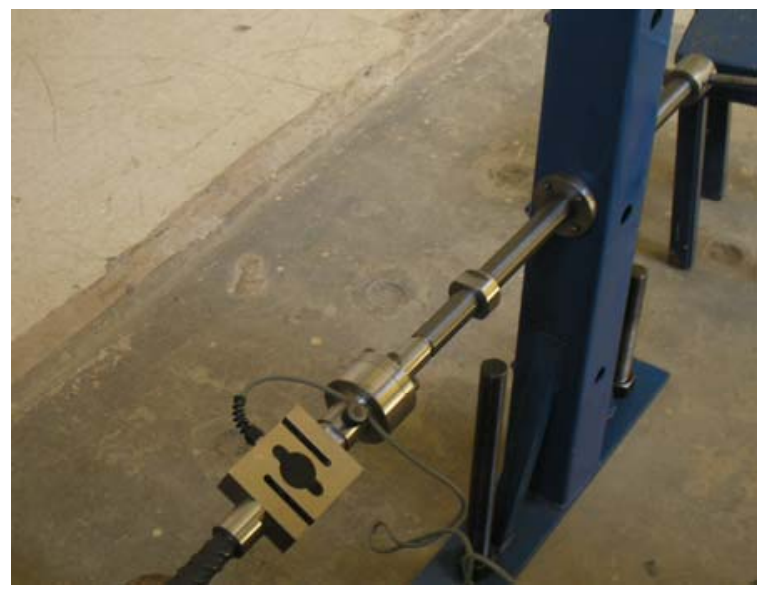

(b)

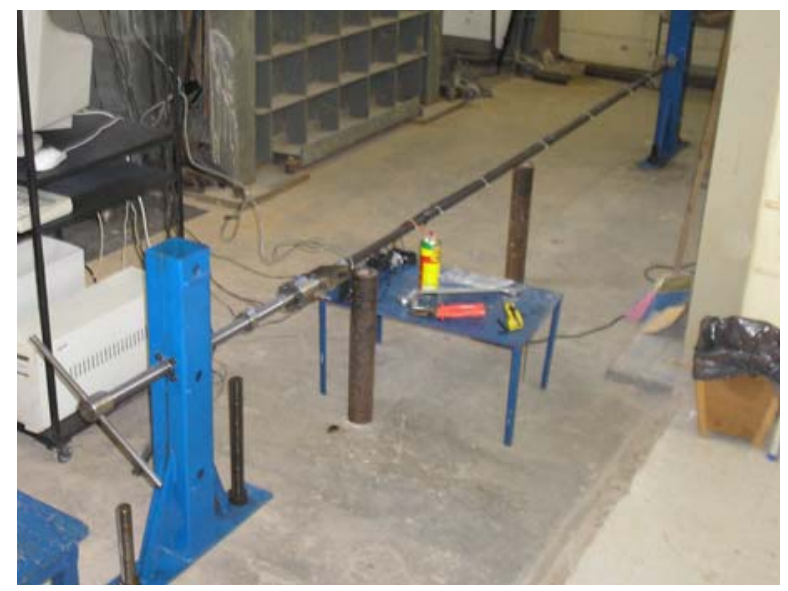

(c)

Figura 3.31. Equipamento desenvolvido para a realização da calibração das barras de aço: (a) detalhe das fixações, (b) detalhe do sistema de aplicação de cargas e (c) vista geral durante a calibração das barras.

A leitura dos strain gages foi realizada pelo sistema de aquisição de dados P3 (Vishay Instruments), o mesmo que fora utilizado nos ensaios de arrancamento de campo. 
Este equipamento possui quatro canais de aquisição de dados. Desta forma, para permitir a aquisição de todos os instrumentos utilizados na etapa dos ensaios, foram utilizados três equipamentos, totalizando 12 canais de leitura. A Figura 3.32 apresenta uma curva de calibração típica do strain gage.

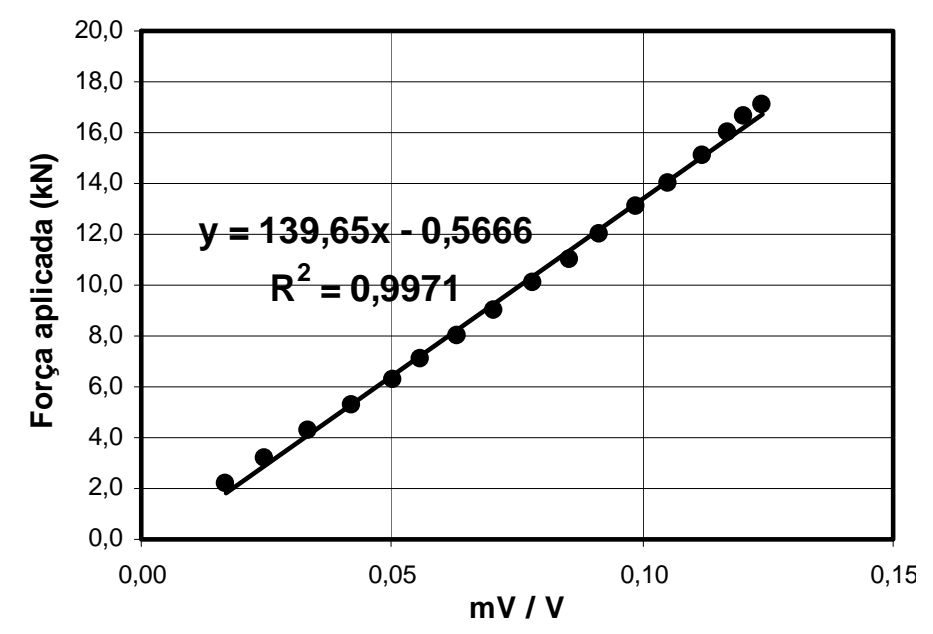

(a)

Figura 3.32. Curva típica de calibração do strain gage.

A Figura 3.33 apresenta uma vista geral das barras de aço instrumentadas, calibradas e prontas para serem utilizadas na construção dos chumbadores testes de campo.

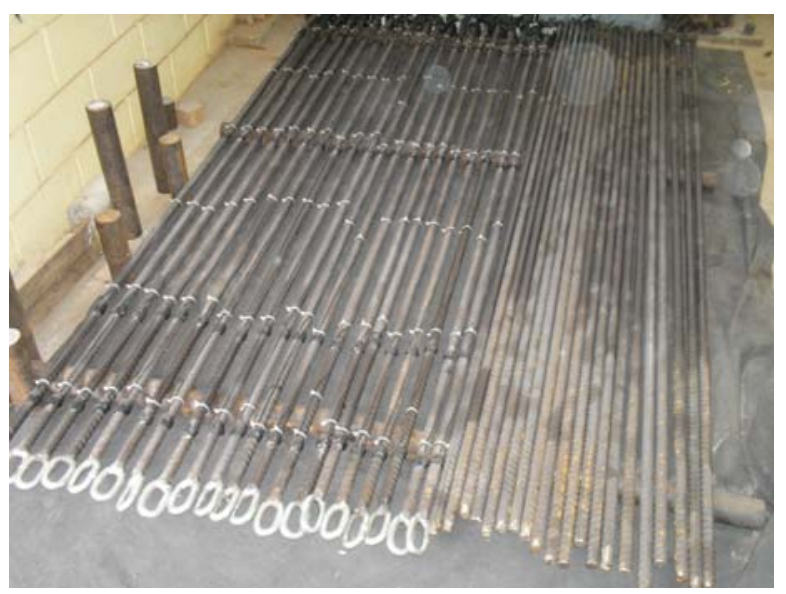

(a)

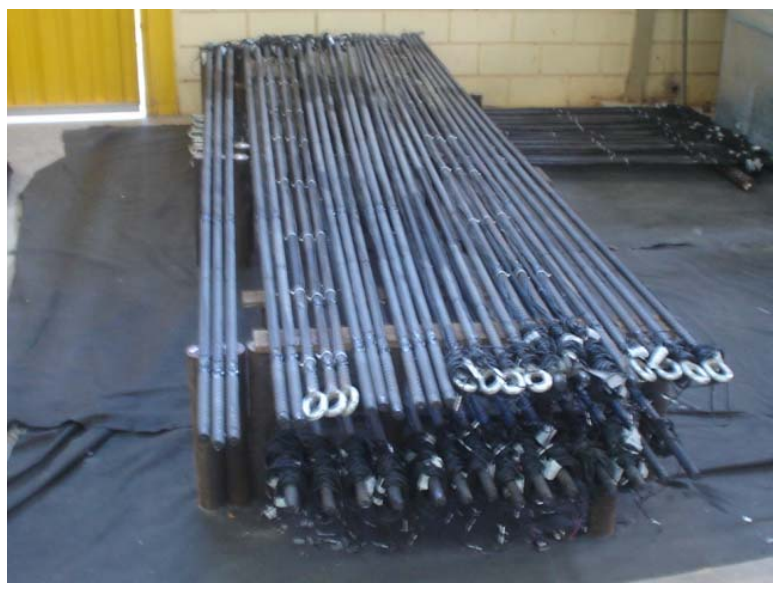

(b)

Figura 3.33. Barras de aço devidamente instrumentadas, calibradas e prontas para serem utilizadas na construção dos chumbadores: (a) detalhe dos chumbadores curtos e (b) longos. 
Análise de diferentes metodologias executivas de solo pregado a partir de ensaios de arrancamento em campo e laboratório

$\mathrm{Na}$ seqüência, serão apresentados os detalhes das metodologias executivas adotadas na construção dos chumbadores testes e a descrição das obras em que foi desenvolvido o programa experimental de campo: Santo André-SP (Obra 1) e Osasco-SP (Obra 2).

\subsubsection{Metodologias Exec utivas}

O programa experimental teve como objetivo avaliar o comportamento de chumbadores executados com diferentes metodologias executivas. Estas metodologias diferem em relação ao número e à localização das injeções. Para cada fase de injeção, foi fixado, junto à barra de aço, um tubo de injeção de polietileno de $10 \mathrm{~mm}$ de diâmetro. Os tubos de injeção foram fixados com extensão de 4,50 m e 7,50 m, para os chumbadores curtos e longos, respectivamente. Estes comprimentos foram dimensionados considerandose a extensão dos trechos injetado e livre, deixando um comprimento adicional de $0,50 \mathrm{~m}$ para permitir a conexão do dispositivo de injeção. As válvulas de injeção foram distribuídas de forma especifica para cada uma das metodologias. Vale a pena ressaltar que as diferentes metodologias foram empregadas em chumbadores curtos, longos, instrumentados e não instrumentados. A seguir, apresentam-se as metodologias adotadas.

Metodologia A: Esta metodologia consiste no preenchimento da cavidade escavada (furo) com calda de cimento de fator água-cimento igual a 0,6. Este procedimento (denominado Bainha) foi realizado sob o efeito da gravidade (sem pressão), a partir de um tubo removível e de forma ascendente (do fundo para a boca do furo). Todos os chumbadores testes foram executados preliminarmente com esta metodologia. As demais metodologias (B,C,D, E e F) apresentam o diferencial de terem sido injetadas, posteriormente, com calda de cimento sob pressão.

Com o objetivo de obter caldas de cimento com maior fluidez, as injeções foram realizadas com caldas contendo fator água-cimento igual a 0,7. Todas as caldas foram preparadas em um misturador de alta turbulência, utilizando o cimento Portland tipo CP III40RS. Os resultados de ensaios de compressão uniaxial apresentaram valor médio superior 
a $21 \mathrm{MPa}$, que se apresenta dentro do valor mínimo estabelecido pelo manual internacional da FHWA (Lazarte et al.,2003).

Na obra de Santo André-SP (Obra 1), alguns chumbadores executados com a metodologia A foram construídos com traços alternativos de calda de cimento. Um dos chumbadores curtos foi executado com calda contendo fator água-cimento igual a 0,45. Em dois chumbadores, sendo um curto e outro longo, utilizou-se uma calda de solo-cimento, e a escolha deste traço baseou-se em ensaios realizados em laboratório. A metodologia em que se utilizou o traço de solo-cimento foi denominada $A^{*}$.

Metodologia B: Chumbador construído com a metodologia A (Bainha) e mais uma fase posterior de injeção. O processo de injeção foi realizado por um tubo perdido, e as válvulas de injeção foram distribuídas igualmente, espaçadas a cada $0,5 \mathrm{~m}$. A Figura 3.34 apresenta a distribuição das válvulas ao longo dos tubos de injeção dos chumbadores curtos (a) e longos (b).

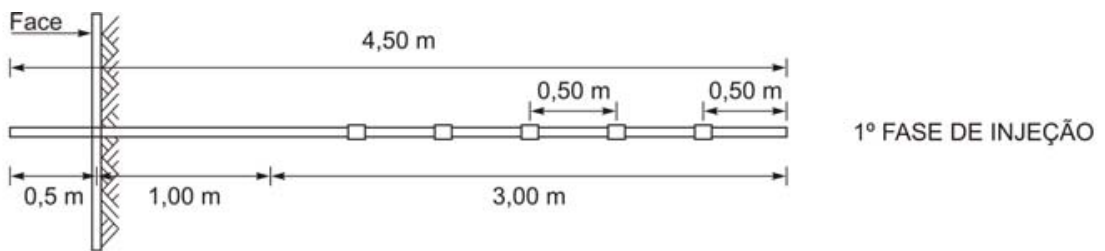

(a)

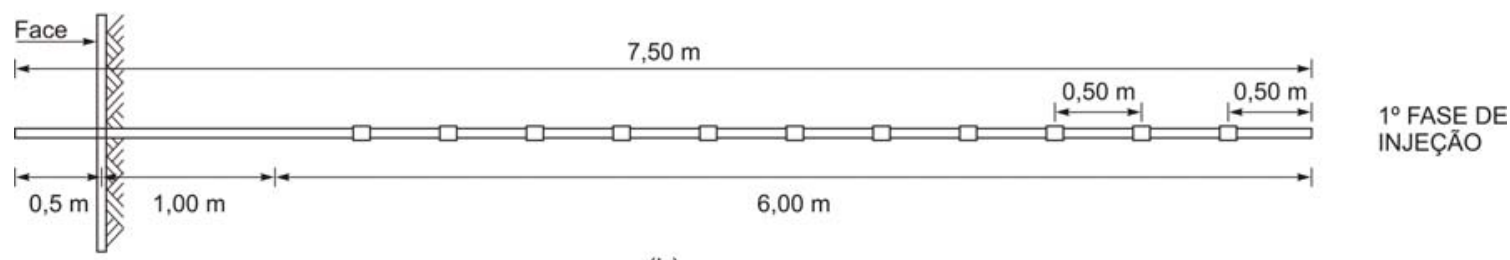

(b)

Figura 3.34. Localização das válvulas nos tubos de injeção dos chumbadores curtos (a) e longos (b) executados com a metodologia $B$.

Metodologia C: Chumbador construído com a metodologia A (Bainha) e mais duas fases posteriores de injeção. As injeções foram realizadas por dois tubos perdidos, e as válvulas de injeção foram distribuídas igualmente, espaçadas a cada $0,5 \mathrm{~m}$. A 
Figura 3.35 apresenta a distribuição das válvulas ao longo dos tubos de injeção dos chumbadores curtos (a) e longos (b).

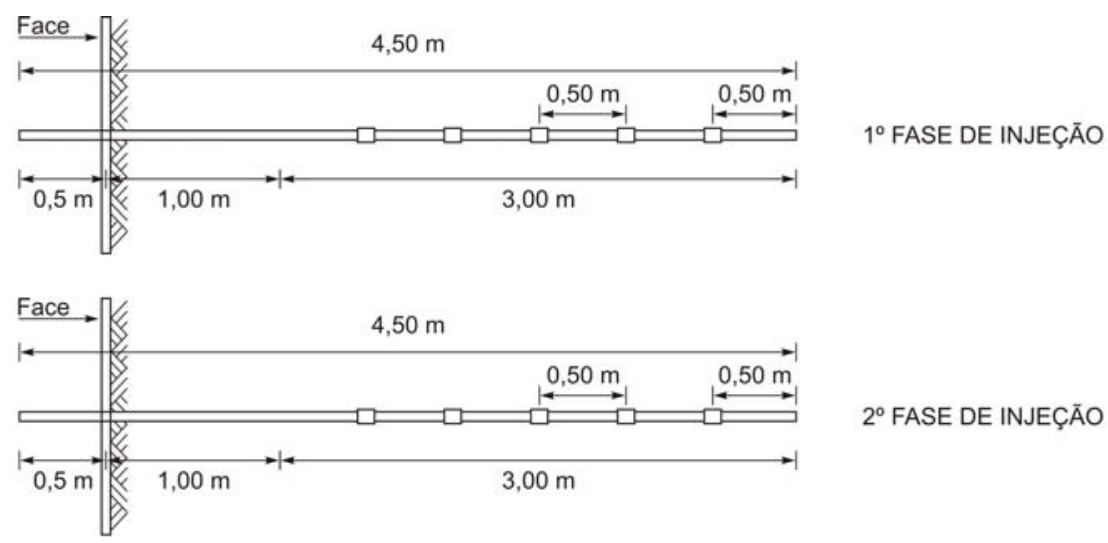

(a)

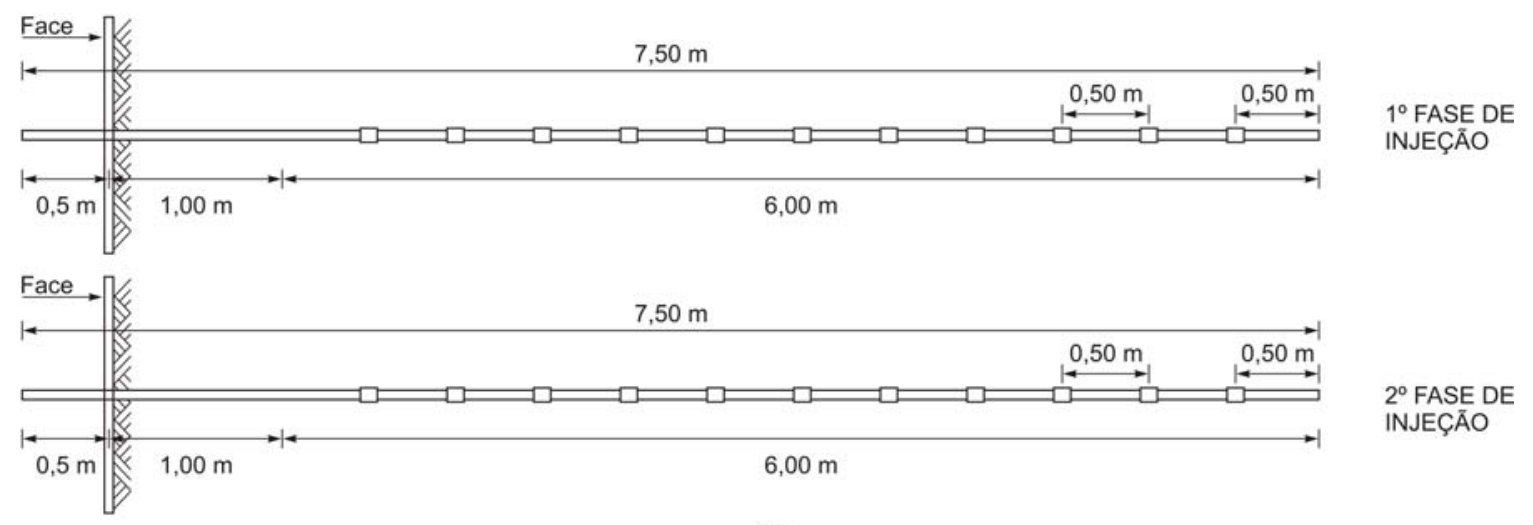

(b)

Figura 3.35. Localização das válvulas nos tubos de injeção dos chumbadores curtos (a) e longos (b) executados com a metodologia $\mathrm{C}$.

Metodologia D: Chumbador construído com a metodologia A (Bainha) e mais três fases posteriores de injeção. As injeções foram realizadas por três tubos perdidos, e as válvulas de injeção foram distribuídas igualmente, espaçadas a cada $0,5 \mathrm{~m}$. A Figura 3.36 apresenta a distribuição das válvulas ao longo dos tubos de injeção dos chumbadores curtos (a) e longos (b). 

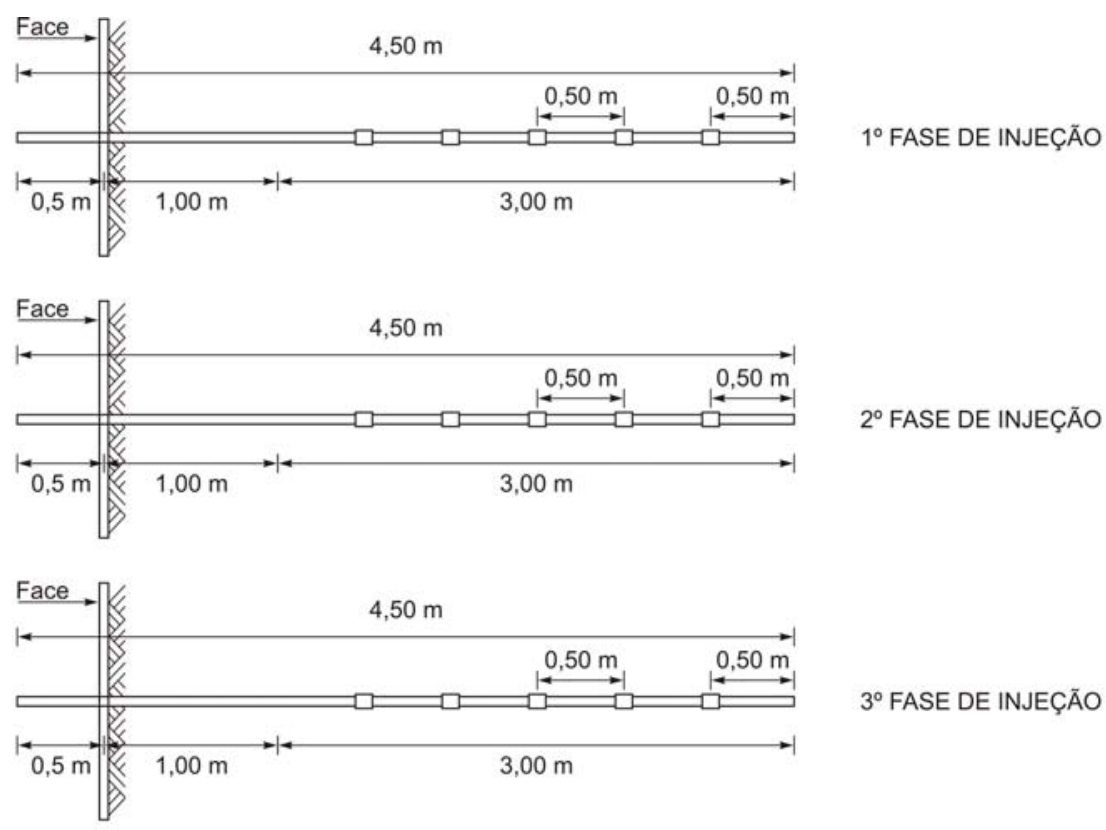

(a)
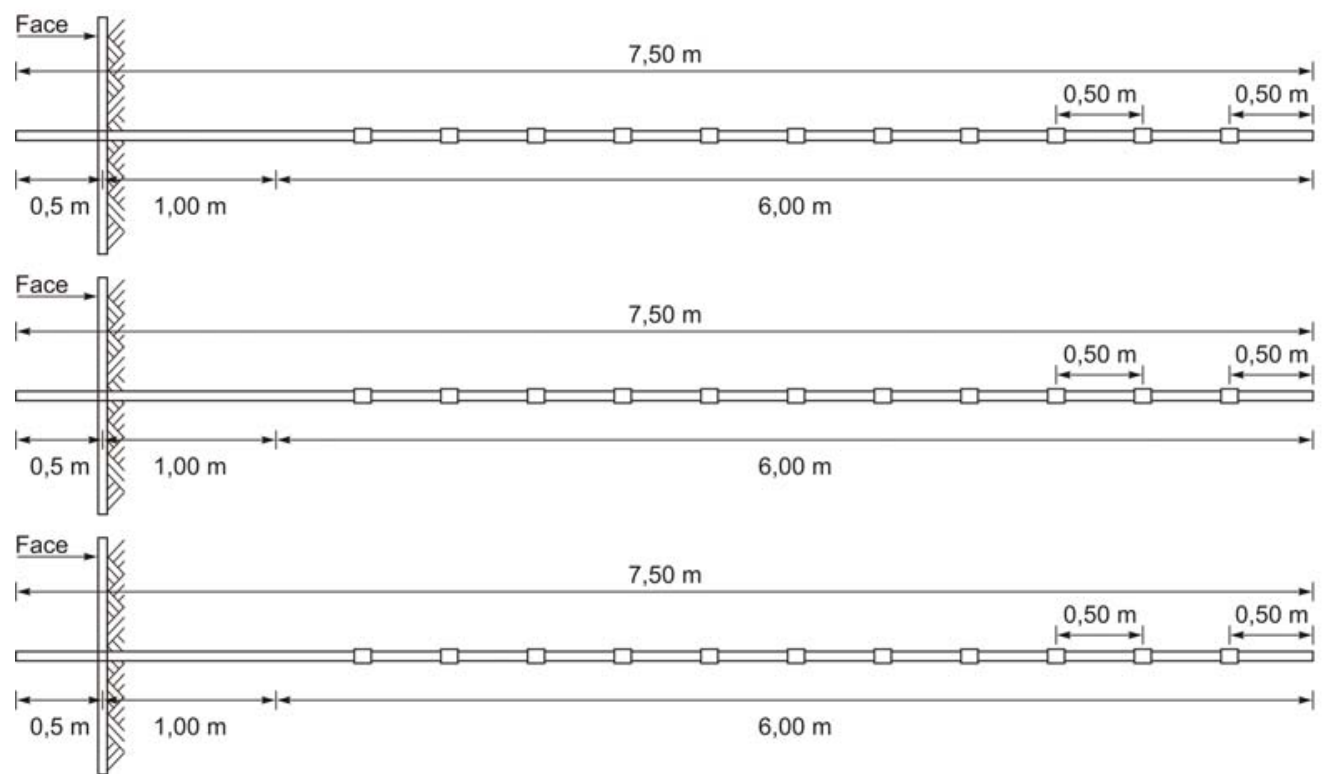

(b)

Figura 3.36. Localização das válvulas nos tubos de injeção dos chumbadores curtos (a) e longos (b) executados com a metodologia $D$.

Metodologia E: Chumbador construído com a bainha (metodologia A) e mais duas fases posteriores de injeção. As injeções foram realizadas por dois tubos perdidos e as válvulas de injeção foram distribuídas de forma localizada. A primeira injeção foi realizada no trecho final do chumbador, com válvulas espaçadas a cada $0,2 \mathrm{~m}$, e a 
segunda injeção foi realizada no restante do trecho injetado, a partir de válvulas distribuídas igualmente, espaçadas a cada 0,5 m.. A Figura 3.37 apresenta a distribuição das válvulas ao longo dos tubos de injeção dos chumbadores curtos (a) e longos (b).

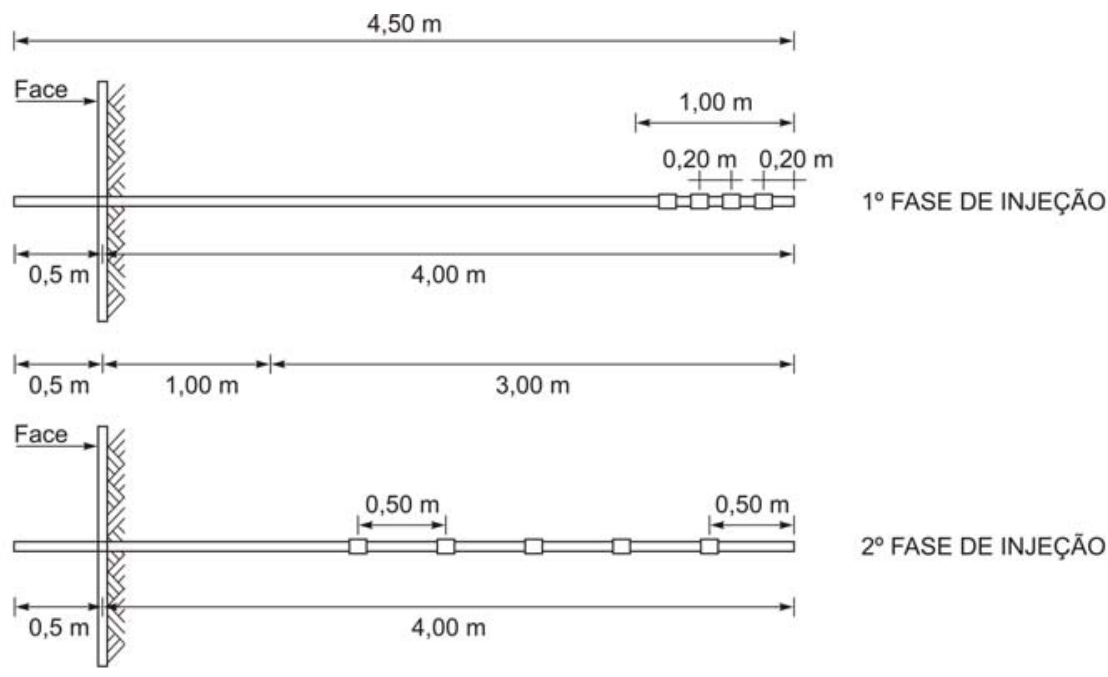

(a)
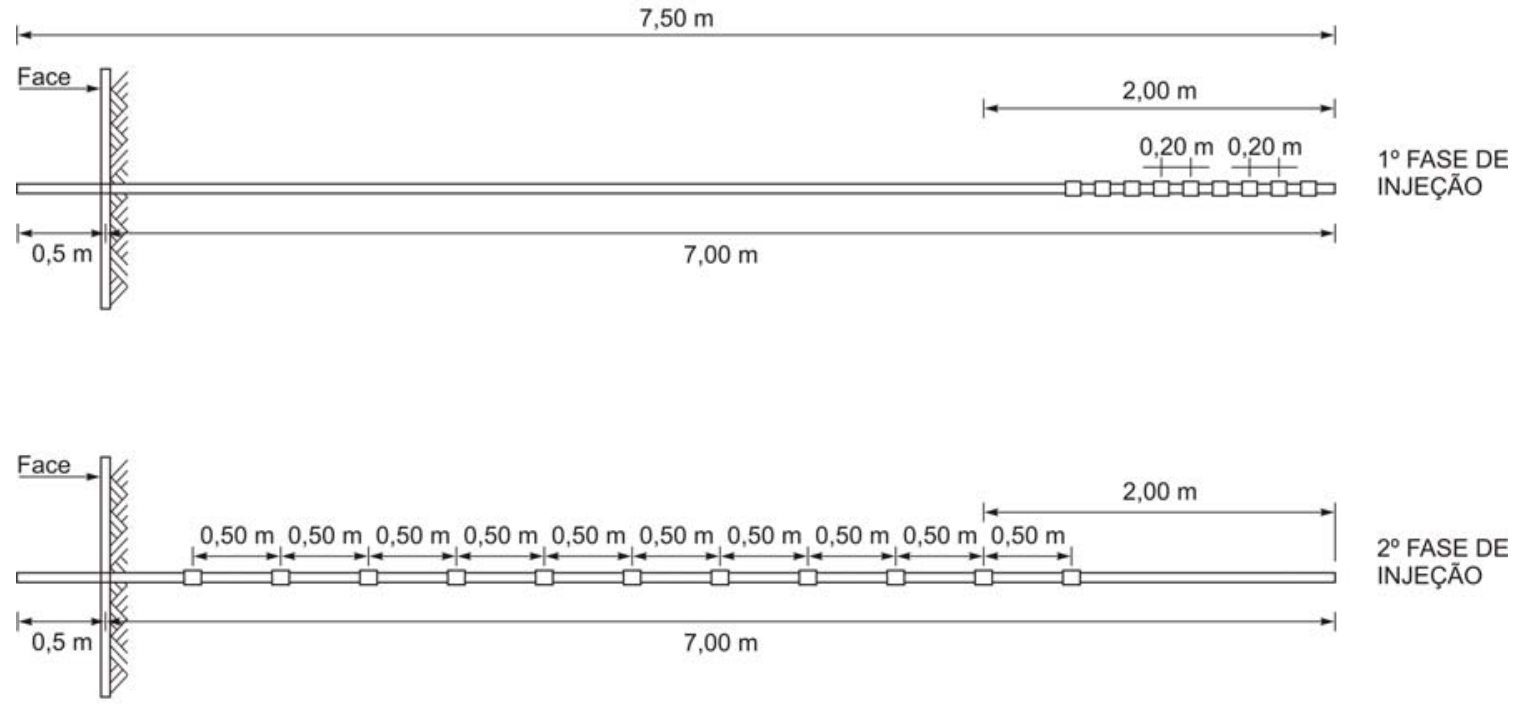

$2^{\circ}$ FASE DE INJEÇÃO

(b)

Figura 3.37. Localização das válvulas nos tubos de injeção dos chumbadores curtos (a) e longos (b) executados com a metodologia $\mathbf{E}$. 
Metodologia F: Chumbador construído com a bainha (metodologia A) e mais três e quatro fases posteriores de injeção, para chumbadores curtos e longos, respectivamente. Para todas as etapas de injeção, as válvulas foram distribuídas de forma localizada, em etapas sucessivas e ascendentes, ou seja, do fundo da perfuração para a face. As válvulas de injeção foram espaçadas a cada $0,5 \mathrm{~m}$, com exceção da última fase dos chumbadores curtos e longos, em que estas válvulas foram espaçadas a cada $0,25 \mathrm{~m}$. A Figura 3.38 apresenta a distribuição das válvulas ao longo dos tubos de injeção dos chumbadores curtos (a) e longos (b).

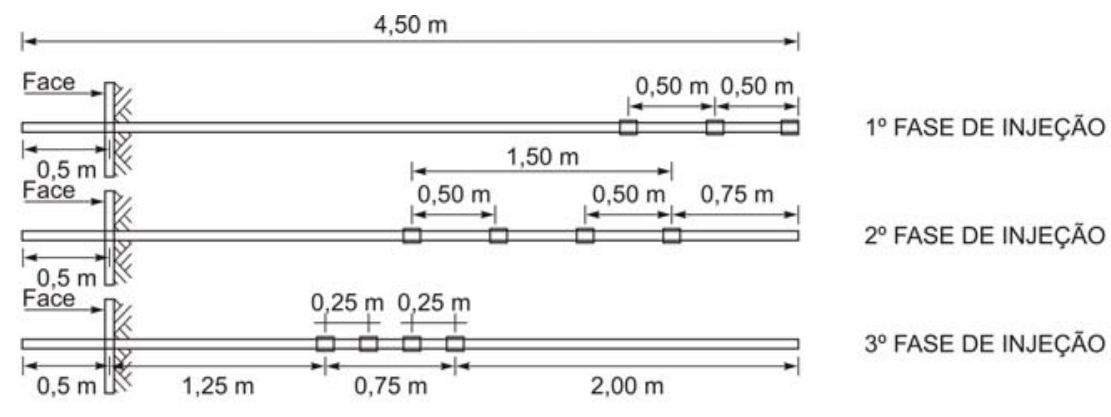

(a)

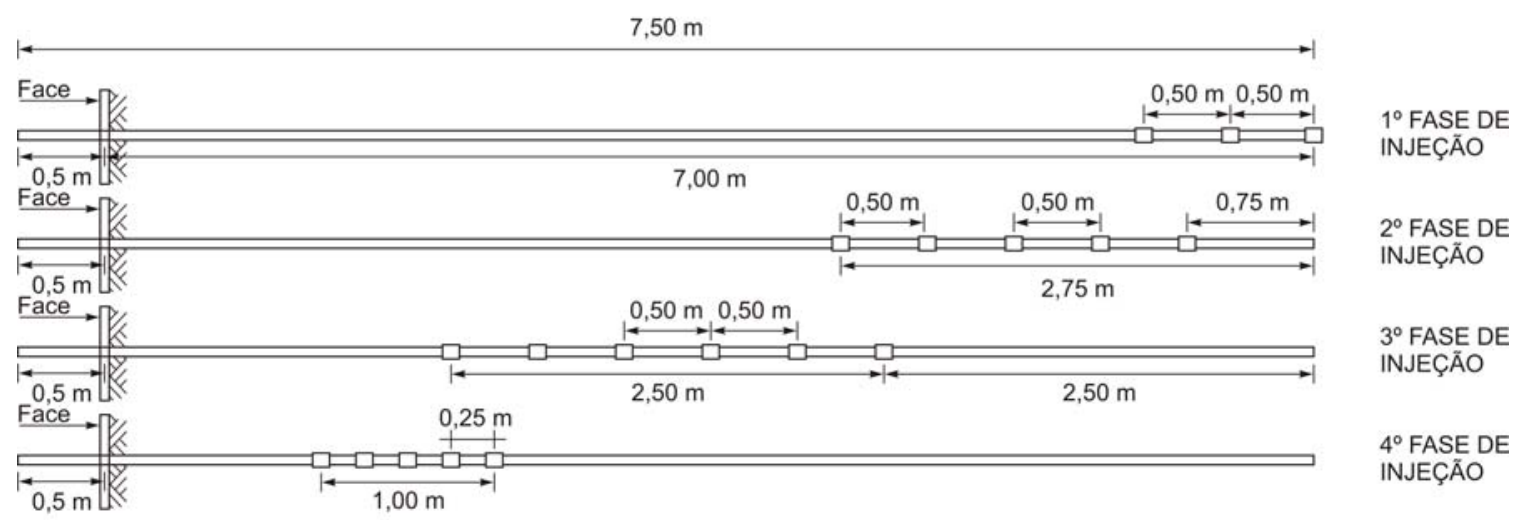

(b)

Figura 3.38. Localização das válvulas nos tubos de injeção dos chumbadores curtos (a) e longos (b) executados com a metodologia $F$.

\subsubsection{Traço Altemativo - Calda de Solo-Cimento}

O estudo de um traço alternativo objetiva avaliar a substituição da calda de cimento por calda de solo-cimento, na tentativa de reduzir o custo desta técnica. O estudo 
para a escolha do traço de solo-cimento foi realizado por Lima (2009), baseando-se em ensaios de fluidez e de compressão simples. Os traços que apresentaram melhor desempenho nestes testes foram submetidos a ensaios de resistência ao cisalhamento de interface, a fim de avaliar a aplicabilidade do solo-cimento em solos pregados. O solo utilizado para a realização do estudo das caldas de solo-cimento foi coletado na mesma cota da linha 2 de chumbadores da obra de Santo André-SP (Obra 1), devidamente preparado em laboratório. As propriedades geotécnicas deste solo encontram-se apresentadas na Tabela 3.10 .

A fim de definir a relação solo/cimento utilizada no traço alternativo, foram realizadas diferentes proporções, variando de 30 a $80 \%$ a massa de solo em relação à massa da mistura solo-cimento. No passo seguinte, foi analisada a relação água/cimento de modo a obter a fluidez desejada. O método utilizado para avaliar esta fluidez foi o ensaio de miniabatimento, o mesmo empregado no estudo de traço de calda de cimento dos chumbadores construídos em laboratório. Para obter a fluidez desejada e permitir o procedimento de injeção, a calda de solo-cimento deve ter um diâmetro de espalhamento de $100 \pm 10 \mathrm{~mm}$. Este valor foi tomado como referência a partir do diâmetro de espalhamento obtido para uma calda de cimento convencional, ou seja, com relação $\mathrm{A} / \mathrm{C}$ igual a 0,6. Os traços determinados e os diâmetros médios obtidos neste ensaio estão expressos na Tabela 3.9 .

Tabela 3.9. Traços utilizados e resultados dos ensaios de miniabatimento (Lima, 2009).

\begin{tabular}{ccccc}
\hline Traço & \% Solo & \% Cimento & Relação A/C & Diâmetro (mm) \\
\hline 1 & 30 & 70 & 0,6 & 101,43 \\
2 & 40 & 60 & 0,7 & 106,95 \\
3 & 50 & 50 & 0,8 & 99,30 \\
4 & 60 & 40 & 1,0 & 102,15 \\
5 & 70 & 30 & 1,4 & 99,70 \\
6 & 80 & 20 & 2,3 & 102,95 \\
\hline
\end{tabular}

Com a determinação dos traços da calda de solo-cimento, atendendo aos critérios de fluidez, foram definidos seis traços de calda solo-cimento e moldados 18 corpos de prova, sendo 3 para cada traço. Os corpos de prova foram moldados com dimensões de 10 
$\mathrm{cm}$ de altura e $5 \mathrm{~cm}$ de diâmetro (Figura 3.39). Após a sua moldagem, foram submetidos à cura em câmara úmida e, posteriormente, preparados para serem submetidos aos ensaios de compressão uniaxial.

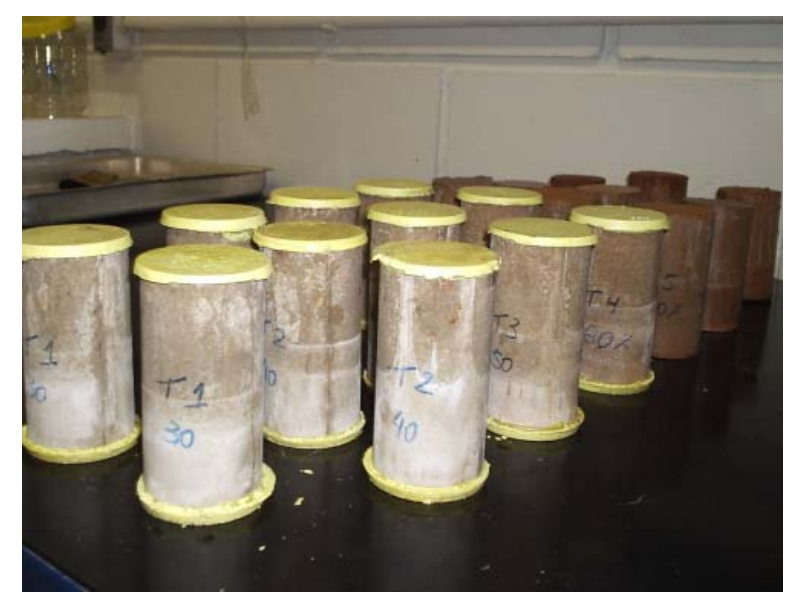

(a)

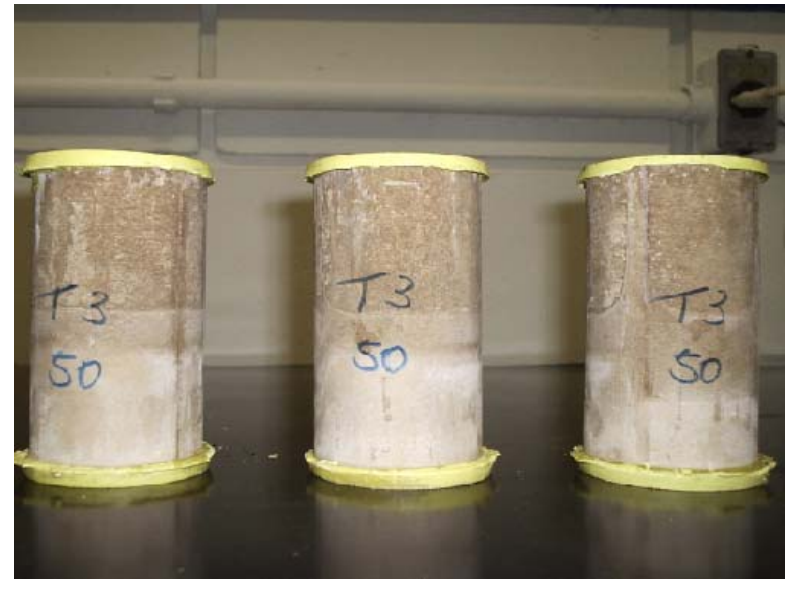

(b)

Figura 3.39. Corpos de prova utilizados no ensaio de compressão uniaxial (Lima, 2009).

Os ensaios de compressão uniaxial foram realizados para 7, 14 e 28 dias. Os corpos de prova cilíndricos foram ensaiados em prensa universal existente no Laboratório de Geossintéticos, a uma velocidade de $12,7 \mathrm{~mm} / \mathrm{min}$. A Figura 3.40 apresenta, para os diferentes traços estudados, a variação da resistência à compressão uniaxial ao longo dos três tempos de cura.

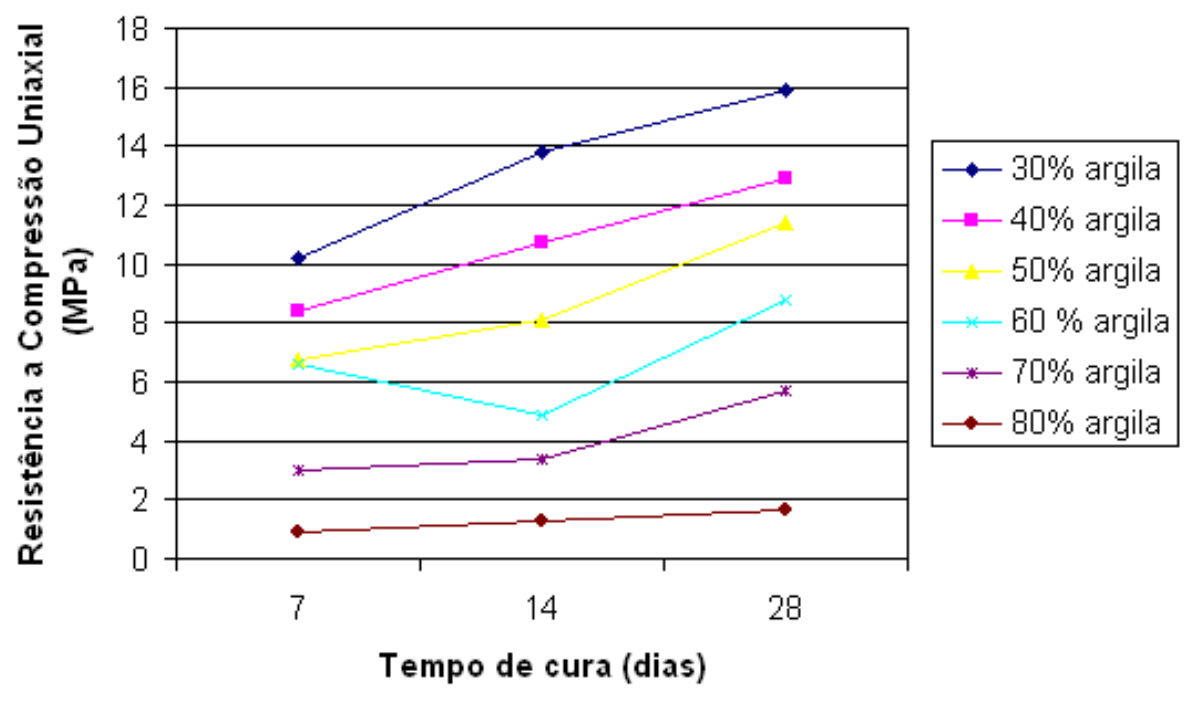

Figura 3.40. Variação da resistência à compressão uniaxial com o tempo de cura (Lima,2009). 
Os resultados da Figura 3.40 mostram que, de forma geral, houve um ganho de resistência com o tempo de cura, e, conforme esperado, ocorreu um decréscimo de resistência com o aumento de percentual de solo.

A partir dos resultados dos ensaios realizados para a definição do traço de calda de solo-cimento, a metodologia $A^{*}$ foi definida com a seguinte porcentagem em massa: $40 \%$ de solo seco ao ar e $60 \%$ de cimento. Para esta mistura, foi adotada a relação água-cimento de 0,7 .

\subsubsection{Obra 1- Santo André-SP}

Trata-se de uma obra em que a técnica de solo pregado foi utilizada para conter escavações verticais realizadas para a implantação de subsolos em um empreendimento localizado em Santo André-SP. As escavações foram realizadas ao longo do perímetro do terreno. Foram construídas duas contenções ao longo de $50,0 \mathrm{~m}$ de extensão e duas contenções ao longo de 20,0 m de extensão, abrangendo uma área de face de $963 \mathrm{~m}^{2}$.

A Figura 3.41 apresenta a localização, em planta, das contenções de solo pregado. O programa experimental foi desenvolvido em um trecho da Vista 1 (indicado no desenho), em que as condições de contorno, ou seja, geologia e estado de tensões, se aproximavam. $\mathrm{O}$ trecho de estudo apresenta extensão aproximada de $20,0 \mathrm{~m}$ e altura de $6,15 \mathrm{~m}$.

\section{Planta}

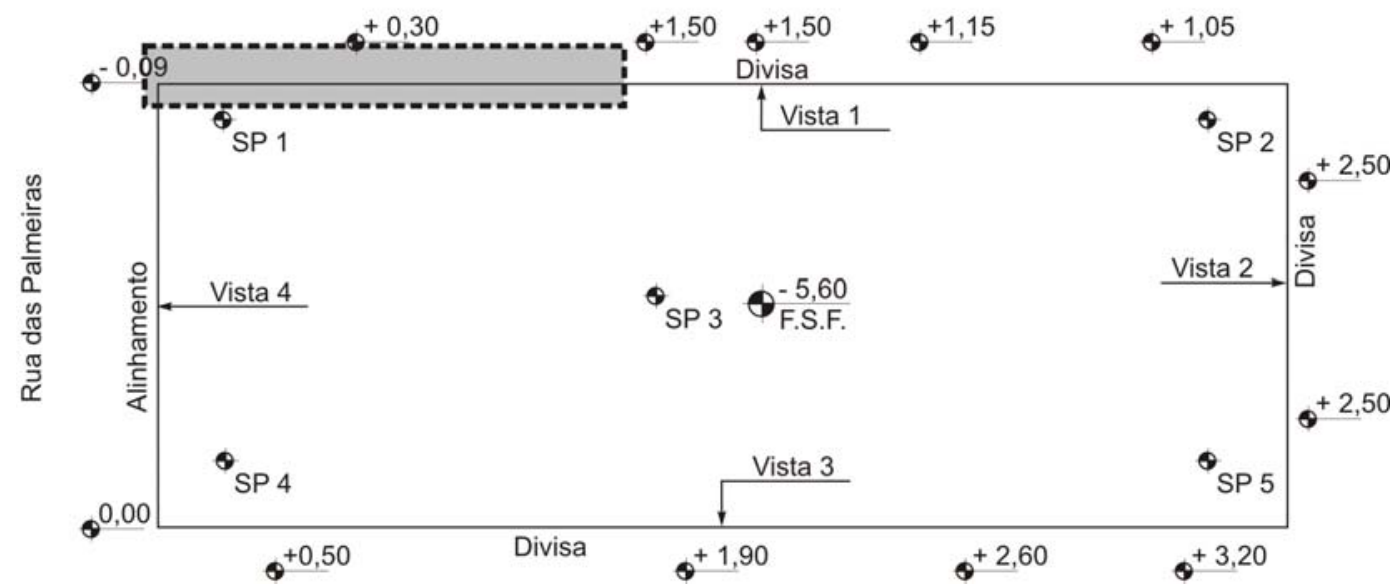

Figura 3.41. Vista em planta das contenções com destaque para a área de estudo. 


\subsubsection{Investigações Geotéc nicas}

$\mathrm{Na}$ região de estudo, a sondagem de simples reconhecimento mais representativa (SP-01) permitiu identificar três camadas com características geotécnicas distintas. Entre 0 e 0,70 m, identificou-se um aterro de areia fina à média, argilosa. A partir desta profundidade, observou-se um perfil de alteração de solo residual. Até a profundidade média de 4,0 m, identificou-se uma argila silto-arenosa vermelha/marrom (solo residual jovem) com $\mathrm{N}_{\mathrm{SPT}}$ médio igual a 3. Abaixo desta camada, observou-se um solo saprolitico até a profundidade investigada, de aproximadamente $8,0 \mathrm{~m}$. A Figura 3.42 mostra um corte que ilustra a distribuição das camadas de solo, os respectivos valores de $\mathrm{N}_{\mathrm{SPT}}$ e as profundidades em que foram construídos os chumbadores testes, ou seja, na camada de solo residual jovem, na profundidade de 1,80 m (Linha 2) e na camada de solo saprolitico, na profundidade de 5,30 m (Linha 5). Nesta última profundidade, obteve-se o valor de $\mathrm{N}_{\mathrm{SPT}}$ igual a 5, que foi crescente com a profundidade.

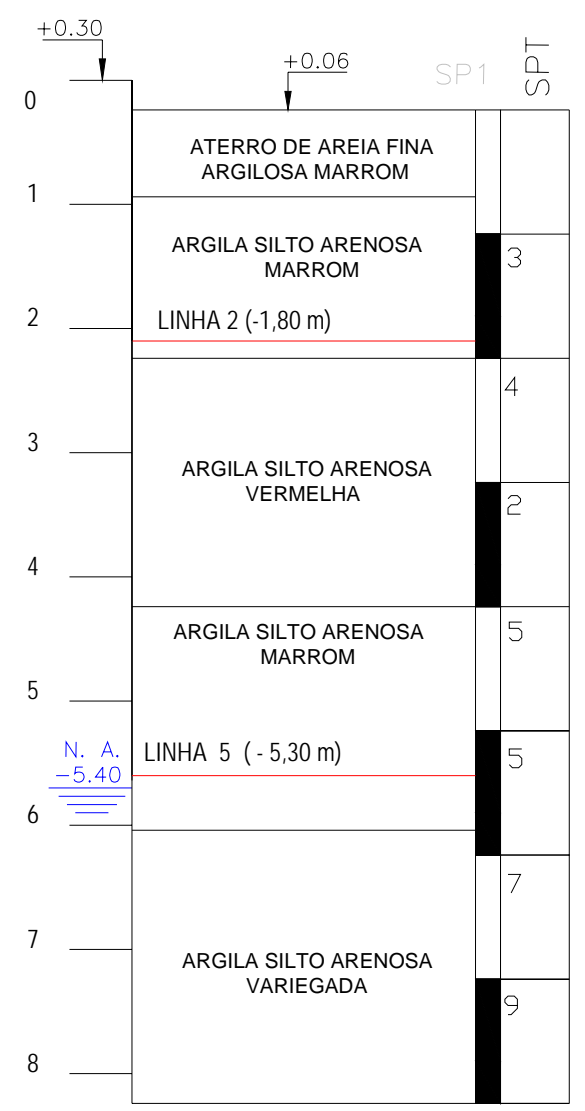

Figura 3.42. Distribuição das camadas de solo na obra de Santo André-SP. 
Para permitir a realização de ensaios de laboratório, foram coletadas, nas duas profundidades de interesse, amostras deformadas e indeformadas de solos. As amostras indeformadas foram retiradas a partir de escavação manual, utilizando-se uma caixa metálica cúbica de $0,25 \mathrm{~m}$ como fôrma. Para garantir a proteção mecânica durante o transporte e evitar perdas de umidade, as amostras foram envolvidas com faixas e parafina, e armazenadas em caixa de madeira envolvida com pó de serra, até serem armazenadas em câmera úmida do Laboratório de Geotecnia da EESC/USP. A Figura 3.43 ilustra o procedimento utilizado para a retirada da amostra indeformada (a) e o armazenamento das amostras em caixa de madeira (b).

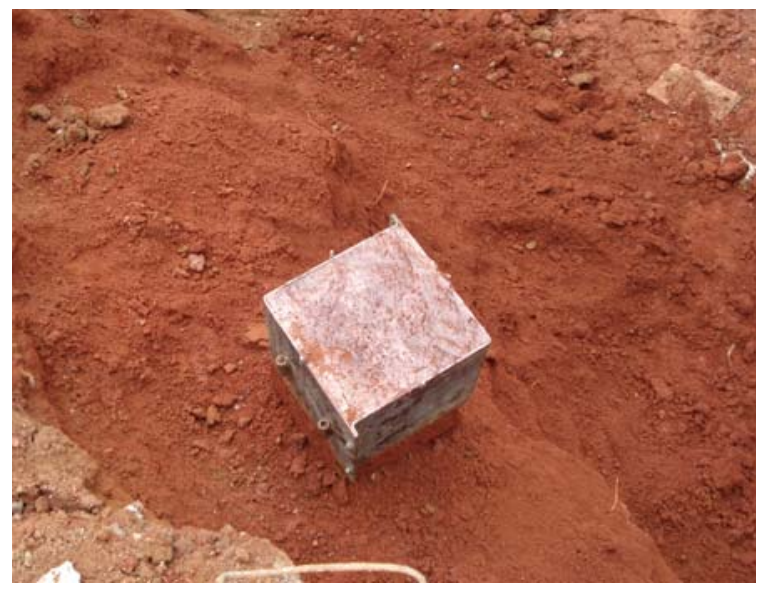

(a)

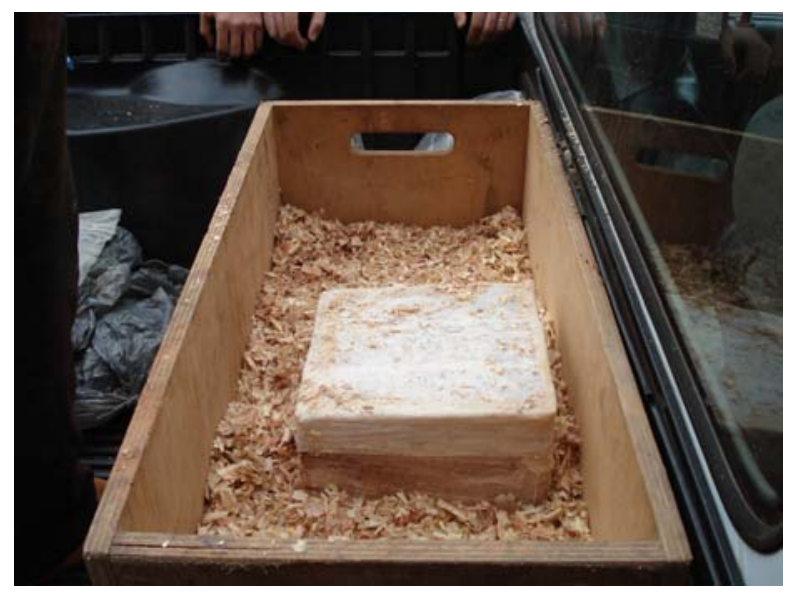

(b)

Figura 3.43. (a) Detalhe da coleta de amostra indeformada e (b) do armazenamento em caixa de madeira.

A Tabela 3.10 apresenta os resultados dos ensaios geotécnicos realizados. 
Tabela 3.10. Características geotécnicas dos solos utilizados.

\begin{tabular}{ccc}
\hline Propriedade & Linha 2 & Linha 5 \\
\hline Massa Específica dos Sólidos $\left(\rho_{\mathrm{s}}\right) \mathrm{g} / \mathrm{cm}^{3}$ & 2,798 & 2,817 \\
Teor de Argila (\%) & 46,8 & 38,7 \\
Teor de Silte (\%) & 18,2 & 16,3 \\
Teor de Areia (\%) & 35,0 & 45,0 \\
LL (\%) & 48 & 56 \\
LP $(\%)$ & 27 & 32 \\
Peso Específico $\left(\mathrm{kN} / \mathrm{m}^{3}\right)$ & 14,4 & 18,1 \\
Umidade Natural $(\%)$ & 23,1 & 30,3 \\
\hline
\end{tabular}

Foram realizados ensaios de resistência ao cisalhamento, tipo triaxial consolidado e não drenado (CU), e ensaios de cisalhamento direto rápido, em amostras indeformadas na umidade de campo. As tensões utilizadas foram de 35,100 e $200 \mathrm{kPa}$, para confinamento no triaxial e tensão normal no cisalhamento direto, respectivamente. A Figura 3.44 apresenta as envoltórias de resistência total e efetiva em termos de coordenadas p e q, obtidas a partir de ensaios triaxiais em amostras de solos das linhas 2 (a) e 5 (b).

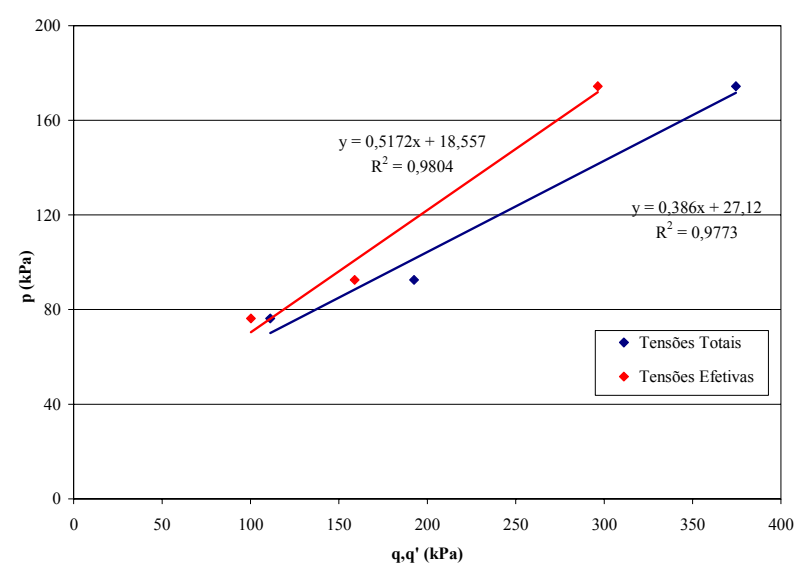

(a)

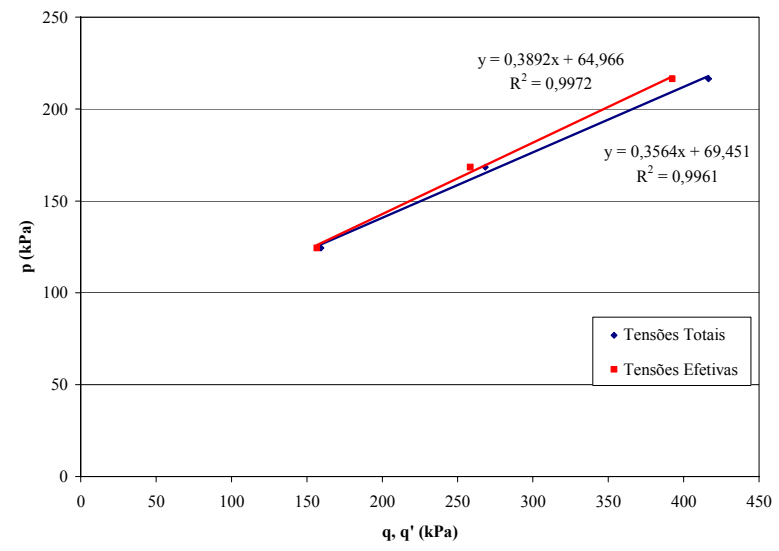

(b)

Figura 3.44. Envoltórias de resistência total e efetiva obtidas a partir de ensaios triaxias em amostras de solos das linhas 2 (a) e 5 (b) (Lima, 2009).

A Figura 3.45 ilustra as curvas Tensão Cisalhante x Deslocamento do ensaio de cisalhamento direto e as envoltórias de resistência obtidas 


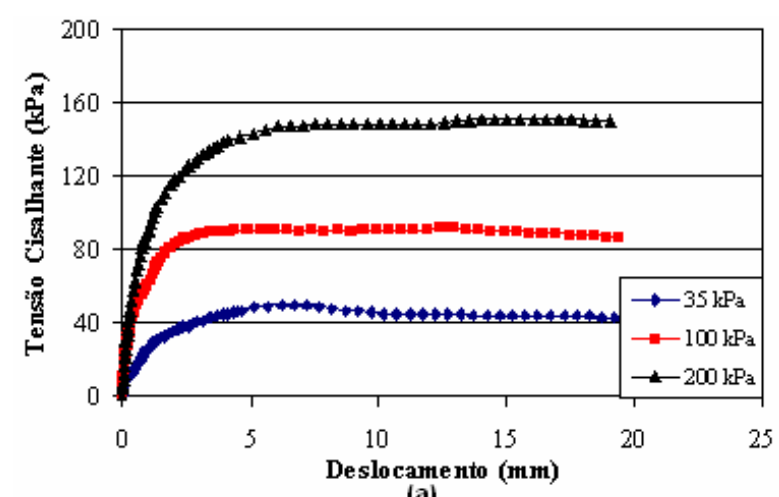

(a)

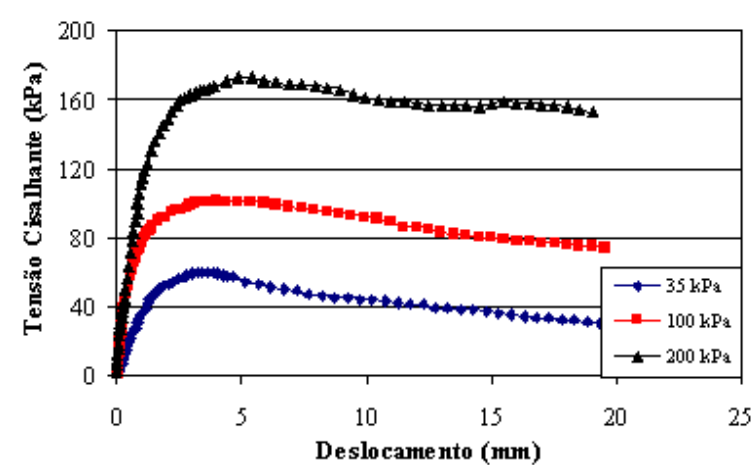

(c)
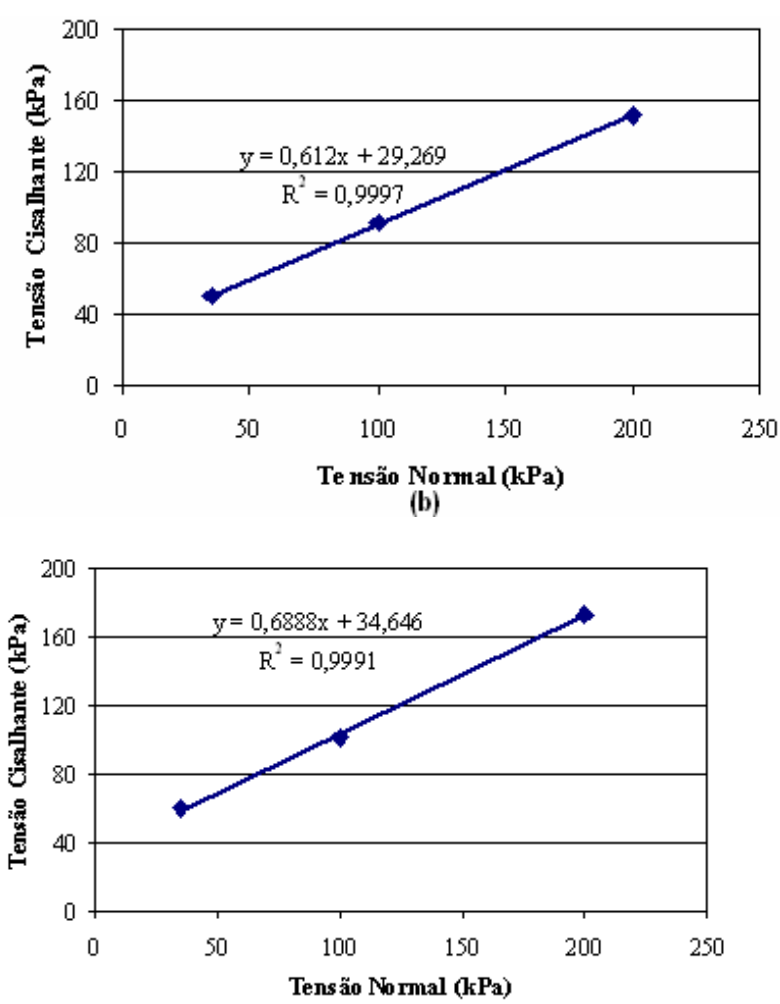

(d)

Figura 3.45. Curva Tensão Cisalhante x Deslocamento para os solos das linhas 2 (a) e 5 (c) e envoltória de resistência para os solos das linhas 2 (b) e 5 (d) (Lima, 2009).

A Tabela 3.11 apresenta um resumo dos parâmetros de resistência (c e $\phi)$ totais e efetivos obtidos para as duas profundidades de interesse, a partir dos ensaios triaxiais e de cisalhamento direto.

Tabela 3.11. Parâmetros totais e efetivos de resistência ao cisalhamento.

\begin{tabular}{lc|cccc}
\hline \multirow{2}{*}{ Local } & \multirow{2}{*}{ Ensaio } & \multicolumn{2}{|c}{ Total } & \multicolumn{2}{c}{ Efetiva } \\
& & $\mathbf{c}$ & $\boldsymbol{\phi}$ & $\mathbf{c}^{\prime}$ & $\boldsymbol{\phi}^{\prime}$ \\
& & $\mathbf{( k P a )}$ & $\left.\mathbf{(}^{\circ}\right)$ & $\mathbf{( k P a )}$ & $\left(^{\circ}\right)$ \\
\hline \multirow{2}{*}{ Linha 2 } & Triaxial & 29,4 & 22,7 & 21,7 & 31,1 \\
& Cisal. Direto & 29,3 & 31,5 & -- & -- \\
\multirow{2}{*}{ Linha 5 } & Triaxial & 74,4 & 20,9 & 70,6 & 22,9 \\
& Cisal. Direto & 34,6 & 34,6 & -- & -- \\
\hline
\end{tabular}


A Tabela 3.11 mostrou um ganho acentuado de resistência da linha 5 em relação à linha 2. Este incremento era esperado em função do perfil de alteração do solo existente no local, ou seja, o solo saprolitico (linha 5) deve ter resistência superior a um solo residual mais alterado (linha 3).

$\mathrm{Na}$ região de estudo, também foram realizados ensaios pressiométricos. Estes ensaios foram realizados nas duas profundidades representativas dos chumbadores testes. Os ensaios foram realizados com o pressiômetro Camkometer, composto por uma sapata cortante e uma broca de arraste, que, quando submetido a um esforço vertical e à circulação de água, avança no solo, provocando o mínimo de perturbação possível no entorno do seu diâmetro. A operação de perfuração ficou a cargo da empresa Engesolos, enquanto a operação do ensaio pressiométrico ficou a cargo do Laboratório de Mecânica dos Solos do Departamento de Engenharia e Fundações da Escola Politécnica da USP. A Figura 3.46 apresenta detalhes da execução do ensaio pressiométrico na obra. 


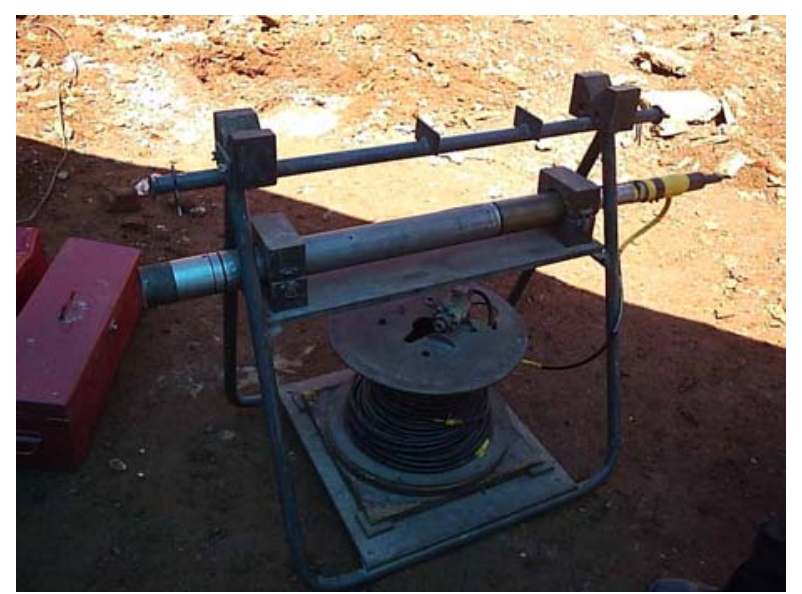

(a)

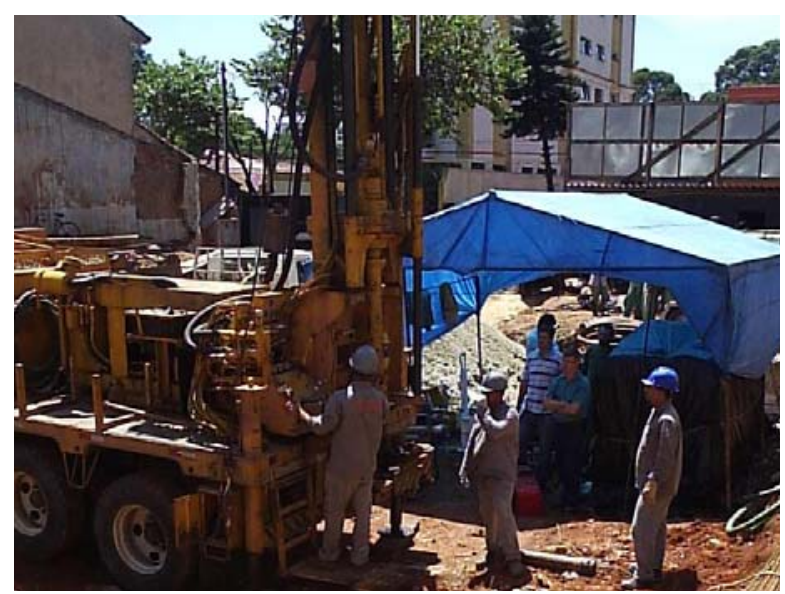

(c)

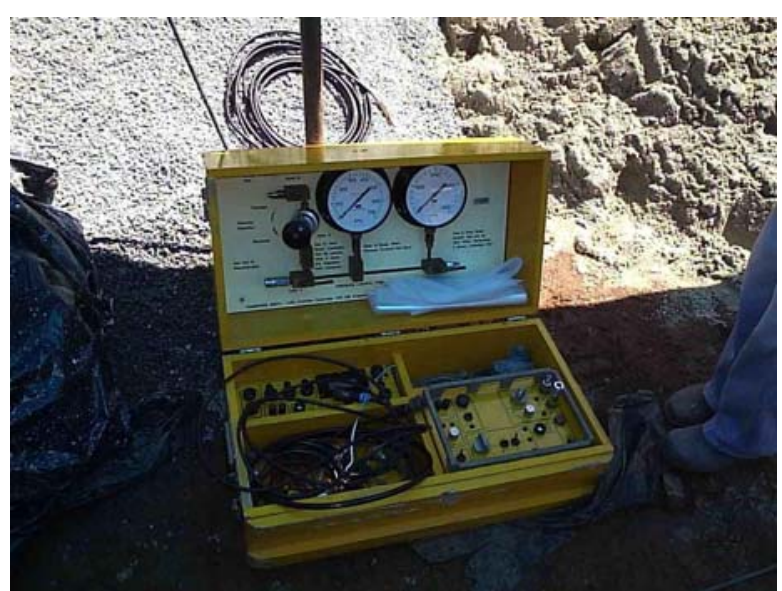

(b)

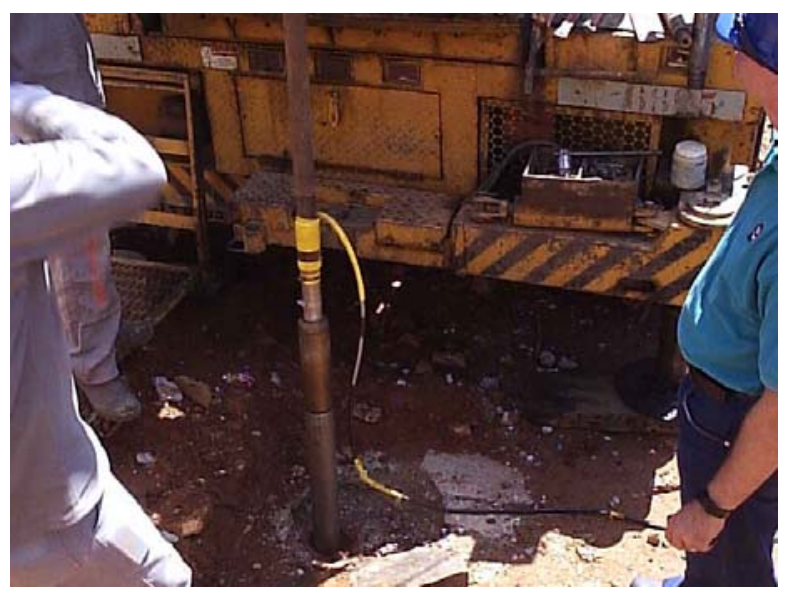

(d)

Figura 3.46. (a) Detalhe do pressiômetro Camkometer, (b) do sistema de aplicação de pressão, (c) e (d) da cravação do pressiômetro auto perfurante.

O primeiro ensaio (linha 2), denominado B52T1, não pôde ser feito por autoperfuração, já que havia sido realizada uma pré-escavação do terreno e a cota de interesse estava muito próxima da superfície. Por isso, tentou-se fazer um pré-furo com um Shelby de diâmetro inferior ao diâmetro do pressiômetro. Como o solo local estava úmido, o pré-furo ficou com diâmetro maior que o esperado, e este ensaio não apresentou resultado. A expansão máxima do pressiômetro não chegou a encostar no solo.

O segundo ensaio (linha 5), denominado B54T2, foi realizado com autoperfuração e lavagem. O ensaio foi realizado conforme metodologia adotada universalmente, ou seja, com as pressões internas crescentes e com velocidade controlada, registrando-se os deslocamentos dos três braços de referência, por meio de transdutores. Para este ensaio, foi 
possível obter a curva pressão x deslocamento da cavidade bem definida (Figura 3.47-a). A Figura 3.47 (b) apresenta um detalhe em que se pode identificar o valor da pressão aplicada, $\mathrm{p}_{\mathrm{o}}$, a partir do qual a membrana começa a se deslocar lateralmente. Para a determinação deste parâmetro, utilizou-se o método de "lift off", que consiste na avaliação da pressão em que começa a ocorrer a expansão da cavidade.
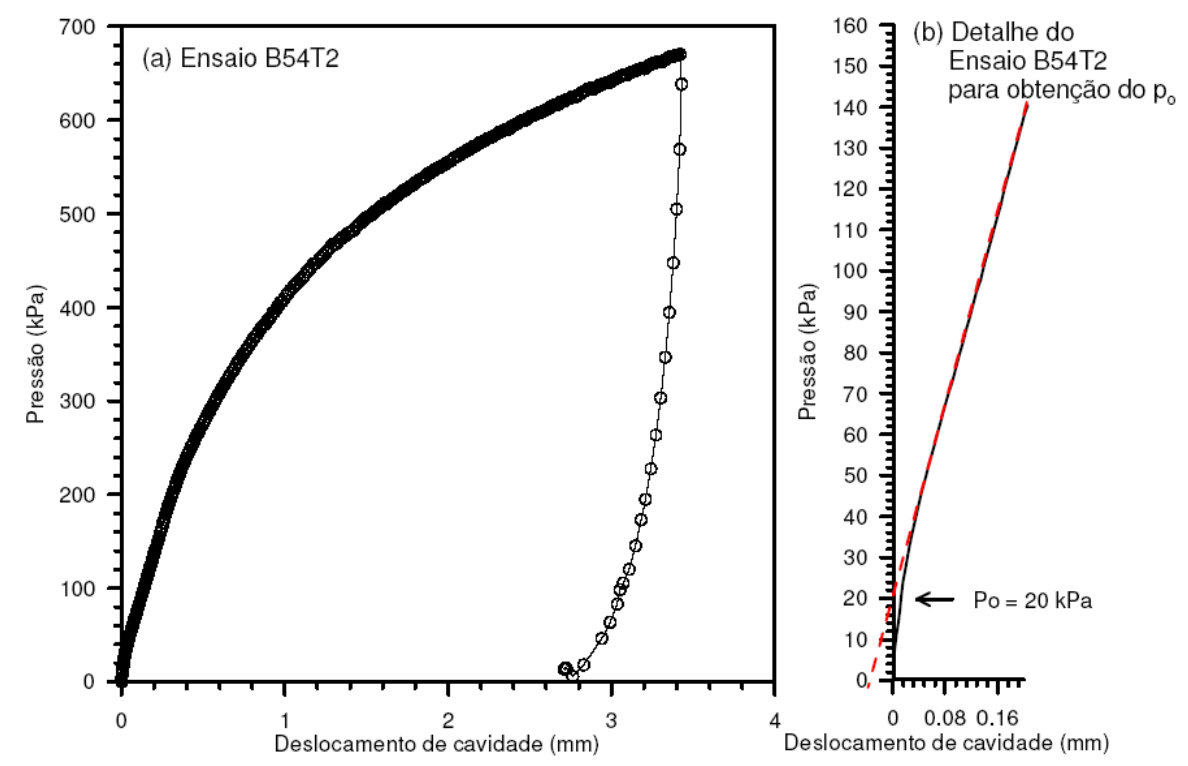

Figura 3.47. (a) Curva pressão total $x$ deslocamento da cavidade do ensaio e (b) detalhe para a obtenção do $\mathrm{p}_{0}$ para o ensaio pressiométrico da linha 5 (ensaio B54T2).

$\mathrm{O}$ ensaio não atingiu a pressão limite. Entretanto a curva pressão total $\mathrm{x}$ deslocamento mostra uma tendência de estabilização, sendo portanto adotada a pressão limite de $680 \mathrm{kPa}$. O valor da resistência foi obtido pelo Método das subtangentes, proposto por Palmer. Está apresentada na Figura 3.48 a curva tensão cisalhante x deformação de cavidade. A curva ficou bem definida, e, a partir dela, é possível estimar a resistência do solo nessa profundidade em 210kPa. Aparentemente, não há uma resistência de pico bem definida, e o solo se plastifica continuamente. 


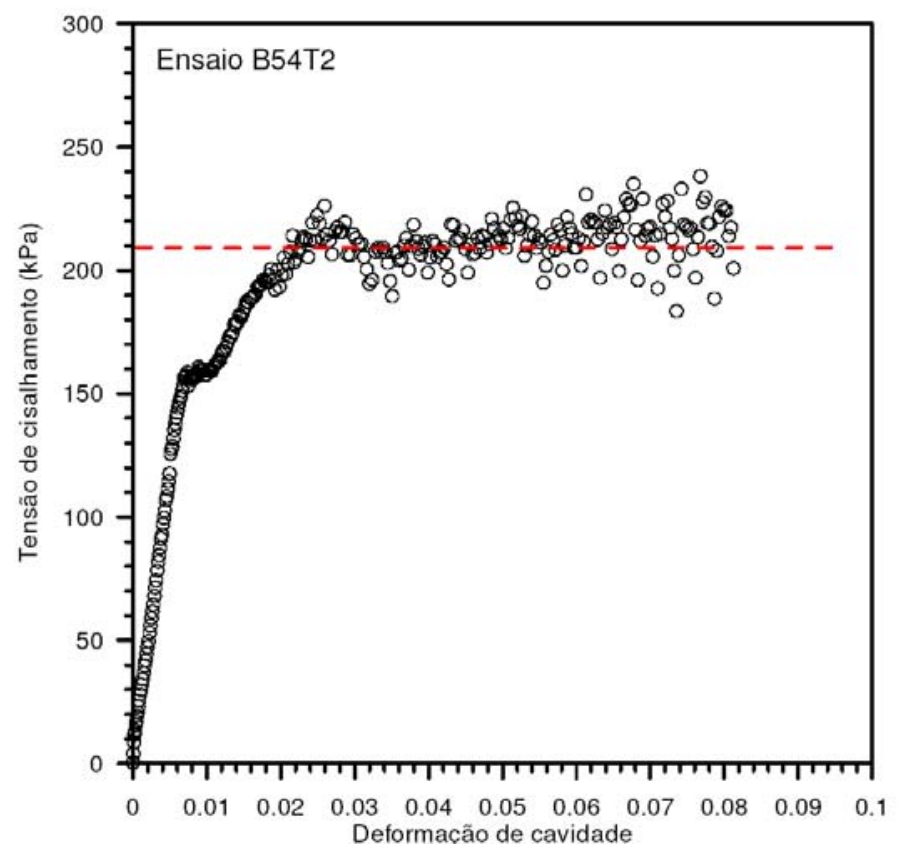

Figura 3.48. Curva tensão de cisalhamento $x$ deformação da cavidade para o ensaio pressiométrico da linha 5 (ensaio B54T2).

\subsubsection{Exec ução dos Chumbadores Testes}

Os chumbadores testes foram distribuídos ao longo de duas profundidades (linhas 2 e 5), com o objetivo de avaliar a influência das diferentes metodologias executivas na resistência ao cisalhamento de interface, para diferentes tipos de solos. A Figura 3.49 apresenta a distribuição dos chumbadores testes ao longo das linhas 2 e 5 . Os chumbadores encontram-se numerados e identificados quanto ao seu comprimento e à metodologia empregada na sua execução (letras no centro da circunferência). 


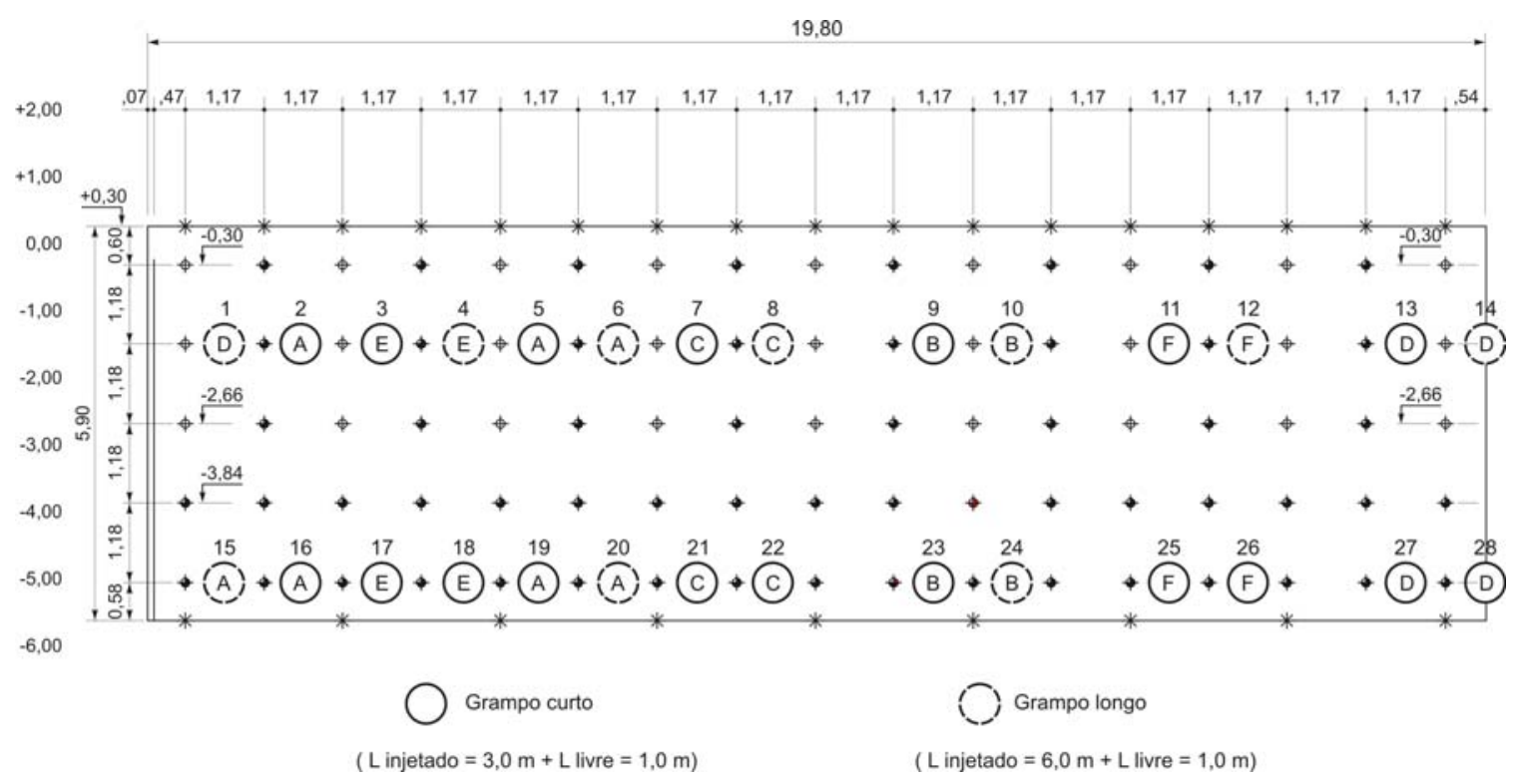

Figura 3.49. Distribuição, numeração, comprimento e metodologia executiva adotada na execução dos chumbadores testes ao longo das linhas 2 e 5 .

A Figura 3.49 mostra que, na linha 2, foram construídos 7 chumbadores longos e 7 chumbadores curtos. A partir da dificuldade encontrada em realizar ensaios de arrancamento em chumbadores longos construídos com um maior número de injeções, a linha 5 foi construída com 11 chumbadores curtos e apenas 3 chumbadores longos, executados com as metodologias A, A* e B. Todos os chumbadores testes foram executados com perfuratriz manual, utilizando o procedimento de lavagem do furo, obtendo-se diâmetro de perfuração de $76 \mathrm{~mm}$ e inclinação de $10^{\circ}$ em relação à direção horizontal. Foram utilizadas barras de aço CA-50 com diâmetro nominal de 25,3 mm.

Os chumbadores testes foram construídos entre os chumbadores de projeto da obra. Os chumbadores de projeto foram inicialmente construídos somente com a bainha, para evitar a influência das injeções nos chumbadores testes. Após a realização dos ensaios de arrancamento, estes chumbadores foram injetados.

A preparação das barras de aço foi finalizada na própria obra. Nesta etapa, inicialmente, foram realizadas as junções das barras de aço, por meio das luvas metálicas, e o cobrimento da barra de aço ao longo do trecho injetado foi garantido a partir da fixação de centralizadores espaçados a cada $0,5 \mathrm{~m}$. Os tubos de injeção foram fixados junto às barras de aço, conforme a metodologia de execução adotada. Para evitar problemas de obstrução destas manchetes durante a etapa construtiva, os furos foram envolvidos com fita 
Análise de diferentes metodologias executivas de solo pregado a partir de ensaios de arrancamento em campo e laboratório

adesiva. Para garantir a integridade do trecho livre de 1,0 $\mathrm{m}$ de comprimento, este trecho da barra de aço foi envolvido por uma mangueira plástica e, posteriormente, por graxa espalhada. Adicionalmente, foi instalado um obturador, que consiste em uma espuma enrolada na barra de aço. A Figura 3.50 apresenta os detalhes da preparação da barra de aço no canteiro da obra.

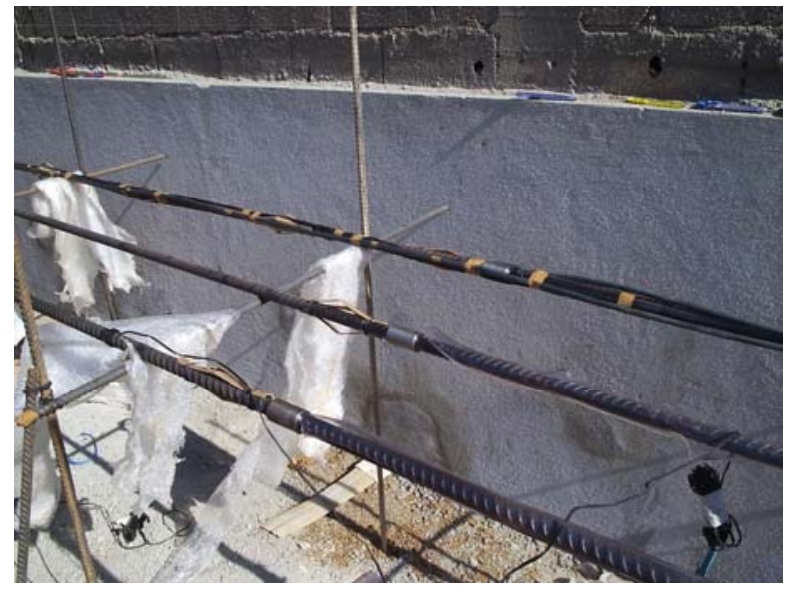

(a)

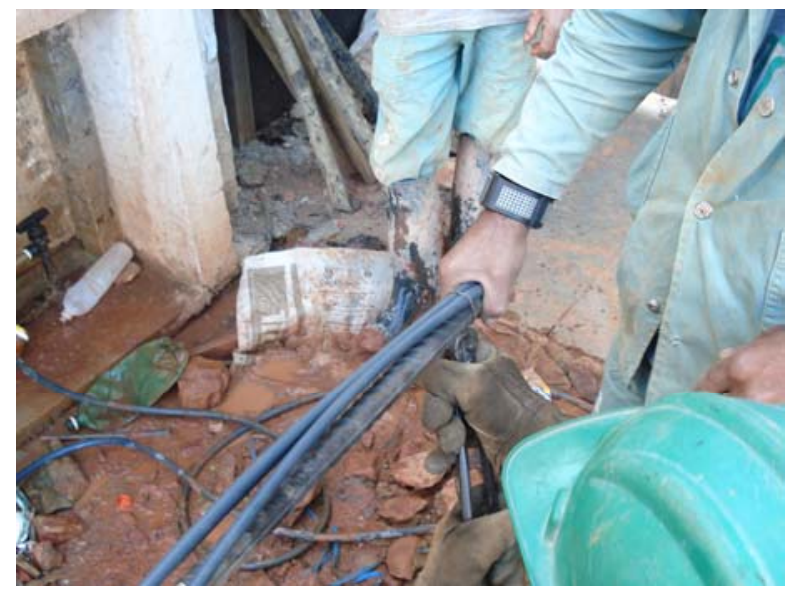

(c)

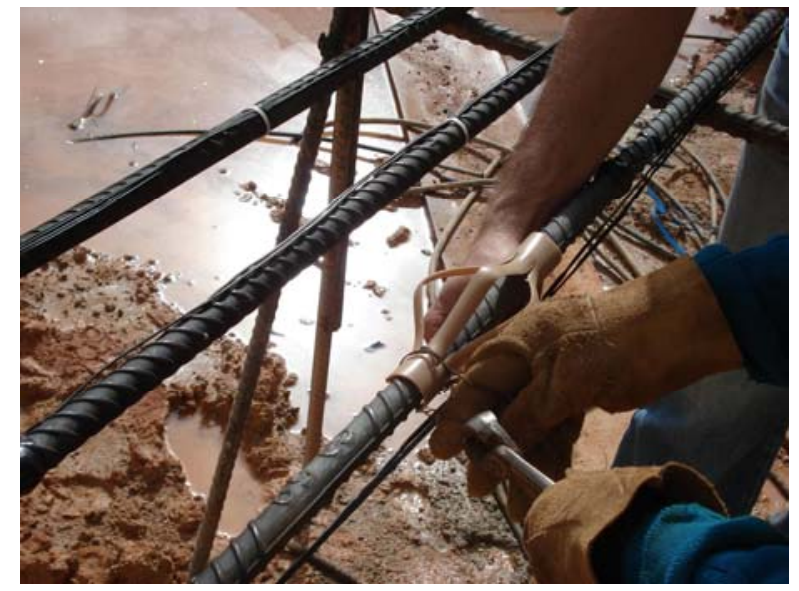

(b)

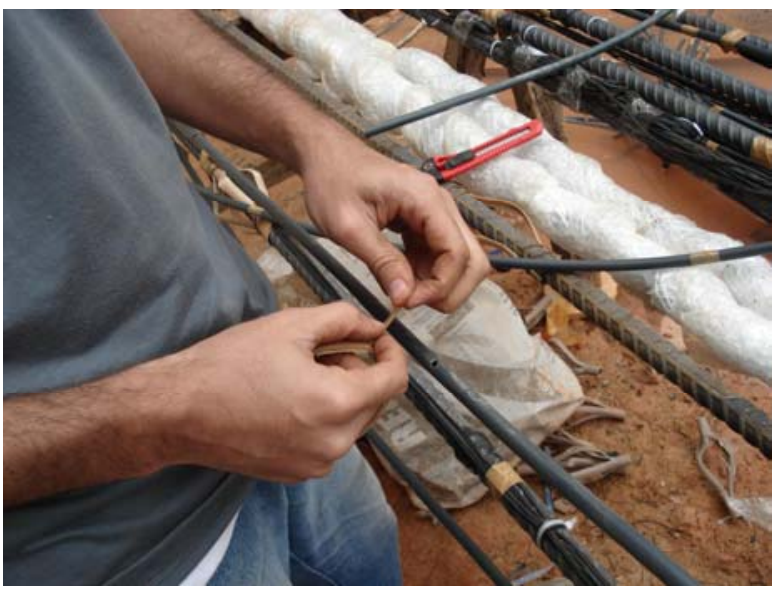

(d) 


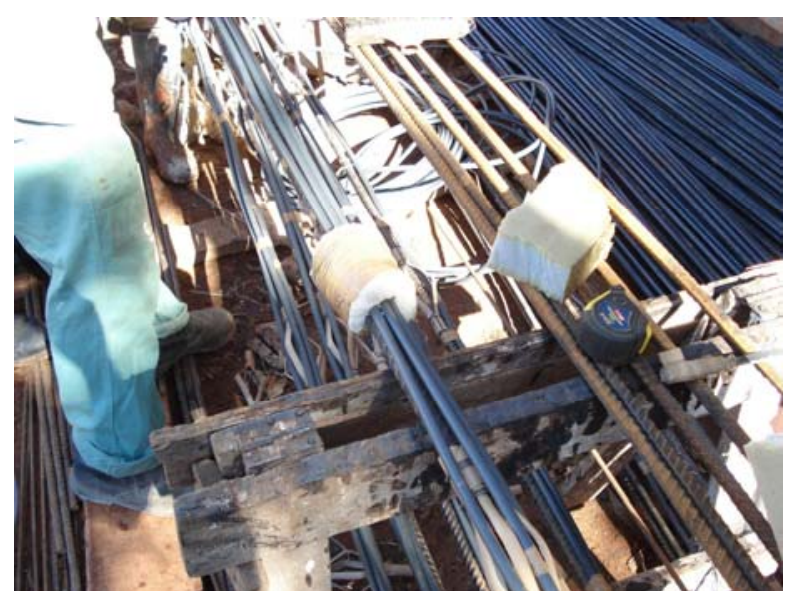

(e)

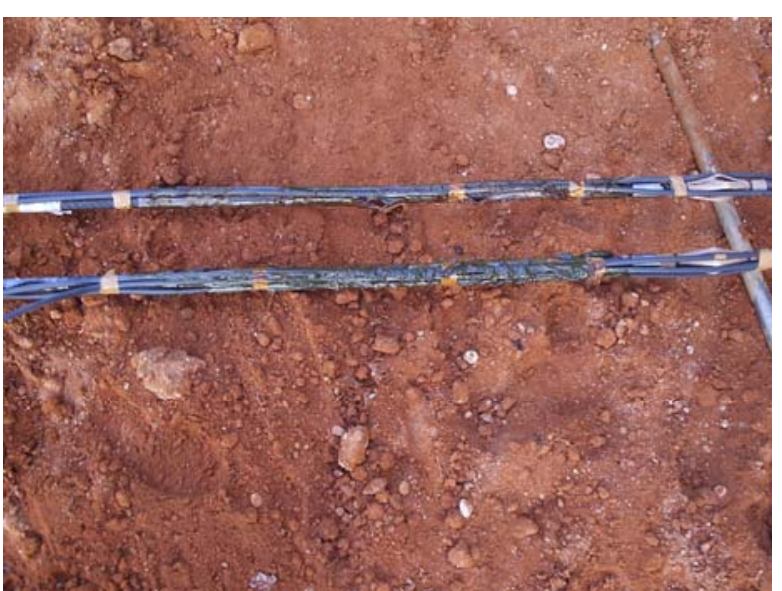

(f)

Figura 3.50. Detalhe da preparação das barras de aço. (a) Junção das barras de aço com luvas metálicas, (b) fixação de centralizadores a cada $0,5 \mathrm{~m}$, (c) fixação dos tubos de injeção, (d) proteção das válvulas de injeção com fitas adesivas, (e) obturador de espuma enrolada no inicio do trecho livre e (f) proteção do trecho livre com mangueira plástica e graxa.

A Figura 3.51 (a) mostra a localização inicial do trecho de estudo, onde foram construídos os chumbadores testes após a realização da primeira linha de chumbadores, ou seja, este trecho se apresenta pronto para ser escavado e receber a segunda linha de chumbadores. As setas pretas indicam a posição em que seriam construídos os chumbadores de projeto. A Figura 3.51 (b) mostra a etapa de escavação, em nichos, da segunda linha de chumbadores.

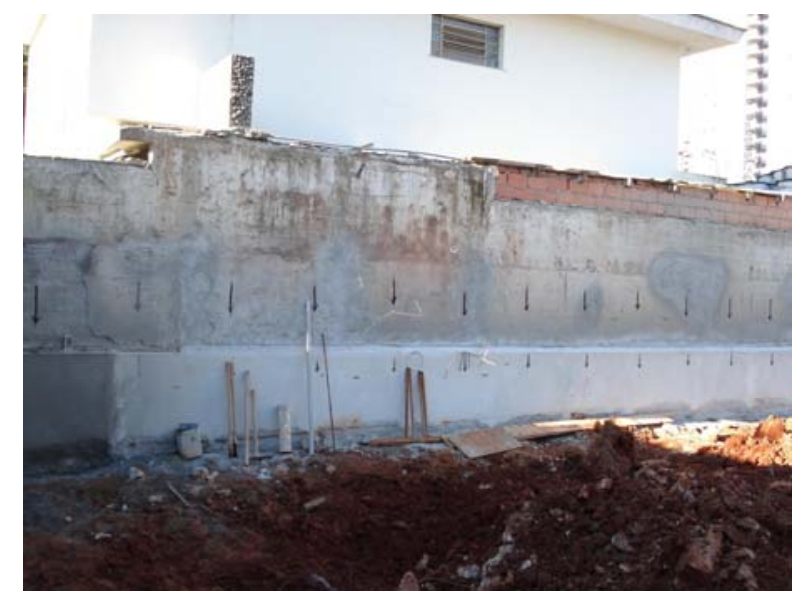

(a)

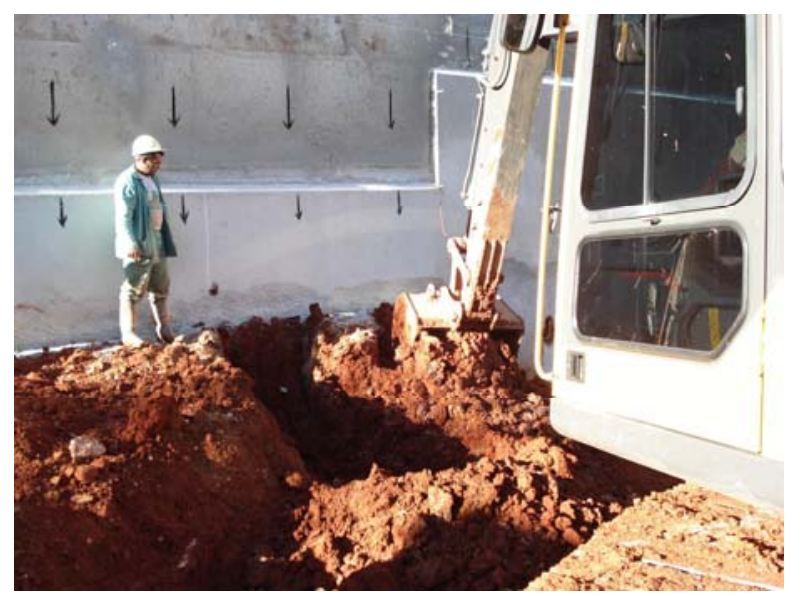

(b)

Figura 3.51. (a) Localização do trecho estudado após o termino da linha 1 de chumbadores e (b) detalhe da escavação, em nichos, para a realização da segunda linha de chumbadores. 
Após a etapa de escavação da segunda linha, foram realizadas as perfurações do maciço de solo para a execução dos chumbadores testes e de projeto. Após o termino da perfuração, era então realizado o preenchimento do furo com calda de cimento (Bainha), até que a calda de cimento extravasasse limpa, pela boca do furo. As barras de aço, devidamente preparadas, foram então inseridas no maciço de solo. A Figura 3.52 representa a etapa da perfuração do maciço de solo (a), da execução da Bainha (b) e a inserção da barra de aço no maciço de solo (c).

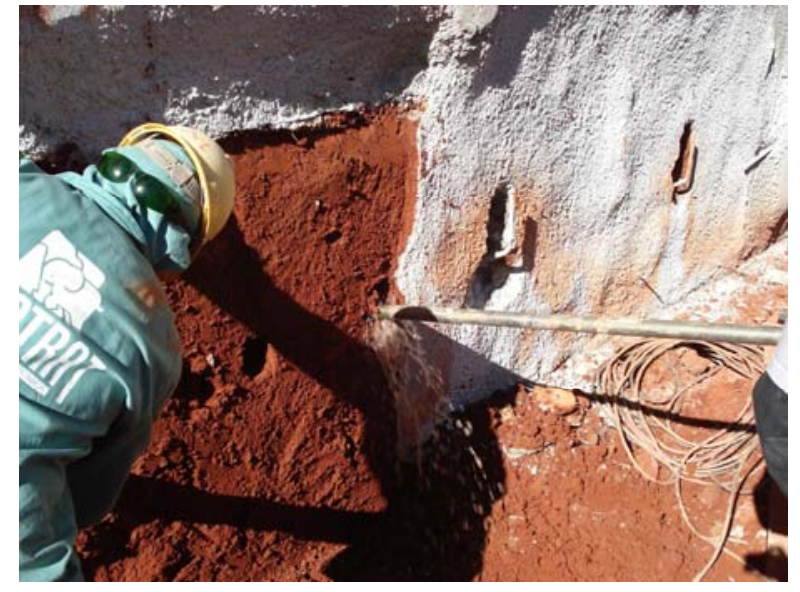

(a)

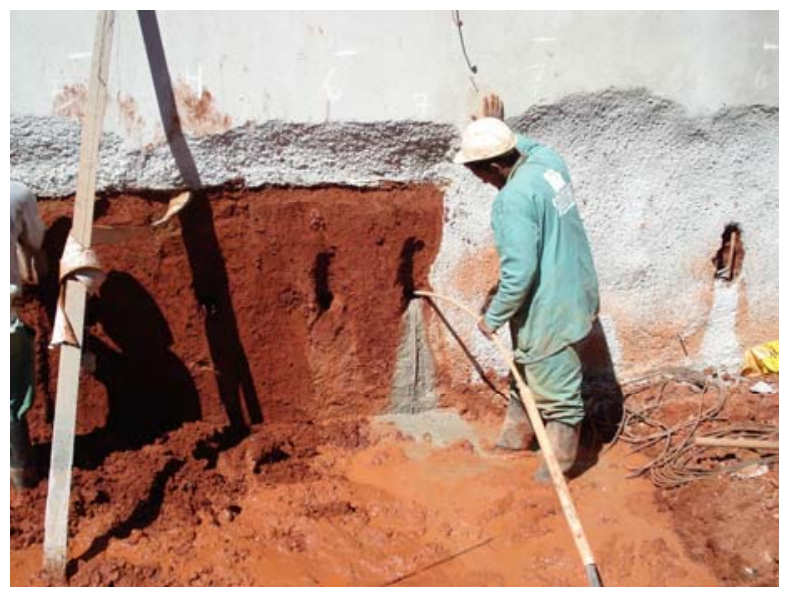

(b)

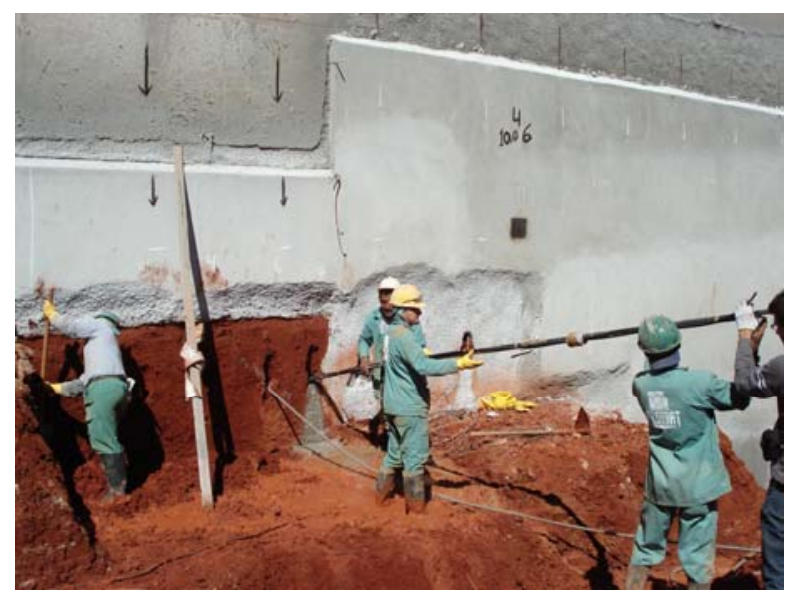

(c)

Figura 3.52. (a) Detalhe da perfuração com lavagem de água, (b) do preenchimento do furo com calda de cimento e (c) da inserção da barra de aço no maciço de solo. 
Após a execução dos chumbadores, realizou-se a primeira projeção de concreto projetado sobre a face. Vale a pena lembrar que, durante esta etapa, tomou-se o cuidado de proteger a cabeça do chumbador, para evitar a penetração de concreto projetado para dentro do furo. A Figura 3.53 apresenta os detalhes da execução do concreto projetado e a vista geral dos chumbadores após a sua execução.

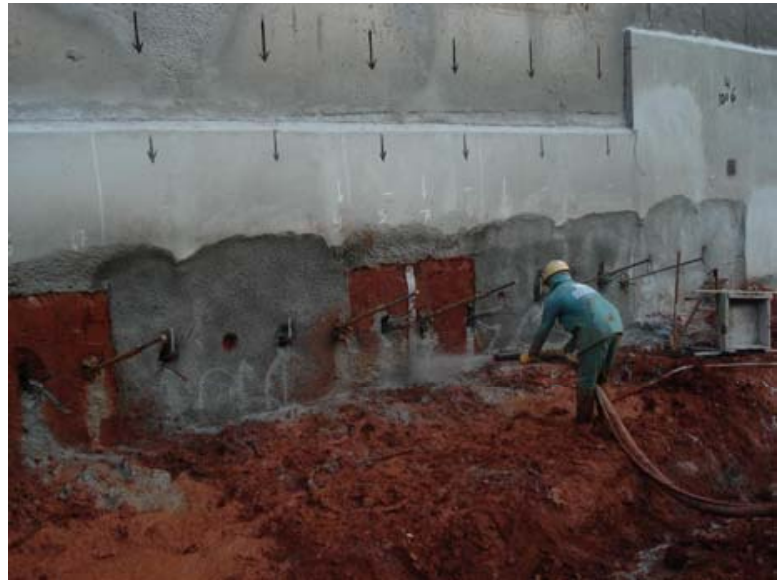

(a)

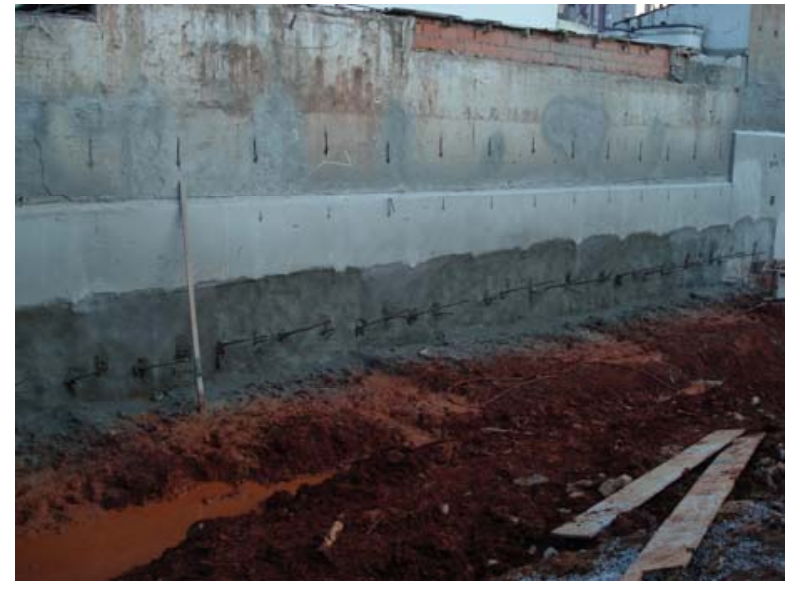

(b)

Figura 3.53. (a) Jateamento de concreto projetado e (b) vista dos chumbadores executados.

As injeções foram iniciadas após um intervalo mínimo de 12 horas da execução da bainha, obedecendo ao procedimento da obra, de realizar uma injeção por dia. Durante esta etapa foram controlados a pressão e o volume da injeção. O controle do volume injetado foi realizado medindo-se o nível de calda de cimento dentro do tanque misturador. A determinação das pressões de injeção foi realizada por um manômetro, localizado na saída da bomba de injeção. A Figura 3.54 apresenta os detalhes da conexão da mangueira de injeção junto à tubulação dos chumbadores, do controle do volume injetado e do manômetro utilizado para a quantificação das pressões de injeção. 
Análise de diferentes metodologias executivas de solo pregado a partir de ensaios de arrancamento em campo e laboratório

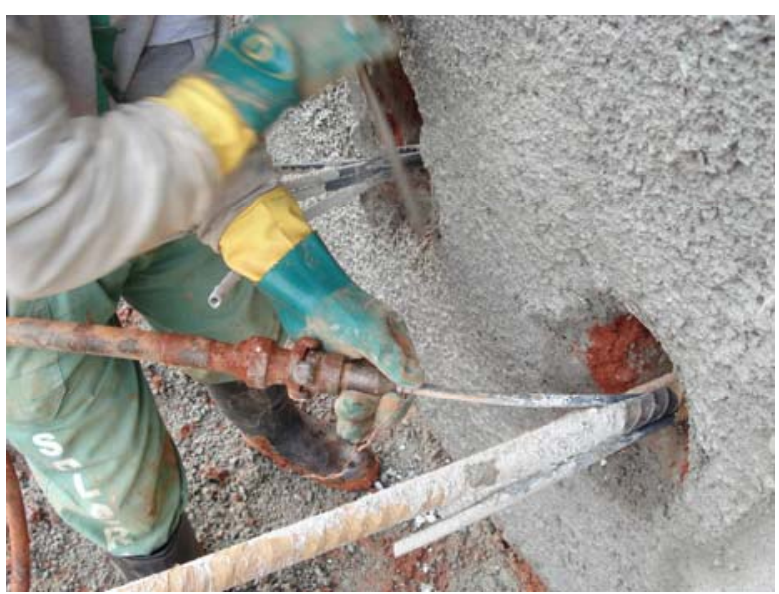

(a)

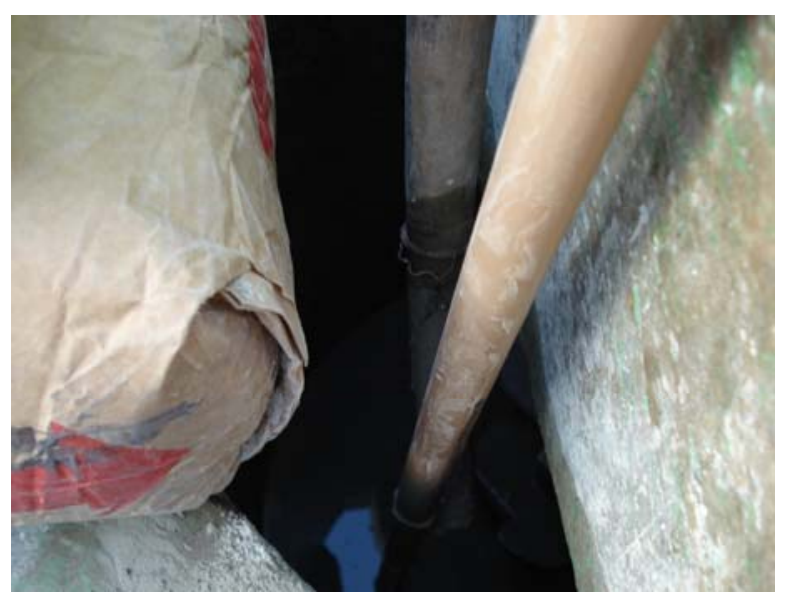

(c)

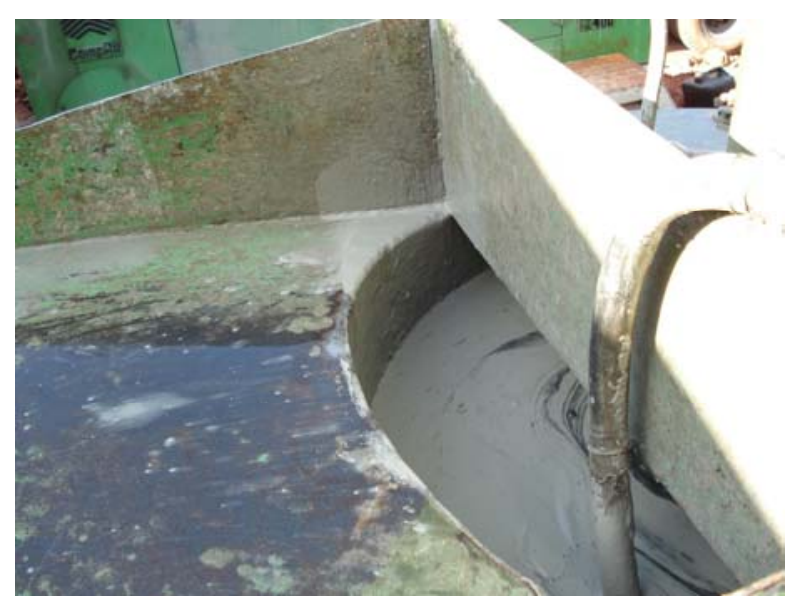

(b)

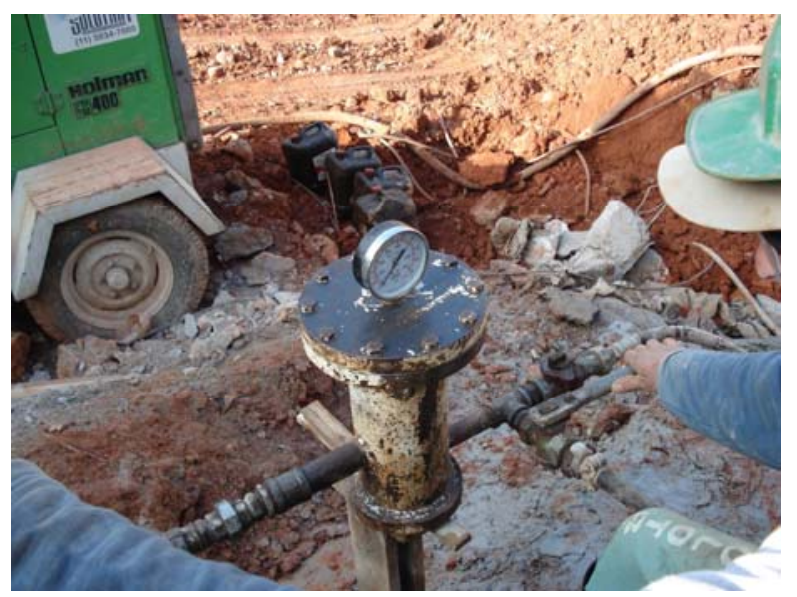

(d)

Figura 3.54. (a) Detalhe da fixação da mangueira de injeção nos tubos de injeção, (b) da preparação da calda de cimento no misturador, (c) do controle de calda de cimento injetado e (d) do manômetro na saída da bomba de injeção.

A Tabela 3.12 apresenta um resumo do controle de execução dos chumbadores testes executados na linha 2 do trecho estudado. 
Tabela 3.12. Controle de execução dos chumbadores testes da linha 2 (Obra 1).

\begin{tabular}{|c|c|c|c|c|c|c|c|c|c|c|c|c|c|c|c|c|c|c|}
\hline \multicolumn{4}{|c|}{ Chumbador } & \multicolumn{2}{|c|}{ Bainha } & \multicolumn{4}{|c|}{$1^{\mathrm{a}}$ Fase } & \multicolumn{4}{|c|}{$2^{\mathrm{a}}$ Fase } & \multicolumn{4}{|c|}{$3^{\mathrm{a}}$ Fase } & \multirow{2}{*}{$\begin{array}{c}\text { Total volume } \\
\text { Injetado (litros) }\end{array}$} \\
\hline Id & Met. & Tipo & Instr. & Data & Hora & Data & Hora & $\frac{\text { Pressão }}{(\mathrm{MPa})}$ & $\frac{\text { Volume }}{\text { (litros) }}$ & Data & Hora & $\frac{\text { Pressão }}{\text { (MPa) }}$ & $\frac{\text { Volume }}{\text { (litros) }}$ & Data & Hora & $\frac{\text { Presão }}{\text { (MPa) }}$ & $\frac{\text { Volume }}{\text { (litros) }}$ & \\
\hline 1 & $\mathrm{D}$ & Longo & não & $6 / 5 / 08$ & $15: 15$ & $7 / 5 / 08$ & $08: 30$ & - & 33,5 & $8 / 5 / 08$ & $08: 45$ & 1,0 & 51,0 & $9 / 5 / 08$ & $07: 36$ & 0,7 & & 845 \\
\hline 2 & A & Curto & não & $7 / 5 / 08$ & $15: 45$ & & & & & & & & & & & & & 00 \\
\hline 3 & $\mathrm{E}$ & Curto & não & $6 / 5 / 08$ & $15: 10$ & $7 / 5 / 08$ & $08: 20$ & - & 24,0 & $8 / 5 / 08$ & $08: 40$ & 0,5 & 15,0 & & & & & 390 \\
\hline 4 & E & Longo & não & $6 / 5 / 08$ & $15: 10$ & $7 / 5 / 08$ & $08: 20$ & 1,0 & 24,0 & $8 / 5 / 08$ & $08: 40$ & 0,5 & 51,0 & & & & & 75,0 \\
\hline 5 & A & Curto & $\operatorname{sim}$ & $7 / 5 / 08$ & $15: 30$ & & & & & & & & & & & & & 0.0 \\
\hline 6 & A & Longo & $\operatorname{sim}$ & $7 / 5 / 08$ & $15: 20$ & & & & & & & & & & & & & 00 \\
\hline 7 & $\mathrm{C}$ & Curto & não & $6 / 5 / 08$ & $11: 50$ & $7 / 5 / 08$ & $08: 10$ & - & 51,0 & $8 / 5 / 08$ & $08: 30$ & 2,0 & & & & & & 51,0 \\
\hline 8 & $\mathrm{C}$ & Longo & não & $6 / 5 / 08$ & $11: 50$ & $7 / 5 / 08$ & $08: 10$ & - & 51,0 & $8 / 5 / 08$ & $08: 30$ & 0,5 & 51,0 & & & & & 102,0 \\
\hline 9 & B & Curto & $\operatorname{sim}$ & 7/5/08 & 15:00 & $8 / 5 / 08$ & $08: 20$ & 1,0 & 10,0 & & & & & & & & & 10,0 \\
\hline 10 & B & Longo & sim & $7 / 5 / 08$ & 15:00 & $8 / 5 / 08$ & $08: 20$ & 1,0 & 24,0 & & & & & & & & & 24,0 \\
\hline 11 & $\mathrm{~F}$ & Curto & $\operatorname{sim}$ & $7 / 5 / 08$ & $14: 20$ & $8 / 5 / 08$ & $08: 10$ & 0,6 & 51,0 & $9 / 5 / 08$ & $07: 32$ & 0,4 & 7,0 & $10 / 5 / 08$ & 07:44 & 1,6 & & 58,0 \\
\hline 12 & $\mathrm{~F}$ & Longo & sim & $7 / 5 / 08$ & $14: 20$ & $8 / 5 / 08$ & $08: 10$ & 0,6 & 51,0 & $9 / 5 / 08$ & $07: 28$ & 0,6 & 51,0 & $10 / 5 / 08$ & $07: 40$ & 1,5 & & 102,0 \\
\hline 13 & $\mathrm{D}$ & Curto & não & $6 / 5 / 08$ & $11: 30$ & $7 / 5 / 08$ & 08:00 & - & 15,0 & $8 / 5 / 08$ & 08:00 & - & 51,0 & $9 / 5 / 08$ & $07: 28$ & 1,5 & & 66,0 \\
\hline 14 & D & Longo & não & $6 / 5 / 08$ & $11: 30$ & $7 / 5 / 08$ & 08:00 & - & 24,0 & $8 / 5 / 08$ & 08:00 & 0,5 & 51,0 & $9 / 5 / 08$ & 07:23 & 1,6 & & 75,0 \\
\hline
\end{tabular}


A partir da Tabela 3.12, verifica-se que a pressão máxima de injeção foi de 1,6 MPa, obtida para a terceira fase de injeção. Observa-se também que os volumes de injeção nunca foram superiores a 51 litros, ou seja, volume equivalente a uma calda de cimento preparada com um saco de cimento $(50 \mathrm{~kg})$ e relação água-cimento igual a 0,7 . Este volume foi utilizado como critério de parada, por considerar que maiores volumes de injeção poderiam ser danosos a edificações vizinhas, já que, provavelmente, teriam encontrado algum vazio excessivo no maciço de solo. Os resultados obtidos a partir do controle de execução poderão ser melhor avaliados e comparados após as análises dos resultados dos ensaios de arrancamento.

Foram coletadas amostras das caldas de cimento injetadas e moldadas para serem submetidas a ensaios de compressão uniaxial. Após 14 dias da execução dos chumbadores, as caldas de cimento apresentaram resistência superior a $21 \mathrm{MPa}$, mínimo recomendado pelo manual internacional da FHWA (Elias et al., 2003), e os chumbadores foram liberados para serem submetidos ao ensaio de arrancamento. A metodologia e as considerações dos ensaios realizados serão apresentadas adiante.

Após a realização dos ensaios, o trecho em estudo foi liberado para o prosseguimento das escavações da obra, até atingir a profundidade da linha 5, em que novos chumbadores testes foram construídos. Os procedimentos empregados nas etapas de perfuração, execução da bainha, inserção das barras de aço no maciço de solo e injeção de calda de cimento foram os mesmos dos já apresentados para a execução da linha 2. A Figura 3.55 apresenta uma vista geral durante a escavação, em nichos, dos chumbadores testes da linha 5 (a), após a construção dos chumbadores de projeto e projeção da primeira camada de concreto projetado (b) e após a execução dos chumbadores testes (c).

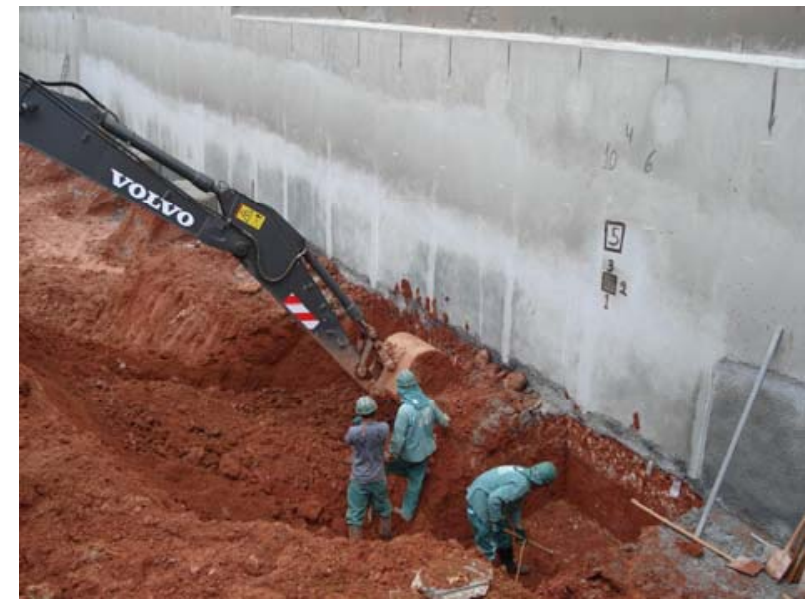

(a)

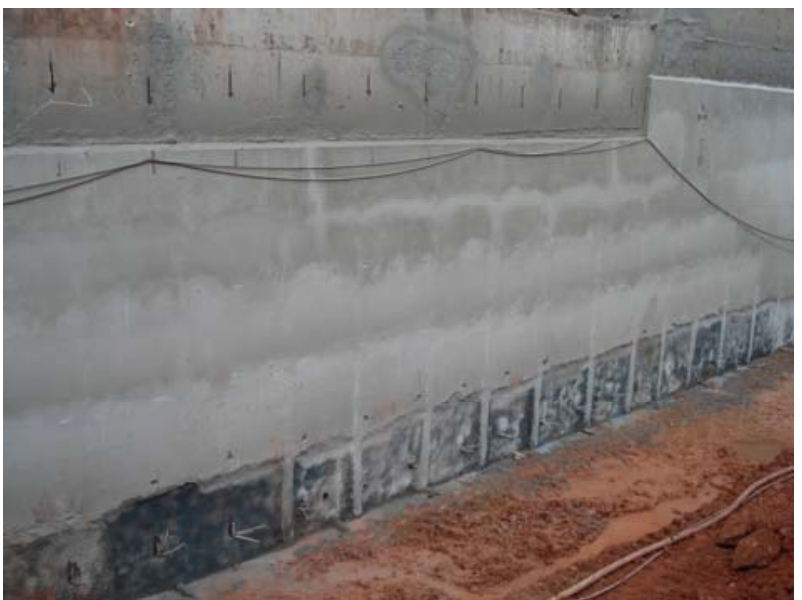

(b) 


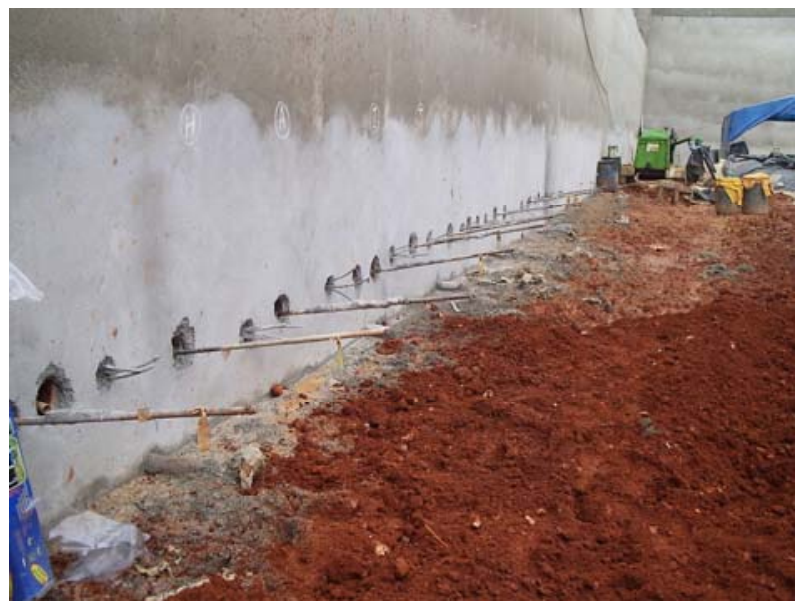

(c)

Figura 3.55. Etapas de construção os chumbadores testes da linha 5. (a) Etapa de escavação em nichos, (b) após a execução dos chumbadores da obra e (c) após a execução dos chumbadores testes.

A Tabela 3.13 apresenta um resumo do controle de execução dos chumbadores testes executados na linha 5 . 
Tabela 3.13. Controle de execução dos chumbadores testes da linha 5 (Obra 1).

\begin{tabular}{|c|c|c|c|c|c|c|c|c|c|c|c|c|c|c|c|c|c|c|}
\hline \multicolumn{4}{|c|}{ Chumbador } & \multicolumn{2}{|c|}{ Bainha } & \multicolumn{4}{|c|}{$1^{\mathrm{a}}$ Fase } & \multicolumn{4}{|c|}{$2^{a}$ Fase } & \multicolumn{4}{|c|}{$3^{\mathrm{a}}$ Fase } & \multirow{2}{*}{$\begin{array}{c}\text { Total volume } \\
\text { Injetado (litros) }\end{array}$} \\
\hline Id & Met. & Tipo & Instr. & Data & Hora & Data & Hora & $\frac{\text { Pressão }}{\text { (MPa) }}$ & $\begin{array}{l}\text { Volume } \\
\text { (litros) }\end{array}$ & Data & Hora & $\frac{\text { Pressão }}{\text { (MPa) }}$ & $\begin{array}{l}\text { Volume } \\
\text { (litros) }\end{array}$ & Data & Hora & $\frac{\text { Presão }}{\text { (MPa) }}$ & $\begin{array}{l}\text { Volume } \\
\text { (litros) }\end{array}$ & \\
\hline 15 & $\mathrm{~A}^{*}$ & Longo & $\operatorname{sim}$ & $17 / 6 / 08$ & $16: 30$ & & & & & & & & & & & & & 00 \\
\hline 16 & $\mathrm{~A}^{*}$ & Curto & $\operatorname{sim}$ & $17 / 6 / 08$ & $16: 30$ & & & & & & & & & & & & & 0,0 \\
\hline 17 & E & Curto & $\operatorname{sim}$ & $17 / 6 / 08$ & $16: 00$ & $18 / 6 / 08$ & 07:30 & 0,5 & 4,0 & $19 / 6 / 08$ & $07: 43$ & 1,0 & 0,0 & & & & & 4,0 \\
\hline 18 & E & Curto & não & $17 / 6 / 08$ & $16: 00$ & $18 / 6 / 08$ & $07: 36$ & 0,5 & 7,0 & $19 / 6 / 08$ & 07:54 & 0,8 & 0,0 & & & & & 7,0 \\
\hline 19 & A & Curto & $\operatorname{sim}$ & $17 / 6 / 08$ & $16: 00$ & & & & & & & & & & & & & 0,0 \\
\hline 20 & $\mathrm{~A}$ & Longo & $\operatorname{sim}$ & $17 / 6 / 08$ & $15: 50$ & & & & & & & & & & & & & 0,0 \\
\hline 21 & $\mathrm{C}$ & Curto & $\operatorname{sim}$ & $17 / 6 / 08$ & $15: 50$ & $18 / 6 / 08$ & 07:39 & 1,0 & 51,0 & $19 / 6 / 08$ & $07: 48$ & 1,1 & 7,0 & & & & & 58,0 \\
\hline 22 & $\mathrm{C}$ & Curto & não & $17 / 6 / 08$ & $15: 50$ & $18 / 6 / 08$ & 07:42 & 0,4 & 7,0 & $19 / 6 / 08$ & $07: 57$ & 2,0 & 0,0 & & & & & 7,0 \\
\hline 23 & B & Curto & $\operatorname{sim}$ & $17 / 6 / 08$ & $15: 40$ & $18 / 6 / 08$ & $07: 46$ & 1,0 & 3,5 & & & & & & & & & 3,5 \\
\hline 24 & B & Longo & $\operatorname{sim}$ & $17 / 6 / 08$ & $15: 40$ & $18 / 6 / 08$ & $07: 48$ & 1,2 & 7,0 & & & & & & & & & 7,0 \\
\hline 25 & $\mathrm{~F}$ & Curto & $\operatorname{sim}$ & $17 / 6 / 08$ & $15: 40$ & $18 / 6 / 08$ & $07: 50$ & 0,6 & 0,0 & $19 / 6 / 08$ & 08:00 & 1,0 & 51,0 & $20 / 6 / 08$ & $07: 49$ & 1,3 & 51,0 & 102,0 \\
\hline 26 & $\mathrm{~F}$ & Curto & não & $17 / 6 / 08$ & $15: 40$ & $18 / 6 / 08$ & $07: 53$ & 0,7 & 51,0 & $19 / 6 / 08$ & 08:04 & 0,5 & 51,0 & 20/6/08 & $07: 53$ & 0,6 & 0,0 & 102,0 \\
\hline 27 & D & Curto & $\operatorname{sim}$ & $17 / 6 / 08$ & $15: 30$ & $18 / 6 / 08$ & 07:55 & 0,5 & 3,5 & $19 / 6 / 08$ & 08:06 & 0,8 & 0,0 & 20/6/08 & $07: 58$ & 0,5 & 51,0 & 54,5 \\
\hline 28 & $\mathrm{D}$ & Curto & $\operatorname{sim}$ & $17 / 6 / 08$ & $15: 30$ & $18 / 6 / 08$ & 07:59 & 0,6 & 7,0 & $19 / 6 / 08$ & 08:08 & 2,0 & 7,0 & $20 / 6 / 08$ & 08:00 & 1,2 & 51,0 & 65,0 \\
\hline
\end{tabular}


A partir da Tabela 3.13, verifica-se que a pressão máxima de injeção foi de 2,0 $\mathrm{MPa}$, obtida para a segunda fase de injeção. Assim como na linha 2, o critério de parada da injeção foi adotado com volume de calda de cimento de 51 litros, ou seja, volume equivalente a uma calda de cimento preparada com um saco de cimento (50 kg), e com relação água-cimento igual a 0,7 . O controle de execução poderá ser mais bem avaliado e comparado após as análises dos resultados de arrancamento.

\subsubsection{Obra 2- Osasco-SP}

Trata-se de uma obra em que a técnica de solo pregado foi utilizada para conter escavações verticais, realizadas para a implantação de um empreendimento comercial localizado em Osasco-SP. Para a estabilização das escavações, foram construídas quatro contenções (vistas 1 a 4) abrangendo uma área de face de $704 \mathrm{~m}^{2}$. A Figura 3.56 apresenta a localização, em planta, das contenções de solo pregado. O programa experimental foi desenvolvido em um trecho da vista 1 (indicado no desenho), em que as condições de contorno, ou seja, geologia e estado de tensões, se aproximavam. O trecho de estudo apresenta extensão de $25,0 \mathrm{~m}$ e altura constante de 5,30 m. 
Análise de diferentes metodologias executivas de solo pregado a partir de ensaios de arrancamento em campo e laboratório

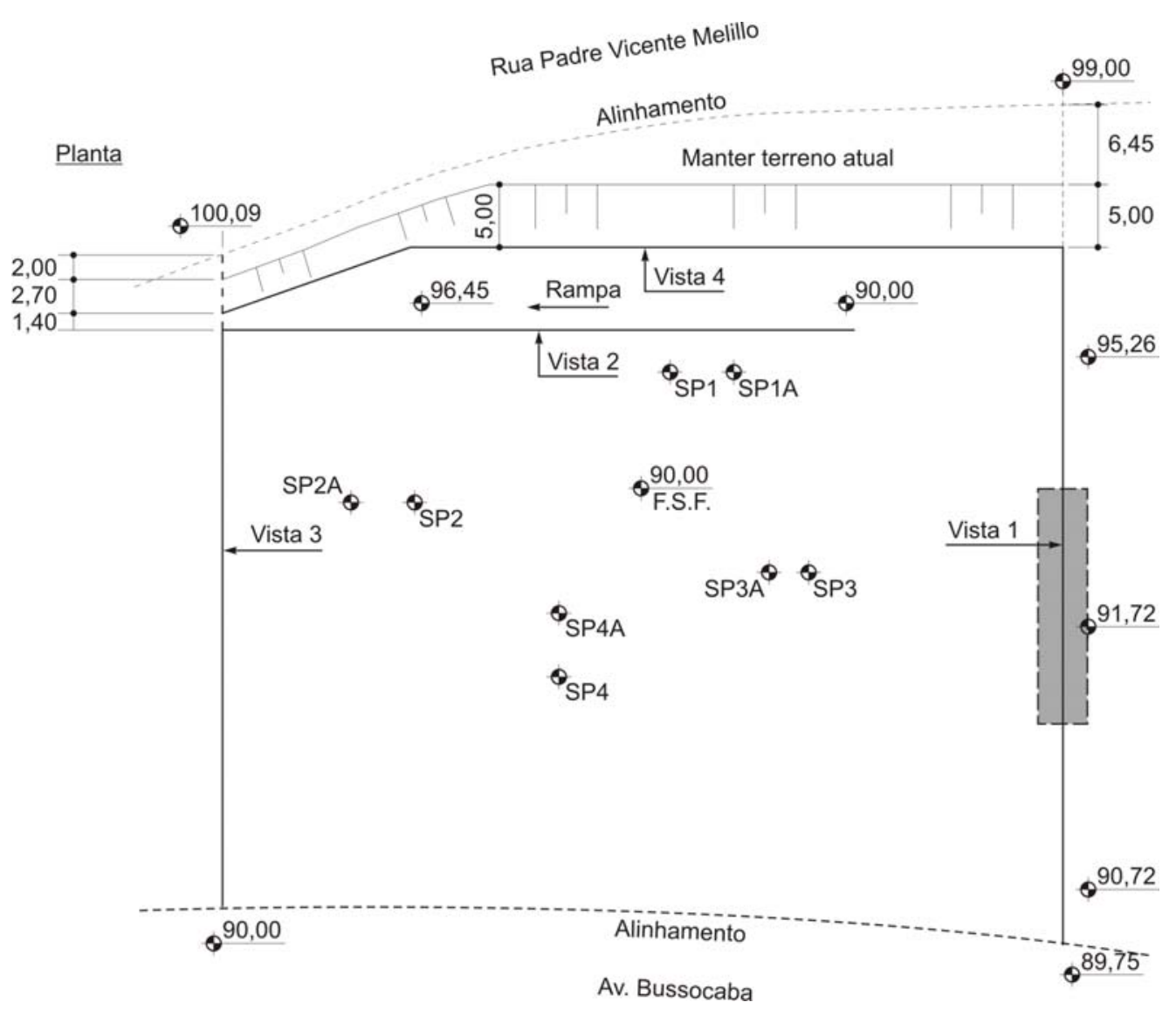

Figura 3.56. Vista em planta das contenções, com destaque para a área de estudo.

\subsubsection{Investigações Geotéc nic as}

$\mathrm{Na}$ região de estudo, a sondagem de simples reconhecimento mais representativa (SP-03) permitiu identificar três camadas com características geotécnicas distintas. Entre 0 e 1,00 m, identificou-se um aterro de argila arenosa, pouco siltosa, vermelha. A partir desta profundidade, observou-se um perfil de alteração de solo residual de gnaisse. Até a profundidade de $3,0 \mathrm{~m}$, identificou-se uma argila porosa, arenosa, pouco siltosa com NSPT médio igual a 2. Abaixo desta camada e até a profundidade de 5,0 $\mathrm{m}$, observou-se um silte arenoso, amarelo e cinza claro. Por fim, até o impenetrável (7,40 m), o subsolo é composto por um solo saprolítico constituído por areia fina, pouco siltosa, com fragmentos de rocha cinza clara. A Figura 3.57 mostra um corte que ilustra a distribuição das camadas de solo, os respectivos valores de $\mathrm{N}_{\mathrm{SPT}} \mathrm{e}$ as profundidades em que foram construídos os chumbadores testes, ou seja, na profundidade de 2,70 m (Linha 3) com $\mathrm{N}_{\mathrm{SPT}}$ igual a 3 e na 
Análise de diferentes metodologias executivas de solo pregado a partir de ensaios de arrancamento em campo e laboratório

camada de solo saprolitico, na profundidade de 4,80 m (Linha 5). Na profundidade de 4,80 $\mathrm{m}$, obteve-se o valor de $\mathrm{N}_{\mathrm{SPT}}$ igual a 5, sendo crescente até o impenetrável.

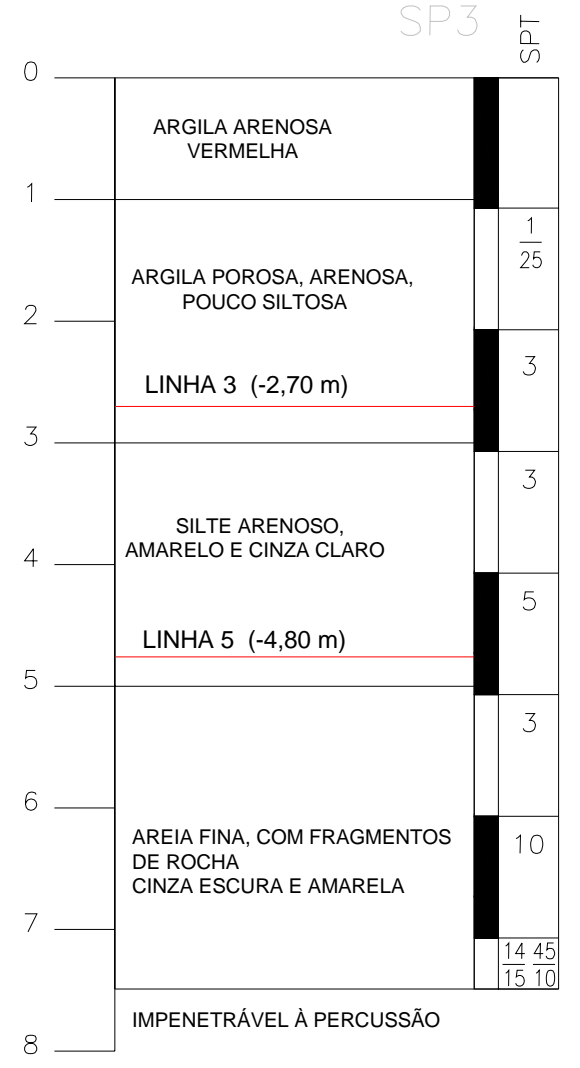

Figura 3.57. Distribuição das camadas de solo na obra de Osasco-SP.

Para permitir a realização de ensaios de laboratório, foram coletadas, nas duas profundidades de interesse, amostras deformadas e indeformadas de solos. As amostras indeformadas foram retiradas a partir de escavação manual, utilizando-se uma caixa metálica cúbica de $0,25 \mathrm{~m}$ como fôrma. Para garantir a proteção mecânica durante o transporte e evitar perdas de umidade, as amostras foram envolvidas com faixas e parafina e armazenadas em caixa de madeira envolvida com pó de serra, até serem armazenadas em câmera úmida do Laboratório de Geotecnia da EESC/USP. A Figura 3.58 apresenta a coleta das amostras indeformadas (a) e a sua proteção com parafina (b). 
Análise de diferentes metodologias executivas de solo pregado a partir de ensaios de arrancamento em campo e laboratório

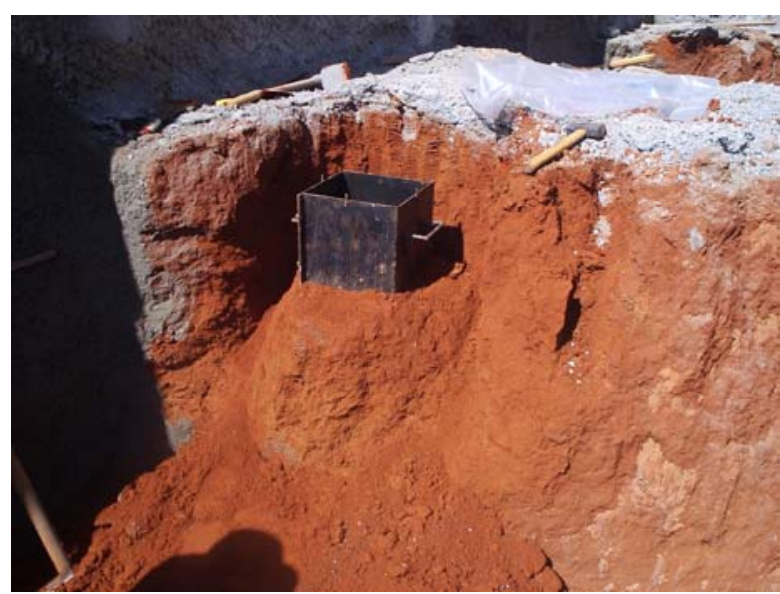

(a)

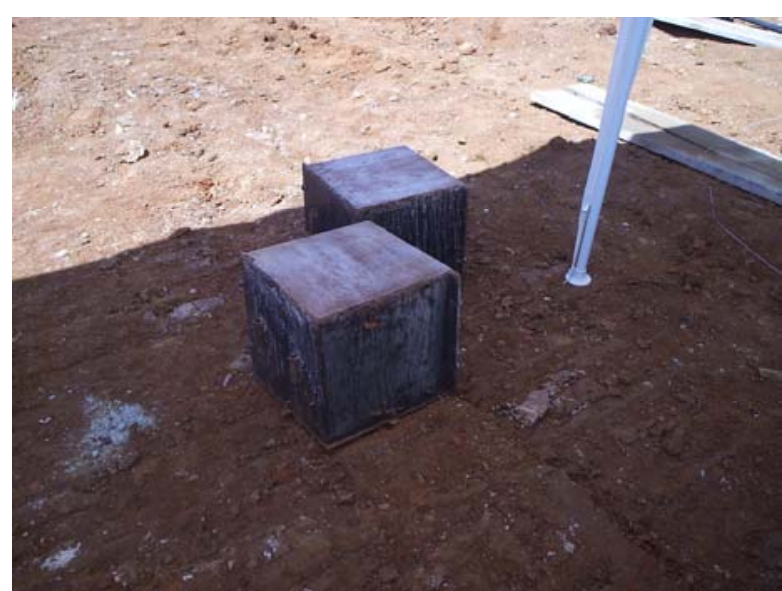

(b)

Figura 3.58. (a) Detalhe da coleta de amostra indeformada e (b) da proteção com parafina.

A Tabela 3.14 apresenta os resultados dos ensaios geotécnicos realizados.

Tabela 3.14. Características geotécnicas dos solos utilizados.

\begin{tabular}{ccc}
\hline Propriedade & Linha 3 & Linha 5 \\
\hline Massa Específica dos Sólidos $\left(\rho_{\mathrm{s}}\right) \mathrm{g} / \mathrm{cm}^{3}$ & 2,649 & 2,632 \\
Teor de Argila (\%) & 44,8 & 42,5 \\
Teor de Silte (\%) & 15,2 & 12,5 \\
Teor de Areia (\%) & 40,0 & 45,0 \\
LL (\%) & 56 & 54 \\
LP (\%) & 33 & 31 \\
Peso Específico $\left(\mathrm{kN} / \mathrm{m}^{3}\right)$ & 17,1 & 19,5 \\
Umidade Natural $(\%)$ & 31,0 & 20,3 \\
\hline
\end{tabular}

Foram realizados ensaios de compressão triaxial, do tipo consolidado não drenado (CU), e ensaios de cisalhamento direto na umidade natural. As tensões de confinamento utilizadas no ensaio triaxial e as tensões verticais do ensaio de cisalhamento direto foram de 25,50 e $100 \mathrm{kPa}$. Estas tensões foram adotadas de modo a serem compatíveis com as tensões verticais atuantes sobre os chumbadores executados.

A Figura 3.59 apresenta as envoltórias de resistência total e efetiva em termos de coordenadas p e q, obtidas a partir de ensaios triaxiais em amostras de solos das linhas 3 (a) e 5 (b). 
Análise de diferentes metodologias executivas de solo pregado a partir de ensaios de arrancamento em campo e laboratório

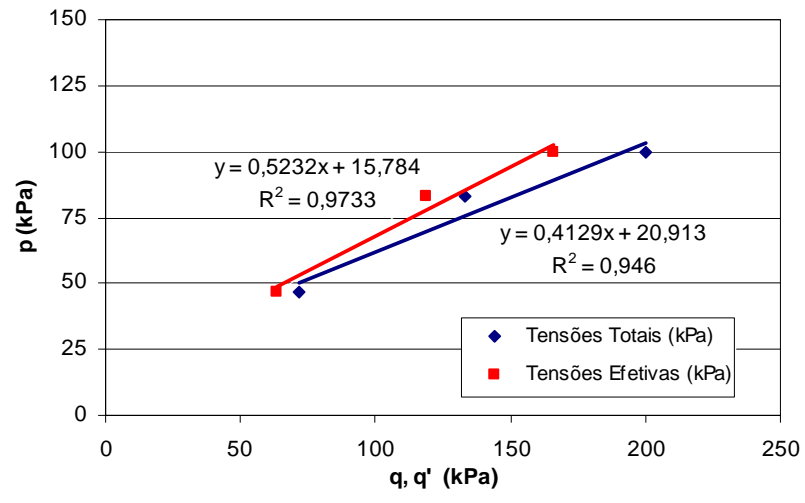

(a)

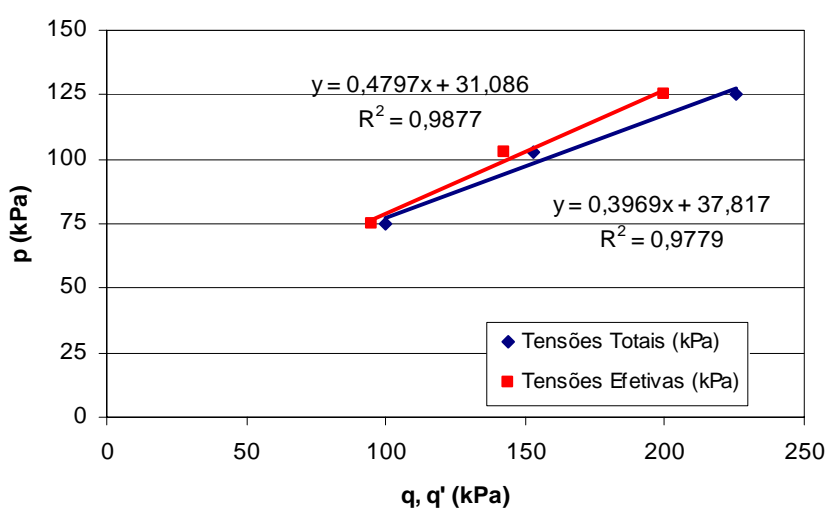

(b)

Figura 3.59. Envoltórias de resistência total e efetiva obtidas a partir de ensaios triaxias em amostras de solos das linhas 3 (a) e 5 (b) (Lima, 2009).

Também foram realizados ensaios de cisalhamento direto. Estes parâmetros possibilitaram uma comparação com os valores obtidos de ensaio triaxial e de cisalhamento direto de interface. A Figura 3.60 ilustra as curvas de Tensão Cisalhante x Deslocamento do ensaio de cisalhamento direto e as envoltórias de resistência obtidas.

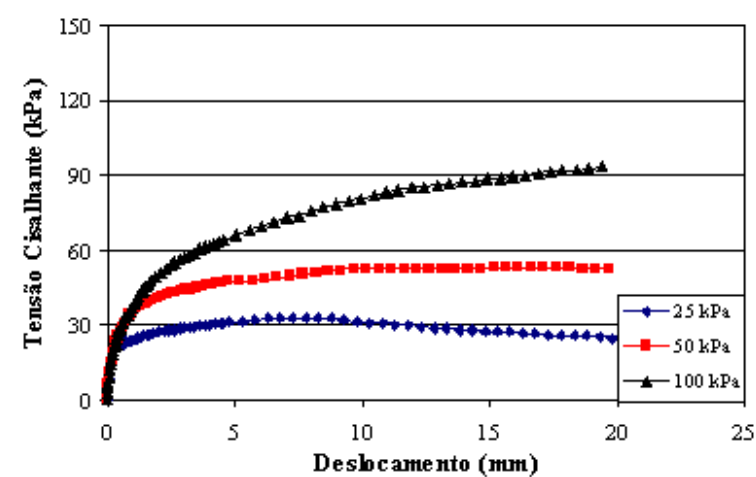

(a)

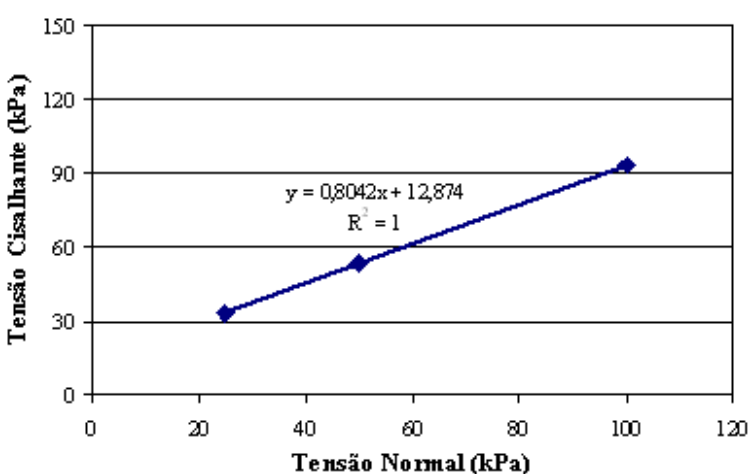

(b) 


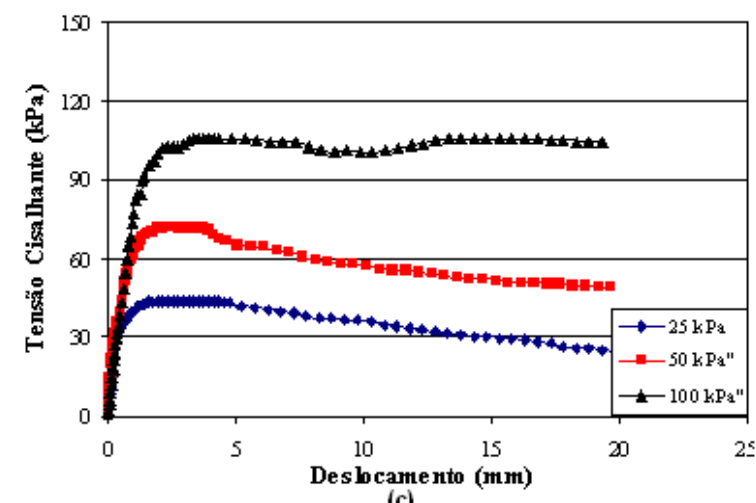

(c)

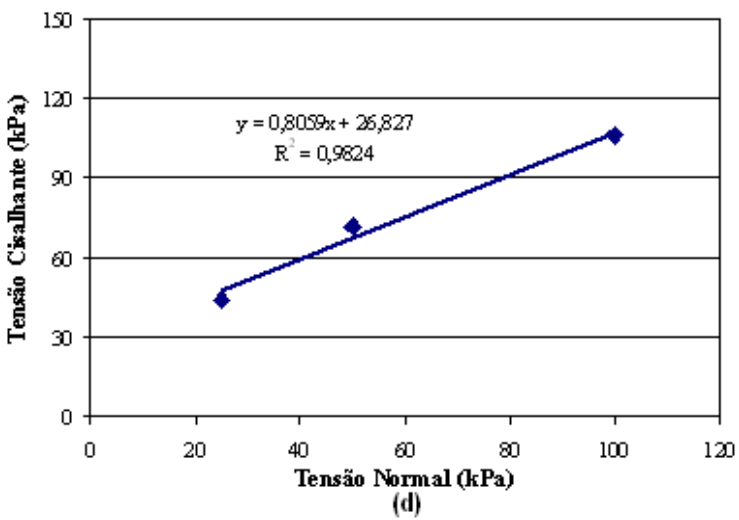

(d)

Figura 3.60. Curva Tensão Cisalhante x Deslocamento para os solos das linhas 3 (a) e 5 (c) e envoltória de resistência para os solos das linhas 3 (b) e 5 (d) (Lima, 2009).

O solo da linha 3 é uma argila arenosa porosa. As curvas resultantes dos ensaios de cisalhamento, sob diferentes tensões normais não apresentaram pico. Portanto, o critério de ruptura empregado foi definido a partir das deformações de 15 a $20 \%$, tomando como referência Vilar (2003). Já as amostras de solo da linha 5, sob tensões normais de 25 e 50 $\mathrm{kPa}$, apresentaram um pico bem definido. No entanto, para a tensão de $100 \mathrm{kPa}$, o solo apresentou um comportamento plástico, ou seja, sem um pico definido.

A Tabela 3.15 apresenta um resumo dos parâmetros de resistência (c e $\phi)$ totais e efetivos obtidos para as duas profundidades de interesse, a partir dos ensaios triaxiais e de cisalhamento direto.

Tabela 3.15. Parâmetros totais e efetivos de resistência ao cisalhamento.

\begin{tabular}{lc|cccc}
\hline \multirow{2}{*}{ Local } & \multirow{2}{*}{ Ensaio } & \multicolumn{2}{|c}{ Total } & \multicolumn{2}{c}{ Efetiva } \\
& & $\mathbf{c}$ & $\boldsymbol{\phi}$ & $\mathbf{c}^{\prime}$ & $\boldsymbol{\phi}^{\prime}$ \\
& & $(\mathbf{k P a})$ & $\left.\mathbf{(}^{\circ}\right)$ & $\mathbf{( k P a )}$ & $\left.\mathbf{(}^{\circ}\right)$ \\
\hline \multirow{2}{*}{ Linha 3 } & Triaxial & 22,9 & 24,4 & 18,5 & 31,5 \\
& Cisal. Direto & 12,9 & 38,8 & - & - \\
\multirow{2}{*}{ Linha 5 } & Triaxial & 41,2 & 23,4 & 35,5 & 28,7 \\
& Cisal. Direto & 26,8 & 38,9 & - & - \\
\hline
\end{tabular}

Como esperado, o solo da linha 5 apresenta resistência superior ao da linha 3. Isto se deve, provavelmente, às diferenças entre as gêneses destes solos. Enquanto o solo da linha 3, mais superficial, foi classificado como uma argila arenosa e de natureza porosa, o solo da linha 5 foi classificado como uma areia argilosa e de natureza saprolítica. 


\subsubsection{Exec ução dos Chumbadores Testes}

Os chumbadores testes foram distribuídos ao longo de duas profundidades (linhas 3 e 5), com o objetivo de avaliar a influência das diferentes metodologias executivas na resistência ao cisalhamento de interface, para diferentes tipos de solos. A Figura 3.61 apresenta a distribuição dos chumbadores testes ao longo das linhas 3 e 5 . Os chumbadores encontram-se numerados e identificados quanto ao seu comprimento e à metodologia empregada na sua execução (letras no centro da circunferência).

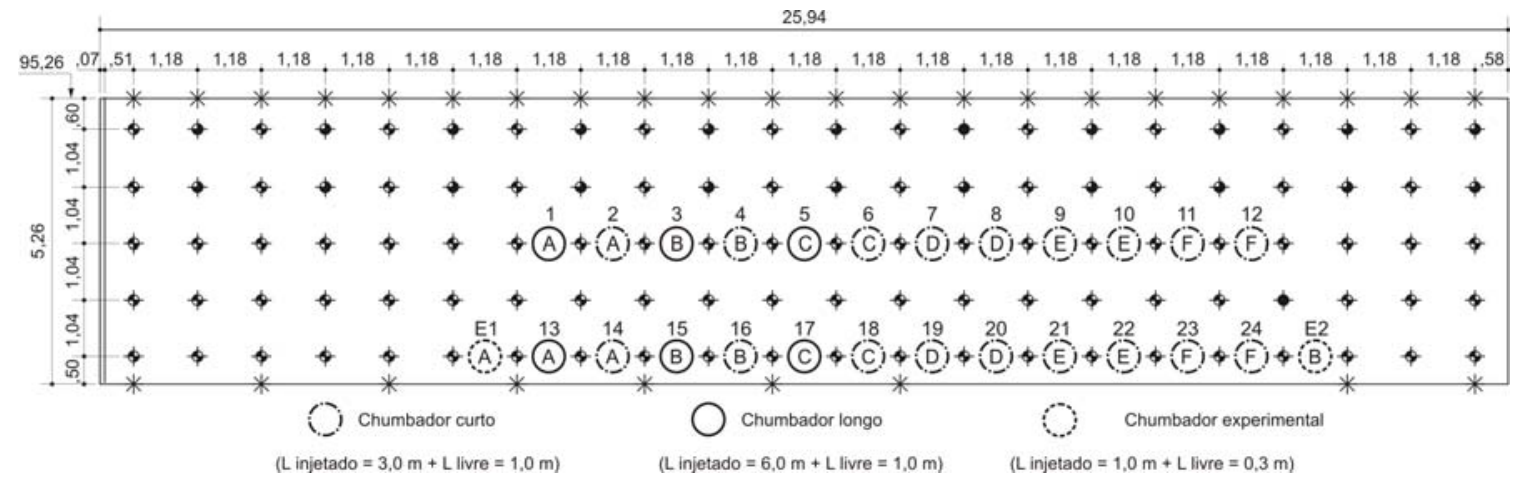

Figura 3.61. Distribuição, numeração, comprimento e metodologia executiva adotada na execução dos chumbadores testes das linhas 3 e 5 .

A partir da distribuição dos chumbadores testes apresentadas na Figura 3.61, observa-se que as linhas 3 e 5 foram construídas com 3 chumbadores longos e 9 chumbadores curtos. Para verificar o comportamento de chumbadores de menor comprimento, foram construídos dois chumbadores adicionais (E1 e E2) com 1,30 m de comprimento, sendo $1,00 \mathrm{~m}$ de comprimento injetado e $0,30 \mathrm{~m}$ de comprimento livre. $\mathrm{O}$ chumbador "E1" foi construído com a metodologia A, enquanto o chumbador "E2" foi construído com a metodologia B.

Os chumbadores da obra de Osasco-SP foram executados com os mesmos materiais (barra de aço CA-50 de $25,3 \mathrm{~mm}$ de diâmetro) e seguindo os mesmos procedimentos executivos da obra de Santo André-SP (obra 1), empregados nas etapas de preparação, perfuração, execução da bainha, inserção das barras de aço no maciço de solo e injeção. Buscando-se quantificar a influência de diferentes sistemas construtivos na 
resistência ao cisalhamento de interface solo/reforço, os chumbadores foram executados seguindo as metodologias executivas já apresentadas anteriormente.

A Figura 3.62 apresenta uma vista geral do local onde foram construídos os chumbadores testes (a) e da etapa de escavação, em nichos, para a execução dos chumbadores das linhas 3 (b) e 5 (c).

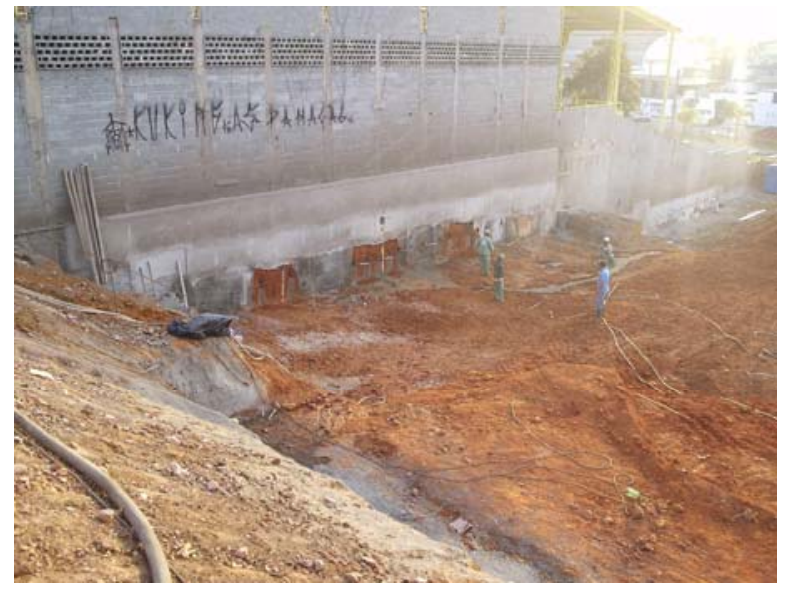

(a)

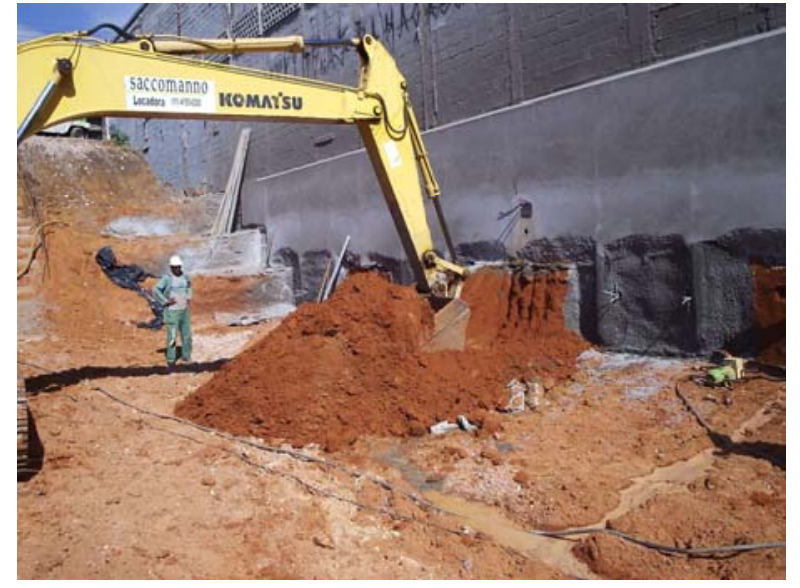

(b)

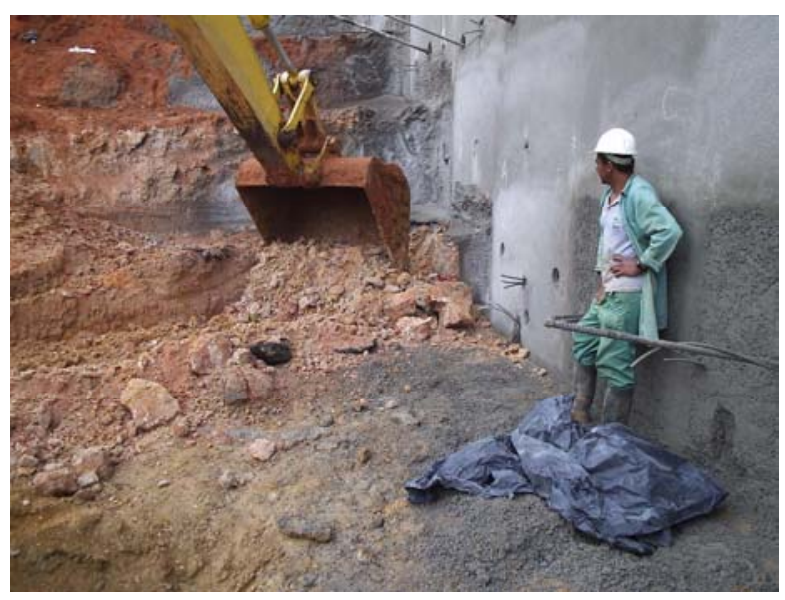

(c)

Figura 3.62. (a) Vista geral do local em que foram construídos os chumbadores testes e detalhes das etapas de escavação, em nichos, para a execução dos chumbadores testes das linhas 3 (b) e 5 (c).

A Figura 3.63 ilustra as etapas de execução dos chumbadores testes das linhas 3 e 5. Vale a pena ressaltar que, nesta obra, em virtude do cronograma ser mais enxuto, após a execução da linha 3, as escavações para as linhas subseqüentes prosseguiram normalmente 
até a linha 5. Sendo assim, os ensaios de arrancamento foram executados em uma mesma fase para as linhas 3 e 5 .

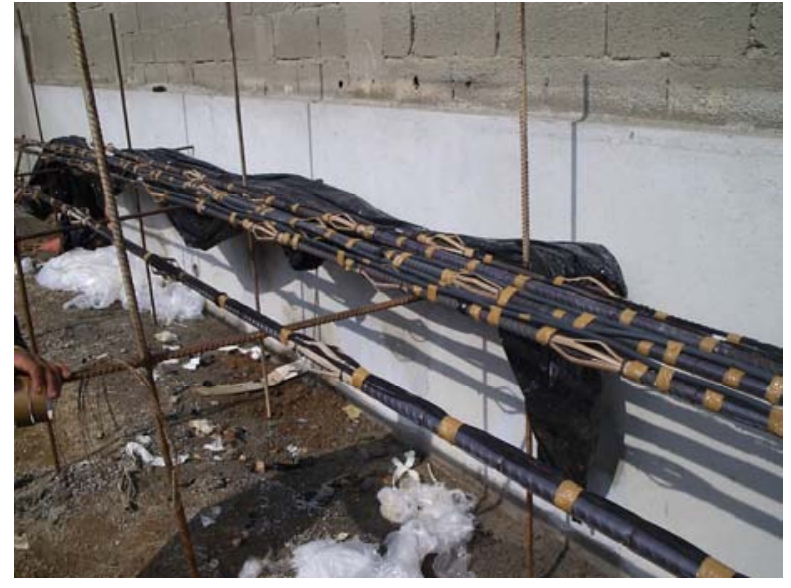

(a)

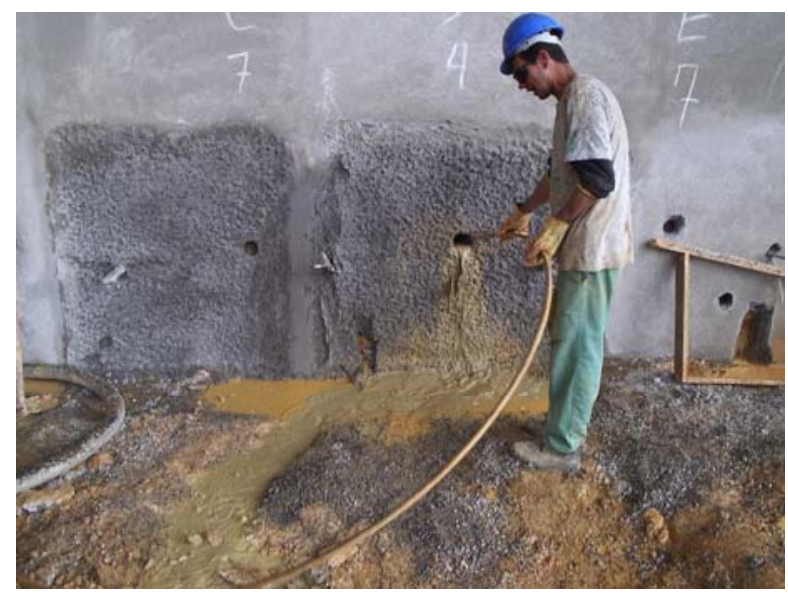

(c)

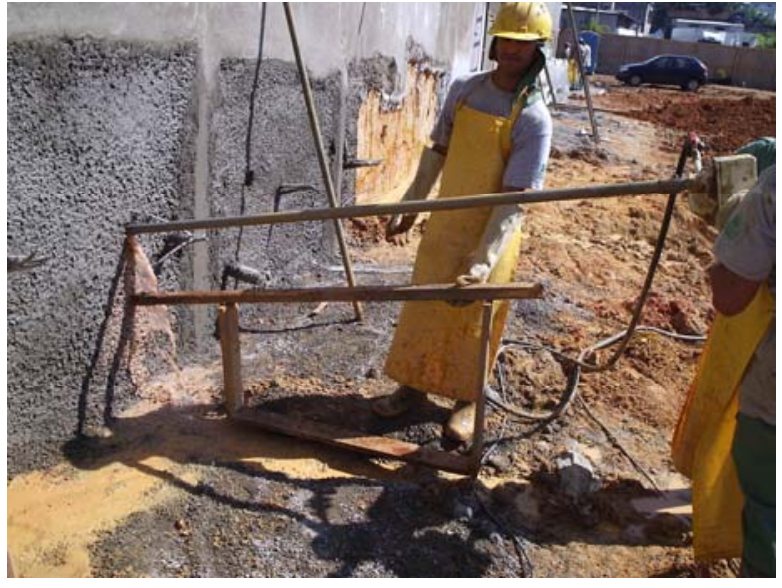

(b)

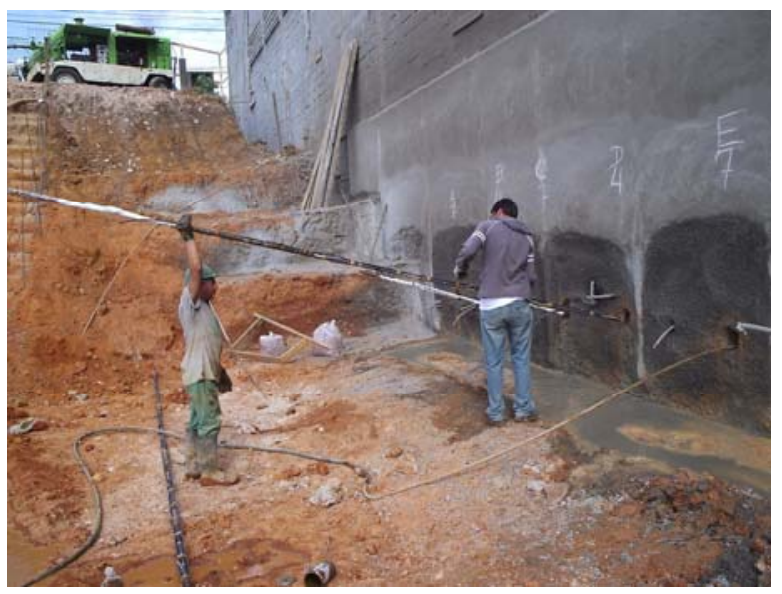

(d) 


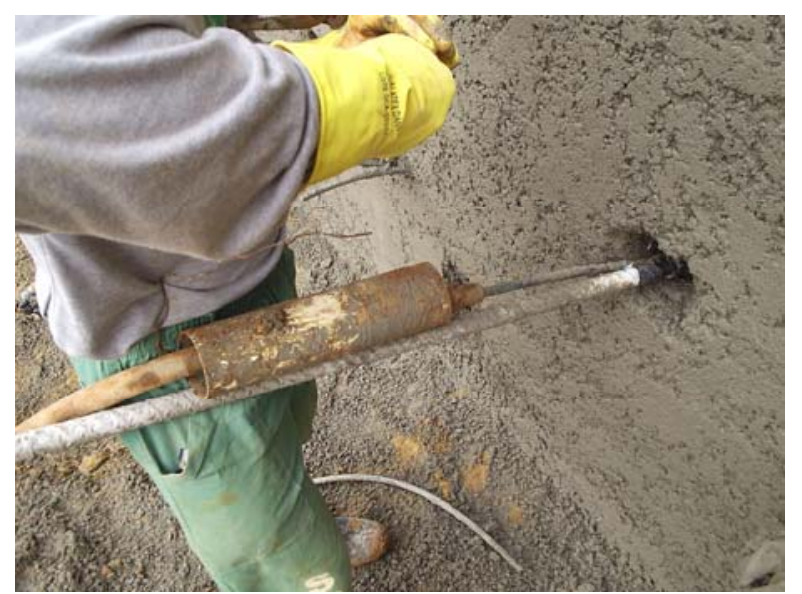

(e)

Figura 3.63. Etapas de execução dos chumbadores testes das linhas 3 e 5. (a) Preparação dos chumbadores, (b) perfuração com lavagem de água, (c) preenchimento do furo com calda de cimento (bainha), (d) inserção da barra de aço no maciço de solo e (e) injeção de calda de cimento.

As injeções foram iniciadas após um intervalo mínimo de 12 horas da execução da bainha, obedecendo ao procedimento da obra, de realizar uma injeção por dia. Assim como na obra 1, controlou-se o volume e a pressão de injeção. As Tabelas 3.16 e 3.17 apresentam o resumo do controle de execução dos chumbadores testes executados nas linhas 3 e 5, respectivamente. 
Tabela 3.16. Controle de execução dos chumbadores testes da linha 3 (Obra 2).

\begin{tabular}{|c|c|c|c|c|c|c|c|c|c|c|c|c|c|c|c|c|c|c|}
\hline \multicolumn{4}{|c|}{ Chumbador } & \multicolumn{2}{|c|}{ Bainha } & \multicolumn{4}{|c|}{$1^{a}$ Fase } & \multicolumn{4}{|c|}{$2^{\mathrm{a}}$ Fase } & \multicolumn{4}{|c|}{$3^{\text {a }}$ Fase } & \multirow{2}{*}{$\begin{array}{c}\text { Total Volume } \\
\text { Injetado (litros) }\end{array}$} \\
\hline Id & Met. & Tipo & Instr. & Data & Hora & Data & Hora & $\frac{\text { Pressão }}{(\mathrm{MPa})}$ & $\begin{array}{l}\text { Volume } \\
\text { (litros) }\end{array}$ & Data & Hora & $\begin{array}{l}\text { Pressão } \\
\text { (MPa) }\end{array}$ & $\begin{array}{l}\text { Volume } \\
\text { (litros) }\end{array}$ & Data & Hora & $\begin{array}{l}\text { Presão } \\
\text { (MPa) } \\
\end{array}$ & $\begin{array}{l}\text { Volume } \\
\text { (litros) }\end{array}$ & \\
\hline 1 & A & Longo & $\operatorname{sim}$ & $24 / 7 / 08$ & $13: 10$ & & & & & & & & & & & & & 0,0 \\
\hline 2 & A & Curto & não & $24 / 7 / 08$ & $13: 15$ & & & & & & & & & & & & & 0,0 \\
\hline 3 & B & Longo & $\operatorname{sim}$ & $24 / 7 / 08$ & $13: 20$ & $25 / 7 / 08$ & 08:10 & 2,0 & 40,0 & & & & & & & & & 40,0 \\
\hline 4 & B & Curto & $\operatorname{sim}$ & $24 / 7 / 08$ & $13: 25$ & $25 / 7 / 08$ & 08:15 & 2,0 & 10,0 & & & & & & & & & 10,0 \\
\hline 5 & $\mathrm{C}$ & Longo & $\operatorname{sim}$ & $24 / 7 / 08$ & $13: 30$ & $25 / 7 / 08$ & 08:20 & 1,2 & 30,0 & $26 / 7 / 08$ & 09:00 & 2,0 & 12,0 & & & & & 42,0 \\
\hline 6 & $\mathrm{C}$ & Curto & $\operatorname{sim}$ & $23 / 7 / 08$ & $16: 20$ & $24 / 7 / 08$ & 09:40 & 1,5 & 30,0 & $25 / 7 / 08$ & $08: 25$ & 1,5 & 10,0 & & & & & 40,0 \\
\hline 7 & $\mathrm{D}$ & Curto & $\operatorname{sim}$ & $23 / 7 / 08$ & $16: 25$ & $24 / 7 / 08$ & 09:45 & 1,0 & 12,0 & $25 / 7 / 08$ & 08:30 & 1,2 & 30,0 & $26 / 7 / 08$ & 09:10 & 2,0 & 0 & 42,0 \\
\hline 8 & $\mathrm{D}$ & Curto & não & $23 / 7 / 08$ & $16: 30$ & $24 / 7 / 08$ & 09:50 & 1,2 & 10,0 & $25 / 7 / 08$ & $08: 40$ & 1,0 & 30,0 & $26 / 7 / 08$ & 09:15 & 1,5 & 0 & 40,0 \\
\hline 9 & E & Curto & $\operatorname{sim}$ & $23 / 7 / 08$ & $16: 35$ & $24 / 7 / 08$ & 09:55 & 1,5 & 30,0 & $25 / 7 / 08$ & 08:50 & 1,5 & 0,0 & & & & & 30,0 \\
\hline 10 & E & Curto & não & $23 / 7 / 08$ & $16: 40$ & $24 / 7 / 08$ & $10: 00$ & 1,5 & 30,0 & $25 / 7 / 08$ & 08:55 & 1,2 & 30,0 & & & & & 60,0 \\
\hline 11 & $\mathrm{~F}$ & Curto & $\operatorname{sim}$ & $23 / 7 / 08$ & $16: 45$ & $24 / 7 / 08$ & 10:05 & 1,2 & 10,0 & $25 / 7 / 08$ & 09:05 & 1,5 & 0,0 & $26 / 7 / 08$ & 09:25 & 1,5 & 0 & 10,0 \\
\hline 12 & $\mathrm{~F}$ & Curto & não & $23 / 7 / 08$ & $16: 50$ & $24 / 7 / 08$ & $10: 10$ & 1,5 & 5,0 & $25 / 7 / 08$ & 09:10 & 2,0 & 10,0 & $26 / 7 / 08$ & 09:35 & 2,0 & 0 & 15,0 \\
\hline
\end{tabular}


Tabela 3.17. Controle de execução dos chumbadores testes da linha 5 (Obra 2).

\begin{tabular}{|c|c|c|c|c|c|c|c|c|c|c|c|c|c|c|c|c|c|c|}
\hline \multicolumn{4}{|c|}{ Chumbador } & \multicolumn{2}{|c|}{ Bainha } & \multicolumn{4}{|c|}{$1^{\mathrm{a}}$ Fase } & \multicolumn{4}{|c|}{$2^{\mathrm{a}}$ Fase } & \multicolumn{4}{|c|}{$3^{\mathrm{a}}$ Fase } & \multirow{2}{*}{$\begin{array}{c}\text { Total Volume } \\
\text { Injetado (litros) }\end{array}$} \\
\hline Id & Met. & Tipo & Instr. & Data & Hora & Data & Hora & $\frac{\text { Pressão }}{\text { (MPa) }}$ & $\begin{array}{l}\text { Volume } \\
\text { (litros) }\end{array}$ & Data & Hora & $\frac{\text { Pressão }}{\text { (MPa) }}$ & $\begin{array}{l}\text { Volume } \\
\text { (litros) }\end{array}$ & Data & Hora & $\begin{array}{l}\text { Presão } \\
\text { (MPa) }\end{array}$ & $\begin{array}{l}\text { Volume } \\
\text { (litros) }\end{array}$ & \\
\hline 13 & A & Longo & $\operatorname{sim}$ & $6 / 8 / 08$ & 11:05 & & & & & & & & & & & & & 0,0 \\
\hline 14 & A & Curto & $\operatorname{sim}$ & $6 / 8 / 08$ & $11: 10$ & & & & & & & & & & & & & 0,0 \\
\hline 15 & B & Longo & $\operatorname{sim}$ & $6 / 8 / 08$ & $11: 15$ & $7 / 8 / 08$ & 09:00 & 2,0 & 40,0 & & & & & & & & & 40,0 \\
\hline 16 & B & Curto & não & $5 / 8 / 08$ & $13: 30$ & $6 / 8 / 08$ & 09:30 & 1,0 & 10,0 & & & & & & & & & 10,0 \\
\hline 17 & $\mathrm{C}$ & Longo & $\operatorname{sim}$ & $6 / 8 / 08$ & $11: 20$ & $7 / 8 / 08$ & 09:10 & 1,2 & 30,0 & $8 / 8 / 08$ & 08:45 & 2,0 & 0,0 & & & & & 30,0 \\
\hline 18 & $\mathrm{C}$ & Curto & não & $5 / 8 / 08$ & $13: 35$ & $6 / 8 / 08$ & 09:40 & 1,5 & 5,0 & $7 / 8 / 08$ & 09:20 & 1,5 & 10,0 & & & & & 15,0 \\
\hline 19 & D & Curto & $\operatorname{sim}$ & $5 / 8 / 08$ & $13: 40$ & $6 / 8 / 08$ & 09:45 & 1,5 & 5,0 & $7 / 8 / 08$ & 09:25 & 1,2 & 30,0 & $8 / 8 / 08$ & 08:00 & 1,5 & 0,0 & 35,0 \\
\hline 20 & D & Curto & não & $5 / 8 / 08$ & $13: 45$ & $6 / 8 / 08$ & 09:50 & 1,5 & 0,0 & $7 / 8 / 08$ & 09:30 & 1,0 & 30,0 & $8 / 8 / 08$ & 08:10 & 1,5 & 0,0 & 30,0 \\
\hline 21 & E & Curto & $\operatorname{sim}$ & $5 / 8 / 08$ & $13: 50$ & 6/8/08 & 09:55 & 1,5 & 0,0 & $7 / 8 / 08$ & 09:40 & 1,5 & 10,0 & & & & & 10,0 \\
\hline 22 & $\mathrm{E}$ & Curto & não & $5 / 8 / 08$ & $13: 55$ & 6/8/08 & 10:00 & 1,2 & 0,0 & $7 / 8 / 08$ & 09:50 & 1,2 & 30,0 & & & & & 30,0 \\
\hline 23 & F & Curto & $\operatorname{sim}$ & $5 / 8 / 08$ & $14: 00$ & 6/8/08 & 10:05 & 1,2 & 0,0 & $7 / 8 / 08$ & $10: 00$ & 1,5 & 0,0 & $7 / 8 / 08$ & $10: 10$ & 1,5 & 0,0 & 0,0 \\
\hline 24 & $\mathrm{~F}$ & Curto & não & $5 / 8 / 08$ & $14: 05$ & 6/8/08 & $10: 10$ & 1,5 & 0,0 & $7 / 8 / 08$ & $10: 10$ & 2,0 & 0,0 & $8 / 8 / 08$ & 08:20 & 2,0 & 0,0 & 0,0 \\
\hline
\end{tabular}


A partir das Tabelas 3.16 e 3.17 verifica-se que a pressão máxima de injeção foi de 2,0 MPa, obtida para as diferentes fases de injeção. Assim como na obra 1, o critério de parada da injeção adotado foi o volume de calda de cimento de 51 litros, ou seja, o volume equivalente a uma calda de cimento preparada com um saco de cimento $(50 \mathrm{~kg})$ e relação água-cimento igual a 0,7 . Os resultados obtidos mostram que as injeções foram finalizadas antes de se atingir o critério de parada do volume, com pressões superiores às verificadas na obra 1. Este fato remete a uma melhor integridade dos chumbadores para menores números de injeções, ou seja, os chumbadores podem ter comportamentos mais homogêneos para este tipo de solo. O controle de execução poderá ser mais bem avaliado e comparado após as análises dos resultados de arrancamento.

A Figura 3.64 apresenta uma vista geral (a) e detalhada (b) da cortina de solo pregado, após a realização dos chumbadores testes das linhas 3 e 5, ou seja, antes da realização dos ensaios de arrancamento.

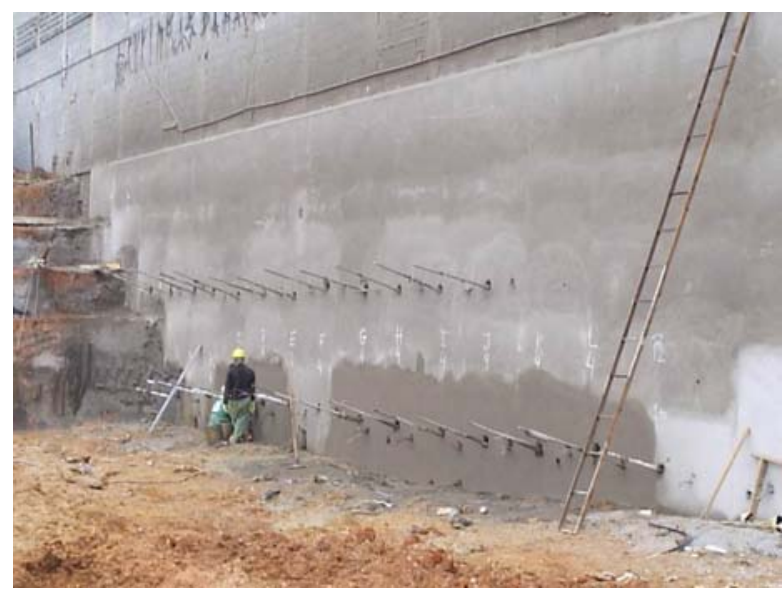

(a)

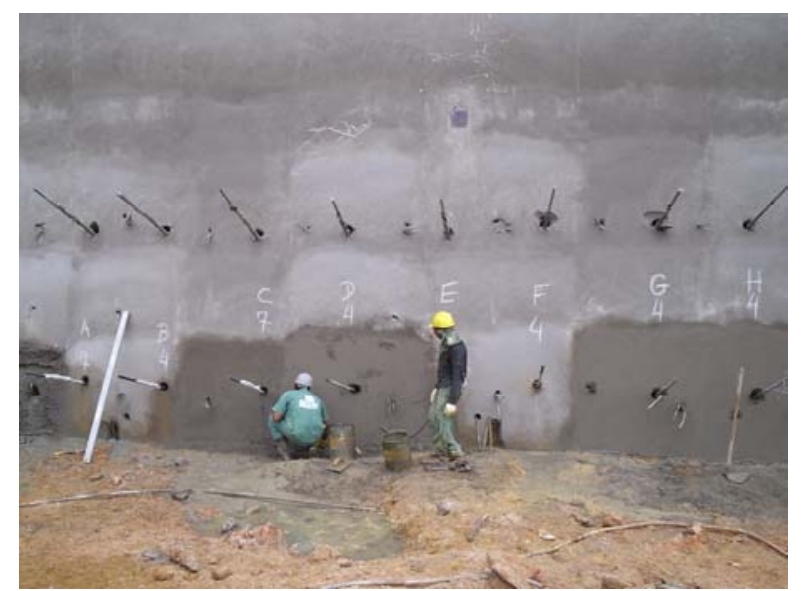

(b)

Figura 3.64. (a) Vista geral e (b) detalhada da cortina de solo pregado após a realização dos chumbadores testes das linhas 3 e 5 . 


\subsubsection{Ensaios de Arrancamento}

Para a realização dos ensaios de arrancamento, foram utilizados os seguintes equipamentos e acessórios:

(1) Placa de reação de aço, quadrada $(0,8 \mathrm{~m} \times 0,8 \mathrm{~m})$, com reforços em cantoneira distribuídos ao longo de sua área. A borda apresenta espessura de 5,0 mm, e a região interna apresenta espessura de $2,5 \mathrm{~mm}$;

(2) Suportes metálicos com furo central, para apoio do cilindro hidráulico. Estes suportes foram construídos para permitir o ajuste dos equipamentos na mesma inclinação da barra de aço. Esta peça possui seção retangular de 0,40 m x 0,15 m e uma furação central de $0,10 \mathrm{~m}$ de altura por $0,04 \mathrm{~m}$ de largura. A regulagem da inclinação é realizada por dois pares de parafusos acoplados em cada uma das extremidades da peça. Para permitir o perfeito ajuste/posicionamento dos equipamentos, foi necessário confeccionar chapas cilíndricas de 0,15 m de diâmetro, $25 \mathrm{~mm}$ de espessura e furação central de $35 \mathrm{~mm}$. Estas chapas eram apoiadas sobre o suporte metálico e serviam como apoio para o cilindro hidráulico;

(3) Macaco Hidráulico, da marca Enerpac, com furo central e $300 \mathrm{kN}$ de capacidade;

(4) Adaptador entre o macaco hidráulico e a célula de carga. Este adaptador metálico foi construído para promover a fixação da célula de carga no macaco hidráulico. A fixação junto ao macaco é realizada a partir de rosca, enquanto a fixação junto à célula de carga ocorre por seis conjuntos compostos por porcas, arruelas e parafusos;

(5) Célula de carga com furação central, apresentando $340 \mathrm{kN}$ de capacidade;

(6) Porcas e contra-porcas;

(7) Placa de referência com seção quadrada de $0,3 \times 0,3 \mathrm{~m}$ e espessura de 2,0 mm;

(8) Haste metálica apoiada em um tripé, para fixação dos transdutores de deslocamento de forma independente do movimento do macaco e da face de concreto projetado;

(9) Dois transdutores de deslocamento $(100 \mathrm{~mm})$ fixados à haste metálica, com bases magnéticas;

(10) Bomba hidráulica elétrica (inicialmente), sendo posteriormente substituída por bamba manual; 
Análise de diferentes metodologias executivas de solo pregado a partir de ensaios de arrancamento em campo e laboratório

(11) Sistema de aquisição de dados composto por três equipamentos de leitura P3, da marca Vishay Instruments. Estes equipamentos são portáteis, de pequena dimensão, e cada um deles apresenta quatro canais de leitura.

A Figura 3.65 mostra esses equipamentos e acessórios (1-9), utilizados para a realização dos ensaios de arrancamento no programa experimental de campo.

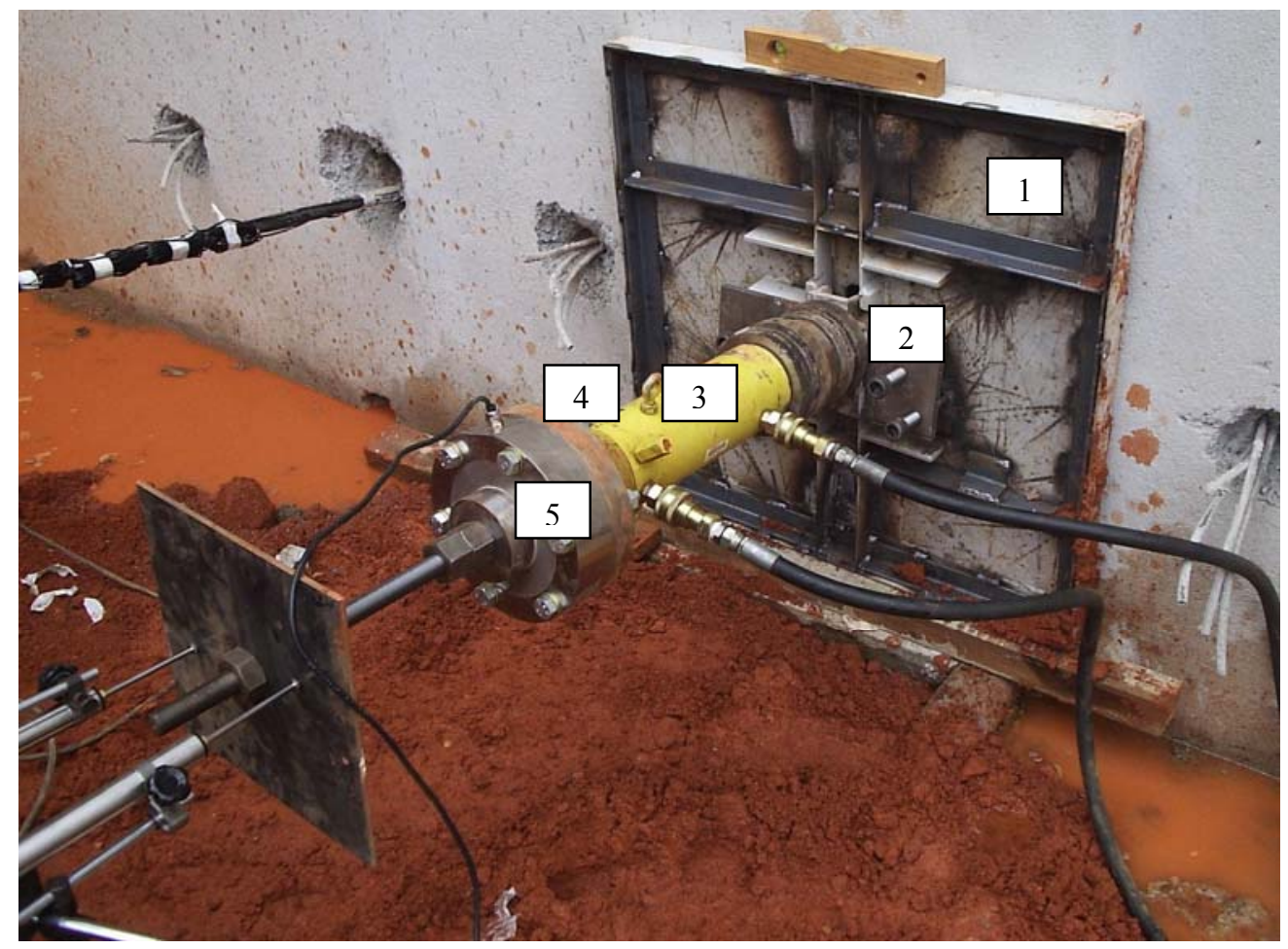




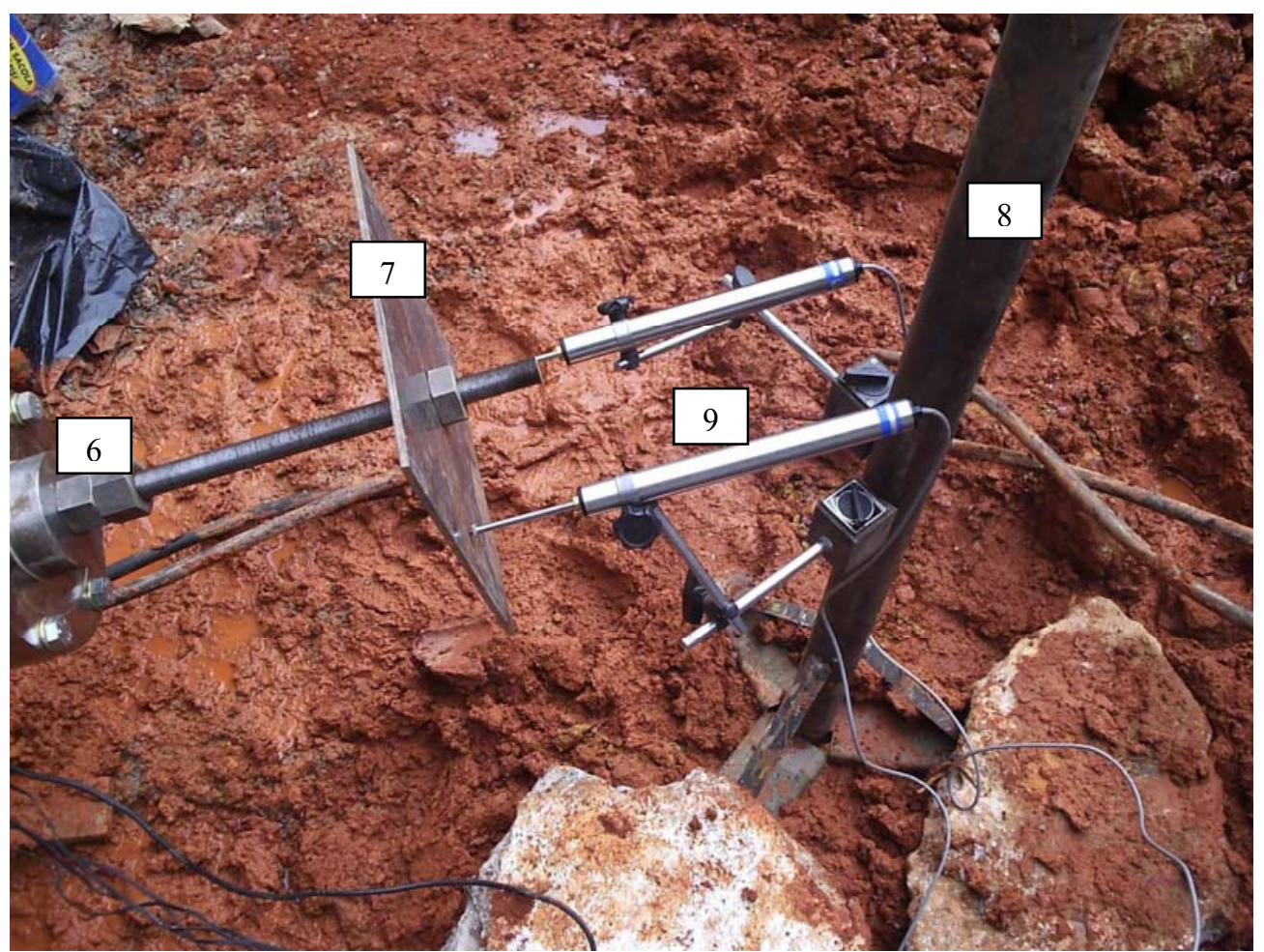

Figura 3.65. Detalhes dos equipamentos utilizados para a realização dos ensaios de arrancamento no programa experimental de campo.

Todos os chumbadores foram ensaiados com um mesmo procedimento. A primeira parte dos ensaios consistiu na aplicação de uma pequena carga (aperto da porca), para garantir um melhor ajuste do conjunto placa de reação, macaco-bomba, célula de carga e transdutor de deslocamento. O sistema de aquisição era iniciado e começava-se o ensaio. A partir dos equipamentos disponíveis, a metodologia utilizada no ensaio foi uma mistura entre o procedimento estabelecido por Clouterre (1991) - deslocamento controlado e as metodologias usuais da prática brasileira - força controlada (Springer, 2006). As cargas eram aplicadas ao chumbador por meio de macaco hidráulico, em estágios de 5,0 kN, de forma que os deslocamentos, devidamente controlados, fossem analisados concomitantemente, já que o sistema de leitura fazia a aquisição automática da célula de carga, dos transdutores de deslocamento e dos strain gages. Entre cada estágio de carregamento, aguardava-se o período de tempo necessário para a estabilização dos deslocamentos e das leituras dos strain gages. O ensaio de arrancamento foi realizado até atingir a condição de ruptura, definida por uma ruptura frágil (pico) ou uma ruptura plástica 
(deslocamentos crescentes sem incremento de carga). A Figura 3.66 apresenta o sistema de leitura utilizado para realizar a aquisição dos instrumentos e dos strain gages.

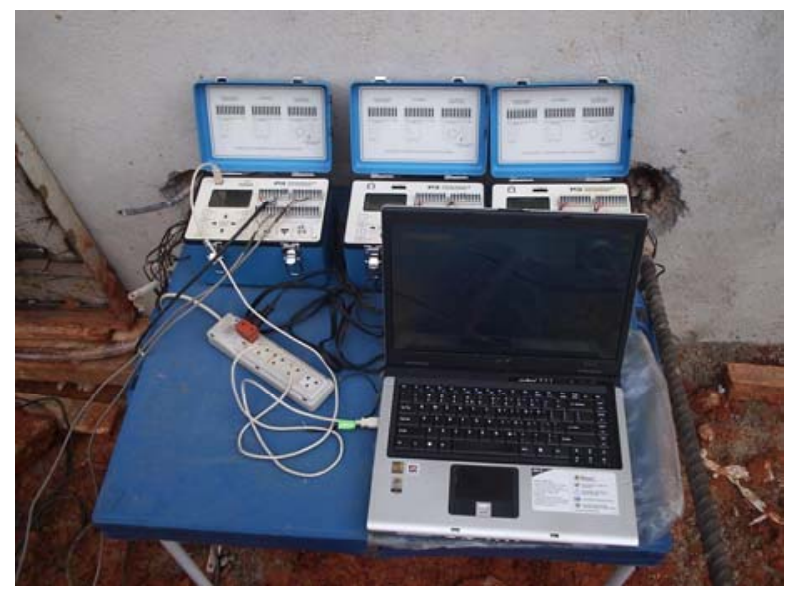

Figura 3.66. Detalhe do sistema de aquisição utilizado nos ensaios.

A Figura 3.67 apresenta o esquema de montagem utilizado para a realização dos ensaios de arrancamento nas linhas 2 (a) e 5 (b) da obra 1 e linhas 3 (c) e 5 (d) da obra 2.

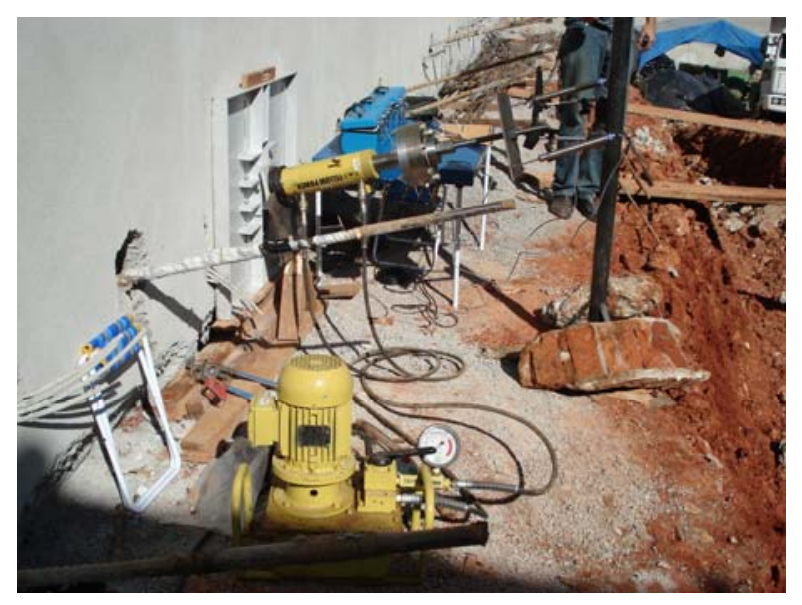

(a)

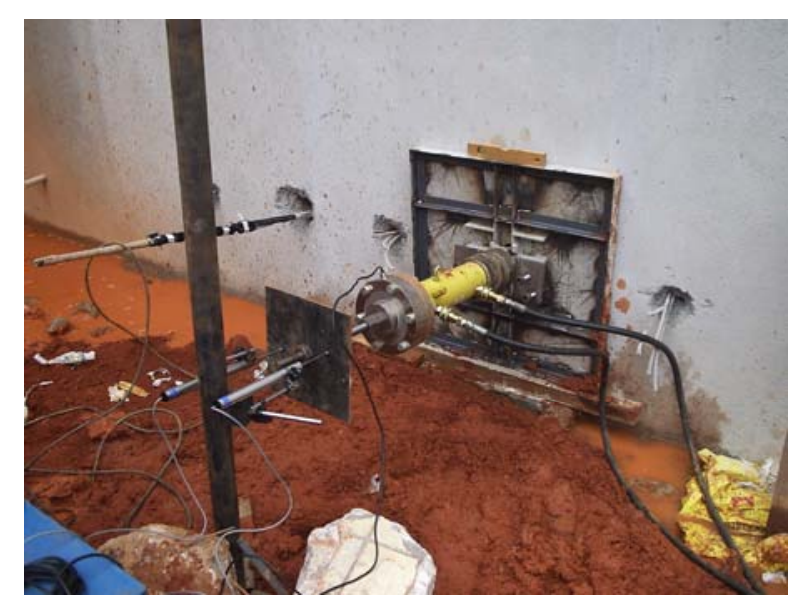

(b) 


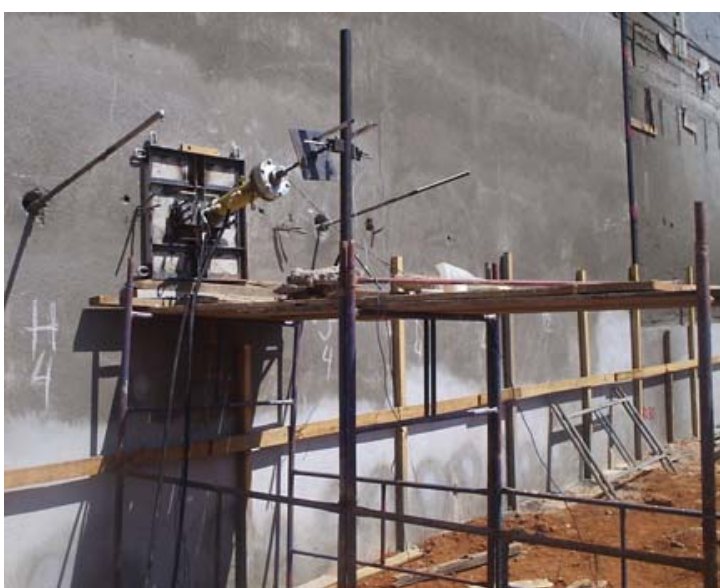

(c)

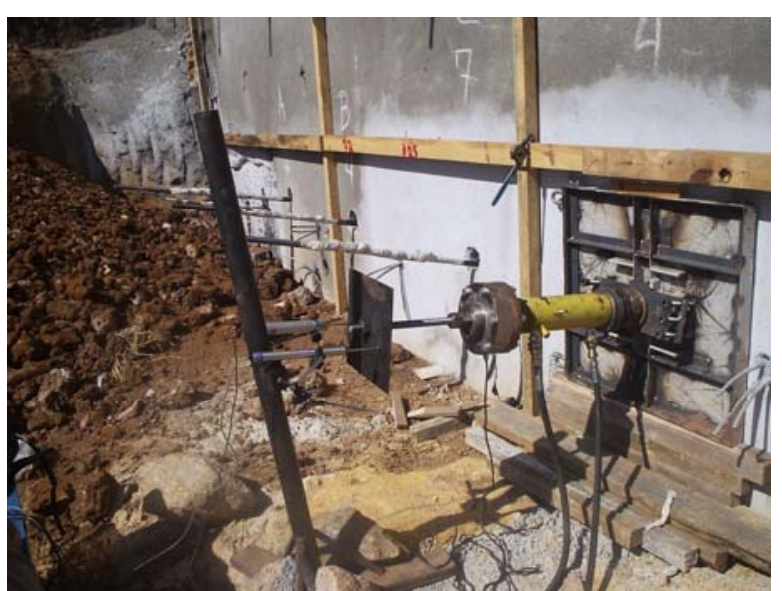

(d)

Figura 3.67. Detalhe dos equipamentos e esquema de montagem utilizada para a realização dos ensaios de arrancamento na linha 2 (a) e linha 5 (b) da obra 1 e na linha 3 (c) e linha 5 (d) da obra 2.

Os resultados obtidos serão apresentados no Capítulo 5 (Resultados e Análises). Vale a pena ressaltar que durante a realização dos ensaios, foram encontradas algumas dificuldades, como problemas na bomba elétrica, que culminaram na sua troca por uma bomba hidráulica manual, e o aparecimento de trincas horizontais e verticais durante a realização dos ensaios dos chumbadores longos. A placa de reação precisou passar por algumas adaptações, como, por exemplo, a mudança da fixação da chapa metálica para a regulagem da inclinação dos equipamentos. Este fato impediu que fossem ultrapassadas cargas de $200 \mathrm{kN}$, inviabilizando o término de alguns ensaios de chumbadores longos, principalmente aqueles realizados com maiores números de injeções. A Figura 3.68 apresenta detalhe das trincas horizontais e verticais na face de concreto projetado.

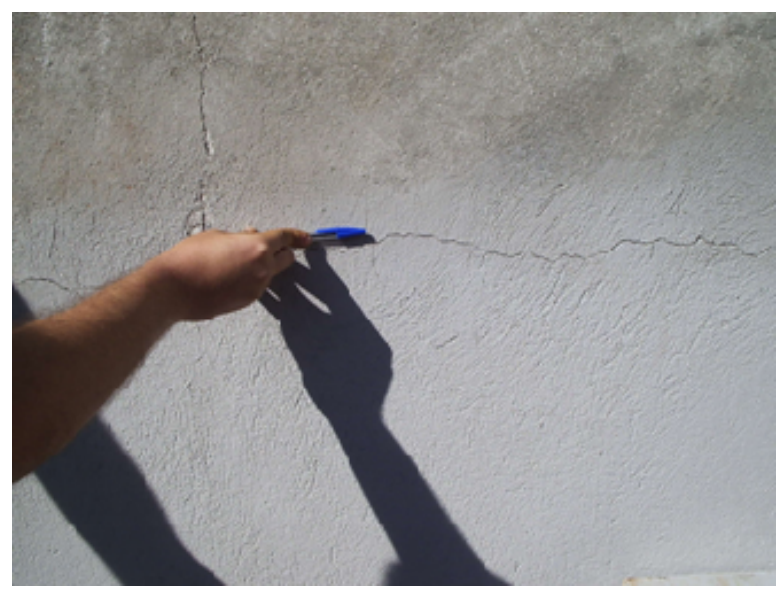

Figura 3.68. Detalhe das trincas horizontais e verticais que sugiram durante a realização do ensaio. 


\section{RESULTADOS E ANÁUSES - PROGRAMA EXPERIMENTALDE LABORATÓRIO}

Neste capítulo, são apresentados os resultados obtidos e as análises desenvolvidas a partir da execução do programa experimental de laboratório, descrito no Capítulo 3. Primeiramente, são mostrados os resultados dos ensaios de arrancamento, a partir de curvas carga x deslocamento e em termos do parâmetro de resistência ao cisalhamento soloreforço $\left(q_{s}\right)$. Estes resultados são comparados em função das diferentes metodologias executivas e profundidades empregadas na construção dos chumbadores. Adicionalmente, também são apresentadas curvas de distribuição do carregamento ao longo do comprimento dos reforços, obtidas pelo monitoramento dos strain gages posicionados nas barras de aço.

Os ensaios de arrancamento permitiram quantificar melhorias na resistência ao cisalhamento de interface, a partir das injeções do chumbador, e estabelecer equações que relacionam o valor de $q_{s}$ com o volume injetado de calda de cimento, sendo uma importante ferramenta para analisar o desempenho do chumbador. Todos os chumbadores ensaiados foram exumados, e os resultados são apresentados destacando-se os aspectos da sua integridade e uniformidade do diâmetro.

\subsection{ENSAIOSDE ARRANCAMENTO}

A Figura 4.1 apresenta as curvas carga $\mathrm{x}$ deslocamento obtidas a partir de ensaios de arrancamento, realizados em nove reforços que compõem a estrutura de solo pregado. Para poder analisar a influência das diferentes metodologias executivas na resistência ao cisalhamento de interface solo-reforço, os resultados são apresentados para cada uma das linhas de chumbadores. 

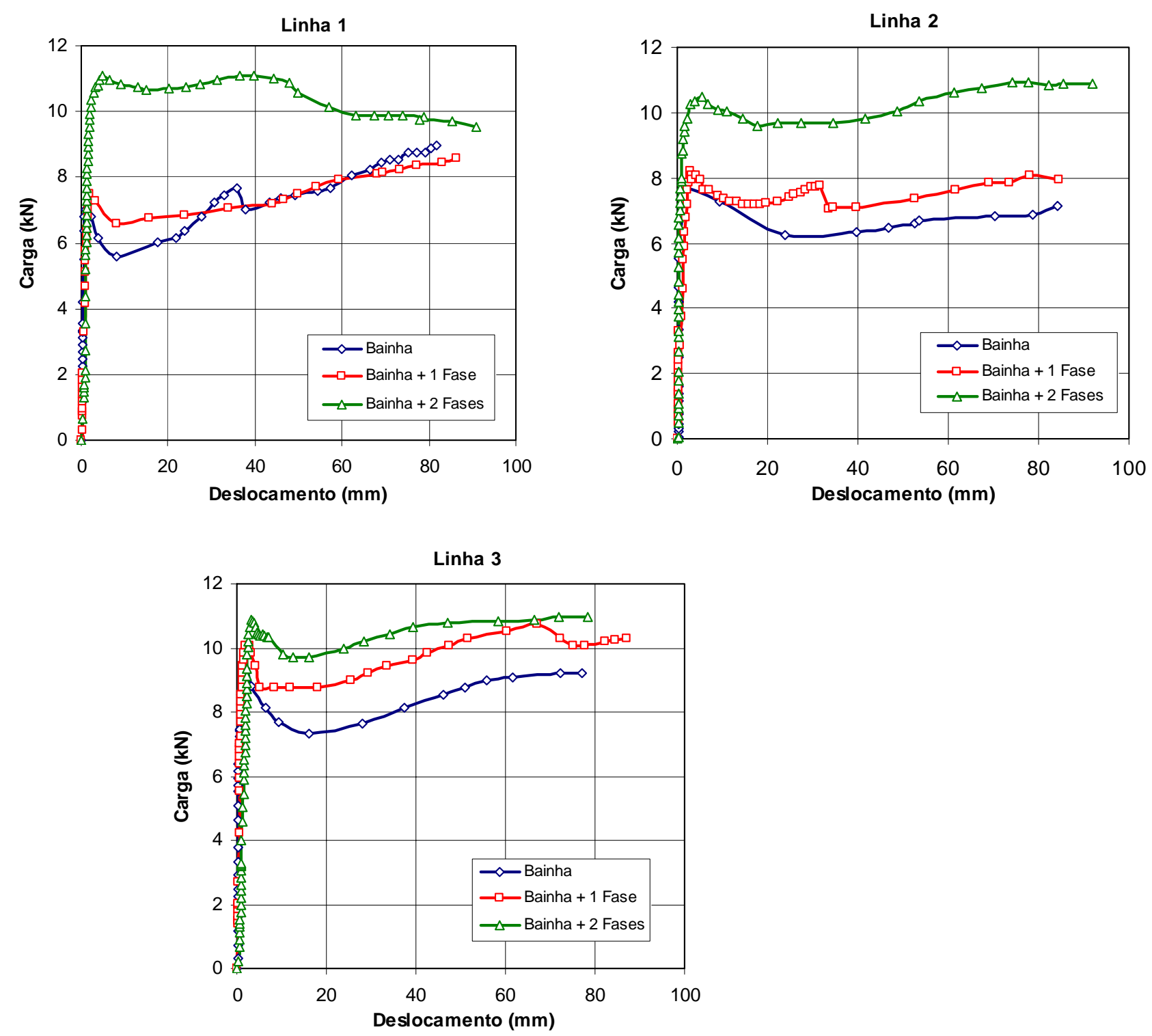

Figura 4.1. Curvas carga $x$ deslocamento para as diferentes metodologias executivas empregadas em cada linha de reforço.

A partir da Figura 4.1, nota-se que após atingir o carregamento de pico, a carga tende inicialmente para um valor residual menor, convergindo posteriormente para uma tendência a um incremento de carga com o aumento do deslocamento. Tal fato pode ser decorrente de eventuais imperfeições existentes (variação no diâmetro) no trecho livre (0,30 m). Ao analisar os deslocamentos, verifica-se, de forma geral, que, para a mobilização total da resistência ao cisalhamento de interface, os deslocamentos foram pequenos, da ordem de 
1 a 6 mm, tornando-se maiores à medida que se aumentaram o uso das fases de injeção dos chumbadores. Os deslocamentos médios para os chumbadores construídos somente com a Bainha, Bainha +1 Fase e Bainha +2 Fases foram, respectivamente, 1,46 mm, 2,28 mm e $4,62 \mathrm{~mm}$.

A resistência ao cisalhamento de interface $\left(q_{s}\right)$ foi obtida a partir dos valores de pico das curvas carga $\mathrm{x}$ deslocamento dos reforços. A Tabela 4.1 apresenta um resumo dos resultados obtidos a partir dos ensaios de arrancamento.

Tabela 4.1. Resumo dos resultados obtidos a partir dos ensaios de arrancamento.

\begin{tabular}{cccccc}
\hline Linha & Descrição & $\begin{array}{c}\mathbf{T}_{\mathbf{m a ́ x}} \\
\mathbf{( k N )}\end{array}$ & $\begin{array}{c}\text { Deslocamento } \\
\mathbf{( m m )}\end{array}$ & $\boldsymbol{q}_{s} \mathbf{( k P a )}$ & A.R. (\%) \\
\hline \multirow{2}{*}{1} & Bainha & 7,02 & 1,00 & 59,13 & 0 \\
& Bainha + 1 Fase & 7,48 & 1,88 & 63,01 & 6,5 \\
& Bainha + 2 Fases & 11,09 & 4,94 & 93,39 & 57,9 \\
\hline \multirow{2}{*}{2} & Bainha & 7,68 & 1,45 & 64,73 & 0 \\
& Bainha + 1 Fase & 8,20 & 2,99 & 69,08 & 36,7 \\
\hline \multirow{2}{*}{3} & Bainha + 2 Fases & 10,48 & 5,47 & 88,26 & 0 \\
& Bainha + 1 Fase & 10,06 & 1,98 & 78,58 & 7,8 \\
& Bainha + 2 Fases & 10,82 & 3,46 & 84,79 & 16,0 \\
\hline
\end{tabular}

Nota: $\mathrm{T}_{\text {máx: }}$ carga máxima obtida durante o ensaio; $q_{s}$ : resistência ao cisalhamento de interface; A.R.(\%): aumento relativo de resistência, tomando-se como referência o chumbador construído somente com a Bainha.

Para as três linhas de reforços, os ensaios de arrancamento resultaram em valores crescentes de $q_{s}$ com o aumento do número das fases de injeção. Para os reforços executados somente com a Bainha, o valor médio de $q_{s}$ foi de $67,5 \mathrm{kPa}$, enquanto para os reforços executados com uma fase adicional de injeção, o valor médio de $q_{s}$ foi de 72,3 kPa (acréscimo de 7,1\%), e para os executados com duas fases adicionais de injeção, o valor médio foi de 90,9 kPa (acréscimo de 34,6\%).

Byrne et al. (1998) apresentam faixas de valores de resistência de interface $\left(q_{s}\right)$ para vários tipos de solo e chumbadores executados sem injeção. Os valores de resistência de interface para solos arenosos variam de $50 \mathrm{kPa}$ (areia siltosa) a $240 \mathrm{kPa}$ (areia siltosa muito densa) e entre 100 e 200 kPa para argilas arenosas. O intervalo de variação da 
resistência de interface obtida para o solo pregado de laboratório (areia argilosa) encontrase no intervalo de variação sugerido por Byrne et al. (1998).

Após a realização da perfuração do terreno, o solo circundante é submetido a um alivio de tensões. Se existirem vazios causados pela exudação da calda de cimento ou falha na injeção, a tensão de contato entre a calda de cimento e o solo é muito pequena e desconhecida. Entretanto, ao se utilizar a técnica de injeção, estas incertezas podem ser desconsideradas. Neste sentido, o aumento do $q_{s}$ com o incremento de fases de injeção, deve-se provavelmente ao preenchimento dos vazios da calda de cimento, permitindo a reconstituição do confinamento existente antes da perfuração.

Um dos fatores que mais influencia o valor de $q_{s}$ é a tensão normal atuante na superfície do reforço. Existe a corrente de pesquisadores que acredita que o valor de $q_{s}$ é constante com o aumento da profundidade, pois considera que a tendência de diminuição da dilatância é compensada pelo aumento da tensão vertical. Entretanto, a outra corrente acredita que esta consideração é uma hipótese simplificadora, pois há uma grande dispersão observada através dos resultados dos ensaios de arrancamento, para um mesmo solo e uma mesma técnica.

A Figura 4.2 apresenta as curvas carga x deslocamento para os diferentes métodos construtivos empregados. Esta representação busca avaliar o efeito da profundidade nos ensaios de arrancamento realizados.
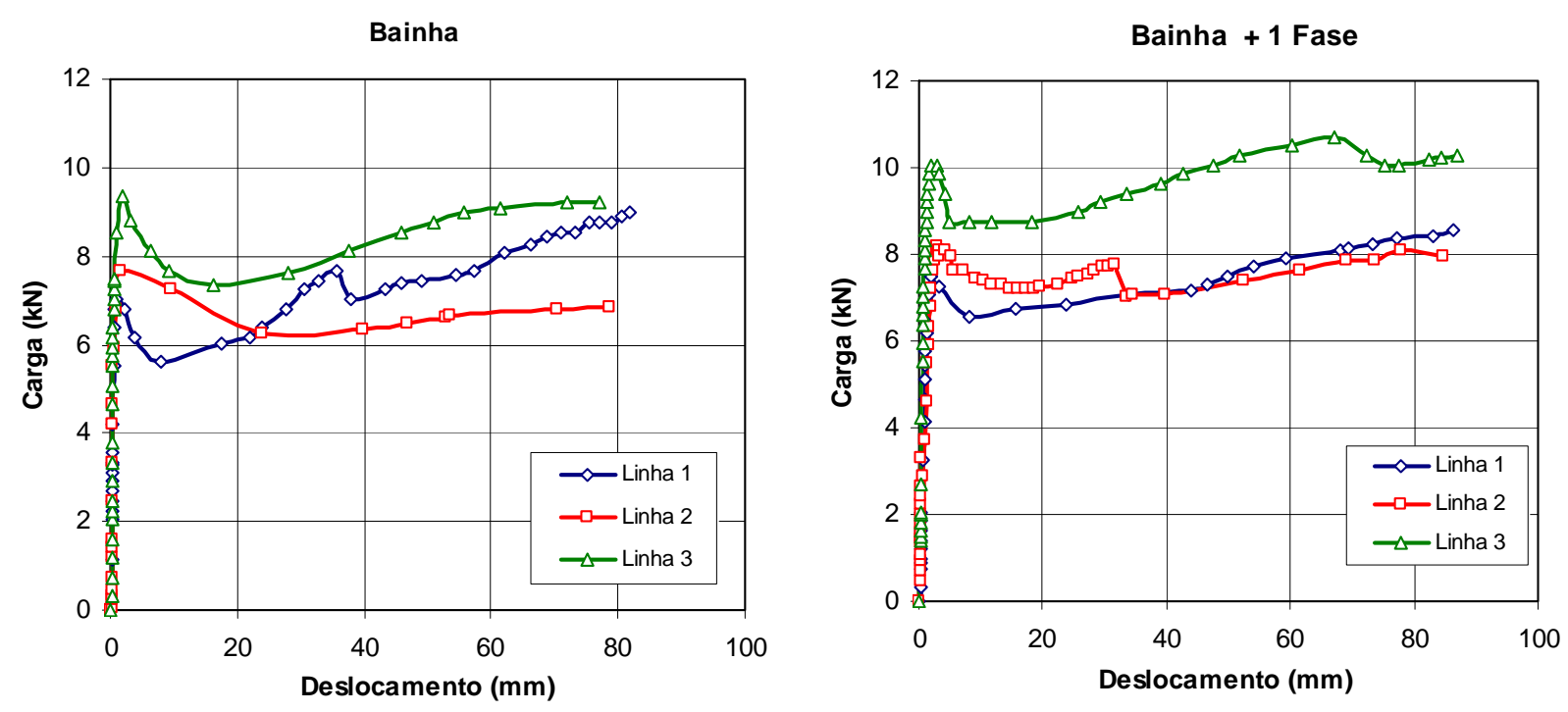


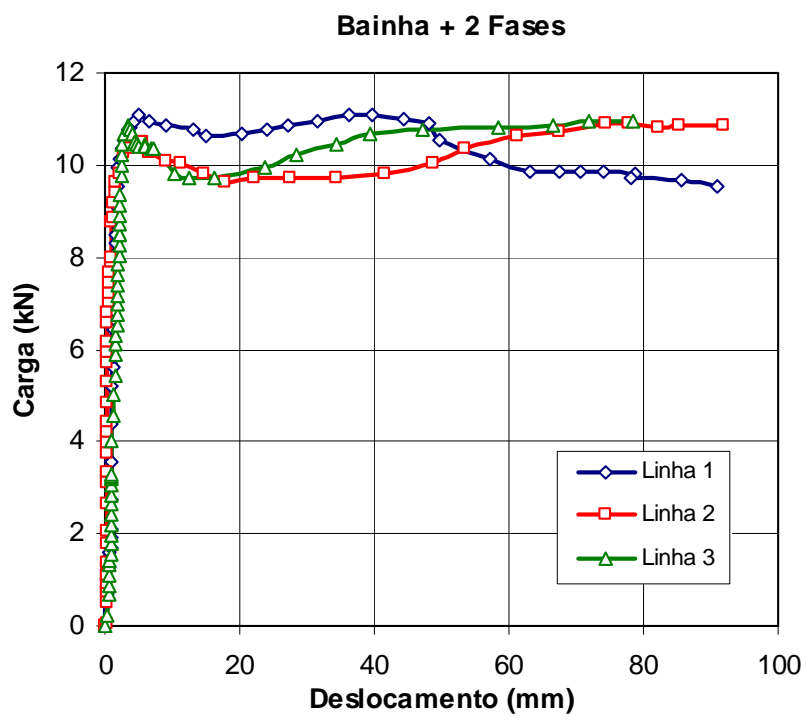

Figura 4.2. Curvas carga $x$ deslocamento comparativas para as diferentes linhas de reforço, para cada metodologia construtiva.

Ao comparar o mesmo método construtivo, nas diferentes profundidades, verificase que as curvas tornaram-se mais próximas à medida que se aumentaram o número de injeções. A Figura 4.3 apresenta a variação de $q_{s}$ com a relação profundidade (z) e altura $(\mathrm{H})$, para cada uma das metodologias executivas.

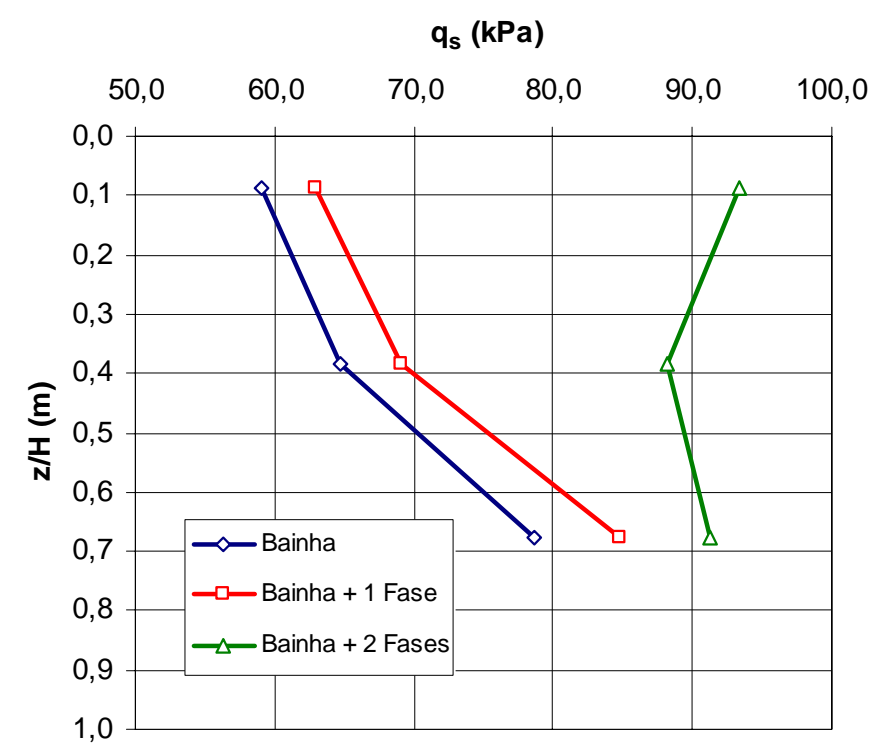

Figura 4.3. Variação de $q_{s}$ com a profundidade, para cada uma das metodologias executivas. 
Ao analisar a variação da resistência de interface $\left(q_{s}\right)$, nota-se que, para os reforços construídos com Bainha e Bainha + 1 Fase, a resistência ao cisalhamento de interface é crescente ao longo da profundidade. Entretanto, os chumbadores construídos com Bainha + 2 Fases apresentaram valores de $q_{s}$ muito próximos com o aumento da profundidade, sendo ligeiramente maior para o chumbador posicionado na linha 1 . O menor confinamento da linha 1, somado as duas fases de injeção, faz com que haja uma tendência de uniformização da resistência ao arrancamento mobilizada através do perfil de solo reforçado.

O processo de escavação e de inserção dos chumbadores acaba alterando o estado de tensões do maciço de solo. Na tentativa de avaliar as magnitudes das tensões normais médias atuantes ao longo do trecho injetado de cada linha de chumbador, foi realizada uma simulação numérica com o software de elementos finitos Plaxis v.8. Para tal, foi considerada a situação anterior à realização dos ensaios de arrancamento, ou seja, após o processo de "escavação" e inserção dos chumbadores e a aplicação da sobrecarga de 50 kPa. Para simular a laje de reação de concreto existente sob o maciço reforçado, foi considerado um solo com módulo de deformabilidade igual ao do concreto $\left(2,1 \times 10^{7} \mathrm{kPa}\right)$. A Figura 4.4 apresenta a distribuição de tensões verticais no maciço compactado, antes de iniciar os ensaios de arrancamento.

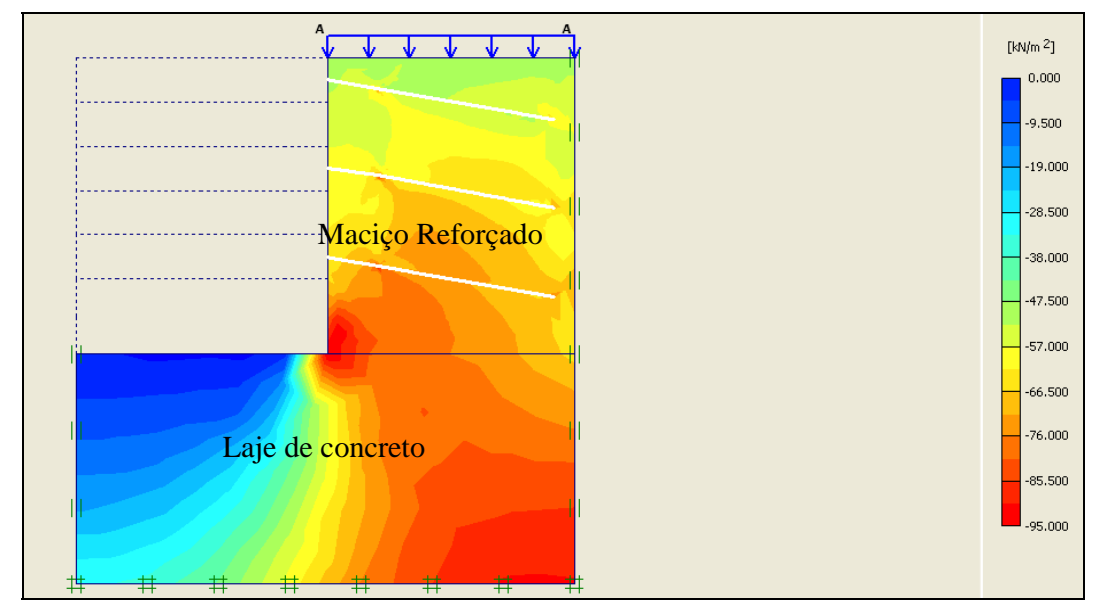

Figura 4.4. Distribuição das tensões verticais efetivas ao longo da profundidade.

A Tabela 4.2 apresenta os valores médios de tensão vertical efetiva atuante em cada linha de chumbador e o aumento relativo A.R (\%) em relação à linha 1. 
Tabela 4.2. Valores médios de tensão vertical efetiva $\left(\sigma_{v}{ }^{\prime}\right)$ atuante em cada linha de chumbador.

\begin{tabular}{ccc}
\hline $\begin{array}{c}\text { Linha de } \\
\text { chumbador }\end{array}$ & $\sigma_{\mathbf{v}}{ }^{\prime}(\mathbf{k P a})$ & A.R (\%) \\
\hline 01 & 54,14 & 0 \\
02 & 63,57 & 17,4 \\
03 & 69,85 & 29,0 \\
\hline
\end{tabular}

Na tentativa de verificar um padrão de comportamento ao longo da profundidade, foram plotadas curvas de tensão vertical efetiva x $q_{s}$ (Figura 4.5).

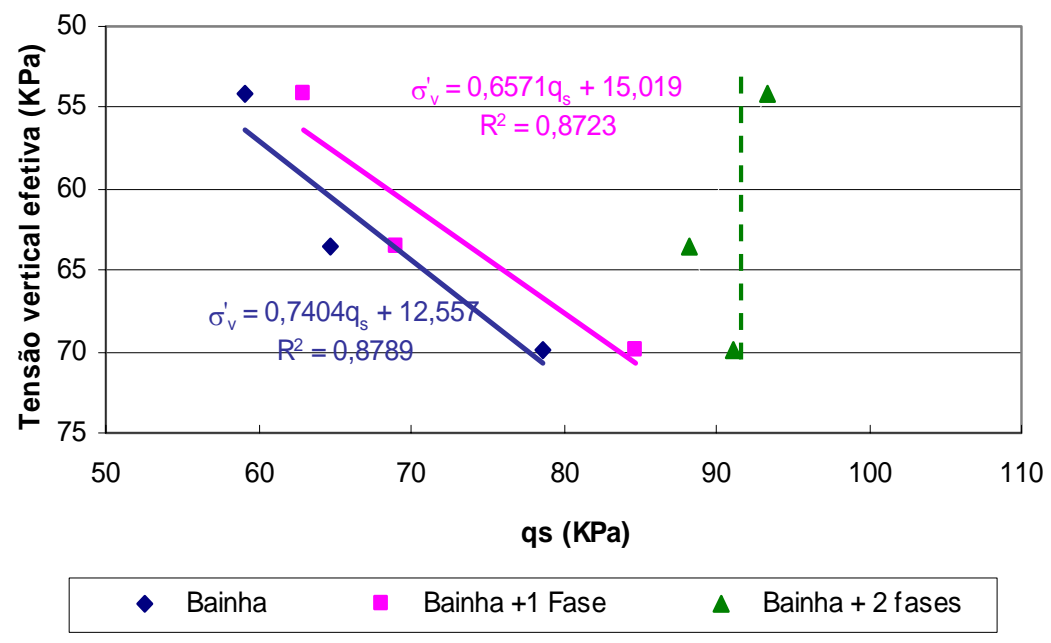

Figura 4.5. Curvas tensão vertical efetiva $\mathrm{x} \boldsymbol{q}_{s}$ para as diferentes metodologias construtivas.

A partir da Figura 4.5, observa-se que, para os chumbadores construídos com Bainha e Bainha +1 , foi possível estabelecer um ajuste linear do incremento de $q_{s}$ a partir do acréscimo de tensão vertical, obtendo valores de $\mathrm{R}^{2}$ da ordem de 0,87 . Entretanto, para os chumbadores executados com Bainha +2 , os valores de $q_{s}$ apresentaram-se muito próximos com a variação da profundidade, sendo representados pela linha tracejada.

Na tentativa de estabelecer um padrão de comportamento para os diferentes métodos executivos, foi realizada uma análise adicional a partir das curvas carga $\mathrm{x}$ deslocamento, em relação dos valores de rigidez $\left(\mathrm{k}_{\beta}\right)$. Até atingir a carga máxima de arrancamento, foram identificadas quatro etapas diferentes: (i) Etapa 1: refere-se ao trecho inicial da curva. Sua ocorrência é conseqüência do ajuste do sistema de ensaio de 
arrancamento, mas nem sempre é identificada; (ii) Etapa 2: refere-se à etapa de maior rigidez do ensaio, comum a todos os ensaios; (iii) Etapa 3: apresenta rigidez inferior àquela da etapa anterior, comum a todos os ensaios; (iv) Etapa 4: corresponde ao trecho de carregamento de pico e de rigidez muito pequena, em que o chumbador desloca-se (cisalhase) em relação ao solo. A Figura 4.6 representa um resultado típico obtido a partir dos ensaios de arrancamento realizados.

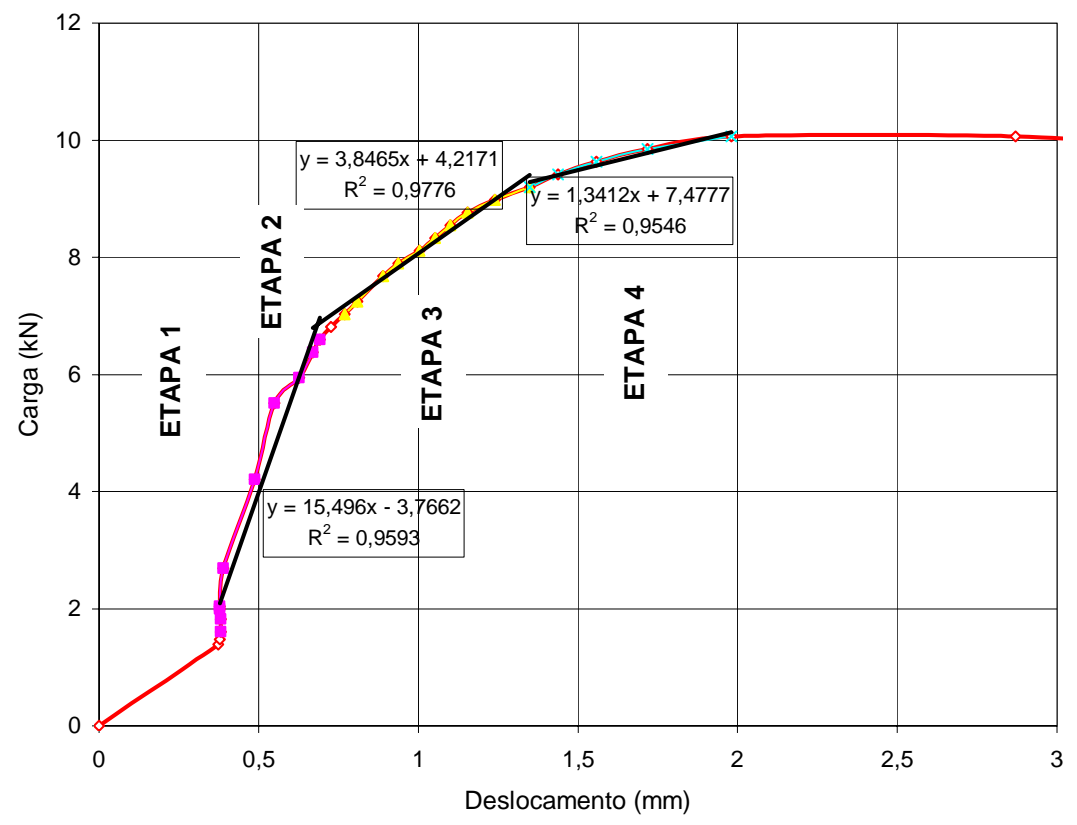

Figura 4.6. Curva carga $x$ deslocamento típica dos ensaios de arrancamento realizados.

Considerando as etapas acima mencionadas, calculou-se o valor de rigidez $\mathrm{k}_{\beta}$ para as etapas 2, 3 e 4. Na Tabela 4.3, apresenta-se, para cada uma das etapas, os valores limites de carga $\left(F_{n}\right)$, deslocamento $\left(L_{n}\right)$ e rigidez $\left(K_{\beta}\right)$. 
Tabela 4.3. Etapas dos ensaios de arrancamento dos chumbadores.

\begin{tabular}{|c|c|c|c|c|c|c|c|c|c|c|c|c|}
\hline \multirow[b]{2}{*}{ Linha } & \multirow[b]{2}{*}{ Descrição } & \multicolumn{2}{|c|}{ Etapa 1} & \multicolumn{3}{|c|}{ Etapa 2} & \multicolumn{3}{|c|}{ Etapa 3} & \multicolumn{3}{|c|}{ Etapa 4} \\
\hline & & $\begin{array}{c}F_{1} \\
(k N)\end{array}$ & $\begin{array}{c}\mathbf{L}_{1} \\
(\mathbf{m m})\end{array}$ & $\begin{array}{c}F_{2} \\
(\mathbf{k N})\end{array}$ & $\begin{array}{c}\mathbf{L}_{2} \\
(\mathbf{m m})\end{array}$ & $\begin{array}{c}\mathbf{k}_{\beta-2} \\
(\mathbf{k N} / \mathbf{m})\end{array}$ & $\begin{array}{c}F_{3} \\
(\mathbf{k N})\end{array}$ & $\begin{array}{c}\mathbf{L}_{3} \\
(\mathbf{m m})\end{array}$ & $\begin{array}{c}\mathbf{k}_{\beta-3} \\
(\mathbf{k N} / \mathbf{m})\end{array}$ & $\begin{array}{c}F_{4} \\
(\mathbf{k N})\end{array}$ & $\begin{array}{c}\mathbf{L}_{4} \\
(\mathbf{m m})\end{array}$ & $\begin{array}{c}\mathbf{k}_{\beta-4} \\
(\mathbf{k N} / \mathbf{m})\end{array}$ \\
\hline \multirow{3}{*}{1} & Bainha & - & - & 3,28 & 0,32 & 10250 & 6,37 & 0,67 & 8829 & 7,02 & 1,00 & 1970 \\
\hline & Bainha + 1 & 0,75 & 0,36 & 4,66 & 0,87 & 7592 & 7,04 & 1,57 & 3400 & 7,48 & 1,88 & 1419 \\
\hline & Bainha + 2 & 1,78 & 0,79 & 5,60 & 1,11 & 12013 & 9,52 & 1,79 & 5748 & 11,09 & 4,94 & 498 \\
\hline \multirow{3}{*}{2} & Bainha & 1,39 & 0,25 & 4,64 & 0,43 & 18056 & 6,81 & 0,86 & 5047 & 7,68 & 1,45 & 1475 \\
\hline & Bainha + 1 & - & - & 2,86 & 0,67 & 4269 & 7,20 & 2,10 & 3035 & 8,20 & 2,99 & 1124 \\
\hline & Bainha + 2 & 0,71 & 0,26 & 5,27 & 0,31 & 91200 & 9,17 & 1,29 & 3971 & 10,48 & 5,47 & 313 \\
\hline \multirow{3}{*}{3} & Bainha & 0,74 & 0,23 & 4,64 & 0,27 & 92929 & 8,55 & 0,84 & 6896 & 9,33 & 1,94 & 710 \\
\hline & Bainha + 1 & 1,48 & 0,38 & 6,59 & 0,69 & 16290 & 9,20 & 1,35 & 3979 & 10,06 & 1,98 & 1361 \\
\hline & Bainha +2 & 0,67 & 0,61 & 2,84 & 0,92 & 6933 & 10,00 & 2,46 & 4655 & 10,82 & 3,29 & 987 \\
\hline
\end{tabular}

Frank e Zhao (1982) propuseram uma lei de mobilização da resistência ao arrancamento de chumbadores. Esta lei considera que o ponto de inflexão entre as etapas 2 e 3 ocorre quando há mobilização de 50\% da carga máxima e a relação entre a rigidez de cada etapa $\left(\mathrm{k}_{\beta-2} / \mathrm{k}_{\beta-3}\right)$ é de 5 . Na etapa 4 , considera-se uma rigidez nula, uma vez que foi atingida a carga máxima necessária para promover o cisalhamento da interface soloreforço. Na Tabela 4.4, são apresentados os porcentuais da carga máxima no ponto de inflexão e a razão de rigidez obtida a partir dos ensaios para cada metodologia construtiva.

Tabela 4.4. Porcentuais de carga no ponto de inflexão e razão de rigidez.

\begin{tabular}{cccc}
\hline \multirow{2}{*}{ Descrição } & Linha & Etapa 2 & \\
\cline { 3 - 3 } & & \% $\mathbf{F}_{\text {máx }}$ & $\begin{array}{c}\text { Razão de Rigidez } \\
\mathbf{K}_{\boldsymbol{\beta}-\mathbf{2}} / \mathbf{K}_{\boldsymbol{\beta} \text {-3 }}\end{array}$ \\
\hline \multirow{3}{*}{ Bainha } & 1 & 46,72 & 1,2 \\
& 2 & 60,42 & 3,6 \\
& 3 & 49,73 & 13,5 \\
\hline \multirow{3}{*}{ Bainha +1} & 1 & 62,30 & 2,2 \\
& 2 & 34,88 & 1,4 \\
& 3 & 65,51 & 4,1 \\
\hline \multirow{3}{*}{ Bainha +2} & 2 & 50,50 & 2,1 \\
& 3 & 50,29 & 23,0 \\
& 2 & 26,25 & 1,5 \\
\hline
\end{tabular}


Em relação ao porcentual de carga mobilizada no ponto de inflexão, obtiveram-se valores médios de 52,3, 54,2 e 42,3\% para Bainha, Bainha + 1 Fase e Bainha + 2 Fases, respectivamente. Estes valores se aproximam dos valores obtidos por Frank e Zhao (1982).

Ao analisar a razão de rigidez, observam-se valores médios de 6,1, 2,6 e 8,8 para Bainha, Bainha +1 Fase e Bainha +2 Fases, respectivamente, porém com elevado coeficiente de variação. Como os valores obtidos para Bainha (linha 3) e Bainha +2 Fases (linha 2) apresentaram resultados discrepantes em relação aos demais, resolveu-se então realizar nova análise excluindo estes dados. Assim, obtiveram-se os valores médios de 2,4, 2,6 e 1,8 para Bainha, Bainha +1 Fase e Bainha +2 Fases, respectivamente. A partir desta consideração, constatou-se que o coeficiente de variação reduziu com o aumento do número de injeções. Springer (2006), ao realizar ensaios de arrancamento em chumbadores com uma fase de injeção, obteve razão de rigidez igual a 2, próxima dos valores obtidos.

\subsubsection{Influência do Volume Injetado}

Os resultados obtidos mostram que o valor de $q_{s}$ está intimamente relacionado com o volume de injeção obtido para cada metodologia executiva. Na tentativa de verificar uma tendência de comportamento, os valores de $q_{s}$ e do volume de injeção das diferentes metodologias são apresentadas em um mesmo gráfico, para cada uma das linhas de chumbadores (Figura 4.7).
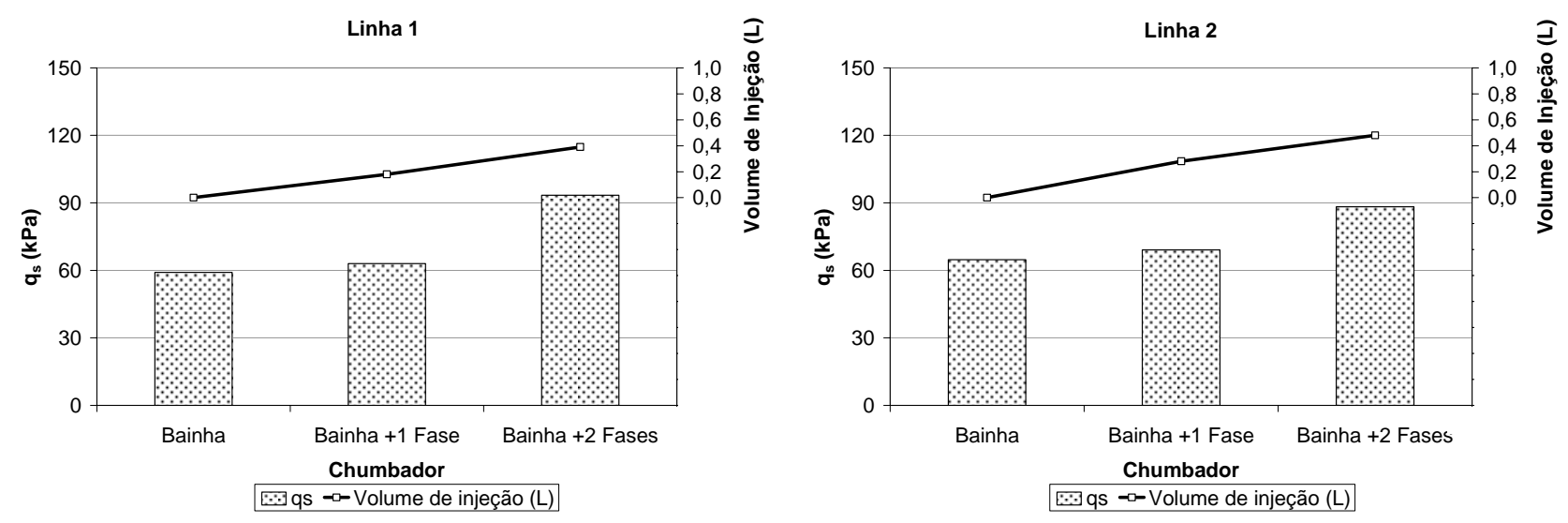


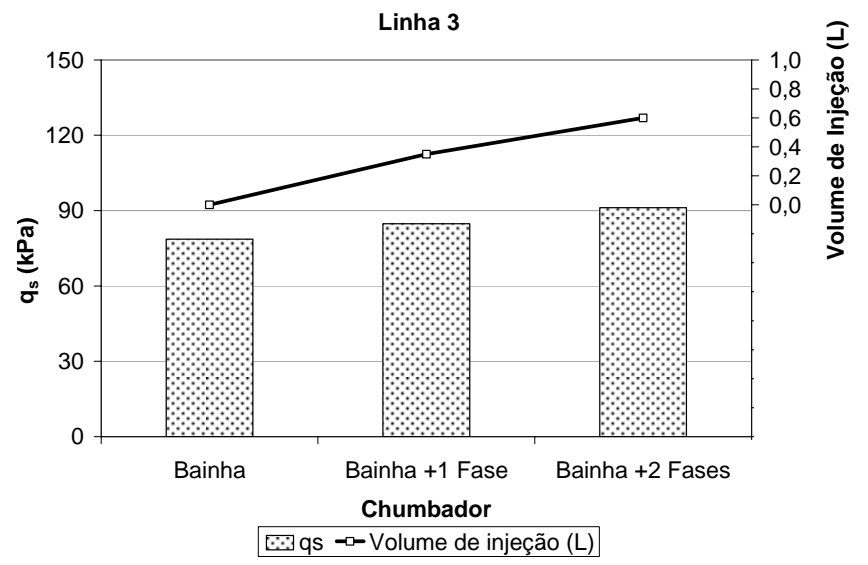

Figura 4.7. Variações de $q_{s}$ e dos volumes de injeção para as diferentes metodologias executivas das Linhas 1, 2 e 3.

A partir da Figura 4.7, nota-se, claramente, que os ganhos no parâmetro $q_{s}$ estão diretamente relacionados com a metodologia executiva e, consequentemente, com os incrementos dos volumes injetados de calda de cimento. Tal fato explica o melhor desempenho dos chumbadores executados com as metodologias Bainha +1 Fase e Bainha + 2 Fases. As fases de injeção reduzem os vazios existentes após a execução da Bainha, melhorando a integridade do chumbador ao longo do trecho injetado, refletindo diretamente no parâmetro $q_{s}$. A partir da exumação dos chumbadores, estas constatações foram confirmadas.

A partir das análises apresentadas, verificou-se, quantitativamente, a interdependência entre o parâmetro $q_{s}$ e o volume de injeção. A fim de permitir posteriores comparações com ensaios realizados em chumbadores de diferentes geometrias, foi atribuído um fator adimensional "V”, que representa a relação entre o volume injetado de calda de cimento e o volume da cavidade escavada. A Figura 4.8 apresenta uma correlação entre os dois parâmetros ( $q_{s}$ x Fator V), para cada uma das linhas de chumbadores (a) e para todos os chumbadores (b). 


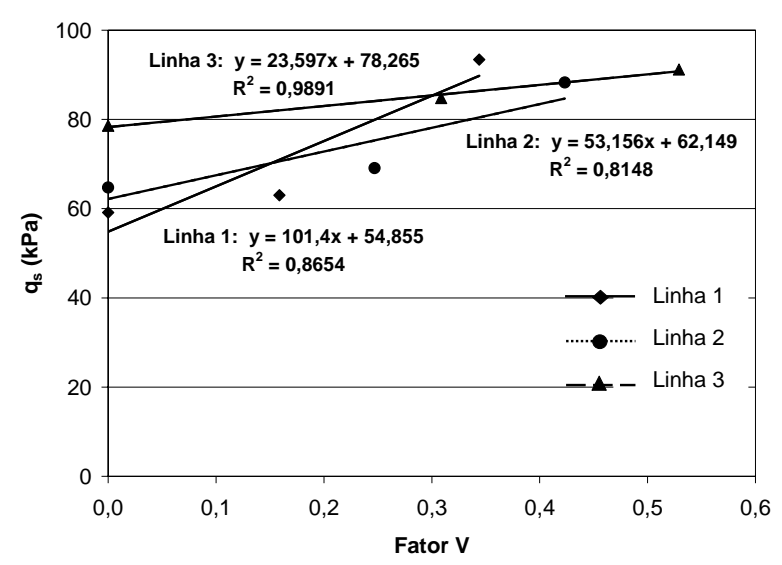

(a)

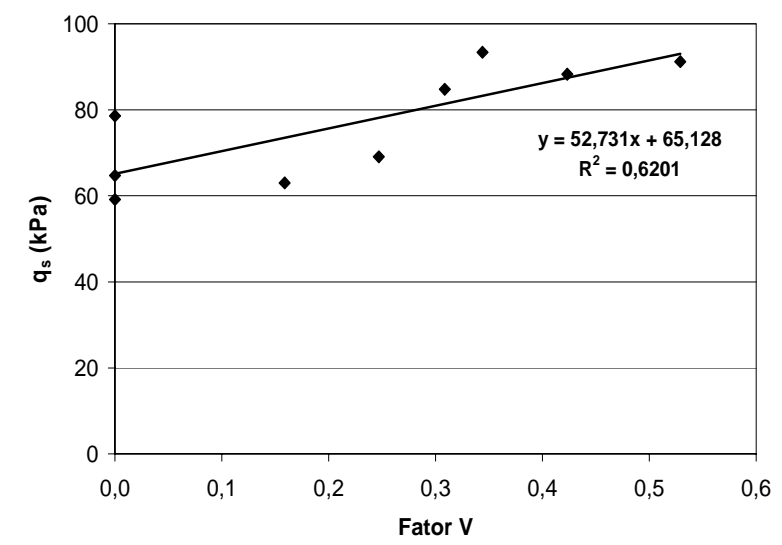

(b)

Figura 4.8. Variações de $q_{s}$ e dos volumes de injeção para as diferentes metodologias executivas das Linhas 1, 2 e 3 (a) e para todos os chumbadores (b).

Os ajustes lineares da Figura 4.8-a apresentaram valores de $\mathrm{R}^{2}$ aceitáveis, considerando-se o pequeno espaço amostral e as variabilidades inerentes às metodologias executivas adotadas para a construção dos chumbadores. Os coeficientes lineares das equações do ajuste equivalem a um volume de injeção igual a zero, ou seja, representam a metodologia Bainha. Considerando esta situação, somente o valor de $q_{s}$ da Linha 1 (Figura 4.8-a), representado por 54,85 kPa, é inferior ao mínimo sugerido pela GeoRio (1999) de 60 kPa. A Figura 4.8-b, representa a tentativa de estabelecer um padrão de comportamento de relação do valor de $q_{s}$ com o volume de injeção. $\mathrm{O} \mathrm{R}^{2}$ para o ajuste linear foi inferior aos obtidos para cada linha, porém mais representativo quando consideramos que possui um maior espaço amostral. O coeficiente linear foi de aproximadamente $65 \mathrm{kPa}$, próximo ao mínimo sugerido pela GeoRio (1999), e o coeficiente angular foi de 52,7.

Com estes resultados, verifica-se que a determinação do volume de injeção é uma excelente opção no controle de qualidade de execução do chumbador. Ao realizar este controle, é possível, para um mesmo tipo de solo, estimar o valor de $q_{s}$, a partir do volume injetado para cada chumbador, e a sua variação no maciço. A partir destas constatações em laboratório, a Figura 4.9 apresenta uma proposta para otimização de projeto e controle de desempenho na técnica de solo pregado. Vale a pena ressaltar que a metodologia proposta é válida para um mesmo tipo de solo. 


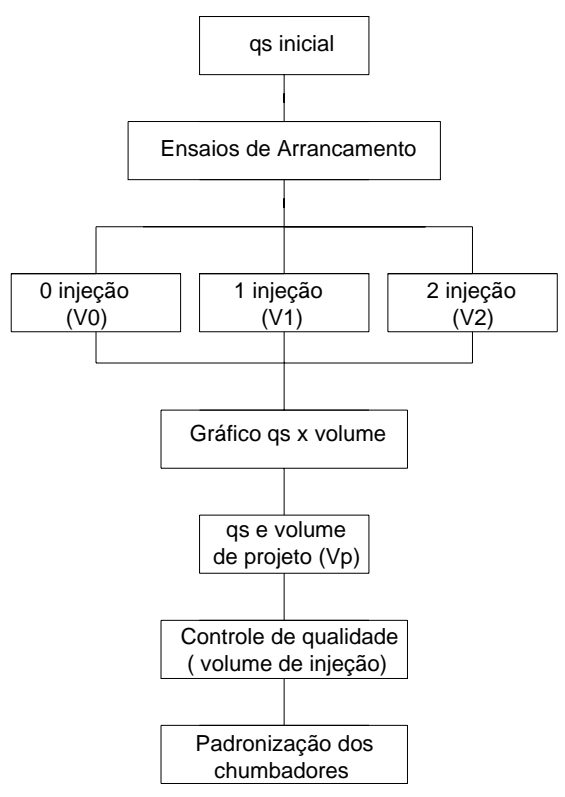

Figura 4.9. Proposta para otimização de projeto e controle de desempenho na técnica de solo pregado.

A proposta apresentada na Figura 4.9 considera a realização de ensaios de arrancamento em pelo menos três chumbadores executados com diferentes números de injeções (0, 1 e 2). Estes ensaios de arrancamento são fundamentais para a verificação do $q_{s}$ inicial, estimado em projeto. Para tanto, os valores de $q_{s}$ obtidos a partir dos ensaios de arrancamento devem ser plotados em função dos fatores adimensionais de volume (V0, V1 e V2), determinados para os diferentes números de injeções. Ao analisar estes valores, o projetista poderá determinar um $q_{s}$ de projeto e o seu correspondente volume injetado de calda de cimento. Para garantir as premissas assumidas no projeto e padronizar o desempenho dos chumbadores executados, os volumes de injeção devem ser objetos de um rigoroso controle na obra.

\subsubsection{Instrumentação dos Reforços}

A instrumentação realizada nos reforços permitiu verificar a distribuição das cargas durante o ensaio, ao longo do comprimento dos reforços. A Figura 4.10 apresenta a distribuição de cargas ao longo do comprimento dos reforços para oito barras de aço, já que uma das barras apresentou problemas com a aquisição de dados. Foram plotados quatro níveis de carregamento em relação à carga de ruptura (25, 50, 75 e 100\%). 

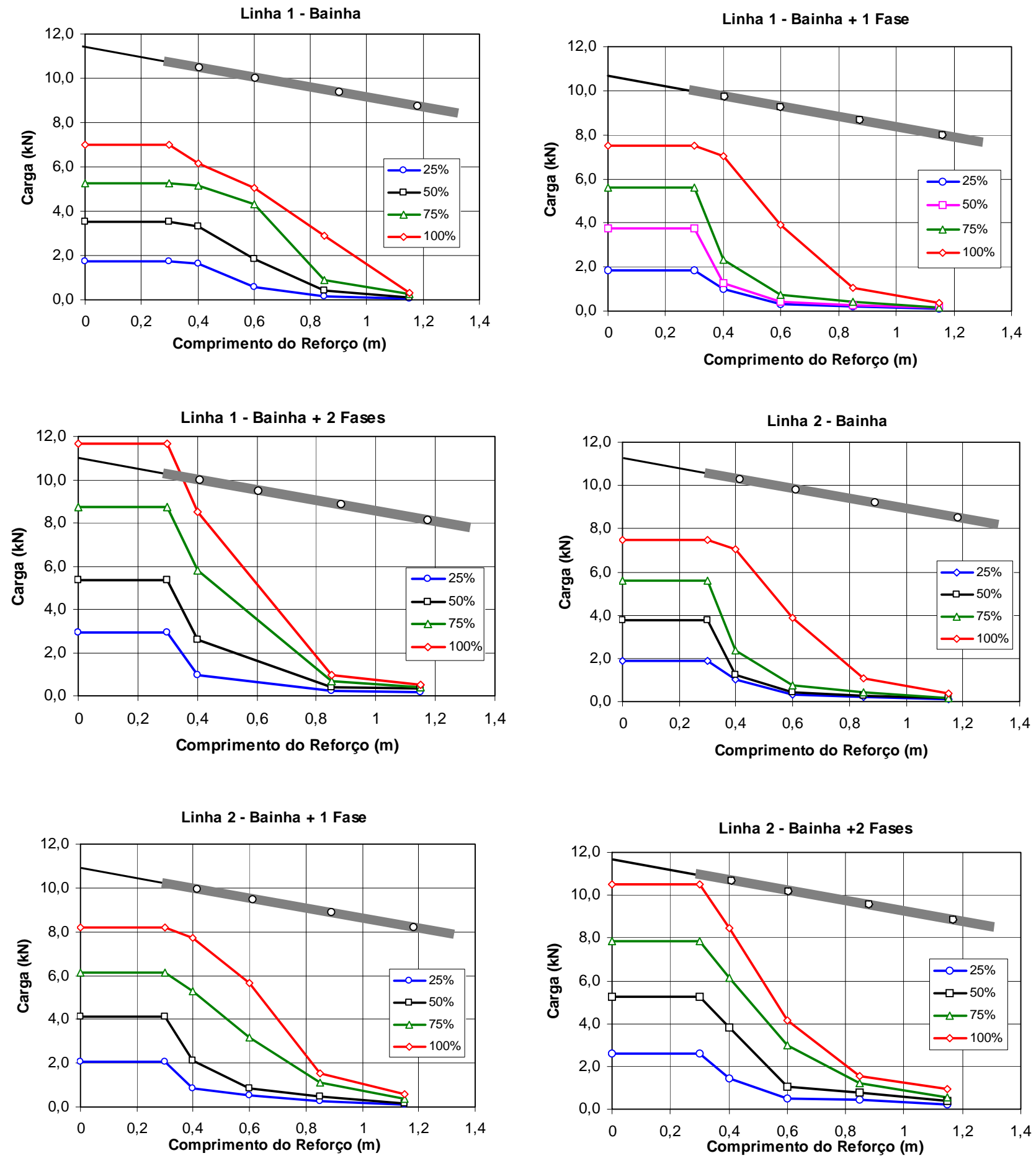

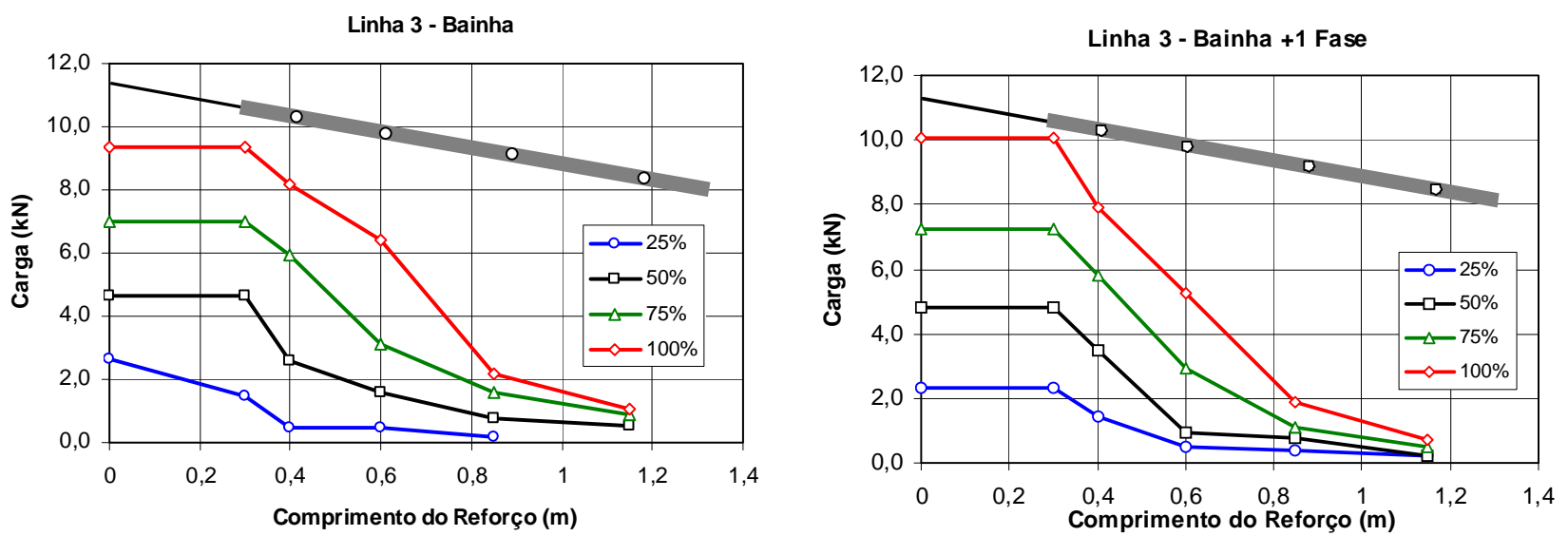

Figura 4.10. Distribuição de carga ao longo do comprimento do reforço (percentagem de carga em relação à carga de ruptura), durante os ensaios.

Observa-se que os reforços apresentam comportamentos semelhantes no tocante à mobilização das cargas, durante a realização do ensaio de arrancamento. Como o arrancamento ocorre no contato solo-reforço, a mobilização da resistência é gradual, ou seja, da cabeça em direção à parte interna do chumbador. Nota-se a tendência de uma distribuição triangular das cargas ao longo da barra. Para os quatro níveis de carregamento, as cargas mostraram-se máximas na face, nas proximidades do ponto de aplicação de carga, tendo sua magnitude reduzida ao longo do reforço. Ao analisar as curvas referentes a $100 \%$ da carga de arrancamento, verifica-se que o comprimento total dos reforços foi praticamente solicitado.

\subsubsection{Exumação dos Reforços}

Todos os chumbadores executados foram exumados. Apresenta-se nas Figuras 4.11 (a), (b) e (c) uma vista geral da constituição dos chumbadores das linhas 1, 2 e 3, respectivamente, após o processo de exumação. 


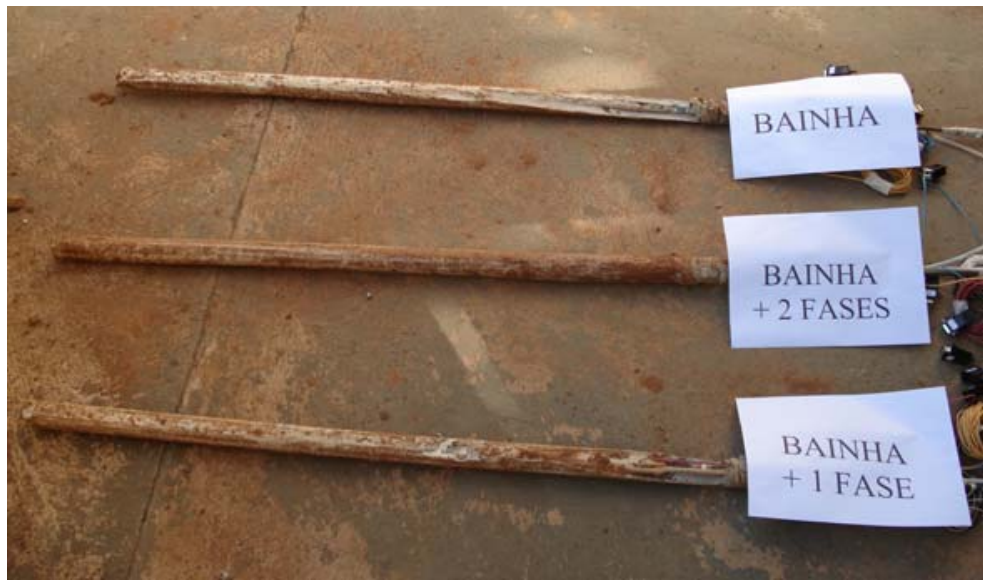

(a)

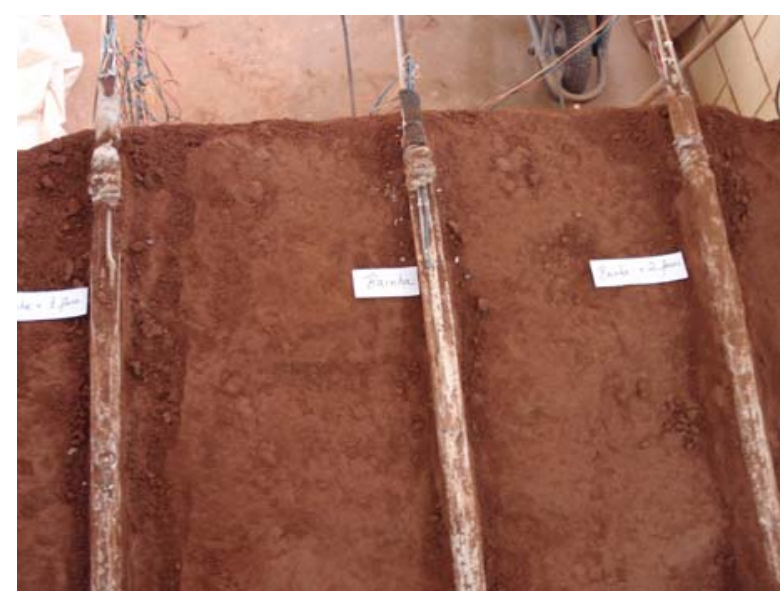

(b)

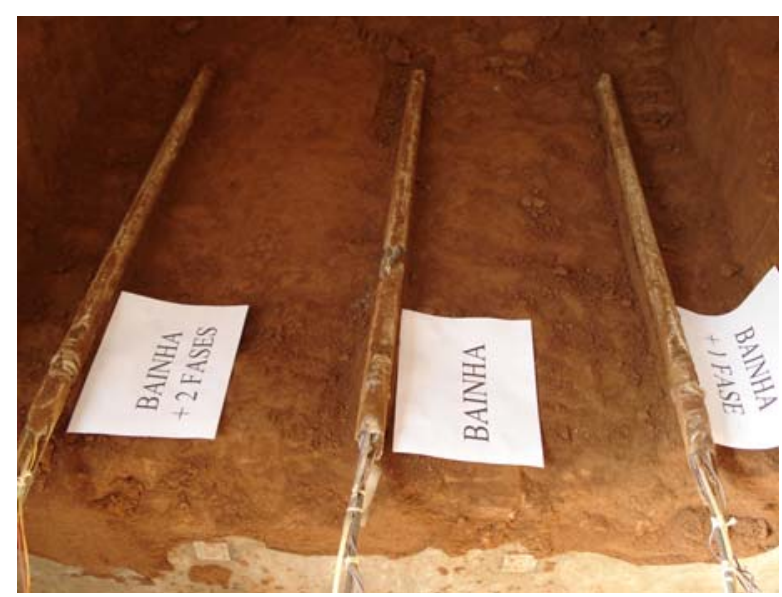

(c)

Figura 4.11. Chumbadores após o processo de exumação: (a) linha 1; (b) linha 2 e (c) linha 3.

A partir da exumação dos chumbadores, verificou-se a presença de alguns vazios de calda de cimento ao longo do trecho injetado. Estes vazios apresentaram-se de forma mais evidente nos chumbadores executados somente com a Bainha. O ineficiente preenchimento de calda de cimento ocorreu, principalmente, atrás do obturador de espuma. Para os chumbadores executados com Bainha +1 Fase, verificou-se um melhor preenchimento destes vazios, enquanto os executados com Bainha + 2 Fases apresentaramse mais íntegros ao longo do seu comprimento. Para permitir uma análise quantitativa desse efeito, mediram-se os diâmetros dos chumbadores em quatro posições diferentes (0,125 m, 0,375 m, 0,625 m e 0,875 m), em relação ao inicio do trecho injetado de 1,0 m. Para cada posição, foram tomadas três leituras e calculado o valor médio. As Figuras 4.12 
(a), (b) e (c) apresentam os diâmetros médios medidos para cada uma das linhas, em função do diâmetro de referência (38 mm).

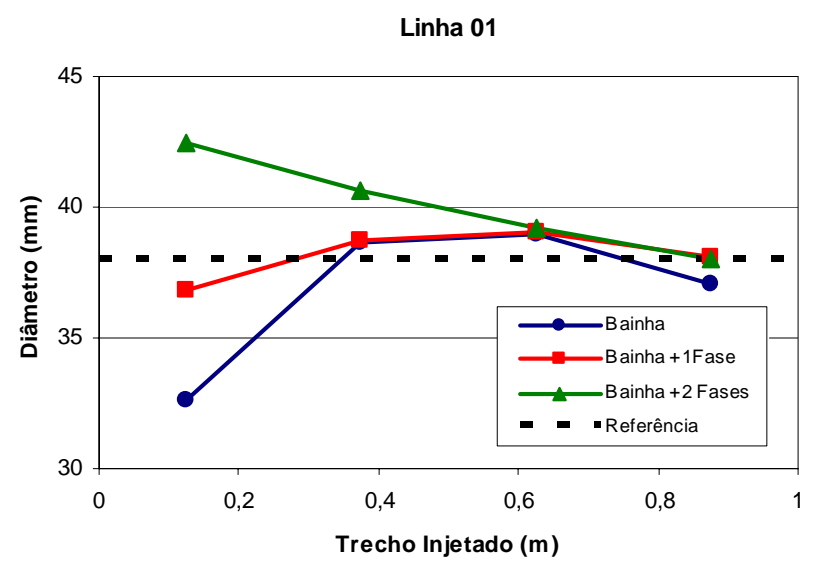

(a)

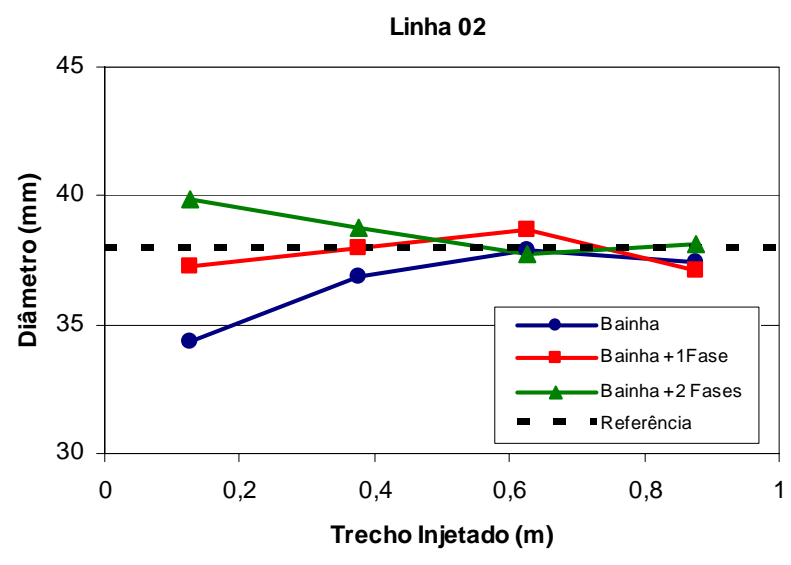

(b)

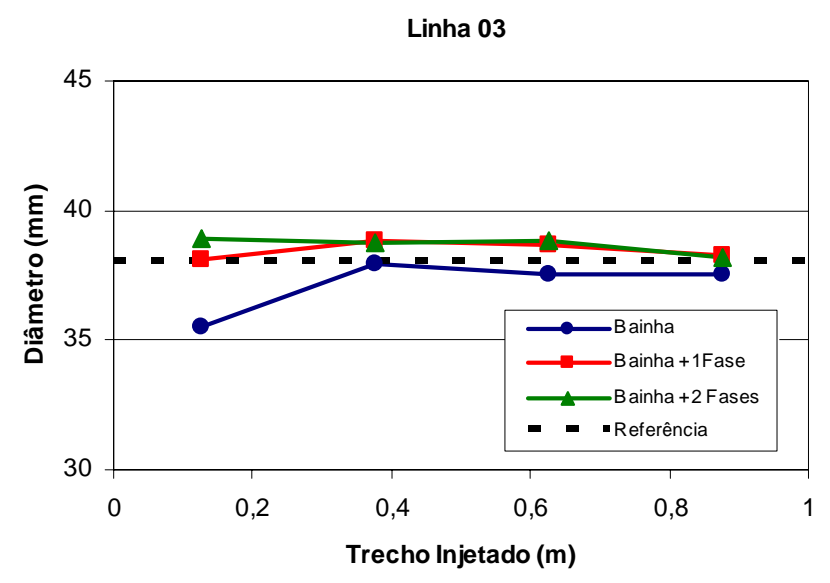

(c)

Figura 4.12. Variação do diâmetro médio ao longo trecho injetado: (a) linha 1, (b) linha 2 e (c) linha 3.

As medidas dos diâmetros confirmaram as constatações qualitativas (visuais). Conforme mencionado, as maiores variações na seção transversal do chumbador ocorreram no inicio do trecho injetado (atrás do obturador). Para Bainha +2 Fases, as seções transversais sempre foram superiores ao valor de referência. Com o aumento da profundidade, a amplitude da diferença entre as medidas para os diferentes métodos construtivos diminuiu, ficando muito próximas na última linha. Estas constatações em relação à integridade do chumbador podem ser totalmente relacionadas com os resultados dos ensaios de arrancamento apresentados anteriormente. 
Além das constatações apresentadas, foi possível verificar que: (a) não houve enraizamento da calda de cimento no solo compactado. Entretanto, houve a formação de um solo mais rígido, com calda de cimento no entorno dos reforços injetados; (b) Observou-se que todos os reforços foram arrancados no contato calda de cimento/solo. Este fato deve-se ao espaço vazio de aproximadamente $60 \mathrm{~mm}$ a partir da extremidade final dos reforços arrancados; (c) não houve vestígios de fissuração transversal e longitudinal ao longo do comprimento do reforço, e (d) o trecho livre apresentou-se bem preservado. Isto mostra que o sistema utilizado como obturador trabalhou de forma adequada.

\subsubsection{Monitoramento do Solo Pregado}

A Figura 4.13 apresenta a evolução da força de tração dos reforços instrumentados ao longo do tempo, durante a etapa de construção do solo pregado. Para cada linha de chumbador são apresentadas três curvas, uma para cada metodologia executiva. Entretanto, para a linha 3, são apresentadas duas curvas, já que uma delas (Bainha +2 Fases) apresentou problemas de aquisição de dados. As etapas finais da construção e aplicação da sobrecarga de $50 \mathrm{kPa}$ estão representadas, respectivamente, pelas linhas verticais (A) e (B). Vale a pena relembrar que as posições dos strain gages (SG 01 a 04), a partir do inicio do trecho injetado, são, respectivamente, as seguintes: $0,10 \mathrm{~m}, 0,30 \mathrm{~m}, 0,55 \mathrm{~m}$ e 0,85 m.
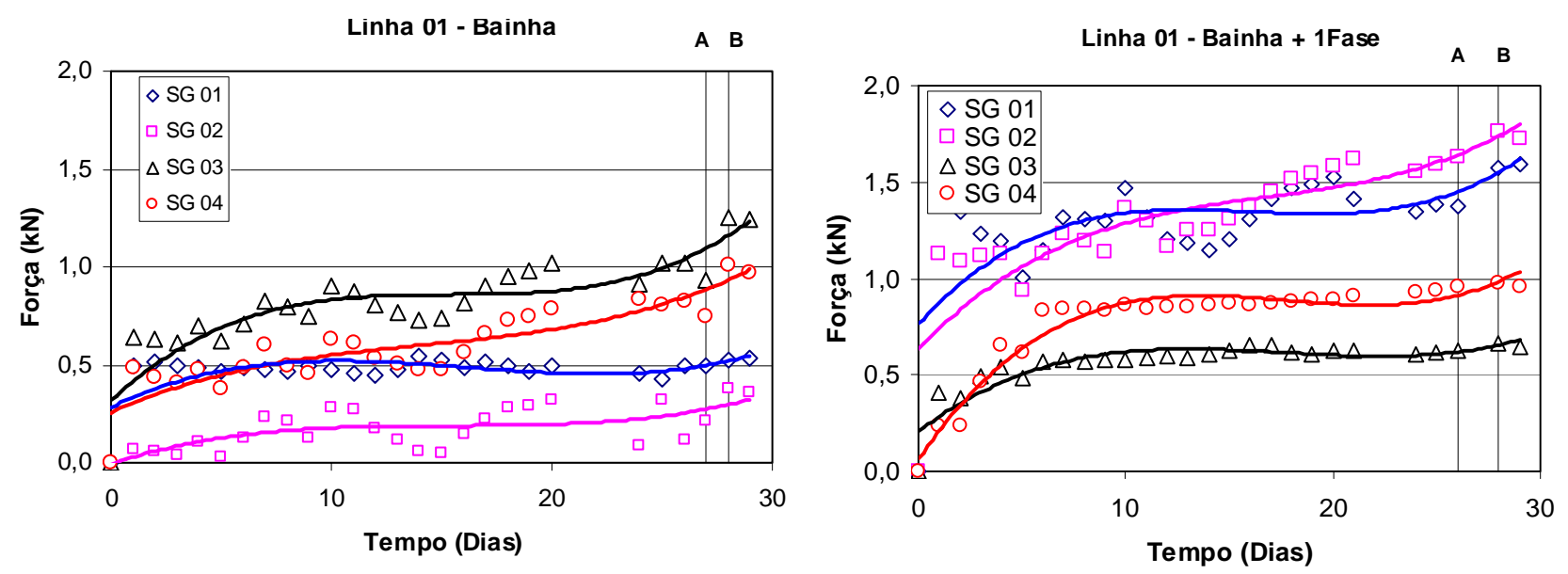

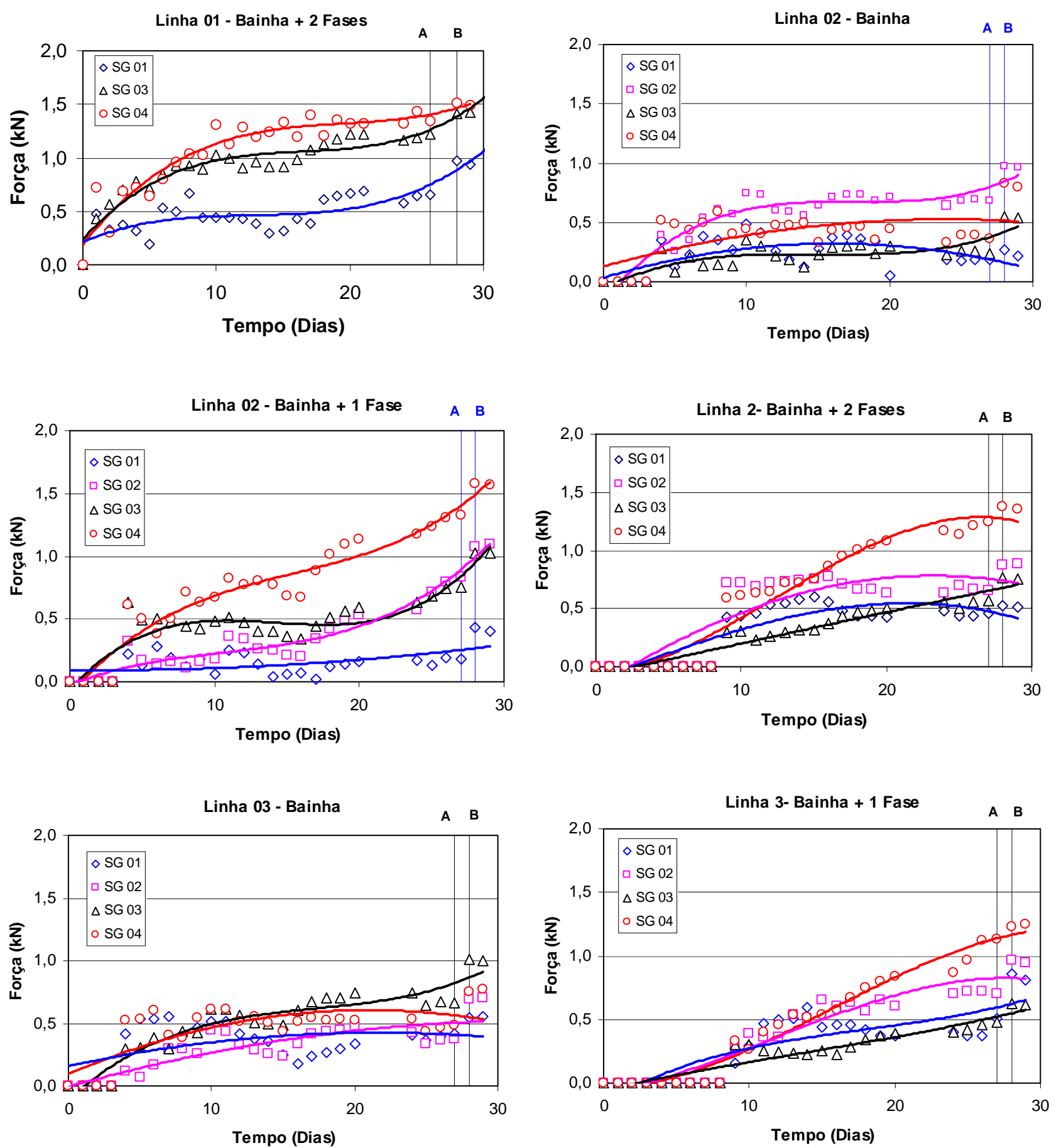

Figura 4.13. Evolução das cargas de tração ao longo do tempo nos reforços instrumentados.

Verificou-se, de forma geral, que as cargas de tração nos reforços aumentaram durante a construção da estrutura de solo pregado, e, sobretudo, com a aplicação da sobrecarga. Um chumbador da linha 02 (Bainha) e outro da linha 3 (Bainha) não mostraram 
o mesmo comportamento e mantiveram-se praticamente constantes ao longo do tempo, sofrendo apenas um incremento de carga após a aplicação da sobrecarga. Adicionalmente, verifica-se que a parte final do trecho injetado foi a mais solicitada. Somente o reforço posicionado na linha 1 (Bainha +1 Fase) apresentou uma inversão de esforços, com os maiores esforços atuando no início do trecho injetado. A Tabela 4.5 apresenta um resumo das posições e das cargas máximas medidas ao longo do trecho injetado, durante a fase de construção e após a aplicação da sobrecarga. Apresenta-se, também, o acréscimo de carga atuante após a aplicação da sobrecarga.

Tabela 4.5. Posição e cargas máximas medidas ao longo do trecho injetado.

\begin{tabular}{|c|c|c|c|c|c|}
\hline \multirow[b]{2}{*}{ Linha } & \multirow[b]{2}{*}{ Descrição } & \multirow{2}{*}{$\begin{array}{c}\text { Posição (m)/ } \\
\text { SG }\left(\mathbf{n}^{0}\right)\end{array}$} & \multicolumn{2}{|c|}{ Carga máxima (kN) } & \multirow{2}{*}{$\begin{array}{c}\text { Acréscimo } \\
\text { (\%) }\end{array}$} \\
\hline & & & Fase Construção & $\begin{array}{c}\text { Sobrecarga } \\
\text { (50kPa) }\end{array}$ & \\
\hline \multirow{3}{*}{1} & Bainha & $0,55(03)$ & 1,024 & 1,252 & 22,3 \\
\hline & Bainha + 1 Fase & $0,30(02)$ & 1,627 & 1,758 & 8,1 \\
\hline & Bainha +2 Fases & $0,85(04)$ & 1,414 & 1,511 & 6,9 \\
\hline \multirow{3}{*}{2} & Bainha & $0,85(04)$ & 0,738 & 0,972 & 31,7 \\
\hline & Bainha + 1 Fase & $0,85(04)$ & 1,322 & 1,578 & 19,4 \\
\hline & Bainha +2 Fases & $0,85(04)$ & 1,248 & 1,372 & 9,9 \\
\hline \multirow{2}{*}{3} & Bainha & $0,55(03)$ & 0,739 & 1,009 & 36,5 \\
\hline & Bainha +1 Fase & $0,85(04)$ & 1,127 & 1,230 & 9,1 \\
\hline
\end{tabular}

A partir da Tabela 4.5, verifica-se que, para as três linhas estudadas, os chumbadores que foram submetidos a alguma injeção (uma os duas fases) foram os mais solicitados. Este fato pode ser decorrente do melhor contato entre o solo e o reforço e, consequentemente, da melhoria na transferência de esforços. Na fase de construção, a carga máxima atingida foi de 1,627 kN para o reforço posicionado na linha 1 e construído com a Bainha +1 Fase. Os acréscimos de carga após a aplicação da sobrecarga não foram de grande magnitude, mas foram maiores nos reforços executados somente com a Bainha, atingindo o valor máximo de 36,5 \% na linha 3. 


\subsubsection{Análises de Estabilidade do Solo Pregado}

A estrutura de solo pregado construída em laboratório foi submetida a análises de estabilidade. Para tal, utilizou-se o programa de computador Slope/W, que analisa simultaneamente os métodos Ordinary, de Bishop e de Janbu. Para realizar as análises, foram consideradas as seguintes condições: estabilidade do maciço após o processo de compactação, após a aplicação de uma sobrecarga de 50 kPa e ainda com a inserção dos reforços. Para avaliar a melhoria da estabilidade do maciço a partir das diferentes metodologias executivas, foi realizada uma análise para os diferentes parâmetros $q_{s}$, representativos de cada metodologia. As análises foram realizadas considerando-se superfícies potenciais de ruptura cilíndricas. O fator de segurança mínimo recomendado para as análises de estabilidade é de 1,50.

Para as análises de estabilidade, consideraram-se dois solos: o solo compactado e um solo de fundação. Os parâmetros de resistência do solo compactado foram apresentados no Capítulo 3. O solo de fundação é teórico e foi considerado com elevada resistência para induzir a superfície de ruptura pelo solo compactado. As Figuras 4.14 (a) e (b) apresentam, respectivamente, as análises de estabilidade realizadas para o modelo de solo pregado após o processo de compactação e após a aplicação da sobrecarga de 50kPa. 


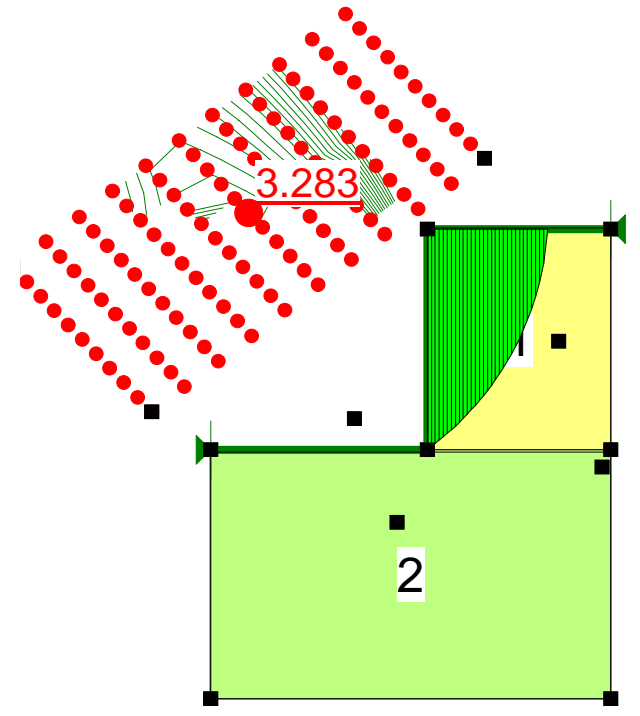

(a)

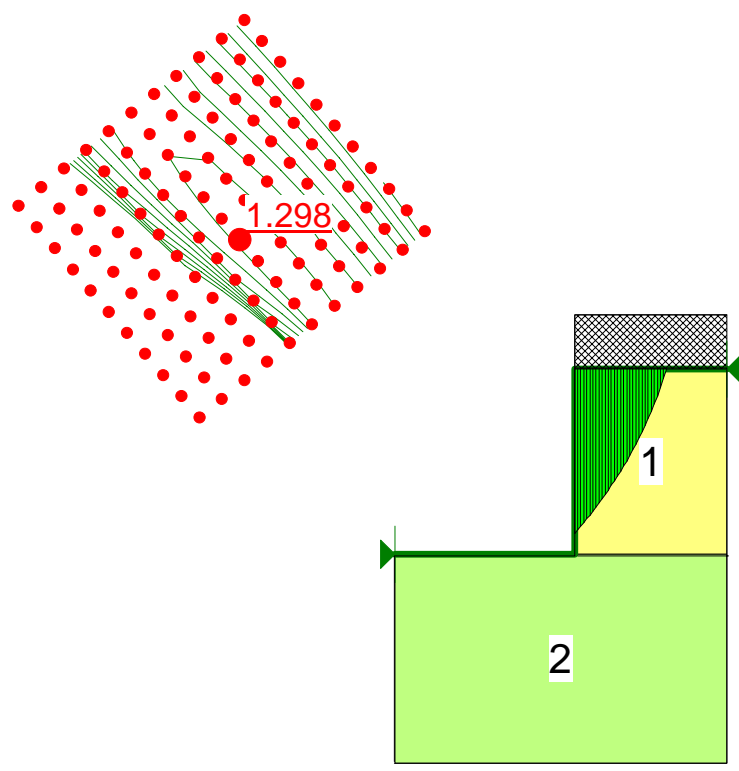

(b)

Figura 4.14. Análise de estabilidade da caixa de ensaios após o processo de compactação (a) e após a aplicação da sobrecarga (b).

Na Tabela 4.6, são apresentados os fatores de segurança obtidos para as situações consideradas. Esses fatores de segurança referem-se ao método de Bishop.

Tabela 4.6. Fatores de Segurança das análises de estabilidade.

\begin{tabular}{cc}
\hline Situação & Fator de Segurança (FS) \\
\hline Maciço após compactação* & 3,283 \\
Maciço compactado com sobrecarga de $50 \mathrm{kPa}$ & 1,298 \\
\hline
\end{tabular}

Obs.: * Sem aplicação de sobrecarga.

O fator de segurança (FS), obtido para a condição de maciço compactado após a aplicação de sobrecarga, mostra uma condição não desejável em projetos de estabilidade de taludes (FS $<1,5)$. Após a realização dos ensaios de arrancamento, determinou-se o valor da resistência de interface $\left(q_{s}\right)$ médio para cada uma das metodologias construtivas. Os valores de $q_{s}$ empregados foram de 67,5 kPa, 72,3 kPa e 92,6 kPa, para Bainha, Bainha +1 Fase e Bainha +2 Fases, respectivamente. As demais características e parâmetros considerados nas análises são apresentados na Tabela 4.7. 
Tabela 4.7. Características e parâmetros empregados nos chumbadores.

\begin{tabular}{cc}
\hline Característica / Parâmetro & Valor adotado \\
\hline Diâmetro do furo (m) & 0,038 \\
Fator de segurança ao arrancamento & 1,0 \\
Espaçamento dos reforços (m) & 0,45 \\
Capacidade elástica da barra de aço CA-50 (kN) & 15,58 \\
Fator de Segurança da barra de aço & 1,15 \\
Resistência ao cisalhamento da barra de aço* & 0 \\
\hline Os.: * Considerou-se que os reforços resistem somente aos esforços de tração.
\end{tabular}

A Figura 4.15 apresenta os resultados das análises de estabilidade para cada uma das metodologias executivas, com o seu respectivo fator de segurança.

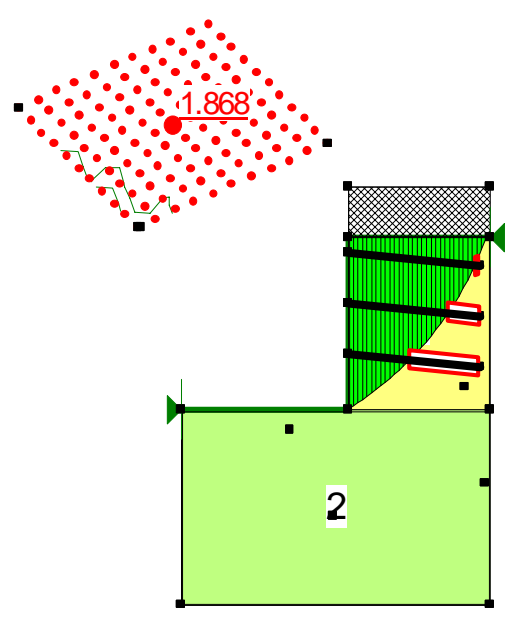

(a)

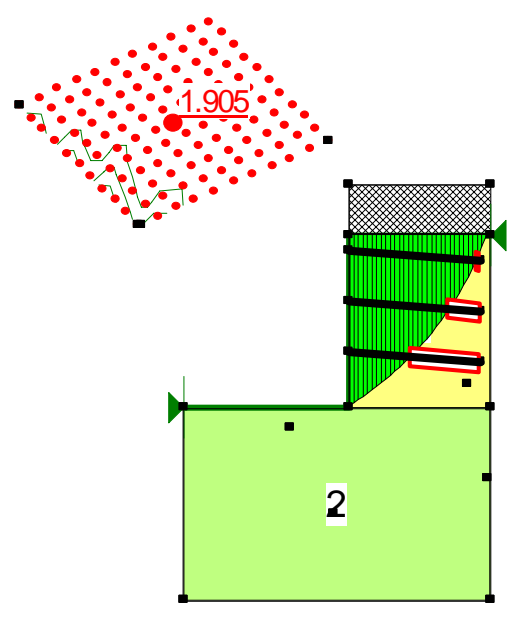

(b)

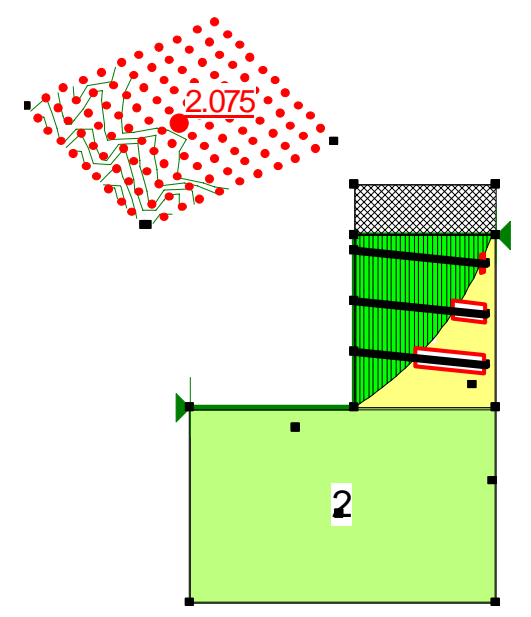

(c)

Figura 4.15. Análise de estabilidade para os diferentes métodos construtivos. (a) Bainha, (b) Bainha +1 Fase, (c) Bainha +2 Fases.

Para as três situações analisadas, o maciço de solo apresenta estabilidade satisfatória (FS>1,5). Conforme esperado, o aumento da resistência ao cisalhamento de interface $\left(q_{s}\right)$ implica em um ganho de segurança e em economia em obras, já que, para um mesmo fator de segurança, pode-se economizar na distribuição e no comprimento dos 
chumbadores. O fator de segurança obtido utilizando-se a metodologia Bainha +1 Fase $(1,905)$ apresentou-se próximo da metodologia Bainha (1,868). Entretanto, para a metodologia Bainha +2 Fases, o incremento do fator de segurança $(2,075)$ foi mais substancial. 


\section{RESULTADOS E ANÁUSES - PROGRAMA EXPERIMENTALDE CAMPO}

Neste capítulo, são apresentados os resultados obtidos e as análises desenvolvidas a partir da realização do programa experimental de campo, em duas obras distintas: Santo André-SP e Osasco-SP.

Os resultados são apresentados separadamente para cada uma das linhas (cotas de ensaio) das obras. Primeiramente, são mostrados os resultados dos ensaios de arrancamento, a partir de curvas carga x deslocamento. Os parâmetros de resistência ao cisalhamento de interface solo-reforço $\left(q_{s}\right)$ são analisados comparativamente, a partir da metodologia executiva, do comprimento do chumbador e do volume injetado de calda de cimento. Adicionalmente, também são apresentadas as curvas típicas de distribuição do carregamento ao longo do comprimento dos reforços, obtidas pelo monitoramento dos strain gages posicionados nas barras de aço.

Os resultados obtidos permitiram estabelecer equações que relacionam o parâmetro $q_{s}$ com o volume injetado de calda de cimento, sendo uma importante ferramenta para avaliar as premissas adotadas em projeto e estimar este parâmetro a partir de um controle realizado em campo.

A partir dos resultados das investigações geotécnicas e dos ensaios de caracterização geotécnica, foi realizada uma previsão deste parâmetro pelos principais métodos teóricos e empíricos encontrados na literatura. Estes resultados foram comparados com os obtidos a partir dos ensaios de arrancamento. 


\subsection{ENSAIOS REAUZADOS}

Na Tabela 5.1, apresenta-se o resumo dos ensaios de arrancamento realizados. São informados os números totais de chumbadores executados, ensaiados e finalizados (em que foi possível atingir a condição de ruptura). Dentre os ensaios não finalizados, apresentam-se as causas para a sua inutilização, bem como a sua quantificação. Os dados são apresentados separadamente, para as duas obras do programa experimental de campo, informando a quantidade de chumbadores instrumentados ou não.

Tabela 5.1. Resumo dos ensaios de arrancamento realizados.

\begin{tabular}{|c|c|c|c|c|c|c|}
\hline \multirow{3}{*}{$\begin{array}{l}\text { Informações dos } \\
\text { Chumbadores }\end{array}$} & \multicolumn{6}{|c|}{ Número de Chumbadores } \\
\hline & \multicolumn{3}{|c|}{ Obra 1} & \multicolumn{3}{|c|}{ Obra 2} \\
\hline & Instrumentados & $\begin{array}{c}\text { Não } \\
\text { Instrumentados } \\
\end{array}$ & Total & Instrumentados & $\begin{array}{c}\text { Não } \\
\text { Instrumentados }\end{array}$ & Total \\
\hline Executados & 17 & 11 & 28 & 17 & 9 & 26 \\
\hline Ensaiados & 17 & 9 & 26 & 17 & 9 & 26 \\
\hline Finalizados & 15 & 6 & 21 & 15 & 8 & 23 \\
\hline Paralisados & 2 & 3 & 5 & 2 & 0 & 2 \\
\hline Problemas na Aquisição & 0 & 0 & 0 & 0 & 1 & 1 \\
\hline
\end{tabular}

A Tabela 5.1 mostra que, para a obra de Santo André-SP (obra 1), vinte e um ensaios de arrancamento foram finalizados, ou seja, atingiram a condição de ruptura, e cinco ensaios foram paralisados antes de atingir esta condição. A paralisação dos ensaios foi motivada pelo aparecimento de trincas no paramento de concreto projetado, face aos elevados carregamentos alcançados durante a realização dos ensaios. A partir destes acontecimentos, dois chumbadores executados não foram sequer ensaiados. Na obra de Osasco-SP (obra 2), todos os chumbadores executados foram submetidos ao ensaio de arrancamento. Três ensaios de arrancamento não foram finalizados, sendo que dois deles foram paralisados antes de atingir a ruptura (elevado carregamento), e o outro foi perdido por problemas no sistema de aquisição de dados.

Para aumentar a confiabilidade dos ensaios e permitir uma análise mais criteriosa da distribuição do carregamento ao longo do comprimento dos chumbadores, 63,0\% dos 
chumbadores ensaiados foram instrumentados com strain gages. Os resultados dos ensaios de arrancamento dos chumbadores são apresentados separadamente, para as duas obras em que se realizou o programa experimental de campo.

\subsection{ENSAIOS DE ARRANCAMENTO - SANTO ANDRÉ-SP (OBRA 1)}

Para permitir a realização de análises comparativas das diferentes metodologias executivas empregadas na construção dos chumbadores, os resultados são apresentados separadamente, para cada uma das linhas (cotas de ensaio) onde foram executados. Com o objetivo de padronizar e facilitar a sua interpretação, são apresentados nas Tabelas 5.2 e 5.3, para as linhas 2 e 5, respectivamente. São apresentados o número, a metodologia construtiva, o comprimento e o tipo de cada chumbador.

Tabela 5.2. Identificação e características dos chumbadores da linha 2.

\begin{tabular}{cccc}
\hline $\mathbf{N}^{\circ}$ Chumbador & Metodologia & Comprimento (m) & Tipo \\
\hline 1 & D & 6,0 & Longo \\
2 & A & 3,0 & Curto \\
3 & E & 3,0 & Curto \\
4 & E & 6,0 & Longo \\
5 & A & 3,0 & Curto \\
6 & A & 6,0 & Longo \\
7 & C & 3,0 & Curto \\
8 & C & 6,0 & Longo \\
9 & B & 3,0 & Curto \\
10 & B & 6,0 & Longo \\
11 & F & 3,0 & Curto \\
12 & F & 6,0 & Longo \\
13 & D & 3,0 & Curto \\
14 & D & 6,0 & Longo \\
\hline
\end{tabular}


Tabela 5.3. Identificação e características dos chumbadores da linha 5.

\begin{tabular}{cccc}
\hline $\mathbf{N}^{\circ}$ Chumbador & Metodologia & Comprimento (m) & Tipo \\
\hline 15 & A $^{*}$ & 6,0 & Longo \\
16 & A $^{*}$ & 3,0 & Curto \\
17 & E & 3,0 & Curto \\
18 & E & 3,0 & Curto \\
19 & A & 3,0 & Curto \\
20 & A & 6,0 & Longo \\
21 & C & 3,0 & Curto \\
22 & C & 3,0 & Curto \\
23 & B & 3,0 & Curto \\
24 & B & 6,0 & Longo \\
25 & F & 3,0 & Curto \\
26 & F & 3,0 & Curto \\
27 & D & 3,0 & Curto \\
28 & D & 3,0 & Curto \\
\hline
\end{tabular}

A Tabela 5.2 mostra que, para a linha 2, foi executado o mesmo número de chumbadores curtos e longos. Para cada uma das metodologias estudadas, foram construídos, pelo menos, um chumbador curto e outro longo. Na linha 5 (Tabela 5.3), foram executados apenas três chumbadores longos, em virtude das dificuldades já mencionadas anteriormente. Vale lembrar que, como aspecto inovador, foram construídos dois chumbadores com a metodologia A* (bainha executada com calda de solo-cimento).

\subsubsection{Ensaios de Arrancamento - Linha 2}

A Figura 5.1 apresenta as curvas carga $\mathrm{x}$ deslocamento obtidas a partir dos ensaios de arrancamento realizados nos chumbadores curtos (02 e 05) e longo (06), executados com a metodologia A. 


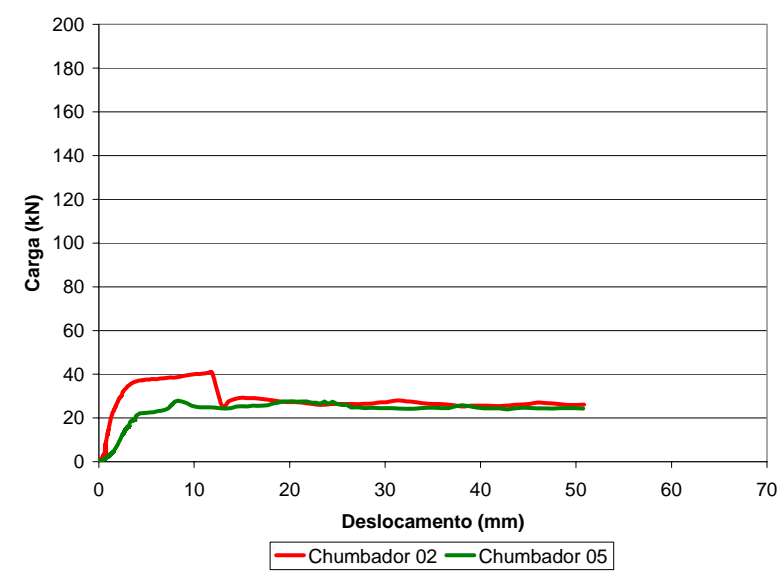

(a)

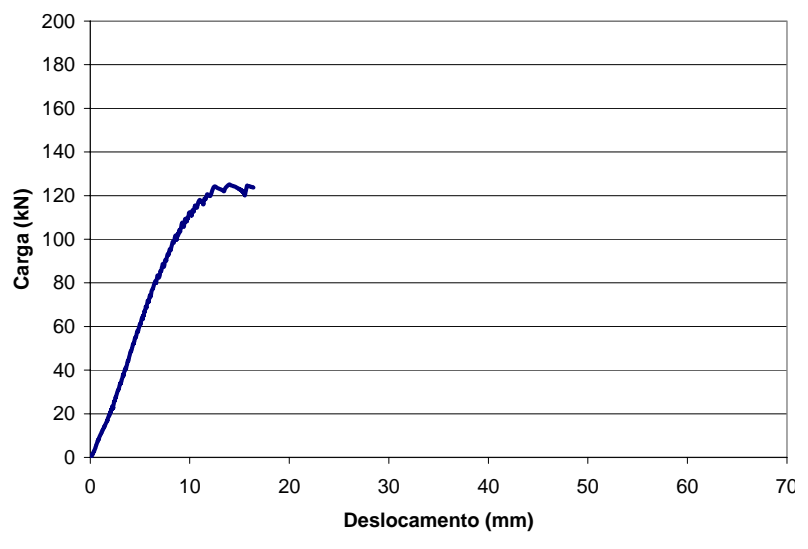

(b)

Figura 5.1. Curvas carga $x$ deslocamento dos chumbadores curtos (a) e longo (b) construídos com a metodologia A.

A partir da Figura 5.1, observa-se que as curvas carga $\mathrm{x}$ deslocamento dos chumbadores curtos 02 e 05 , realizados com a metodologia A, apresentaram ruptura frágil e posterior concordância nas cargas residuais. As cargas máximas apresentaram valores distintos, sendo representadas por $40,7 \mathrm{kN}$ e $27,9 \mathrm{kN}$, respectivamente. Este fato se deve as eventuais imperfeições existentes (variação do diâmetro) ao longo do chumbador, comuns a esta metodologia executiva. O ensaio no chumbador longo (06) foi paralisado com deslocamentos da ordem de $18 \mathrm{~mm}$, entretanto, foi possível definir a carga de ruptura em $125,0 \mathrm{kN}$.

A Figura 5.2 apresenta os resultados obtidos para os chumbadores curto (09) e longo (10) executados com a metodologia B. 


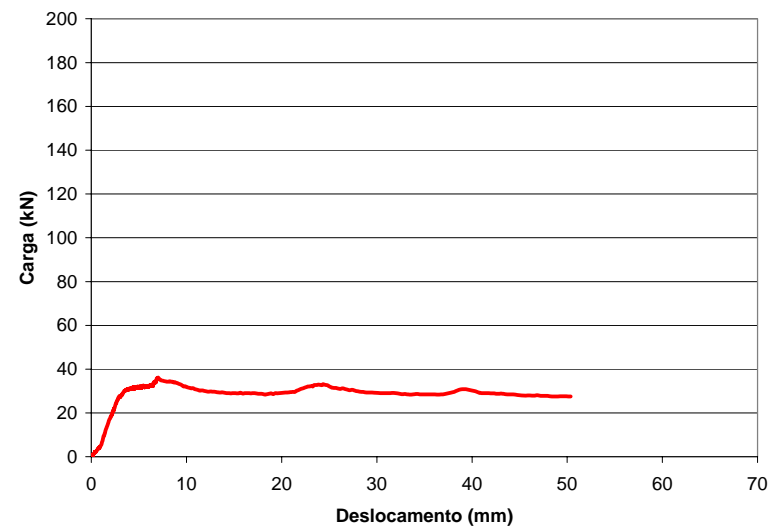

(a)

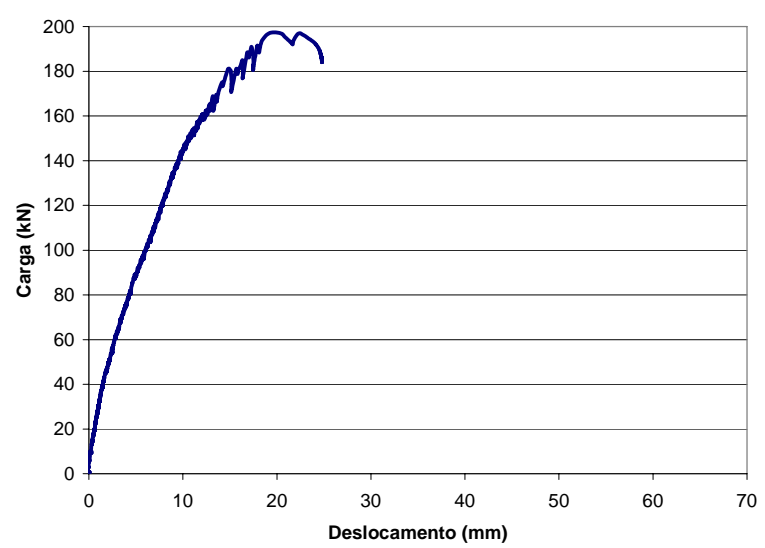

(b)

Figura 5.2. Curvas carga $x$ deslocamento dos chumbadores curto (a) e longo (b) construídos com a metodologia B.

A Figura 5.2 mostra que a curva carga x deslocamento do chumbador curto 09, realizado com a metodologia $\mathrm{B}$, apresentou um comportamento semelhante ao do chumbador 05 (metodologia A), mas com carga de ruptura superior e igual a 36,2 kN, para deslocamento de 7,0 mm. O carregamento de pico ficou próximo da carga residual. Ao analisar o comportamento do chumbador longo (10), verifica-se que mesmo não tendo atingido elevado deslocamento, foi possível definir a carga de ruptura em 197,3 kN, para deslocamento de 19,3 mm.

A Figura 5.3 apresenta os resultados obtidos para os chumbadores curto (07) e longo (08) executados com a metodologia C.

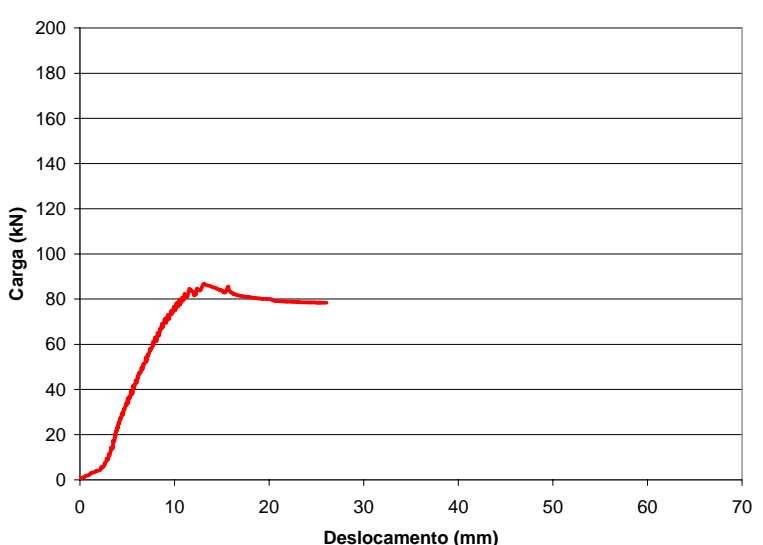

(a)

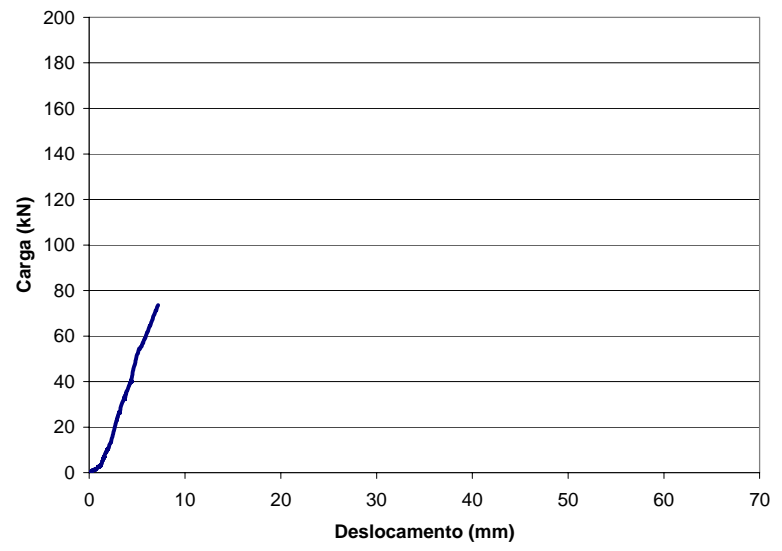

(b)

Figura 5.3. Curvas carga $x$ deslocamento dos chumbadores curto (a) e longo (b) construídos com a metodologia $\mathbf{C}$. 
A Figura 5.3 (a) mostra que o chumbador curto (07) apresentou uma carga de ruptura bem definida, de $85,8 \mathrm{kN}$, para deslocamento de $13,7 \mathrm{~mm}$, e posterior estabilização em um valor residual. O ensaio de arrancamento do chumbador longo (08) foi interrompido antes de atingir o carregamento de ruptura, bem como o critério de deslocamento definido por Clouterre (1991). Este fato se deve às limitações impostas pelo conjunto macacobomba e ao aparecimento de trincas ao longo do paramento de concreto projetado.

Os resultados dos ensaios de arrancamento realizados nos chumbadores curto (13) e longo (14) executados com a metodologia D são apresentados na Figura 5.4.

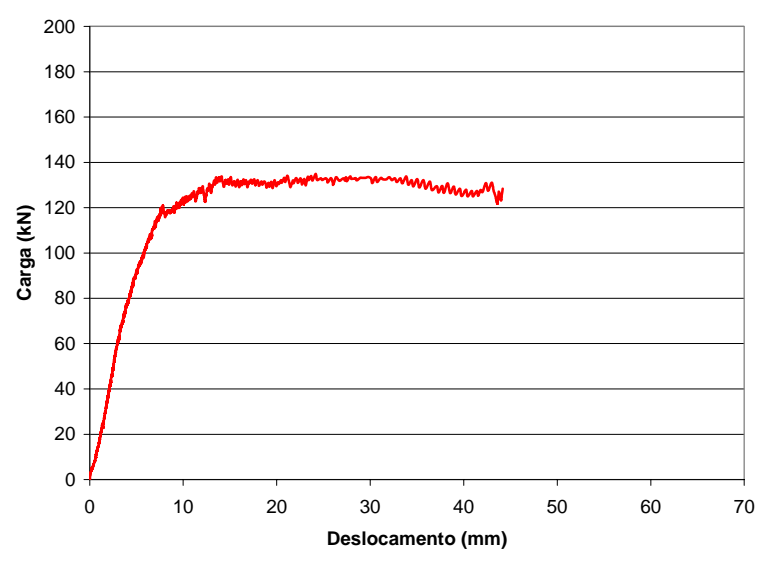

(a)

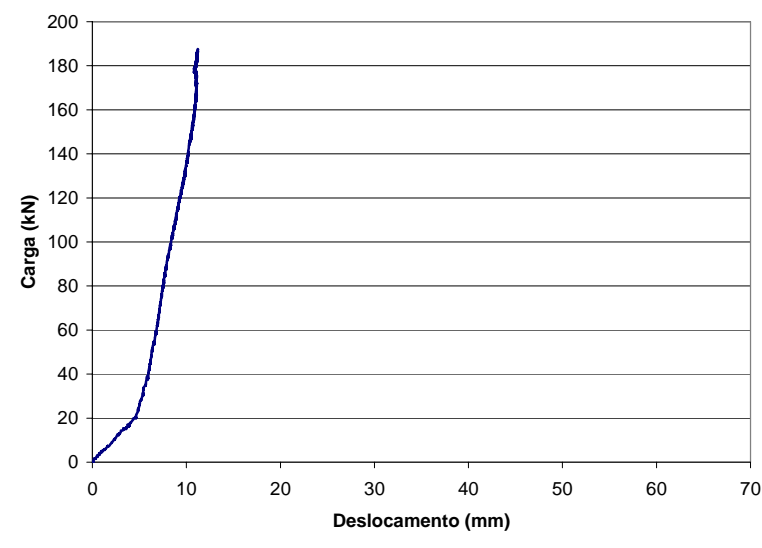

(b)

Figura 5.4. Curvas carga $x$ deslocamento dos chumbadores curto (a) e longo (b) construídos com a metodologia D.

A partir da curva carga x deslocamento apresentada na Figura 5.4 (a), verifica-se que o chumbador curto (13) apresenta o seguinte comportamento: um trecho elástico bem definido e uma posterior ruptura por plastificação. Clouterre (1991) define que este critério de ruptura deve ser verificado para deslocamentos de até $30 \mathrm{~mm}$. Para este chumbador, a carga de ruptura foi definida em 133,8 kN, para deslocamento de 14,1 mm. Para padronizar este comportamento, neste trabalho, este tipo de ruptura será nomeado de ruptura plástica. Como as cargas obtidas para o chumbador longo (14) foram elevadas, o ensaio também foi interrompido antes da definição da ruptura (Figura 5.4-b). Este fato se deve as mesmas justificativas já apresentadas anteriormente, para os chumbadores longos. 
A Figura 5.5 apresenta o resultado do ensaio de arrancamento realizado no chumbador curto (03) executado com a metodologia E. Para esta metodologia, não foi possível a realização do ensaio no chumbador longo (04).

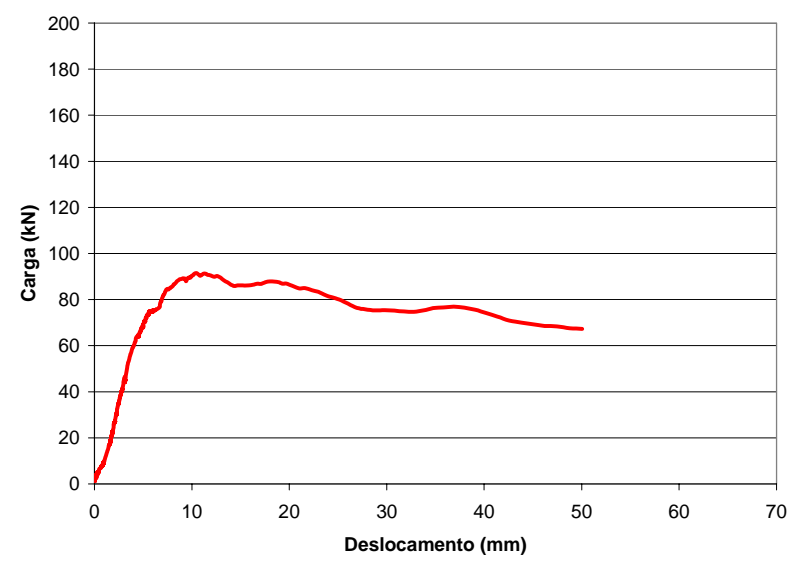

Figura 5.5. Curva carga $x$ deslocamento do chumbador curto construído com a metodologia $E$.

O chumbador curto (03), realizado com a metodologia $E$, apresentou curva carga $\mathrm{x}$ deslocamento com ruptura frágil, carga de pico de $91,5 \mathrm{kN}$ e deslocamento de 10,4 mm. Conforme esperado, as cargas tenderam para um valor residual para maiores deslocamentos.

As curvas carga $\mathrm{x}$ deslocamento dos ensaios de arrancamento realizados nos chumbadores curto (11) e longo (12), executados com a metodologia F, são apresentadas na Figura 5.6.

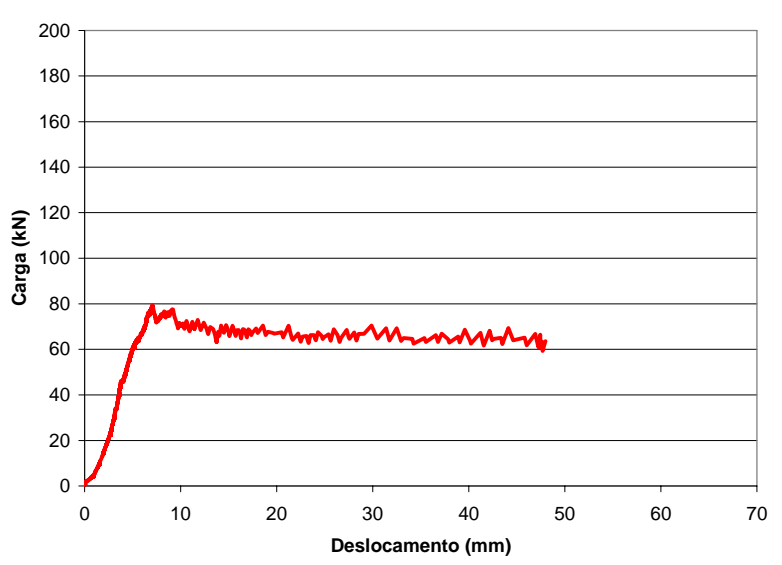

(a)

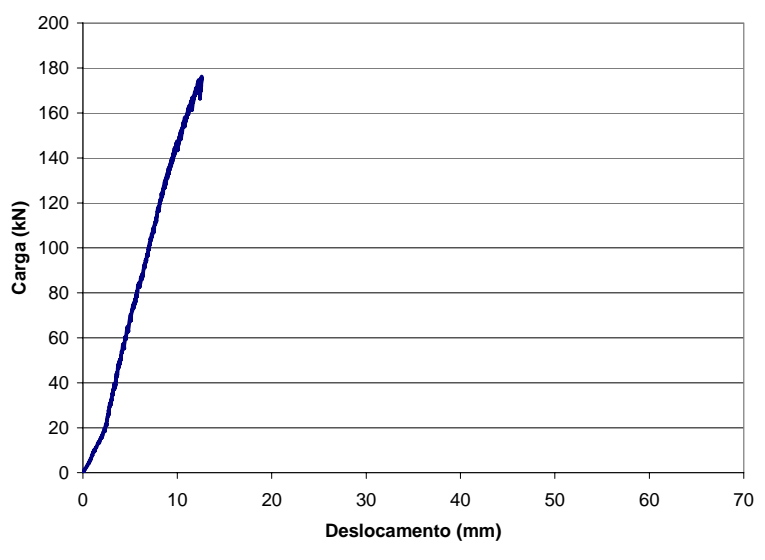

(b)

Figura 5.6. Curvas carga $x$ deslocamento dos chumbadores curto (a) e longo (b) construídos com a metodologia F. 
A Figura 5.6 (a) mostra que o chumbador curto (11) apresentou comportamento semelhante aos demais chumbadores curtos, ou seja, uma ruptura frágil, com carga de ruptura bem definida $(79,4 \mathrm{kN})$, para um deslocamento de $7,1 \mathrm{~mm}$, além de posterior estabilização em um valor residual. O ensaio de arrancamento do chumbador longo (12) também foi interrompido antes de atingir o carregamento de ruptura (Figura 5.6-b). Este fato também se deve as mesmas limitações já mencionadas.

A Tabela 5.4 apresenta o resumo dos resultados dos ensaios de arrancamento realizados nos chumbadores curtos e longos construídos na linha 2, com as diferentes metodologias executivas. São apresentados os principais parâmetros obtidos a partir dos ensaios, que são: carga máxima de ruptura ( $\left.\mathrm{T}_{\text {máx }}\right)$, carga máxima de ruptura por metro linear de chumbador, deslocamento referente à carga máxima, resistência ao cisalhamento de interface solo-reforço $\left(q_{s}\right)$ e modo de ruptura (quando esta ocorre), nomeando $\mathrm{F}$ para ruptura frágil e P para ruptura plástica. Os chumbadores que não atingiram a ruptura foram identificados por NR

Tabela 5.4. Resumo dos resultados dos ensaios de arrancamento da linha 2.

\begin{tabular}{|c|c|c|c|c|c|c|c|c|}
\hline \multicolumn{4}{|c|}{ Chumbador } & \multirow[b]{2}{*}{$\mathbf{T}_{\text {máx }}(\mathbf{k N})$} & \multirow[b]{2}{*}{$\begin{array}{c}\text { Tmáx/m } \\
(\mathbf{k N})\end{array}$} & \multirow[b]{2}{*}{$\begin{array}{c}\text { Deslocamento } \\
\text { (mm) }\end{array}$} & \multirow[b]{2}{*}{$\begin{array}{c}\mathbf{q}_{\mathrm{s}} \\
(\mathbf{k P a})\end{array}$} & \multirow[b]{2}{*}{$\begin{array}{l}\text { Modo de } \\
\text { Ruptura }\end{array}$} \\
\hline $\mathbf{N}^{\circ}$ & Metodologia & $\begin{array}{c}\text { Comprimento } \\
\text { (m) }\end{array}$ & Tipo & & & & & \\
\hline 1 & D & 6,0 & Longo & - & - & - & - & - \\
\hline 2 & A & 3,0 & Curto & 40,7 & 13,6 & 11,9 & 56,7 & F \\
\hline 3 & E & 3,0 & Curto & 91,5 & 30,5 & 10,4 & 127,4 & $\mathrm{~F}$ \\
\hline 4 & E & 6,0 & Longo & - & - & - & - & - \\
\hline 5 & A & 3,0 & Curto & 27,9 & 8,3 & 8,3 & 38,8 & F \\
\hline 6 & A & 6,0 & Longo & 125,0 & 20,8 & 13,9 & 87,1 & $\mathrm{~F}$ \\
\hline 7 & $\mathrm{C}$ & 3,0 & Curto & 85,8 & 14,3 & 13,7 & 119,5 & $\mathrm{~F}$ \\
\hline 8 & $\mathrm{C}$ & 6,0 & Longo & 73,6 & 24,5 & 7,2 & 51,2 & NR \\
\hline 9 & B & 3,0 & Curto & 36,2 & 12,1 & 7,0 & 50,4 & $\mathrm{~F}$ \\
\hline 10 & B & 6,0 & Longo & 197,3 & 32,9 & 19,3 & 137,3 & $\mathrm{~F}$ \\
\hline 11 & $\mathrm{~F}$ & 3,0 & Curto & 79,4 & 26,5 & 7,1 & 110,6 & $\mathrm{~F}$ \\
\hline 12 & $\mathrm{~F}$ & 6,0 & Longo & 176,2 & 29,4 & 12,6 & 122,6 & NR \\
\hline 13 & D & 3,0 & Curto & 133,8 & 44,6 & 14,1 & 186,3 & $\mathrm{P}$ \\
\hline 14 & $\mathrm{D}$ & 6,0 & Longo & 179,4 & 29,9 & 10,8 & 124,9 & NR \\
\hline
\end{tabular}


Frente ao grande número de resultados apresentados para uma mesma cota (linha) de ensaios, foram realizadas análises para a verificação do comportamento do parâmetro $q_{s}$ em função da metodologia executiva, do volume de injeção de calda de cimento e do comprimento do chumbador. Adicionalmente, também são apresentados os resultados obtidos a partir da instrumentação realizada com strain gages ao longo da barra de aço.

\subsubsection{Influência da Metodologia Executiva}

Para permitir a análise comparativa das diferentes metodologias executivas, as curvas carga x deslocamento são apresentadas, de forma agrupada, para os chumbadores curtos (Figura 5.7) e longos (Figura 5.8).

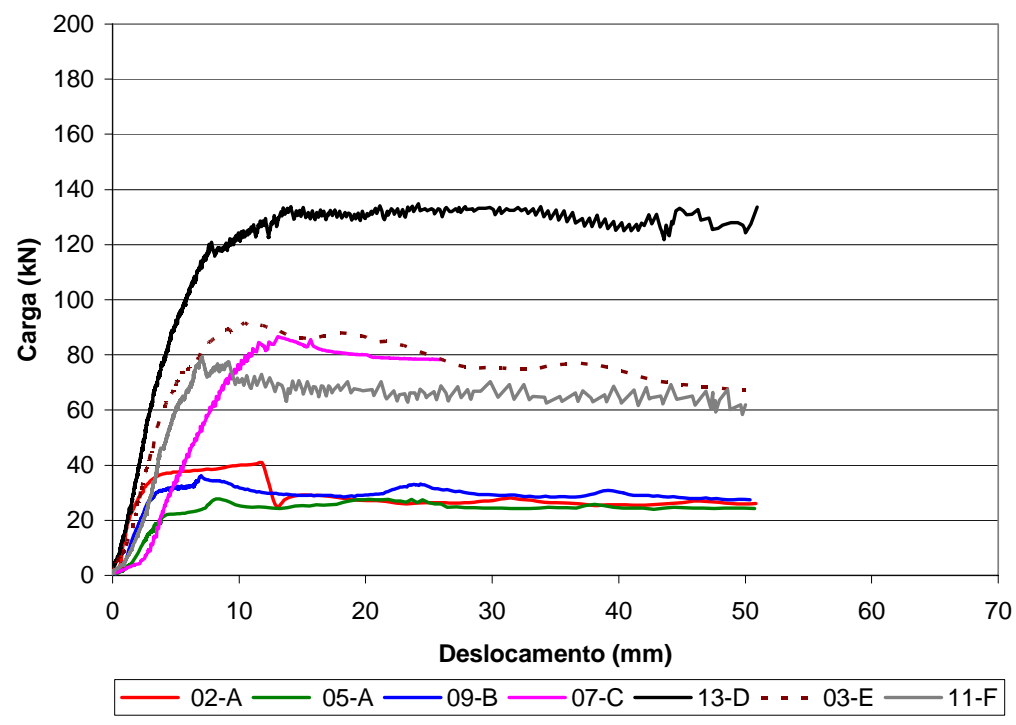

Figura 5.7. Curvas carga $\mathbf{x}$ deslocamento dos chumbadores curtos executados com as diferentes metodologias executivas. 


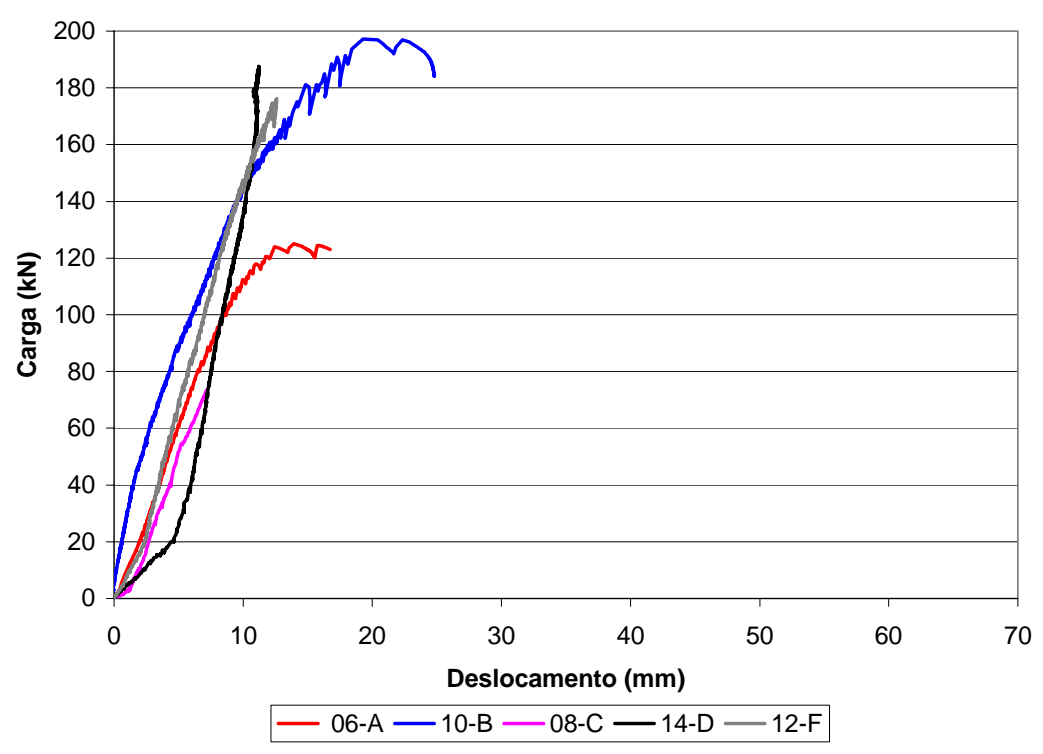

Figura 5.8. Curvas carga $\mathrm{x}$ deslocamento dos chumbadores longos executados com as diferentes metodologias executivas.

As curvas carga x deslocamento apresentadas nas Figuras 5.7 e 5.8 mostram um aumento significativo das cargas de arrancamento, quando comparamos as metodologias executivas em que houve alguma fase de injeção de calda de cimento com a metodologia A, tomada como referência. Para poder avaliar e quantificar a influência das diferentes metodologias executivas, são apresentados gráficos contendo o valor de $q_{s}$ para cada uma das metodologias executivas. Para facilitar a análise comparativa, os valores percentuais apresentados foram referenciados (100\%) em relação aos valores de $q_{s}$ da metodologia A. A Figura 5.9 mostra estas análises para os chumbadores curtos. Vale a pena lembrar que, para estes chumbadores executados com a metodologia A, o parâmetro $q_{s}$ foi calculado a partir da média dos valores obtidos para os chumbadores 02 e 05. 


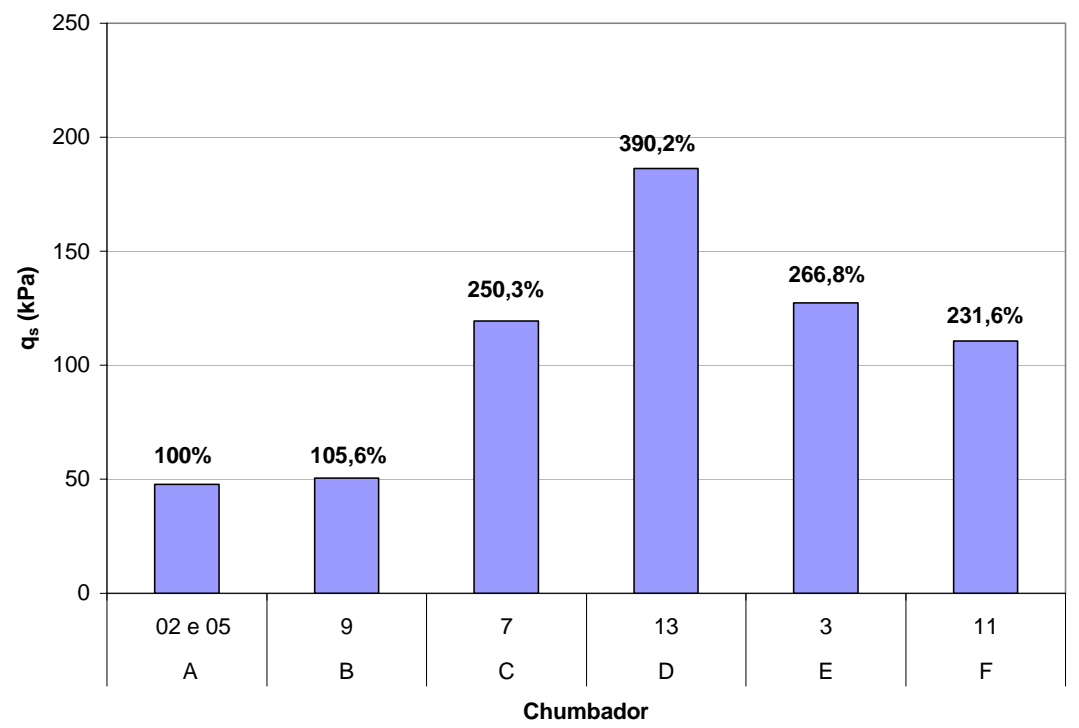

Figura 5.9. Análise comparativa entre os valores de $q_{s}$ obtidos para os chumbadores curtos executados com as diferentes metodologias executivas.

Da Figura 5.9, é possível observar que o valor de $q_{s}$ obtido para a metodologia B foi $5,6 \%$ superior ao valor obtido para a metodologia A, ou seja, houve um pequeno incremento na resistência ao cisalhamento de interface. Este fato sugere que o chumbador executado com a metodologia B apresenta imperfeições ao longo do trecho injetado, similares aos da metodologia A. Os incrementos de $q_{s}$ para as metodologias C, E e F foram próximos e da ordem de 150,3, 166,8 e 131,6\%, respectivamente. O chumbador executado com a metodologia $\mathrm{D}$ foi o que obteve o melhor desempenho em termos de $q_{s}$. O ganho neste parâmetro foi da ordem de 290,2\%, em relação ao chumbador executado somente com a bainha (metodologia A).

Previa-se, inicialmente, que os chumbadores executados com as metodologias $\mathrm{C}$ e E (bainha +2 fases) apresentassem resultados de mesma ordem de grandeza. Da mesma forma, esperavam-se comportamentos similares para as metodologias D e F (bainha +3 fases). Entretanto, este fato foi verificado somente para a primeira situação. Assim como ocorreu no programa experimental de laboratório, também era esperado que, teoricamente, os resultados de $q_{s}$ para as metodologias $\mathrm{D}$ e $\mathrm{F}$ seriam superiores às metodologias $\mathrm{C}$ e $\mathrm{E}$. Esta previsão foi apenas confirmada para a metodologia D. 
A Figura 5.10 apresenta a análise comparativa realizada para os chumbadores longos.

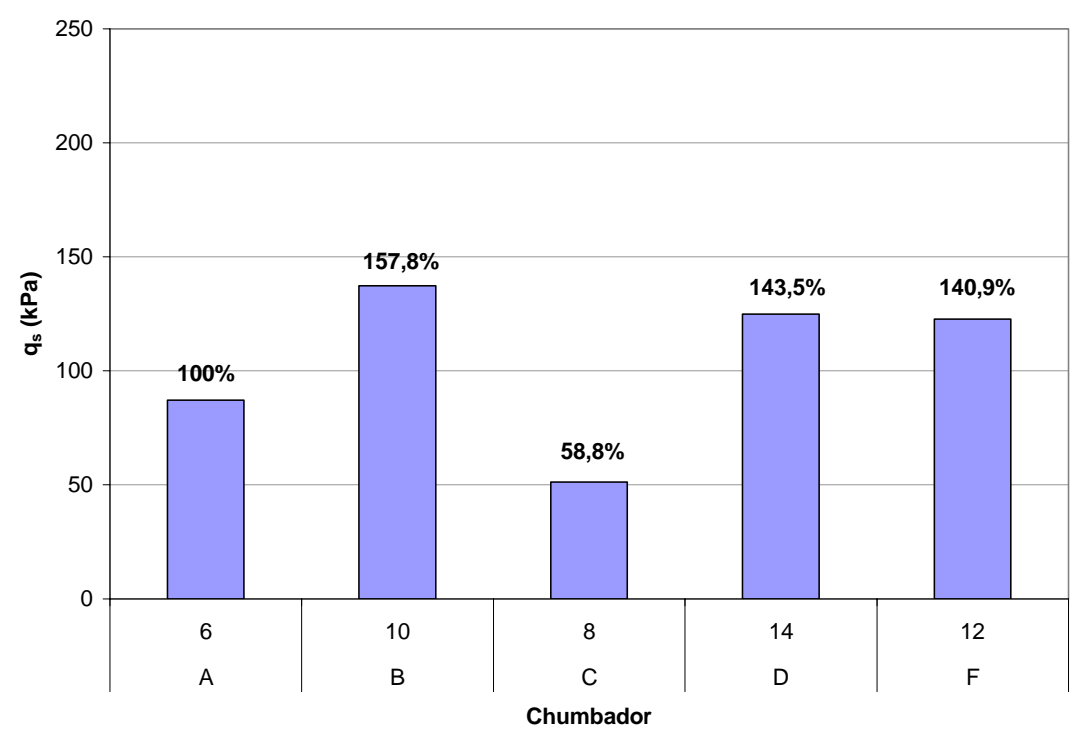

Figura 5.10. Análise comparativa entre os valores de $q_{s}$ obtidos para os chumbadores longos executados com as diferentes metodologias executivas.

A partir dos valores de $q_{s}$ apresentados na Figura 5.10 e lembrando que somente os chumbadores 06 (metodologia A) e 10 (metodologia B) atingiram a condição de ruptura, é possível tecer os seguintes comentários:

$>$ Conforme esperado, o valor de $q_{s}$ obtido para a metodologia B foi 57,8\% superior ao valor de $q_{s}$ de referência (metodologia A).

Como a condição de ruptura não foi atingida para os chumbadores executados com as metodologias C, D e F, não foi possível, para estas metodologias, realizar a análise comparativa. Entretanto, como esperado, verificou-se que, mesmo sem finalizar os ensaios, os chumbadores executados com as metodologias D e F apresentaram resultados de $q_{s}$ superiores à metodologia $\mathrm{A}$, tomada como referência.

A partir dos resultados obtidos, verifica-se que o valor de $q_{s}$ está intimamente relacionado com a metodologia executiva e, consequentemente, com o volume de calda de cimento que foi injetado para as diferentes metodologias executivas. 


\subsubsection{Influência do Volume de Injeção de Calda de Cimento}

Na tentativa de verificar uma tendência de comportamento, os valores de $q_{s}$ e dos volumes de injeção dos chumbadores curtos são apresentados em um mesmo gráfico (Figura 5.11). Para facilitar a visualização, os volumes injetados também são apresentados ao longo do gráfico.

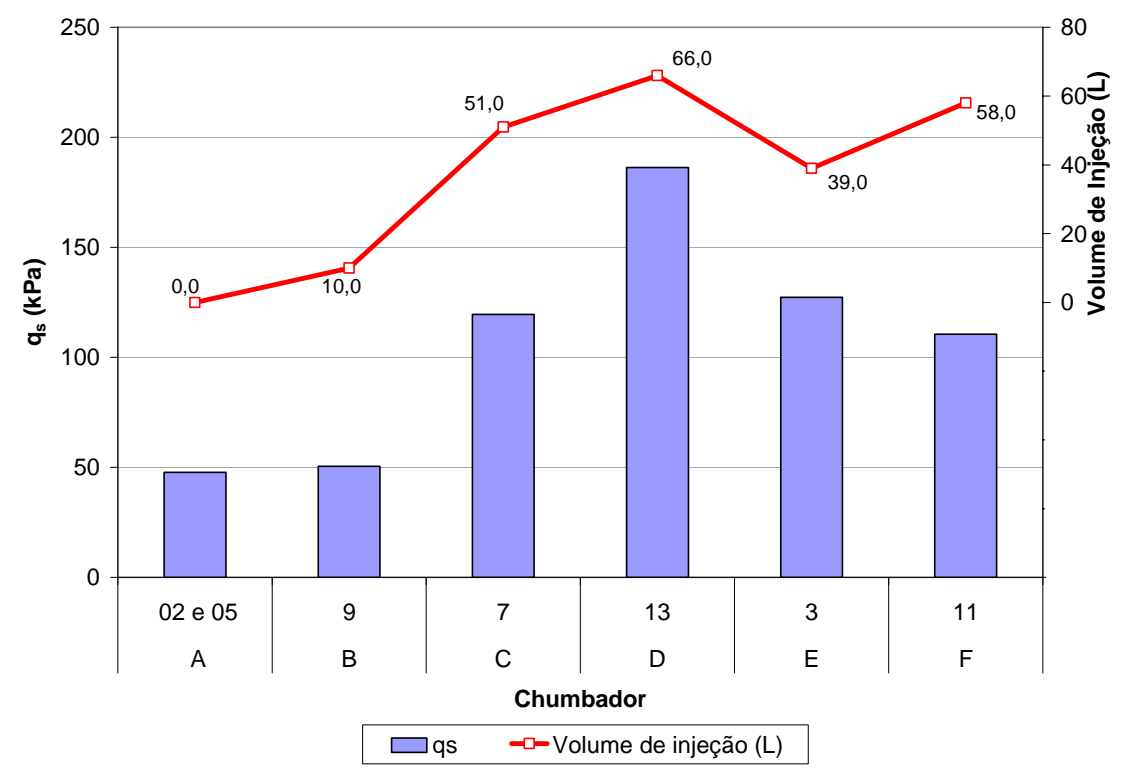

Figura 5.11. Variações de $q_{s}$ e dos volumes de injeção dos chumbadores curtos para as diferentes metodologias executivas.

Os resultados apresentados na Figura 5.11 mostram, claramente, que os ganhos no parâmetro $q_{s}$ estão diretamente relacionados com a metodologia executiva e, consequentemente, com os volumes de injeção de calda de calda de cimento determinados para cada metodologia executiva. Ao analisar o chumbador curto executado com a metodologia $\mathrm{B}$, verifica-se que a proximidade do parâmetro $q_{s}$ em relação à metodologia $\mathrm{A}$ pode ser explicada pelo menor volume injetado (10,0 litros). Para o chumbador longo executado com esta mesma metodologia, houve um ganho em termos de $q_{s}$ de 57,8 \% (Figura 5.10) e o volume injetado foi de 24,0 litros. A similaridade dos parâmetros $q_{s}$ para os chumbadores curtos executados com as metodologias C,E e F são justificadas pelos 
volumes injetados de 51,0, 39,0 e 58,0 litros, respectivamente. O melhor desempenho da metodologia $\mathrm{D}$ deve-se ao maior volume injetado (66,0 litros).

Embora não tenha sido possível a realização da exumação dos chumbadores, como realizado em laboratório, os ensaios de arrancamento comprovam que a melhoria no desempenho deve-se à melhoria da integridade do chumbador e as eventuais ramificações das injeções no maciço de solo.

A partir das análises apresentadas, verificou-se, quantitativamente, a interdependência entre o parâmetro $q_{s}$ e o volume de injeção. Assim como no programa experimental de laboratório, foi atribuído um fator adimensional "V”, que representa a relação entre o volume injetado e o volume da cavidade escavada. A Figura 5.12 apresenta uma correlação entre os dois parâmetros $\left(q_{s} \times\right.$ Fator V).

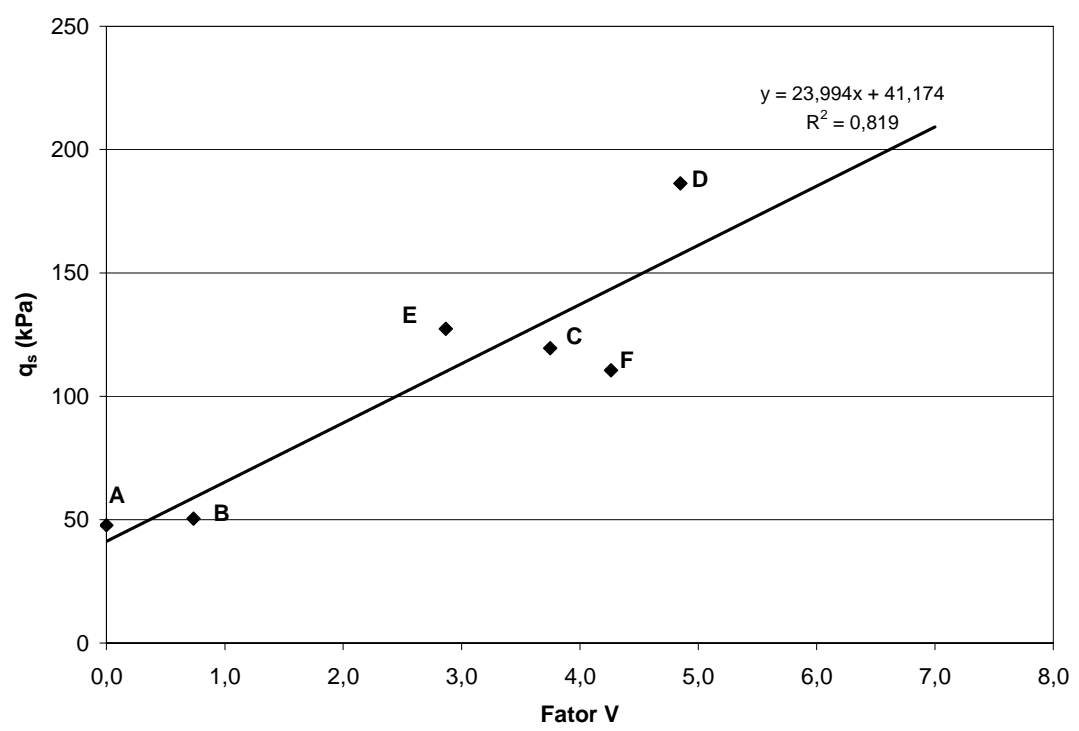

Figura 5.12. Valores de $q_{s} \times$ Fator $V$ para os chumbadores curtos executados com as diferentes metodologias executivas.

O ajuste linear apresentado na Figura 5.12 mostra um valor de $\mathrm{R}^{2}$ aceitável, considerando-se o pequeno espaço amostral e as variabilidades inerentes às metodologias executivas adotadas para a construção dos chumbadores. O coeficiente linear da equação do ajuste equivale a um volume de injeção igual a zero, ou seja, representa a metodologia $\mathrm{A}$ 
(bainha). Considerando esta situação, o valor de $q_{s}$, representado por $41,2 \mathrm{kPa}$, é inferior ao mínimo sugerido pela GeoRio (1999), de $60 \mathrm{kPa}$.

Os resultados obtidos confirmam a constatação apresentada no programa experimental de laboratório. A determinação do volume de injeção é uma excelente opção no controle de qualidade de execução do chumbador. Recomenda-se que, para obras que apresentem o mesmo solo característico da linha 2, adote-se a função $q_{s}=23,99 \mathrm{x}$ "Fator $\mathrm{V} ”+41,2(\mathrm{kPa})$.

\subsubsection{Influência do Comprimento do Chumbador}

Seguindo a seqüência de análises, avaliou-se a influência do comprimento dos chumbadores na resistência ao cisalhamento de interface solo-reforço $\left(q_{s}\right)$. Tomou-se como referência apenas as metodologias A e B, visto que, somente para elas, a condição de ruptura é atendida, tanto para os chumbadores curtos como para os longos. A Figura 5.13 apresenta as curvas carga $\mathrm{x}$ deslocamento, considerando-se estas duas condições.

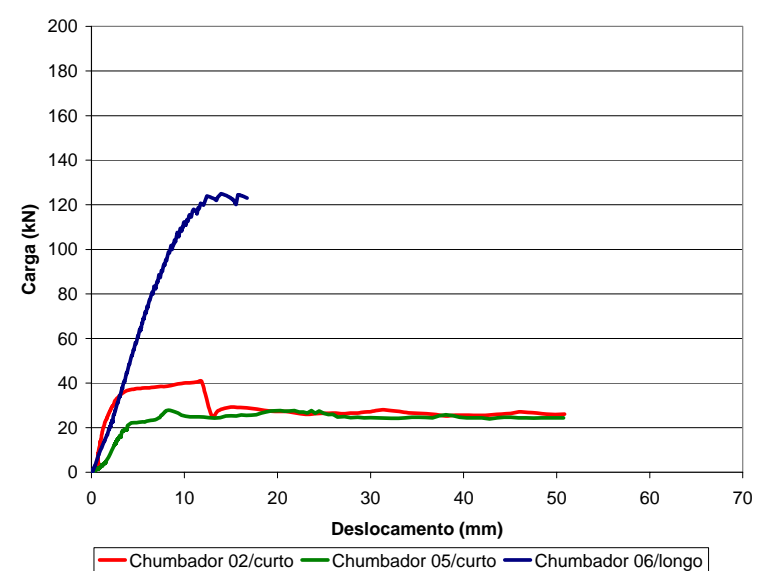

(a)

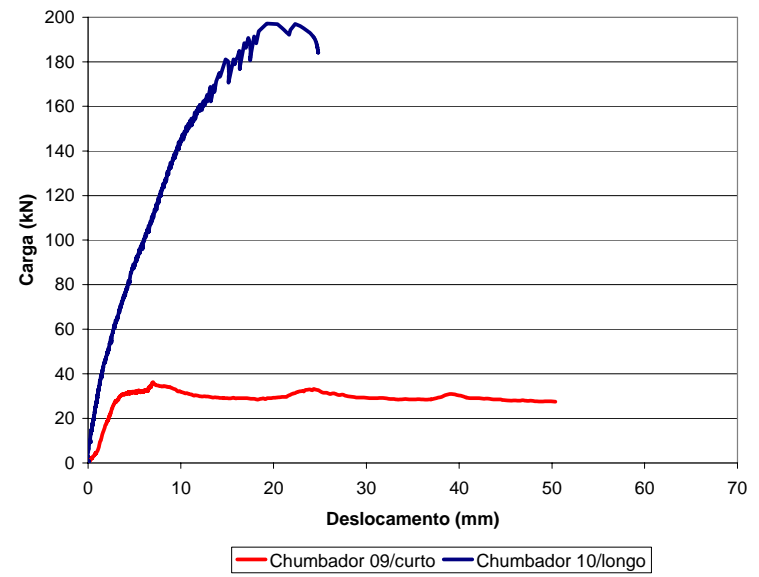

(b)

Figura 5.13. Curvas carga $\mathrm{x}$ deslocamento dos chumbadores curtos e longos executados com as metodologias A (a) e B (b).

A partir das comparações apresentadas nas Figuras 5.13 (a) e (b), esperava-se, teoricamente, que o carregamento de pico do chumbador longo fosse se duplicar em relação ao chumbador curto, dado os comprimentos executados. Porém, este comportamento não 
foi observado. As cargas de pico obtidas para os chumbadores longos, em relação às metodologias A e B foram, respectivamente, 3,6 e 5,4 vezes superiores aos valores observados para os chumbadores curtos.

A disparidade dos resultados obtidos para os chumbadores curtos e longos se deve as possíveis imperfeições do preenchimento da calda de cimento ao longo do trecho injetado. Para a metodologia A, o maior comprimento dos chumbadores longos pode ter minimizado estas imperfeições, já que o maior comprimento do trecho inclinado e injetado pode ter provocado um melhor preenchimento da cavidade escada. A discrepância dos resultados envolvendo os chumbadores curtos e longos executados com a metodologia B também pode ser justificada pelo volume injetado. Enquanto para o chumbador curto o baixo volume injetado fez com que o seu desempenho se assemelhasse ao da metodologia A, para o chumbador longo, o volume injetado foi representativo (24,0 litros), melhorando bastante o seu desempenho.

A fim de quantificar a influência do comprimento dos chumbadores, foram apresentados gráficos que relacionam o valor de $q_{s}$ em chumbadores curtos e longos, para as metodologias A e B (Figura 5.14). Para a análise comparativa, os valores percentuais apresentados foram referenciados (100\%) em relação aos valores de $q_{s}$ dos chumbadores curtos.

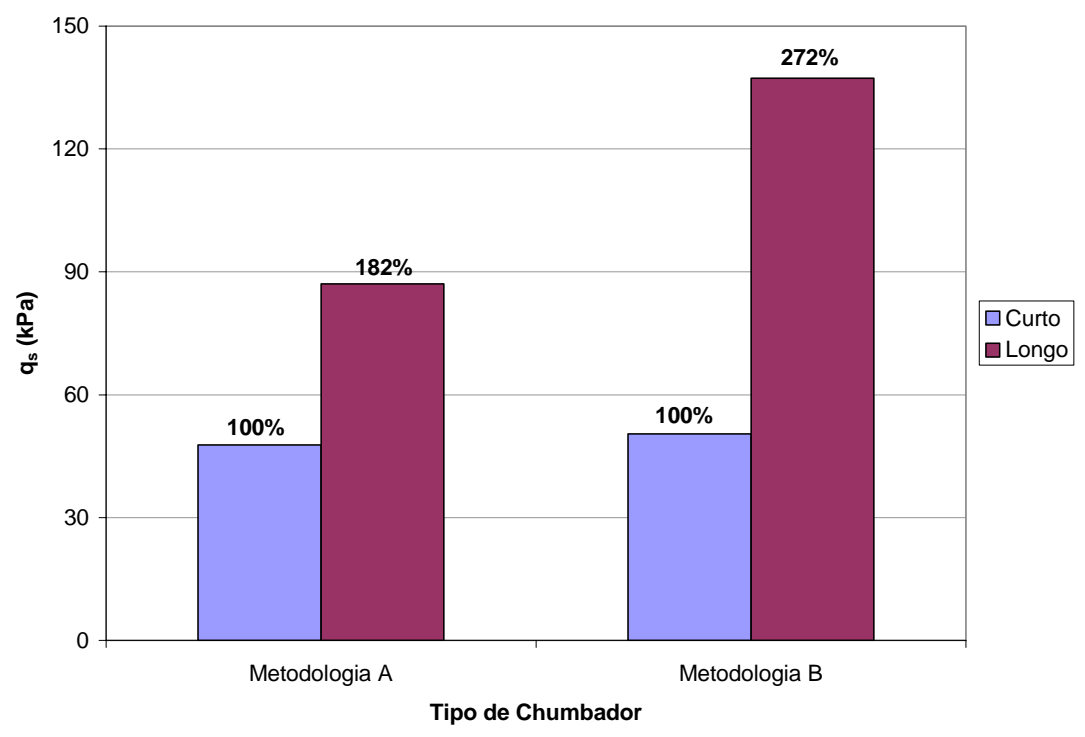

Figura 5.14. Variação de $q_{s}$ para os diferentes tipos de chumbadores (curtos e longos), considerando as metodologias A e B. 
Da análise comparativa dos valores de $q_{s}$ apresentados na Figura 5.14, é possível observar que os valores obtidos para os chumbadores longos foram 182\% e $272 \%$ superiores aos valores obtidos para os chumbadores curtos, comparando-se as metodologias A e B, respectivamente.

\subsubsection{Resultados da Instrumentação}

A utilização de strain gages ao longo do comprimento das barras de aço permitiu verificar a distribuição dos carregamentos durante a realização do ensaio. Os dados advindos da instrumentação proporcionaram uma maior previsão e confiabilidade dos resultados. A partir da similaridade dos comportamentos observados, são apresentadas as curvas típicas obtidas para chumbadores curtos e longos. A Figura 5.15 mostra curvas com quatro níveis de carregamento em relação à carga de ruptura (25, 50, 75 e 100\%).

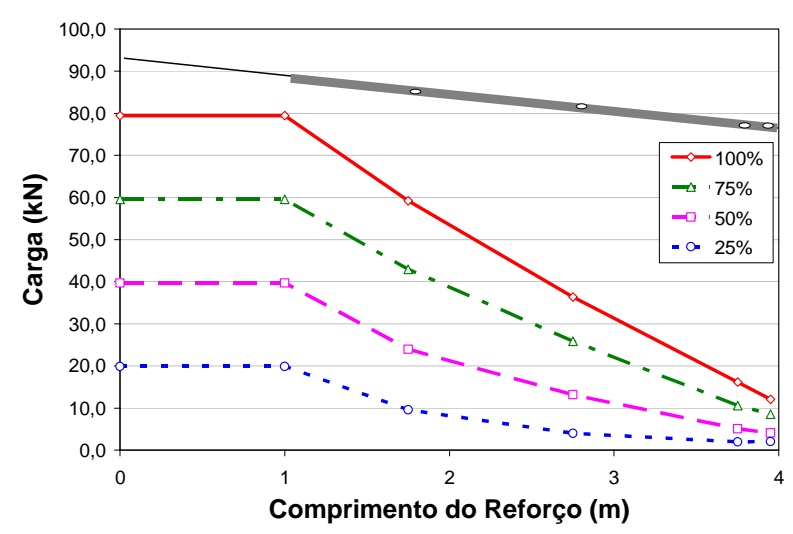

(a)

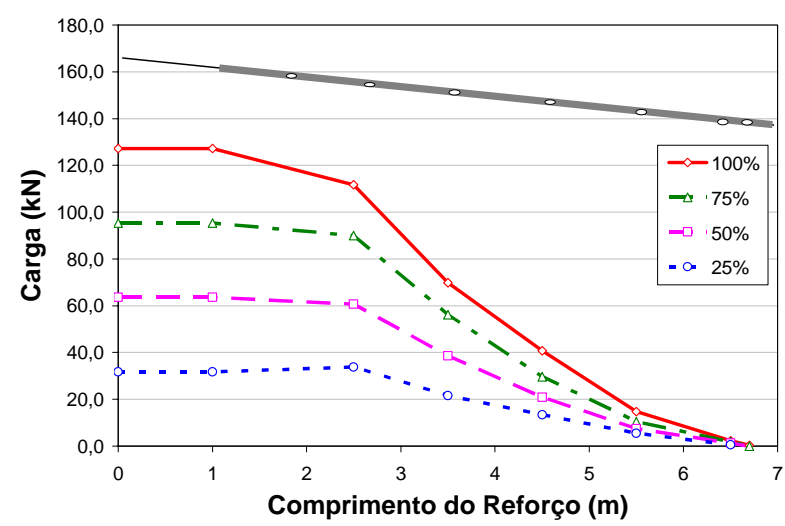

(b)

Figura 5.15. Distribuição das cargas ao longo do comprimento dos chumbadores curto (a) e longo (b), em percentagem em relação à carga de ruptura.

A partir da Figura 5.15, observa-se que os chumbadores apresentaram comportamentos semelhantes no tocante à mobilização das cargas, durante a realização do ensaio de arrancamento. Como arrancamento ocorre no contato solo-reforço, a mobilização da resistência é gradual, ou seja, da cabeça em direção à parte interna do chumbador. Notase a tendência de uma distribuição triangular das cargas ao longo da barra. Para o 
chumbador curto, todo o seu comprimento foi mobilizado durante a realização do ensaio. Para o chumbador longo, as cargas de arrancamento no final do trecho injetado foram praticamente inexistentes.

\subsubsection{Ensaios de Arrancamento - linha 5}

A Figura 5.16 apresenta as curvas carga x deslocamento obtidas a partir dos ensaios de arrancamento realizados nos chumbadores curto (19) e longo (20), executados com a metodologia A.

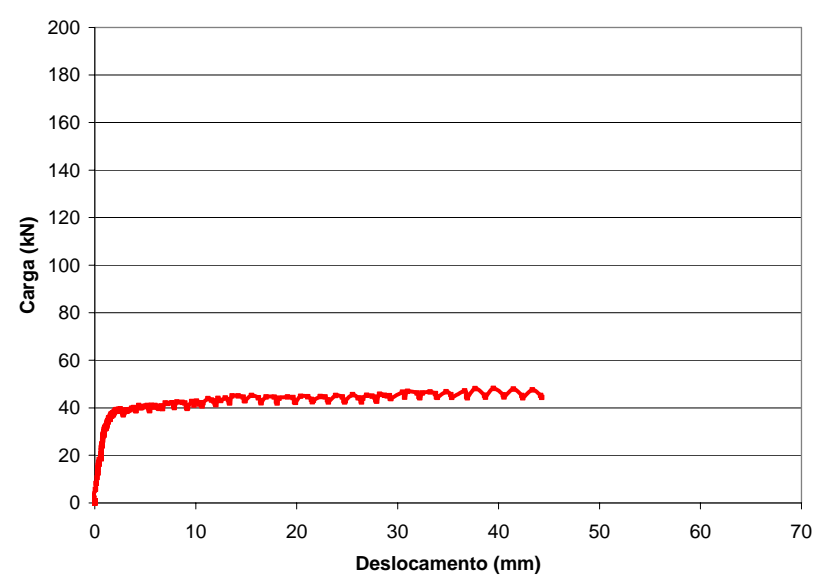

(a)

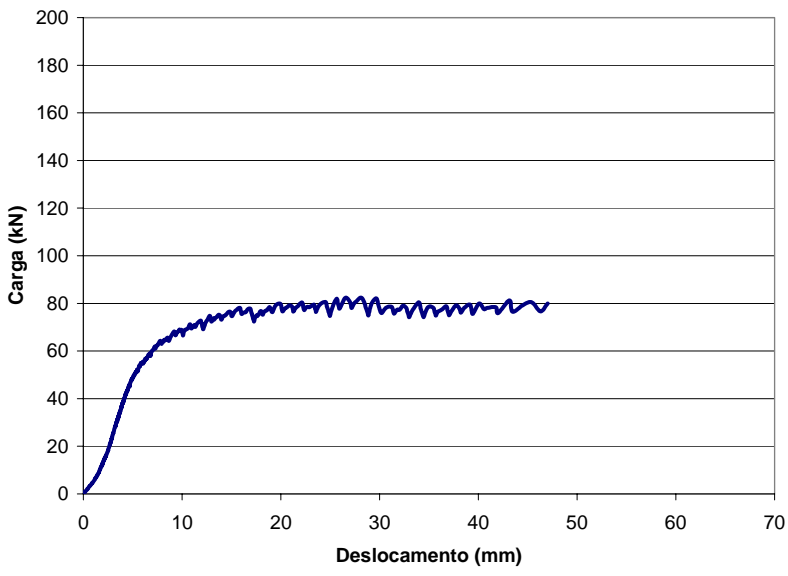

(b)

Figura 5.16. Curvas carga $x$ deslocamento dos chumbadores curto (a) e longo (b) construídos com a metodologia A.

A partir das curvas carga x deslocamento apresentadas na Figura 5.16, observa-se que a ruptura, para os chumbadores curto e longo, foi plástica. As cargas máximas obtidas para os chumbadores curto e longo foram de 45,2 e 82,4 kN, para deslocamentos de 15,5 e 28,1 mm, respectivamente.

A Figura 5.17 apresenta os resultados obtidos para o chumbadores curto (16) e longo (15), executados com a metodologia $A^{*}$. 
Análise de diferentes metodologias executivas de solo pregado a partir de ensaios de arrancamento realizados em campo e laboratório

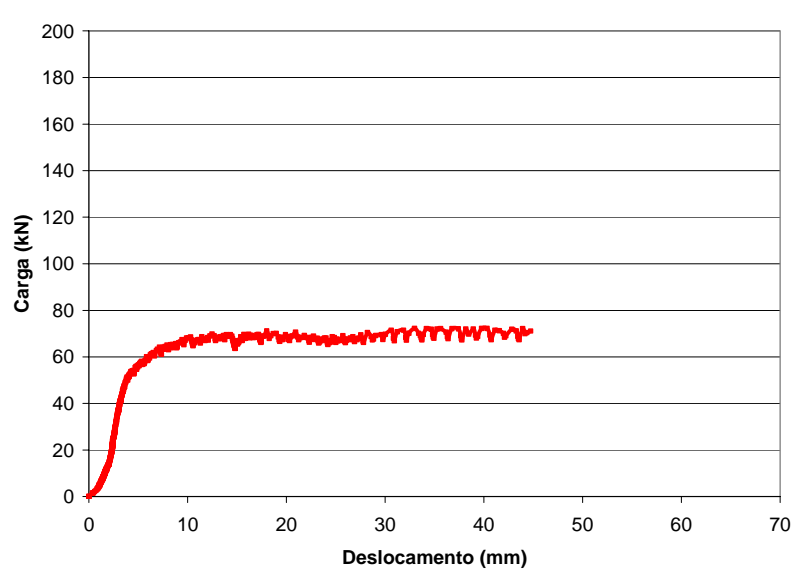

(a)

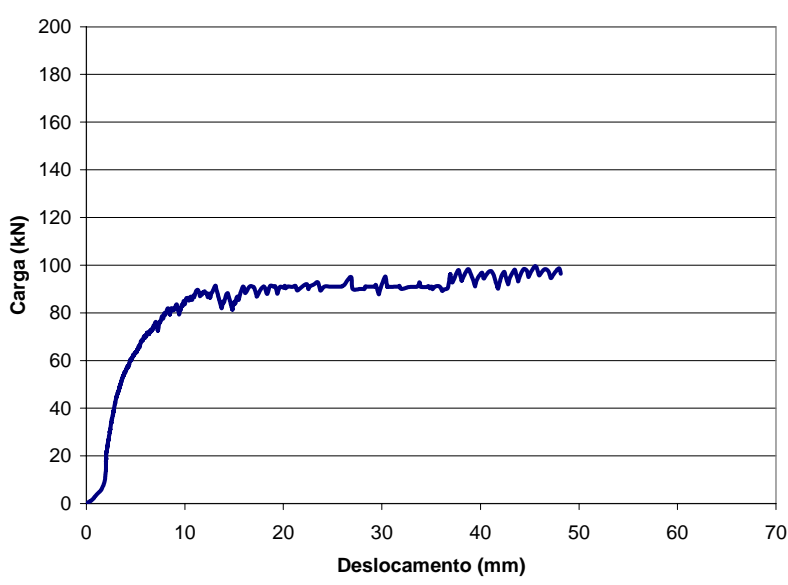

(b)

Figura 5.17. Curvas carga $x$ deslocamento dos chumbadores curto (a) e longo (b) construídos com a metodologia A*.

A Figura 5.17 mostra que as curvas carga $\mathrm{x}$ deslocamento obtidas para a metodologia $A^{*}$ apresentaram o mesmo padrão de comportamento dos chumbadores executados com a metodologia A, ou seja, ruptura plástica. Vale a pena destacar que a carga máxima obtida para o chumbador curto foi de $71,1 \mathrm{kN}$ e para o chumbador longo foi de 91,4 kN. Os deslocamentos referentes a estes carregamentos foram de 13,1 e 18,0 mm, respectivamente.

A Figura 5.18 apresenta os resultados obtidos para os chumbadores curto (23) e longo (24), executados com a metodologia B. 


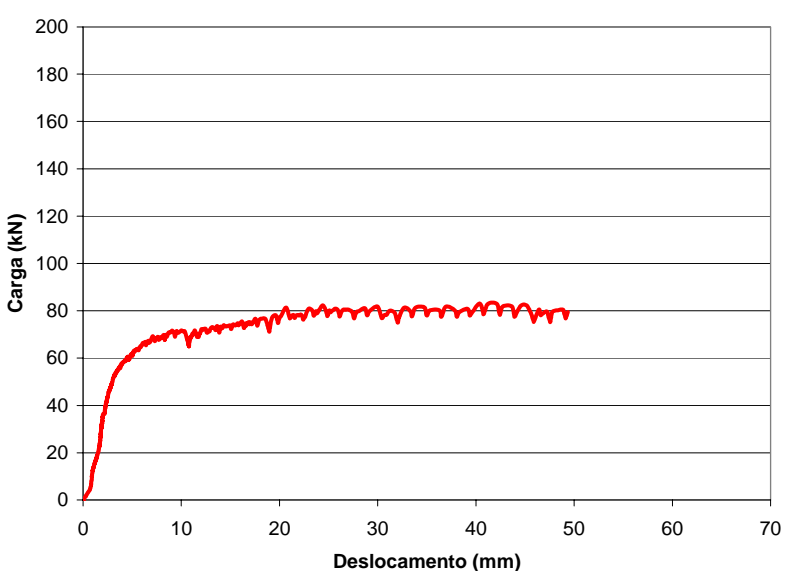

(a)

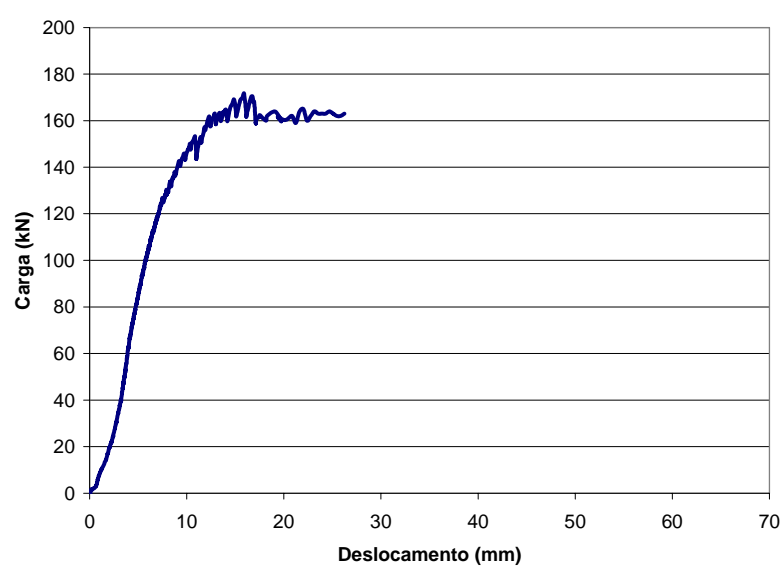

(b)

Figura 5.18. Curvas carga $x$ deslocamento dos chumbadores curto (a) e longo (b) construídos com a metodologia B.

O chumbador curto construído com a metodologia B (Figura 5.18-a) apresentou um comportamento semelhante aos demais chumbadores das metodologias A e A*, ou seja, ruptura plástica. A carga máxima de $82,3 \mathrm{kN}$ foi obtida para um deslocamento de 24,4 mm. O ensaio de arrancamento do chumbador longo (Figura 5.18-b) apresentou ruptura frágil, com carga de pico de 171,8 kN, para um deslocamento de 15,9 mm.

Os resultados dos ensaios de arrancamento realizados nos chumbadores curtos (21) e (22), executados com a metodologia C, são apresentados na Figura 5.19.

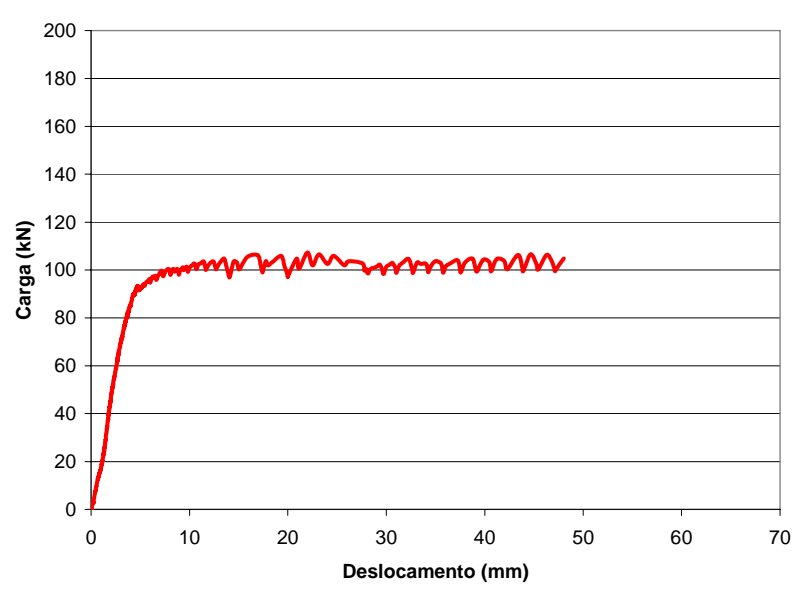

(a)

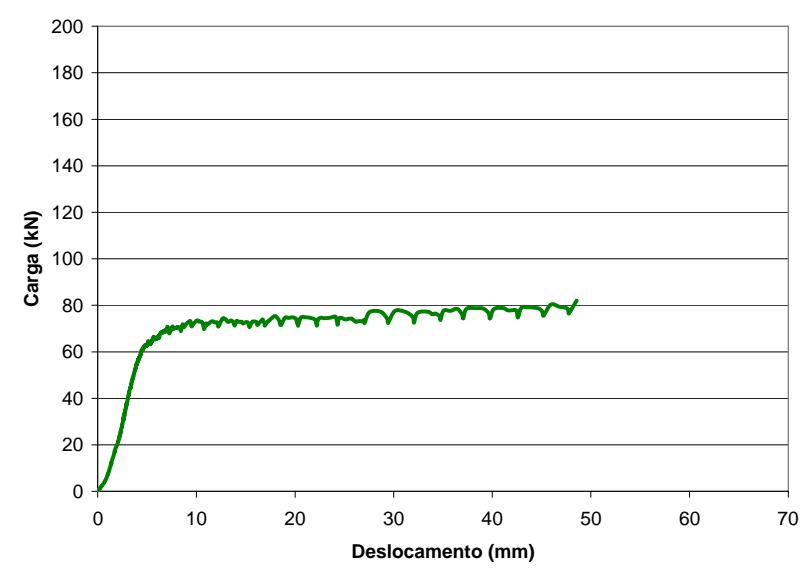

(b)

Figura 5.19. Curvas carga $x$ deslocamento dos chumbadores curtos 21 (a) e 22 (b) construídos com a metodologia C. 
Os chumbadores curtos 21 e 22, executados com a metodologia C, apresentaram comportamentos similares com ruptura plástica. Embora tenham sido executados com a mesma metodologia, as cargas máximas obtidas $(107,3$ e 75,4 kN) apresentaram variação de $42 \%$, para deslocamentos de 22,0 e 18,0 mm, respectivamente. Esta variação também está relacionada com os volumes injetados de calda de cimento. Enquanto para o chumbador 21 foram injetados 58,0 litros de calda de cimento, para o chumbador 22 foram injetados 7,0 litros. Estas constatações serão mais bem apresentadas em análises subseqüentes.

A Figura 5.20 apresenta os resultados dos ensaios de arrancamento realizados nos chumbadores curtos (27) e (28), executados com a metodologia D.

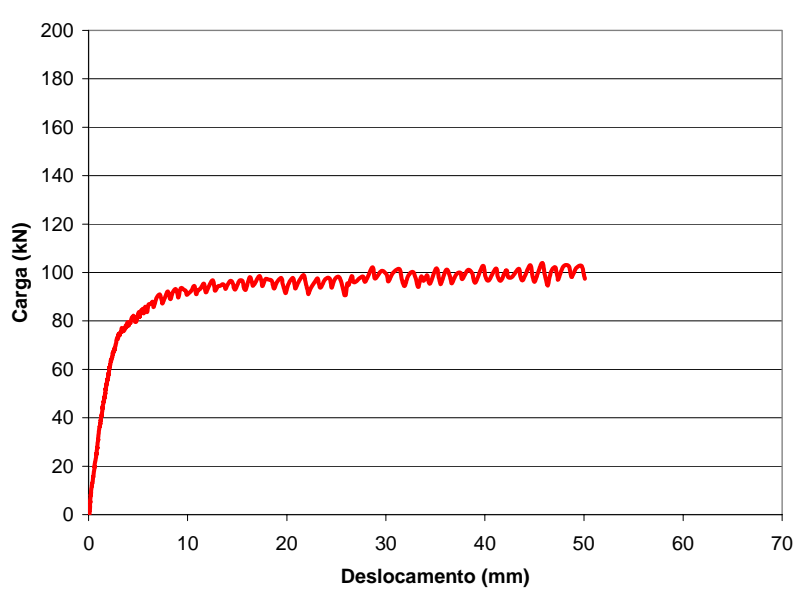

(a)

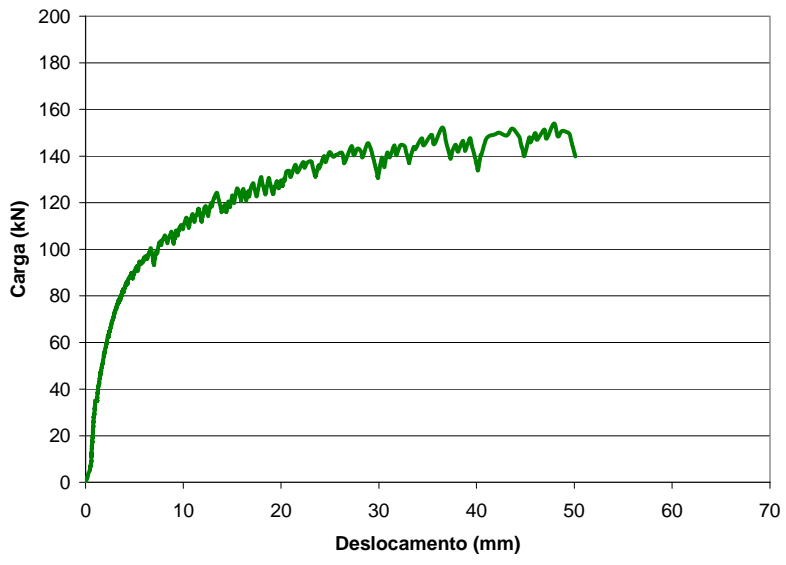

(b)

Figura 5.20. Curvas carga $x$ deslocamento dos chumbadores curtos 27 (a) e 28 (b) construídos com a metodologia D.

Os chumbadores curtos 27 e 28, executados com a metodologia D, também apresentaram ruptura plástica. Embora tenham sido executados com a mesma metodologia, as cargas máximas obtidas (98,9 e 145,5 kN) apresentaram variação de 47\%, para deslocamentos de 21,7 e 28,9 mm, respectivamente. O consumo de calda de cimento nas injeções do chumbador 28 foi superior ao observado para o chumbador 27, justificando assim este incremento na carga máxima.

A Figura 5.21 apresenta os resultados obtidos para os chumbadores curtos (17 e 18), executados com a metodologia E. 


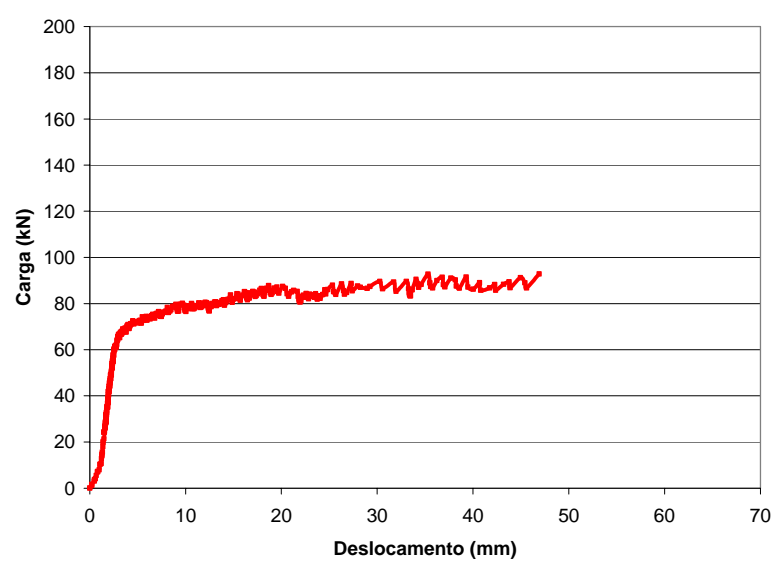

(a)

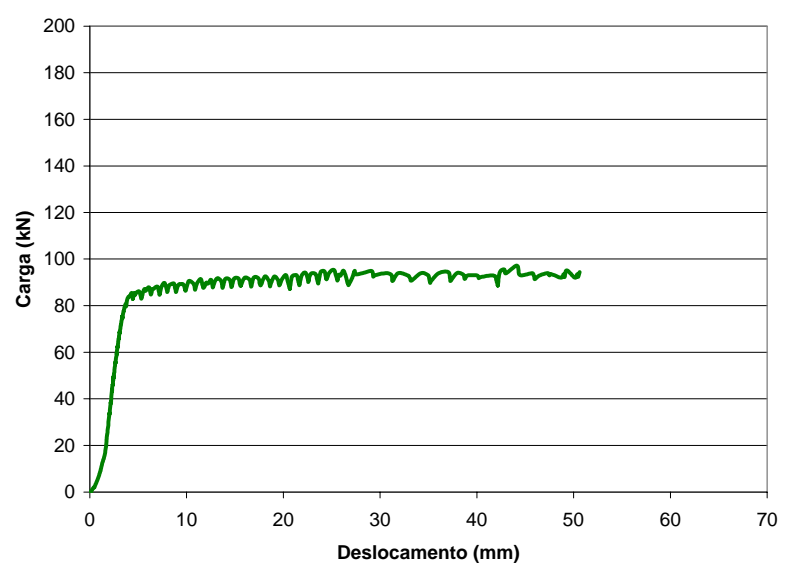

(b)

Figura 5.21. Curvas carga x deslocamento dos chumbadores curtos 17 (a) e 18 (b), construídos com a metodologia E.

A Figura 5.21 mostra que as rupturas nos chumbadores curtos 17 e 18 foram plásticas. As curvas carga x deslocamento são bem parecidas, e as cargas máximas obtidas (87,8 e 95,5 kN) apresentaram uma pequena variação (18\%), se comparada com os chumbadores executados com a metodologia D. Os deslocamentos, referentes às cargas máximas, foram de 18,7 e 25,2 mm, respectivamente. Esta pequena variação nos resultados também pode ser explicada pela proximidade dos volumes injetados. Para os chumbadores 17 e 18, foram injetados 4,0 e 7,0 litros de calda de cimento, respectivamente.

A Figura 5.22 apresenta as curvas carga $\mathrm{x}$ deslocamento obtidas dos ensaios de arrancamento realizados nos chumbadores curtos (25) e (26), executados com a metodologia F. 


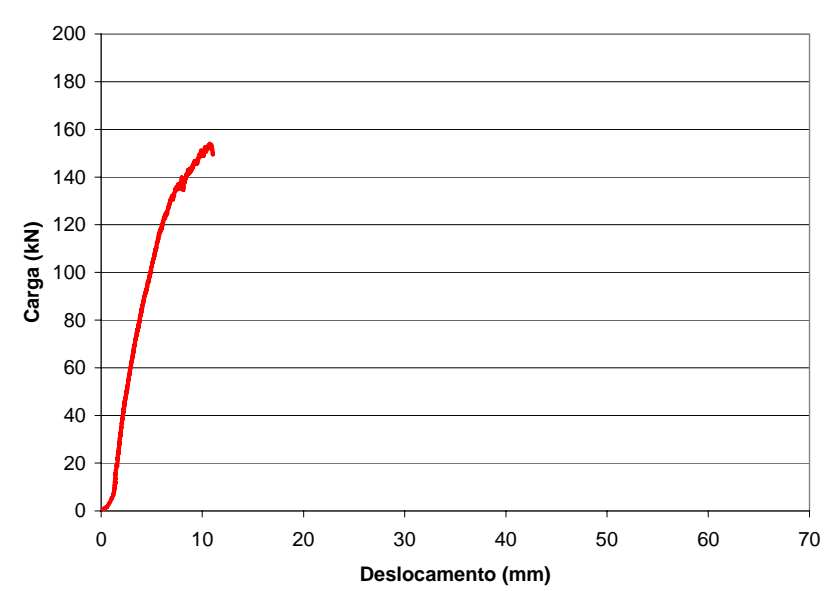

(a)

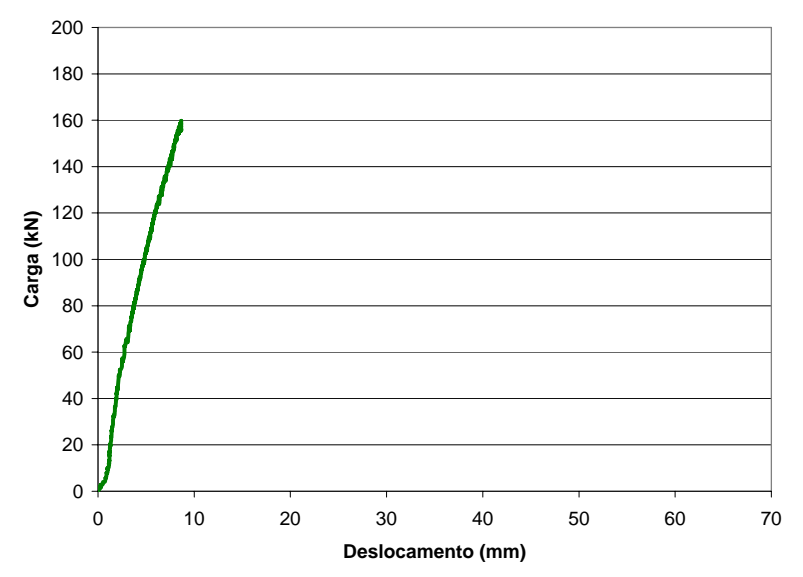

(b)

Figura 5.22. Curvas carga $x$ deslocamento dos chumbadores curtos 25 (a) e 26 (b) construídos com a metodologia F.

Os ensaios de arrancamento nos chumbadores curtos 25 e 26 foram interrompidos antes de atingir o carregamento de ruptura. Este fato se deve aos elevados carregamentos, às limitações do conjunto macaco-bomba e ao aparecimento de trincas no paramento de concreto projetado. Mesmo sem finalizar os ensaios, verificou-se uma boa similaridade dos trechos elásticos, e, a partir do carregamento médio atingido (157 kN), verificou-se que esta metodologia apresentou um excelente desempenho. Os elevados carregamentos podem ser explicados pelos grandes volumes injetados. Para cada um dos chumbadores, foram injetados 102 litros de calda de cimento.

A Tabela 5.5 apresenta o resumo dos resultados dos ensaios de arrancamento realizados nos chumbadores curtos e longos construídos na linha 5, com as diferentes metodologias executivas. São apresentados os principais parâmetros obtidos a partir dos ensaios, que são: carga máxima de ruptura $\left(\mathrm{T}_{\text {máx }}\right)$, carga máxima de ruptura por metro linear de chumbador, deslocamento referente à carga máxima, resistência ao cisalhamento de interface solo-reforço $\left(q_{s}\right)$ e modo de ruptura (quando esta ocorre), nomeando F para ruptura frágil e P para ruptura plástica. Os chumbadores que não atingiram a ruptura foram identificados por NR. 
Tabela 5.5. Resumo dos resultados dos ensaios de arrancamento da linha 5.

\begin{tabular}{|c|c|c|c|c|c|c|c|c|}
\hline \multicolumn{4}{|c|}{ Chumbador } & \multirow[b]{2}{*}{$\begin{array}{l}T_{\text {máx }} \\
(\mathbf{k N})\end{array}$} & \multirow[b]{2}{*}{$\begin{array}{c}\text { Tmáx/m } \\
\text { (kN) }\end{array}$} & \multirow[b]{2}{*}{$\begin{array}{c}\text { Deslocamento } \\
\text { (mm) }\end{array}$} & \multirow[b]{2}{*}{$\begin{array}{c}\mathbf{q}_{\mathrm{s}} \\
(\mathbf{k P a})\end{array}$} & \multirow[b]{2}{*}{$\begin{array}{l}\text { Modo de } \\
\text { Ruptura }\end{array}$} \\
\hline $\mathbf{N}^{\circ}$ & Metodologia & $\begin{array}{c}\text { Comprimento } \\
\text { (m) }\end{array}$ & Tipo & & & & & \\
\hline 15 & $A^{*}$ & 6,0 & Longo & 91,4 & 15,2 & 13,1 & 63,7 & $\mathrm{P}$ \\
\hline 16 & $A^{*}$ & 3,0 & Curto & 71,1 & 23,7 & 18,0 & 99,1 & $\mathrm{P}$ \\
\hline 17 & $\mathrm{E}$ & 3,0 & Curto & 87,8 & 29,3 & 18,7 & 122,2 & $\mathrm{P}$ \\
\hline 18 & E & 3,0 & Curto & 95,5 & 31,8 & 25,2 & 133,0 & $\mathrm{P}$ \\
\hline 19 & A & 3,0 & Curto & 45,2 & 15,1 & 15,5 & 63,0 & $\mathrm{P}$ \\
\hline 20 & A & 6,0 & Longo & 82,4 & 13,7 & 28,1 & 57,4 & $\mathrm{P}$ \\
\hline 21 & C & 3,0 & Curto & 107,3 & 35,8 & 22,0 & 149,4 & $\mathrm{P}$ \\
\hline 22 & $\mathrm{C}$ & 3,0 & Curto & 75,4 & 25,1 & 18,0 & 105,0 & $\mathrm{P}$ \\
\hline 23 & B & 3,0 & Curto & 82,3 & 27,4 & 24,4 & 114,6 & $\mathrm{P}$ \\
\hline 24 & B & 6,0 & Longo & 171,8 & 28,6 & 15,9 & 119,6 & F \\
\hline 25 & $\mathrm{~F}$ & 3,0 & Curto & 154,0 & 51,3 & 10,7 & 214,4 & NR \\
\hline 26 & F & 3,0 & Curto & 159,7 & 53,2 & 8,7 & 222,4 & NR \\
\hline 27 & D & 3,0 & Curto & 98,9 & 33,0 & 21,7 & 137,7 & $\mathrm{P}$ \\
\hline 28 & $\mathrm{D}$ & 3,0 & Curto & 145,5 & 48,5 & 28,9 & 202,6 & $\mathrm{P}$ \\
\hline
\end{tabular}

As análises dos resultados obtidos seguiram as mesmas premissas da linha 2, ou seja, foram realizadas em termos da metodologia executiva, do volume de injeção de calda de cimento e do comprimento do trecho injetado do chumbador.

\subsubsection{Influência da Metodologia Executiva}

Para permitir a análise qualitativa e comparativa das diferentes metodologias executivas, são apresentadas as curvas carga x deslocamento de forma agrupada, para os chumbadores curtos (Figura 5.23) e para os longos (Figura 5.24). 


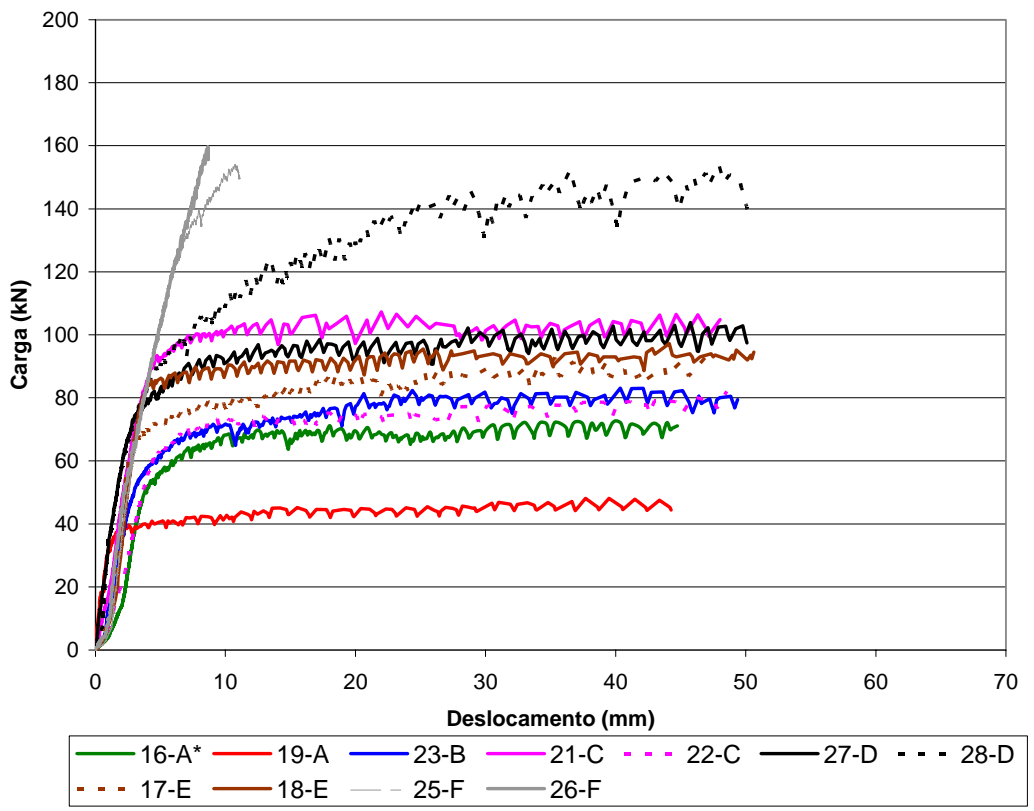

Figura 5.23. Curvas carga $x$ deslocamento dos chumbadores curtos executados com as diferentes metodologias executivas.

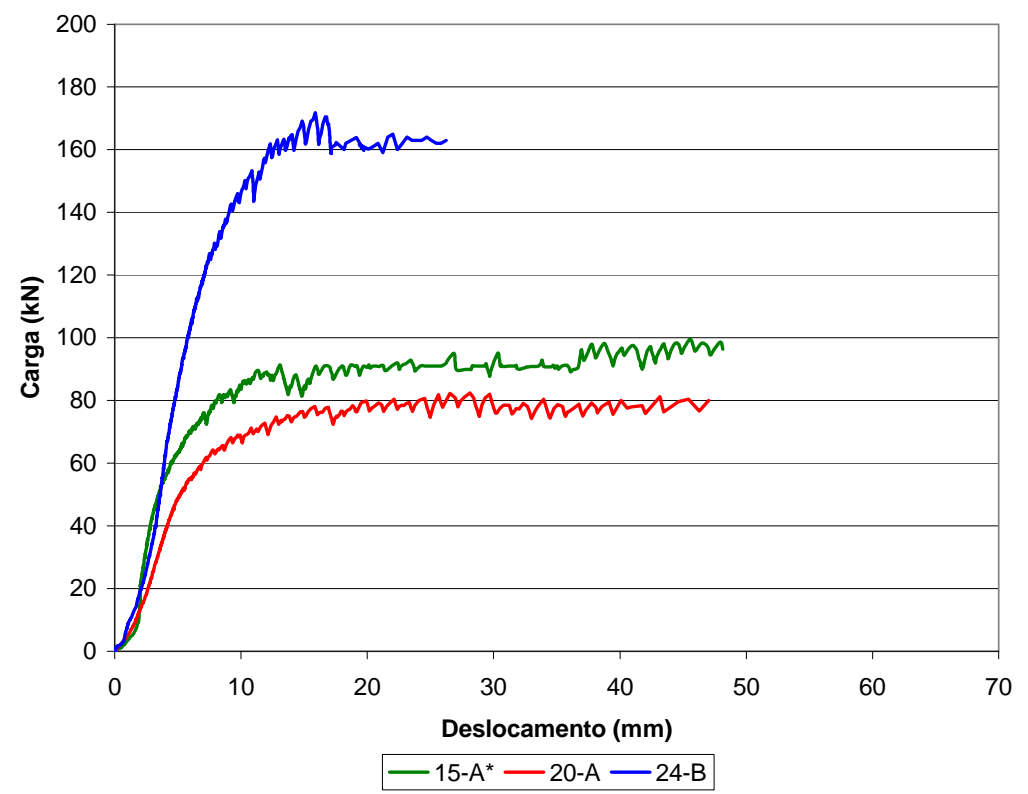

Figura 5.24. Curvas carga $x$ deslocamento dos chumbadores longos executados com as diferentes metodologias executivas.

As Figuras 5.23 e 5.24 permitem comparar, qualitativamente, os resultados obtidos para os chumbadores curtos e longos, respectivamente. Os resultados mostram um aumento 
significativo das cargas de arrancamento, quando comparamos as metodologias executivas em que houve alguma fase de injeção de calda de cimento com a metodologia A, tomada como referência. Para poder avaliar e quantificar a influência das diferentes metodologias executivas, foram apresentados gráficos com o valor de $q_{s}$ para cada uma das metodologias. Os valores percentuais apresentados foram sempre referenciados em relação aos valores de $q_{s}$ da metodologia A (100\%). As Figuras 5.25 e 5.26 apresentam, para os chumbadores curtos e longos, respectivamente, os gráficos comparativos do parâmetro $q_{s}$ para as diferentes metodologias executivas.

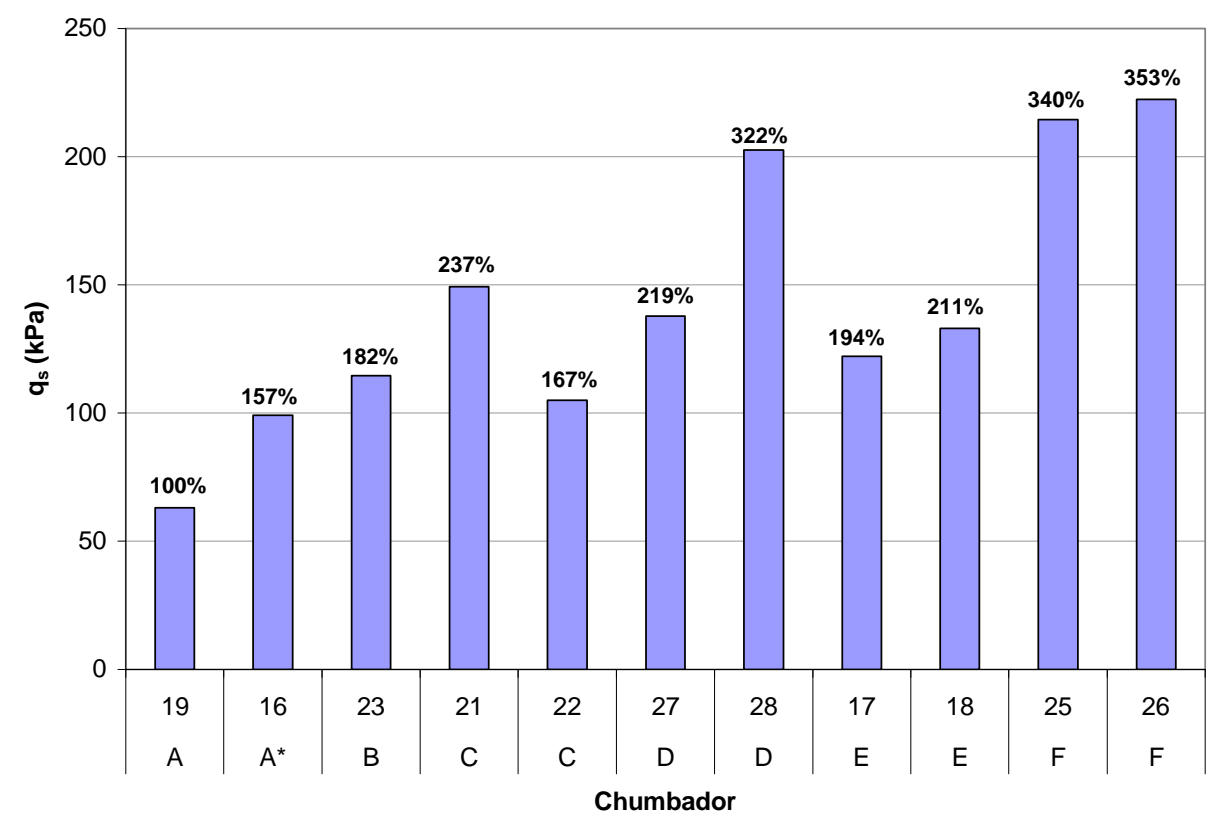

Figura 5.25. Análise comparativa entre os valores de $q_{s}$ obtidas para os chumbadores curtos executados com as diferentes metodologias executivas. 


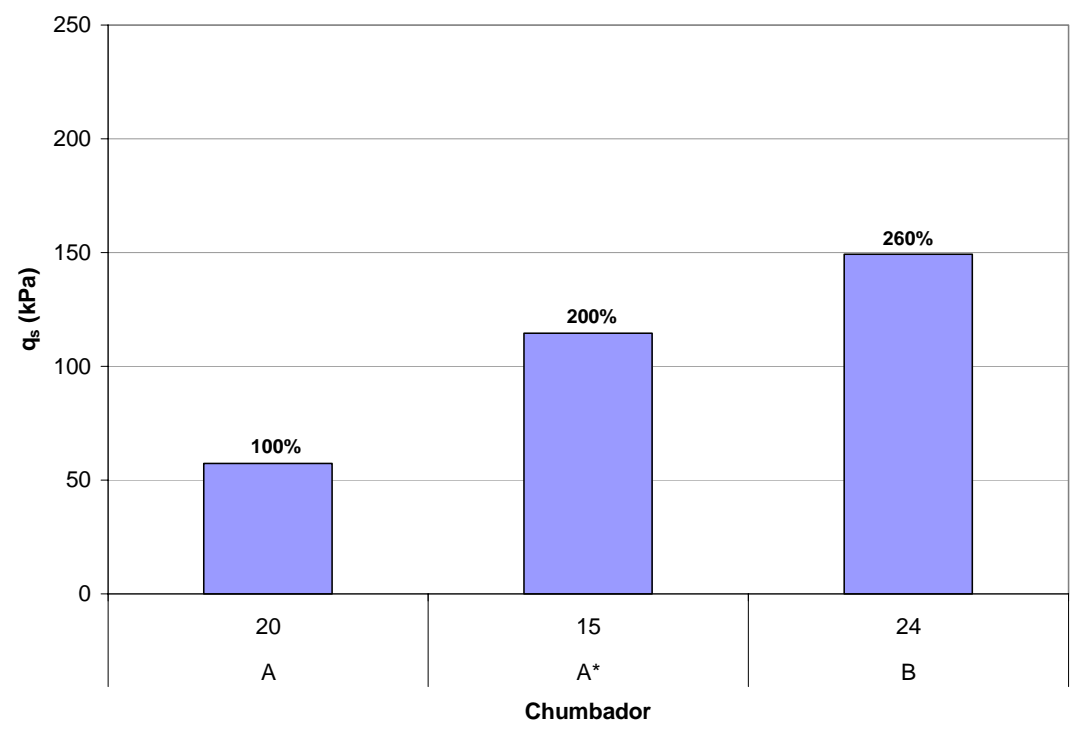

Figura 5.26. Análise comparativa entre os valores de $q_{s}$ obtidos para os chumbadores longos executados com as diferentes metodologias executivas.

Ao analisar as Figuras 5.25 e 5.26, é possível observar que, de uma maneira geral, os valores de $q_{s}$ apresentaram ganho bastante significativo em relação à metodologia de referência (A). Outra constatação importante foi o melhor desempenho do chumbador executado com a metodologia $A^{*}$ em relação ao executado com a metodologia A. Esta melhoria foi observada para os chumbadores curto e longo, e foram de 57\% e 100\%, respectivamente. Embora estes chumbadores não tenham sido injetados, é possível concluir que a mistura de solo-cimento acaba minimizando eventuais imperfeições ocasionadas pela exudação da calda de cimento ao longo do comprimento do chumbador.

Os resultados dos chumbadores curtos e longos, executados com a metodologia B, apresentam-se dentro do esperado. Para o chumbador curto, o parâmetro $q_{s}$ apresentou-se em uma faixa intermediária entre a metodologia A e as demais. Para o chumbador longo, o acréscimo em relação à metodologia $\mathrm{A}$ foi de $160 \%$. Conforme mencionado, o volume injetado para este chumbador foi considerável e explica este incremento.

Para as demais metodologias (C, D, E e F), foram executados dois chumbadores curtos. Os resultados de $q_{s}$ obtidos para as metodologias C e D apresentaram uma grande variação. Entretanto, este fato não foi observado para os chumbadores 17 e 18, executados com a metodologia E. A variabilidade dos resultados está relacionada com a variação do 
volume injetado para cada chumbador, conforme mencionado anteriormente. Assim como ocorreu na linha 2, os chumbadores construídos com a metodologia D também apresentaram um desempenho satisfatório. O maior número de injeções realizadas (bainha + 3 fases) fez com que o chumbador 28 apresentasse um ganho de $222 \%$, enquanto o incremento de $q_{s}$ para o chumbador 27 foi de $119 \%$.

Os chumbadores executados com a metodologia $\mathrm{F}$, mesmo não tendo os ensaios finalizados, foram os que obtiveram o melhor desempenho em termos de $q_{s}$. O ganho médio neste parâmetro foi de $246 \%$, em relação ao chumbador executado com a metodologia A.

\subsubsection{Influência do Volume de Injeção de Calda de Cimento}

Para o tipo de solo da linha 5 da obra de Santo André-SP, também é verificado que o parâmetro $q_{s}$ está relacionado com o volume de injeção de calda de cimento obtido para cada metodologia executiva. A Figura 5.27 apresenta, em um mesmo gráfico, os valores de $q_{s}$ e do volume de injeção dos chumbadores curtos. Para facilitar a visualização, os volumes injetados também são apresentados ao longo do gráfico.

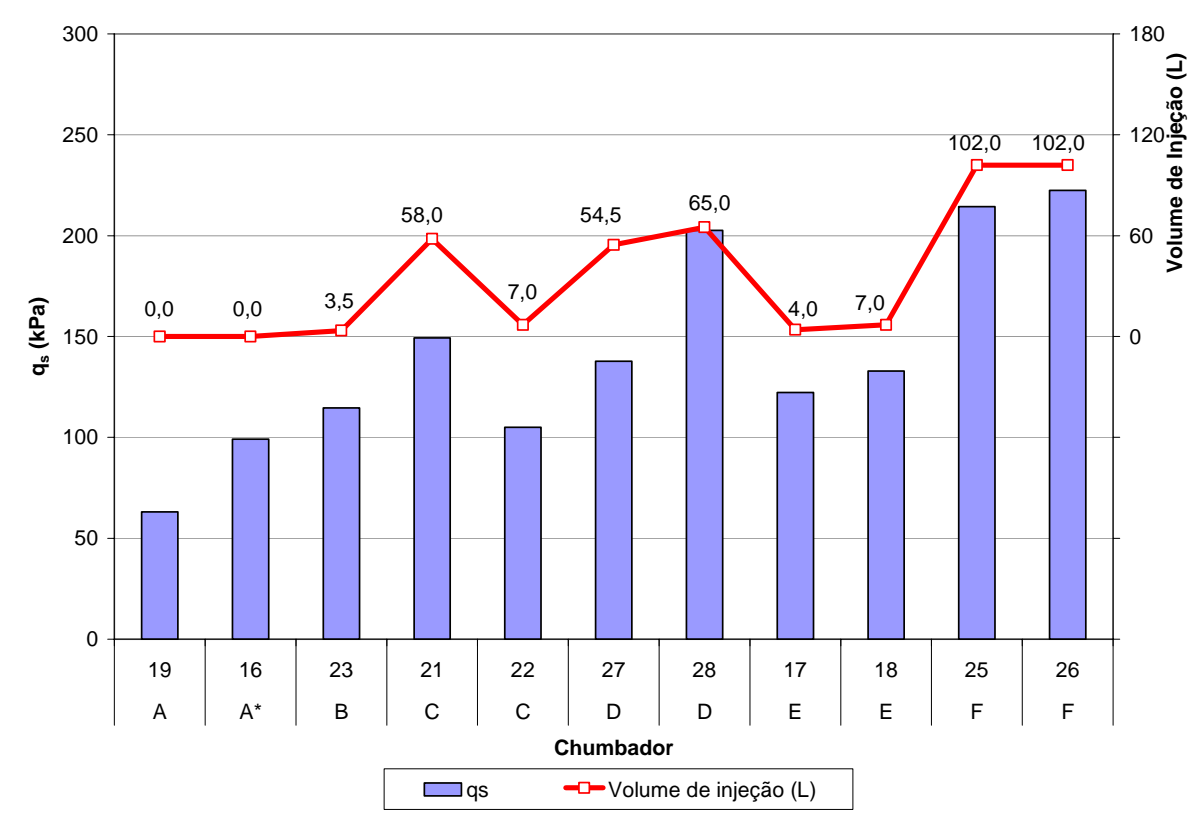

Figura 5.27. Variações de $q_{s}$ e dos volumes de injeção dos chumbadores curtos executados com as diferentes metodologias executivas. 
A partir dos valores de $q_{s}$ apresentados concomitantemente com os volumes de injeção, confirma-se que os ganhos neste parâmetro estão diretamente relacionados com a metodologia executiva e, consequentemente, com os volumes de injeção. Os ganhos substanciais em termos de $q_{s}$, principalmente para as metodologias C, D e F, são explicados pelo incremento do volume injetado. Embora não tenha sido possível a realização da exumação dos chumbadores, como fora realizado em laboratório, os ensaios comprovam que a melhoria no desempenho deve-se a melhoria da integridade do chumbador e as eventuais ramificações das injeções de calda de cimento no maciço de solo.

A Figura 5.27 também ajuda a explicar o resultado abaixo do esperado dos chumbadores 22 (metodologia C), 17 e 18 (metodologia E). Embora estes chumbadores tenham sido construídos com duas fases de injeção, os volumes injetados foram baixos e da ordem de 7,0, 4,0 e 7,0 litros, respectivamente. Estes volumes estão muito próximos do volume injetado da metodologia B (3,5 litros). Tal fato explica a proximidade dos resultados destes chumbadores. Da mesma forma que na linha 2, verificou-se, quantitativamente, a interdependência entre o valor de $q_{s}$ e o volume de injeção. Para tentar estabelecer uma previsão de comportamento, a Figura 5.28 apresenta uma correlação entre o parâmetro $q_{s}$ e o fator adimensional "V".

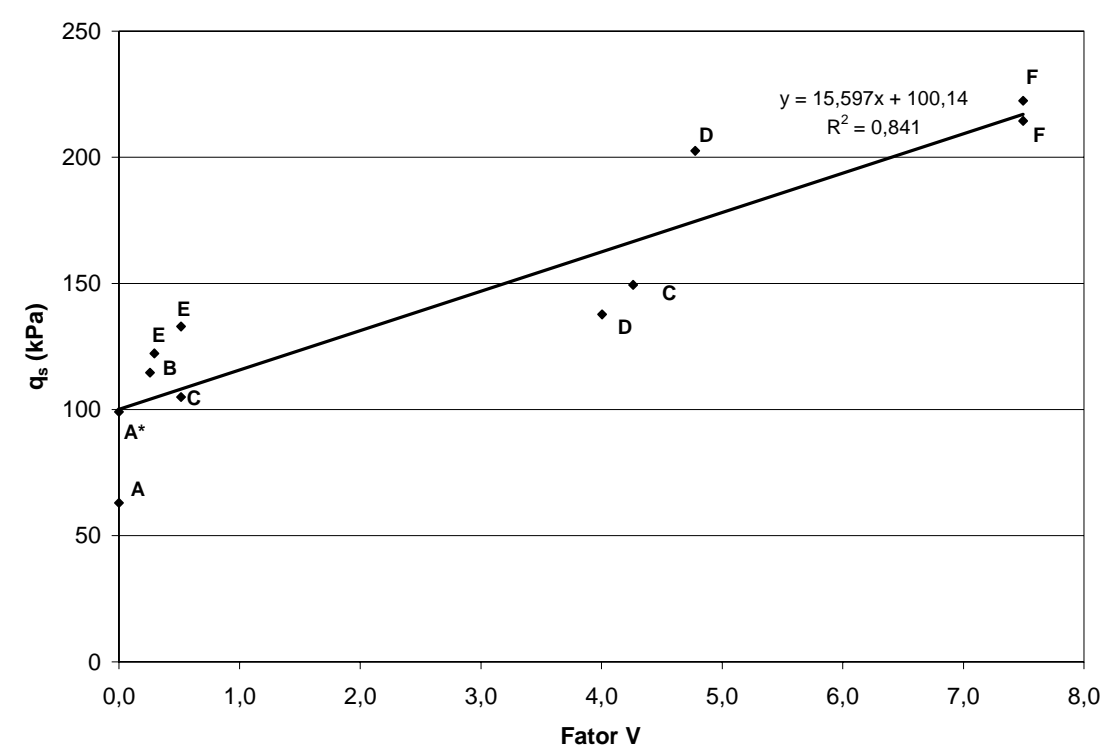

Figura 5.28. Valores de $q_{s} \times$ volume de injeção para os chumbadores curtos, executados com as diferentes metodologias executivas. 
Assim como para a linha 2, o ajuste linear apresentado na Figura 5.28 apresentou valor de $\mathrm{R}^{2}$ aceitável, considerando-se o pequeno espaço amostral e as variabilidades inerentes às metodologias executivas adotadas na construção dos chumbadores. Considerando-se o ajuste para um volume de injeção igual a zero, representativo da metodologia A (bainha), o valor de $q_{s}$ pode ser representado por 100,14 kPa. Este valor é superior ao valor da linha 2 e ao mínimo sugerido pela GeoRio (1999) de 60 kPa.

Os valores de $q_{s}$ obtido para a metodologia A, em chumbador curto e longo, foi de 63,0 e 57,4 kPa, respectivamente. Para os chumbadores curtos e longos da metodologia A*, os valores correspondem a 99,1, e 63,7 kPa, respectivamente. Como o valor advindo do ajuste é de 100,14 kPa, obteve-se assim uma variação aproximada de 60\% para a metodologia A e 1\% para a metodologia A*, levando-se em consideração apenas os chumbadores curtos. A partir destes valores, acredita-se que os resultados obtidos para a metodologia A estão aquém do esperado. Quando comparada à metodologia $\mathrm{A} *$, quase não se observa variação de $q_{s}$, mostrando a validade da equação ajustada.

Os resultados obtidos confirmam a constatação do programa experimental de laboratório e da linha 2. A determinação do volume de injeção é uma excelente opção no controle de qualidade de execução do chumbador. Recomenda-se que, para obras que apresentem o mesmo solo característico da linha 5, adote-se a função $q_{s}=15,60 \mathrm{x}$ "Fator V” $+100,14(\mathrm{kPa})$.

\subsubsection{Influência do Comprimento do Chumbador}

Seguindo a seqüência de análises, avaliou-se a influência do comprimento dos chumbadores na resistência ao cisalhamento de interface solo-reforço. Tomou-se como referência as metodologias A, A* e B, em que foram executados chumbadores curtos e longos. Cabe novamente ressaltar que essas metodologias apresentaram maior variabilidade nos resultados de $q_{s}$, devido a possíveis imperfeições ao longo do trecho injetado. A Figura 5.29 apresenta as curvas carga x deslocamento considerando-se estas três condições. 


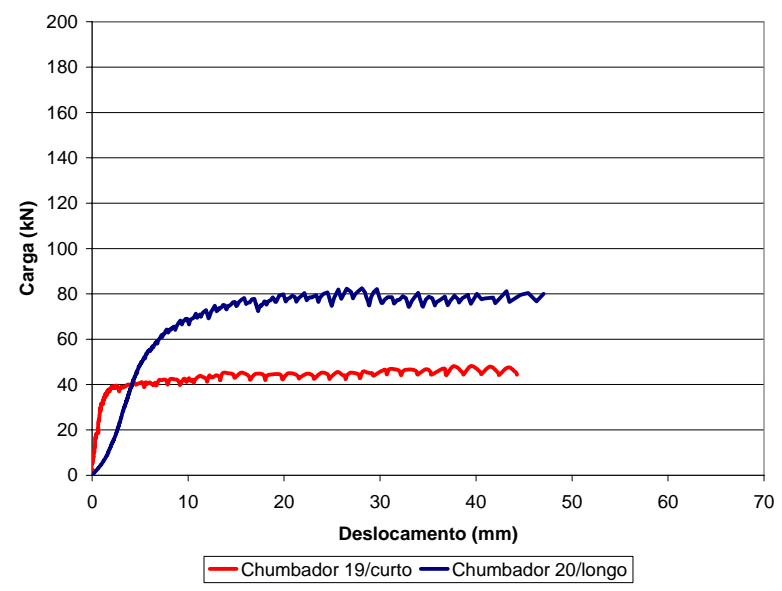

(a)

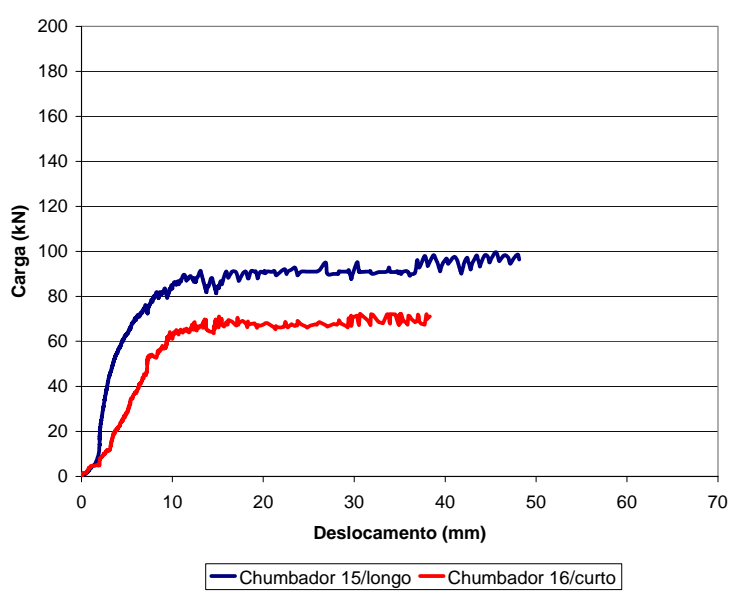

(b)

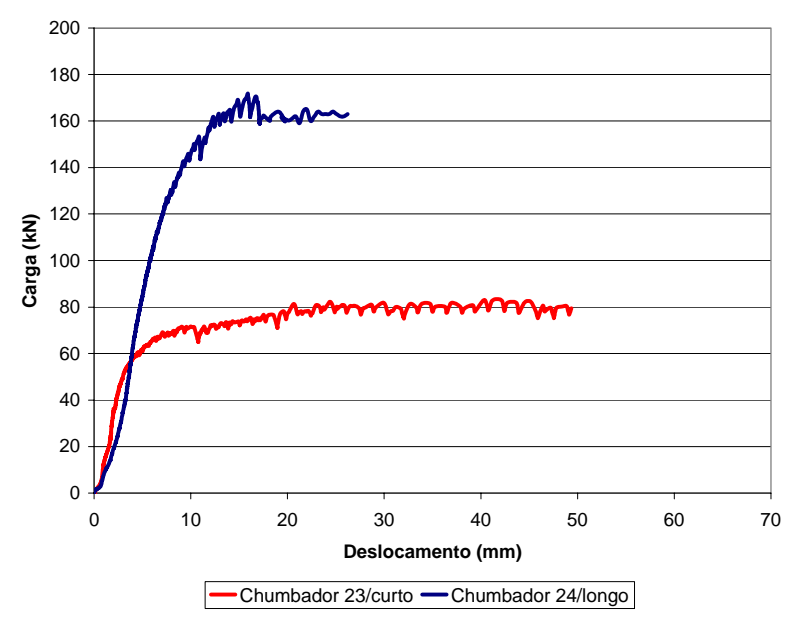

(c)

Figura 5.29. Curvas carga $x$ deslocamento para chumbadores curtos e longos executados com as metodologias A (a), A* (b) e B (c).

A partir dos resultados comparativos apresentados na Figura 5.29, verificou-se um comportamento diferente do observado na linha 2. Como esperado, teoricamente, a carga máxima obtida para os chumbadores longos, construídos com as metodologias A e B, ficou próxima de se duplicar em relação aos respectivos chumbadores curtos, dada a duplicidade do seu comprimento. Enquanto para a metodologia A o incremento foi de 82\%, para a metodologia B, o incremento foi de 108\%. Porém, este comportamento não foi observado para a metodologia A*. Para esta condição, o incremento da carga foi de apenas $28,5 \%$. 
Para a execução dos chumbadores com a metodologia $A^{*}$, estimou-se o volume necessário de calda de solo-cimento para o preenchimento das cavidades escavadas com um acréscimo de $10 \%$, considerando-se eventuais perdas e/ou surgência de ramificações no interior do maciço de solo. Primeiramente, foi executado o chumbador curto, e o critério de parada para a completa execução da bainha foi atendido, ou seja, a calda de solo-cimento extravasou pela boca do furo. Na execução do chumbador longo, este procedimento não foi verificado, porém todo o volume de calda de solo-cimento previsto foi utilizado. Este fato pode justificar o baixo incremento de carga do chumbador longo, em relação ao curto.

A fim de quantificar a influência do comprimento do chumbador em termos do parâmetro $q_{s}$, é apresentado na Figura 5.30 um comparativo entre os chumbadores curtos e longos. Para facilitar a análise comparativa, os valores percentuais apresentados foram referenciados em relação aos valores de $q_{s}$ dos chumbadores curtos (100\%).

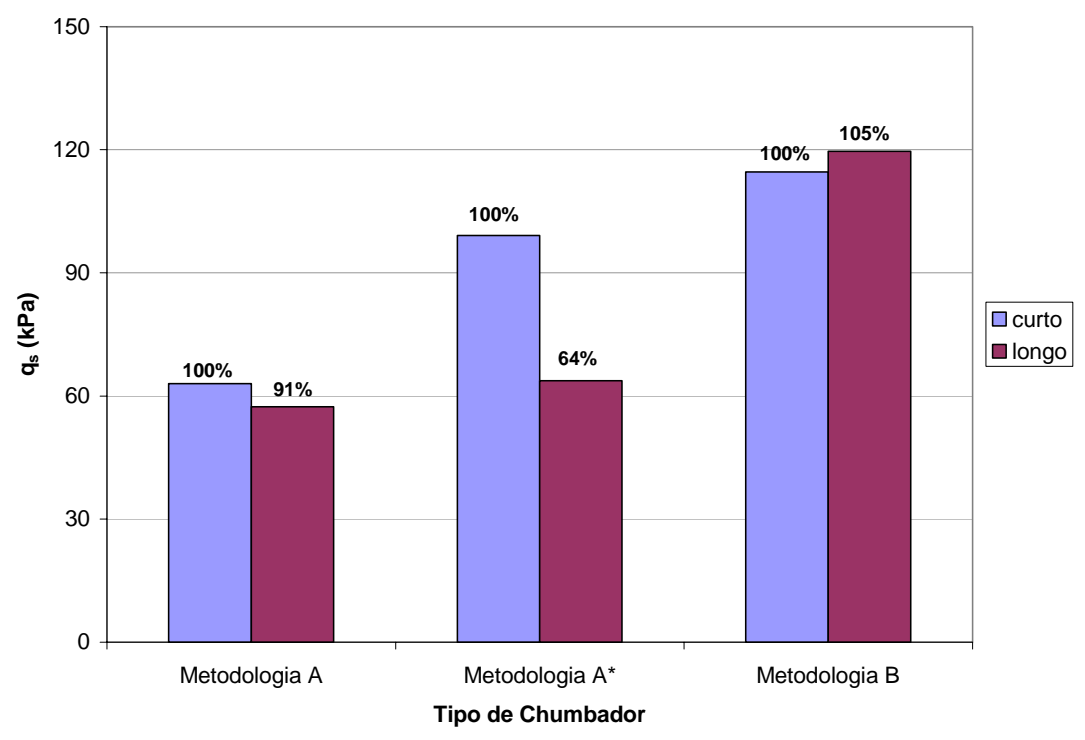

Figura 5.30. Variação de $q_{s}$ para os diferentes tipos de chumbadores (curtos e longos), considerando-se as metodologias $\mathrm{A}, \mathrm{A}^{*}$ e $\mathrm{B}$.

As análises comparativas da Figura 5.30 somente representam em termos de $q_{s}$ as constatações já apresentadas. Observa-se que, para as metodologias A e B, os valores de $q_{s}$ praticamente independem do comprimento dos chumbadores, haja visto a variação 
máxima de 9\%. Entretanto, para a metodologia A*, esta variação foi bastante significativa e com redução da ordem de 36\%.

\subsubsection{Resultados da Instrumentação}

A Figura 5.31 apresenta curvas típicas de carga x deslocamento para chumbadores curtos (a) e longos (b), obtidas para quatro níveis de carregamento, em relação à carga de ruptura (25, 50, 75 e 100\%).

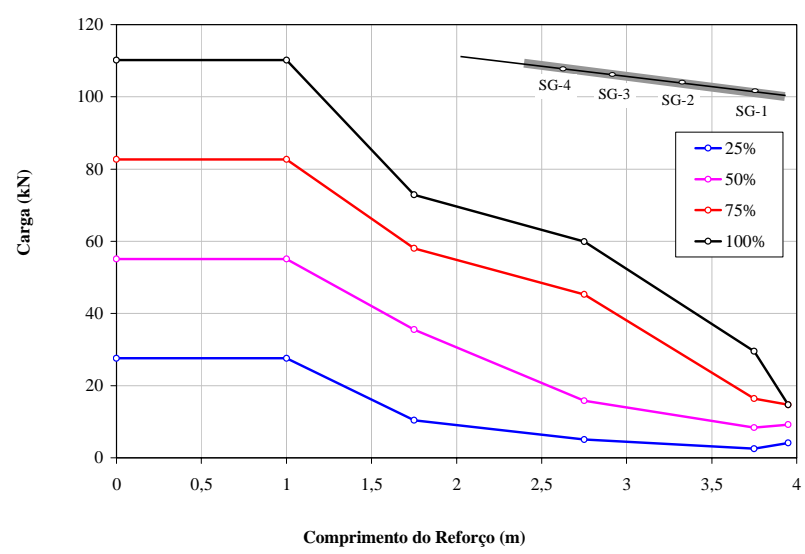

(a)

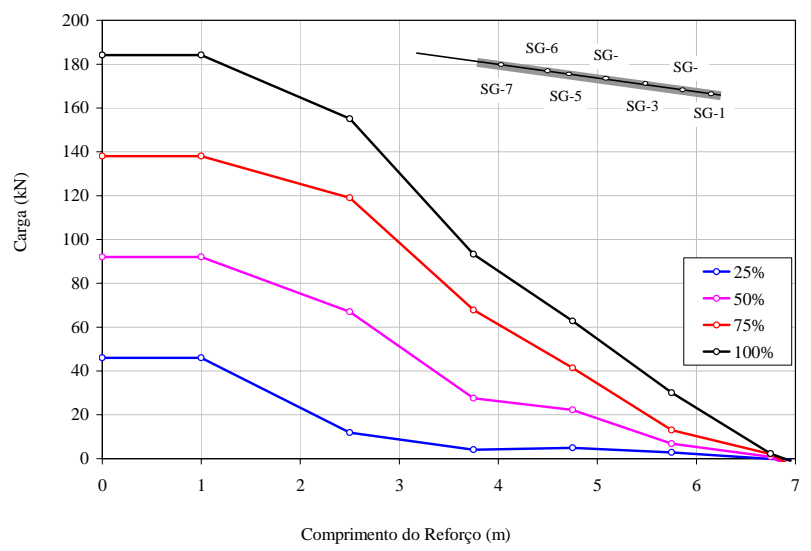

(b)

Figura 5.31. Distribuição das cargas ao longo do comprimento para chumbadores curto (a) e longo (b), em porcentagem, em relação à carga de ruptura.

Assim como observado na linha 2, a distribuição das cargas ao longo dos chumbadores curtos e longos foi parecida, e o mesmo é válido no tocante à mobilização das cargas, ou seja, o chumbador curto foi todo mobilizado, enquanto para os chumbadores longos as cargas de arrancamento no final do trecho injetado foram praticamente inexistentes. 


\subsection{ENSAIOS DE ARRANCAMENTO - OSASCO-SP (OBRA 2)}

Para padronizar e facilitar a interpretação dos resultados, as Tabelas 5.6 e 5.7 apresentam, respectivamente, para as linhas 3 e 5, o número, a metodologia construtiva utilizada, o comprimento e o tipo de cada chumbador.

Tabela 5.6. Identificação e características dos chumbadores da linha 3.

\begin{tabular}{cccc}
\hline $\mathbf{N}^{\circ}$ Chumbador & Metodologia & Comprimento (m) & Tipo \\
\hline 1 & A & 6,0 & Longo \\
2 & A & 3,0 & Curto \\
3 & B & 6,0 & Longo \\
4 & B & 3,0 & Curto \\
5 & C & 6,0 & Longo \\
6 & C & 3,0 & Curto \\
7 & D & 3,0 & Curto \\
8 & D & 3,0 & Curto \\
9 & E & 3,0 & Curto \\
10 & E & 3,0 & Curto \\
11 & F & 3,0 & Curto \\
12 & F & 3,0 & Curto \\
\hline
\end{tabular}

Tabela 5.7. Identificação e características dos chumbadores da linha 5.

\begin{tabular}{cccc}
\hline $\mathbf{N}^{\circ}$ Chumbador & Metodologia & Comprimento (m) & Tipo \\
\hline 13 & A & 6,0 & Longo \\
14 & A & 3,0 & Curto \\
15 & B & 6,0 & Longo \\
16 & B & 3,0 & Curto \\
17 & C & 6,0 & Longo \\
18 & C & 3,0 & Curto \\
19 & D & 3,0 & Curto \\
20 & D & 3,0 & Curto \\
21 & E & 3,0 & Curto \\
22 & E & 3,0 & Curto \\
23 & F & 3,0 & Curto \\
24 & F & 3,0 & Curto \\
E1 & A & 1,0 & Experimental \\
E2 & B & 1,0 & Experimental \\
\hline
\end{tabular}


As Tabelas 5.6 e 5.7 mostram que, para as linhas 3 e 5, foram executados os mesmos números de chumbadores. Seguiu-se o mesmo critério utilizado na linha 5 da obra de Santo André-SP (Obra 1), ou seja, somente três chumbadores longos foram executados. Estes reforços foram construídos com as metodologias (A, B e C), que, teoricamente, atingem os menores carregamentos. Na linha 5, como aspecto inovador, foram construídos dois chumbadores experimentais com 1,0 m de comprimento. Estes chumbadores foram construídos com as metodologias A e B.

\subsubsection{Ensaios de Arrancamento - Linha 3}

A Figura 5.32 apresenta as curvas carga $\mathrm{x}$ deslocamento obtidas a partir dos ensaios de arrancamento, realizados nos chumbadores curto (02) e longo (01), executados com a metodologia A.

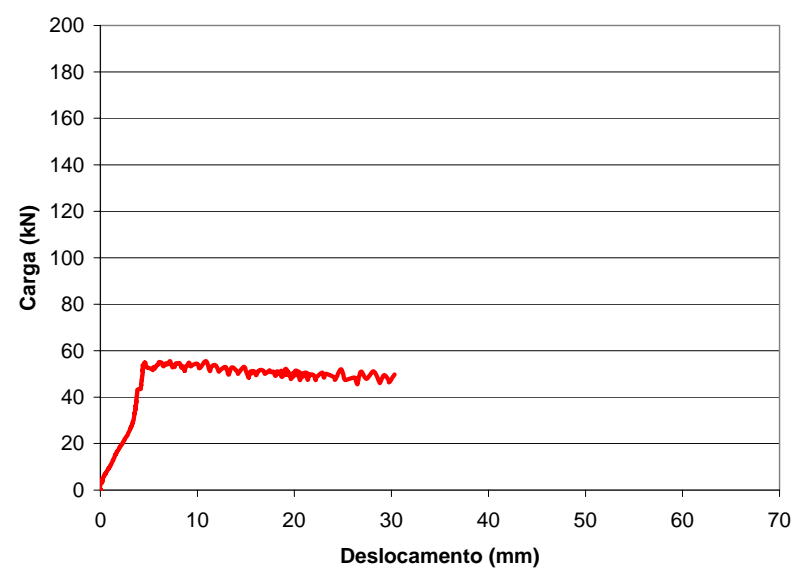

(a)

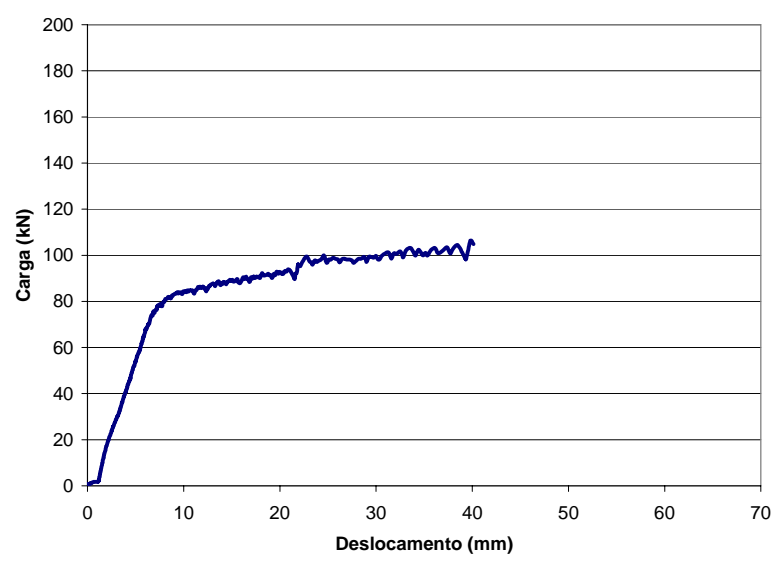

(b)

Figura 5.32. Curvas carga $x$ deslocamento dos chumbadores curto (a) e longo (b), construídos com a metodologia A.

A Figura 5.32 mostra que o chumbador curto (02) apresentou ruptura frágil, com carga de pico de 55,5 kN, para um deslocamento de 10,9 mm, tendendo posteriormente a um valor residual. Ao analisar o comportamento do chumbador longo (01), verifica-se que a ruptura foi plástica, atingindo a carga máxima de 99,9 kN, para um deslocamento de 25,8 $\mathrm{mm}$. 
A Figura 5.33 apresenta os resultados dos ensaios de arrancamento realizados nos chumbadores curto (04) e longo (03), executados com a metodologia B.

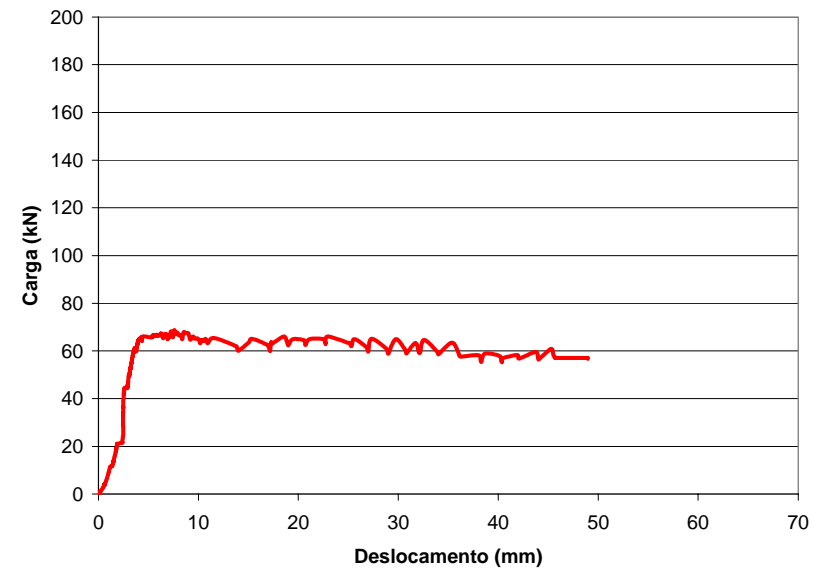

(a)

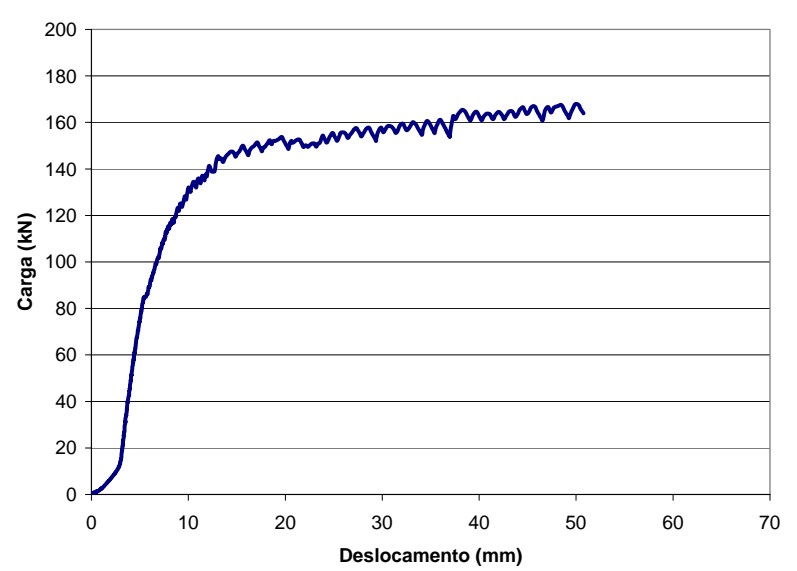

(b)

Figura 5.33. Curvas carga $x$ deslocamento dos chumbadores curto (a) e longo (b), construídos com a metodologia B.

O resultado do ensaio de arrancamento obtido para o chumbador curto (04) apresentou ruptura frágil, com carga de pico de 68,8 kN, para um deslocamento de 7,6 mm. Após o pico, as cargas tenderam a um valor residual. Ao analisar o comportamento do chumbador longo (03), verifica-se que a ruptura foi plástica, atingindo a carga máxima de $157,8 \mathrm{kN}$, para um deslocamento de $26,3 \mathrm{~mm}$.

Os resultados dos ensaios de arrancamento realizados nos chumbadores curto (06) e longo (05), executados com a metodologia C, são apresentados na Figura 5.34. 


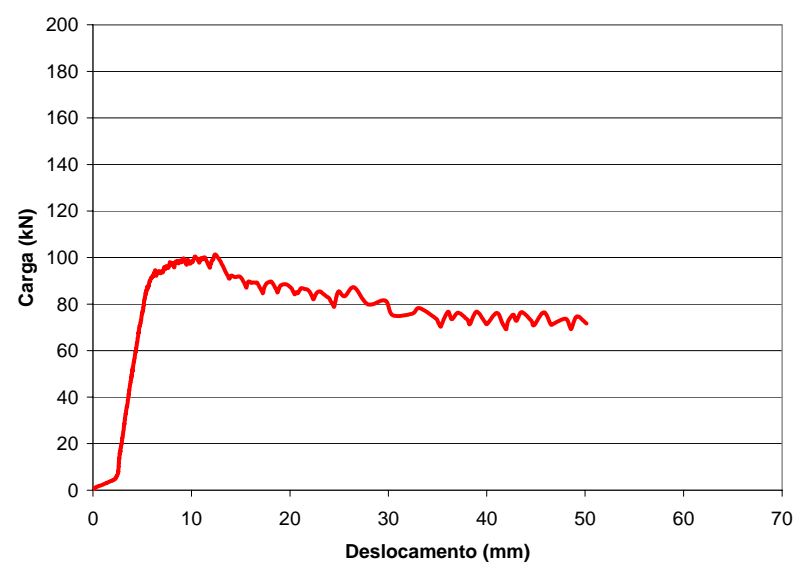

(a)

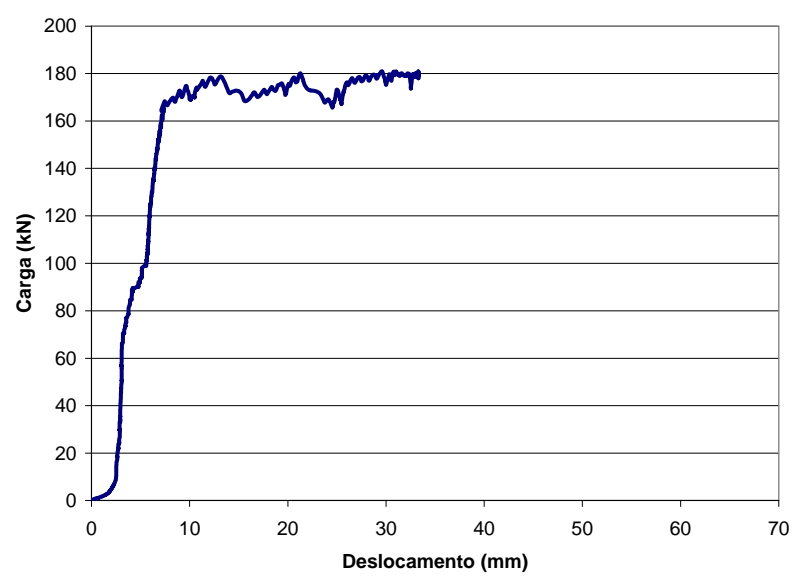

(b)

Figura 5.34. Curvas carga $x$ deslocamento dos chumbadores curto (a) e longo (b), construídos com a metodologia C.

As curvas carga x deslocamento apresentadas na Figura 5.34, para chumbadores curto (06) e longo (05), apresentaram ruptura frágil. O chumbador curto apresentou carga de pico de 101,3 kN, para um deslocamento de 12,4 mm. Para o chumbador longo, o carregamento de pico foi de 180,1 kN, para um deslocamento de 21,3 mm.

A Figura 5.35 mostra os resultados dos ensaios de arrancamento realizados nos chumbadores curtos (07) e (08), executados com a metodologia D.

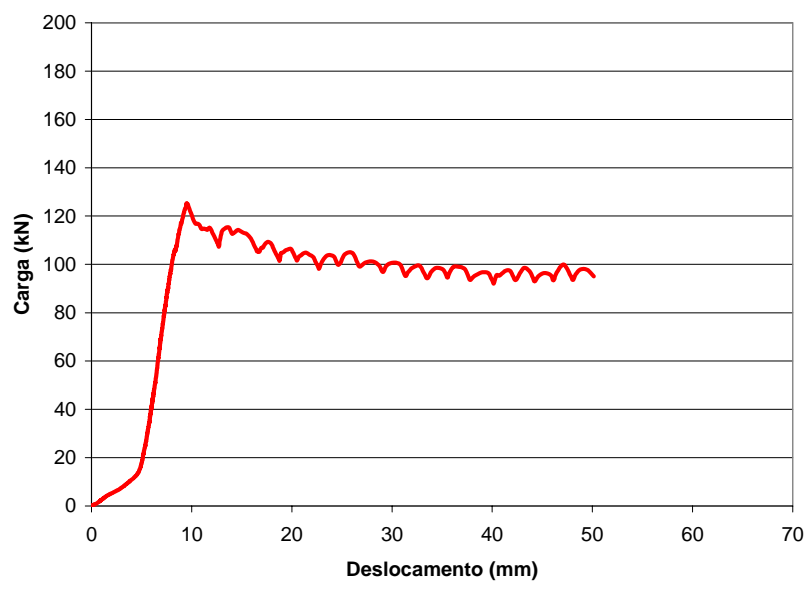

(a)

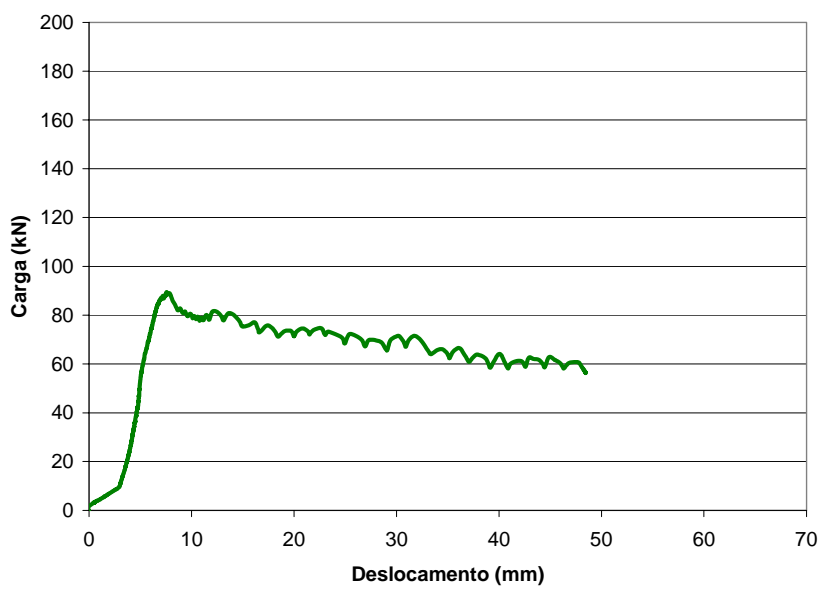

(b)

Figura 5.35. Curvas carga $x$ deslocamento dos chumbadores curtos 07 (a) e 08 (b) construídos com a metodologia D. 
Os chumbadores curtos 07 e 08, executados com a metodologia D, apresentaram comportamento similar e ruptura frágil. Para o chumbador curto 07, a carga de pico foi de 125,3 kN, para um deslocamento de 9,5 mm. O chumbador curto 08 apresentou carga de pico de 89,5 kN, para um deslocamento de 7,6 mm. Embora tenham sido executadas com a mesma metodologia, as cargas de pico apresentaram variação de $40 \%$. Os volumes injetados de calda de cimento foram de 42,0 e 40,0 litros, respectivamente.

A Figura 5.36 apresenta o resultado do ensaio de arrancamento realizado no chumbador curto 09, construído com a metodologia E. Problemas na aquisição de dados não permitiram a apresentação do resultado do chumbador curto 11.

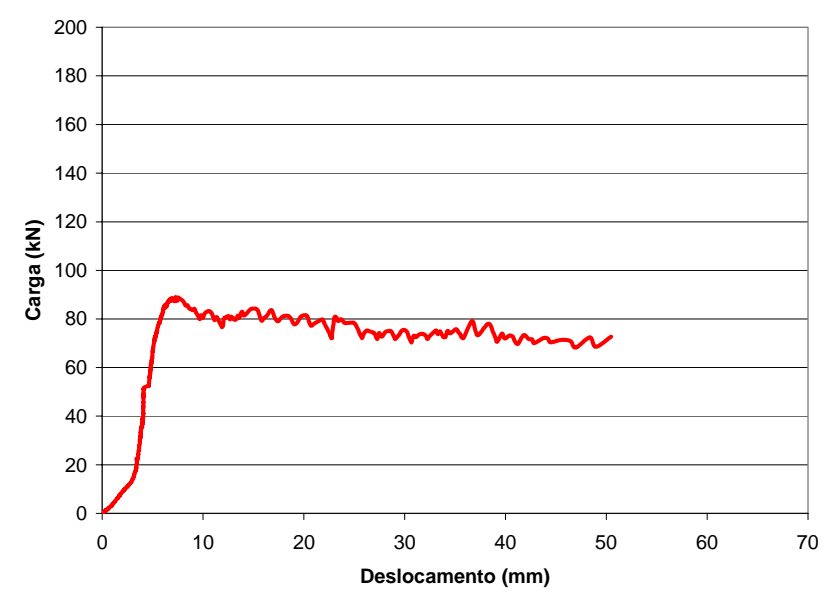

(a)

Figura 5.36. Curva carga x deslocamento do chumbador curto construído com a metodologia E.

O chumbador 09 apresentou ruptura frágil, com carregamento de pico de 88,9 kN, para deslocamento de 7,3 mm. Assim como nos demais ensaios em que se verificou este tipo de ruptura, as cargas tenderam para um valor residual.

A Figura 5.37 apresenta os resultados dos ensaios de arrancamento realizados nos chumbadores curtos (11) e (12), executados com a metodologia F. 


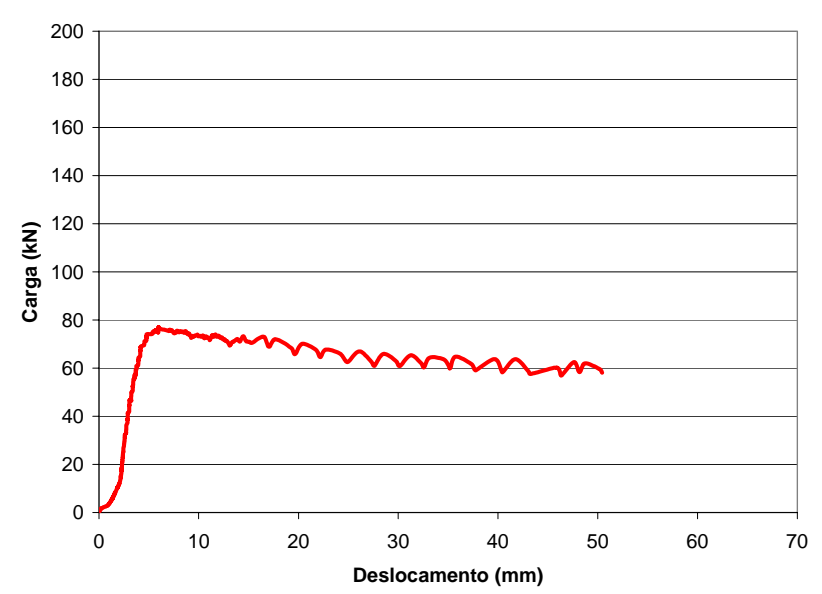

(a)

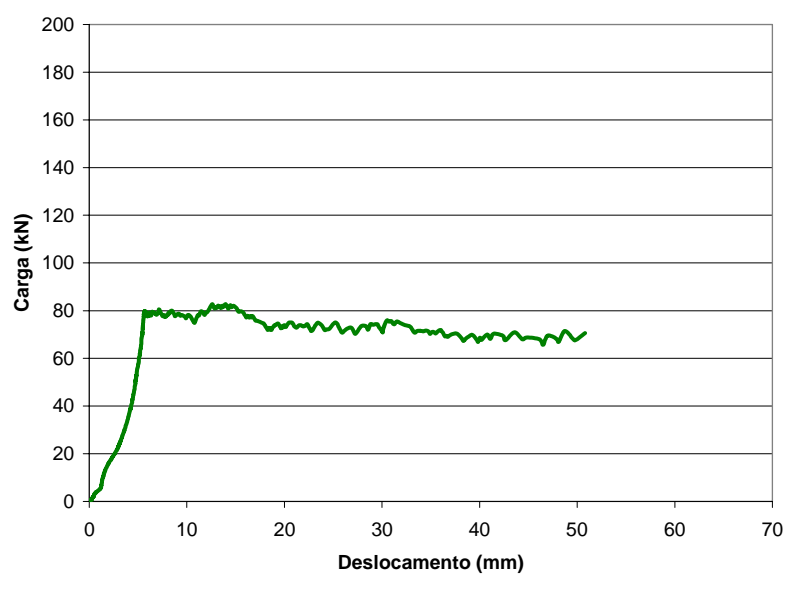

(b)

Figura 5.37. Curvas carga $x$ deslocamento dos chumbadores curtos 11 (a) e 12 (b) construídos com a metodologia F.

Os chumbadores curtos 11 e 12, executados com a metodologia F, apresentaram ruptura frágil e conseqüente estabilização para um valor residual. Para o chumbador 11, o carregamento de pico foi de 77,1 kN para um deslocamento de 6,0 $\mathrm{mm}$. O carregamento de pico para o chumbador 12 foi de 82,7 kN, para um deslocamento de $12 \mathrm{~mm}$. As cargas de pico apresentaram pequena variação (7\%). A proximidade dos volumes injetados, 10 litros para o chumbador 11 e 15,0 litros para o chumbador 12, justificam o comportamento similar.

A Tabela 5.8 apresenta o resumo dos resultados dos ensaios de arrancamento realizados nos chumbadores curtos e longos construídos na linha 3, com diferentes metodologias executivas. São apresentados os principais parâmetros obtidos a partir dos ensaios, que são: carga máxima de ruptura $\left(\mathrm{T}_{\text {máx }}\right)$, carga máxima de ruptura por metro linear de chumbador, deslocamento referente à carga máxima, resistência ao cisalhamento de interface solo-reforço $\left(q_{s}\right)$ e modo de ruptura (quando esta ocorre), nomeando F para ruptura frágil e P para ruptura plástica. Os chumbadores que não atingiram a ruptura foram identificados por NR. 
Tabela 5.8. Resumo dos resultados dos ensaios de arrancamento da linha 3.

\begin{tabular}{|c|c|c|c|c|c|c|c|c|}
\hline \multirow[b]{2}{*}{$\mathbf{N}^{\circ}$} & \multicolumn{2}{|c|}{ Chumbador } & \multirow[b]{2}{*}{ Tipo } & \multirow[b]{2}{*}{$\mathbf{T}_{\text {máx }}(\mathbf{k N})$} & \multirow[b]{2}{*}{$\begin{array}{c}\text { Tmáx/m } \\
\text { (kN) }\end{array}$} & \multirow[b]{2}{*}{$\begin{array}{c}\text { Deslocamento } \\
\text { (mm) }\end{array}$} & \multirow[b]{2}{*}{$\begin{array}{c}q_{s} \\
(\mathbf{k P a})\end{array}$} & \multirow[b]{2}{*}{$\begin{array}{l}\text { Modo de } \\
\text { Ruptura }\end{array}$} \\
\hline & Metodologia & $\begin{array}{c}\text { Comprimento } \\
\text { (m) }\end{array}$ & & & & & & \\
\hline 1 & A & 6,0 & Longo & 99,9 & 16,7 & 25,8 & 69,6 & $\mathrm{P}$ \\
\hline 2 & A & 3,0 & Curto & 55,5 & 18,5 & 10,9 & 77,3 & $\mathrm{~F}$ \\
\hline 3 & B & 6,0 & Longo & 157,8 & 26,3 & 28,6 & 109,9 & $P$ \\
\hline 4 & B & 3,0 & Curto & 68,8 & 22,9 & 7,6 & 95,8 & $\mathrm{~F}$ \\
\hline 5 & C & 6,0 & Longo & 180,1 & 30,0 & 21,3 & 125,4 & $\mathrm{~F}$ \\
\hline 6 & C & 3,0 & Curto & 101,3 & 33,8 & 12,4 & 141,1 & $\mathrm{~F}$ \\
\hline 7 & $\mathrm{D}$ & 3,0 & Curto & 125,3 & 41,8 & 9,5 & 174,4 & $\mathrm{~F}$ \\
\hline 8 & $\mathrm{D}$ & 3,0 & Curto & 89,5 & 29,8 & 7,6 & 124,6 & $\mathrm{~F}$ \\
\hline 9 & E & 3,0 & Curto & 88,9 & 29,6 & 7,3 & 123,7 & $\mathrm{~F}$ \\
\hline 10 & E & 3,0 & Curto & - & - & - & - & - \\
\hline 11 & $\mathrm{~F}$ & 3,0 & Curto & 77,1 & 25,7 & 6,0 & 107,3 & $\mathrm{~F}$ \\
\hline 12 & F & 3,0 & Curto & 82,7 & 27,6 & 12,6 & 115,1 & $\mathrm{~F}$ \\
\hline
\end{tabular}

Na seqüência, são apresentadas as análises realizadas para a melhor interpretação dos resultados obtidos. Foi avaliada a influência da metodologia executiva, do volume injetado e do comprimento dos chumbadores (trecho injetado) no resultado do ensaio de arrancamento. Adicionalmente, são apresentados os resultados da instrumentação das barras de aço com strain gages.

\subsubsection{Influência da Metodologia Executiva}

Para realizar a análise comparativa das diferentes metodologias executivas, são apresentadas as curvas carga $\mathrm{x}$ deslocamento, de forma agrupada, para os chumbadores curtos (Figura 5.38) e longos (Figura 5.39). 


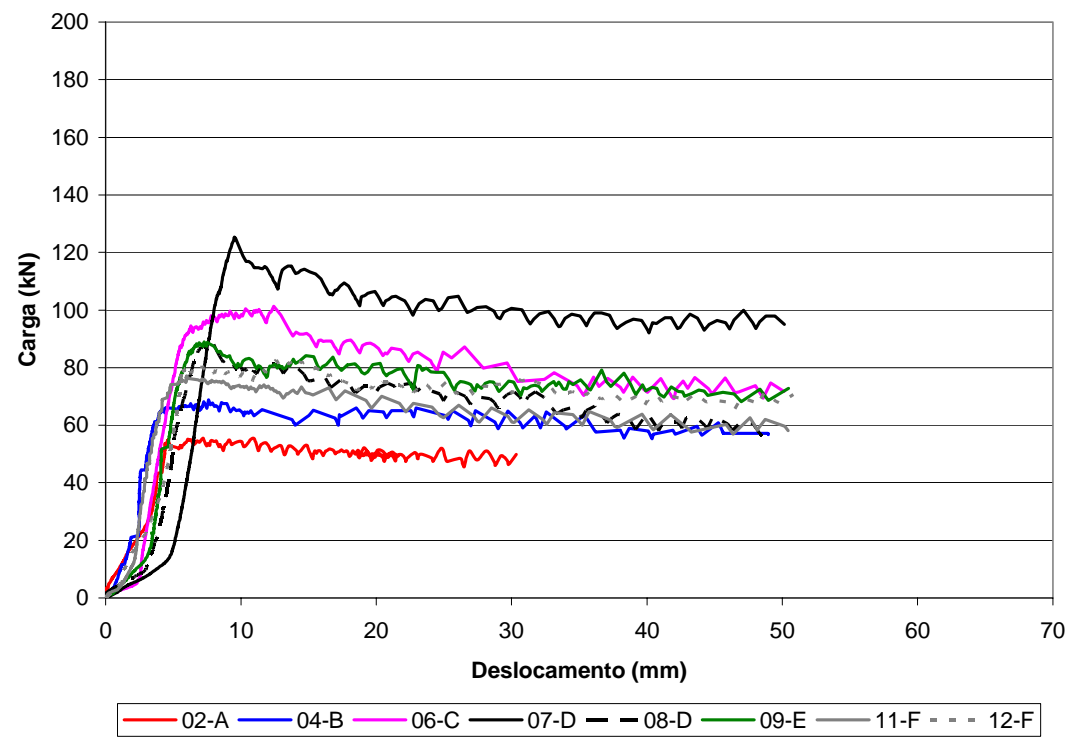

Figura 5.38. Curvas carga $\mathrm{x}$ deslocamento dos chumbadores curtos executados com as diferentes metodologias executivas.

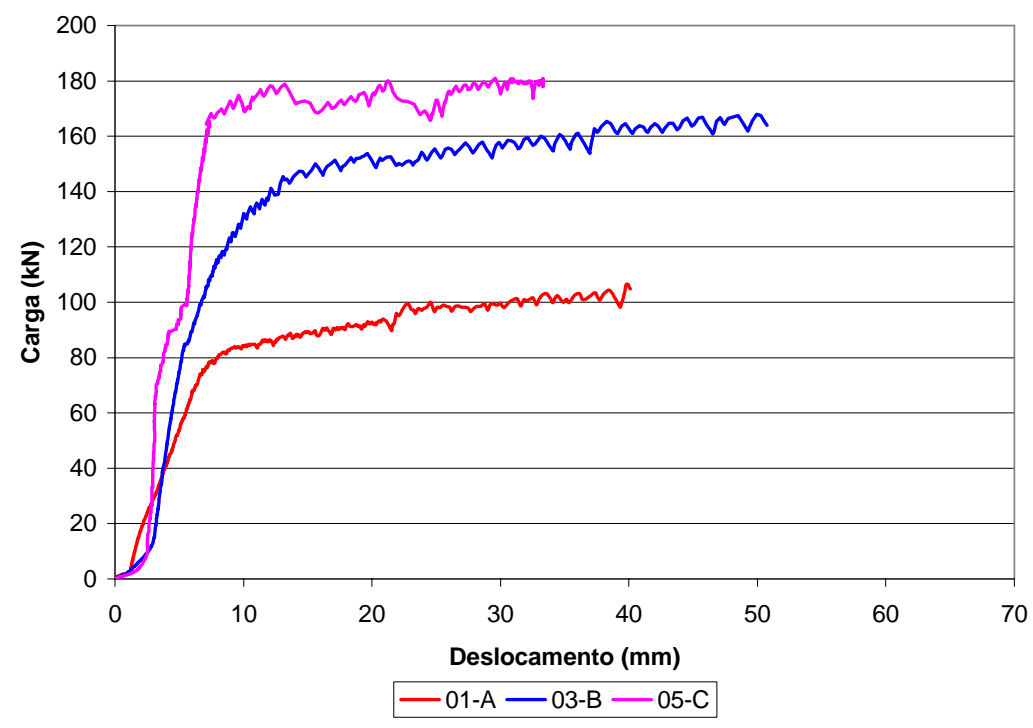

Figura 5.39. Curvas carga $\mathrm{x}$ deslocamento dos chumbadores longos executados com as diferentes metodologias executivas.

As Figuras 5.38 e 5.39 permitem avaliar, qualitativamente, os resultados obtidos para os chumbadores curtos e longos, respectivamente. Os resultados mostram um aumento significativo das cargas de arrancamento, quando comparamos as metodologias executivas 
em que houve alguma fase de injeção de calda de cimento com a metodologia A, tomada como referência. Em termos de deslocamentos, pode-se afirmar que, para os chumbadores curtos, as cargas máximas foram obtidas com menores deslocamentos médios (9,2 mm) do que para os chumbadores longos, para os quais valor médio foi de 25,2 mm.

As Figuras 5.40 e 5.41 apresentam, para chumbadores curtos e longos, os gráficos comparativos do parâmetro $q_{s}$ para as diferentes metodologias executivas. Os valores percentuais apresentados foram sempre referenciados em relação aos valores de $q_{s}$ da metodologia A (100\%).

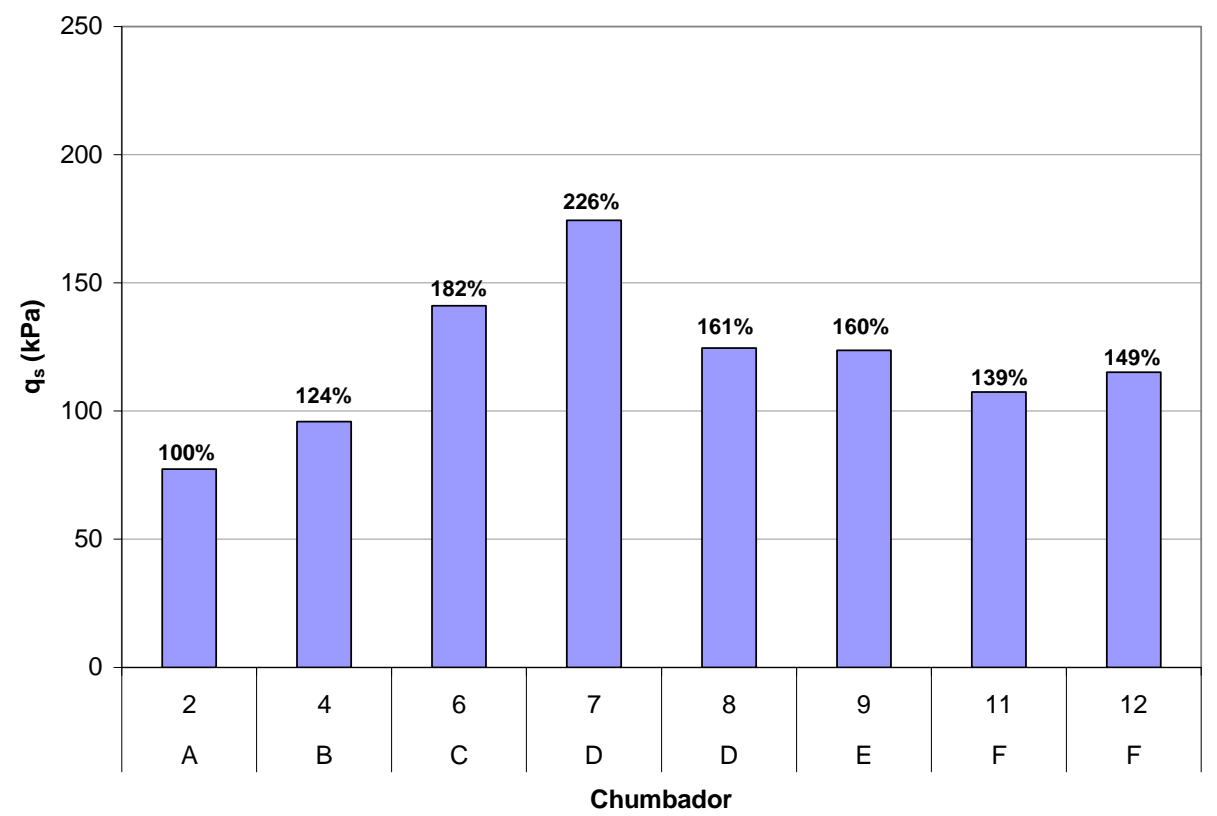

Figura 5.40. Análise comparativa entre os valores de $q_{s}$ obtidos para os chumbadores curtos executados com as diferentes metodologias executivas. 


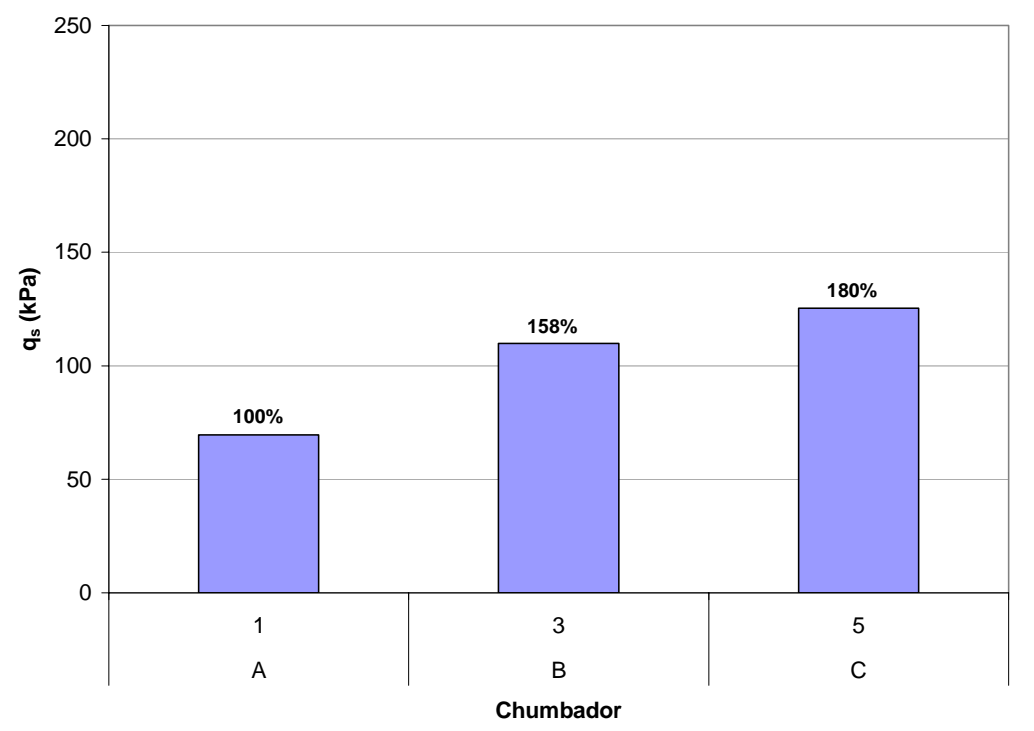

Figura 5.41. Análise comparativa entre os valores de $q_{s}$ obtidos para os chumbadores longos executados com as diferentes metodologias executivas.

Das análises comparativas apresentadas nas Figuras 5.40 e 5.41 observa-se que, de maneira geral, os valores de $q_{s}$ apresentaram um ganho em relação à metodologia $\mathrm{A}$, tomada como referência. Os incrementos de $q_{s}$ observados para a metodologia B foram de $24 \%$ e $58 \%$, para os chumbadores curto e longo, respectivamente. Conforme esperado, os incrementos de $q_{s}$ para os chumbadores curto e longo executados com a metodologia C foram superiores às metodologias A e B. O maior número de injeções foi responsável por um ganho médio de $81 \%$.

Confirmando o resultado de experiências anteriores, principalmente as de laboratório, os chumbadores executados com as metodologias C e E (bainha +2 fases) apresentaram resultados de mesma ordem de grandeza. Enquanto o chumbador executado com a metodologia C apresentou um incremento de $q_{s}$ de $82 \%$, para a metodologia E, o incremento foi de $60 \%$. Estes resultados mostram uma pequena variação de $22 \%$, que também pode ser justificada pelo volume de injeção de calda de cimento.

Da mesma forma, também foram verificados comportamentos similares para as metodologias D e F (bainha + 3 fases), em chumbadores curtos, com exceção feita ao chumbador curto 07, executado com a metodologia D. O incremento de $q_{s}$ para este chumbador foi de $126 \%$, muito superior aos demais. Além disso, somente este chumbador 
apresentou desempenho dentro do esperado, superior às metodologias C e E (bainha +2 fases). Os valores de $q_{s}$ para os chumbadores executados com a metodologia $F$ ficaram abaixo do esperado e superaram apenas os chumbadores executados com as metodologias A e B. O ganho médio desta metodologia foi de $44 \%$ e $20 \%$, em relação às metodologias A e $\mathrm{B}$, respectivamente.

\subsubsection{Influência do Volume de Injeção de Calda de Cimento}

Para as condições verificadas na linha 3 de Osasco-SP (obra 2), o valor de $q_{s}$ também está relacionado com o volume de injeção de calda de cimento de cada metodologia executiva. A Figura 5.42 apresenta, em um mesmo gráfico, os valores de $q_{s} \mathrm{e}$ dos volumes de injeção dos chumbadores curtos. Para facilitar a visualização, os volumes injetados também são apresentados ao longo do gráfico.

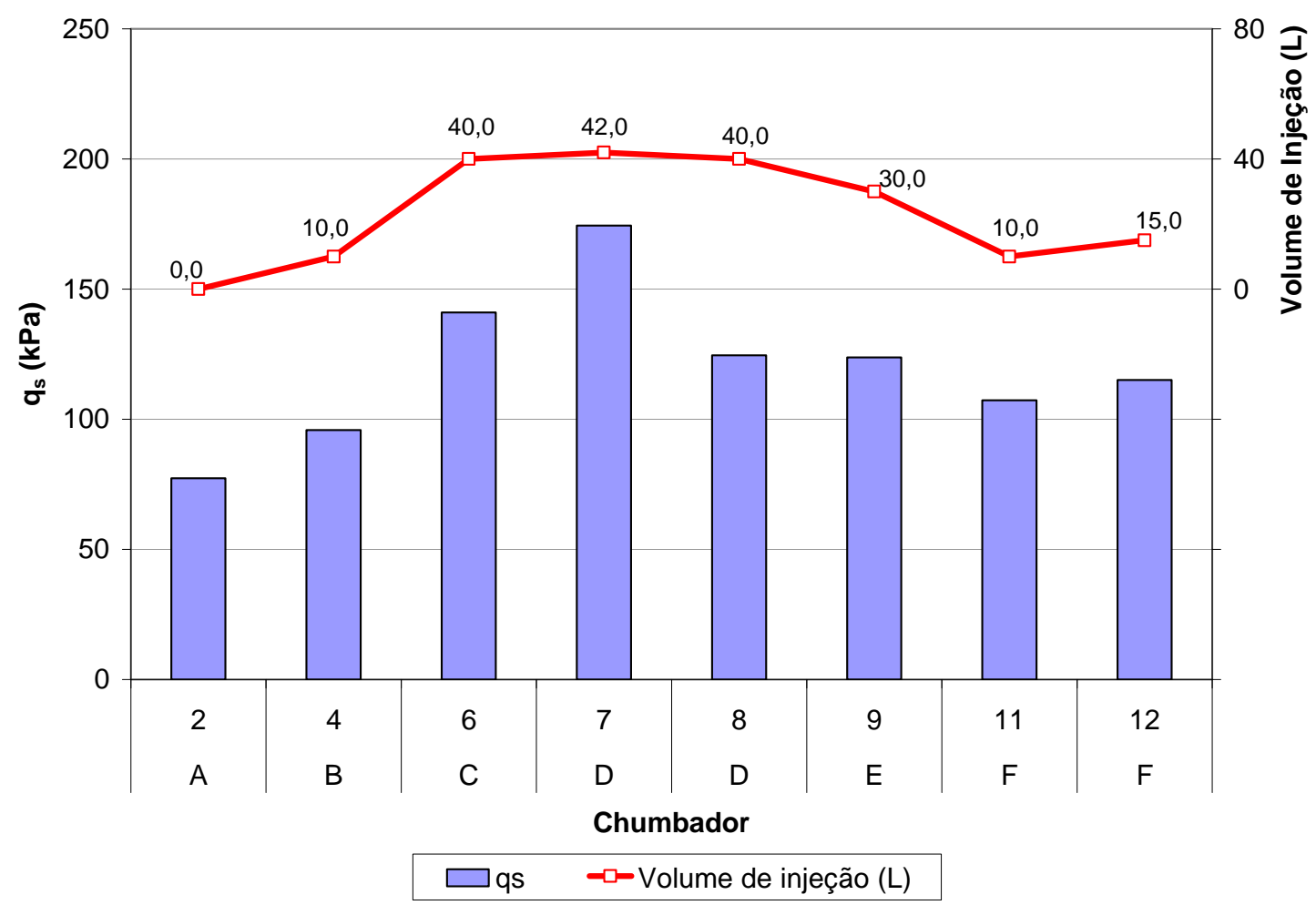

Figura 5.42. Variações de $q_{s}$ e dos volumes de injeção dos chumbadores curtos executados com as diferentes metodologias executivas. 
Os valores de $q_{s}$ apresentados concomitantemente com os volumes de injeção ajudam a explicar o comportamento dos chumbadores executados com as diferentes metodologias executivas. Os maiores incrementos de $q_{s}$ obtidos para os chumbadores 7 (metodologia D) e 6 (metodologia C) são explicados pelos maiores volumes injetados. Entretanto, o desempenho do chumbador 8, executado com a metodologia D, não condiz com o seu volume injetado, de mesma ordem de grandeza dos anteriores. Tal fato pode ser justificado por eventuais ramificações existentes no maciço de solo.

Em termos comparativos, o desempenho do chumbador $\mathrm{E}$, mencionado anteriormente, pode ser justificado pelo volume de calda de cimento que foi injetado para a sua execução. A Figura 5.42 também explica o rendimento abaixo do esperado dos chumbadores 11 e 12, executados com a metodologia F. Embora estes chumbadores tenham sido construídos com 3 fases de injeção, o volume que fora injetado está muito próximo do chumbador 04, executado com a metodologia B. Este fato justifica a proximidade destes resultados.

A partir das análises apresentadas, confirmou-se, quantitativamente, a interdependência entre o parâmetro $q_{s}$ e o volume de injeção. A Figura 5.43 apresenta uma correlação entre o parâmetro $q_{s}$ e o fator adimensional "V", definido nos resultados da linha 2 da obra de Santo André-SP. 


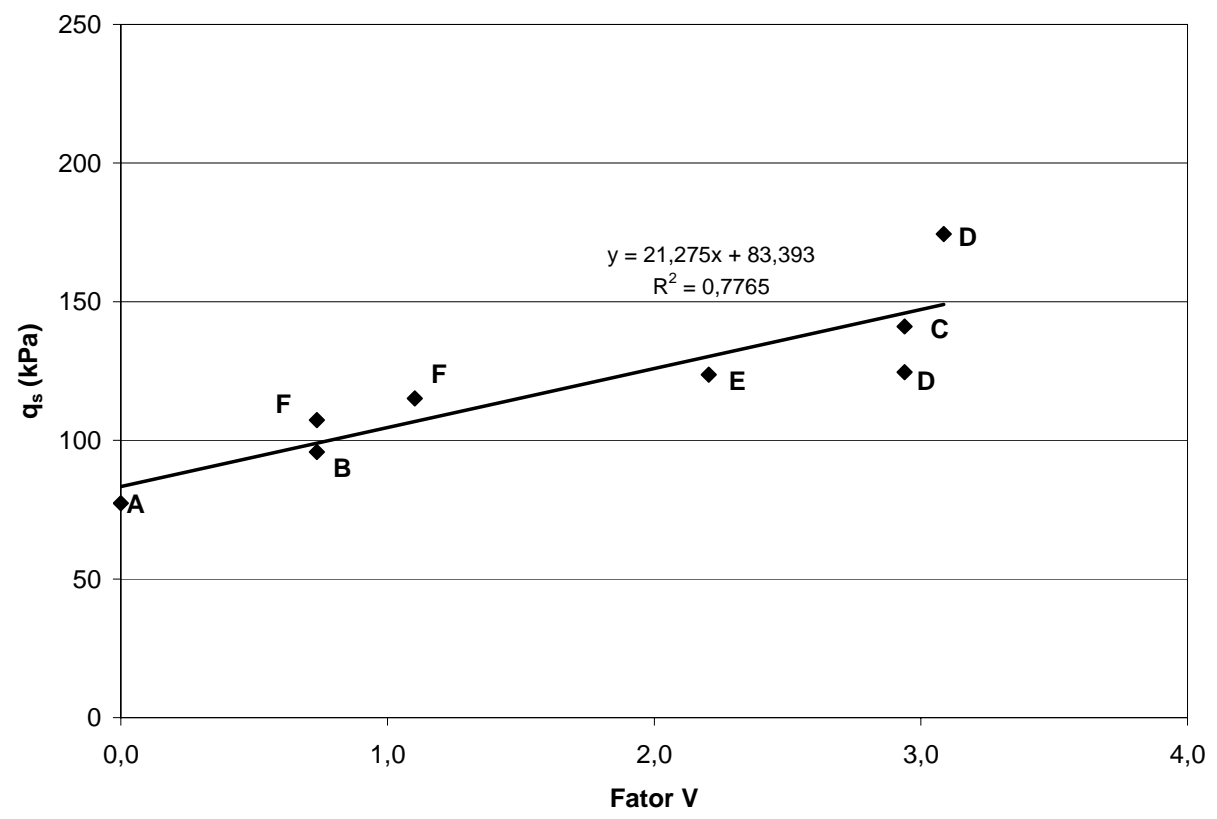

Figura 5.43. Valores de $q_{s} x$ volume de injeção para os chumbadores curtos executados com as diferentes metodologias executivas.

Assim como para a obra 1, o ajuste linear apresentado na Figura 5.43, apresentou valor de $\mathrm{R}^{2}$ aceitável, considerando-se o pequeno espaço amostral e as variabilidades inerentes às metodologias executivas adotadas para a construção dos chumbadores. Considerando-se o ajuste para um volume de injeção igual a zero, representativo da metodologia A (bainha), o valor de $q_{s}$ pode ser representado por 83,4 $\mathrm{kPa}$. Este valor é superior ao mínimo sugerido pela GeoRio (1999) de $60 \mathrm{kPa}$. Os valores de $q_{s}$ obtidos para a metodologia A, em chumbadores curto e longo, foram de 69,6 e 77,3 kPa, respectivamente. Como o valor advindo do ajuste é de 83,4 kPa, obteve-se assim uma variação aproximada de $20 \%$ para a metodologia A, levando-se em consideração apenas os chumbadores curtos. Acredita-se que, com esses valores, o resultado obtido para a metodologia A está um pouco aquém do estimado pela equação ajustada, mas dentro de uma faixa aceitável, que valida esta equação.

Os resultados obtidos confirmam a constatação do programa experimental de laboratório e da obra 1. A determinação do volume de injeção é uma excelente opção no controle de qualidade de execução do chumbador. Recomenda-se que, para obras que 
apresentem o mesmo solo característico da linha 5, adote-se a função $q_{s}=21,27 \mathrm{x}$ "Fator V” + 83,39 (kPa).

\subsubsection{Influência do Comprimento dos Chumbadores}

Seguindo-se a seqüência de análises, também foi avaliada a influência do comprimento dos chumbadores na resistência ao cisalhamento de interface solo-reforço. As metodologias A, B e C foram tomadas como referência, já que somente para elas foram executados chumbadores curtos e longos. A Figura 5.44 apresenta as curvas carga $\mathrm{x}$ deslocamento obtidas considerando-se estas três condições.

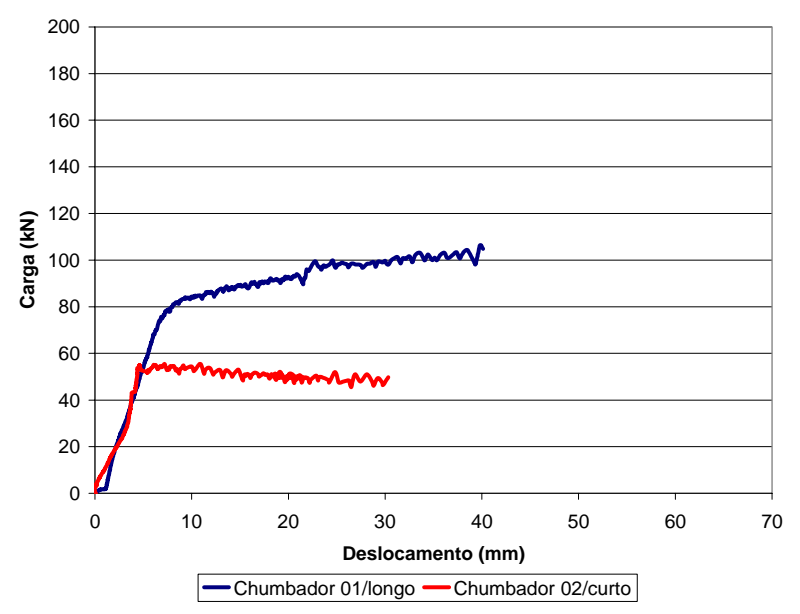

(a)

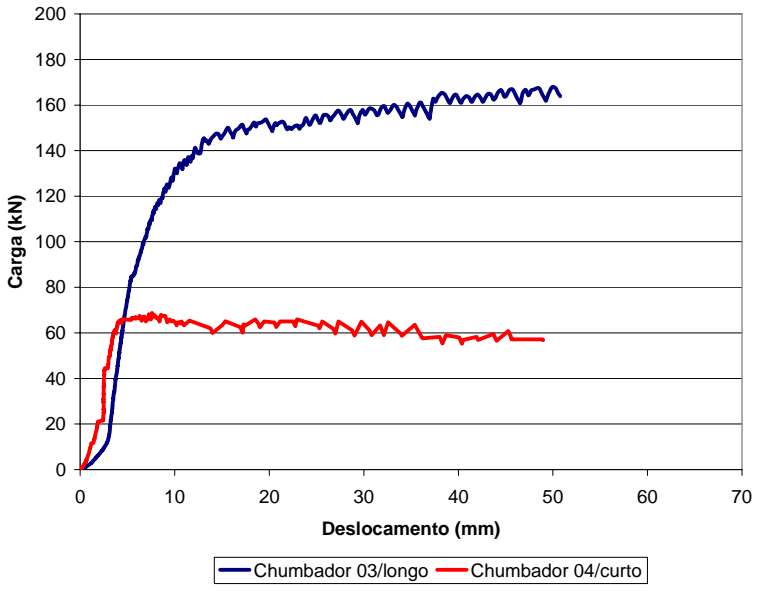

(b) 


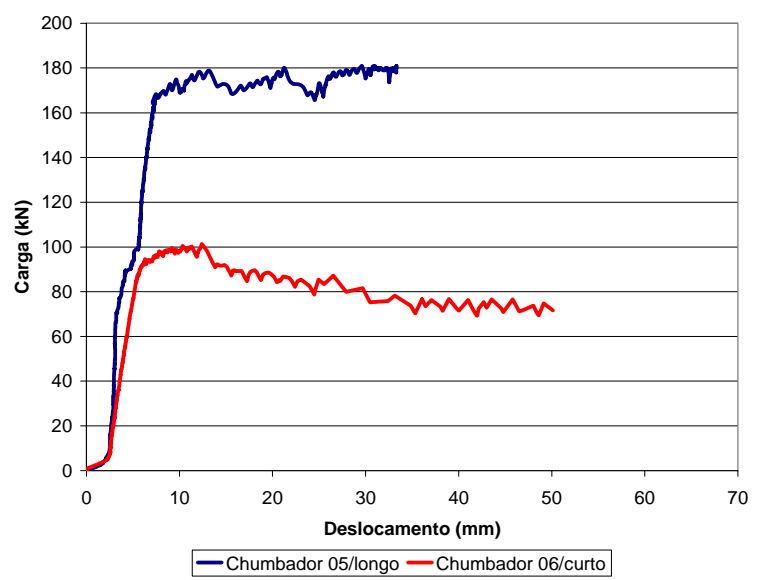

(c)

Figura 5.44. Curvas carga $x$ deslocamento para chumbadores curtos e longos executados com as metodologias A (a), B (b) e C (c).

A partir dos resultados comparativos apresentados na Figura 5.44, verificou-se um comportamento semelhante ao observado na linha 5 da obra de Santo André-SP (obra 1). Como esperado, teoricamente, o carregamento de pico dos chumbadores longos construídos com as metodologias A, B e C ficou próximo de se duplicar em relação aos chumbadores curtos, dada a duplicidade do seu comprimento. Enquanto para as metodologias A e C o incremento foi de $80 \%$, para a metodologia B, o incremento foi de $130 \%$. Ao analisar o incremento, em termos médios de $97 \%$, esta duplicidade pode ser considerada.

A fim de quantificar a influência do comprimento do chumbador em termos de $q_{s}$, é apresentado na Figura 5.45, um comparativo entre os chumbadores curtos e longos. Para facilitar a análise comparativa, os valores percentuais apresentados foram referenciados em relação aos valores de $q_{s}$ dos chumbadores curtos (100\%). 


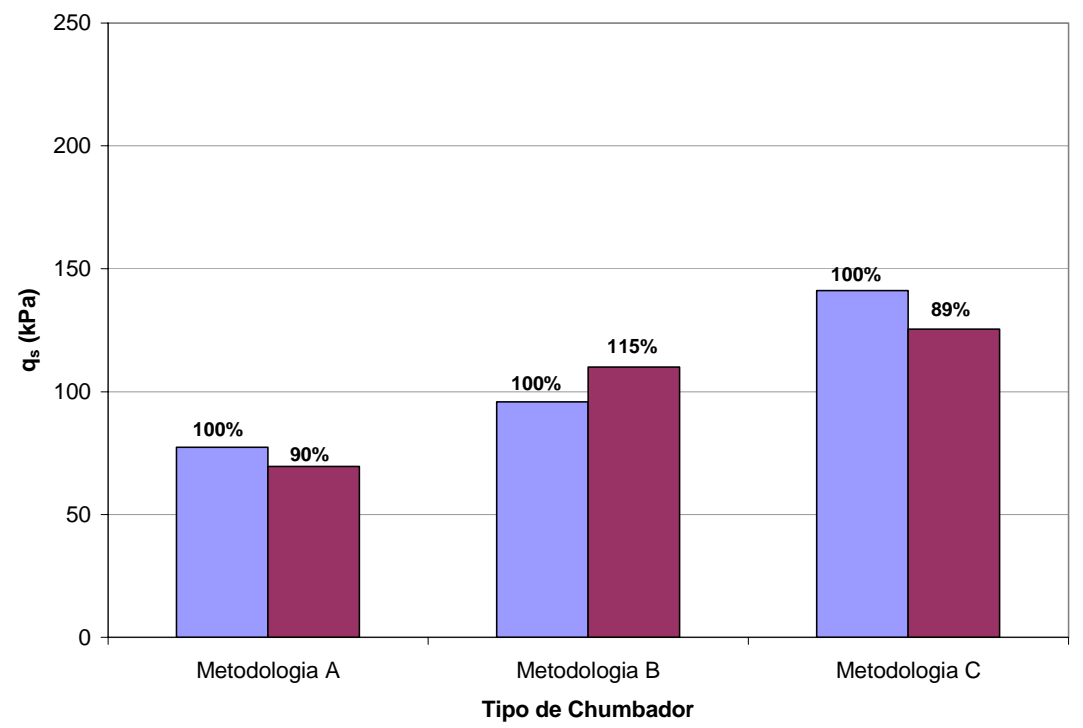

Figura 5.45. Variação de $q_{s}$ para os diferentes tipos de chumbadores (curtos e longos), considerando as metodologias A, B e C.

A partir da Figura 5.45, observa-se que, para as três metodologias analisadas, os valores de $q_{s}$ praticamente independem do comprimento dos chumbadores, haja vista a variação máxima de 15\%.

\subsubsection{Resultados da Instrumentação}

A Figura 5.46 apresenta curvas típicas de carga x deslocamento para chumbadores curtos (a) e longos (b), obtidas para quatro níveis de carregamento, em relação à carga de ruptura (25, 50, 75 e 100\%). 

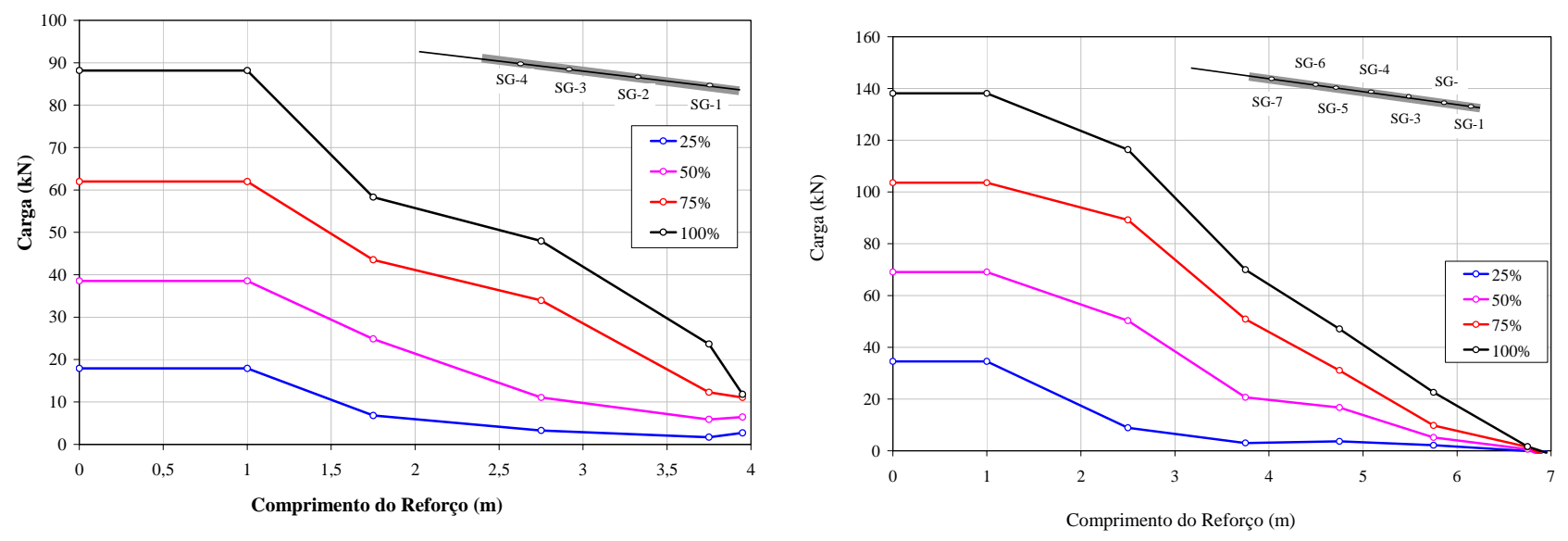

Figura 5.46. Distribuição das cargas ao longo do comprimento para chumbadores curto (a) e longo (b), em percentagem em relação à carga de ruptura.

A distribuição das cargas ao longo dos chumbadores curtos e longos seguiu a mesma tendência dos resultados de instrumentação já apresentados. $\mathrm{O}$ mesmo é válido no tocante à mobilização das cargas, ou seja, o chumbador curto foi todo mobilizado, enquanto para os chumbadores longos, as cargas de arrancamento no final do trecho injetado foram praticamente inexistentes.

\subsubsection{Ensaios de Arancamento - Linha 5}

A Figura 5.47 apresenta as curvas carga $\mathrm{x}$ deslocamento obtidas a partir de ensaios de arrancamento realizados nos chumbadores curto (14), longo (13) e experimental (E1), construídos com a metodologia A. 


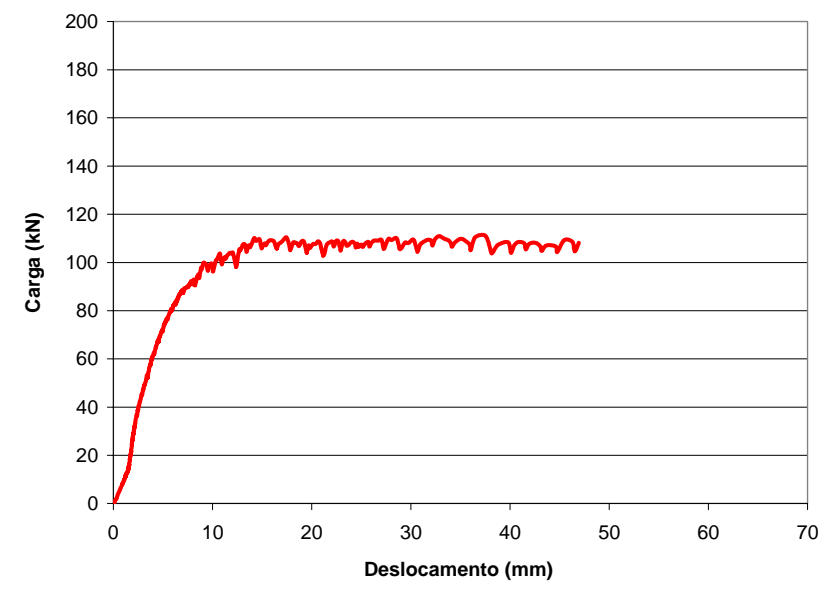

(a)

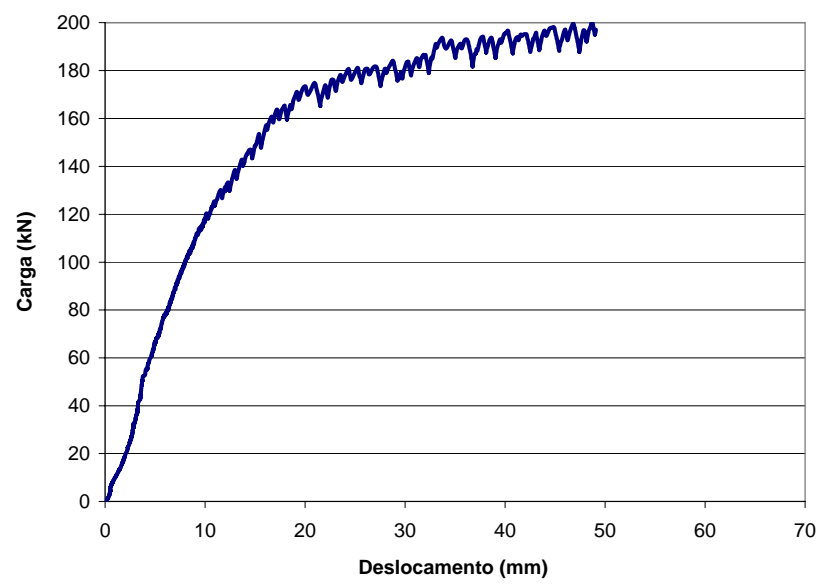

(b)

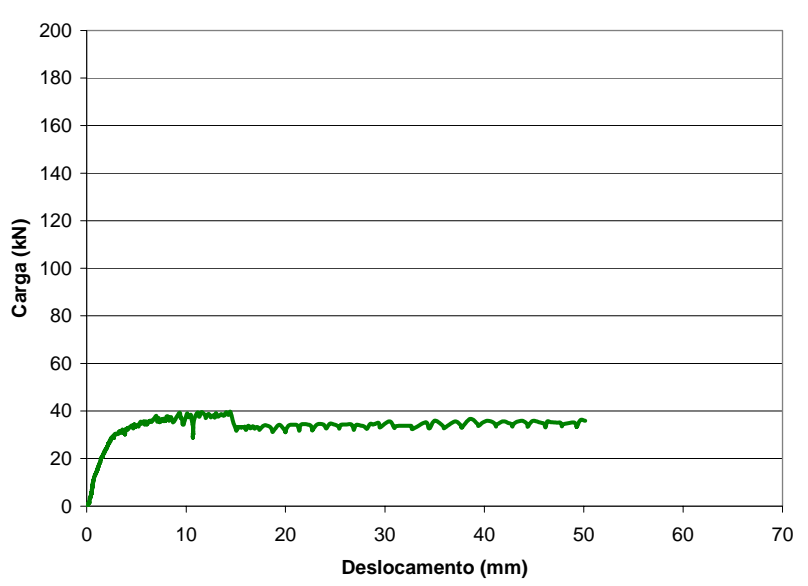

(c)

Figura 5.47. Curvas carga $x$ deslocamento dos chumbadores curto (a), longo (b) e experimental (c) construídos com a metodologia $\mathrm{A}$.

A partir da Figura 5.47, observa-se que os chumbadores curto e longo apresentaram ruptura plástica. O carregamento máximo para o chumbador curto foi de $110,2 \mathrm{kN}$, ao passo que, para o chumbador longo, foi de 184,1 kN. Os deslocamentos foram de 14,2 e 28,8 mm, respectivamente. O chumbador experimental (E1) apresentou ruptura frágil e carregamento de pico de 39,7 kN, para deslocamentos de 14,4 mm.

A Figura 5.48 apresenta os resultados dos ensaios de arrancamento realizados nos chumbadores curto (16), longo (15) e experimental (E2), construídos com a metodologia B. 


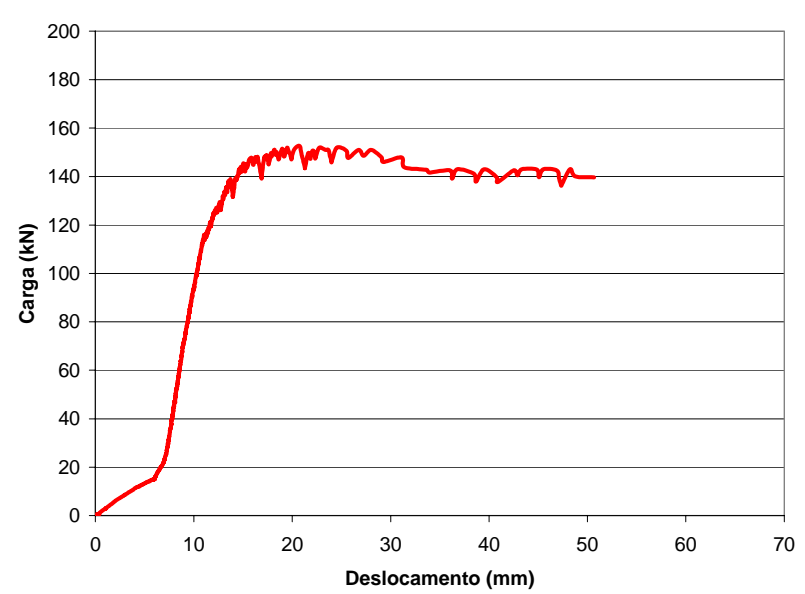

(a)

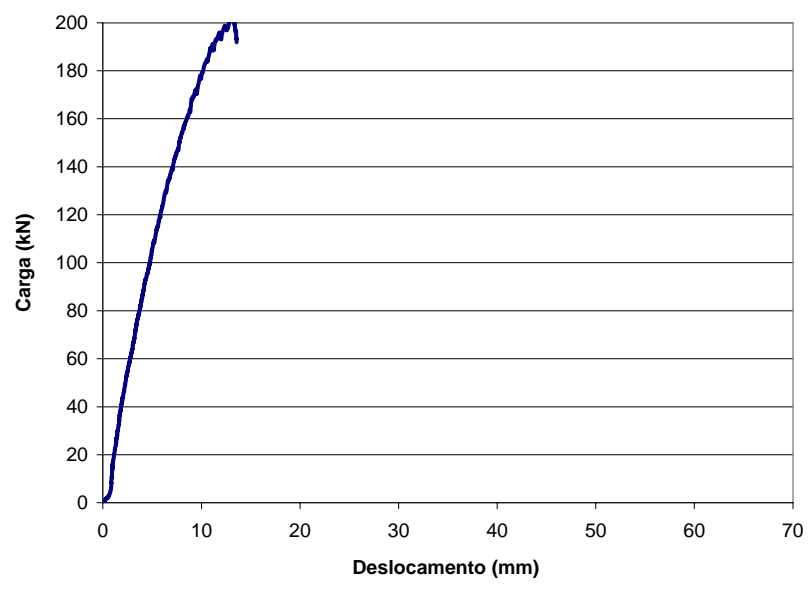

(b)

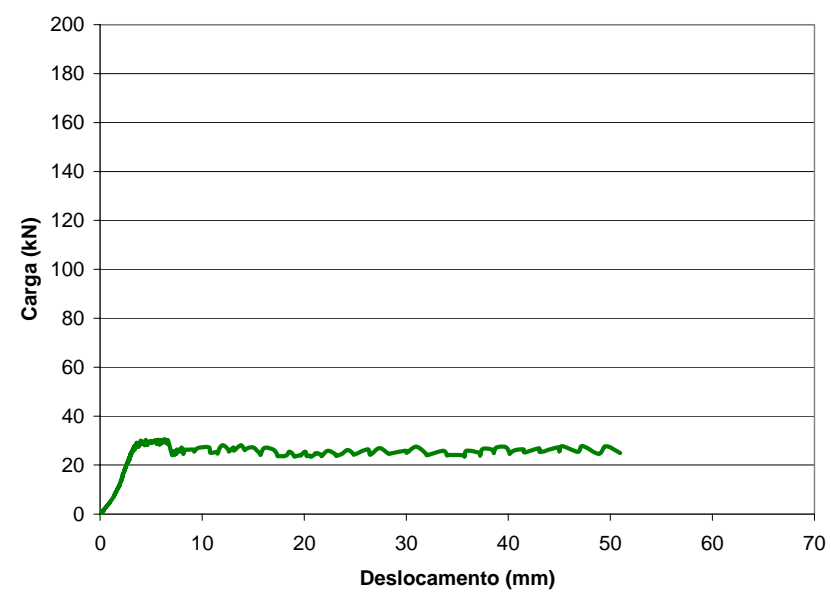

(c)

Figura 5.48. Curvas carga $x$ deslocamento dos chumbadores curto (a), longo (b) e experimental (c) construídos com a metodologia $B$.

Os chumbadores curto e experimental apresentaram ruptura frágil. A carga de pico do chumbador curto foi de 152,6 kN, para deslocamento de 20,7 mm. O chumbador experimental apresentou carga de pico de 30,6 kN, para deslocamento de 6,3 mm. Analisando o resultado do chumbador longo, observa-se que, apesar de não ter atingido a condição de ruptura, a carga máxima do ensaio $(202,5 \mathrm{kN})$ é superior àquela do mesmo chumbador executado com a metodologia A.

A Figura 5.49 apresenta as curvas carga $\mathrm{x}$ deslocamento obtidas a partir de ensaios de arrancamento realizados em chumbadores curto (18) e longo (17), construídos com a metodologia C. 


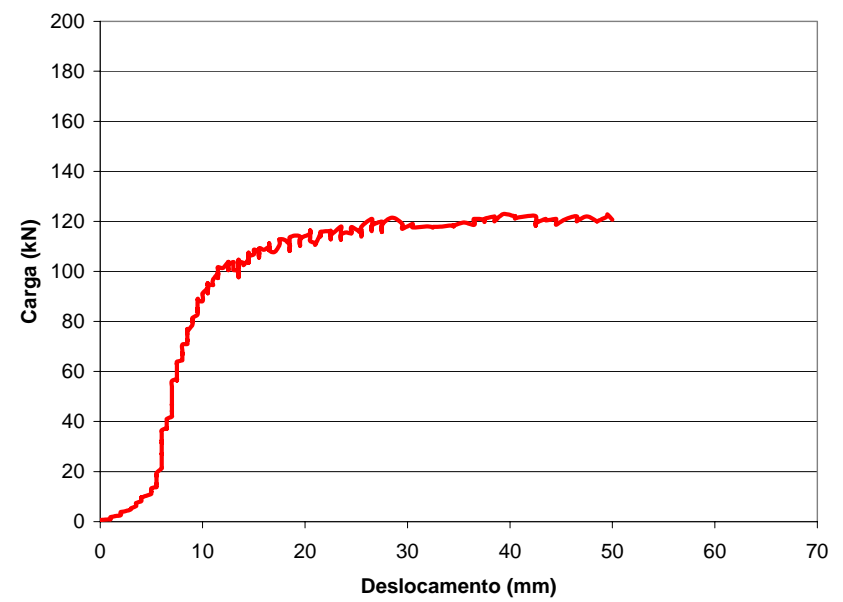

(a)

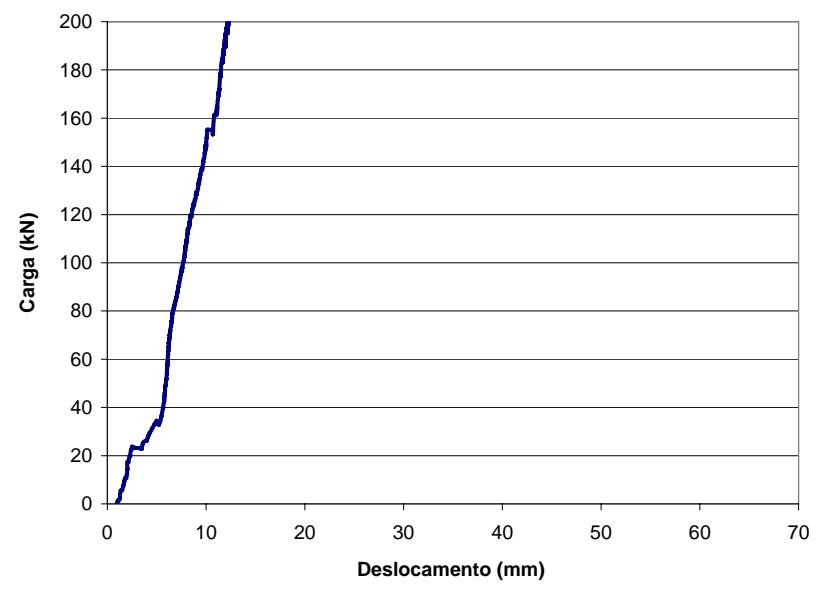

(b)

Figura 5.49. Curvas carga $x$ deslocamento dos chumbadores curto (a) e longo (b) construídos com a metodologia $\mathrm{C}$.

Os resultados apresentados na Figura 5.49 mostram que, para o chumbador curto, a ruptura foi plástica, com carga máxima de $121,5 \mathrm{kN}$ e deslocamento de $28,5 \mathrm{~mm}$. Assim como verificado na metodologia B, o ensaio de arrancamento no chumbador longo foi paralisado antes de atingir o critério de ruptura. O carregamento aplicado (202,3 kN) referese ao limite máximo imposto pelo conjunto macaco-bomba e foi o mesmo das metodologia B. Os resultados dos ensaios de arrancamento realizados nos chumbadores curtos (20) e (19), executados com a metodologia D, são apresentados na Figura 5.50.

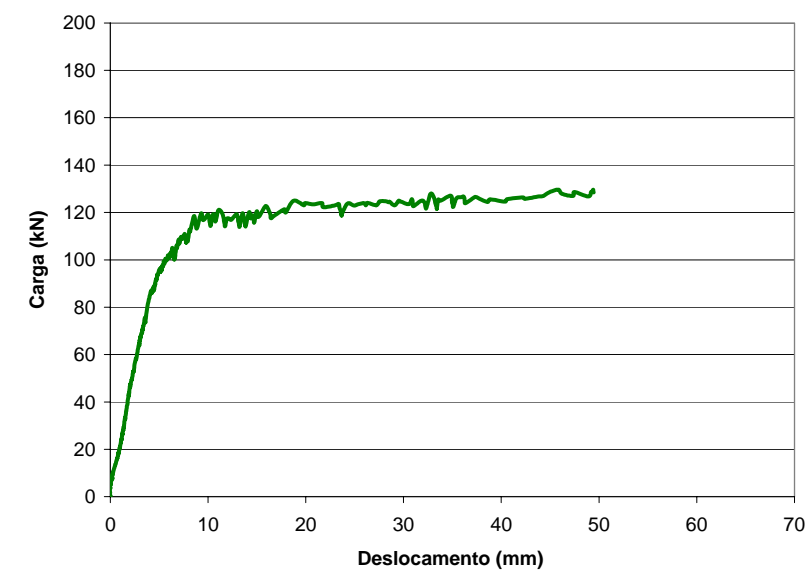

(a)

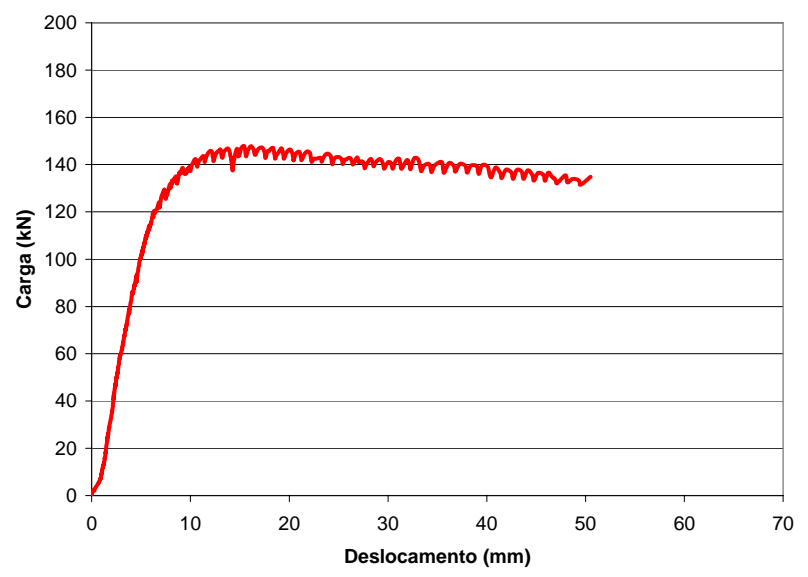

(b)

Figura 5.50. Curvas carga x deslocamento dos chumbadores curtos 19 (a) e 20 (b) construídos com a metodologia D. 
Os resultados dos ensaios de arrancamento apresentados na Figura 5.50 mostram que, para o chumbador 19, a ruptura foi plástica, enquanto para o chumbador 20, foi frágil. As cargas máximas foram de 125,0 e $147,9 \mathrm{kN}$, para deslocamentos de $18,8 \mathrm{~mm}$ e 15,4 mm, para os chumbadores 19 e 20, respectivamente. A variação entre estes carregamentos foi de $18 \%$. A proximidade dos volumes injetados de calda de cimento, 35 litros para o chumbador 19 e 30 litros para o chumbador 20, remetem a comportamento similar.

A Figura 5.51 apresenta as curvas carga $\mathrm{x}$ deslocamento dos ensaios de arrancamento realizados nos chumbadores curtos (21) e (22), executados com a metodologia E.

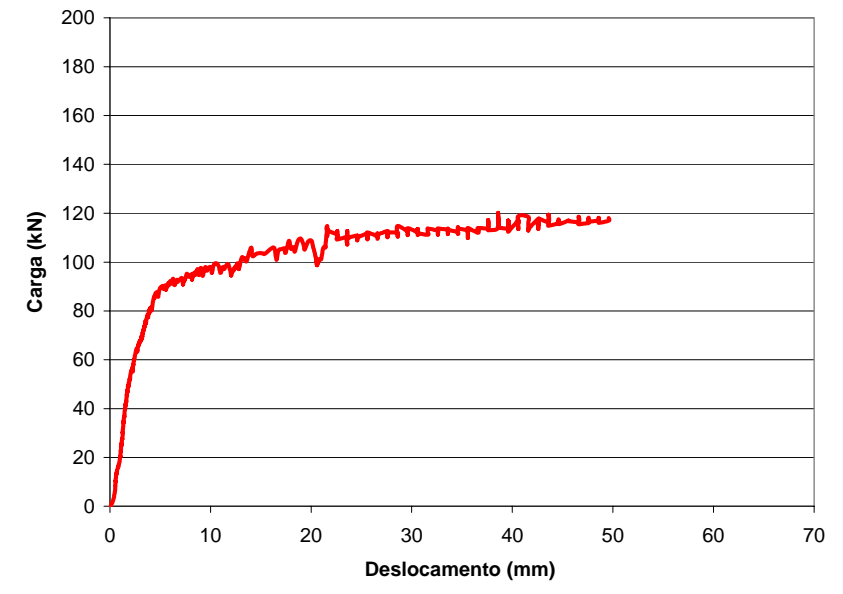

(a)

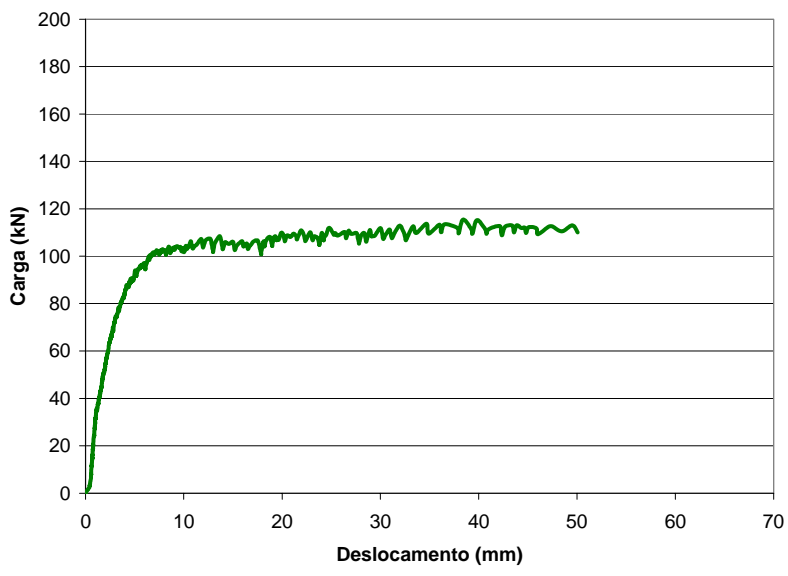

(b)

Figura 5.51. Curvas carga x deslocamento dos chumbadores curtos 21 (a) e 22 (b), construídos com a metodologia E.

Os resultados apresentados na Figura 5.51 mostram que os chumbadores curtos apresentaram ruptura plástica. As cargas máximas foram de 114,8 e 112,0 kN, para os chumbadores 21 e 22, respectivamente. Os deslocamentos referentes às cargas máximas também foram próximos, da ordem de 21,6 e 24,8 mm, respectivamente. A variação entre estes carregamentos foi mínima e igual a $2 \%$, embora o volume injetado de calda de cimento no chumbador 22 (30 litros) tenha sido três vezes superior ao volume injetado no chumbador 21 (10 litros). Tal fato pode ser justificado por eventuais ramificações existentes no maciço de solo. 
A Figura 5.52 apresenta as curvas carga $\mathrm{x}$ deslocamento dos ensaios de arrancamento realizados nos chumbadores curtos 23 e 24, executados com a metodologia F.

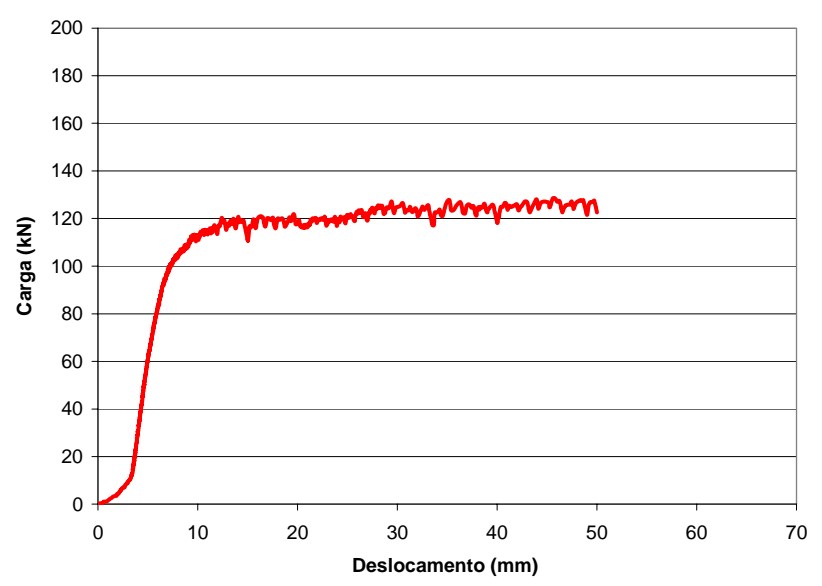

(a)

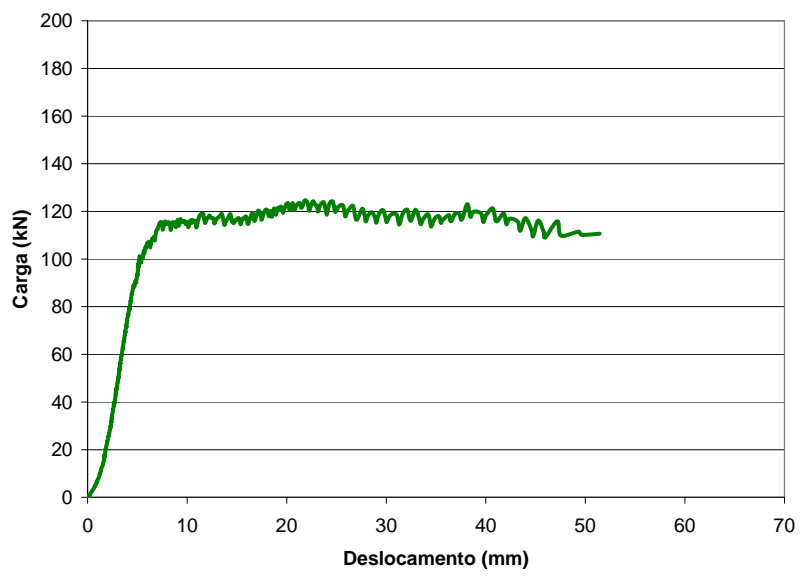

(b)

Figura 5.52. Curvas carga $x$ deslocamento dos chumbadores curtos 23 (a) e 24 (b) construídos com a metodologia F.

Os resultados apresentados na Figura 5.52 são parecidos. Os dois chumbadores curtos apresentaram ruptura plástica e as cargas máximas foram de 127,3 e 124,7 kN, para os chumbadores 23 e 24, respectivamente. Os deslocamentos referentes às cargas máximas foram de 29,4 e 21,8 mm, para os chumbadores 23 e 24, respectivamente. A variação entre estes carregamentos foi igual à observada para a metodologia $\mathrm{E}$, ou seja, igual a $2 \%$. Para estes chumbadores não foi injetado nenhum volume de calda de cimento e as pressões de injeção foram da ordem de 1,5 MPa.

A Tabela 5.9 apresenta o resumo dos resultados dos ensaios de arrancamento executados na linha 5, para os chumbadores curtos e longos. São apresentados os principais parâmetros obtidos a partir dos ensaios, que são: carga máxima de ruptura ( $\left.T_{\text {máx }}\right)$, carga máxima de ruptura por metro linear de chumbador, deslocamento referente à carga máxima, resistência ao cisalhamento de interface solo-reforço $\left(q_{s}\right)$ e modo de ruptura (quando esta ocorre), nomeando F para ruptura frágil e P para ruptura plástica. Os chumbadores que não atingiram a ruptura foram identificados por NR. 
Tabela 5.9. Resumo dos resultados dos ensaios de arrancamento da linha 5.

\begin{tabular}{|c|c|c|c|c|c|c|c|c|}
\hline \multicolumn{4}{|c|}{ Chumbador } & \multirow[b]{2}{*}{$\begin{array}{l}\mathbf{T}_{\text {máx }} \\
(\mathbf{k N})\end{array}$} & \multirow[b]{2}{*}{$\begin{array}{c}\text { Tmáx/m } \\
\text { (kN) }\end{array}$} & \multirow[b]{2}{*}{$\begin{array}{l}\text { Deslocamento } \\
(\mathrm{mm})\end{array}$} & \multirow[b]{2}{*}{$\underset{(\mathrm{kPa})}{\mathbf{q}_{\mathrm{s}}}$} & \multirow[b]{2}{*}{$\begin{array}{l}\text { Modo de } \\
\text { Ruptura }\end{array}$} \\
\hline $\mathbf{N}^{\circ}$ & Metodologia & $\begin{array}{c}\text { Comprimento } \\
\text { (m) }\end{array}$ & Tipo & & & & & \\
\hline 13 & A & 6,0 & Longo & 184,1 & 30,7 & 28,8 & 128,2 & $\mathrm{P}$ \\
\hline 14 & A & 3,0 & Curto & 110,2 & 36,7 & 14,2 & 153,4 & $P$ \\
\hline 15 & B & 6,0 & Longo & 202,5 & 33,8 & 13,2 & 141,0 & NR \\
\hline 16 & B & 3,0 & Curto & 152,6 & 50,9 & 20,7 & 212,5 & $\mathrm{~F}$ \\
\hline 17 & C & 6,0 & Longo & 202,3 & 33,7 & 12,3 & 140,8 & NR \\
\hline 18 & C & 3,0 & Curto & 121,5 & 40,5 & 28,5 & 169,2 & $\mathrm{P}$ \\
\hline 19 & $\mathrm{D}$ & 3,0 & Curto & 125,0 & 41,7 & 18,8 & 174,1 & $\mathrm{~F}$ \\
\hline 20 & $\mathrm{D}$ & 3,0 & Curto & 147,9 & 49,3 & 15,4 & 205,9 & $\mathrm{~F}$ \\
\hline 21 & E & 3,0 & Curto & 114,8 & 38,3 & 21,6 & 159,8 & $\mathrm{P}$ \\
\hline 22 & E & 3,0 & Curto & 112,0 & 37,3 & 24,8 & 156,0 & $\mathrm{P}$ \\
\hline 23 & $\mathrm{~F}$ & 3,0 & Curto & 127,3 & 42,4 & 29,4 & 177,2 & $\mathrm{P}$ \\
\hline 24 & F & 3,0 & Curto & 124,7 & 41,6 & 21,8 & 173,6 & $P$ \\
\hline E1 & A & 1,0 & Experimental & 39,7 & 39,7 & 14,4 & 166,0 & $\mathrm{~F}$ \\
\hline $\mathrm{E} 2$ & $\mathrm{~B}$ & 1,0 & Experimental & 30,6 & 30,6 & 6,3 & 128,0 & $\mathrm{~F}$ \\
\hline
\end{tabular}

Na seqüência, são apresentadas as análises realizadas para a melhor interpretação dos resultados obtidos. Foi avaliada a influência da metodologia executiva, do volume injetado e do comprimento dos chumbadores (trecho injetado) no resultado do ensaio de arrancamento. Adicionalmente, são apresentados os resultados da instrumentação das barras de aço com strain gages.

\subsubsection{Influência da Metodologia Executiva}

Para permitir a análise qualitativa e comparativa das diferentes metodologias executivas, são apresentadas as curvas carga x deslocamento, de forma agrupada, para os chumbadores curtos (Figura 5.53) e longos (Figura 5.54). 


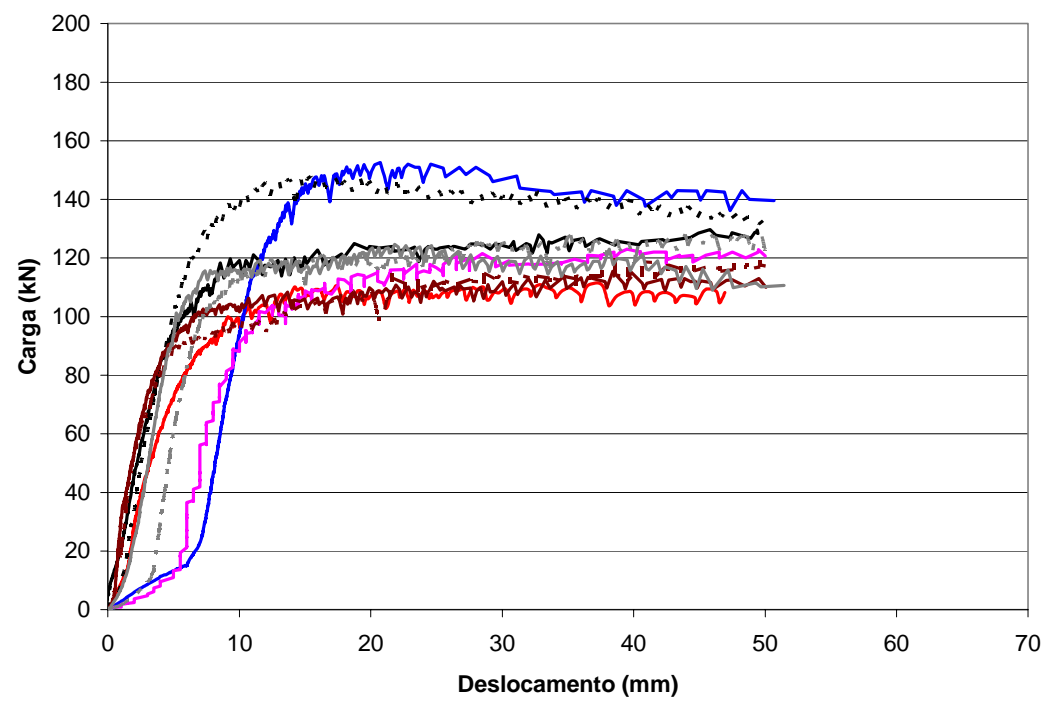

$-14-\mathrm{A} \longrightarrow 16-\mathrm{B} \longrightarrow 18-\mathrm{C} \longrightarrow$ 19-D - - 20-D - - 21-E $-22-\mathrm{E}-\mathrm{-}$ 23-F $-24-\mathrm{F}$

Figura 5.53. Curvas carga $\mathrm{x}$ deslocamento dos chumbadores curtos executados com as diferentes metodologias executivas.

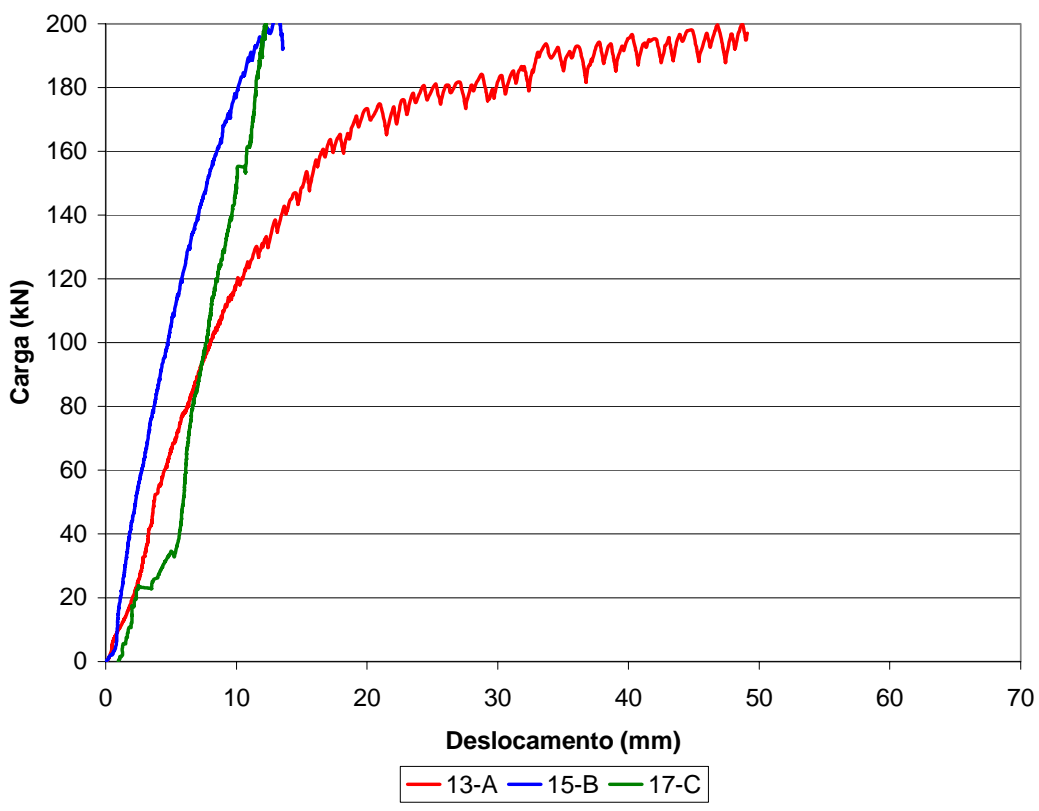

Figura 5.54. Curvas carga $\mathrm{x}$ deslocamento dos chumbadores longos executados com as diferentes metodologias executivas.

As Figuras 5.53 e 5.54 permitem avaliar, comparativamente, os resultados obtidos para os chumbadores curtos e longos, respectivamente. Para a linha 5 de Osasco-SP, 
diferentemente do observado nas análises anteriores, as curvas carga $\mathrm{x}$ deslocamento apresentaram-se mais próximas, ou seja, a amplitude entre as cargas máximas foi menos significativa.

As Figuras 5.55 e 5.56 apresentam, para os chumbadores curtos e longos, os gráficos comparativos do parâmetro $q_{s}$ em função das diferentes metodologias executivas. Os valores percentuais apresentados foram referenciados em relação aos valores de $q_{s}$ da metodologia A (100\%).

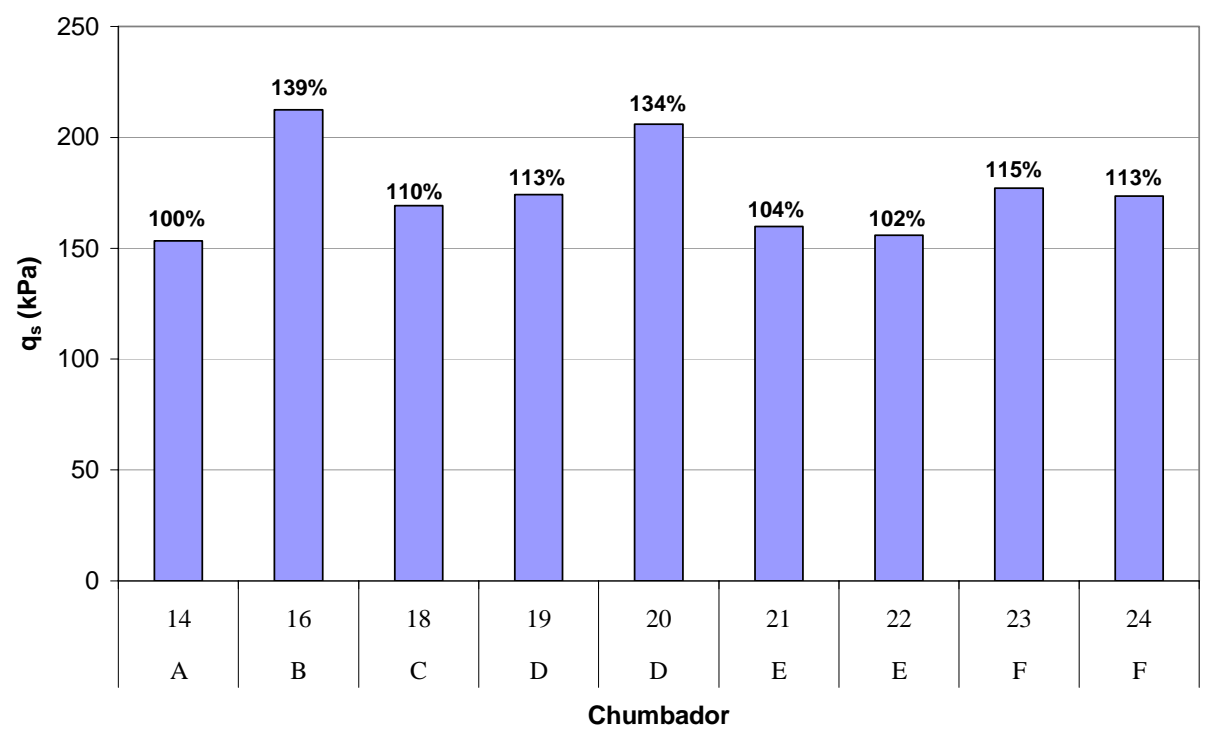

Figura 5.55. Análise comparativa entre os valores de $q_{s}$ obtidas para os chumbadores curtos, executados com as diferentes metodologias executivas. 


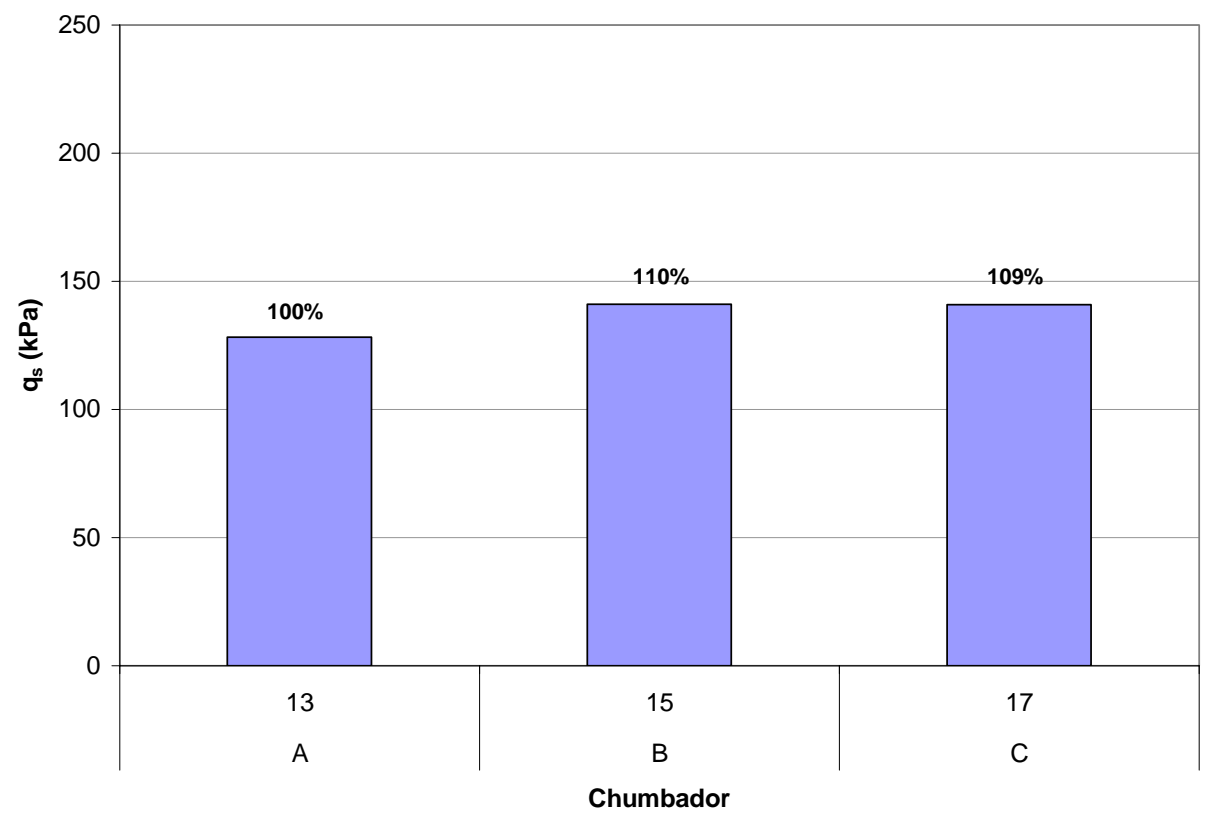

Figura 5.56. Análise comparativa entre os valores de $q_{s}$ obtidas para os chumbadores longos, executados com as diferentes metodologias executivas.

Ao analisar a Figura 5.55, verifica-se que a faixa de variação do parâmetro $q_{s}$, para as diferentes metodologias, foi menor quando comparada com as outras análises realizadas, ou seja, a influência do número de injeções foi menos significativa no desempenho dos chumbadores.Em termos absolutos, notou-se que os valores de $q_{s}$ foram superiores aos obtidos para as outras linhas de chumbadores testes, analisadas anteriormente. Esta constatação provavelmente pode ser explicada pelas condições do maciço de solo encontradas no local, o que será mais bem analisado no item 5.4. Conclui-se ainda que o melhor desempenho foi observado para os chumbadores executados com as metodologias B (chumbador 16) e D (chumbador 20), para os quais os incrementos foram de $39 \%$ e $34 \%$, respectivamente.

Os valores de $q_{s}$ apresentados para os chumbadores longos (Figura 5.56) não permitiram uma análise mais elaborada, já que os chumbadores 15 e 17 não atingiram a condição de ruptura. 


\subsubsection{Influência do Volume de Injeção}

Como os valores de $q_{s}$ para os chumbadores curtos apresentaram-se próximos, tentou-se explicar este comportamento relacionando, assim como nas demais linhas, com os volumes de injeção de calda de cimento obtidos para cada uma das metodologias executivas. A Figura 5.57 apresenta, em um mesmo gráfico, os valores de $q_{s}$ e dos volumes de injeção dos chumbadores curtos. Para facilitar a visualização, os volumes injetados também são apresentados ao longo do gráfico.

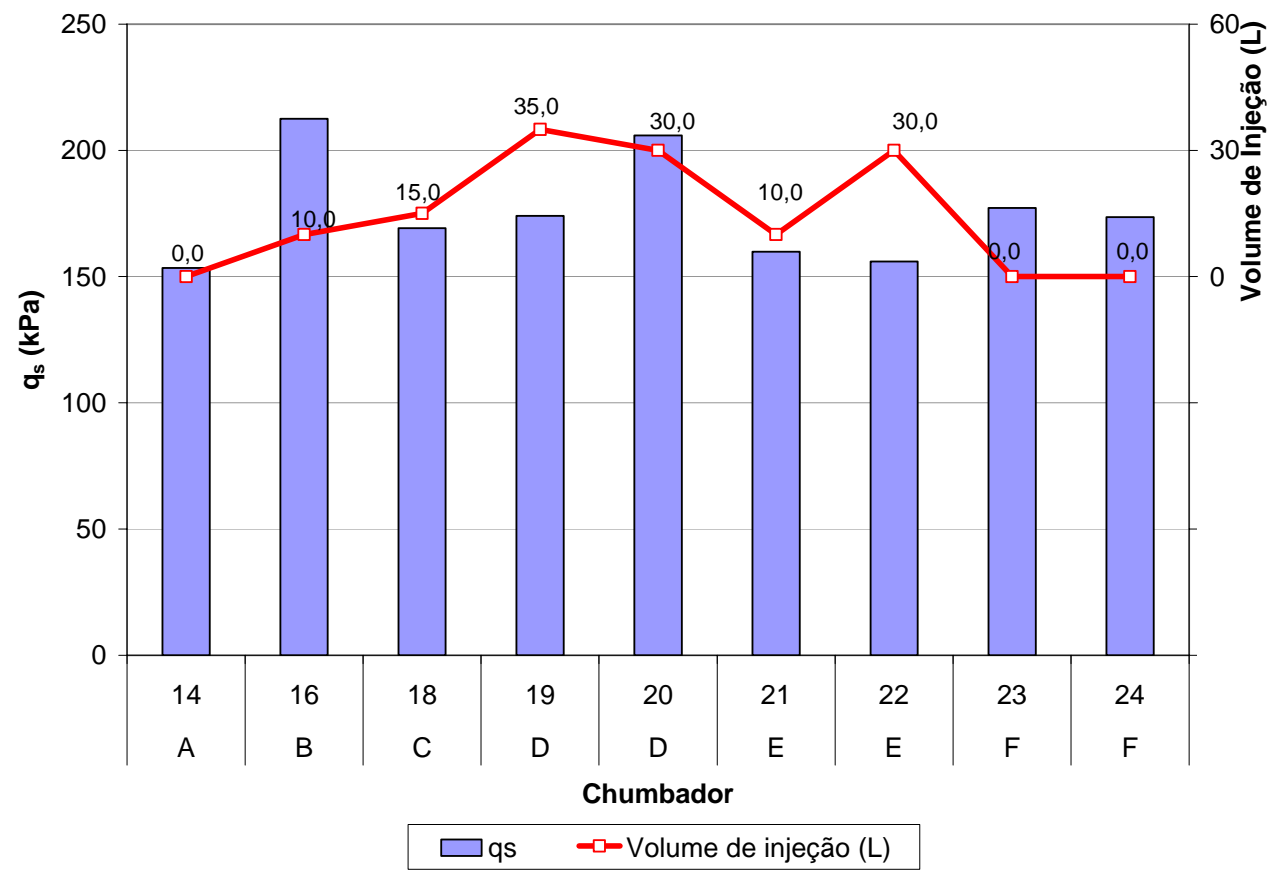

Figura 5.57. Variações de $q_{s}$ e dos volumes de injeção dos chumbadores curtos executados com as diferentes metodologias executivas.

A partir dos valores de $q_{s}$ apresentados concomitantemente com os volumes de injeção, nota-se que os resultados desta linha saíram do padrão observado para as demais linhas de chumbadores analisadas. Observa-se que, de maneira geral, os volumes injetados para os chumbadores executados com as metodologias D e E foram menores que nas linhas anteriores, enquanto para os dois chumbadores executados com a metodologia $\mathrm{F}$, foram 
inexistentes. Analisando desta forma, é justificável a proximidade observada dos valores de $q_{s}$

Estima-se que um solo saprolitico, residual de gnaisse, apresente-se mais compacto e menos poroso quando comparado ao solo residual jovem existente na linha 3 . Este fato justifica a pouca possibilidade de surgência de ramificações da calda de cimento, apresentando um comportamento similar ao solo pregado construído com solo compactado em laboratório.

Mesmo diante das considerações apresentadas, assim como nas demais linhas analisadas, tentou-se estabelecer um ajuste entre os dois parâmetros ( $q_{s}$ e Fator "V”). Os resultados estão apresentados na Figura 5.58.

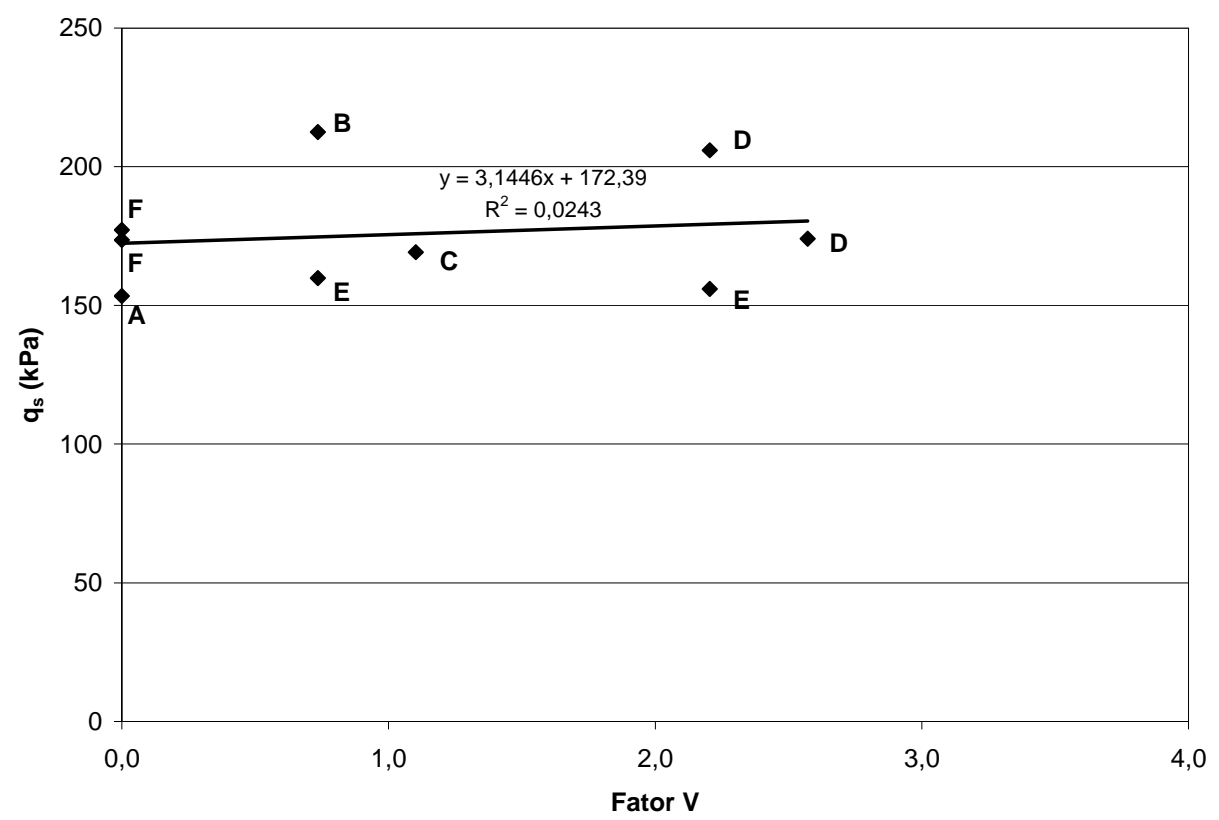

Figura 5.58. Valores de $q_{s} \mathbf{x}$ Fator $\mathbf{V}$ para os chumbadores curtos executados com as diferentes metodologias executivas.

A Figura 5.58, conforme esperado, mostra um comportamento diferenciado em relação às demais linhas analisadas. Para esta situação, o valor de $q_{s}$ mostrou ser independente do volume injetado de calda de cimento, apresentando coeficiente angular, para a reta de ajuste, próximo de zero. Acredita-se que, para este tipo de solo, não ocorra 
surgência de ramificações e, assim, o preenchimento da cavidade escavada seja atingido mais facilmente e com menores volumes injetados.

\subsubsection{Influência do Comprimento dos Chumbadores}

A influência do comprimento dos chumbadores na resistência ao cisalhamento de interface solo-reforço também foi avaliada para esta obra e profundidade (linha 5). Este efeito foi avaliado para as metodologias A e B, porém, para os chumbadores longos, somente a metodologia A atingiu a condição de ruptura. Para estas metodologias, os chumbadores foram executados com 1,0, 3,0 e 6,0 m de comprimento injetado. A Figura 5.59, apresenta as curvas carga $\mathrm{x}$ deslocamento para as duas metodologias analisadas.

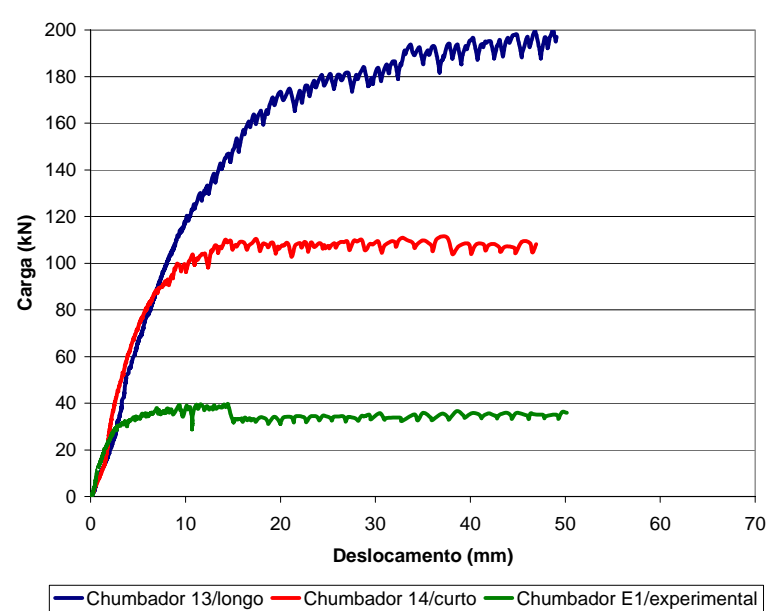

(a)

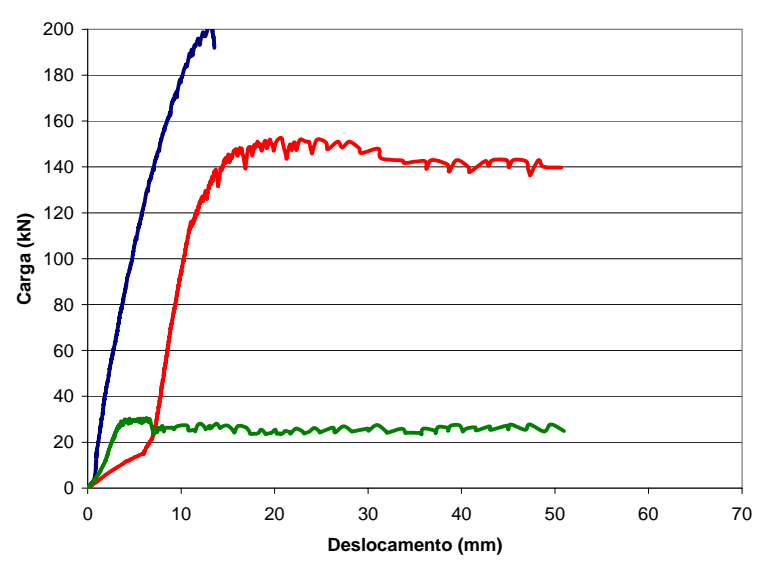

- Chumbador 15/longo — Chumbador 16/curto —Chumbador E2/experimental

(b)

Figura 5.59. Curvas carga $x$ deslocamento para chumbadores curtos, longos experimentais executados com as metodologias A (a) e B (b).

Os resultados apresentados na Figuras 5.59 mostram que há uma relação entre as cargas máximas obtidas nos ensaios de arrancamento. A Figura 5.60 apresenta os diferentes valores de $q_{s}$ para as metodologias A e B, quantificando esta relação. 


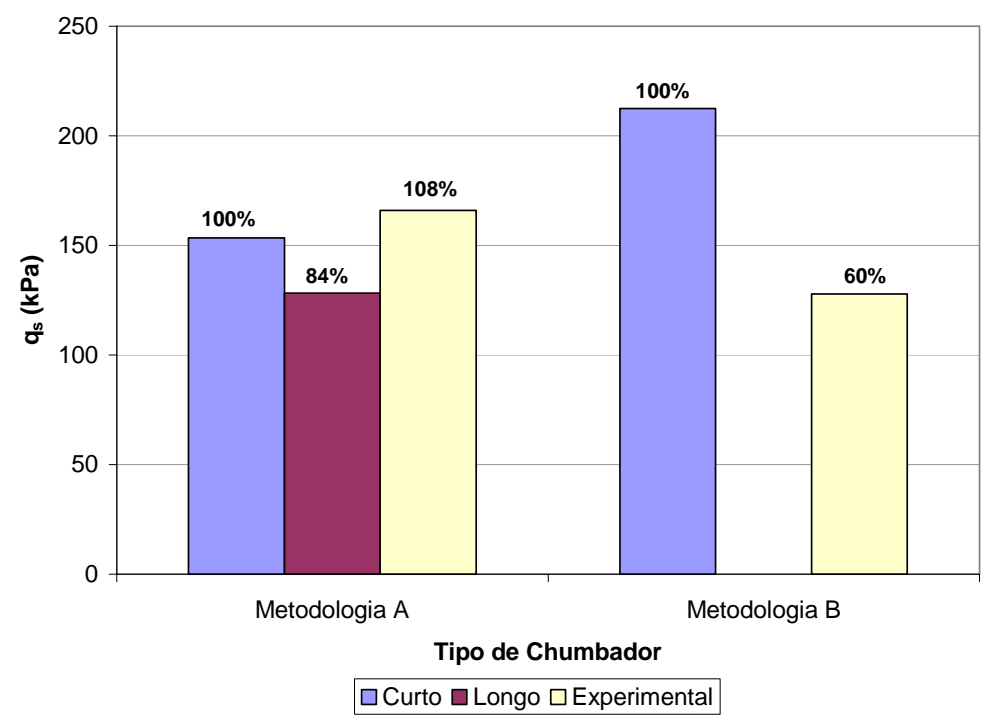

Figura 5.60. Variação de $q_{s}$ para os diferentes tipos de chumbadores (curtos, longos e experimentais), considerando-se as metodologias A e B.

Da análise comparativa dos valores de $q_{s}$ apresentados na Figura 5.60, é possível observar que os diferentes tipos de chumbadores executados com a metodologia A apresentaram resultados próximos, com variação máxima de 16\%. Na análise dos chumbadores executados com a metodologia B, não foi considerado o chumbador longo (ensaio não finalizado). Da análise dos chumbadores curto e especial, verificou-se uma grande variação dos resultados de $q_{s}$, da ordem de $40 \%$. Para a metodologia A, os resultados do parâmetro $q_{s}$ mostraram ser independentes dos comprimentos dos chumbadores. Para a metodologia B, este comportamento não foi observado.

\subsubsection{Resultados da Instrumentação}

A Figura 5.61 apresenta, para os chumbadores curtos e longos, curvas típicas com quatro níveis de carregamento em relação à carga de ruptura (25, 50, 75 e 100\%). 


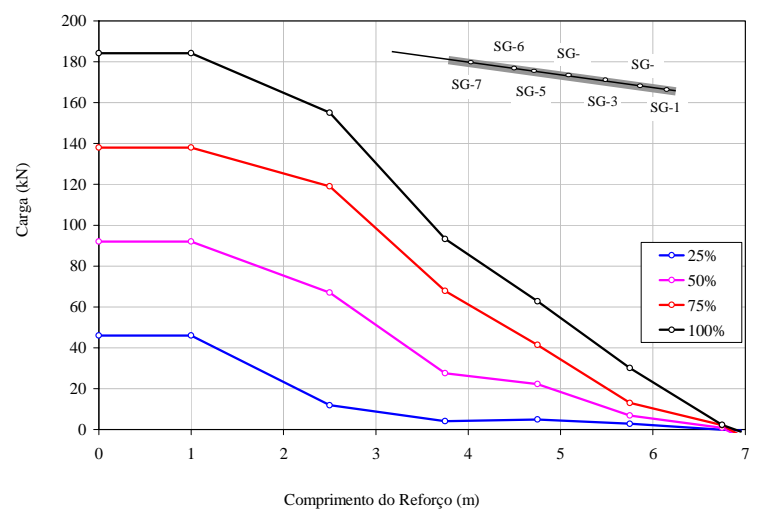

(a)

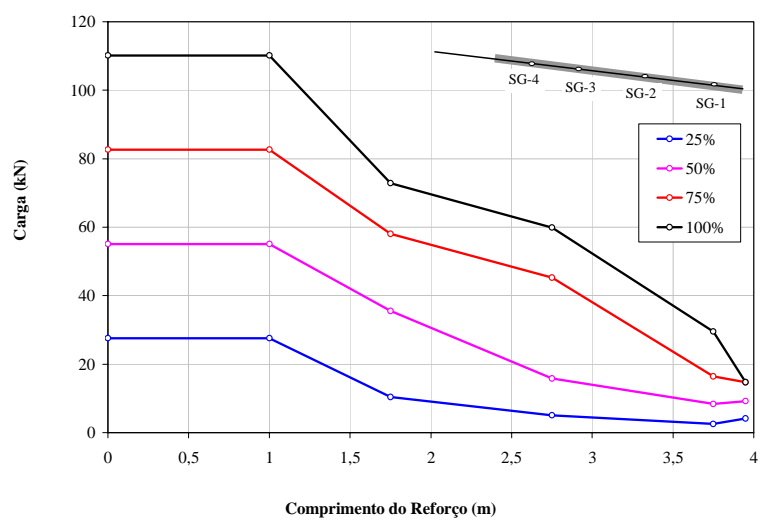

(b)

Figura 5.61. Distribuição de carga ao longo do comprimento para chumbadores longo (a) e curto (b), em percentagem em relação à carga de ruptura.

A distribuição das cargas ao longo dos chumbadores curtos e longos foi parecida, e o mesmo é válido no tocante à mobilização das cargas, ou seja, o chumbador curto foi todo mobilizado, enquanto para os chumbadores longos, as cargas de arrancamento no final do trecho injetado foram praticamente inexistentes.

\subsection{ANÁUSE GERAL DOS RESULTADOSOBTIDOS}

As análises apresentadas foram realizadas para as diferentes profundidades de ensaios (linhas) das obras estudadas. Entretanto, para poder analisar os resultados de uma maneira mais global, todos os parâmetros $q_{s}$ determinados para os chumbadores curtos são apresentados nas Tabelas 5.10. Adicionalmente, são apresentados os aumentos relativos (AR) em porcentagem, tomando-se como referência os respectivos chumbadores executados com a metodologia A. 
Tabela 5.10. Resumo dos resultados dos chumbadores curtos executados nas diferentes profundidades e obras e com as diferentes metodologias executivas.

\begin{tabular}{|c|c|c|c|c|}
\hline \multirow{3}{*}{ Metodologia } & \multicolumn{4}{|c|}{$\mathrm{q}_{\mathrm{s}}-\mathrm{kPa}(\mathrm{AR}-\%)$} \\
\hline & \multicolumn{2}{|c|}{ Santo André-SP (Obra 1) } & \multicolumn{2}{|c|}{ Osasco-SP (Obra 2) } \\
\hline & Linha 2 & Linha 5 & Linha 3 & Linha 5 \\
\hline A & 47,8 & 63,0 & 77,3 & 153,4 \\
\hline $\mathrm{A}^{*}$ & - & $99,1(57,0)$ & - & - \\
\hline B & $50,4(5,4)$ & $114,6(82,0)$ & $95,8(24,0)$ & $212,5(39,0)$ \\
\hline $\mathrm{C}$ & $119,5(150,3)$ & $149,4(119,0) / 105,0(67,0)$ & $141,1(82,0)$ & $162,9(10,0)$ \\
\hline $\mathrm{D}$ & $186,3(190,2)$ & $137,7(119,0) / 202,6(222,0)$ & $174,4(126,0) / 124,6(61,0)$ & $174,1(13,0) / 205,9(34,0)$ \\
\hline E & $127,4(166,8)$ & $122,2(94,0) / 133,0(111,0)$ & $123,7(60,0)$ & $159,8(4,0) / 156,0(2,0)$ \\
\hline $\mathrm{F}$ & $110,6(131,6)$ & $214,4(240,0) / 222,4(253,0)$ & $107,3(39,0) / 115,1(49,0)$ & $177,2(15,0) / 173,6(13,0)$ \\
\hline
\end{tabular}

Ao analisar os resultados apresentados na Tabela 5.10, é possível tecer os seguintes comentários:

Para as metodologias em que foi possível a construção de dois chumbadores, as análises apresentadas na seqüência foram realizadas em relação ao seu valor médio;

Verifica-se que, para a metodologia A, os valores de $q_{s}$ foram crescentes da linha 2 da obra 1 para a linha 5 da obra 2;

Para a metodologia B, também foi verificada esta mesma tendência, entretanto, para o chumbador da linha 5 da obra 1, o resultado ficou acima do esperado. Como para esta metodologia executiva foi realizada somente uma fase de injeção, os volumes injetados foram preponderantes para a melhor integridade dos chumbadores e incrementos no parâmetro $q_{s}$;

Para as metodologias C, D, E e F, também se visualizou uma tendência de incremento nos valores de $\mathrm{q}_{s}$ da linha 2 da obra 1 para a linha 5 da obra 2, entretanto, o maior número de injeções e volume injetado promoveram uma maior padronização nos resultados;

Para as metodologias C, D, E e F, os valores dos aumentos relativos (AR) do parâmetro $q_{s}$ apresentaram-se de forma decrescente da linha 2 da obra 1 para a linha 5 da obra 2, com exceção dos chumbadores da linha 5 da obra 1, executados com as metodologias B e F, para os quais os aumentos relativos ficaram acima do esperado. 
Na tentativa de avaliar as considerações apresentadas, a Tabela 5.11 apresenta o resumo das propriedades dos solos onde foram construídos os chumbadores testes (granulometria, classificação unificada, índices físicos e parâmetros efetivos de resistência).

Tabela 5.11. Resumo das propriedades dos solos estudados.

\begin{tabular}{ccccc}
\hline \multirow{2}{*}{$\begin{array}{c}\text { Propriedades dos } \\
\text { Solos }\end{array}$} & \multicolumn{2}{c}{ Santo André-SP } & \multicolumn{2}{c}{ Osasco-SP } \\
\cline { 2 - 5 } Linha 2 & Linha 5 & Linha 3 & Linha 5 \\
\hline Argila (\%) & 46,8 & 38,7 & 44,8 & 42,5 \\
Silte (\%) & 18,2 & 16,3 & 15,2 & 12,5 \\
Areia (\%) & 35,0 & 45,0 & 40,0 & 45,0 \\
Classificação & $\mathrm{CL}$ & $\mathrm{CH}$ & $\mathrm{CH}$ & $\mathrm{CH}$ \\
Unificada & & & & \\
C' $^{\prime}(\mathrm{kPa})$ & 21,7 & 70,6 & 18,7 & 63,3 \\
$\phi^{\prime}\left({ }^{0}\right)$ & 31,1 & 22,9 & 31,5 & 20,5 \\
$\gamma_{\mathrm{s}}\left(\mathrm{kN} / \mathrm{m}^{3}\right)$ & 27,98 & 28,17 & 26,49 & 26,32 \\
$\gamma_{\left(\mathrm{kN} / \mathrm{m}^{3}\right)}$ & 14,4 & 18,1 & 17,1 & 19,5 \\
$\mathrm{~W}(\%)$ & 23,1 & 30,3 & 31,0 & 20,3 \\
$\gamma_{\mathrm{d}}\left(\mathrm{kN} / \mathrm{m}^{3}\right)$ & 11,7 & 13,9 & 13,1 & 16,2 \\
$\mathrm{e}$ & 1,39 & 1,06 & 1,02 & 0,62 \\
$\mathrm{n}(\%)$ & 58,0 & 51,5 & 50,5 & 38,3 \\
$\mathrm{Sr}(\%)$ & 46,8 & 79,8 & 78,9 & 86,1 \\
\hline
\end{tabular}

A Tabela 5.11 ajuda o entendimento dos resultados obtidos e dos comportamentos observados. O acréscimo do parâmetro $q_{s}$ e a conseqüente diminuição do aumento relativo (AR) das linhas 2 da obra 1 para a linha 5 da obra 2 devem-se a melhor integridade do chumbador ao longo do trecho injetado. As metodologias executivas e, consequentemente, os volumes injetados são fundamentais na melhoria do parâmetro $q_{s}$. Entretanto, eles estão diretamente relacionados com os tipos de solos estudados. Embora as granulometrias dos solos e as classificações unificadas sejam parecidas, as diferentes estruturas dos solos encontrados nas linhas das obras estudadas influenciaram significativamente os resultados obtidos.

Os valores crescentes de $q_{s}$, da linha 2 da obra 1 para a linha 5 da obra 2, podem estar relacionados com o índice de vazios e com a porosidade dos solos. A Tabela 5.11 mostra que estes índices físicos apresentaram-se de forma decrescente da linha 2 da obra 1 
para a linha 5 da obra. Como para a metodologia A não foi realizada nenhuma injeção, os maiores vazios podem ter provocado maior penetração da calda de cimento, não garantindo a integridade do chumbador. O mesmo raciocínio se aplica para a linha 5 da obra 2, onde as diferentes metodologias executivas não apresentaram aumentos significativos (AR) se comparados com as demais linhas.

Para as demais metodologias, observou-se que as injeções foram promovendo o preenchimento destes vazios, melhorando e padronizando o comportamento dos chumbadores. Como os índices físicos mencionados (índice de vazios e porosidade) apresentam-se de forma decrescentes da linha 2 da obra 1 para a linha 5 da obra 2, os volumes injetados também se apresentaram de forma decrescente, haja visto os baixos volumes e as elevadas pressões de injeção verificadas principalmente na linha 5 da obra 2, em que se observou o menor índice de vazios. Esta constatação também permite justificar o decréscimo dos aumentos relativos (AR) da linha 2 da obra 1 para a linha 5 da obra 2 . Como a exudação da calda de cimento é menor, menores volumes injetados são necessários, a integridade dos chumbadores é alcançada mais facilmente e, consequentemente, menores serão os aumentos relativos (AR) para as diferentes metodologias executivas.

Para os chumbadores longos, foram apresentados somente os resultados em que foi possível atingir a condição de ruptura (Tabela 5.12).

Tabela 5.12. Resumo dos resultados dos chumbadores longos executados nas diferentes profundidades e obras e com as diferentes metodologias executivas.

\begin{tabular}{ccccc}
\hline \multirow{2}{*}{ Metodologia } & \multicolumn{4}{c}{$\mathbf{q}_{\mathbf{s}}-\mathbf{k P a}$ (AR - \%) } \\
\cline { 2 - 5 } & \multicolumn{2}{c}{ Santo André-SP (Obra 1) } & \multicolumn{2}{c}{ Osasco-SP (Obra 2) } \\
\cline { 2 - 5 } & Linha 2 & Linha 5 & 69,6 & Linha 5 \\
\hline \multirow{2}{*}{ A } & 87,1 & 57,4 & - & 128,2 \\
A* & - & $63,7(10,9)$ & $109,9(57,9)$ & - \\
B & $137,3(57,3)$ & $119,6(108,4)$ & $125,4(80,2)$ & - \\
C & - & - & - \\
\hline
\end{tabular}

A partir do pequeno número de ensaios realizados e finalizados, fica difícil realizar análises mais específicas. Entretanto, é possível observar que, para a metodologia A, a linha 5 da obra 2 apresentou o melhor desempenho, e que a proximidade dos parâmetros $q_{s}$ da 
linha 5 da obra 1 com a linha 3 da obra 2, assim como para os chumbadores curtos, pode estar relacionada com o similar índice de vazios.

\subsection{COMPARAÇÃO COM MÉTODOS TEÓRICOS E EMPÍRICOS DE PREVISÃO}

Muitos autores desenvolveram métodos de previsão de resistência ao cisalhamento de interface $\left(q_{s}\right)$ a partir de modelos teóricos e empíricos. Todos estes métodos de previsão foram realizados considerando-se chumbadores executados com calda de cimento sem injeção (preenchimento por gravidade) e encontram-se devidamente comentados no Capítulo Revisão Bibliográfica. Entre os métodos teóricos, foram analisados os de Heymann et al. (1992), Jewell (1990) e Cartier e Gigan (1983). Entre os métodos empíricos, foram analisados os de Bustamante e Doix (1985), Heymann et al. (1992), Ortigão e Palmeira (1997) e Proto Silva (2005). Para os métodos de Heymann et al. (1992) e Proto Silva (2005) foram utilizadas duas correlações disponíveis na literatura e que foram denominadas na Revisão Bibliográfica como 1 e 2.

Os métodos teóricos e empíricos para a previsão do parâmetro $q_{s}$ foram calculados a partir dos resultados das investigações geotécnicas realizadas (sondagens à percussão e ensaios pressiométricos) e das análises dos ensaios de caracterização geotécnica realizadas em laboratório, a partir da coleta das amostras indeformadas. O método empírico de Proto Silva (2005) foi calculado a partir dos resultados dos ensaios de cisalhamento de interface realizados por Lima (2009).

Para permitir a comparação dos métodos teóricos e empíricos de previsão com os ensaios de arrancamento realizados in situ, são apresentados os gráficos de $q_{s} \mathrm{x}$ método teórico/empírico, para as diferentes linhas e obras analisadas. Para tornar a comparação mais realística, somente os resultados dos ensaios de arrancamento em chumbadores executados com a metodologia A são apresentados. Como, para uma mesma linha, ocorreu alguma variação entre os resultados dos chumbadores curtos e longos, ambos são apresentados, e a faixa de valores entre eles é comparada com os métodos teóricos. O valor médio entre eles foi adotado como referência (100\%). 
A Figura 5.62 apresenta a comparação entre os ensaios de arrancamento (metodologia A) e os métodos teóricos e empíricos de previsão para a linha 2 da obra de Santo André-SP (obra 1).

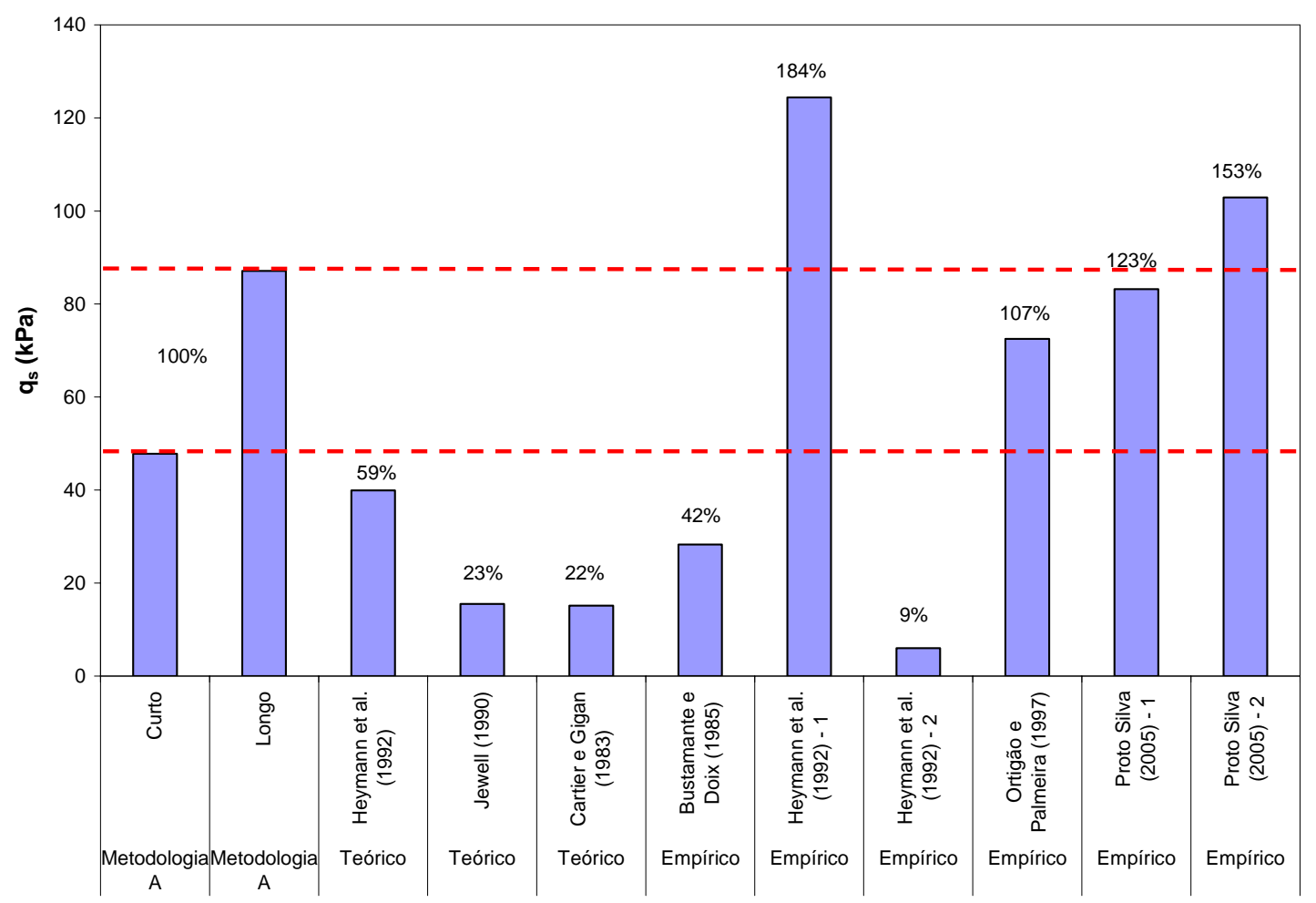

Figura 5.62. Comparativo entre os ensaios de arrancamento (metodologia A) e os métodos de previsão teóricos e empíricos para a linha 2 da obra de Santo André-SP.

Ao analisar os resultados apresentados na Figura 5.62, observa-se que os métodos empíricos de Ortigão e Palmeira (1997) e Proto Silva (2005)-1, que consideram a resistência ao cisalhamento de interface solo-calda de cimento, foram os que ficaram dentro da faixa de valores dos ensaios de arrancamento. Em termos percentuais, os parâmetros $q_{s}$ estimados a partir destes métodos foram 7 e 23\%, respectivamente, superiores aos obtidos in situ a partir dos ensaios de arrancamento. Os métodos empíricos de Heymann et al. (1992) apresentaram uma discrepância entre as previsões. Tal fato pode ser justificado pelas correlações terem sido elaboradas a partir de resultados de ensaios de arrancamento e de parâmetros geotécnicas de solos da África do Sul. Os métodos teóricos se mostraram ser muito conservadores e subestimaram o parâmetro $q_{s}$. Dentre os métodos teóricos, o de Heymann et al.(1992) foi o que forneceu a melhor previsão. 
A Figura 5.63 apresenta a comparação entre os ensaios de arrancamento (metodologia A) e os métodos teóricos e empíricos de previsão para a linha 5 da obra de Santo André-SP (obra 1).

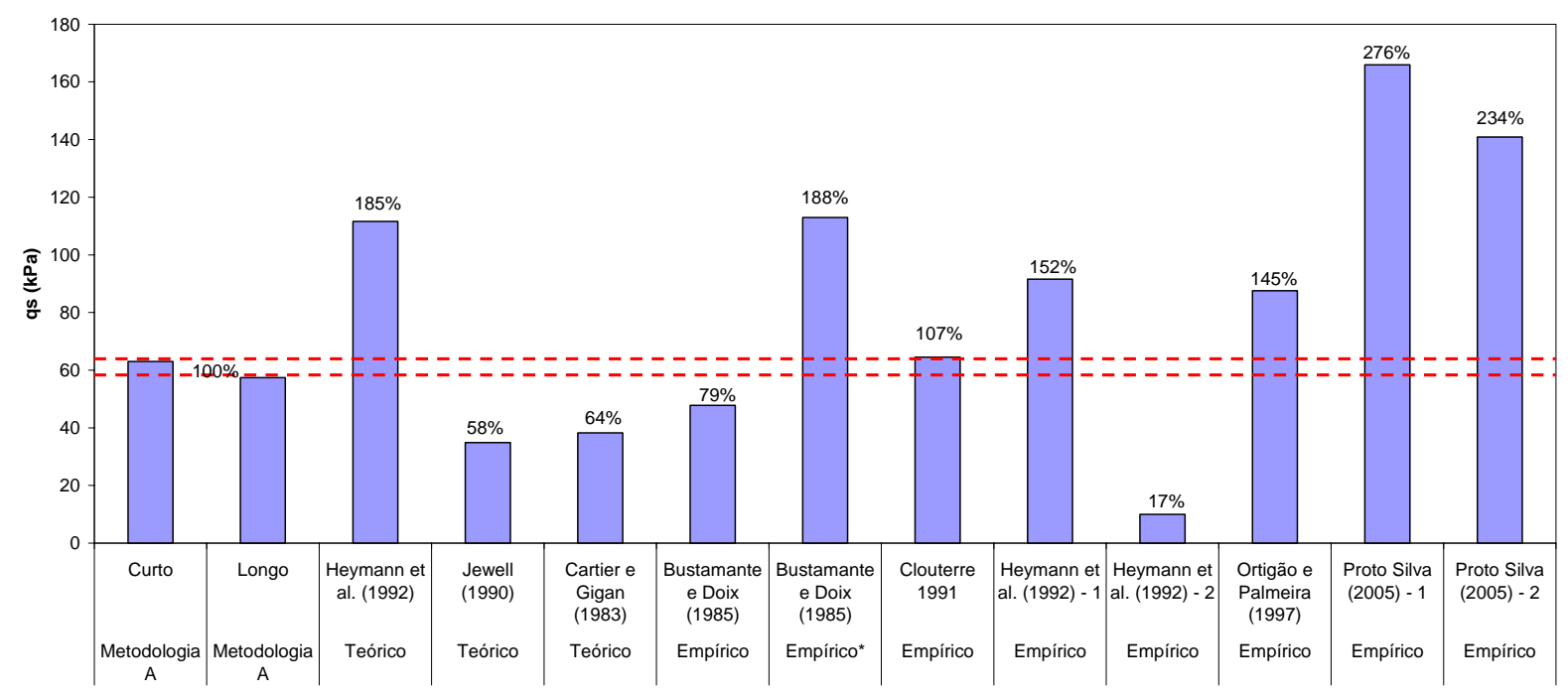

Figura 5.63. Comparativo entre os ensaios de arrancamento (metodologia A) e os métodos de previsão teóricos e empíricos para a linha 5 da obra de Santo André-SP.

Os resultados apresentados na Figura 5.63 mostram que a melhor previsão foi realizada pelo método empírico de Clouterre (1991). Esta previsão foi realizada a partir da pressão limite obtida a partir do ensaio pressiométrico. Embora só tenha sido aproveitado um ensaio de arrancamento, este mostrou uma excelente concordância com o banco de dados Francês, composto por 450 ensaios de arrancamento. Em geral, os demais métodos empíricos superestimaram o parâmetro $q_{s}$, com exceção do método de Heymann et al. (1992) - 2, que mais uma vez se mostrou inconsistente. O método empírico de Bustamante e Doix (1985), que também está relacionado com resultados de ensaio pressiométricos, não mostrou, para a situação analisada, ter a mesma eficiência do Clouterre (1991). Os resultados dos métodos teóricos para esta linha também mostraram ser conservadores, com exceção do método de Heymann et al. (1992), que superestimou a previsão do parâmetro $q_{s}$ em $85 \%$. 
A Figura 5.64 apresenta a comparação entre os ensaios de arrancamento (metodologia A) e os métodos teóricos e empíricos de previsão para a linha 3 da obra de Osasco-SP (obra 2).

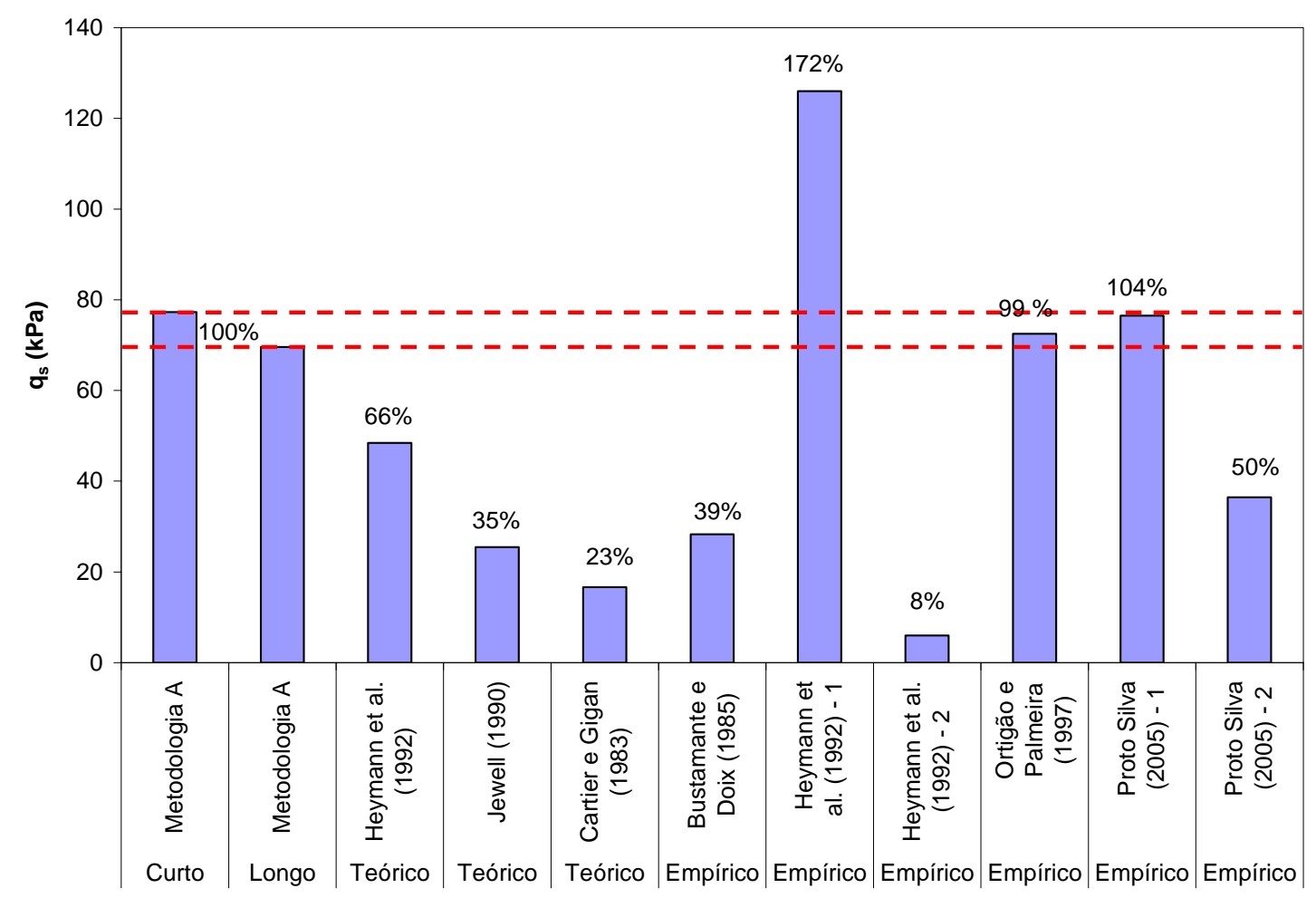

Figura 5.64. Comparativo entre os ensaios de arrancamento (metodologia A) e os métodos de previsão teóricos e empíricos para a linha 3 da obra de Osasco-SP.

Os resultados comparativos apresentados para a linha 3 da obra de Osasco apresentaram resultados parecidos com a linha 2 de Santo André-SP. Tal fato pode ser explicado pela similaridade das geologias dos locais e pela proximidade dos parâmetros de resistência obtidos a partir de ensaios de laboratório. Sendo assim, os métodos empíricos de Ortigão e Palmeira (1997) e Proto Silva (2005)-1, que consideram a resistência ao cisalhamento de interface solo-calda de cimento, foram os que mais se aproximaram dos ensaios de arrancamento in situ. Em termos percentuais, os parâmetros $q_{s}$ estimados a partir destes métodos foram $1 \%$ inferior e $4 \%$ superior aos obtidos a partir dos ensaios de arrancamento. Assim como na linha 2 de Santo André-SP, os métodos empíricos de Heymann et al. (1992) apresentaram uma discrepância entre as previsões. Os métodos 
teóricos se mostraram ser muito conservadores e subestimaram o parâmetro $q_{s}$. Dentre os métodos teóricos, o de Heymann et al.(1992) foi o que forneceu a melhor previsão.

A Figura 5.65 apresenta a comparação entre os ensaios de arrancamento (metodologia A) e os métodos teóricos e empíricos de previsão para a linha 5 da obra de Osasco-SP (obra 2).

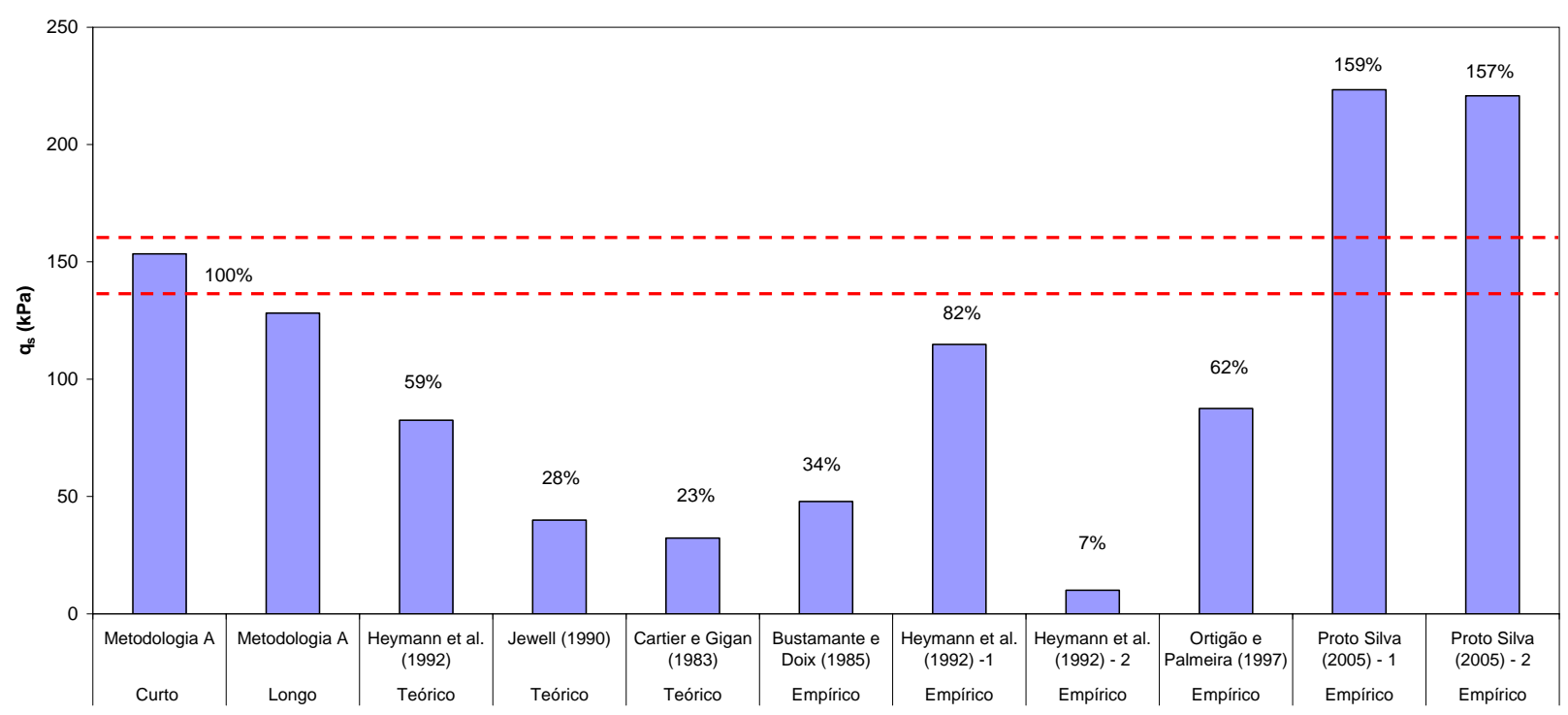

Figura 5.65. Comparativo entre os ensaios de arrancamento (metodologia A) e os métodos de previsão teóricos e empíricos para a linha 5 da obra de Osasco-SP.

Os resultados apresentados na Figura 5.65 mostram que para esta linha e obra, as previsões não foram muito satisfatórias. Tal fato pode ser justificado pela maior heterogeneidade deste tipo de solo (residual de gnaisse). Em geral, os métodos teóricos de previsão foram bastante conservadores. Os métodos empíricos apresentaram resultados superiores e inferiores aos resultados obtidos in situ a partir de ensaios de arrancamento. Dentre os métodos empíricos, o de Heymann et al. (1992) foi o que mais se aproximou dos ensaios in situ (variação de 18\%). Os métodos de Proto Silva (2005) apresentaram previsões similares e, em média, 58\% superiores aos referidos ensaios.

As previsões teóricas e empíricas realizadas para os diferentes tipos de solos mostraram resultados heterogêneos. Este fato justifica a importância da realização de 
ensaios de arrancamento in situ para a determinação mais realística e confiável da resistência ao cisalhamento de interface solo-reforço $\left(q_{s .}\right)$.

\subsection{PROPOSTA DE METODOLOGIA PARA O CONTROLE DE QUAUDADE}

A partir das análises realizadas, assim como já realizado na etapa experimental de laboratório, é proposta uma metodologia para otimização de projeto e controle de desempenho na técnica de solo pregado. A Figura 5.66 apresenta a metodologia proposta. Vale a pena ressaltar que a metodologia proposta é válida para um mesmo tipo de solo.

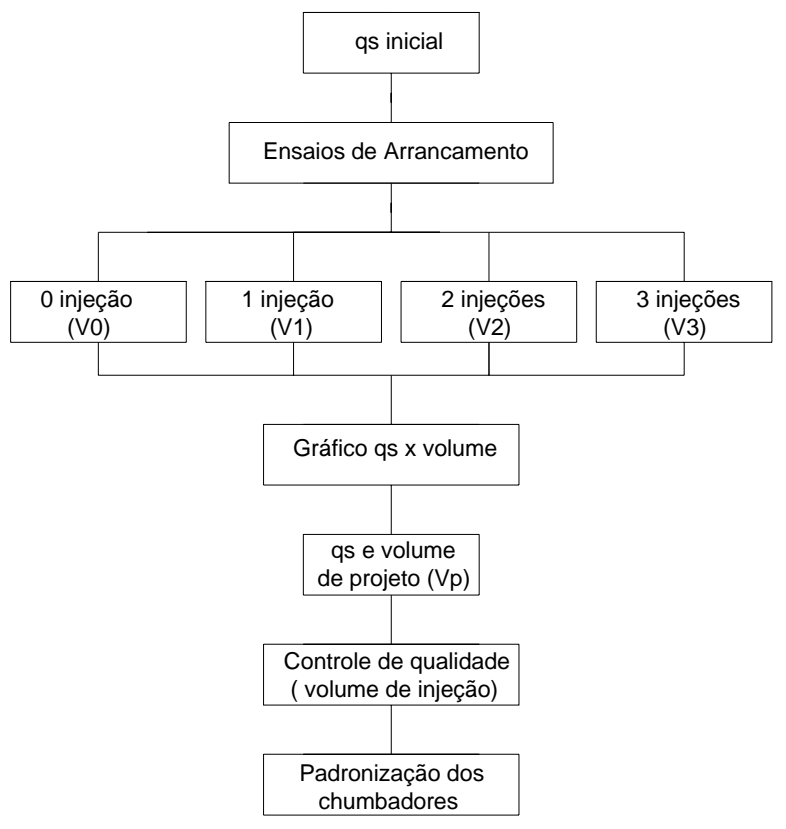

Figura 5.66. Proposta para otimização de projeto e controle de desempenho na técnica de solo pregado.

A partir dos resultados obtidos em campo, sugere-se a realização de uma alteração da metodologia proposta em laboratório. Para aumentar o espaço amostral, recomenda-se a realização de ensaios de arrancamento em pelo menos quatro chumbadores, executados com diferentes números de injeções (0, 1, 2 e 3). Estes ensaios de arrancamento são fundamentais para a verificação do $q_{s}$ inicial, estimado em projeto. Para tanto, os valores de $q_{s}$ obtidos a partir dos ensaios de arrancamento devem ser plotados em função dos fatores adimensionais de volume (V0, V1, V2 e V3), determinados para os diferentes números de 
injeções. Ao analisar estes valores, o projetista poderá determinar um $q_{s}$ de projeto e seu correspondente volume injetado de calda de cimento.

Para garantir as premissas assumidas no projeto e padronizar o desempenho dos chumbadores executados, os volumes de injeção devem ser objetos de um rigoroso controle na obra. Para melhorar a qualidade e poder confirmar a integridade dos chumbadores, o controle dos volumes injetados deve ser realizado concomitantemente com o controle das pressões de injeção.

A partir dos resultados verificados em campo, recomenda-se que, para todas as fases de injeção, as válvulas sejam igualmente espaçadas ao longo de todo o trecho injetado. Assim como nesta pesquisa, recomenda-se utilizar o espaçamento de 0,5 m.

Os ensaios de arrancamento devem ser realizados em chumbadores curtos, ou seja, com três metros de trecho injetado e um metro de trecho livre. A realização de ensaios neste tipo de chumbador mostrou-se ser prática e eficiente. 


\section{CONCLUSÕES}

Esta tese consistiu no estudo de diferentes metodologias executivas de chumbadores, dentro da técnica de solo pregado. Avaliou-se a influência destas metodologias executivas no principal parâmetro de projeto desta solução de estabilização: a resistência ao cisalhamento de interface solo-reforço $\left(q_{s}\right)$.

As principais informações para o desenvolvimento da tese foram provenientes de ensaios de arrancamento de chumbadores realizados em laboratório e em campo (caso real). O programa experimental de laboratório envolveu a construção de uma estrutura de solo pregado com dimensões reduzidas. Foram construídos nove chumbadores, com três diferentes metodologias executivas, variando-se o número de injeções.

O programa experimental de campo foi desenvolvido em duas obras (Santo AndréSP e Osasco-SP) e permitiu a realização de 52 ensaios de arrancamento em chumbadores curtos e longos. Os chumbadores foram construídos em diferentes profundidades (linhas) e com diferentes metodologias executivas. As metodologias executivas foram idealizadas para permitir a análise de diferentes números e posições das injeções. Também foram construídos dois chumbadores com um traço alternativo de calda de solo-cimento.

Portanto, com base nas informações obtidas neste trabalho, as seguintes conclusões são delineadas:

\subsection{PROGRAMA EXPERIMENTALDE LABORATÓRIO}

- Para as três linhas de reforços, os ensaios de arrancamento resultaram em valores de resistência ao cisalhamento de interface $\left(q_{s}\right)$ crescente com o aumento das fases de injeção. Este incremento deve-se, provavelmente, a melhor integridade do chumbador e a conseqüente redução dos vazios, permitindo a reconstituição do confinamento existente antes da perfuração. 
- A utilização de strain gages para a instrumentação das barras permitiu uma avaliação da qualidade do ensaio, possibilitando ainda a visualização da distribuição dos esforços ao longo do comprimento dos chumbadores.

- A resistência ao cisalhamento de interface $\left(q_{s}\right)$ aumentou ao longo da profundidade para os reforços construídos com Bainha e Bainha +1 Fase. Entretanto, para os chumbadores construídos com Bainha +2 Fases, os valores de $q_{s}$ ficaram muito próximos com o aumento da profundidade. Para os chumbadores construídos com Bainha e Bainha +1 , foi possível estabelecer um ajuste linear do incremento de $q_{s}$ a partir do acréscimo de tensão vertical, determinada a partir de software de elementos finitos.

- Os resultados obtidos mostraram que o valor de $q_{s}$ está intimamente relacionado com o volume de injeção obtido, para cada metodologia executiva. A exumação dos chumbadores confirmou estas considerações. A quantificação do volume injetado é uma excelente opção para a determinação de $q_{s}$ de projeto e para a realização do controle de qualidade de execução do chumbador.

\subsection{PROGRAMA EXPERIMENTALDE CAMPO}

Com base nos resultados obtidos, as conclusões para o programa experimental de campo são apresentadas para as diferentes situações analisadas:

\subsubsection{Influência das Metodologias Exec utivas}

- A avaliação da influência da metodologia executiva foi mais conclusiva para os chumbadores curtos, já que somente para eles foi possível realizar os ensaios de arrancamento para todas as metodologias executivas.

- De uma maneira geral, verificou que os resultados dos ensaios de arrancamento mostraram um aumento significativo do parâmetro $q_{s}$, quando foram comparadas as diferentes metodologias executivas, em que houve alguma fase de injeção de calda de cimento, com a metodologia A, tomada como referência. Os resultados mostraram-se bem coerentes e com aumentos gradativos para os chumbadores 
executados com o maior número de injeções. Em geral, os chumbadores executados com as metodologias D e F apresentaram os desempenhos mais satisfatórios.

- Outra constatação importante foi o melhor desempenho do chumbador executado com a metodologia $A^{*}$, em relação ao executado com a metodologia A na linha 5 da obra 1. Esta melhoria foi observada para os chumbadores curto e longo e foram de $57 \%$ e 100\%, respectivamente. Embora estes chumbadores não tenham sido injetados, é possível concluir que a mistura de solo-cimento acaba minimizando eventuais imperfeições ocasionadas pela exudação da calda de cimento ao longo do comprimento do chumbador.

- Embora a localização das válvulas de injeção não tenha influenciado sobremaneira os resultados, a distribuição dessas válvulas igualmente espaçadas (0,50 m) é o mais recomendado. Os melhores desempenhos foram observados para este tipo de distribuição (metodologia D).

- Os resultados também permitiram constatar que o incremento no parâmetro $q_{s}$ está relacionado com o volume de calda de cimento que foi injetado, ou seja, com o volume necessário para garantir uma boa integridade do trecho injetado e/ou ramificações. Os maiores números de injeções aumentam as chances deste fato ocorrer.

\subsubsection{Influência do Volume de Injeção de Calda de Cimento}

- A partir dos valores de $q_{s}$ apresentados concomitantemente com os volumes de injeção, conclui-se que os ganhos neste parâmetro estão diretamente relacionados com a metodologia executiva e, consequentemente, com os volumes de injeção. Os maiores ganhos em termos de $q_{s}$, principalmente, para as metodologias C, D, E e F, são explicados pelo incremento do volume injetado.

- Da mesma forma que no programa experimental de laboratório, verificou-se, para as linhas 2 e 5 da obra de Santo André-SP (obra 1) e para a linha 3 da obra de OsascoSP, a interdependência entre o valor de $q_{s}$ e o volume de injeção. Foi atribuído um fator adimensional "V", que representa a relação entre o volume injetado e o volume da cavidade escavada. Para cada uma das situações analisadas, foi 
determinada uma função que correlaciona os parâmetros $q_{s}$ e o Fator V. As funções obtidas são:

Laboratório: $q_{s}=52,73$ x “Fator V” + 65,13 (kPa).

Linha 2 - obra 1: $q_{s}=23,99$ x “Fator V" + 41,2 (kPa).

Linha 5 - obra 1: $q_{s}=15,60 \mathrm{x}$ "Fator V" + 100,14 (kPa).

Linha 3 - obra 2: $q_{s}=21,27 \mathrm{x}$ "Fator V" + 83,39 (kPa).

- Com estes resultados, verifica-se que a determinação do volume de injeção é uma excelente opção no controle de qualidade de execução do chumbador. Ao realizar este controle, é possível, para um mesmo tipo de solo, estimar o valor de $q_{s}$, a partir do volume injetado para cada chumbador, e a sua variação no maciço.

- A linha 5 da obra 2 apresentou um comportamento diferenciado em relação às demais linhas analisadas. Para esta situação, o valor de $q_{s}$ se mostrou ser independente do volume injetado de calda de cimento, apresentando coeficiente angular, para a reta de ajuste, próximo de zero. Acredita-se que, para este tipo de solo, não ocorram surgências de ramificações, e, assim, o preenchimento da cavidade escavada seja atingido mais facilmente e com menores volumes injetados.

- A partir dos resultados obtidos, foi proposta uma metodologia para a otimização de projeto e o controle de desempenho na técnica de solo pregado. A metodologia obtida a partir do programa experimental de campo foi expandida em relação à preconizada no programa experimental de laboratório e deve ser a utilizada. Vale a pena ressaltar que a metodologia proposta é válida para um mesmo tipo de solo.

\subsubsection{Influência do Comprimento dos Chumbadores}

- As análises da influência do comprimento dos chumbadores foram realizadas para os chumbadores em que foi possível finalizar os ensaios. Em geral, foram realizadas para as metodologias $\mathrm{A}, \mathrm{A} *$, B e C.

- Para a linha 5 da obra 1 e para as linhas 3 e 5 da obra, como esperado teoricamente, as cargas máximas obtidas para os chumbadores longos, construídos com as metodologias A e B, de uma maneira geral, ficaram próximas de se duplicarem em 
relação aos respectivos chumbadores curtos, dada a duplicidade do seu comprimento.

- Para a linha 2 da obra 1, este comportamento não foi observado. As cargas de pico obtidas para os chumbadores longos em relação às metodologias A e B foram, respectivamente, 3,6 e 5,4 vezes superiores aos valores observados para os chumbadores curtos. A disparidade dos resultados obtidos para os chumbadores curtos e longos se deve as possíveis imperfeições do preenchimento da calda de cimento ao longo do trecho injetado. O maior comprimento dos chumbadores longos pode ter minimizado estas imperfeições, já que o maior comprimento do trecho inclinado e injetado pode ter provocado um melhor preenchimento da cavidade escada.

\subsubsection{Instrumentação com Strain Gages}

- Os chumbadores apresentaram comportamentos semelhantes no tocante à mobilização das cargas durante a realização do ensaio de arrancamento. Assim como verificado nos ensaios de laboratório, a mobilização da resistência foi gradual, ou seja, da face em direção à extremidade interna do chumbador. Notou-se a tendência de uma distribuição triangular das cargas ao longo da barra. As curvas típicas foram apresentadas com quatro níveis de carregamento, em relação à carga de ruptura (25, 50, 75 e 100\%) Para o chumbador curto, todo o seu comprimento foi mobilizado durante a realização do ensaio. Para o chumbador longo, as cargas de arrancamento no final do trecho injetado foram praticamente inexistentes.

\subsubsection{Análise Geral dos Resultados Obtidos}

- O acréscimo do parâmetro $q_{s}$ e a conseqüente diminuição do aumento relativo (AR) da linha 2 da obra 1 para a linha 5 da obra 2 devem-se a melhor integridade do chumbador ao longo do trecho injetado. As metodologias executivas e, consequentemente, os volumes injetados são fundamentais na melhoria do parâmetro $q_{s}$. Entretanto, eles estão diretamente relacionados aos 
tipos de solos estudados. Embora as granulometrias dos solos e as classificações unificadas sejam parecidas, as diferentes estruturas dos solos encontrados nas linhas das obras estudadas influenciaram significativamente os resultados obtidos.

- Os valores crescentes de $q_{s}$ da linha 2 da obra 1 para a linha 5 da obra 2 podem estar relacionados com o índice de vazios e com a porosidade dos solos. Estes índices físicos apresentaram-se de forma decrescente da linha 2 da obra 1 para a linha 5 da obra 2. Como para a metodologia A não foi realizada nenhuma injeção, os maiores vazios podem ter provocado maior penetração da calda de cimento, não garantindo a integridade do chumbador. O mesmo raciocínio se aplica para a linha 5 da obra 2, onde as diferentes metodologias executivas não apresentaram aumentos significativos (AR), se comparados com as demais linhas.

- Para as demais metodologias, observou-se que as injeções foram promovendo o preenchimento destes vazios, melhorando e padronizando o comportamento dos chumbadores.

- A partir do pequeno número de ensaios realizados e finalizados, não foi possível realizar análises mais específicas para os chumbadores longos. Entretanto, verificou-se que, para a metodologia A, a linha 5 da obra 2 apresentou o melhor desempenho, e a proximidade dos parâmetros $q_{s}$ da linha 5 da obra 1 com a linha 3 da obra 2, assim como para os chumbadores curtos, pode estar relacionada com o similar índice de vazios.

\subsubsection{Comparação com Métodos Teónic os e Empínicos de Previsão}

- A linha 2 da obra 1 e a linha 3 da obra 2 apresentaram previsões teóricas e empíricas bastante similares. Tal fato pode ser explicado pela similaridade das geologias dos locais e pela proximidade dos parâmetros de resistência obtidos a partir de ensaios de laboratório. Sendo assim, os métodos empíricos de Ortigão e Palmeira (1997) e Proto Silva (2005)-1, que considera a resistência ao 
cisalhamento de interface solo-calda de cimento, foram os que mais se aproximaram dos ensaios de arrancamento in situ.

- Para a linha 5 da obra 1, o destaque foi a previsão de Clouterre (1991), realizada a partir do ensaio pressiométrico. Embora a previsão tenha sido realizada apenas com um resultado de ensaio pressiométrico, este método de previsão se mostrou ser bastante consistente.

- Em geral, os métodos teóricos de previsão se mostraram ser bastante conservadores. O método de Heymann et al.(1992) foi o que forneceu a melhor previsão.

- Os métodos de previsão não foram muito satisfatórios para a linha 5 da obra 2. Tal fato pode ser justificado pela maior heterogeneidade observada para este tipo de solo (residual de gnaisse).

- A partir das comparações realizadas, ficou constatado que a realização de ensaios de arrancamento é de fundamental importância para a estimativa real do parâmetro $q_{s}$ e a realização de projetos mais confiáveis e seguros.

\subsection{SUGESTÕES PARA PESQUISAS FUTURAS}

Para as pesquisas futuras que visarem dar continuação aos estudos desenvolvidos neste trabalho, com relação às estruturas de contenção em solo pregado, são sugeridos os seguintes aspectos:

a) Desenvolver um sistema/equipamento específico que permita um controle mais rigoroso do volume de injeção de calda de cimento em obras de solo pregado.

b) Realizar simulações numéricas das obras analisadas com software de elementos finitos 3D, aproveitando o banco de dados obtidos a partir das investigações geotécnicas e campanha de ensaios de arrancamento. Estas simulações devem avaliar, numericamente, o desempenho das diferentes metodologias executivas e os mecanismos de transferência de carga em interfaces solo/reforço durante a execução dos ensaios de arrancamento. 


\section{REFRÊNCIAS BIBUOG RÁPCAS}

Abramento, M; Koshima, A. \& Zirlis, A.C. (1998). Reforço do Terreno - Solo

Grampeado. Fundações Teoria e Prática, São Paulo, Editora Pini, 2ª edição, p.641-690.

Aitcin, P. C. (2000). Concreto de Alto Desempenho. São Paulo, Editora Pini, 666 p.

American Society for Testing and Materials. (1993). D 4643 - Microwave Method of Drying Soils, New York.

. (2000). D 2487 - Standard Practice for Classification of Soils for Engineering Purposes (Unified Soil Classification System), New York.

Associação Brasileira de Normas Técnicas. (1980). NBR 9180 - Solo: Determinação do Limite de Plasticidade, Rio de Janeiro, ABNT.

. (1984). NBR 6459 - Solo: Determinação do Limite de Liquidez, Rio de Janeiro, ABNT.

. (1984). NBR 7181 - Solo: Análise Granulométrica, Rio de Janeiro, ABNT.

(1984). NBR 7182 - Solo: Ensaio de Compactação, Rio de Janeiro, ABNT.

(1987). NBR 9813 - Determinação da Massa Específica Aparente In Situ com o Emprego do Cilindro de Cravação, Rio de Janeiro, ABNT. 
- (1995). NBR 5629 - Tirantes Ancorados no Terreno/Procedimento, Rio de Janeiro, ABNT.

. (1995). NBR 6502 - Rochas e Solos, Rio de Janeiro, ABNT.

. (1995). NBR 6508 - Solo: Determinação da Massa Especifica dos Sólidos, Rio de Janeiro, ABNT.

Azambuja, E; Strauss, M. \& Silveira, F.G. (2003). Sistemas de Contenção em Solo Grampeado na Cidade de Porto Alegre, RS. In: Workshop: Solo Grampeado - Projeto, Execução, Instrumentação e Comportamento, Anais..., São Paulo, p. 21-34.

Baker, R.F. \& Yoder, E.J. (1958). Stability Analysis and Design of Control Works in Landslides and Engineering Practice. HRB Special Publication, p. 189-216.

Barley, A.D; Davise, M.C.R. \& Jones, A.M. (1997). Review of Current Field Testing Methods for Soil Nailing. In: Ground Improvement Geosystems: 3rd International Conference, Proceedings, London, U.K, p. 477-483.

Berardi,G. \& La Magna, A. (1984). Lê Project du Reseau de Pieux. In: Int Conf. In situ Soil and Rock Reinforcement, Proceedings, Paris, p.33-38.

Beveredge, R.L.W. (1973). Repairs and Extension to Concrete Structures Using ResinAnchored Bars. In: Civil Engineering \& Public Works Review, 7p.

Borja, R.I; Lai, T.Y; Regueiro, R.A. \& Sama, K. (1999). Modeling Strain Localization in Soil-Nailed Escavations. In:. XI Congresso Panamericano de Mecânica dos Solos e Engenharia de Fundações, Anais...., Foz do Iguaçu. 
Boulon, M; Plytas, C. \& Foray, P. (1986). Comportement D’Interface et Prevision du Frottement Lateral de Long des Pieux et Des Tyrants d’ancrage. In: Revue Française de Géotechnique, p.31-48.

Bridle, R.J. \& Barr, B.I.G. (1990). The Analysis and Design of Soil Nails. In: Internacional Reinforced Soil Conference, Proceedings, Glasgow, p.249-254.

British Standard. (1995). BS 8006: Code of Practice for Strengthened /Reinforced Soils and other fills.

Bruce, D.A. \& Jewell, R.A. (1986). Soil Nailing: Application and Practice-part 1”. Ground Engineering, 20, no 1, p. 10-15.

Bustamante, M. \& Doix, B. (1985). Une Méthode Pour le Calcul des Tirants et dês Micropieux Injectées. Bulletin de Liaison des Laboratoire des Ponts et Chaussées, Paris, n. 140 , p. $75-92$.

Byrne, R. J. (1998). Manual for Design and Contruction Monitoring of Soil Nail Wall. Report No. FHWA-SA-96-069R. Washington, 568p.

Camargo, V.E.L.B.(2005). Comparação de Métodos de Análise de Estruturas de Solo Grampeado. São Paulo, 120p. Dissertação (mestrado) - Escola Politécnica, Universidade de São Paulo.

Camberfort, H. (1964). Injection des Sols, Paris.

Cardoso, A.S. \& Gonçalves M. (1998). Behaviour of Excavations Supported by Nailing. In: Applications of Computation Mechanicals in Geotechnical Engineering, Proceedings, Balkema, Rotterdam. 
Cartier, G. \& Gigan, J.P. (1983). Experiments and Observations on Soil Nailing Structures. In: 8th European Conference on Soil Mechanics and Foundation Engineering, Proceedings, Finland, 23-26, p. 473-476.

Chang, K.T. \& Milligan, G.W.E. (1996). Effects of the Transition Zone in a Nailed Wall Model Test. In: Earth Reinforcement, Balkema, Rotterdam, p. 333-338.

Christopher, B.R; Gill, S.A; Giroud, J.P; Juran, I; Mitchell, J.K; Schlosser, F.E \& Dunnicliff, J. (1990). Reinforced Soil Structures, Vol.1, Design and Constructions Guidelines. Report FHWA-RD-89-043, US DOT Federal Highway Administration, 301p.

Chu, L.M. \& Yin, J.H. (2005). A Laboratory Device to Test the Pull-Out Behavior of Soil Nails. In: Geotechnical Testing Journal, Vol.28, N5, p. 499-513.

Clouterre (1991). Recommandations Clouterre. Project National Clouterre, Presses de 1’ENPC, Paris, 269p.

Dash, U. \& Jovino, P.L. (1980). Construction of a Root-Pile Wall at Monessen, Pennsylvania. Transportation Research, Record.

Duncan, J.M; Byrne, P; Wong, K.S. \& Mabry, P. (1980). Strengh, Stress-Strain and Bulk Modulus Parameters for Finite Element Analyses of Stresses and Movements in Soil Masses. In: Geotechnical Engineering Resolution UCB/GT/80-01, University of California.

Dyer, N.R. \& Milligan, G.W.E. (1984). A Photoelastic Investigation of The Interaction of a Cohesionless Soil With Reinforcement Placed at Different Orientations. In: Conference on In Situ Soil and Rock Reinforcement, Proceedings, p. 257-262.

Ehrlich, M. (1992). Sistemas de Contenção de Solos-Reforçados. In: $1^{\text {a }}$ Conferencia Brasileira Sobre Estabilidade de Encostas (COBRAE), Anais..., Rio de Janeiro, p. 35-45. 
Ehrlich, M. (2003). Solos Grampeados - Comportamento e Procedimentos de Análise. In: Workshop: Solo Grampeado - Projeto, Execução, Instrumentação e Comportamento, Anais..., São Paulo, p. 127-137.

Ehrlich, M; Almeida, M.S.S. \& Lima, A.M. (1996). Parametric Numerical Analyses of Soil Nailing Systems. In: Earth Reinforcement, Proceedings, Balkema, Rotterdam.

Elias, V; Lazaert, C.A \& Espinoza, D. (2003). Soil Nail Walls. In: Geotechnical Engineering Circular-7, Departament of Transportation Federal Highway Administration (FHWA), 460p.

Falconi, F.F. \& Alonso, U.R. (1996). Considerações sobre o Dimensionamento de uma Estrutura de Contenção de Solo Grampeado. In: Seminário de Engenharia de Engenharia de Fundações Especiais e Geotecnia., Anais..., p.301-308.

Falconi, F.F. \& Alonso, U.R. (1997). Controle de Qualidade em Estruturas de Contenção em Solo Grampeado. In: 2nd Pan-Am.Symp.Landslides, 2nd COBRAE, Anais...., p.203210.

Farias, M. M. (2001). Aspectos Práticos Sobre a Implementação de Modelos Elastoplásticos. In: $4^{\circ}$ Simpósio Brasileiro de Aplicações de Informática em Geotecnia (INFOGEO), Anais..., Curitiba (PR).

Feijó, R. L. (2007). Monitoração de uma Escavação Experimental Grampeada em Solo Residual Gnáissico Não Saturado. Rio de Janeiro, RJ, Tese de Doutorado, Universidade Federal do Rio de Janeiro/COPPE.

Feijó, R. L. \& Ehrlich, M. (2001). Resultados de Ensaios de Arrancamento em Grampos Injetados em Dois Pontos do Município do Rio de Janeiro. In: III Conferência Brasileira sobre Estabilidade de Encostas, Anais...., Rio de Janeiro, p. 517-524. 
Feijó, R.L. \& Ehrlich, M. (2005). Resultados do Monitoramento de uma Obra Experimental em Solo Grampeado. In: COBRAE - Conferência Brasileira de Encostas, Rio de Janeiro, Anais..., vol II, p. 633-641.

França, F.A.N. (2007). Ensaios de Arrancamento e Comportamento de um Modelo de Solo Grampeado Construído em Laboratório. São Carlos, 115p. Dissertação (Mestrado em Geotecnia)-Escola de Engenharia de São Carlos, Universidade de São Paulo.

França, F.A.N. \& Bueno, B.S. (2009). Comportamento de um Modelo de Laboratório em Solo Grampeado. In: Revista Geotecnia (No prelo).

Frank, R. \& Zhao, S.R. (1983). Estimation par lês Parametres Pressiométriques de l'enfoncement Sous Charge Axiale de Pieux Fores Dans lês Sols Fins. In: Journal of Southwestern Jiaotong University Sichmuan, p.1-10.

Frazen, G. (1998). Soil Nailing - A Laboratory and Field Study of Pullout Capacity. Doctoral Thesis, Department of Geotechnical Engineering, Chalmers University of Technology, Sweden.

Freitas Neto, O. (2008). Resistência ao Cisalhamento de um Solo Não Saturado com Medida Direta de Suç̧ão. São Carlos, 115p. Dissertação (Mestrado em Geotecnia) Escola de Engenharia de São Carlos, Universidade de São Paulo.

Gassler, G. (1990). In-situ Techniques of Reinforced Soil. In: Performance of Reinforced Soil Structures, British Geotechnical Society, p.185-196.

Gassler, G. \& Gudehus, G. (1981). Soil Nailing- Some Aspects of a New Technique. In: 10th Int. Conf.Soil Mech.and Foundation.Eng., Proceedings, Stockholm, p.665-670.

GeoRio (1999). Manual Técnico de Encostas: Ancoragem e Grampos. Fundação GeoRio, 184p. 
Gerscovich, D.M.S; Sayão, A.S.F.J; Springer, F.O. \& Lima, A.P. (2002). Deformabilidade de Escavações com Solo Pregado. In: VIII Congresso Nacional de Geotecnia, v.3,Lisboa, Anais..., p. 1579-1588.

Gomes, R.S. (1993). Interação Solo-Reforço e Mecanismos de Ruptura em Solos Reforçados com Geotêxteis. São Carlos, 271p. Tese Doutorado-Escola de Engenharia de São Carlos, Universidade de São Paulo.

Gudehus, G. (1983). Design Concept for Pile Dowels in Clay Slopes. In: 8th Eur. Conf. on Soil Mech. And Found.Eng., Proceedings, Helsinki.

Guilloux, A. \& Jailloux, J.M. (1979). Comportment d'un Mur Experimental en Terre Armee vis-à-vis de la corrosion. In: InternationalConf, on Soil Reinforcement: Reinforcement Earth and Other Techniques, Proceedings, Paris, p.503-508.

Guilloux,, A. \& Schlosser, F. (1982). Soil Nailing: Practical Applications. In: Symposium on Recent Developments in Ground Improvement Techniques, Proceedings, Bangkok, vol. 29, p. 389-397.

Guimarães Filho, J.D. (1985). Consolidação de Solos por Injeções: Discussão Sobre Uma Prática Bem Sucedida mas que não está de Acordo com as Teorias Clássicas Existentes. Revista Solos e Rochas, Vol.7, p. 99-107.

Guimarães Filho, J.D. (1994). O alívio Controlado de Tensões na Técnica de Solo Grampeado. Revista Solos e Rochas, São Paulo, Vol. 7, n 3, p.195-201.

Hanna, T.H. (1982). Foundation in Tension: Ground Anchor. Trans Tech Publiations Series on Rock and Soils Mechanics, vol 6.

Henriques Junior, P.R.D. (2007). Simulação Numérica de Ensaios de Arrancamento de Grampos. Rio de Janeiro, 241p. Dissertação de Mestrado, Universidade Federal do Rio de Janeiro, COPPE. 
Heymann, G; Rohde, A.W; Schwartz, K. \& Friedlaender, E. (1992). Soil Nail Pull Out Resistance in Residual Soils. In: International Symposium on Earth Reinforcement Practice, Proceedings, Fukuoka/kyushu/Japan, vol.1, p.487-492.

Hovart,C.\& Rami, R. (1975). Elargissement de I’Emprise SNCF pour la Dessert de SaintQuenti-enYvelines.In: Revue Travaux, p.44-49.

Jewell, R.A. (1990). Review of Theoretical Models for Soil Nailing. In: Internacional Reinforced Soil Conference, Proceedings, Glasgow, p.265-275.

Jewell, R.A. (1980). Some Effects of Reinforcement on Mechanical Behaviour of Soils. Phd Thesis, University of Cambridge, Cambridge, England.

Jones, C.J.F.P. (2000). Geosynthetics in Reforced Structures. In: EuroGeo, The second European Geossynthetics Conference, Proceedings, Italy.

Junaideen, S.M; Tham, L.G; Law, C.F; Lee, C.F. \& Yue, Z.Q. (2004). Laboratory Study of Soil-Nail Interaction in Loose, Completely Decomposed Granite. In: Canadian Geotechnical Journal, Vol. 41, p. 274-286.

Juran, I \& Elias, V.F.H. (1991). Ground anchors and Soil Nails in Retaining Structures. In: Foundation Engineerin Handbook, p.868-905.

Juran, I; Baudrand, G; Farrag, E. \& Elias, V. (1990). Design of Nailed Retaining Structures. ASCE Conf on Design and Perfomance of Earth Retaining Structures, Cornell University, Ithaca, Geotechnical Publication, New York, n² 25, p. 644-659.

Kakuda, F.M. (2005). Estudo de Ensaios de Arrancamento de Geogrelha com Utilização de um Equipamento Reduzido. São Carlos, 124p. Dissertação (Mestrado em Geotecnia) - Escola de Engenharia de São Carlos, Universidade de São Paulo. 
Lee, C.F; Law, K.T; Tham,L.G; Yue, Z.Q. \& Junaideen, S.M. (2004). Design of a Large Soil Box for Studying Soil-Nail Interaction in Loose Fill. In: Soft Soil Engineering, p. 413-418.

Leite, R. A. (2007). Mobilização de Resistência ao Arrancamento de Grampos com Fibras de Polipropileno. Rio de Janeiro, 135p. Dissertação de Mestrado, Universidade Federal do Rio de Janeiro, COPPE.

Lima, A.M.L. (1996). Análise Numérica de Escavação em Solo Grampeado. Rio de Janeiro, 120p. Dissertação de Mestrado, Universidade Federal do Rio de Janeiro, COPPE.

Lizzi, F. (1970). Reticoli di Pali Radice per il Maglioramento delle Caractteristiche di Resistenza del Terreno. In: Convegno di Geotechnica, Proceedings, Bari.

Lizzi, F. (1982).The Static Restoration of Monuments. Sagep Publisher.

Lopes, F.R. (1995). Métodos Numéricos em Geotecnia. Notas de aula, Universidade Federal do Rio de Janeiro, COPPE.

Marchal, J. (1984). Reinforcement dês Sols par Clouage. Étude Expérimentale em Laboratoire. In: Conf. In Situ Soil and Rock Reinforcement, Proceedings, p.275-278.

Mitchell, J.M. \& Villet, W.C.B. (1987). Reinforcement of Earth Slopes and Embankments. NCHRP Report N0 290, TRB, USA Transportation, Research Board, National Research Council. Washington D.C, USA, 323p.

Moraes, L. J; Arduino, E. G. A. (2003). Estabilização de Taludes por Solo Grampeado em Manaus-AM. In: Solo Grampeado - Projeto, Execução, Instrumentação e Comportamento, ABMS, São Paulo, Anais..., v. 1, p. 121-125.

Nonveiller, E. (1989). Grouting, Theory and Practice. New York, 250p. 
Oliveira, V. S. (2006). Análise de Estabilidade Bi e Tridimensional de Talude Estabilizado em Solo Grampeado. Florianópolis, SC. Dissertação de Mestrado. Universidade Federal de Santa Catarina, Brasil.

Ortigão, J.A.R; Palmeira, E.M; Zirlis, A. (1995). Experience with Soil Nailing in Brazil: 1970-1994. Institution of Civil Engineers, Geotechnical Engineering, Proceedings, London, Vol. 113, paper n ${ }^{\circ}$ 10584, p.93-106.

Ortigão, J.A.R. \& Palmeira, E.M. (1992). Solo Grampeado: Técnica para Estabilização de Encostas e Escavações. In: COBRAE - Conferência Brasileira de Encostas, Rio de Janeiro, Anais..., vol 1, p. 57-74.

Ortigão, J.A.R. (1997). Pullout Tests in Soil Nailing Structures. Revista Solos e Rochas, São Paulo, Vol.20, nº 1, p.39- 43.

Ortigão, J.A.R; Fannin, R.J.(1992). Tiedback Walls to Soil Nailing: the Practice in Vancouver and in Rio de Janeiro. Geotechnical News, Vancouver, Canadá.

Ortigão, J.A.R; Zirlis. A.C \& Palmeira, E.M. (1993). Experiência com Solo Grampeado no Brasil: 1970-1993. Revista Solos e Rochas, São Paulo, vol.16, n 4, p.660-675.

Pitta, C.A; Souza, G.J.T. \& Zirlis, A.C.(2003). Solos Grampeados - Alguns Detalhes Executivos e Casos de Obras. In: Workshop: Solo Grampeado - Projeto, Execução, Instrumentação e Comportamento, São Paulo, Anais...., p.1-20.

Plumelle, C. (1979). Etude Experimentale du Comportement dês Tirants d'Ancrage. These de Docteur - Ingénieur, Université P. et M. Curie.

Plumelle, C. (1986). Full Scale Experimental Nailed Soil Retaining Structures. Revue Française de Geotechnique, ${ }^{\circ}$ 40, p. 45-50. 
Proto Silva, T. (2005). Resistência ao Arrancamento de Grampos em Solo Residual de Gnaisse. Rio de Janeiro, 128p. Dissertação de Mestrado, PUC- Rio de Janeiro.

Saramago, R.P; Mendonça, M.B; Brugger, P.L.\& Ferreira, J.A. (2005). Muro de Solo Grampeado com Face em Blocos Pré-Moldados. In: IV COBRAE, Anais..., p.827-833.

Schlosser, F. (1982). Behaviour and Design of Soil Nailing. In: Symposium on Recent Developments in Ground Improvement Techniques, Proceedings, Bangkok, p. 399-413.

Sheahan, T.C. \& Alvarado, I. (1996). A New Experimental Device for Determining Reinforcement Mechanisms in Soil Nails. In: International Symposium on Earth Reinforcement, Proceedings, p. 145-150.

Shen, C.K; Bang, S; Romstand, K.M; Kulchin, L. \& Denatale, J.S. (1981). Field Measurements of Earth Support System. Journal da ASCE, vol.107, pp.1625-1642.

Silva, A.E.F; Vidal, D. (1999). Estruturas em Solo Reforçado e os Métodos de Dimensionamento por Equilíbrio Limite. In: Simpósio Brasileiro sobre Aplicações de Geossintéticos, Anais..., Rio de Janeiro, p.139-147.

Silva, J. C. (1999). Análise Numérica de Estruturas Grampeadas. Rio de Janeiro/RJ. Dissertação de Mestrado, Departamento de Engenharia Civil, Pontifícia Universidade Católica do Rio de Janeiro.

Soares, J. E. S. \& Gomes, R. C. (2003). Um Caso de Solo Grampeado na Encosta da BR101 em Angra dos Reis, RJ. In: Solo Grampeado - Projeto, Execução, Instrumentação e Comportamento, ABMS, Anais..., v. 1, p. 49-56.

Springer, F.O. (2006). Ensaios de Arrancamento de Grampos em Solo Residual de Gnaisse. Rio de Janeiro, 310p. Tese de Doutorado, Departamento de Engenharia Civil, Pontifícia Universidade Católica do Rio de Janeiro. 
Springer, F.O; Gercovich, D.M.S. \& Sayão A.S.F.J. (2001). Deformabilidade de Taludes com Solo Grampeado. III Conferência Brasileira sobre Estabilidade de Encostas (COBRAE), Anais..., p. 483-490.

Stocker, M.F; Korber, G.W; Gassler, G. \& Gudehus, G. (1979). Soil Nailing. In: Conferência Internacional de Solos Reforçados, Proceedings, Paris, Vol 2, p. 469-474.

Vale, R. A. M. (2002). Modelagem Numérica de uma Escavação Profunda Escorada com Parede Diafragma. Rio de Janeiro, 142p. Dissertação de Mestrado. Universidade Federal do Rio de Janeiro, COPPE.

Viana, P. M. F. (2003). Geovala: Um Novo Processo Construtivo para Dutos Enterrados. São Carlos, SP. Tese (Doutorado em Geotecnia) - Escola de Engenharia de São Carlos, Universidade de São Paulo.

Vidal, H. (1966). La Terre armée. In: Institut Technique du Bâtiment et Dês Travaux Publics, 19, Proceedings, França, n.223-4.

Vilar, O.M. (2003). Introdução à Mecânica dos Solos Não Saturados. Apostila - Notas de Aula da disciplina Resistência ao cisalhamento nos solos (SGS 5846) - Departamento de Geotecnia, Escola de Engenharia de São Carlos, Universidade de São Paulo.

Zirlis, A.C.(1998). Reforço do Terreno - Solo Grampeado. Fundações Teoria e Prática, PINI- ABMS-ABEF, Capítulo 18.3.1, São Paulo, p. 641-642 e p 656-668.

Zirlis, A.C; Pitta, C.A; Souza, G.J.T. \& Oliveira, M. (1992). Soil Nailing: Chumbamento de Solos, Experiência de Uma Equipe na Aplicação do Método. In: COBRAE Conferência Brasileira de Encostas, Rio de Janeiro, Anais..., vol 1, p. 81-99.

Zirlis, A.C; Pitta, C.A. \& Souza, G.J.T. (2005). Solo Grampeado - Aspectos Executivos do Chumbador, 10p. 